\title{
Movimiento vivenciado y movimiento neutro. \\ Estudio sobre la expresividad de la representación del movimiento en animación
}

\author{
TESIS DOCTORAL \\ Presentada por \\ Rosa Gertrudis Peris Medina \\ Dirigida por \\ Carmen Lloret Ferrándiz
}

Septiembre, 2015

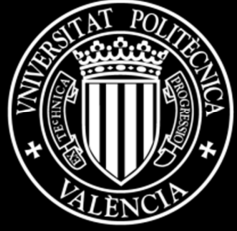

UNIVERSITAT POLITĖCNICA DE VALÈNCIA 



\title{
Movimiento vivenciado y movimiento neutro. Estudio sobre la expresividad de la representación del movimiento en animación
}

\author{
TESIS DOCTORAL \\ Presentada por \\ Rosa Gertrudis Peris Medina \\ Dirigida por \\ Carmen Lloret Ferrándiz
}

Septiembre, 2015

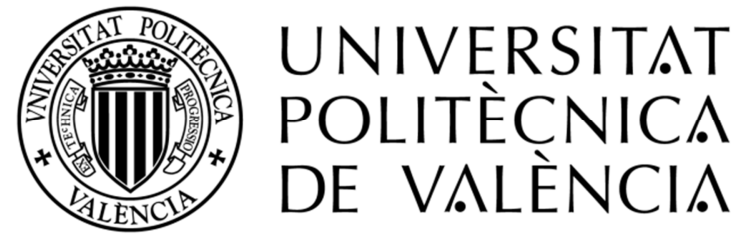



A mis padres, a mis hermanas, a Raimund y a Mar de Luna por su apoyo incondicional. 

El valor de la fuerza de voluntad abre caminos.

(Walt Disney) 



\section{Agradecimientos}

En primer lugar quiero expresar mi agradecimiento a la directora de esta tesis, la doctora Dña. Carmen Lloret, al profesor Raimund Krumme, tutor durante mi estancia en la Küsthochschule für Medien de Colonia, a mi familia, a Mar de Luna y a mis amigos.

También quiero expresar mi agradecimiento a la Generalitat Valenciana, por concederme una beca de Formación de Personal Investigador de carácter predoctoral entre 2008 y 2012, y la beca para estancias fuera de la Comunidad Valenciana en 2011; a la Universidad Politécnica de Valencia; al grupo de investigación Expresión plástica del movimiento: animación y lumino-cinetismo por el acceso a su colección de libros y películas; a la Küsthochschule für Medien de Colonia por recibirme como guest student, experiencia tan enriquecedora como inolvidable que ha marcado un antes y un después en mi vida; y a la abadía Real de Fontevraud, que financió parte de una de las películas que estoy realizando, así como por el acceso a su colección particular de películas y por la maravillosa experiencia que supuso mi estancia en ese pequeño paraíso terrenal.

Agradezco también el apoyo de todas las personas que han colaborado de una manera u otra en el desarrollo de esta investigación, en espacial a la doctora Charo Serra y otros doctores. 


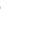


MOTIVOS DE LA ELECCIÓN DEL TEMA _ $\quad 17$

DEFINICIÓN DE LA INVESTIGACIÓN _ _ _ _ _ $\quad 17$

Definición del tema ........ 17

Acotación del campo de estudio _..._ 18

Hipótesis ....... 20

Objetivos … 20

$\begin{array}{ll}\text { ESTADO DE LA CUESTIÓN .... } & 21\end{array}$

PERTINENCIA DE LA INVESTIGACIÓN . $\quad 25$

METODOLOGÍA 26

ESTRUCTURA DE LA TESIS _. 29

ACLARACIONES … 32

1. DEFINICIÓN DE MOVIMIENTO VIVENCIADO Y

MOVIMIENTO NEUTRO. SUS CUALIDADES EN LA

PLÁSTICA Y EN ANIMACIÓN

1.1. CONCEPTOS DE MOVIMIENTO VIVENCIADO Y MOVIMIENTO NEUTRO

1.1.1. Definición de movimiento vivenciado … _ _ _ $\quad 39$

1.1.2. Definición de movimiento matemático y movimiento neutro

1.2. EXPRESIÓN DEL MOVIMIENTO VIVENCIADO

1.2.1. Qué es el movimiento vivenciado en la plástica .... 55

1.2.2. Características del movimiento vivenciado en animación

A. ESTIMULACIÓN DE LA SENSACIÓN CINÉTICA QUE SE TIENE AL EXPERIMENTAR Y AL OBSERVAR EL

MOVIMIENTO

B. EXPRESIÓN DE CARACTERÍSTICAS PARTICULARES DE CADA MOVIMIENTO 
C. LOS ACONTECIMIENTOS TIENEN LUGAR EN UN ESPACIO

VIVENCIAL

D. EL MOVIMIENTO TRANSMITE EL CONTENIDO EMOCIONAL

\subsection{EXPRESIÓN DEL MOVIMIENTO NEUTRO}

1.3.1. Qué es el movimiento neutro en la plástica

1.3.2. Características del movimiento neutro en

animación

A. AUSENCIA DE CINESTESIA EN LA REPRESENTACIÓN DEL MOVIMIENTO

B. HOMOGENEIZACIÓN DEL MOVIMIENTO

B.1. Movilidad característica de la técnica

B.2. Signos gráficos procedentes del cómic y recursos de representación móvil

B.3. Compendio de recursos estilísticos

C. LOS ACONTECIMIENTOS TIENEN LUGAR EN UN ESPACIO MATEMÁTICO-NEUTRO

D. EL MOVIMIENTO NO TRANSMITE EL CONTENIDO EMOCIÓNAL

\section{REPRESENTACIÓN DEL MOVIMIENTO} VIVENCIADO Y EL MOVIMIENTO NEUTRO EN ANIMACIÓN. COMPONENTES DINÁMICOS

\subsection{REPRESENTACIÓN DEL MOVIMIENTO EN}

ANIMACIÓN. ASPECTOS TÉCNICOS

2.1.1. TIPOS DE MOVIMIENTO

A. MOVIMIENTO PRESENTADO Y MOVIMIENTO REPRESENTADO

Movimiento presentado

Representación del movimiento

B. MOVIMIENTO REAL Y VIRTUAL

Movimiento real

Movimiento virtual

2.1.3. COMPONENTES PLÁSTICOS Y DINÁMICOS DE LA 
A. TÉCNICA PLÁSTICA Y TÉCNICA DE ANIMACIÓN ……………….............. 138

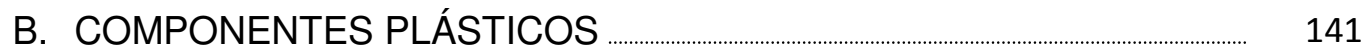

C. QUÉ SON LOS COMPONENTES DINÁMICOS DE LA ANIMACIÓN

\subsection{4. ¿CÓMO SE OBTIENEN EL MOVIMIENTO} VIVENCIADO Y EL NEUTRO?

\subsection{COMPONENTES DINÁMICOS DE LA ANIMACIÓN}

A. QUE ÉS

B. LA EXPRESIVIDAD DEL MOVIMIENTO A TRAVÉS DEL CAMBIO DE IMAGEN

B. 1. Frecuencia de imágenes por segundo. Velocidad de proyección

- Imágenes / Fotogramas

- Variación de frecuencia de ips

B.2. El paso entre fotogramas

- Cambio instantáneo y fundidos encadenados

- Combinación de efectos

B.3. Vibración de la imagen

- A qué se debe. Usos y efectos

- Cuando no hay vibración

- Vibración o no vibración

C. CONCLUSIONES SOBRE LA INFLUENCIA DEL CAMBIO DE IMAGEN EN LA REPRESENTACIÓN DEL MOVIMIENTO VIVENCIADO Y EL MOVIMIENTO NEUTRO

2.2.2. LA VALORACIÓN ESPACIO-TEMPORAL

A. QUÉ ES

B. LA EXPRESIVIDAD DEL MOVIMIENTO A TRAVÉS DE LA COMPOSICIÓN MÓVIL

B.1. El espacio compositivo. Formato y otras consideraciones

B.2. La composición móvil en el plano

- Plano de cámara fija

Composición estática

Predominio del movimiento de personajes. Composición móvil como coreografía

- Movimientos de cámara. El punto de vista móvil

Movimiento de cámara sin acción de otros elementos

Movimiento de cámara más acción de otros elementos

- Cambio de formato

B.3. Sucesión de planos y planos-secuencia. Evolución de la imagen

- Sucesión de planos 
Lo que sucede en cada plano. Nuevo plano-nueva composición

Conexión entre planos

- Planos-secuencia. Desarrollo de la composición de la imagen

B.4. Evolución total de la película

- Relación entre la composición móvil y la intensidad cinética

- Cambio de composición o composición constante

- Composición total

- Continuidad compositiva

C. CONCLUSIONES SOBRE LA INFLUENCIA DE LA COMPOSICIÓN MÓVIL EN LA REPRESENTACIÓN DEL MOVIMIENTO VIVENCIADO Y EL MOVIMIENTO NEUTRO

\subsubsection{DISTRIBUCIÓN DE LA INTENSIDAD CINÉTICA}

A. QUÉ ES

B. LA EXPRESIVIDAD DEL MOVIMIENTO A TRAVÉS DE LA DISTRIBUCIÓN DE LA INTENSIDAD CINÉTICA

B1. La intensidad

- Intensidad alta o baja para expresar el movimiento

B.2. Distribución de la intensidad

- Intensidad regular o irregular, por contraste y rítmica.

Variedades y uso expresivo

- Cambio de intensidad creciente-decreciente.

Variedades y uso expresivo

Cambio de intensidad progresivo

Cambio de intensidad inmediato

C. CONCLUSIONES SOBRE LA INFLUENCIA DE LA DISTRIBUCIÓN DE LA INTENSIDAD CINÉTICA EN LA REPRESENTACIÓN DEL MOVIMIENTO VIVENCIADO Y EL MOVIMIENTO NEUTRO.

A. QUÉ ES

B. LA EXPRESIVIDAD DEL MOVIMIENTO A TRAVÉS DE LA PRESENTACIÓN DE LA HISTORIA

B.1. El punto de vista desde el que se presenta la historia

B.2. La representación del tiempo

- Orden

- Duración

- Frecuencia

B.3. Giros narrativos

B.4. Relación con la intensidad cinética

C. CONCLUSIONES SOBRE LA INFLUENCIA DE LA

PRESENTACIÓN DE LA HISTORIA EN LA REPRESENTACIÓN

DEL MOVIMIENTO VIVENCIADO Y EL MOVIMIENTO NEUTRO 
3. REPRESENTACIÓN DEL MOVIMIENTO VIVENCIADO Y NEUTRO A TRAVÉS DE LA VALORACIÓN ESPACIO-TEMPORAL

3.1. QUÉ ES

\subsection{ELEMENTOS QUE PARTICIPAN EN LA VALORACIÓN} ESPACIO-TEMPORAL

3.2.1. MECÁNICA DEL MOVIMIENTO

A. REGISTRO DE LA MECÁNICA REAL

B. TOMAR INFORMACIÓN DETALLADA DE LA MECÁNICA REAL

C. BASARSE EN LAS LEYES DE LA MECÁNICA CLÁSICA

3.2.2. ALTERACIÓN DE LA MECÁNICA: ALTERACIÓN DEL ESPACIO Y EL TIEMPO ‥ 279

A. EXAGERACIÓN DEL TIEMPO …__... 279

A.1. Aumento o reducción de la velocidad total de la acción ………....... 280

A.2. Exageración del tiempo y del espacio dentro de la acción _............. 282

B. VALORACIÓN ESPACIO-TEMPORAL REGULAR ................................. 282

C. ALTERACIÓN DE LA MECÁNICA …_............................................. 285

D. VALORACIÓN ESPACIO-TEMPORAL SEGÚN UN ESTILO DE ANIMACIÓN

3.2.3. INTERPRETACIÓN ESPACIO-TEMPORAL POR ORDEN CRONOLÓGICO O YUXTAPOSICIÓN DE FASES

A. OTRA MANERA DE ALTERAR LA MECÁNICA ............................................... 301

B. EXPERIMENTACIÓN PLÁSTICA ................................................................. 305

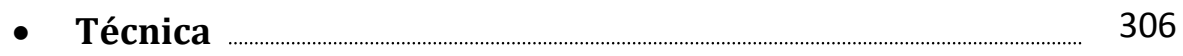

- Elección del motivo a representar …………................................. 308

- Variaciones gráficas y de animación .................................................... 308

- Digitalización de la imagen y extracción de

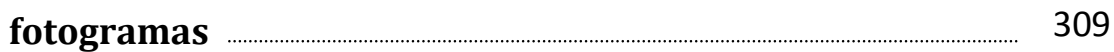

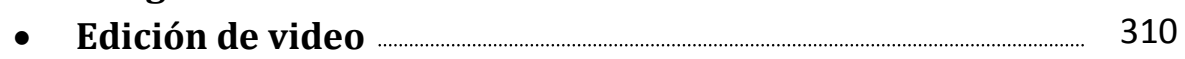

- Resultados ......................................................................................... 310

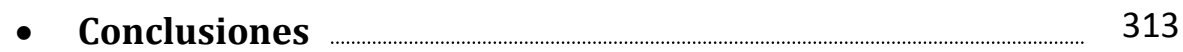

\subsubsection{SENSACIÓN DEL MOVIMIENTO EN CADA} FOTOGRAMA

A. QUÉ ES EL DINAMISMO EN IMÁGENES ESTÁTICAS . ............................... 315

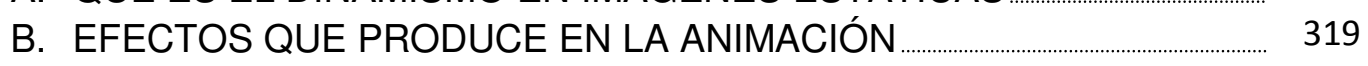

C. CUANDO NO HAY SENSACIÓN DE MOVIMIENTO EN LOS FOTOGRAMAS INDIVIDUALES 


\subsubsection{CUANDO EL MOVIMIENTO VIENE DADO POR LA} TÉCNICA

A. ROTOSCOPIA

B. CAPTURA DE MOVIMIENTO

C. ANIMACIÓN CG (ANIMACIÓN GENERADA POR ORDENADOR)

\subsection{CONCLUSIONES: INFLUENCIA DE LA VALORACIÓN} ESPACIO-TEMPORAL EN LA REPRESENTACIÓN DEL MOVIMIENTO VIVENCIADO Y EL MOVIMIENTO NEUTRO

\section{NATURALISMO Y EXPRESIVIDAD DEL} MOVIMIENTO EN ANIMACIÓN

4.1. NATURALISMO DEL MOVIMIENTO EN ANIMACIÓN

4.1.1. CONSIDERACIONES SOBRE EL NATURALISMO

EN EL ARTE APLICADAS A LA ANIMACIÓN

Representar es interpretar

Lógica e intuición

Voluntad de verdad y voluntad de invención

Mímesis

Evocación e información

Lo externo-lo interno

4.1.2. QUÉ ES REPRESENTAR DE FORMA NATURALISTA EL MOVIMIENTO EN ANIMACIÓN

Cine de acción real y animación. Dos medios de

interpretación del movimiento.

Fotografía y acción real ¿Modelos de movimiento

naturalista en animación?

Representación naturalista y no naturalista en animación

4.1.3. EL LENGUAJE CINEMATOGRÁFICO Y EL PLÁSTICO

A. EL LENGUAJE CINEMATOGRÁFICO PROPIO DEL CINE DE ACCIÓN REAL EN ANIMACIÓN

Composición móvil

Imitación de efectos ópticos

Se evita la vibración de la imagen

El lenguaje corporal de los personajes animados imita los recursos del arte dramático

Diferentes niveles de recreación del lenguaje del cine de acción real

B. ÉNFASIS EN LAS CUALIDADES PLÁSTICAS DE LA ANIMACIÓN. INDEPENDENCIA DEL LENGUAJE 
Composición móvil

Superficie plástica

Vibración de la imagen

Representación de emociones y sentimientos por medio

de la expresión plástica del movimiento

\subsection{RELACIÓN ENTRE MOVIMIENTO VIVENCIADO $Y$}

\section{MOVIMIENTO NO NATURALISTA}

Alteración de la mecánica

Vibración de la imagen

Inserción de los acontecimientos en un espacio

independiente de la perspectiva de geometría proyectiva

Tendencia a la variedad de lenguajes

\subsubsection{REPRESENTACIÓN NATURALISTA - MOVIMIENTO} VIENCIADO

\subsection{RELACIÓN ENTRE MOVIMIENTO NEUTRO $Y$}

\subsubsection{PUNTOS COMUNES}

La mecánica del movimiento

Se evita la vibración de la imagen

Inserción de los acontecimientos en un espacio

perspectivo de geometría proyectiva

Tendencia a la homogeneidad

\subsubsection{REPRESENTACIÓN NO NATURALISTA-} MOVIMIENTO NEUTRO

4.4. DIFERENTES NIVELES DE NATURALISMO EN EL DISEÑO DEL MÓVIL Y LAS ACCIONES QUE REALIZA EN RELACIÓN A LA EXPRESIVIDAD DE SU MOVIMIENTO

4.4.1. FORMA Y DINAMISMO: EL DISEÑO DEL MÓVIL Y

\section{LA EXPRESIÓN DE SU MOVIMIENTO}

A. CONSIDERACIONES

B. COMBINACIONES

$1^{\mathrm{er}}$ caso: Movimiento vivenciado - móvil no naturalista

2ำ caso: Movimiento vivenciado - móvil naturalista

3 o caso: Movimiento neutro - móvil no naturalista

\subsubsection{LA EXPRESIÓN DEL MOVIMIENTO EN RELACIÓN}


A. CONSIDERACIONES

B. COMBINACIONES.

$1^{\text {er }}$ caso: Movimiento vivenciado - temática fantástica

2o caso: Movimiento vivenciado - temática realista

3o caso: Movimiento neutro - temática fantástica

ANEXOS

Anexo 1

Anexo 2

Anexo 3

Anexo 4

Capítulo 1

Capítulo 2

Capítulo 3

Capítulo 4 



\section{INTRODUCCIÓN}

\section{MOTIVOS DE LA ELECCIÓN DEL TEMA}

El tema de esta investigación surgió por la atracción que siento, como muchas otras personas, por algunas animaciones que son sorprendentes a la vista, que emocionan a través del movimiento y la estética, películas que, en definitiva, como artista, me despiertan deseos de expresar así el movimiento, de provocar esas sensaciones al espectador y a mí misma como primera contempladora de la obra. Con la aspiración de analizar la expresión plástica del movimiento de estas obras y así defender su valía a través del discurso teórico, el planteamiento inicial estaba orientado a comparar la animación artística con la industrial. Pero gracias al visionado de muchas más películas de las que conocía hasta el momento, el contacto con profesionales de la animación y también la estancia en la Kunsthochschule für Medien Köln (Academia de Artes Media de Colonia) y en la Abadía Real de Fontevraud, mi conocimiento sobre la animación se hizo más amplio y, en consecuencia, la postura inicial se flexibilizó. Y así, poco a poco, fue tomando forma una idea que se desligaba de la comparación entre arte e industria, con la que me sentía incómoda, y que en este caso ofrecía una perspectiva de enfrentamiento que no me permitía observar el fenómeno con claridad. Bajo esta nueva visión encontré el verdadero germen del estudio: la expresividad del movimiento en animación.

\section{DEFINICIÓN DE LA INVESTIGACIÓN}

\section{Definición del tema}

Hay muchos lenguajes en animación, gran variedad en la expresión del movimiento; algunos recursos de representación se perpetúan y otros desaparecen, las técnicas también evolucionan, las tradicionales se mantienen vivas y se desarrollan otras nuevas. Desde que se expandió más allá del cine y la televisión, hace tiempo que la animación llegó a prácticamente todos los contextos imaginables, en los que se ha consolidado adoptando los más variopintos formatos, desde instalaciones artísticas hasta aplicaciones en smartphones o artilugios como las gafas 
de google; en tan sólo dos años, cualquier novedad deja de serlo. Dentro de toda esa diversidad, el espectador puede detectar que las animaciones que se dan en unos contextos no tienen las mismas características que las que se dan en otros; así, durante el despegue de un avión, los pasajeros pueden ver un video explicativo sobre seguridad abordo que será sustancialmente diferente a los dibujos animados que minutos más tarde verán en sus dispositivos electrónicos para amenizar el viaje.

En el campo de la animación conviven películas de muy distintas finalidades y de diferentes niveles de expresividad. Unas animaciones despiertan fuertes y muy directas sensaciones a través del movimiento, la sensación de vivir o revivir el movimiento, o transmiten las impresiones dinámicas que provoca su observación; frente a estas animaciones de expresividad tan potente, hay otras que son más bien "asépticas" pero que, sin embargo, son apropiadas para su ámbito y cuya razón de ser no es la rivalidad con las animaciones de mayor expresividad. La diferencia entre ambos tipos de animación no se puede explicar meramente a través de dicotomías como animación industrial-animación artística, representación naturalista-representación no naturalista o estilo popular de animación-estilo personal.

Esta investigación se centra en la definición y descripción de las representaciones del movimiento en animación que presentan gran expresividad y expresividad mínima, a las que hemos denominado "movimiento vivenciado" y "movimiento neutro". Así mismo, se estudian recursos cinematográficos a través de los cuales se manifiestan estos fenómenos y la relación de la expresividad con el naturalismo de la representación dinámica.

\section{Acotación del campo de estudio}

El objeto de estudio son las animaciones figurativas que representan el movimiento como vivenciado o como neutro, sin delimitación de antigüedad, nacionalidad ni técnica. Esto no significa que hayamos estudiado todas las películas de animación figurativas que existen hasta ahora, sino que hemos buscado en todas las obras que nos ha sido posible (sin más delimitación que el que sean figurativas) la representación del movimiento como vivenciado y como neutro, criterio que reduce considerablemente el campo, ya que estos conceptos en muchas ocasiones no se materializan de manera absoluta o "pura", y a veces no se dan en toda la obra, ni siquiera en escenas completas. El motivo por el que hemos escogido el campo de la figuración es porque a través de él se pueden comprender los 
conceptos de movimiento vivenciado y neutro al establecer fácilmente conexiones con nuestra experiencia sensorial dinámica.

Dado que en todos los contextos hay animaciones de diferentes grados de expresividad, las animaciones estudiadas proceden tanto del ámbito independiente como del comercial, de la industria del entretenimiento, del campo artístico, científico y educativo; todas ellas son interesantes para este estudio. Aunque el movimiento vivenciado es más abundante en la animación artística, también se da en el contexto industrial; y el movimiento neutro, aunque propio de la animación del ámbito científico y educativo, puede encontrarse en el terreno artístico. Abarcar todos estos ámbitos y técnicas es una necesidad de la investigación, ya que limitándonos a un sólo contexto o técnica podríamos extraer conclusiones erróneas respecto a las formas en que se presentan el movimiento vivenciado y el neutro, y respecto a cómo se realizan. Por ejemplo, si analizáramos sólo el campo artístico no podríamos observar el movimiento neutro más que en su faceta retórica o como falta de intensidad expresiva, con lo que perderíamos de vista su papel altamente eficaz en la transmisión directa de información. O si analizáramos sólo las animaciones hechas con una técnica concreta, no podríamos conocer en qué medida la técnica influye en la expresividad de la representación del movimiento.

La investigación se centra exclusivamente en la parte visual de la animación. El audio no forma parte de este estudio, aunque se hará alguna referencia a éste de manera muy aislada.

Ciertamente la identificación del movimiento como vivenciado o como neutro se basa principalmente en las sensaciones que éstos despiertan en el espectador, pero no nos adentraremos en los mecanismos perceptivos que actúan durante la observación de la obra y que son responsables de que se vivan experiencias sensoriales; nos centraremos en el concepto en sí y no en los mecanismos físicos perceptivos que generan tal sensación en el cuerpo. Así mismo, tampoco hemos abordado cuestiones psicológicas relacionadas con la creatividad. Ambos son temas de gran envergadura y fuera de nuestro campo de conocimiento.

Finalmente queremos aclarar que el campo de estudio de esta investigación no incluye el concepto de "movimiento vivencial" del que se habla en danza, porque, a pesar de su nombre, se separa del tema del presente trabajo al referirse al movimiento como acto vital del ser humano y a la armonía de éste con su propio cuerpo. 


\section{Hipótesis}

La representación del movimiento en animación se presenta en infinidad de niveles de intensidad expresiva, desde el más neutro hasta el más vivenciado (aquel que evoca la sensación de movimiento como si se viviera en primera persona). Centrándonos en estos niveles extremos, creemos que aunque tienen diferencias muy notorias (lo cual los hace apropiados para diversos ámbitos según el objetivo de la obra), ambos utilizan los mismos recursos cinematográficos y de representación del movimiento, incluidos diversos grados de naturalismo, pero dirigidos a obtener diferentes efectos visuales $y$, por supuesto, a provocar diferente impacto en el espectador.

\section{Objetivos}

\section{Objetivos generales}

- Detectar y estudiar las características que definen el movimiento vivenciado y el neutro en la plástica, profundizando en la animación.

- Analizar la influencia de los medios técnicos, plásticos y cinematográficos sobre la representación del movimiento vivenciado y neutro por medio del estudio detallado de los componentes dinámicos de la animación.

- Averiguar si la expresión del movimiento como vivenciado o como neutro determina el grado de naturalismo de la representación.

\section{Objetivos específicos}

- Definir qué es el movimiento vivenciado y el movimiento neutro.

- Definir qué es la expresión del movimiento vivenciado y el movimiento neutro en el arte plástico.

- Detectar y analizar las características del movimiento vivenciado y el neutro en animación.

- Averiguar a través de qué elementos de la animación se manifiesta la expresividad del movimiento.

- Detectar los componentes dinámicos que forman la animación.

- Estudiar pormenorizadamente la expresividad del movimiento a través de cada componente dinámico: cambio de imagen (transcurso de los fotogramas), valoración espacio-temporal (timing), composición móvil, distribución de la intensidad cinética y relato.

- Averiguar cómo influyen los componentes dinámicos en la expresión del movimiento como vivenciado y como neutro.

- Estudiar las diferentes maneras en que se interpreta la mecánica en animación y su influencia en la expresividad. 
- Investigar por medio de la creación de animaciones la representación del movimiento por orden no cronológico de la acción y averiguar si el movimiento vivenciado se puede expresar de esta manera.

- Analizar la repercusión que la dinámica visual en los fotogramas tiene sobre la expresividad del movimiento.

- Estudiar en qué grado la técnica de animación influye en la expresividad de la representación móvil.

- Examinar qué se considera representar el movimiento de manera naturalista en animación.

- Estudiar si hay características comunes entre movimiento vivenciado y representación no-naturalista, y entre movimiento neutro y naturalismo.

- Localizar y analizar casos de animaciones naturalistas en las que el movimiento se expresa como vivenciado, y animaciones que se alejan de la realidad visual en las que el movimiento es neutro.

- Estudiar la concordancia entre el nivel de naturalismo del móvil y la expresividad del movimiento.

- Considerar si los hechos fantásticos pueden ser expresados como vivenciados, a pesar de no poder ser ni vividos ni observados.

- Expresar el movimiento como vivenciado en obras de animación propias.

\section{ESTADO DE LA CUESTIÓN}

La literatura sobre animación es amplia; existen muchos estudios académicos y otras publicaciones sobre animación. Hay revistas de investigación dedicadas exclusivamente a este campo y también cada vez más tesis doctorales que tratan este medio de expresión desde diferentes perspectivas y sobre temáticas muy específicas: como disciplina artística, como fenómeno antropológico, centradas en avances tecnológicos, en la obra de autores o contextos determinados, etc. Sin embargo, ninguno de estos estudios trata la expresividad de la representación tal y como la planteamos, y las referencias más cercanas al tema normalmente son aisladas o indirectamente relacionadas, aunque algunas de estas referencias han sido muy valiosas:

- Los estudios y libros sobre animación más valiosos para la investigación son aquellos que recogen metodologías de creación, especialmente Disney Animation. The Illusion of life (Animación Disney. La ilusión de vida) (1981) en el que los animadores Thomas y Johnson explican pormenorizadamente el método de trabajo de los estudios Disney. Los autores (dos de los conocidos como the Nine Old Men que dieron forma a este estilo de animación tal y como lo conocemos hoy) hablan 
detalladamente de la búsqueda que siguieron hasta que hallaron un método de representación móvil que cumplía sus objetivos, así como de su experiencia en la realización y su opinión personal sobre el proceso y los resultados. Aunque trata de un estilo muy específico, ésta es una fuente prolífica en referencias al tema objeto de estudio, sobre todo acerca de la representación del movimiento y en concreto sobre el timing, el uso de la acción real en animación y los concepto de realismo y exageración, temas que los autores relacionan a veces directamente con la expresividad.

- En los manuales o libros "How to..." de animación, uno de los formatos más habituales, dirigidos a artistas de mayor o menor experiencia, se perpetúa la metodología explicada en Disney Animation. The Illusion of life, pero bajo la perspectiva de otros animadores. Algunos son muy generales: The Alchemy of Animation. Macking an Animated Film in the Modern Age (La alquimia de la animación. Hacer una película de animación en la Era Moderna) (Hahn, 2008), o La magia del dibujo animado: Actores del lápiz) (García, 2000); y otros están especializados en partes específicas del proceso de creación: Timing for animation (Timing para animación) (Halas, y otros, 1981), Animation Writing and Development. From Script Development to Pitch (Escritura y desarrollo de animación. Del desarrollo del guión al pitch) (Wright, 2005). En ellos encontramos referencias interesantes para estudiar cada componente dinámico de la animación.

- Las monografías sobre técnicas normalmente son muy expositivas, pero también recogen comentarios más personales desde la perspectiva del autor que, según el libro, están más o menos relacionadas con la expresividad de los resultados.

- Hay numeroso libros que recogen metodologías personales de creación de diversos animadores; también de antigüedad diversa, desde la obra de Robert Russet y Cecile Starr Experimental Animation Origins of a New Art (Animación experimental. Orígenes de un nuevo arte) (1976) hasta Drawing for Animation (Dibujo para animación) (2009), escrito por Paul Wells y artistas del campo. Pero no profundizan en el proceso de ningún autor, por lo que las referencias al tema que estudiamos son muy escasas y cuando las hay no aportan información nueva. En las monografías sobre autores sí se estudia detalladamente la metodología y experiencia de artistas específicos, como Jose Manuel Xavier que habla de su concepto de animación y de su propio trabajo en Poetica do Movimento (Poética del movimiento), en el que declara su interés en transmitir el recuerdo de la sensación dinámica aludiendo principalmente a la poesía (2007). El interés de estas publicaciones para la presente tesis depende del caso concreto; destacamos Norman MacLaren. Obra completa 1932-1985 (Bakedano, 1987) y George Schwizgebel. Animated Paintings (George Schwizgebel. Pinturas animadas) (Cotte, 2004) 
donde encontramos reflexiones sobre cuestiones relativas a composición, timing, la frecuencia de imágenes por segundo, etc.

- Así mismo, de las diversas publicaciones de Paul Wells, es Understanding Animation (Entender la animación) (1998) donde se concentran las reflexiones más interesantes para el estudio, sobre todo las referidas al realismo en animación, tema sobre el que también hay información dispersa y repetitiva en las publicaciones mencionadas.

- También encontramos pasajes sobre la representación del movimiento en animación en Esthétique du cinéma d'animation (Estética del cine de animación) (2012), de George Sifianos, consistente en una extensa investigación años atrás comenzada, en la que trata desde las cuestiones más fundamentales de la naturaleza y percepción del movimiento en animación, hasta el concepto de realismo, y realiza una clasificación de técnicas de animación según los materiales. A lo largo de estos temas realiza algunas referencias sobre la expresividad del movimiento.

Los estudios sobre cine también presentan comentarios referentes al tema de la presente investigación, aunque en el terreno del cine, pero que en muchos casos son adaptables a la animación y por tanto aplicables a esta investigación (Deleze, Feldman, Arias, etc.). En el estudio fundamental de Arnheim Kino als Kunst (El cine como arte) (1957), encontramos reflexiones (que se mantienen vivas a pesar de su antigüedad) acerca la representación del movimiento y el espaciotiempo en el cine y de su efecto sobre el espectador.

Para elaborar los conceptos de "movimiento vivenciado" y "movimiento neutro" que aplicamos a la plástica en general pero más detalladamente a la animación, hemos partido principalmente de la observación de películas de animación; y para el trasfondo teórico que nos ayuda a su definición y así comprender el fenómeno expresivo que analizamos, hemos recurrido a estudios de filosofía, arte y estética en los que el tema se trata directa o indirectamente:

- Para la definición teórica de los conceptos que presentamos es crucial la obra de Otto Friedrich Bollnow Mench und Raum (Hombre y espacio) (1969). A partir de las reflexiones filosóficas sobre el hombre y el espacio, Bollnow desarrolla dos conceptos concretos, "espacio vivencial" (erlebter Raum) y "espacio matemático", que hablan de la experiencia y el conocimiento del hombre sobre el espacio que le rodea; el "espacio vivencial" corresponde al espacio determinado directamente por la experiencia física y emocional, por las posibilidades de movimiento y la vivencia; pero con ello no se refiere a la percepción subjetiva de cada individuo (es decir, al "espacio vivenciado"), sino a una concepción de espacio que trasciende a toda la experiencia humana. Mientras que el espacio matemático se corresponde a la interpretación del espacio a través de sistemas objetivos (geometría, mate- 
mática, cartografía, etc.). Bollnow con frecuencia explica el espacio vivencial a través del movimiento, la experiencia dinámica y otras sensaciones tanto físicas como emocionales. El autor desarrolló su teoría sobre el espacio en un contexto en el que el interés sobre el tiempo subjetivo y el tiempo "vivenciado" dieron lugar a plantearse el papel igualmente relevante del espacio en la vida del hombre.

- Otros autores que contribuyeron, a través de sus teorías sobre el tiempo y el espacio, a la configuración del concepto de espacio subjetivo que Bollnow llamó vivencial son Heidegger (El ser y el tiempo) (1962), Graf Dürckheim (Untersunchungen zum gelebten Raum) (Investigaciones sobre el espacio vivido) (1932), Minkowsky (Le temps vécu) (El tiempo vivido) (1933), Gastón Bachellard y Henri Bergson. En Poética del espacio (1958), Bachellard, a través de la fenomenología sobre los espacios que el hombre habita física e íntimamente, reflexiona sobre la transmisión de estas sensaciones en la creación literaria, ideas que a veces pueden extrapolarse a toda creación artística.

-En Ut pictura poesis. La teoría humanística de la pintura (1940), Rensselaer W. Lee habla del concepto de expresión según la teoría humanística del arte de la Edad Moderna (capítulo 3. La expresión). La expresión de una imagen residía en la transmisión del movimiento de sus figuras; a través de su "movimiento expresivo" se transmitían las emociones humanas cuya visión conmovía al espectador. Para producir obras de estas características era imprescindible que el artista sintiera en sí mismo las emociones y movimientos que pretendía representar. Esta idea que ha trascendido a lo largo del tiempo también tiene su modesto reflejo en el trabajo que hemos realizado.

- Destacamos la obras de Arnheim y Gombrich quienes hacen referencia a la vivencia del movimiento, destacamos el capítulo "La imagen cinestésica del cuerpo" (en Arte y percepción visual, de Arnheim) (1979) y la obra "El arte y el ojo" (Gombrich, 1982), estudios en los que ambos autores hablan de la influencia de la experiencia dinámica personal en la expresión artística. Arnheim además diferencia entre el movimiento descrito a través de medios métricos y el movimiento que se vive y experimenta, y la influencia que tienen las sensaciones cenestésicas experimentadas sobre la dinámica visual en la danza.

- La tesis El movimiento real, virtual y óptico. La revelación de su continuidad en las artes plásticas (1985) de Carmen Lloret. Basándose en Bergson, la autora hace hincapié en la intuición del continuo tránsito del devenir en oposición a su fragmentación en instantes, fundamento de este discurso sobre la expresión plástica del movimiento. Por otra parte señala que el concepto de espacio de Bollnow (vivencial) se puede asociar a las representaciones menos realistas del espacio en el arte, es decir, aquellas en las que se priorizan los valores plásticos frente a los miméticos. Esta investigación dedica parte del estudio a la animación. 
También conforman el contexto teórico estudios fundamentales sobre arte, estética, percepción y cultura visual que sirven para conocer conceptos necesarios para profundizar en el estudio de la animación y que han sido muy valiosos en nuestro propósito de tratar correctamente los términos. Nuevamente destacamos los estudios de Arnheim Arte y percepción visual. La psicología del ojo creador (1979) y el de Gombrich La imagen y el ojo: Nuevos estudios sobre la psicología de la representación pictórica (1982), en los que también encontramos varios capítulos que versan sobre la representación del movimiento en el arte. A pesar de su antigüedad muchos de los conceptos que tratan siguen siendo vigentes hoy en día y aunque en estos estudios teóricos no hay referencias a la animación, están vinculados con cuestiones que tratamos a lo largo del estudio.

\section{PERTINENCIA DE LA INVESTIGACIÓN}

La investigación se ha llevado a cabo desde el estudio teórico y la experiencia personal en la creación de animación; se trata del punto de vista de un artista. Por ello creemos que los resultados pueden tener interés tanto para el estudio teórico como para la práctica artística.

Como vemos, hay un vacío en el estudio de la animación desde la perspectiva que proponemos. El estudio de la expresividad y las sensaciones que el movimiento provoca en el espectador es ausente o se reduce a pasajes o comentarios aislados en la literatura sobre el tema. Así pues, la presente investigación, por ser un estudio específico sobre la expresividad del movimiento en animación, es una aportación al conocimiento sobre esta cuestión.

En el campo teórico se aporta nombre y definición de los fenómenos estudiados: "movimiento vivenciado" y "movimiento neutro", dos modos de expresar el movimiento en la plástica y en animación. También se contribuye al conocimiento del campo con la revisión de la dicotomía entre naturalismo y no-naturalismo estudiando su relación con la expresividad del movimiento; y con el estudio pormenorizado de la animación a través de los componentes dinámicos (también una manera original de analizar la animación) y cómo estos se emplean para expresar el movimiento.

Además, consideramos una aportación, no exclusiva de este trabajo pero que no abunda en la literatura sobre animación, la perspectiva conciliadora e integradora de dos diferentes tipos de animación: la artística y la industrial. La investiga- 
ción se ha llevado a cabo enfocando el problema hacia la expresividad de las películas y no hacia el contexto de creación, respetando los diferentes objetivos de las obras.

Así mismo creemos que esta tesis puede resultar útil a los animadores, tanto a los principiantes como a los más experimentados, por el análisis teórico de la expresividad del movimiento y su relación con el nivel de naturalismo, así como por el minucioso análisis de los componentes dinámicos que contiene, que ofrece una visión técnica pero a la vez totalmente orientada a la creación. En los capítulos 2 y 3 se plantean muchas posibilidades de intervención sobre los componentes espacio-temporales, y a lo largo de todo el trabajo se ofrece gran cantidad de ejemplos que muestran diversas maneras de representar el movimiento con expresividad notoria o neutra.

\section{METODOLOGÍA}

Ésta es una investigación cualitativa que se ha desarrollado mediante el estudio bibliográfico, el análisis de películas y la práctica artística; tres vías que se han recorrido al mismo tiempo, en una dirección común.

Estudio de bibliografía: Se comenzó con la revisión de la literatura más próxima al tema, para conocer los antecedentes de la cuestión y recabar información útil que nos ayudara a conformar y apoyar el discurso teórico. A lo largo de todas las fases del trabajo se ha continuado el estudio de bibliografía para conocer conceptos relacionados que se han revelado como necesarios conforme avanzaba la investigación. Se trata de literatura de diversa antigüedad, dependiendo de la necesidad de consultar fuentes primarias o, por el contrario, de conocer la actualidad de conceptos u opiniones.

Estudio de obras: El visionado de películas es parte fundamental del estudio. Se han visionado gran cantidad de animaciones a lo largo de los años que ha durado esta investigación. Se ha tenido acceso a ellas de diversas maneras: a través de colecciones institucionales o privadas (grupo de investigación Expresión plástica del movimiento: animación y luminocinetismo de la UPV, departamento de Film en la KHM, y la Abadía Real de Fontevraud), durante la asistencia a diversos festivales (Festival internacional de cine de animación de Annecy, Monstra-Festival de animación de Lisboa y Cinanima-Festival internacional de cine de animación, en- 
tre otros) e Internet, que en los últimos años se ha convertido en una gran fuente de obras de animación.

Los análisis son de carácter cualitativo, no cuantitativo. Se han realizado con el fin de estudiar activamente las películas y así conocer y recopilar información detallada sobre características cinematográficas y plásticas. Pero no se trata de un estudio estadístico a partir del cual hayamos extraído certezas numéricas. Se ha seguido un método inductivo, de lo particular a lo general; a partir del estudio de películas hemos hallado las cualidades de lo que hemos denominado movimiento vivenciado y movimiento neutro. Así mismo, las observaciones realizadas en la memoria, como aquellas respecto a la frecuencia o influencia de elementos y recursos concretos en la expresión del movimiento vivenciado, se basan en los análisis de animaciones.

Los análisis se amoldan a las necesidades del estudio, por lo que se han ido modificando conforme averiguábamos más sobre el tema. Las conclusiones se han alcanzado en unos casos por acumulación de respuestas, y en otros casos hemos realizado hallazgos importantes sin tener el propósito de ello, hallazgos que han hecho variar el análisis que aplicábamos hasta el momento. Por ejemplo, al principio en las matrices de análisis se determinaban muy específicamente numerosas características cinematográficas y plásticas que creíamos que identificaban el movimiento vivenciado o el neutro (generalmente opuestas entre ellas), de modo que la expresividad de la obra dependía de si reunía unas características formales o cuestiones de representación tales como variedad de trayectorias, técnica empleada, sensación de movimiento en los fotogramas, riqueza visual, cambios de velocidad, independencia del lenguaje de la animación comercial, etc. Pero conforme se analizaban más películas, los conceptos de movimiento vivenciado y neutro fueron haciéndose más consistentes, y la división inicial desapareció, ya que vimos que las características que creíamos rotundamente separadas se daban tanto en uno como en otro modo de expresión, lo que ayudó a comprender que las diferencias entre ambos no son puramente formales, sino que se hayan principalmente en las sensaciones que inspiran. Así que procedimos a observar qué características cinematográficas y técnicas reunían las películas con un tipo u otro de expresividad. En el Anexo I figuran varios análisis en su estado final.

En verdad esta teoría tiene como elemento fundamental al espectador. A pesar de no haber contrastado de manera estadística las impresiones que las películas provocan en los espectadores, podemos afirmar (sin cometer una barbaridad desde el punto de vista de la investigación científica) que hay animaciones más expresivas que otras, o incluso que evocan sensaciones cinestésicas. Ciertamente 
las sensaciones que provoca una obra no son universales, dependen del espectador, de las circunstancias físicas y emocionales en las que se observa la película, etc. Por eso los ejemplos son clarificadores; y aunque puede que no todo el mundo esté de acuerdo con su pertinencia, esto no significa que el concepto que representan no sea acertado.

Animaciones propias: La creación personal ha sido un valioso terreno desde el cual observar y conocer los fenómenos estudiados. La experiencia en la realización de animación ha proporcionado un conocimiento previo de los vericuetos técnicos y plásticos desde el cual interrogarnos sobre los recursos para hacer más o menos expresiva una animación. Los conocimientos adquiridos en la práctica han trascendiendo al estudio teórico, lo que ha supuesto un gran enriquecimiento para la investigación.

Las película se hayan en diferentes estado de realización: cinco están terminadas (dos de ellas sin sonido) y cuatro en proceso (hasta la animática). Estas animaciones sirven de ejemplo a lo largo de la memoria, se explican más detalladamente en el Anexo 1 y se incluyen en el DVD del Anexo 2.

Las motivaciones para realizar cada obra han sido principalmente íntimas, pero en lo que atañe a la representación dinámica, debido al interés personal por expresar con gran intensidad el movimiento, éste se ha tratado de representar como vivenciado en todas las películas. También hemos llevado a cabo una experimentación a través de un método más científico, a partir de una idea que surgió a lo largo de la investigación: la representación del movimiento alterando el orden de su evolución (por fases no cronológicas). Los resultados de esta experimentación se exponen en el capítulo 3 y se incluyen en el DVD el Anexo 2.

Como todo proceso de aprendizaje, tanto las virtudes de estas obras como el reconocimiento de nuestros errores nos han aportado un conocimiento valioso: nos han permitido comprender aspectos que no podíamos resolver (o ni siquiera habíamos tenido en cuenta) sólo por medio de la teoría.

Redacción de la memoria: La redacción de la memoria ha servido para dar forma a las ideas. A medida que se avanzaba en las reflexiones escritas, éstas mismas marcaban la necesidad de ampliar el estudio bibliográfico, seguir profundizando en cuestiones que se revelaban como interesantes para el estudio o investigar nuevas vías que no se había planteado inicialmente. Así pues, la memoria 
se ha redactado alternativamente al estudio bibliográfica y al análisis de películas, y no de manera estrictamente lineal.

Del mismo modo, las conclusiones han sido extraídas conforme se realizaba el estudio, no necesariamente al final.

\section{ESTRUCTURA DE LA TESIS}

El trabajo se divide en cuatro capítulos:

Primer capítulo: Definición de movimiento vivenciado y movimiento neutro. Sus cualidades en la plástica y en la animación, en el que se presentan los términos "movimiento vivenciado" y "movimiento neutro" y se explica la manera en que se muestran en el arte y en la animación.

Encontramos manifestaciones plásticas del movimiento con diferentes grados de expresividad, desde aquellas que trasmiten el movimiento con gran intensidad hasta las que lo representan de la manera más neutra imaginable. En el apartado 1.1 definimos los conceptos de "movimiento vivenciado" y "movimiento neutro", con los que damos nombre a estos dos extremos de expresividad del movimiento. Se explica el origen de los términos a partir, fundamentalmente, de los conceptos de "espacio vivencial" y "espacio matemático" desarrollados por Bollnow.

A continuación, en 1.2., se explica el concepto de movimiento vivenciado aplicado al arte (1.2.1.) y describimos las cualidades que presenta en animación (1.2.2.). El tercer apartado, 1.3., está dedicado al movimiento neutro. En 1.3.1. se expone qué es representar el movimiento de manera neutra en el arte. Y en 1.3.2. describimos las características que definen este tipo de expresión en animación; se trata (como en su homónimo 1.2.2.) de cualidades visuales fundamentadas en las sensaciones que transmite el movimiento y no tanto en características cinematográficas o técnicas.

En este capítulo veremos que las cualidades distintivas de ambos tipos de expresión no se dan siempre juntas y, así mimo, conviven en la misma película con características de expresividad opuesta. La calificación de una animación como vivenciada o neutra depende del protagonismo de unas características u otras. 
Segundo capítulo: Representación del movimiento vivenciado y el movimiento neutro en animación. Componentes dinámicos, en el que se analizan el movimiento vivenciado y el neutro desde una perspectiva cinematográfica y técnica.

El capítulo comienza con un resumen de aspectos técnicos fundamentales de la animación: los tipos de movimiento que participan en la animación (2.1.1.) y el debate sobre la relevancia de los fotogramas como imágenes individuales (2.1.2.). Después de esto, en 2.1.3. diferenciamos entre el papel de la técnica plástica y la técnica de animación, y entre componentes plásticos y dinámicos de este medio de expresión; desglosamos la animación en cinco componentes dinámicos: cambio de imagen, valoración espacio-temporal, composición móvil, distribución de la intensidad cinética y presentación de la historia (el relato). Y concluimos el apartado planteando que la metodología que lleva al artista a representar el movimiento de manera más o menos expresiva o neutra se fundamenta en el objetivo que él mismo se establece, y apuntamos la estrategia fundamental: basarse en las sensaciones que proporciona la experiencia física (en nuestro propio cuerpo) y visual, o aislar la representación de cualquier propósito que no sea puramente expositivo. Con estos tres apartados ubicamos el fenómeno de la expresividad del movimiento en los componentes dinámicos, y sirven como introducción a la segunda parte del capítulo y al capítulo 3 (en los que se desarrollan los componentes dinámicos).

En la segunda parte del capítulo, en 2.2., se procede al análisis pormenorizado de cómo el movimiento vivenciado y el neutro se representan en animación a través de diferentes tratamientos de los componentes espacio-temporales. Cada uno de los parágrafos siguientes (2.2.1. - 2.2.5.) está dedicado a un componente dinámico y sigue la misma estructura: Primero se explica qué es, a continuación estudiamos en qué medida diversos recursos cinematográficos y técnicos que atañen a cada componente influyen en la expresión móvil y para finalizar se incluyen unas conclusiones acerca de cada recurso presentado. Veremos que prácticamente todos los recursos sirven tanto para representar el movimiento vivenciado como el neutro.

Debido a la problemática particular de la valoración espacio-temporal, dedicamos el capítulo 3 exclusivamente a este componente. En el presente capítulo se incluye un planteamiento inicial de las cuestiones tratadas en el capítulo 3. 
Tercer capítulo: Representación del movimiento vivenciado y neutro a través de la valoración espacio-temporal, en el que se analizan diversos aspectos de este componente dinámico en relación a la expresividad de la representación móvil.

La valoración espacio-temporal (la representación detallada del movimiento a través de los fotogramas) es uno de los componentes dinámicos en los que hemos desglosado la animación. Todos los componentes son comunes al cine de acción real, pero en este medio la valoración espacio-temporal procede de la captura cinematográfica de movimiento real, mientras que en animación se requiere la factura manual (en casi todas las técnicas), o en todo caso la creación plástica, de los fotogramas. Debido a esta condición particular de la animación que afecta directamente a la representación del movimiento, dedicamos este capítulo al análisis de diferentes cuestiones que le conciernen: el conocimiento de la mecánica (3.2.1.); la alteración del espacio y el tiempo (3.2.2.); la yuxtaposición de fases no sucesivas de la acción (3.2.3.), apartado en el que incluimos una experimentación plástica de este tipo de valoración espacio-temporal; la sensación de movimiento en las imágenes que componen la película (3.2.4.); y la influencia de los medios mecánicos y semi-mecánicos para realizar la valoración espacio-temporal (3.2.5.).

A través de estos apartados probamos que la expresividad del movimiento se da en todas las técnicas y a través de diversidad de alteraciones de la mecánica, aunque ciertas técnicas y algunas representaciones de la mecánica tienen características que las aproximan al movimiento neutro.

Cuarto capítulo: Naturalismo y expresividad del movimiento en animación, en el que se observa la relación entre ambas características de la representación dinámica.

En 4.1., a modo de introducción, se plantea la naturaleza interpretativa de toda representación y qué se considera naturalismo en animación. A continuación, en 4.2. se analizan los puntos de encuentro entre expresión vivenciada y el movimiento animado que se separa de la realidad (4.2.1.), observando cuestiones como la frecuente desvinculación de la mecánica y la inserción de los acontecimientos en un espacio vivencial, y se muestran casos de animaciones de movimiento naturalista y vivenciado que demuestran que la expresividad no es consecuencia de la desvinculación de la realidad (4.2.2.). En 4.3.1. se observa la relación entre movimiento neutro y representación realista; y en 4.3.2. presentamos ejemplos de animaciones desvinculadas de la realidad dinámica y que tienen movimiento neutro que demuestran que, pese a la existencia de unos puntos comunes entre 
naturalismo y movimiento neutro, estos no indican que el movimiento neutro proceda de la representación naturalista del movimiento.

Para concluir el capítulo, en 4.4. se tratan dos cuestiones más acerca del tema del naturalismo: los efectos que tienen sobre la expresividad del movimiento el diseño del móvil y el tipo de acciones representadas (fantásticas o realistas).

Conclusiones: Al final de cada capítulo se extraen las conclusiones referentes a los temas tratados. $Y$ finalmente se exponen las conclusiones de todo el estudio, entre las que destacan: que curiosamente las cualidades cinematográficas (trayectoria del móvil en la pantalla, cantidad de elementos, duración de los planos, etc.) se dan prácticamente por igual en las animaciones de movimiento vivenciado y las de neutro; que la diferencia mayor radica en lo que se trasmite con ello; que ninguna técnica impide la representación del movimiento con grandes dosis de expresividad (debido a la gran cantidad de elementos maleables de la animación); y que el nivel de naturalismo de la representación dinámica no determina el grado de expresividad.

\section{Relación de anexos:}

Anexo 1: Descripción de las animaciones de realización propia. Premios, selecciones y proyecciones de estas películas.

Anexo 2: DVD con las animaciones de realización propia.

Anexo 3: DVD con algunas de las animaciones que ejemplifican el discurso.

Anexo 4: Muestra de análisis con los que se han estudiado las películas

\section{ACLARACIONES}

\section{Figuras}

Las imágenes que se incluyen en esta memoria ilustran ejemplos a los que se hace referencia en el texto. Las figuras son de varios tipos:

- Fotogramas consecutivos

- Series de fotogramas no consecutivos pero que muestran la evolución visual de una escena, plano o acción.

- Fotogramas representativos de la película, no consecutivos ni resumen del movimiento. 
Las series de fotogramas se han puesto en unos casos para examinar la evolución de la imagen a grandes rasgos o detalladamente; en otros casos, para activar el recuerdo de su movimiento en aquellos lectores que ya las conocen y dar imagen previa de éstas a aquellos que no las han visto nunca, y que, de este modo, las obras de animación tengan presencia visual a lo largo de la explicación escrita.

Con estas imágenes estáticas extraídas de películas en ningún momento pretendemos sustituir a las animaciones originales, y aunque el discurso se puede seguir sin necesidad de ver las animaciones, invitamos a ver los fragmentos de las películas a los que hacemos referencia.

\section{Ejemplos}

Varias de las animaciones que ejemplifican el discurso se incluyen en el DVD del Anexo 3. La mayor parte del resto de obras están disponibles en internet o son más o menos populares. En la filmografía consta la dirección URL de gran parte de las obras a las que nos referimos. La hora, el minuto y el segundo (hh:mm:ss), para poder localizar fácilmente el fragmento descrito, consta en el cuerpo del texto.

\section{DVD de Anexo 2}

Este DVD contienen las animaciones de creación propia que se han realizado desde el inicio de la investigación en 2008 hasta 2014. No todas las obras se encuentran en el mismo estadio de creación.

Éste es un DVD de datos reproducible en cualquier lector de DVD de ordenador, pero no todos los reproductores caseros pueden leerlo, por lo que recomendamos verlo en un ordenador.

\section{DVD de Anexo 3}

Este DVD contiene 16 de las animaciones de las que se habla en la memoria. A lo largo del texto, se indica si la obra de la que se habla está contenida en este DVD con la indicación [en DVD] la primera vez que se menciona.

Estas películas están completas en la mayoría de los casos. Normalmente nos referimos a momentos muy concretos de las películas; la hora, el minuto y el segundo de inicio de la acción o plano que nos interesa consta en el texto, junto a la 
descripción pertinente. Esta indicación se compone de seis números que señalan la hora, el minuto y el segundo precisos (hh:mm:ss).

Se trata de un DVD de datos para reproducir en un ordenador (no todos los reproductores caseros de DVD pueden leerlo), por lo que recomendamos verlo en un ordenador.

\section{Siglas y abreviaturas}

A lo largo del texto aparecen escasas siglas y abreviaturas. Su significado se especifica la primera vez que aparecen en el capítulo y la primera vez que aparecen en el apartado. Pero las incluimos aquí, por si acaso el lector se las encuentra al ojear el texto:

ips: imágenes por segundo

fips: frecuencia de imágenes por segundo

fps: fotogramas por segundo

ffps: frecuencia de fotogramas por segundo

CGA o CG: computer generated animation (animación generada por ordenador) 
1. DEFINICIÓN DE MOVIMIENTO VIVENCIADO Y MOVIMIENTO NEUTRO. SUS CUALIDADES EN LA PLÁSTICA Y EN ANIMACIÓN 

De los muchos elementos que configuran el total de una animación, desde los relacionados con la materialidad del medio hasta los referidos a su significado, en esta investigación nos centraremos en el estudio de la animación como medio para la expresión plástica del movimiento. Al representar el movimiento en animación, medio en el que se genera la ilusión de movimiento, éste adquiere la peculiaridad de ser expresado mediante el transcurso de la obra, lo que hace que surjan representaciones móviles particularmente expresivas. Pero a pesar de que el espectador percibe movimiento en toda película de animación (el movimiento que se muestra en la pantalla), no todas excitan en él sensaciones cinéticas con la misma intensidad. Para definir los dos extremos de intensidad con los que se transmite movimiento, proponemos los conceptos de "movimiento vivenciado" y "movimiento neutro".

En este capítulo se desarrolla la definición de "movimiento vivenciado" y "movimiento neutro". "Movimiento vivenciado" es el término con el que nos referimos a la representación que suscita sensaciones cinéticas en el espectador, haciéndole imaginar lo que se sentiría al experimentar el movimiento representado; a diferencia del "movimiento neutro", que lo presenta de manera fría, sin la misma cualidad sensorial. Pero antes de adentrarnos en su descripción plástica, definiremos estos conceptos en 1.1. Para ello partiremos principalmente de la noción de espacio vivencial y espacio matemático de Bollnow. A continuación expondremos cómo se expresan en animación el movimiento vivenciado y el neutro; con este fin analizaremos las características visuales que presentan ambos tipos de representación móvil (1.2. y 1.3.). 
Movimiento vivenciado y movimiento neutro. Estudio sobre la expresividad de la representación del movimiento en animación 


\subsection{CONCEPTOS DE MOVIMIENTO VIVENCIADO Y MOVI- MIENTO NEUTRO}

En este parágrafo se presentan los conceptos de "movimiento vivenciado" y "movimiento neutro", con los cuales pretendemos dar nombre y estudiar dos tipos de expresión del movimiento que encontramos en la plástica y en la animación. Para definirlos, partimos de los conceptos de espacio vivencial y espacio matemático de Bollnow, así como del movimiento matemático (el estudiado por la ciencia), ya que estos nos dan claves para entender la representación del movimiento. Queremos recalcar que no consideramos que estos conceptos sean la base para representar el movimiento de una u otra manera, ya que cada autor tiene sus propios principios e ideas creativas y tan sólo observando las películas no podemos juzgar los principios filosóficos de los artistas (si es que los usaron para la creación de sus obras) sino que recurrimos a ellos tras observar el fenómeno plástico, buscando comprenderlo mejor.

\subsubsection{DEFINICIÓN DE MOVIMIENTO VIVENCIADO}

Este apartado trata del espacio vivencial de Otto Friedrich Bollnow y de cómo a partir de éste y de la noción de espacio de otros autores, más pasajes literarios en los que se transmite sensaciones dinámicas, desarrollamos la idea de "movimiento vivenciado". Bollnow desarrolla su teoría sobre el espacio en un contexto en el que otros pensadores, como Gaston Bachelard y Graf Dürckheim, también estudian la noción del espacio. En su conocida obra Hombre y espacio (1969), Bollnow explora el concepto de "espacio vivencial" (erlebter Raum), que es el espacio de la vivencia humana, un espacio que se transforma según el ser humano que lo habita, y que tiene cualidades emocionales, pero que va más allá de las experiencias del individuo (por eso Bollnow escogió el término "vivencial" y no "vivenciado") ${ }^{1}$. Aunque las cualidades subjetivas de este espacio están en armonía con la percepción subjetiva del tiempo, el "tiempo vivencial" (aquel en el que transcurre la vida humana) no corresponde exactamente al espacio vivencial. Pero no sólo eso, el

\footnotetext{
${ }^{1}$ Bollnow, 1969, pág. 25
} 
movimiento vivencial se extiende al concepto de espacio en toda la vida del hombre, más allá de la percepción subjetiva del espacio (motivo por el cual Bollnow desecha el término "vivenciado") ${ }^{2}$. A continuación veremos qué puntos de unión existen entre esta filosofía del espacio y el movimiento vivenciado. A diferencia de Bollnow, en este trabajo hablamos de movimiento "vivenciado" y no "vivencial" porque nos referimos a sensaciones que se perciben cuando el movimiento es ejecutado u observado y no al movimiento que define la existencia humana en general.

El autor contrapone esta manera de entender el espacio al espacio matemático: "el espacio susceptible, de ser medido, en sus tres dimensiones, en metros y centímetros", es decir, un espacio tridimensional construido a partir de los ejes de altura, anchura y profundidad, sobre los que se sitúan unos puntos definidos por coordenadas. ${ }^{3}$ El espacio vivencial supone una manera de entender el espacio al margen de las matemáticas. Éste queda determinado fundamentalmente por el hombre y su movimiento:

Como ser creador y desplegador de espacio, el hombre necesariamente no es sólo el origen sino también el centro permanente del espacio. Pero no debe simplificase esto concibiéndolo como si el hombre llevara consigo su espacio, como el caracol su casa, sino que tiene perfectamente sentido cuando se dice, sin reflexionar detenidamente, que el hombre se mueve "en» su espacio. ${ }^{4}$

La manera de percibir el espacio está relacionada con cómo nos movemos en él. Bollnow establece el centro del espacio a partir de la percepción de cada sujeto, que, a su vez, se construye según la noción de arriba - abajo, izquierda - derecha, y delante - detrás. "Se podría tomar el punto cero de este espacio presente de percepción (esencialmente del espacio visual) como punto cero del espacio vivencial.". Y añade que es evidente que el punto cero del espacio visual está entre los ojos, donde empieza la nariz. ${ }^{5}$ El famoso dibujo del campo visual monocular de Ernst Mach es una interpretación de cómo se ve el mundo desde un punto muy cercano al punto cero (Fig. 1). Este dibujo es interesante porque surge de la reflexión acerca de la percepción visual, y aunque el objetivo de esta imagen no fuera representar el espacio vivencial, está relacionada con la representación del mismo en cuanto a que muestra la visión del espacio en primera persona (como veremos en el parágrafo 1.2.2., recrear el campo visual es uno de los recursos que dan paso a la representación del movimiento como vivenciado, aunque no el único).

\footnotetext{
2 Bollnow, 1969, pág. 25

Bollnow, 1969, págs. 23-24

${ }^{4}$ Bollnow, 1969, pág. 30

${ }^{5}$ Bollnow, 1969, págs. 58-59
} 
El espacio vivencial no sólo está determinado por el individuo físico, sino también por sus emociones, de modo que el espacio cambia para cada ser que vive en él. Graff Dürckheim lo expresa así:

El espacio concreto es distinto según el ser cuyo espacio es y según la vida que en él se realiza. Se modifica con el hombre que se encuentra en él, cambia con la actualidad de determinadas posturas y orientaciones que, de modo más o menos momentáneo, dominan todo el "yo". ${ }^{6}$

Fig. 1.

Ernst Mach (1987).

Dibujo del campo visual monocular.

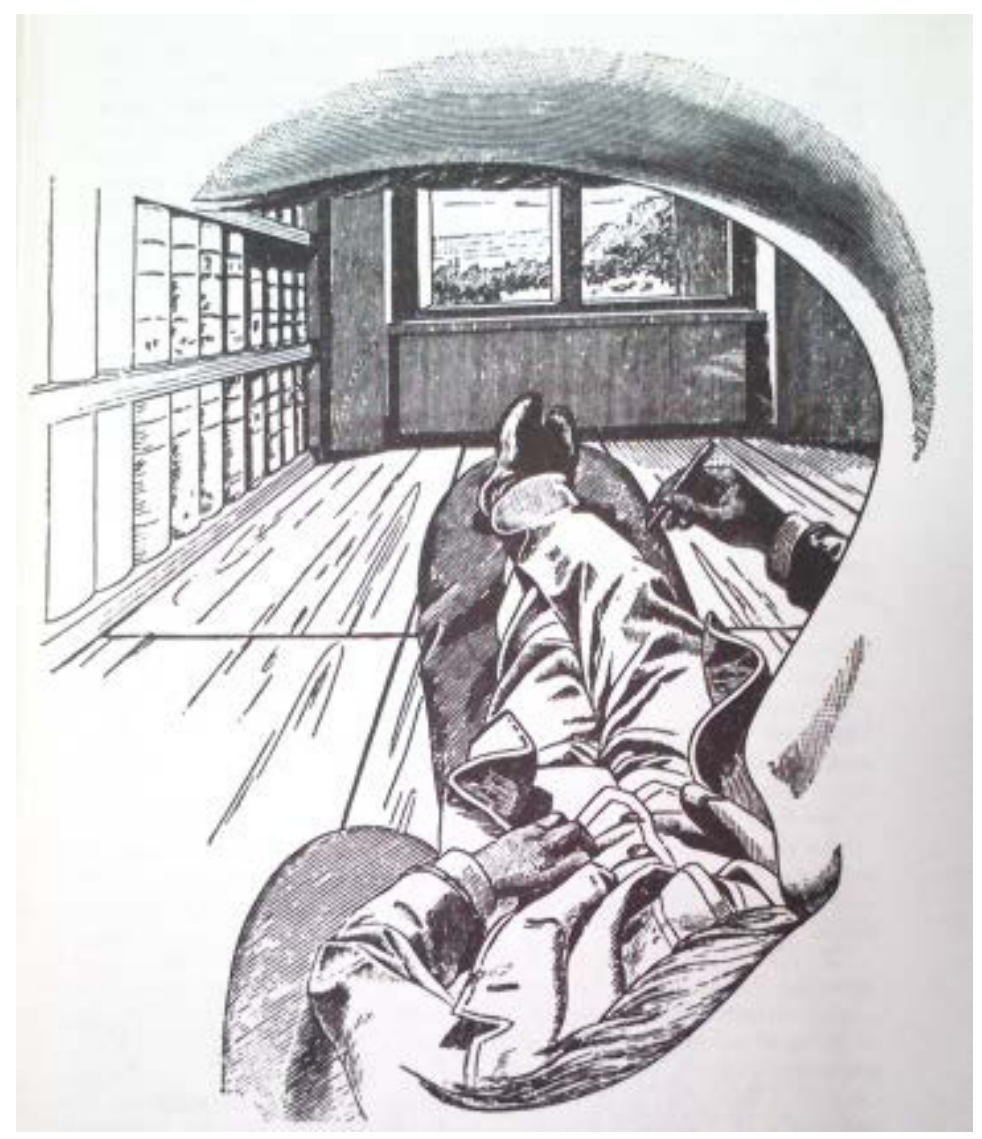

La cualidad emocional del espacio vivencial no se limita al estado de ánimo de cada momento, sino que se configura a través de toda la experiencia humana. Bollnow toma el camino como ejemplo de espacio vivencial. Para ello hace referencia a la novela de Marcel Proust Por el camino de Swan (1913), en la que se describen dos caminos posibles a recorrer desde un mismo punto. El camino y el paisaje trascienden su utilidad práctica hasta convertirse en elemento espiritual. Bollnow, a partir del pasaje de Proust, plantea la idea de que el espacio tiene connotaciones emocionales que pueden marcar al hombre de por vida:

\footnotetext{
${ }^{6}$ Von Dürckheim 1932, 390, en Bollnow, 1969, pág. 27
} 
El paisaje de la adolescencia no sólo ha acuñado la imagen bajo la que se concibe posteriormente todo otro paisaje como apropiado o inapropiado, sino que las dos direcciones en el espacio son durante toda la vida el seguro fundamento para la construcción del mundo espiritual. ${ }^{7}$

Así mismo, el autor establece una comparación entre el espacio matemático y la carretera ${ }^{8}$. Esta figuración del espacio matemático y el vivencial por medio de la carretera (que, con su sistema de señales, es un espacio "objetivado" ${ }^{9}$ ) y los caminos (individualizados, con un ambiente propio que generan un estado de ánimo) son muy reveladores respecto a lo que análogamente es el movimiento neutro y el vivenciado: en el primero se regulariza el dinamismo, tal como la carretera homogeniza el espacio; en el segundo, participa el ser humano de manera decisiva, determinando las cualidades más destacables del movimiento vivido desde su ser (desarrollado en los parágrafos 1.2. y 1.3.).

El concepto de espacio matemático no es suficiente para explicar, comprender o representar la vivencia del espacio. Bollnow cuenta que la limitación de un sistema geométrico para representar el espacio vivencial se hace patente ante la gran diferencia que hay entre la representación del espacio en un plano y cómo éste se percibe sobre terreno: las distancias geométricas, aun meticulosamente medidas, no plasman el esfuerzo que supone recorrerlas, según los obstáculos que haya que atravesar. ${ }^{10}$ El plano tampoco plasma la impresión que el espacio produce en la persona, como pensamientos o recuerdos que suscita. Veremos que existe la misma diferencia entre la expresión plástica del movimiento vivenciado y el movimiento neutro (parágrafos 1.2. y 1.3.).

Bollnow habla de líneas de fuerza que corresponden a las posibles trayectorias desde un punto:

\footnotetext{
La vivienda tiene una abertura única que establece la conexión con el espacio envolvente. Es la puerta de entrada. Desde ellas se despliegan las posibilidades de movimiento como un sistema de líneas de fuerza que se extiende desde su interior, pasando por corredores y escaleras hacia las habitaciones. ${ }^{11}$
}

La visualización de las posibilidades de movimiento como líneas de fuerza está relacionada con cómo la psicología de la forma explica la manera en que percibimos nuestro entorno y a nosotros mismos (el campo). El espacio-tiempo se percibe según las reacciones ante necesidades y estímulos, por lo que éste se capta de

\footnotetext{
${ }^{7}$ Bollnow, 1969, pág. 73

${ }^{8}$ Bollnow, 1969, págs. 99-100

${ }^{9}$ Bollnow, 1969, pág. 99

${ }^{10}$ Bollnow, 1969, pág. 175

${ }^{11}$ Bollnow, 1969, pág. 176
} 
manera diferente según las necesidades y según el sujeto, dando lugar a comprensiones diferentes del campo total. Paul Guillaume describe la percepción del soldado en la guerra y de los jugadores de un equipo deportivo de la siguiente manera:

En el frente el campo está orientado para el combatiente; hay en todos sus puntos una dirección de avance y una dirección de retroceso, una diferencia del peligro y de la dificultad, líneas de fuerza según las cuales el desplazamiento encuentra un máximo de resistencia. Lo mismo ocurre en la cancha de un juego; además de su orientación permanente, los desplazamientos incesantes de los equipos de jugadores dan momentáneamente a sus diferentes partes valores positivos y negativos variables, crean zonas de resistencia y zonas abiertas que orientan los esfuerzos. ${ }^{12}$

La forma en que aquí se detalla el movimiento en el espacio está relacionada con el espacio vivencial y el movimiento vivenciado. Aun siendo una narración muy lógica de la experiencia dinámica, se asemeja al movimiento vivenciado en cuanto a que prescinde del espacio geométrico y de la mecánica clásica, y porque destaca que la percepción de la vivencia del espacio y del tiempo dependen del individuo y su situación emocional.

En las descripciones de Bollnow sobre el espacio vivencial, se hace alusión constante a la relación entre el hombre y su entorno. Para ello el autor hace frecuentes referencias al movimiento. Aunque Bollnow no habla de "movimiento vivenciado", pone de manifiesto que la vivencia del espacio no está exenta de la experiencia dinámica. Así, por ejemplo, sobre el paseo nocturno, observa:

Esto [caminar en la noche] condiciona a la vez mi movimiento, ahora modificado, a través de la oscuridad. Por no abarcar «panorámicamente» este espacio, no tengo en él la holgura necesaria para un movimiento libre, natural. Y cuando está tan oscuro que "no se ve la mano delante de los ojos», sólo puedo moverme en el espacio tanteando prudentemente. En todo instante se teme tropezar con una irregularidad del suelo o darse un golpe doloroso. ${ }^{13}$

Además, en la manera en que presenta tales experiencias, el autor incluye a veces la descripción de sensaciones cinéticas que trasmiten las impresiones que provoca la relación entre el individuo y el espacio. Esto es especialmente relevante para el presente estudio, ya que estos pasajes son en sí una expresión vivenciada del movimiento. Por ejemplo, se refiere al espacio nevado de la siguiente manera:

Es la extraordinaria claridad, la "tiniebla blanca», unida a la imposibilidad de reconocer algo concreto, lo que pone al hombre a la merced de la nada opresora, mucho más de lo que podrían hacerlo las negras tinieblas de la noche. Es la total desmate-

\footnotetext{
${ }^{12}$ Guillaume, 1937, págs. 151-152

${ }^{13}$ Bollnow, 1969, pág. 203
} 
rialización del entorno. El hombre tiene la sensación de precipitarse en la nada porque no ve ningún sólido a que asirse. Cree flotar y caer en la nada. ${ }^{14}$

Encontramos expresión del movimiento vivenciado en otros medios escritos, como la literatura. A veces, tal expresión reside en la elección de las palabras que describen el movimiento, o en destacar una cualidad peculiar de una acción, o en la narración de las sensaciones que despierta en la persona que lo vive o lo observa. Dumas nos proporciona pasajes de estas características en El Conde de Montecristo (1844):

[...] luego sintió Edmundo que le cogían por los pies y por la cabeza y que le balanceaban.

- iA la una! - dijeron los enterradores.

$-i$ A las dos!

- iA las tres!

Dantés se sintió lanzado al mismo tiempo a un inmenso vacío, hendiendo los aires como un pájaro herido de muerte, y bajando, bajando a una velocidad que le helaba el corazón. Aunque le atraía hacia abajo una cosa pesadísima que precipitaba su rápido vuelo, parecióle como si aquella caía durase un siglo, hasta que, por último, con un grito espantable, se hundió en un agua helada que le hizo exhalar un grito, ahogado en el mismo instante de sumergirse.

Edmundo había sido arrojado al mar con una bala de a treinta y seis atada a sus pies. ${ }^{15}$

Y más adelante, cuando el protagonista está en alta mar, flotando sobre una tabla, una lancha se acerca en su ayuda. En su impaciencia, abandona la tabla y nada hacia la lancha:

A un segundo alarido que lanzó, los remeros redoblaron sus esfuerzos y uno de ellos le gritó:

-iÁnimo!

Esta palabra llegó a su oído en el momento en que una oleada pasaba por encima de su cabeza, cubriéndole de espuma.

Cuando volvió a salir a la superficie, Dantés azotaba el agua con esos ademanes desesperados del hombre que se ahoga.

Después exhaló otro grito, y se sintió atraído hacia el fondo del mar como si aún llevara a los pies la bala mortal. ${ }^{16}$

En ambos fragmentos se expresa el movimiento como vivenciado a través de varios elementos: el contraste entre el balanceo (transmitido únicamente por la cuenta) y la larga caída vertical, que destaca la percepción subjetiva de su duración, el uso retórico de la temperatura, así como la comparación entre la caída por el acantilado y el descenso al hundirse en el mar por pura fatiga.

\footnotetext{
${ }^{14}$ Bollnow, 1969, págs. 199-200

${ }^{15}$ Dumas, 1844, pág. 185

${ }^{16}$ Dumas, 1844, pág. 192
} 
También encontramos movimiento vivenciado en la obra de Victor Hugo Los miserables (1860). En la narración de la batalla de Waterloo, el autor describe los escuadrones franceses de caballería galopando a la carga haciendo énfasis en el movimiento fundamentalmente por medio de la comparación y la metáfora:

Subían graves, amenazadores, imperturbables [los jinetes]; y en los intervalos de la mosquetería y la artillería se oía ese pataleo colosal. Como eran dos divisiones, iban en dos columnas; [...] Desde lejos se creía ver alargarse hacia la cima de la meseta dos inmensas culebras de acero. Eso atravesó la batalla como un prodigio. [...]

Parecía que aquella masa se había convertido en un monstruo y no tenía más que un alma. Cada escuadrón ondulaba y se hinchaba como un tentáculo de pulpo. Se los divisaba a través de una vasta humareda desgarrada aquí y allá. Era una confusión de cascos, de gritos, de sables, un saltar tempestuoso de grupas de caballos entre los cañonazos y la música. Un tumulto disciplinado y terrible; y sobre todo ello las corazas, como las escamas sobre la hidra. ${ }^{17}$

La manera en que se presenta este pasaje acentúa el contraste con la culminación de mismo cuando parte de la caballería, en plena carga, se precipita en una zanja:

La segunda fila empujó a la primera y la tercera a la segunda; los caballos se alzaban de manos, reculaban, caían sobre la grupa, se tumbaban con las cuatro patas al aire, derribando y triturando a los jinetes, sin que hubiera medio alguno de retroceder, toda la columna no era ya sino un proyectil; la fuerza adquirida para aplastar a los ingleses aplastó a los franceses, el barranco inexorable no podía rendirse sino lleno hasta el borde, jinetes y caballos rodaron en él mezclados, destrozándose los unos a los otros, formando una sola masa de carne en aquel abismo; y cuando el foso se llenó con hombres vivos, todos los demás pasaron sobre ellos. ${ }^{18}$

En este segundo fragmento, la enumeración de movimientos de los caballos y la reiteración de los hechos prolongan la narración, lo que sugiere la extensa dimensión temporal de la caída y el dramatismo de la escena. Por supuesto, en los cuatro fragmentos también es fundamental para la creación de las escenas la descripción de otras experiencias perceptivas a parte del movimiento, como el sonido y la temperatura. Igualmente, en animación todos los elementos sonoros (música, efectos de sonido y diálogos) participan en la expresividad de la obra e influyen en la representación del movimiento; sin embargo, este es un terreno muy extenso con una complejidad propia en el que no nos adentraremos en la presente tesis.

Y para acabar con la expresión artística del movimiento en el medio escrito, un último ejemplo, esta vez una estrofa del poema de Arberti Chufletillas al niño de la Palma, en el que se refiere a la acción del banderillero al clavar las banderillas

\footnotetext{
${ }^{17}$ Hugo, 1860, págs. 275-276

${ }^{18}$ Hugo, 1860, pág. 276
} 
al toro de esta manera tan audaz, para la cual se basa, sobre todo, en una impresión general y no en la definición de la técnica:

\author{
¡Aire, que al toro torillo \\ le pica el pájaro pillo \\ que no pone el pie en el suelo! ${ }^{19}$
}

Del mismo modo que en la literatura, la expresión del movimiento vivenciado en animación se caracteriza por representar la acción transmitiendo sensaciones cinéticas vividas, imaginadas o soñadas, ligada a veces a sentimientos y emociones, más que a través del desarrollo mecánico de éste o cualquier sistema objetivo de representación. Arnheim explica cómo el coreógrafo Rudolf von Laban cambió su sistema coreográfico para dar prioridad a las sensaciones cinestésicas del cuerpo frente a la descripción formal de los pasos: de observar la trayectoria, el peso y la duración (parámetros métricos) pasó a observar el espacio, el impulso y el tiempo (cualitativos), estos nuevo valores son correspondientes a los anteriores, pero atienden a la percepción del bailarín antes que a la del observador, y así "Al concebir sus actividades en estos términos, el estudiante aprende no por imitación de posiciones corporales desde fuera, sino por comprensión de los impulsos que producen el efecto deseado" ${ }^{20}$.

A partir de las concepciones y representaciones del espacio, el tiempo y el movimiento a través de la experiencia dinámica, como las que hemos visto, hablamos de "movimiento vivenciado", el cual supone una concepción del movimiento desde la vivencia personal. Pero dado que el término "movimiento vivencial" se emplea en el contexto de la danza, nos parece conveniente anotar que con "expresión del movimiento vivenciado" no nos referimos al concepto "movimiento vivencial" como se comprende en la siguiente acepción:

Así el ser humano se inicia en el conocimiento del mundo, mediante el movimiento, vibración creadora de vida, constante, mutable, imperecedero e infinito. Ese movimiento vivencial generador de vida, es la expresión originaria de la danza que surge de lo más entrañable del ser. ${ }^{21}$

Como vemos, la noción de movimiento vivencial en danza está íntimamente ligada a la armonía entre el ser humano y su propio cuerpo como medio de expresión, mientras que el concepto que presentamos surge para definir la representación de la experiencia del movimiento (la experiencia de todo movimiento, desde el más trivial y natural al más excepcional, incluido el movimiento propio de cada

\footnotetext{
${ }^{19}$ Alberti, 1925-1926, pág. 97

${ }^{20}$ Arnheim, 1979, págs. 408-409

${ }^{21}$ Univers Biocèntric, 2013
} 
danza) a través del arte plástico; la expresión corporal y la trascendente naturalidad de su movimiento no forman parte de la definición que presentamos.

También queremos apuntar que concebir el movimiento como duración o como suma de instantes no es una cuestión determinante para el desarrollo del concepto de movimiento vivenciado tal y como lo presentamos, es decir, como término para definir la expresividad del movimiento en la plástica y en la animación. Efectivamente la concepción del movimiento de Bergson como continuo indisoluble puede considerarse en armonía con la teoría del espacio vivencial de Bollnow en cuanto a su oposición a la cualidad medible y fragmentaria ${ }^{22}$. Sin embargo, queremos adentrarnos en otros aspectos: la comprensión de la continua evolución del movimiento no se refiere a la experiencia del movimiento ni a sus cualidades emocionales, como hace Bollnow con el espacio vivencial. Estas características del espacio vivencial son las que aplicamos al movimiento vivenciado, y son las que consideramos más relevantes para entender lo que supone este tipo de expresión dinámica en la plástica y en la animación, junto a su cualidad necesariamente subjetiva, como explicaremos en el apartado 1.2.

Con todo esto no pretendemos establecer una teoría sobre el movimiento en cuanto a experiencia del ser humano, sino acercarnos desde la reflexión teórica a una noción del movimiento que nos permite nombrar y comprender la expresión dinámica que presenta cualidades expresivas notorias en la transmisión del movimiento. Las características que este tipo de movimiento presenta en la plástica, y concretamente en la animación, se desarrollan en el parágrafo 1.2.

\subsubsection{DEFINICIÓN DE MOVIMIENTO MATEMÁTICO Y MOVIMIENTO NEUTRO}

En este apartado hablaremos de qué es el movimiento matemático e introduciremos el concepto de "movimiento neutro", el cual surge para explicar cómo son las representaciones del movimiento que tienen, en cierto modo, las propiedades del movimiento matemático, sean éstas o no aplicación directa del movimiento matemático en la plástica.

\footnotetext{
${ }^{22}$ Lloret Ferrándiz, 1985, pág. 329
} 
Bollnow contrapone el espacio vivencial al espacio matemático (el espacio medible, objetivo). ${ }^{23}$ Pero antes de extender al movimiento el concepto de espacio matemático de este autor (como hemos hecho con el concepto de espacio vivencial en 1.1.1), detengámonos en qué es el movimiento matemático. El movimiento matemático es, esencialmente, el movimiento según lo explica la ciencia. La ciencia analiza bajo parámetros concretos todo tipo de fenómeno móvil; toda acción acometida (independientemente de las circunstancias emocionales) es explicada objetivamente. La ciencia que estudia el movimiento en profundidad es la mecánica teórica, que se divide en tres ramas: mecánica clásica newtoniana, mecánica relativista y mecánica del microcosmos ${ }^{24}$ (conocida hoy en día como "mecánica cuántica"). De éstas, la mecánica newtoniana es la que tiene más influencia en la representación del movimiento en animación. Nos concentraremos en ésta, ya que es interesante ver la diferencia conceptual y lingüística en que se trata el movimiento en comparación con el parágrafo anterior:

La MECÁNICA NEWTONIANA está cimentada sobre un número reducido de postulados [es decir, cosas que no se pueden demostrar] y ha sido edificada con el concurso casi exclusivo del raciocinio y la matemática [sin experimentación], por lo cual recibe habitualmente el calificativo de racional. Las tres partes que la integran son: la $\mathrm{Cl}-$ NEMÁTICA (del grigo kinema, kinematio, movimiento), la ESTÁTICA (del griego statikos, estar de pie), y la DINÁMICA (del griego, dynamis, fuerza). La CINEMÁTICA es una especie de geometría del movimiento en la que se estudian las particularidades de éste, sin hacer intervenir las causas que lo motivan. La ESTÁTICA es la ciencia del equilibrio. La DINÁMICA estudia los movimientos de los cuerpos relacionándolos con las causas productoras de los mismos ${ }^{25}$.

La mecánica newtoniana es de referencia generalizada en los manuales de animación (como veremos en el capítulo 3), por lo que es interesante conocer los términos exactos en los que ésta se plantea para atisbar cuán complejo es el conocimiento científico al que hacen referencia. Incluimos las fórmulas matemáticas porque son una representación del movimiento en lenguaje matemático, y aunque por supuesto no son representaciones plásticas del mismo, es interesante observar que son un lenguaje objetivo, exento de expresividad. Las animaciones con un nivel máximo de neutralidad en la representación móvil están más próximas a estas fórmulas matemáticas que a la expresión artística.

Las leyes de Newton, también conocidas como "leyes del movimiento" son tres principios que explican la mayor parte de los problemas relativos al movimiento de los cuerpos. Su formulación matemática fue publicada por Isaac Newton en su

\footnotetext{
${ }^{23}$ Bollnow, 1969, págs. 23-24

${ }^{24}$ Belda Villena, s/f, pág. -3

${ }^{25}$ Belda Villena, s/f, pág. -3
} 
obra Philosophiae Naturalis Principia Mathematica (Newton, 1726). ${ }^{26}$ Estas leyes son las siguientes:

1a Ley: "Un cuerpo permanecerá en su estado de reposo o movimiento a menos que se le aplique una fuerza que modifique ese estado". ${ }^{27}$ Se formula de la siguiente manera:

$$
\mathbf{E}=\mathbf{v} \cdot \mathbf{t} \text {; siendo } \mathbf{E}=\text { espacio }(\mathrm{m}) ; \mathbf{v}=\operatorname{velocidad}(\mathrm{m} / \mathrm{s}) ; \mathbf{t}=\text { tiempo }(\mathrm{s}) \text {. }
$$

Según esta ley, para que un cuerpo altere su movimiento ha de existir algo que provoque el cambio, y ese algo es la "fuerza", resultado de la acción de un cuerpo sobre otro. Como es sabido, esta ley rebate la idea aristotélica de que un cuerpo sólo puede estar en movimiento si se le aplica una fuerza.

2a Ley: "El cambio de movimiento es proporcional a la fuerza motriz impresa y ocurre según la línea recta a lo largo de la cual se imprime." ${ }^{28}$ Su fórmula es la siguiente:

$$
\mathbf{F}=\mathbf{m} \cdot \mathbf{a} \text {; siendo: } \mathbf{F}=\text { fuerza (newtons), } \mathbf{m}=\text { masa }(\mathrm{kg}), \mathbf{a}=\text { celeración }\left(\mathrm{m} / \mathrm{s}^{2}\right) \text {. }
$$

En relación con esta Ley está el concepto de "cantidad de movimiento" (p), el cual se define como el producto de la masa del cuerpo por su velocidad en un instante dado. Esto significa que un cuerpo muy pesado (por ejemplo un portaviones) que marcha a pequeña velocidad puede tener igual cantidad de movimiento que otro de pequeña masa que va a una gran velocidad (como una bala). $\mathbf{p}=\mathbf{m} \cdot \mathbf{v}$, en $(\mathrm{kg} \cdot \mathrm{m} / \mathrm{s})$.

3a Ley. "Con toda acción ocurre siempre una reacción igual y contraria: o sea, las acciones mutuas de dos cuerpos siempre son iguales y dirigidas en direcciones opuestas." 29 Dicho de otra forma, las fuerzas siempre se presentan en pares de igual magnitud, sentido opuesto y están situadas sobre la misma recta. Pero aunque los pares de acción y reacción tengan el mismo valor y sentidos contrarios, no se anulan entre sí, puesto que actúan sobre cuerpos distintos. Se formula de la siguiente manera:

\footnotetext{
${ }^{26}$ Pickover, 2009

${ }^{27}$ Newton, 1726 en Pickover, 2009: LEX 1. Corpus omne perseverare in statu suo quiescendi vel movendi uniformiter in directum, nisi quatenus illud a viribus impressis cogitur statum suum mutare.

${ }^{28}$ Newton, 1726 en Pickover, 2009: LEX 2. Mutationem motus proportionalem esse vi motrici impressa, et fieri secundum lineam rectam qua vis illa imprimitur .

${ }^{29}$ Newton, 1726 en Pickover, 2009: LEX 3. Actioni contrariam semper et aequalem esse reactionem: sive corporum duorum actiones in se mutuo semper esse aquales et in partes contrarias dirigi.
} 
(ACCIÓN o EMPUJE de cuerpo 1 sobre el cuerpo 2) $\mathbf{F}_{1,2}=-\mathbf{F}_{2,1}$ (REACCIÓN de cuerpo 2 sobre el cuerpo 1)

Mientras que las dos primeras leyes ya habían sido propuestas de otra manera por Galileo, Hooke y Huygens, la tercera ley es original y hace de las leyes de la mecánica un conjunto lógico y completo. ${ }^{30}$

Limitándonos a la Mecánica Clásica, hemos de decir que su conceptualización no está exenta de complejidad y abstracción y que sus aplicaciones en la vida diaria son numerosas. A modo de ejemplo veamos lo que ocurre a un vehículo en movimiento rectilíneo y uniforme cuando entra en un tramo curvo: por la primera ley de Newton su movimiento se rige por la fórmula e=v•t (espacio igual a velocidad por tiempo). Pero esta situación se altera al pasar de la trayectoria recta a la trayectoria curva. La segunda Ley de Newton determina el movimiento circular con una fuerza dirigida hacia el exterior de la curva, que es $\mathbf{F}=\mathbf{m} \cdot \mathbf{a}$ (fuerza igual a masa por aceleración), Ilamada fuerza centrífuga. La aceleración en este movimiento circular es $\mathbf{a}=\mathbf{v}^{2} / \mathbf{r}$ (aceleración igual a la velocidad al cuadrado dividida por el radio de la curvatura) por lo que dicha fuerza es $\mathbf{F c}=\mathbf{m} \cdot\left(\mathbf{v}^{2} / \mathbf{r}\right)$. Según la tercera ley de Newton de acción y reacción, para que haya equilibrio ha de existir otra fuerza de igual magnitud pero dirigida hacia el interior (la fuerza centrípeta). Por otra parte, la masa tiene un peso debido a la gravedad que es $\mathbf{P}=\mathbf{m} \cdot \mathbf{g}$ (peso igual a masa $\mathrm{m}$ por la aceleración de la gravedad g que es $9,8 \mathrm{~m}^{2} / \mathrm{s}$ ). Componiendo vectorialmente la fuerza centrífuga $\mathbf{F c}=\mathbf{m} \cdot\left(\mathbf{v}^{2} / \mathbf{r}\right)$ con peso $\mathbf{P}=\mathbf{m} \cdot \mathbf{g}$ se obtiene que, para contrarrestar aquella, a la carretera hay que hacerle una sobreelevación $\mathbf{h}$ en la parte convexa de la curva (peralte) dada por $\mathbf{h}=(\mathbf{k} \cdot \mathbf{v} \mathbf{2} \cdot \mathbf{a}) / \mathbf{g} \cdot \mathbf{r}$ ( $\mathbf{v}$ es la velocidad media, a es la anchura de la carretera, $\mathbf{g}$ es la aceleración de la gravedad y $\mathbf{r}$ es el radio de la curva) (Fig. 2).

Conscientes de que la complejidad del espacio-tiempo y el movimiento es amplia y minuciosamente estudiada por la ciencia, con este simple resumen de parte de la mecánica no pretendemos más que hacer un acercamiento a cómo es el movimiento según este campo, y así establecer a qué nos referimos con "movimiento matemático".

\footnotetext{
${ }^{30}$ Pickover, 2009
} 


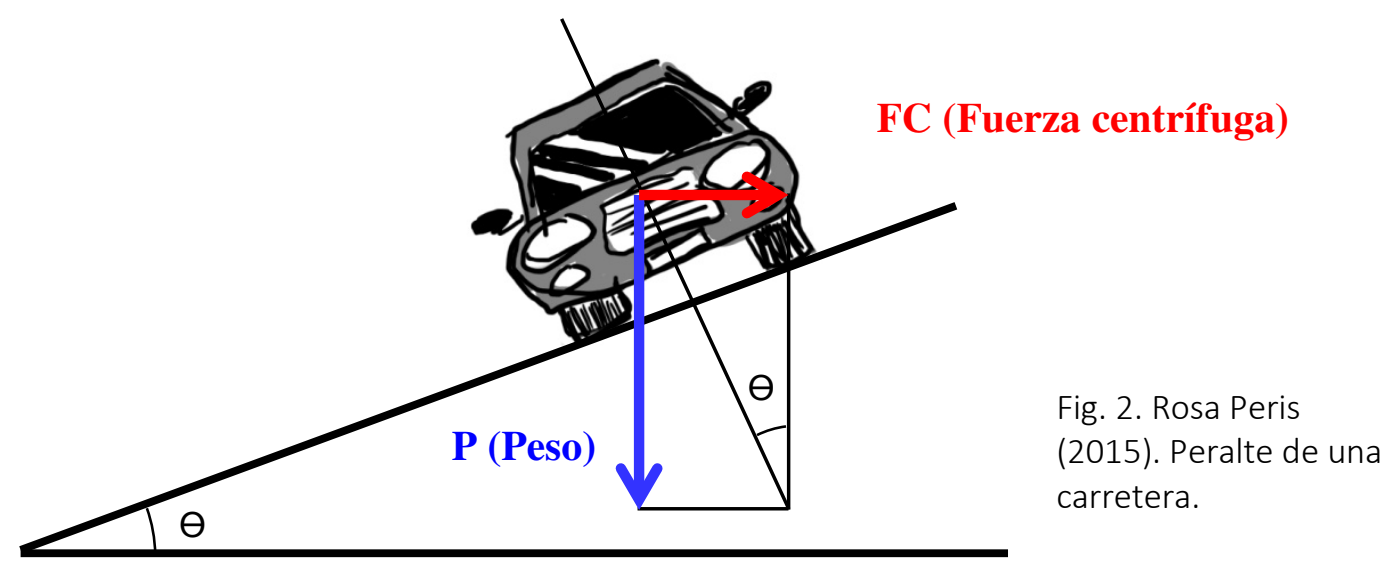

Visto esto, decidimos prescindir del término "matemático" para referirnos a la expresión móvil opuesta al movimiento vivenciado y aplicar en su lugar "movimiento neutro" por varios motivos: por un lado, el término "movimiento matemático" abarca un amplio campo de conocimiento con entidad propia que no queremos hacer más extenso todavía aplicando este vocablo al arte. Por otro lado, consideramos que el término "movimiento neutro" sintetiza mejor las cualidades de la representación móvil opuesta a la vivenciada, porque aunque el término "matemático" hace referencia a cualidades de este tipo de expresión (la objetividad y neutralidad expresiva), al hablar de movimiento matemático en la plástica se establece una conexión directa con el uso de las matemáticas para la representación, y éstas, como veremos en 1.3., pueden ser tan expresivas como las que no la emplean. Del mismo modo, ni el carácter cuantificable y métrico de las matemáticas ni tampoco la fragmentación del movimiento con la que Bergson explica el mecanismo cinematográfico del pensamiento conceptual ${ }^{31}$ nos sirven para entender y explicar el tipo de representación del movimiento a la que nos referimos, ya que el análisis pormenorizado de la mecánica tampoco impide la expresividad en animación (B. de 3.2.1); de hecho, todas las obras de animación figurativas (incluso algunas abstractas) requieren la división de la acción en fases sucesivas. Así pues el término "matemático" resulta inapropiado, ya que el tipo de expresión móvil de la que queremos hablar no se limita a las matemáticas (y a veces incluso no está relacionado con éstas), sino que se caracteriza por la neutralidad expresiva y por carecer de relación con cuestiones sensoriales sobre cómo se percibe o se vive el movimiento (este tema se desarrolla en el apartado 1.3.).

Dado que para definir el movimiento neutro no basta con conocer qué es el movimiento matemático, volvamos al espacio matemático de Bollnow. Del mismo

\footnotetext{
${ }^{31}$ Bergson, 1963, págs. 672-775
} 
modo que Bollnow compara el espacio vivencial con el matemático, existe una relación similar entre el movimiento vivenciado y el movimiento matemático. Primero veamos los valores que Bollnow destaca del espacio matemático, para lo cual se centra en el espacio tridimensional euclidiano:

1) Ningún punto se distingue de los demás. No existe ningún punto natural de intersección de coordenadas, sino que, por razones de conveniencia, se puede convertir cualquier punto en el centro de coordenadas por un simple desplazamiento de los ejes.

2) Tampoco hay dirección que se distinga de otra. Por una simple rotación se puede convertir cualquier dirección del espacio en eje de coordenadas.

El espacio no está estructurado en sí, sino que es completamente uniforme y de este modo se extiende en todas direcciones hacia el infinito. ${ }^{32}$

El espacio matemático, además de ser objetivo, tiene otra cualidad crucial para su enunciación: la homogenización. Bollnow presenta la carretera como espacio matemático partiendo de la idea de Linschoten sobre la homogenización del paisaje por la carretera. ${ }^{33}$ En la carretera, a pesar de atravesar entornos diferentes, el paisaje se hace monótono, ya que la aplicación de un sistema unitario de trazado y señalización produce una regularización del espacio vivencial:

El sistema de señales de tráfico en uno de los grandes cruces de hoy, expresa concretamente esta red de simples distancias. Pero esto significa un empobrecimiento fundamental, pues el espacio individual es objetivado por la carretera, haciendo que regiones cualitativamente distintas en su origen sean susceptibles de un trato cuantitativo. Al espacio se le pueden aplicar ahora las matemáticas; de este modo, la construcción de carreteras (con la técnica topográfica necesaria) es por lo menos uno de los procesos decisivos que conducen a la cristalización del concepto de espacio matemático. ${ }^{34}$

El movimiento neutro tiene el mismo efecto homogenizador sobre la expresión dinámica, como veremos en el apartado 1.3., lo que constituye uno de sus rasgos distintivos.

De la misma manera que las normas del espacio matemático no son válidas para el espacio vivencial ${ }^{35}$, el movimiento vivenciado tampoco puede comprenderse a través del movimiento matemático, y viceversa. Estas concepciones del espacio y el movimiento, surgen desde y para ámbitos distintos, lo que pone de manifiesto la dificultad para explicar unas a través de las otras.

\footnotetext{
${ }^{32}$ Bollnow, 1969, pág. 24

33 "Los caminos no sólo reconstruyen y organizan el espacio, sino que crean uno nuevo, sin cultivar. Mas haciéndolo homogeneizan el mundo". Linschoten, Die Strasse un die unendliche Ferne, en Situation, pág. 259, en Bollnow, 1969, pág. 98

${ }^{34}$ Bollnow, 1969, págs. 99-100

${ }^{35}$ Bollnow, 1969, pág. 24
} 
En los apartados 1.2.1. Qué es el movimiento vivenciado en la plástica y su homónimo 1.3.1. Qué es el movimiento neutro en la plástica, aplicaremos los términos "movimiento vivenciado" y "movimiento neutro" a la plástica en general, planteando, sin centrarnos en un sólo medio plástico, cómo se materializa el concepto, para así establecer a qué nos referimos con "movimiento vivenciado" cuando hablamos de artes plásticas. A continuación, en 1.2.2. y 1.3.2. analizaremos cuáles son las características perceptibles propias de a aquellas obras de animación en las que el movimiento se expresa como vivenciado y en las que se representa como neutro. 
Movimiento vivenciado y movimiento neutro. Estudio sobre la expresividad de la representación del movimiento en animación 


\subsection{EXPRESIÓN DEL MOVIMIENTO VIVENCIADO}

A continuación planteamos qué se considera movimiento vivenciado en las artes plásticas (1.2.1), a modo de introducción para asentar los principios en los que profundizamos en el apartado siguiente (1.2.2.) sobre cómo se presenta el movimiento vivenciado en animación.

\subsubsection{QUÉ ES EL MOVIMIENTO VIVENCIADO EN LA PLÁSTICA}

Partiendo de la idea de espacio vivencial de Otto Friedrich Bollnow y de las anteriores reflexiones sobre el movimiento, se concreta el concepto de movimiento vivenciado. Se trata de un movimiento relativo a la experiencia personal, de manera similar a la experiencia subjetiva del tiempo que tampoco es medible objetivamente. En este apartado aplicaremos este concepto a la plástica para referirnos a la expresión dinámica en la que se representa el movimiento tal y como se percibe, en su infinita variedad, al experimentarlo en primera persona, o que transmite la sensación dinámica que sugiere su observación.

Lo que define la expresión del movimiento como vivenciado es que la obra evoca de manera sinestésica las sensaciones dinámicas que se tienen al vivir 0 al observar el movimiento. La percepción del movimiento en primera persona siempre produce una sensación que deja una huella y que es muy valiosa a la hora de representar tal movimiento. Es la representación de esa honda sensación la que nos permite hablar de "expresión del movimiento vivenciado". Gombrich encuentra parte del origen de la distorsión de las caricaturas en la tendencia a exagerar ciertas sensaciones dinámicas que sentimos en nuestro propio rostro. Detengámonos en sus reflexiones acerca de esto:

nuestro sentido interno de las dimensiones difiere radicalmente de nuestra percepción visual de la proporción. El sentido interno siempre exagera. Intente mover hacia abajo la punta de su nariz, y sentirá que ha adquirido una nariz muy diferente, a pesar de que el movimiento real que haya hecho apenas será probablemente de algunos milímetros. La medida en que la medida de nuestro mapa interno difiere de la del ojo se experimenta muy bien (y con mucho dolor) en el dentista, cuando la muela con la que éste trabaja adquiere proporciones poco menos que gigantescas. No es 
de extrañar que el caricaturista o el expresionista que se basa en su sentido interno tienda a alterar las escalas; puede hacerlo sin entorpecer el sentido de identidad si podemos compartir sus reacciones frente a la misma imagen. ${ }^{36}$

Aunque no podemos afirmar que la exageración sea la clave indiscutible que permite expresar el movimiento como vivenciado, esta cualidad que Gombrich asocia al retrato caricaturesco se da en el movimiento vivenciado. También para expresar el movimiento vivenciado interviene lo que él llama el sentido interno, a través del cual experimentamos el movimiento de manera introspectiva (o muscular). $Y$, de la misma manera, son esas sensaciones las que transmite la obra en la que se expresa el movimiento vivenciado.

La idea de que para expresar el movimiento debe experimentarse profundamente porcede de la Edad Moderna, es una manifestación de las ideas humanistas en el arte. El "movimiento expresivo" era para los humanista la representación del movimiento que transmitía las emociones de los personajes de una imagen ${ }^{37}$. Benedetto Croce defiende que la impresión es la base para la expresión en el arte, sin importar por qué vía se ha alcanzado tal impresión. ${ }^{38}$ En lo que se refiere a expresar el movimiento como vivenciado, el sentido interno del movimiento que experimentamos en primera persona también se combina con las impresiones visuales que el movimiento produce en quienes lo observan "desde fuera". En el dibujo de Giambattista Tiepolo Céfiros con un caballo de Apolo (Fig. 3), el alargamiento visual del cuerpo del caballo y el movimiento en consecuencia de la pareja que lo monta transmite la cadencia deslizante del salto del animal; este alargamiento no se da en la realidad mecánica de la acción, pero sugiere la sensación móvil y visual de ésta. Otra sensación diferente encontramos en el dibujo de Jiri Trnka (Fig. 4), en el que la flexión de las articulaciones y del torso está muy marcada, reflejando un movimiento potente pero forzado que nos permite imaginar lo que sentiríamos en nuestro propio cuerpo si lo articuláramos de manera exagerada. Mientras que en el diseño para Titania (Fig. 5), la redondez de la forma y la sutileza del movimiento del cuerpo recuerdan el ritmo del agua que fluye suavemente en un arroyo; un dibujo muy insinuante, a pesar de que el movimiento sea un tanto más ambiguo. Todas estas imágenes, además de ser composiciones dinámicas, sugieren el movimiento estimulando sensaciones cinéticas a través del dibujo de la acción.

\footnotetext{
${ }^{36}$ Gombrich, 1982, pág. 123

${ }^{37}$ Lee, 1940 , págs. $45-46$

${ }^{38}$ Croce, 1908, págs. 104-105
} 


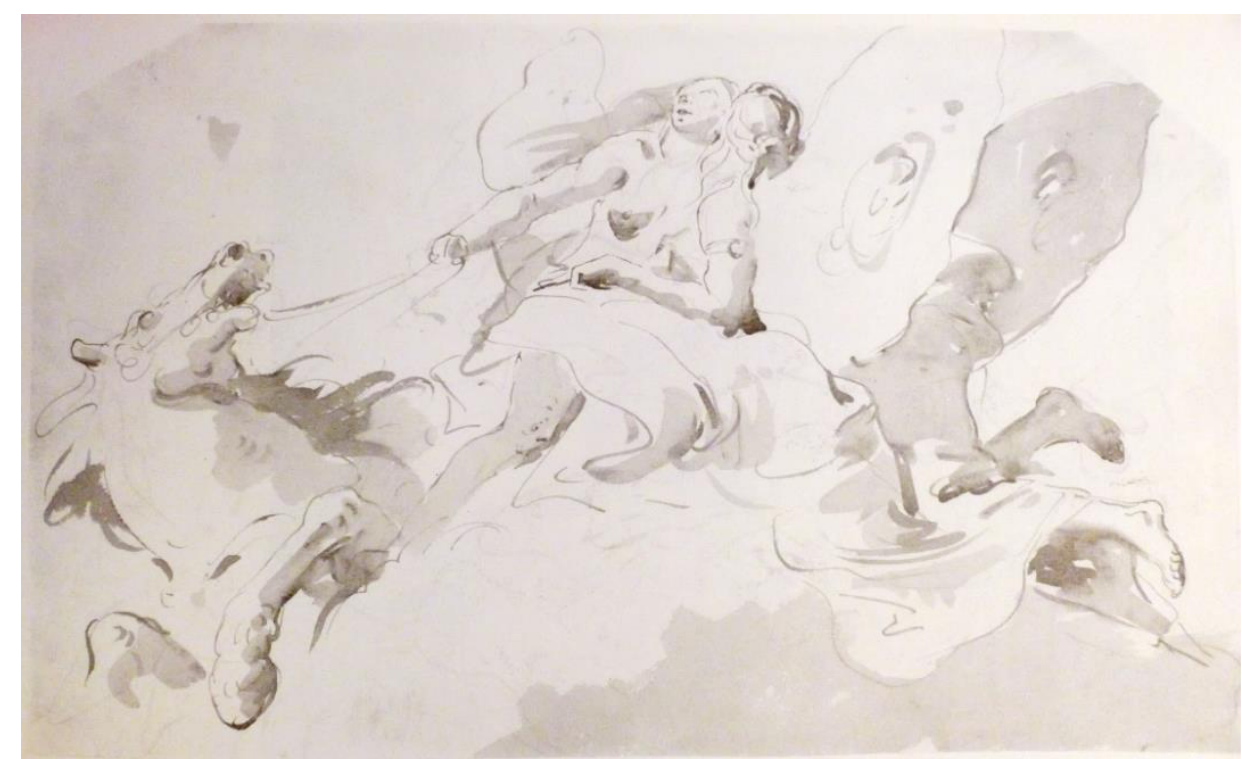

Fig. 3. Giambattista Tiepolo (1739). Céfiros con un caballo de Apolo.

Fig. 4. Jiri Trnka (1912-1959). Diseño para Sen noci svatojanske (Sueño de una noche de verano).
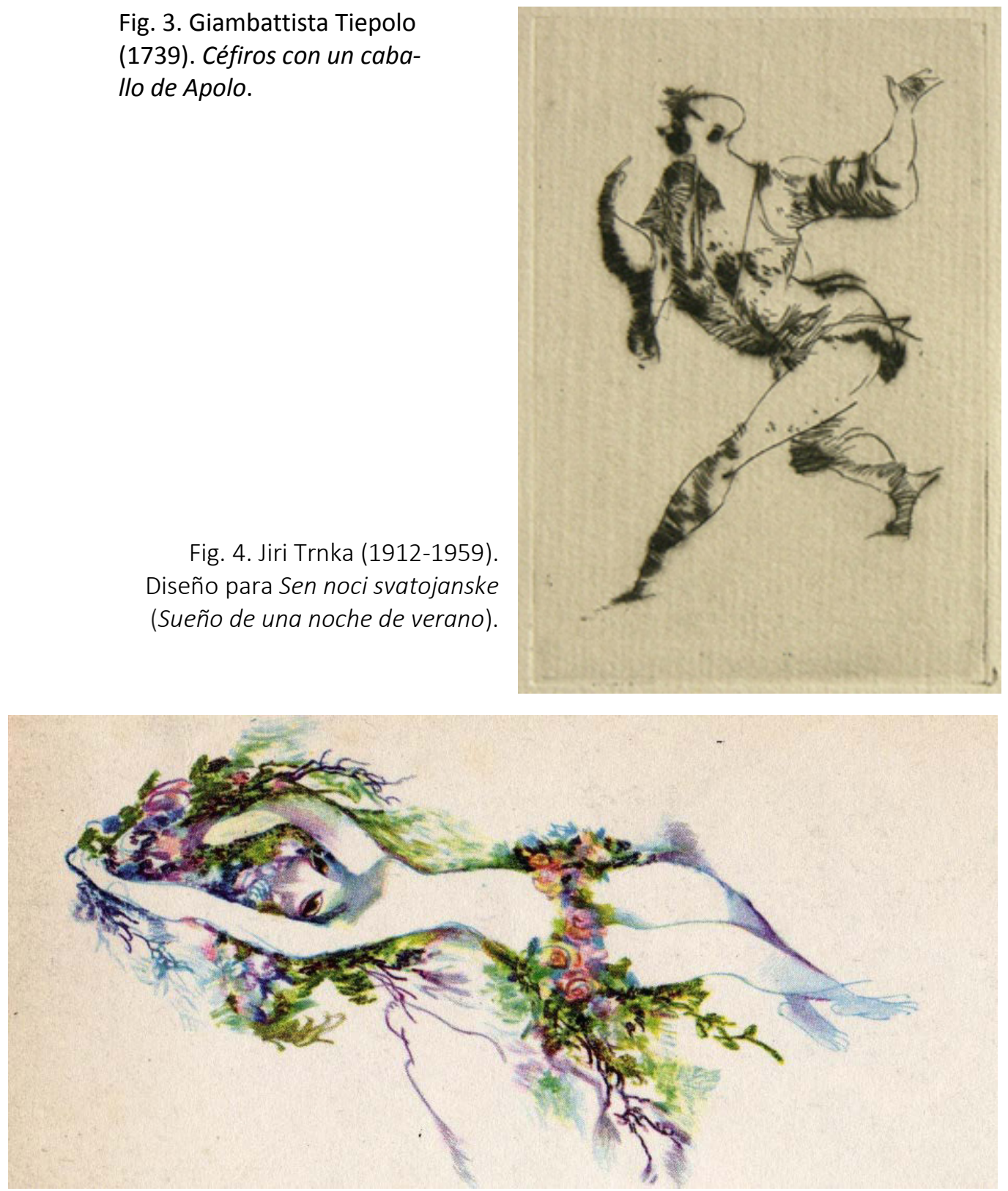

Fig. 5. Jiri Trnka (1912-1959), Diseño para Sen noci svatojanske

(Sueño de una noche de verano). 
La capacidad para transmitir sensaciones dinámicas de manera sinestésica por medio de la imagen es la característica definitoria de la expresión del movimiento vivenciado. Esto supone que no importan tanto los mecanismos por los que la obra se ha configurado, como la intensidad con que la obra influye en el espectador. Obviamente, que la obra produzca tal sensación de sinestesia dinámica depende tanto de la obra en sí como del espectador, por lo que, aunque podamos enunciar los aspectos visuales y técnicos que las obras con movimiento vivenciado suelen presentar (por ejemplo, en el caso de la animación, una de las características habituales es la representación del movimiento sin base de captura de movimiento), no podemos afirmar que el movimiento se exprese como vivenciado porque la obra presente estas características; la capacidad para transmitir sensaciones dinámicas siempre primará sobre las peculiaridades técnicas o visuales a la hora de establecer si una obra expresa el movimiento de esta manera.

En la plástica, el movimiento vivenciado presenta otras características que ayudan a reconocerlo. Una de ellas es que transmite peculiaridades móviles de lo acontecido. Esta segunda característica implica también la suscitación de cinestesia, a través de características más subjetivas de la vivencia, no ciñéndose a la representación de las cualidades básicas del movimiento (dirección, sentido, velocidad y dirección). Por ejemplo, el viaje en una montaña rusa se caracteriza por los cambios de velocidad, los ascensos lentos, y las bajadas y curvas vertiginosas; para representar esto de manera vivenciada, unas cualidades dinámicas se pueden enfatizar más que otras, lo que implica que se represente de multitud de maneras; por ejemplo, siguiendo con el ejemplo de la montaña rusa, una representación puede hacer hincapié en la velocidad y otra, en el drástico cambio de dirección, o la confusión o mareo, la pérdida de percepción de lo que está arriba y lo que está abajo, etc. En dos dibujos que representan personas nadando en los que se plasma el mismo tipo de nado, el primero se detiene en la fusión de los cuerpos con el agua (Rosa Peris, 2010) (Fig. 6), mientras que en el segundo tiene protagonismo la trayectoria y deslizamiento de las figuras en el medio líquido (Juliette Bailly s/f,) (Fig. 7).

La tercera característica para reconocer la expresión móvil vivenciada es que la acción se desarrolla en un espacio vivencial que corresponde a la manifestación plástica del concepto de Bollnow. La representación del movimiento vivenciado incluye, casi incondicionalmente, la expresión de un espacio acorde, al que también llamaremos vivenciado. Así, aunque las referencias espaciales se omitan, o sean mínimas, si el movimiento es vivenciado, denota un espacio en armonía con éste. 
Existe relación entre el espacio vivencial de Bollnow y el espacio plástico en aquellas obras en las que "se persigue la claridad del lenguaje plástico, frente a la fidelidad objetiva del espacio. Lo que trae como consecuencia una concepción subjetiva del espacio, o lo que es mismo, una representación del espacio vivenciado." ${ }^{39}$ Cabe destacar que el espacio vivencial no es un espacio necesariamente exento de geometría; una representación espacial ortogonal-triaxial puede revelar, a través del movimiento que acontece en él, o por otros factores visuales (la proporción, la luz, la composición, etc.), un espacio vivencial. Por ejemplo, en el dibujo de Escher (Fig. 8) en el que, por un juego geométrico, los personajes al bajar las escaleras llegan de nuevo al punto más alto y viceversa, se crea un espacio onírico, conectado con la vivencia subjetiva del espacio al trasgredir la lógica. Un caso menos obvio pero también muy potente es la bóveda en la que se representa la apoteosis de San Ignacio, de Andrea Pozo (Fig. 9), donde el dibujo de la perspectiva produce la ilusión de que el espacio arquitectónico se abre. Esta ilusión se percibe aunque no se observe la composición desde el punto visual privilegiado para ver coherentemente el trazado geométrico; tal vez por eso mismo, porque se mantiene la sensación de apertura arquitectónica al cielo pero se pierde la relación geométrica, la representación espacial cobra un sentido especial, lo que acentúa la dinamización del espacio.

Además de las cualidades visuales, el espacio vivencial en el arte se reconoce por comunicar el contenido emocional. En el cuadro de Munch El asesino, el espacio se manifiesta vivencial al producir emociones más allá de la sensación dinámica. El camino solitario despierta temor por mostrarse como un espacio abierto en el que el personaje se dirige hacia el espectador, el cual está sólo ante un imposible - pero inminente - ataque (Fig. 10). Del mismo modo, el movimiento vivenciado puede amalgamar tanto las características físicas del movimiento como las emociones que suscita la acción, lo que dependería del estado emocional de la persona que lo vive o que lo observa. Volviendo al ejemplo de la montaña rusa, además de los cambios de velocidad y las subidas y bajadas (secuencia dinámica que sería común a la experiencia de todas las personas que realizaran el trayecto), habría una lectura cuyo carácter dependería de los perfiles de los individuos: las personas con vértigo lo vivirían como una experiencia desagradable; las personas con deseos de emociones fuertes vivirían la subida de adrenalina como una experiencia excitante. Aunque más relevante que reflejar el placer o sufrimiento que produce la acción (como nos hemos ceñido en el ejemplo) es que

\footnotetext{
${ }^{39}$ Lloret Ferrándiz, 1985, pág. 337
} 


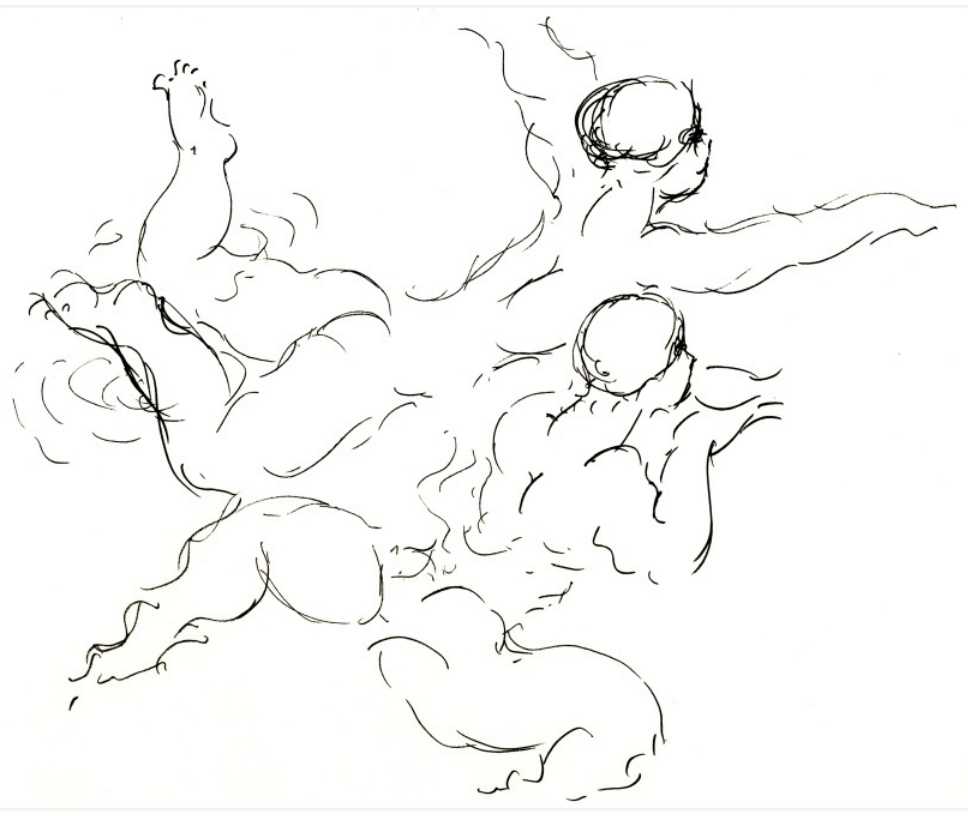

Fig. 6.

Rosa Peris (2010).

Nadadores.

Fig. 7.

Juliette Bailly (S/f). Investigación gráfica para Et hop!

la expresión del movimiento es el principal medio para transmitir el contenido de manera retórica.

Que el movimiento sea vivenciado no significa que se represente la experiencia de vida del artista o movimientos realmente ejecutados por él. No obstante, para crearlo es necesario un ejercicio de introspección (tanto si se ha experimentado tal movimiento en la vida real como si no). La imaginación y las experiencias previas son medios que ayudan al artista a representar la experiencia del movimiento que no vive en primera persona, sino que simplemente observa o inventa. Para ello, el dibujante se transporta a sí mismo hasta un estado emocional o sensorial que le ayuda a detectar cuáles son los elementos distintivos que hacen especial a 
Fig. 8.

Maurits Cornelis

Escher (1960).

Ascenso y descenso.
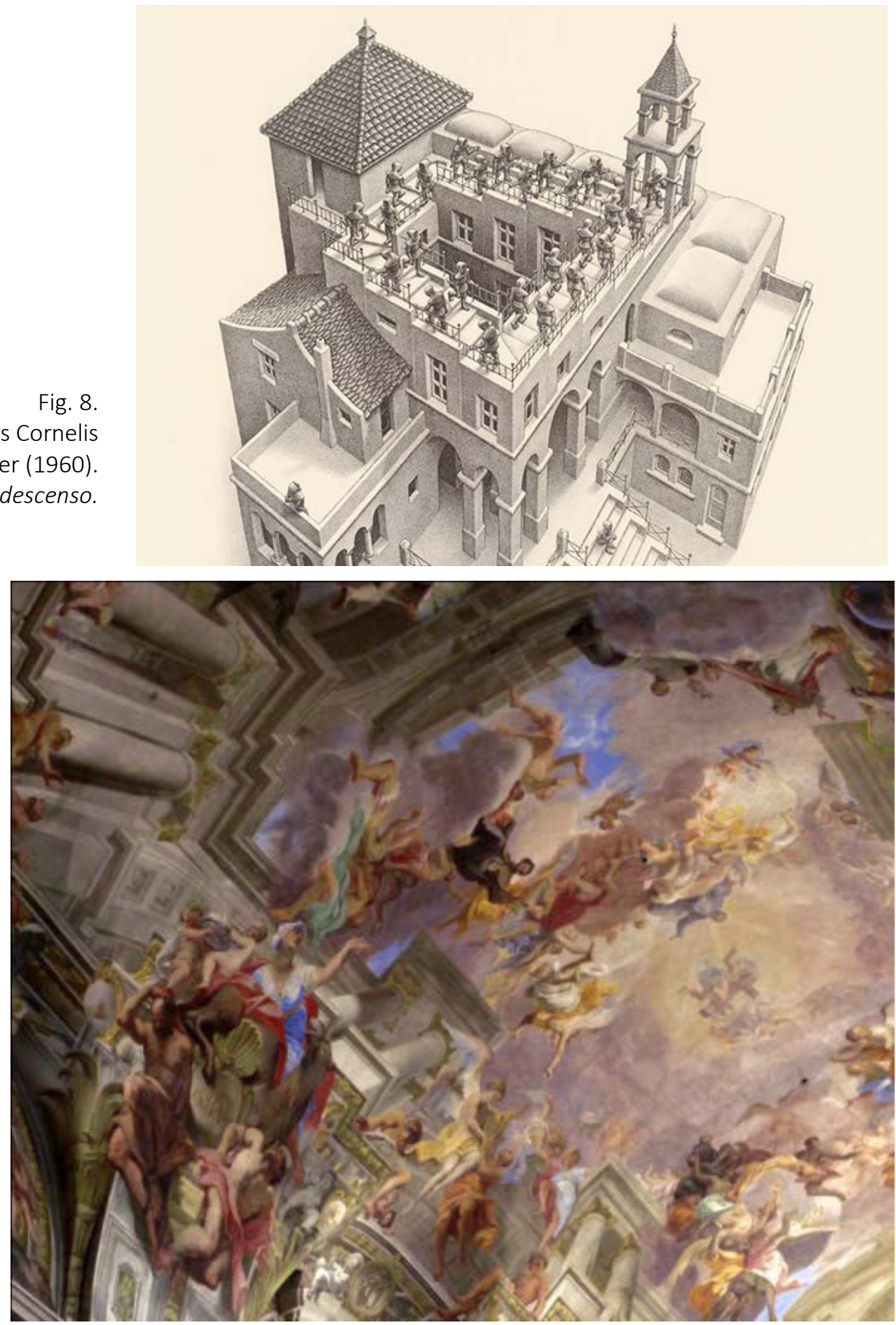

Fig.9. Andrea Pozzo (1626). Apoteosis de San Ignacio (detalle).

cada actividad móvil; esto mismo es lo que se reflejaría en una obra con movimiento vivenciado.

En el apartado siguiente profundizaremos en cómo el movimiento se expresa como vivenciado centrándonos en el campo de la animación, para lo cual aportaremos más ejemplos que ilustren las diferentes características. 


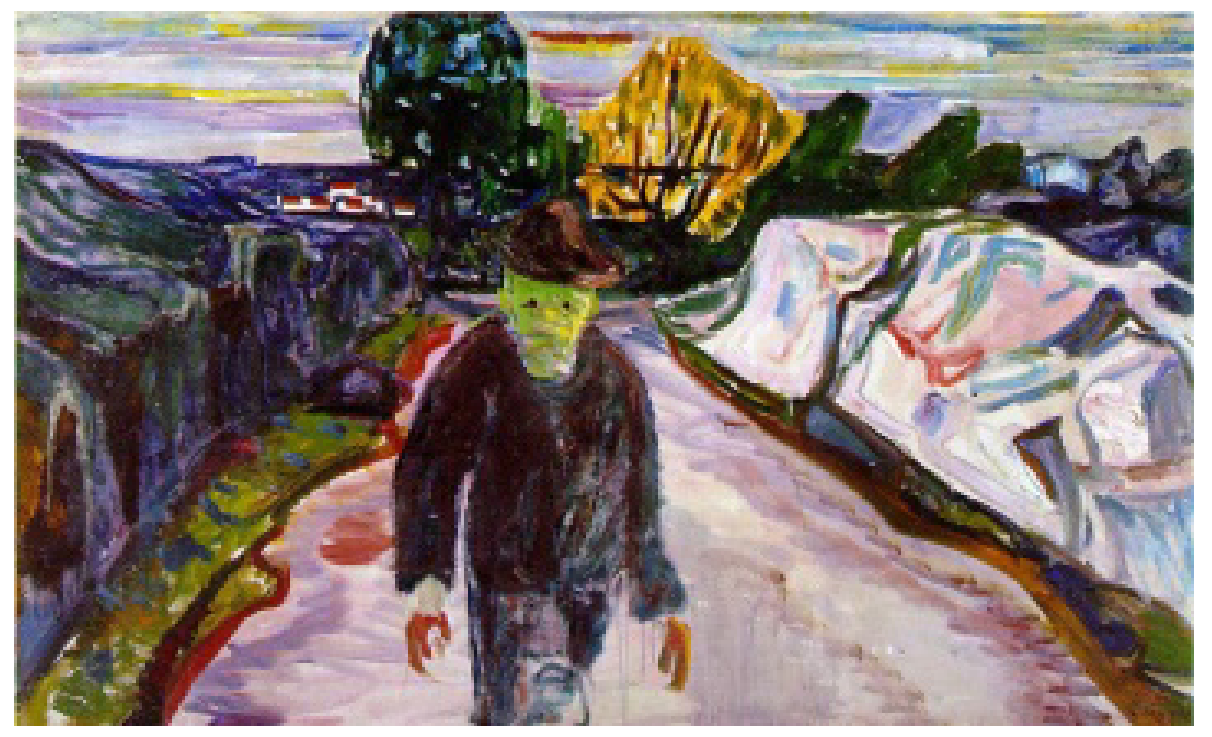

Fig. 10. Edvard Munch (1910). El asesino.

\subsubsection{CARACTERÍSTICAS DEL MOVIMIENTO VIVENCIADO EN ANIMACIÓN}

En toda obra audiovisual, tanto en cine de acción real como en animación, los acontecimientos pueden ser expresados como vivenciados. Para Luis Martín Arias, autor de El cine como experiencia estética, la identificación del espectador con los hechos narrados en la película es la que hace que el espectador viva la película ${ }^{40}$. La identificación es suscitada por las conexiones que el espectador encuentra entre éstos y su propia vida; se trata de una conexión racional en mayor o menor medida. Hay incluso una conexión no racional que nos hace vivir aquello que vemos, vivencia de la que son responsables las llamadas "neuronas espejo" (cuando vemos a alguien bostezar, nosotros también acabamos bostezando) ${ }^{41}$. Ambos fenómenos (la identificación más o menos racional y las sensaciones que nuestro cuerpo "refleja") están emparentados con el movimiento vivenciado en cuanto a que la obra audiovisual despierta en el espectador sensaciones y emociones que trascienden la mera comprensión de lo que se muestra o narra en la película. De hecho, la expresión del movimiento como vivenciado, a través de las sensaciones dinámicas, también genera identificación y experiencias sensoriales. ¿Qué elementos visuales de las películas provocan estas sensaciones? A continuación hablaremos de las características visuales propias de las películas de animación en las que el movimiento es vivenciado. El movimiento vivenciado se encuentra habi-

\footnotetext{
${ }^{40}$ Arias \& Martín, 1997

${ }^{41}$ Delgado J. , s/f
} 
tualmente en animaciones del ámbito artístico y experimental, aunque también se da en obras del contexto industrial, por lo que presentaremos ejemplos de ambos ámbitos.

\section{A. ESTIMULACIÓN DE LA SENSACIÓN CINÉTICA QUE SE TIE- NE AL EXPERIMENTAR Y AL OBSERVAR EL MOVIMIENTO}

La expresión del movimiento vivenciado se caracteriza principalmente por transmitir sensaciones dinámicas. Existen diferentes maneras de estimular sinestésicamente la sensación cinética a través de la imagen animada, al igual que otros estímulos: "Por supuesto, las sensaciones de olfato, equilibrio y tacto no se dan nunca mediante estímulos directos en un film, pero son sugeridas indirectamente a través de la vista" ${ }^{42}$.

Una manera de transmitir la sensación de vivir el movimiento es mostrar el punto de vista del personaje como si las imágenes en pantalla correspondieran a lo que éste ve. En Tekkonkinkreet (Arias M. , 2006) [en DVD] hay varios planos subjetivos. Uno de ellos nos muestra la calle de una ciudad a ojos de uno de los protagonistas, que corre a gran velocidad (00:07:47). La trayectoria circular del punto de vista representa el cambio de dirección del personaje; el desplazamiento del punto de vista sube y baja para transmitir la acción de correr (casi como el efecto "cámara en mano"); además el espacio y las personas que circulan por la calle se ven de distinto tamaño y punto de vista según su posición respecto a la cámara/personaje. Este tipo de efectos están más que aceptados por el espectador, sin embargo, Arnheim observa que el cine no corresponde a la experiencia misma de caminar por la calle debido a varios motivos:

La imagen tomada por una cámara que se mueve a lo largo de una calle no produce la misma experiencia que vivimos al caminar por la calle nosotros mismos. Entonces la calle nos rodea como un entorno amplio, y nuestras experiencias musculares nos dicen que estamos en movimiento. La calle de la pantalla es una parte enmarcada y relativamente pequeña de un entorno mayor, en el que el espectador se encuentra en reposo. $^{43}$

Pero este tipo de planos, además de ser planos subjetivos, al estar acompañados de otras características móviles y visuales como las descritas, sí pueden hacer imaginar, aunque no sea la sensación exacta o realista de recorrer la calle, una

\footnotetext{
${ }^{42}$ Arnheim, 1957, pág. 35

${ }^{43}$ Arnheim, 1979, pág. 382
} 
sensación muy dinámica que recuerda la propia experiencia o que hace imaginar la acción como si se viviera en primera persona. Otros planos más fantásticos y que muestran puntos de vista menos habituales también generan este efecto. En la misma película un complejo movimiento de cámara que muestra la ciudad desde arriba, entre las calles, e incluso en un rápido descenso se sumerge bajo el agua de un canal y emerge de nuevo. Un cuervo vuela siempre cerca del punto de visto, unas veces se adelanta y otras se queda atrás; esto sugiere que la cámara tiene entidad propia, que es un ser que dirige su mirada a aquello que quiere mirar y no simplemente un objetivo que filma "lo que tiene delante". Más sobre este plano en apartado B.2. de 2.2.3 pág. 192.

One of those days (Uno de esos días) (Plympton, 1998) se compone enteramente de este tipo de planos, conocidos como "planos subjetivos". Se muestra estrictamente lo que ve el personaje. La imagen representa su campo visual: sus brazos y piernas aparecen en pantalla cuando estos están ante sus ojos; y, del mismo modo, el rostro del protagonista sólo se ve cuando éste se mira en un espejo (Fig. 11). Al mostrar el punto de vista del personaje percibimos no sólo el movimiento desde su vivencia, sino también que el espacio mismo en el que se desarrolla, el cual se transforma al paso del personaje, es vivencial.
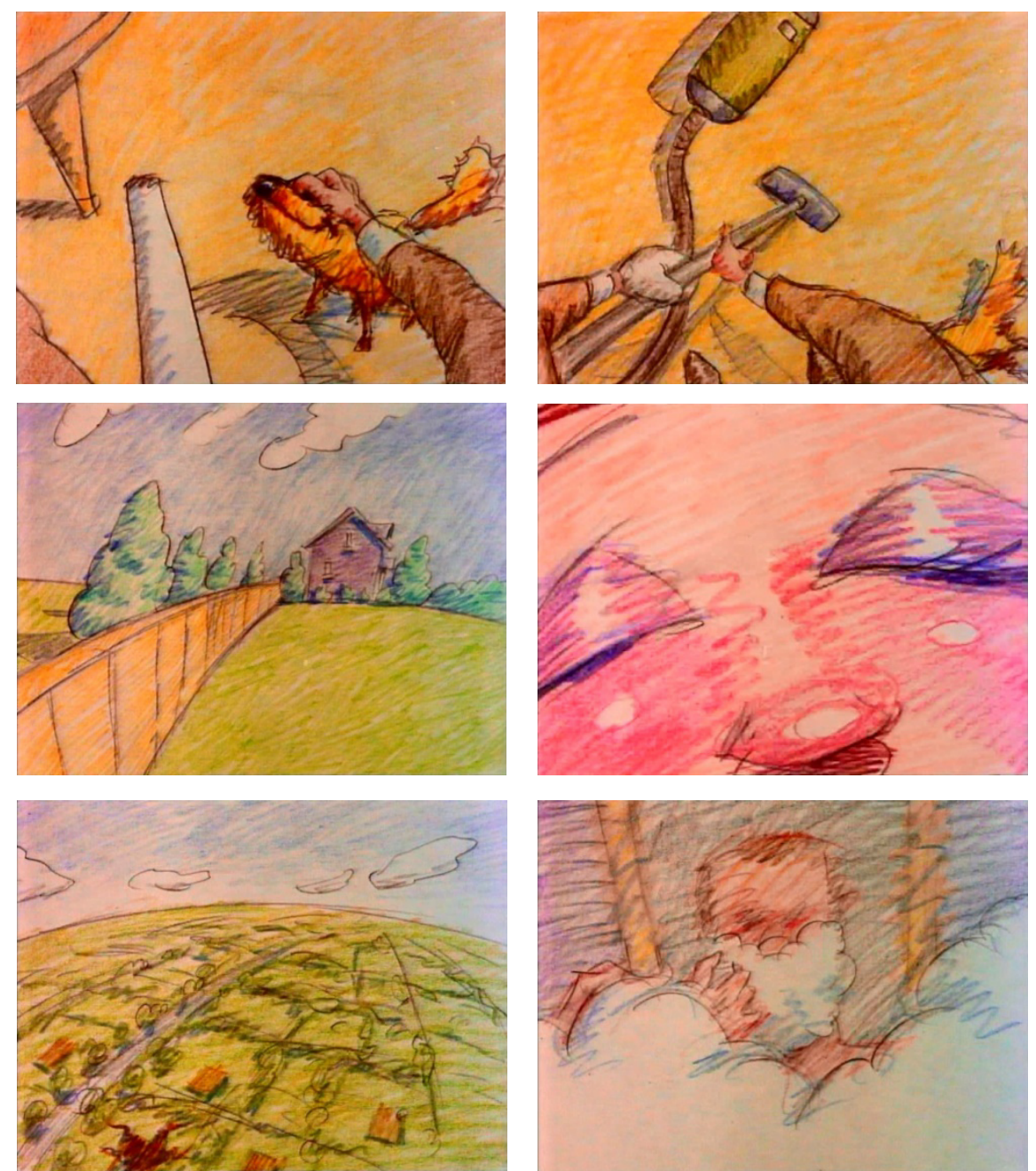

Fig. 11. Bill

Plympton (1998).

One of those days (Uno de esos días). Fotogramas de diversas escenas. 
Sin embargo, mostrar el punto de vista del personaje a modo de plano subjetivo no sugiere cinestesia en todos los casos. En Jumping (Saltar) (Tezuka, 1984) [en DVD] se muestra el mundo desde el punto de vista de una persona que salta progresivamente más alto. Los planos son subjetivos en cuanto a que representan lo que capta la mirada del personaje, pero es en la combinación del punto de vista, el cambio de dirección y sobre todo el cambio de velocidad (disminuyendo progresivamente la velocidad en el ascenso y aumentándola en el descenso) donde reside, en este caso, la expresividad del movimiento. No obstante, se recupera un punto de vista frontal y más convencional en las escenas de las que el personaje es testigo cuando llega al suelo (00:03:16) (Fig. 12). Tales escenas frontales siguen representando la mirada del protagonista-espectador $y$, sin embargo, la evocación cinética se desvanece. Por lo tanto, que la "cámara" muestre el punto de vista de los personajes contribuye a expresar el movimiento como vivenciado, pero tal punto de vista no implica incondicionalmente que el movimiento sea vivenciado.

Pero el movimiento vivenciado no se limita a la representación de la mirada: los movimientos de cámara que representan la mirada de los personajes pueden ser más complejos y mostrar en un único plano el punto de vista del personaje y al personaje alternativamente. En Atama Yama (Monte Cabeza), (Yamamura, 1984) encontramos planos de este tipo. En uno de ellos el protagonista pone pasta dental en el cepillo; vemos sus manos como si se tratase de las nuestras y, a continuación, con un movimiento de cámara, el plano subjetivo deja de ser tal y muestra el rostro y las manos del hombre. De la mirada en primera persona se pasa a ver al personaje "desde fuera" (00:02:22) (Fig. 13). Del mismo modo, en Estória do Gato e da Lua (Historia del gato y la Luna) (Serrazina, 1995), la ciudad se presentan "a vista de gato" a través de un punto de vista que muestra las calles a nivel más bajo de lo habitual y se desplaza tanto en la calzada como subiendo a un tejado. Pero este movimiento de cámara deja de representar la mirada del gato cuando éste salta por delante de la "cámara" y el plano ya no corresponde a la mirada felina. De manera similar, en When the wind blows (Cuando el viento sopla) (Murakami, 1996), en el inserto de la ensoñación de la mujer, encontramos la representación literal del concepto de movimiento vivenciado. La mujer se imagina a sí misma volando con alas de mariposa (00:08:47) (Fig. 14). La imagen muestra el punto de vista del personaje, en este caso lo que vería una mariposa en vuelo. Sin embargo, la imagen no se corresponde a aquella que registraría la cámara al imitar la trayectoria del insecto, sino que es una interpretación de la mirada subjetiva del personaje. En esta escena no sólo se muestra el punto de vista de la mujer, ya que el movimiento de cámara y el movimiento del móvil (aunque a veces son coincidentes) no son el mismo, lo que potencia la sensación 


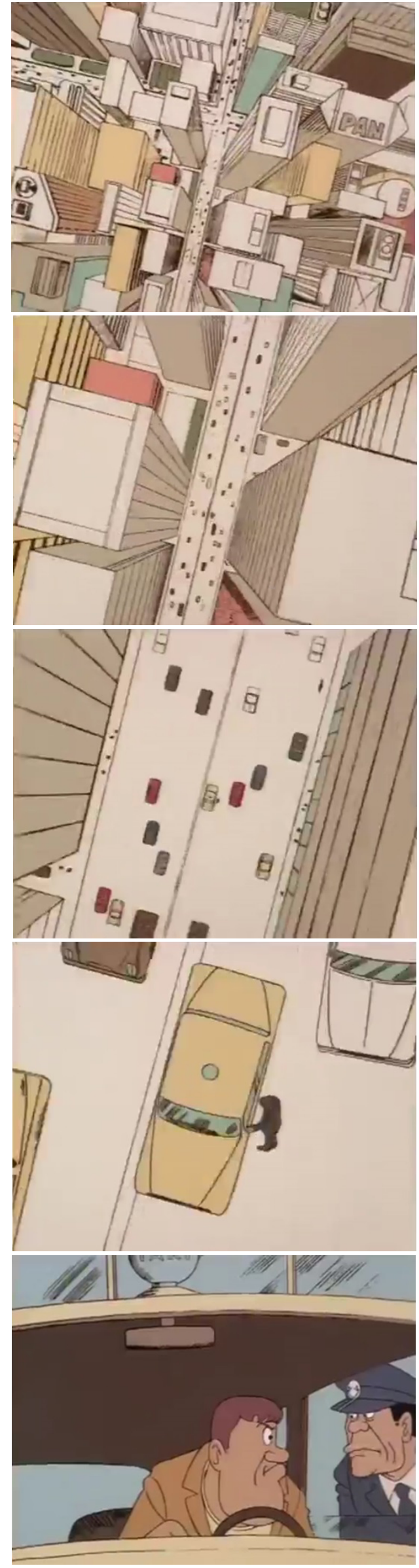

Fig. 12. Osamu Tezuka (1984). Jumping (Saltar). Serie de fotogramas.
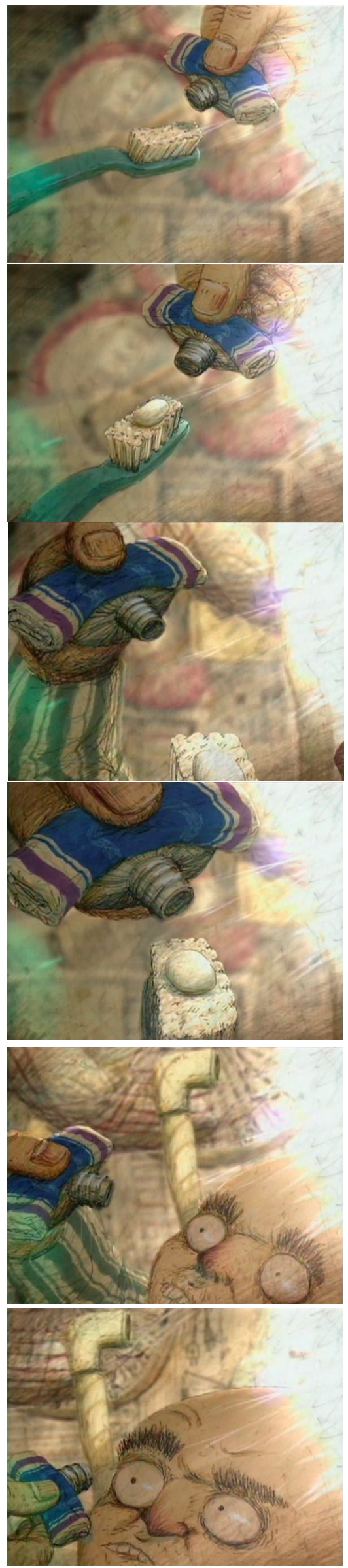

Fig. 13. Koji Yamamura (1984). Atama Yama (Monte Cabeza). Serie de fotogramas. 

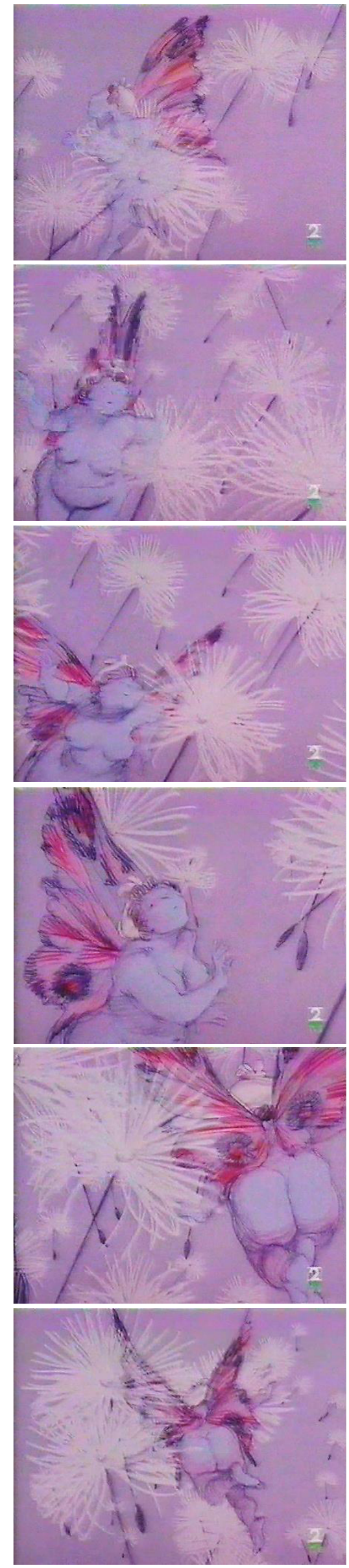
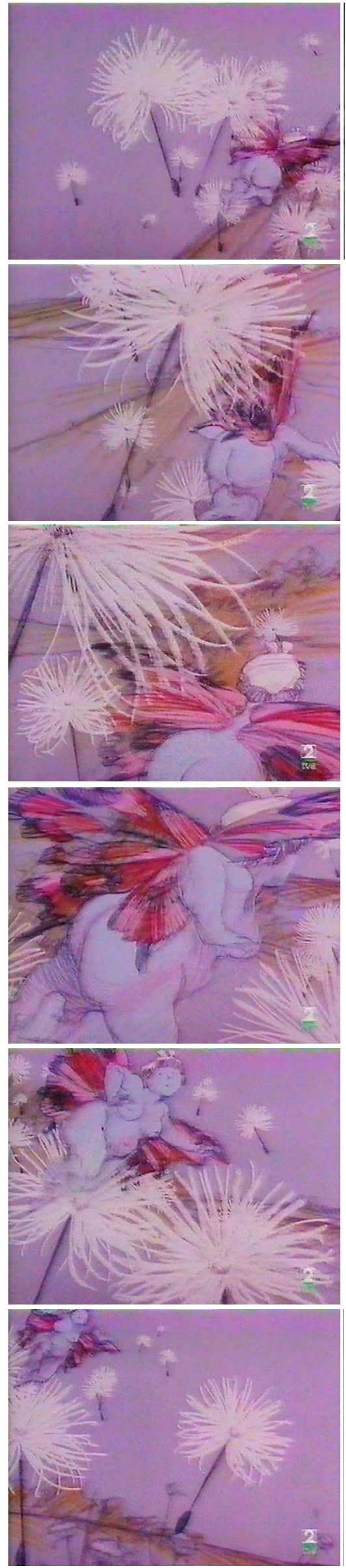

Fig. 14. Jimmy

T. Murakami

(1996). When

the Wind

Blows (Cuando

el viento

sopla). Serie de

fotogramas. 
de estar volando con la mujer-mariposa más que estar mirando a través de sus ojos. En ambos casos el "plano subjetivo" se transforma: ya no representa la mirada del personaje, pero sigue acercando al espectador a la experiencia dinámica.

También se puede expresar el movimiento vivenciado prescindiendo totalmente del plano subjetivo. Martín Arias comenta la escena de Vertigo (Hitchcock, 1958) en que la Scottie rescata a Madeleine cuando ésta se arroja al mar cerca del Golden Gate. El autor compara los planos desde que el hombre se lanza al agua hasta que mete a la chica en el coche con los planos anteriores de la misma escena, y observa cómo se transmite el punto de vista del personaje sin que haya ningún plano subjetivo en la segunda parte de la escena, es decir, sin mostrar directamente lo que ve el personaje:

En efecto, esta serie [de planos] supone una identificación, si no desde el punto de vista visual, si desde el narrativo, como Scottie. Le seguimos, percibimos lo que él percibe: de nuevo es la narración la que, más allá de la estricta consideración formal (visual) del punto de vista, hace posible que el espectador se implique, movilizándose y moviéndose en el interior del film. ${ }^{44}$

El autor se refiere a la implicación del espectador con el conjunto de la historia narrada, pero esto mismo ocurre específicamente con el movimiento: la expresión de la vivencia dinámica trasciende el plano subjetivo. En Crac! (Back, 1981), el baile de una boda se genera por medio de movimientos de cámara que sugieren el ritmo y trayectoria del movimiento de la fiesta, más que corresponder al punto de vista de un personaje concreto (00:03:43) (Fig. 15).

La sensación cinética se obtiene a través de la conjunción de todos los elementos dinámicos de la animación, y no sólo gracias a los planos subjetivos, el punto de vista y los movimientos de cámara. Como vimos en el parágrafo anterior, retomando la reflexión de Gombrich, nuestro "sentido interno" tiende a exagerar, a sentir notablemente los pequeños movimientos (como mover la punta de la nariz hacia abajo $)^{45}$. Reflejar estas sensaciones cinéticas exageradas respecto a la realidad y que nos son sugeridas por la percepción del movimiento en primera persona, sin observarlo desde fuera, supone expresar el movimiento como vivenciado. En Flux (Chris Hinton, 2001) [en DVD] encontramos la materialización plástica de esta idea. La mujer llora ante la marcha de su hija, llanto en el que la nariz experimenta una notable transformación sustancial: se deforma, se vuelve húmeda y blanda, y cambia de color (00:03:43) (Fig. 16). También en I'm Fine Thanks (Estoy bien, gracias) (O’Neill, 2011) encontramos un ejemplo de expresión de sen-

\footnotetext{
${ }^{44}$ Arias \& Martín, 1997, pág. 64

${ }^{45}$ Ver parágrafo 1.2.1., pág. 55
} 
saciones internas que, vistas desde fuera, apenas tienen movimiento: la tensión emocional del protagonista se hace evidente por medio del cambio sustancial de su cabeza. La alteración de forma, tamaño y color se da entre fotogramas consecutivos, provocando un movimiento óptico que transmite malestar (Fig. 19).

En la campaña Got Milk? (¿Tomas leche?) (Krumme, 1996), vemos una representación muy audaz del "sentido interno": las sensación de no poder tragar bien la comida se hace visual por medio de la animación: diversos personajes tragan comidas más o menos secas, la necesidad física de acompañar con líquido la comida (para promover el consumo de leche; el motivo de la campaña) se plasma con la transformación de los personajes en la forma del alimento ingerido (Fig. 17 y 18).

Las exageraciones retóricas y metáforas a veces expresan sensaciones dinámicas, por ejemplo, ante una sorpresa, los ojos se salen de sus órbitas, o cuando nos duele la cabeza, parece que nos va a estallar. Hay muchas otras expresiones que aluden al movimiento: ojos como platos, correr como un rayo, veloz como el viento, correr como alma que lleva el diablo, zigzagueante como un relámpago, ser un torbellino, ver las estrellas, un hormiguero de gente, etc. Estas exageraciones y metáforas son, en ocasiones, el punto de partida de la expresión del movimiento como vivenciado, ya que tienen en común que resaltan con fines expresivos la vivencia dinámica. No obstante, la representación literal de estas metáforas no es infaliblemente expresión del movimiento como vivenciado. Así, en la animación Hände weg! (Manos fuera) (Alkabetz, s/f) cuando unos chicos abuchean a otro, de sus bocas salen manchas negras que rodean la cabeza del niño (Fig. 20). En este caso el malestar del niño se comprende por la representación metafórica del humo negro que lo envuelve, más que por el dinamismo de los hechos, los cuales se presentan rápidamente, como un artículo más en el catálogo de agresiones en el que se inserta la escena, sin llegar a transmitir el daño que causa. Así mismo, en How to kiss (Cómo besar) (Plymton, 1995) encontramos una representación literal de la metáfora "fundirse en un beso", pero la expresión móvil de la acción es tan distante de la sensación de fusión, que tan sólo identificamos el significado de lo que representa. Y en Who framed Rogger Rabbit? (¿Quién engañó a Roger Rabbit?) (Zemeckis, 1988), se da imagen a la metáfora "clavar la mirada" por medio de la metamorfosis de los ojos de un personaje en puñales (01:26:26) (Fig. 21). La evolución de los ojos en puñales evidencia la agresividad de la mirada, pero no la hace más violenta; de hecho, la fuerza de la mirada se percibe con mayor intensidad instantes antes, a través de los ojos saltones. Así pues, la representación icónica de la metáfora no basta para expresar el movimiento vivenciado si ésta no está acompañada de la impresión dinámica a la que hace referencia. 

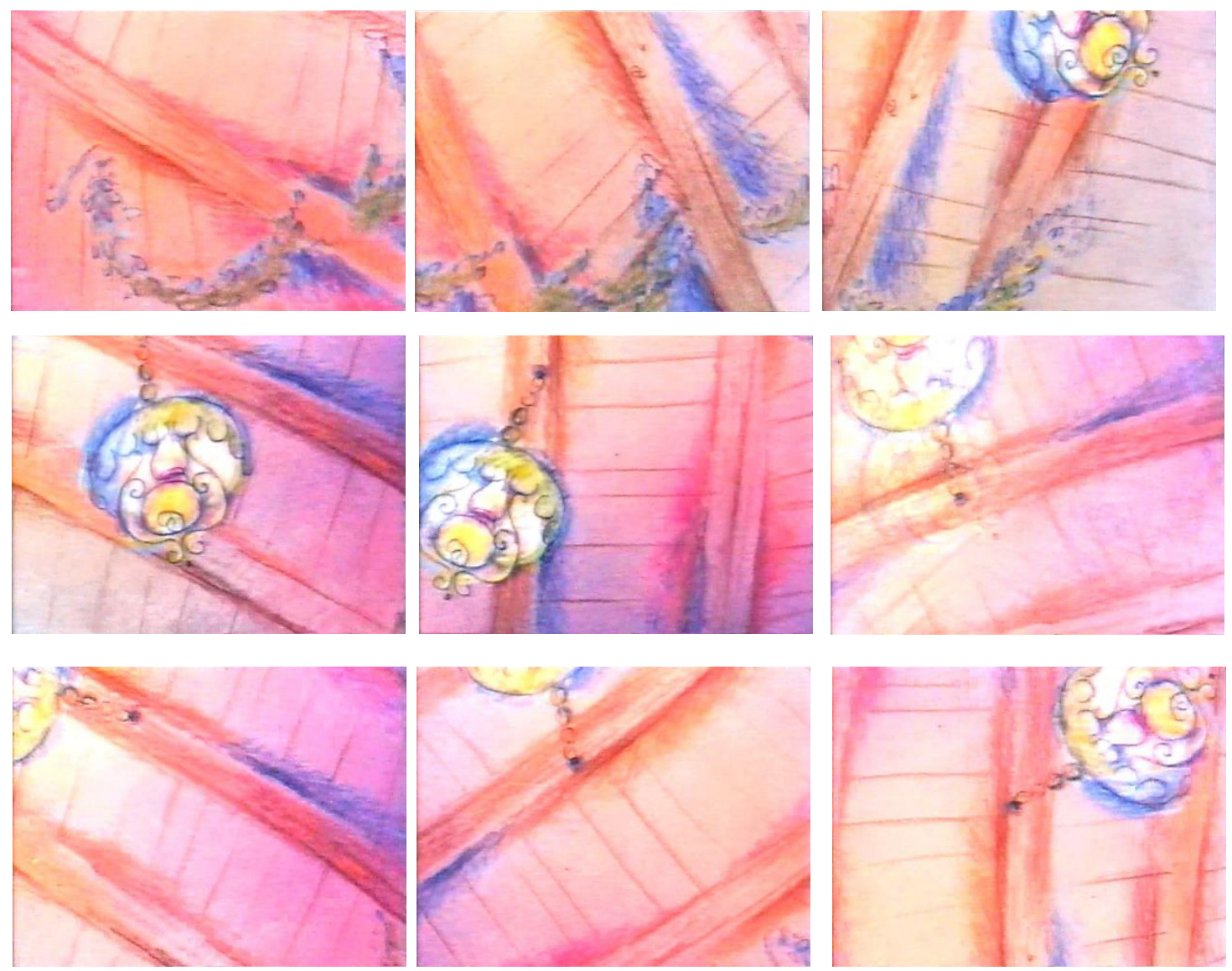

Fig. 15. Frédéric Back (1981). Crac! Serie de fotogramas.
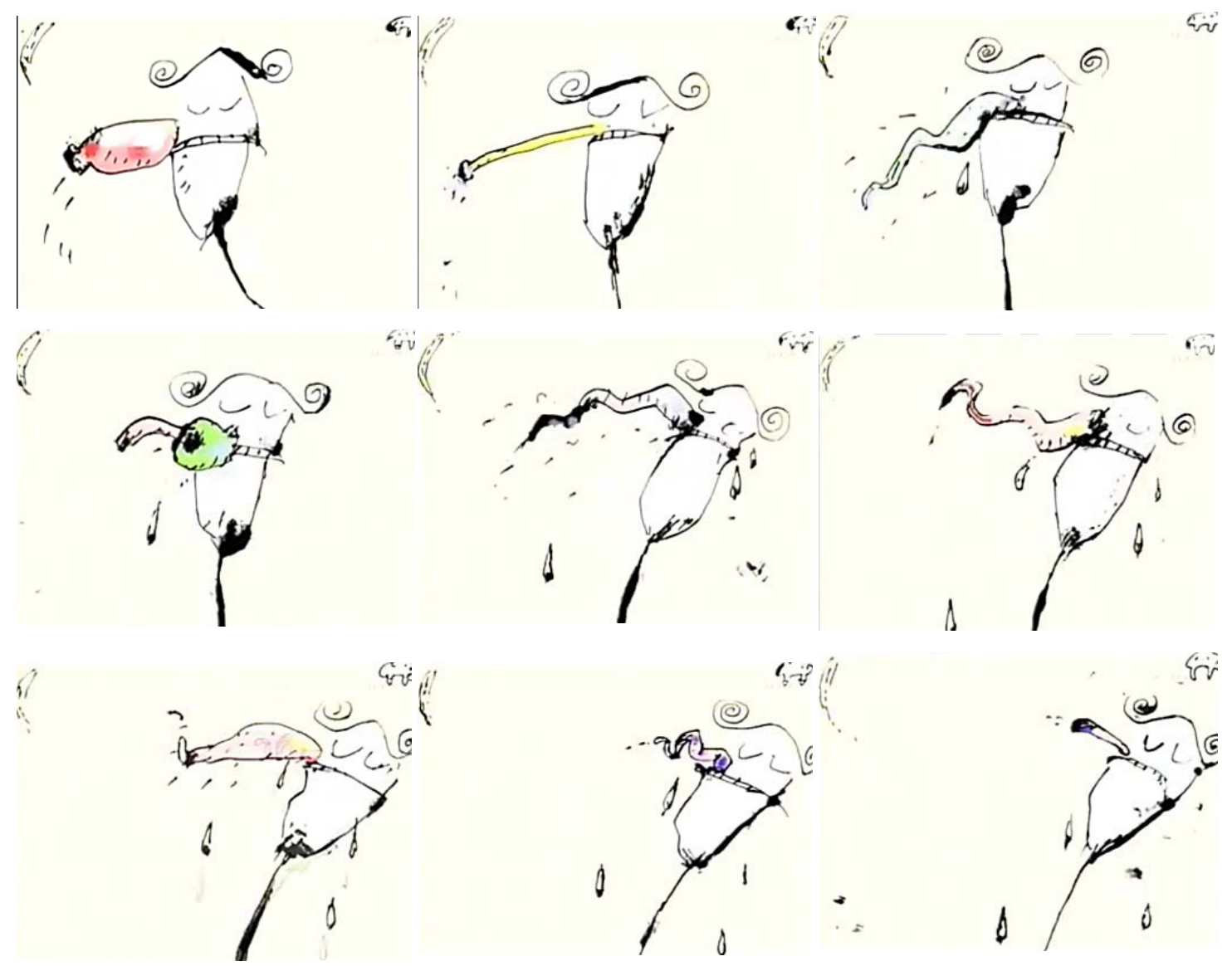

Fig. 16. Chris Hinton (2002). Flux. Fotogramas consecutivos. 

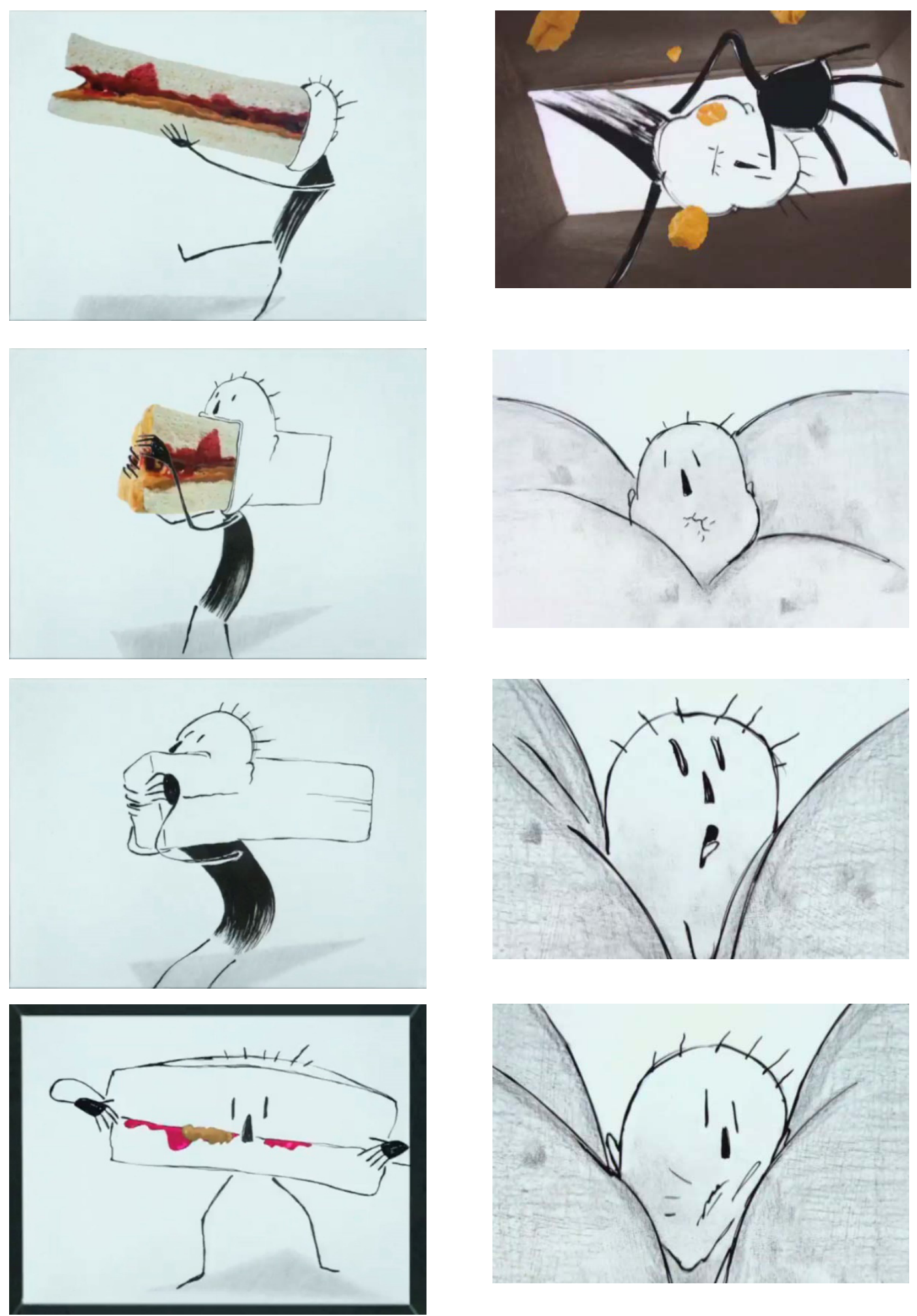

Fig. 17. Raimund Krumme (1996). Sandwich, comercial para la campaña publicitaria Got Milk? para California Milk Processor Board. Serie de fotogramas.

Fig. 18. Raimund Krumme (1996). Flakes, comercial para la campaña publicitaria Got Milk? para California Milk Processor Board. Serie de fotogramas. 

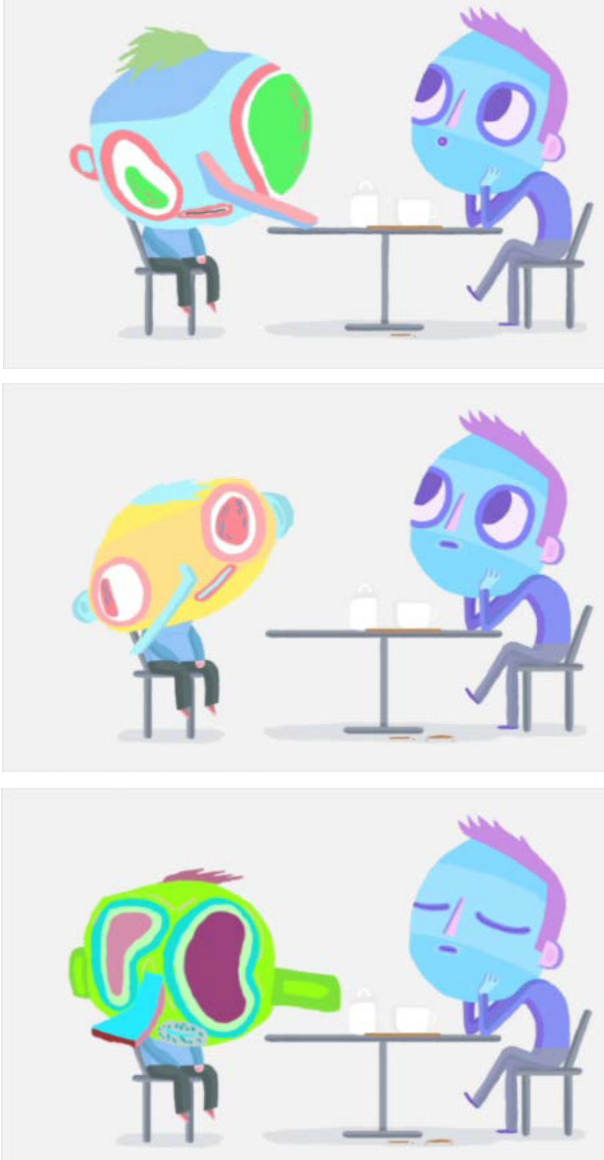
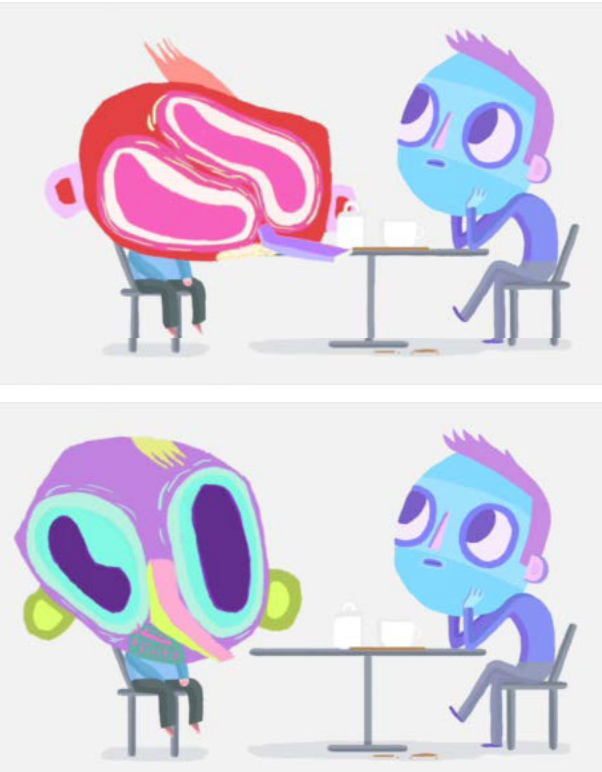

Fig. 19. Eamonn O’Neill (2011).

I'm Fine Thanks (Estoy bien, gracias).

Fotogramas consecutivos.

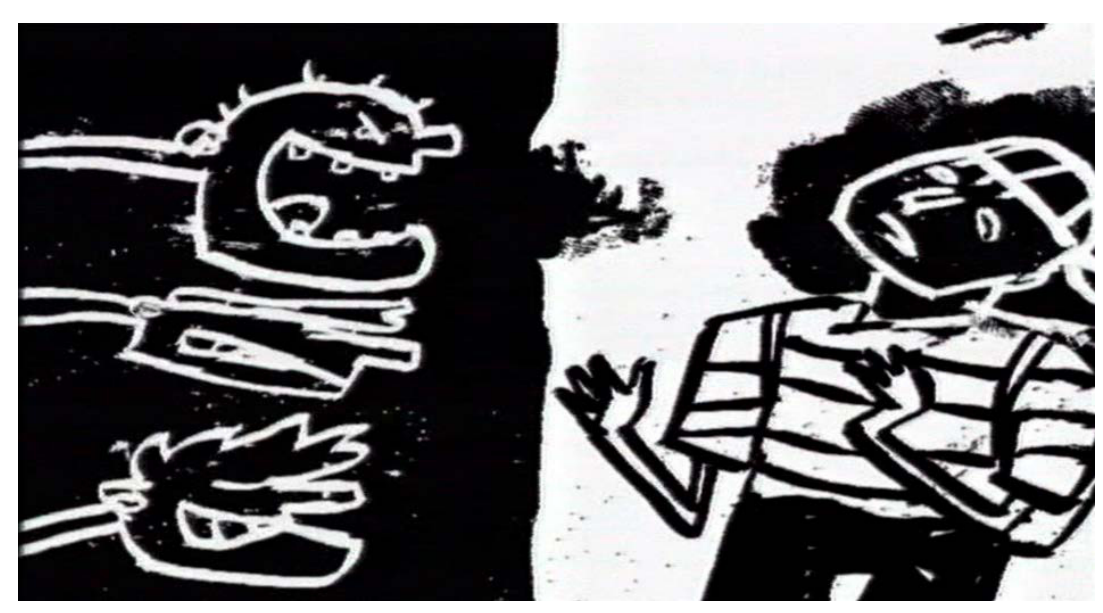

Fig. 20. Gil Alkabetz

(S/F). Hände weg!

(iManos fuera!).
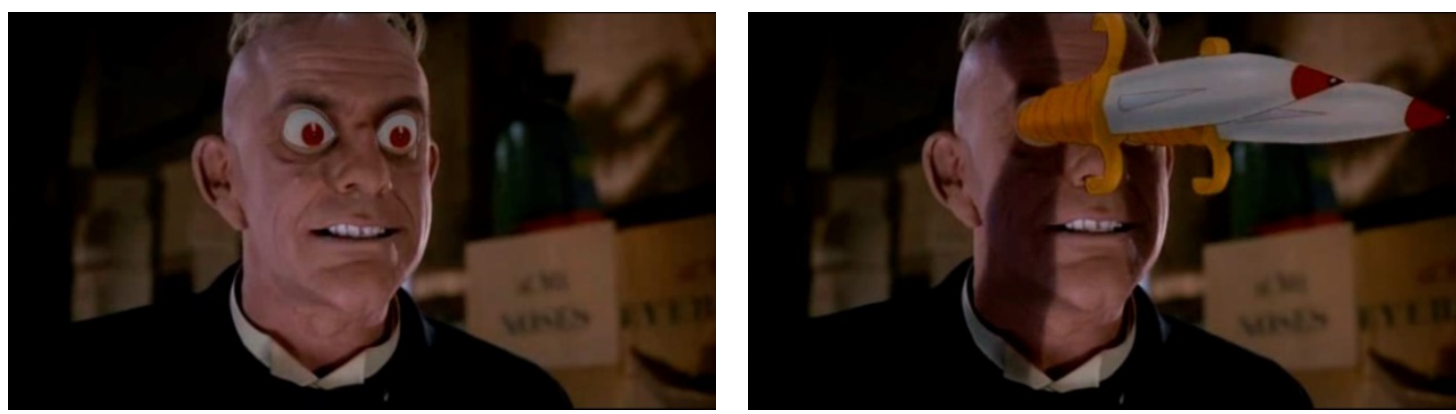

Fig. 21. Robert Zemeckis (1988). Who Framed Roger Rabbit? (¿Quién engañó a Roger Rabbit?). Serie de fotogramas. 
Para que la representación de metáforas e hipérboles en animación expresen el movimiento vivenciado, éstas deben transmitir las características cinéticas que la figura retórica resalta. Así, en Fumiko no Kokuhaku (La confesión de Fumiko) (Ishida, 2009) [en DVD] el movimiento es vivenciado tanto por la exageración retórica de los acontecimientos representados como por sugerir la sensación de velocidad y caída. Una adolescente corre cuesta abajo como consecuencia de un tropiezo; en el descenso, salta por encima de casas y vuela como un proyectil. La aceleración progresiva y la cada vez mayor longitud de las distancias que la chica sobrevuela intensifican la impresión de velocidad. Además de la hipérbole, la película incluye planos bastante largos en los que se muestra "en primera persona" lo que la protagonista ve (Fig. 22). En Rame Dames (Guiol, 2010) las personas viajan en el metro apretadas unas contra otras; la presión hace que se deformen e incluso que se disuelvan en una masa líquida, como una corriente que se desplaza entrando y saliendo del tren. La comparación se transforma en metáfora al representar literalmente una ola de agua que sale a presión del tren (00:01:52) (Fig. 23). Cuando recuperan su forma humana, las personas mantienen el mismo movimiento lento y unificado del líquido, por lo que comprobamos que la comparación se extiende al movimiento de las personas fuera del tren y no se restringe a un juego visual aislado dentro de la película.

Así mismo, una animación con movimiento vivenciado sugiere el dinamismo de los acontecimientos observados desde fuera, es decir, se puede centrar en transmitir las sensaciones dinámicas que sugiere el movimiento al ser contemplado en lugar de cuando se experimenta en primera persona, despertando, igualmente, sensaciones cinéticas. De este modo, los patitos recién nacidos en The owl who married a guss (La lechuza que se casó con un ganso) (Leaf, 1974) se mueven con la fragilidad y alegría que transmiten estas aves; no es una representación que se corresponda con el movimiento real, sino que prioriza la sensación cinética que evocan: cuello estirado, y alitas y patitas inquietas. Los personajes danzantes de Carnival (Young, 1986) (Fig. 24) se muestran al espectador por medio de un plano que no representa la mirada de otro personaje, es decir, no es un plano subjetivo; sin embargo, estos personajes se mueven de tal forma que provocan sensaciones dinámicas que exceden la contemplación del baile (00:01:16). A menudo es difícil determinar cuándo se expresa el movimiento como experimentado o simplemente contemplado, ya que, en todos los casos, para expresar el movimiento como vivenciado es necesario interiorizarlo, ya sea por medio de la experiencia personal o por la introspección (como ejercicio de imaginación). Por ejemplo, el movimiento de un caballo (o de cualquier otro animal) no puede ser experimentado más que por el propio animal, sin embargo, un ejercicio de introspección puede 

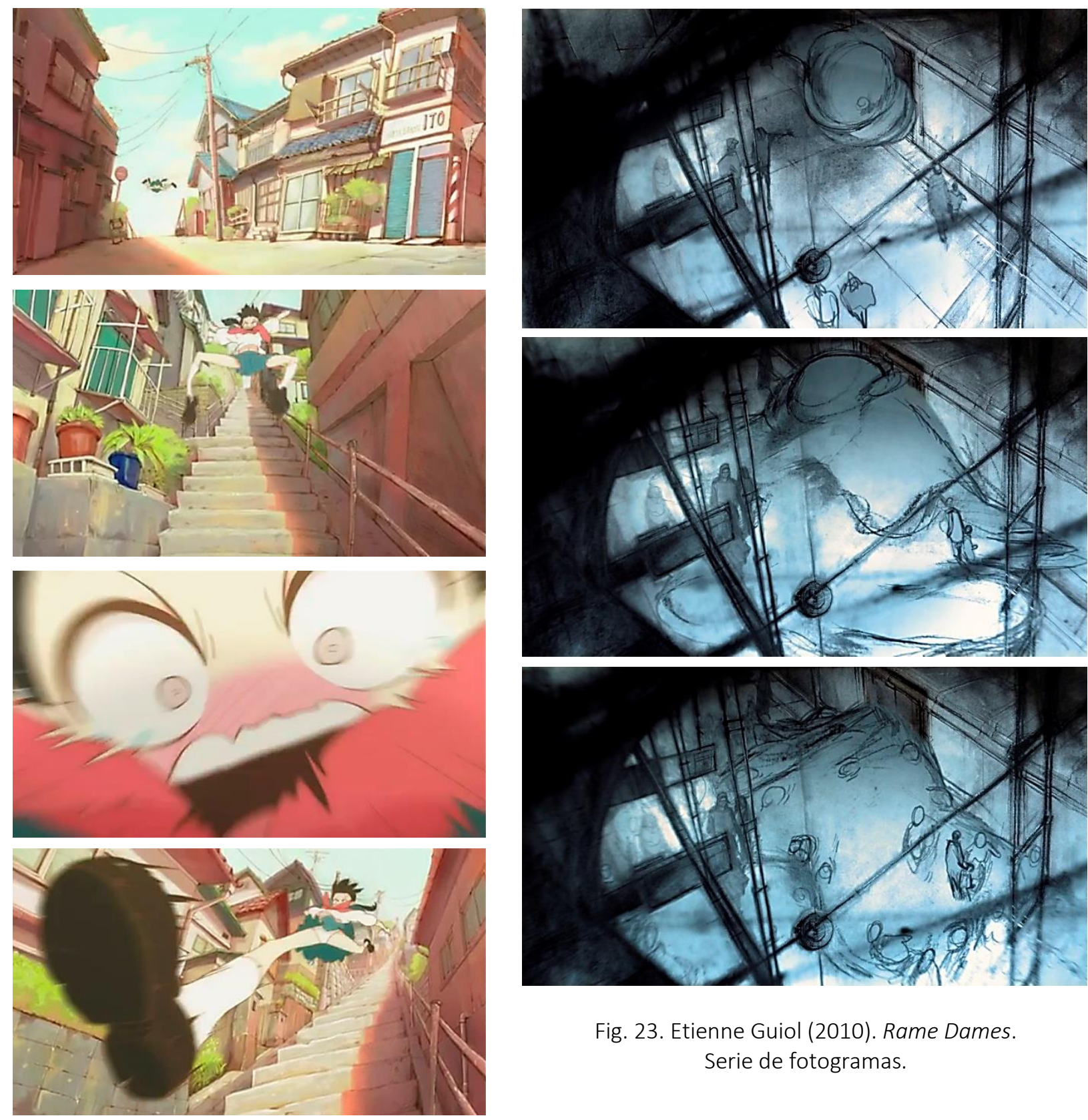

Fig. 23. Etienne Guiol (2010). Rame Dames. Serie de fotogramas.
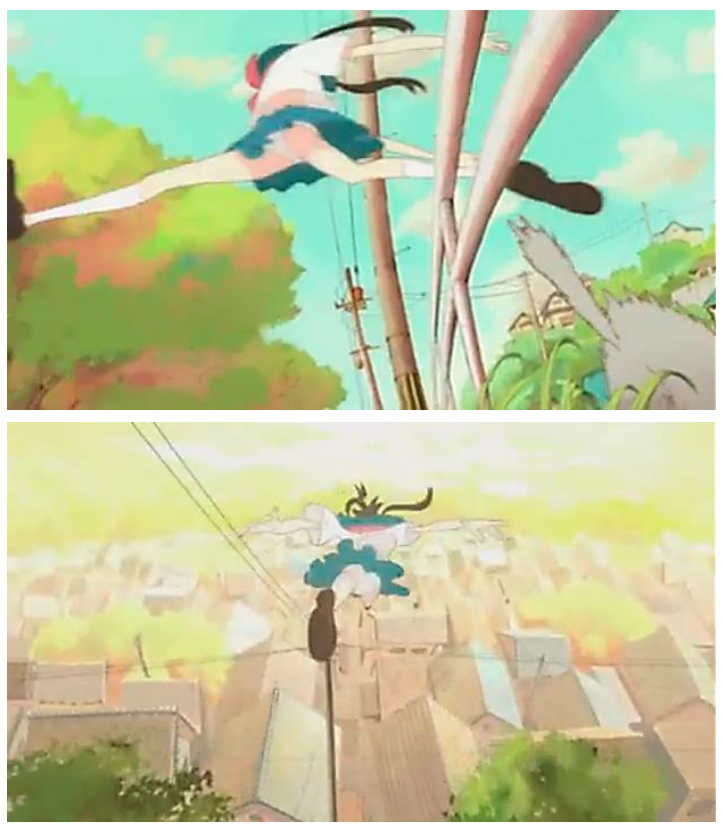

Fig. 22. Hiroyasu Ishida (2009). Fumiko no Kokuhaku (La confesión de Fumiko). Serie de fotogramas. 

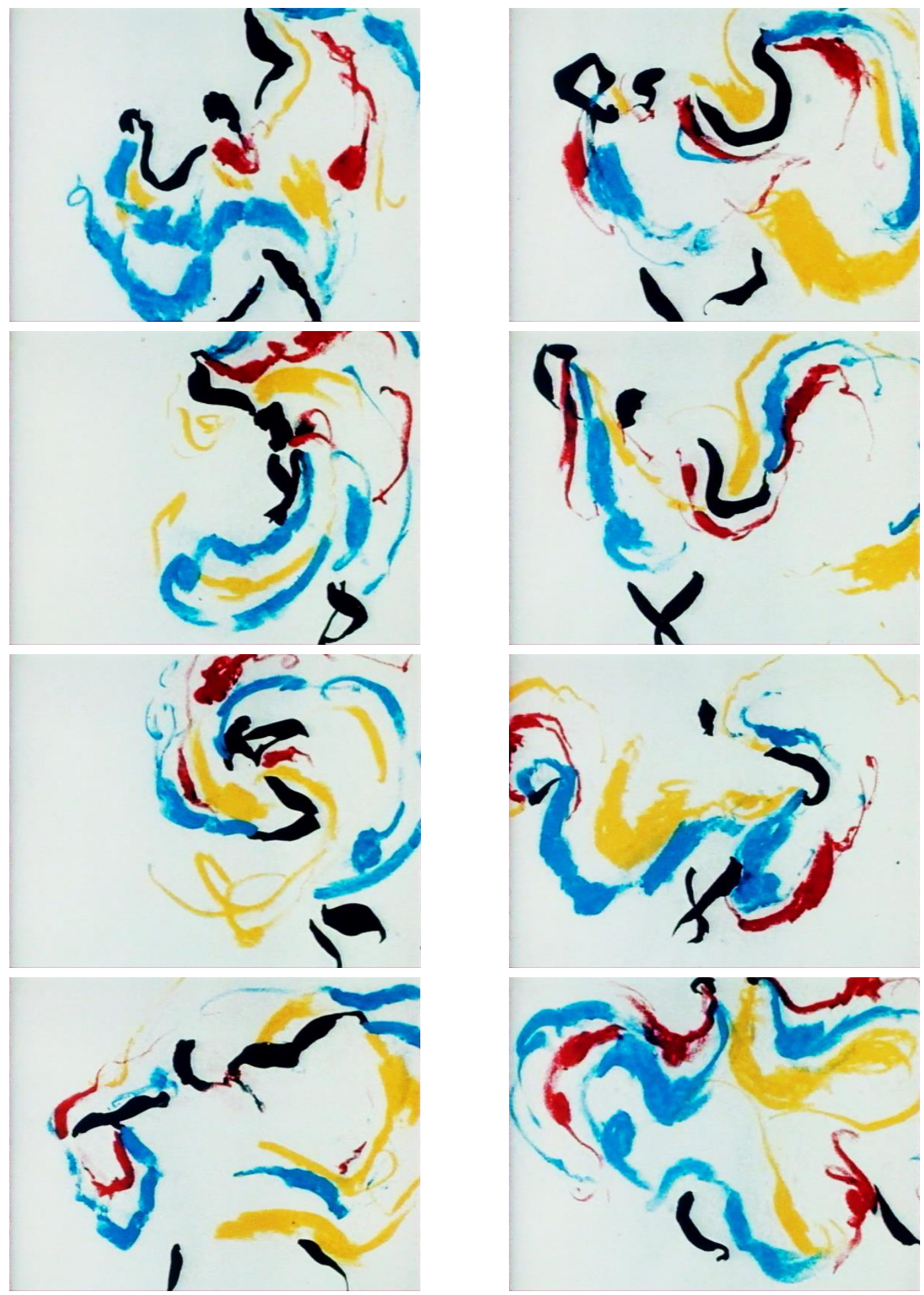

Fig. 24. Susan Young (1986). Carnival (Carnaval). Serie de fotogramas.

ayudar a imaginar el ritmo o la potencia de su movimiento. Transmitir precisamente estas cualidades dinámicas es expresar el movimiento como vivenciado. 
En resumen, una de las características del movimiento vivenciado en animación es que la película transmite sensaciones cinéticas que han sido vividas personalmente, imaginadas, o sugeridas por la observación del movimiento; y esto puede representarse en pantalla ya sea mediante planos subjetivos o no, exageraciones retóricas y metáforas o la visualización de sensaciones internas.

\title{
B. EXPRESIÓN DE CARACTERÍSTICAS PARTICULARES DEL MOVIMIENTO
}

Otra característica de la expresión del movimiento vivenciado en animación es que transmite características particulares de las acciones y sucesos representados. La expresión del movimiento no se delimita a plasmas las cualidades básicas de la acción (dirección, sentido, velocidad y aceleración) sino que introduce el carácter subjetivo: sensación de rapidez, de suavidad, brusquedad...cualidades de la experiencia personal que puede incluso estar relacionadas con las emociones, no sólo con la experiencia cinestésica). La animación con esta cualidad, al hacer alusión a la vivencia subjetiva del movimiento, evoca la sensación cinética que se experimenta al vivirlo o al observarlo, y puede presentar cualidades emocionales. Pero no hay una manera específica para expresar cada movimiento o connotaciones emocionales subjetivas de su experiencia, ya que, como dice Arnheim al hablar del cine:

\begin{abstract}
No existe fórmula que ayude a escoger el aspecto más característico de un objeto: se trata de una cuestión de sensación. Que determinada persona sea «más ella misma» de perfil que de frente, que la palma o el dorso de la mano sea más expresivo, que se capte mejor determinada montaña desde el Norte o el Oeste no son cosas que se puedan averiguar matemáticamente: son cuestiones de sensibilidad delicada. $^{46}$
\end{abstract}

De la expresión de características particulares de la vivencia del movimiento se deriva una gran diversidad de representaciones. Al comparar el mismo acontecimiento en dos películas diferentes vemos la diferencia entre dos maneras de presentar el movimiento; en cada una de ellas destaca una característica singular de lo acontecido. En Le fleuve aux grandes eaux (El poderoso río) (Back, 1993) (00:09:37) (Fig. 25) y en O Človíčkovi (El hombrecito) (Lamka, 1985) (00:04:55) (Fig. 26), vemos una manada de ciervos corriendo. En la primera, a pesar de generar un movimiento global, se advierte el movimiento de cada animal, mientras que en El hombrecito los ciervos se desplazan como una sola pieza, resultando un movi-

\footnotetext{
${ }^{46}$ Arnheim, 1957, pág. 20
} 
miento más regular. A parte de estas diferencias en cuanto a la unidad del fenómeno y siendo muy diferentes en su estética, en ambos casos se transmite su evolución dinámica. En el primero hay un mayor análisis del movimiento del fenómeno, mientras que el segundo es más sintético.

Otros dos ejemplos en los que se extraen cualidades diferentes de un fenómeno similar son: en Stressed (Kelly, 1994) y en Rhapsody in Blue (pasaje de Fantasía 2000 -Goldberg 1999) se da imagen a masas de gente saliendo por lugares estrechos. En ambos ejemplos, la característica resaltada del suceso es la fuerza, velocidad y violencia dinámica con la que el grupo de personas sale por una puerta. En la primera se expresa el suceso como fenómeno unitario, en el que el individuo desaparece en el conjunto (00:04:48) (Fig. 28); en la segunda, el hecho se describe por medio de la yuxtaposición del movimiento de las figuras individuales, pero resaltando la composición general del grupo: su dirección excéntrica y el avance hacia primer plano (00:03:51) (Fig. 27). Esto significa que transmitir características particulares no implica que las representaciones se amalgamen en resultados similares. En Rhapsody in Blue se representa también un grupo de personas saliendo del metro, sin embargo, en esta escena se ha destacado una propiedad dinámica opuesta a la de los dos casos anteriores: la gente sale como un único bloque, pero alegre y ordenado (00:03:51) (Fig. 29); se ha resaltado la comicidad de la unificación de los individuos en un solo "cuerpo", dejando en un segundo plano la confusión propia de la acción. Debido a otros factores como la composición del movimiento en la pantalla y la intensidad cinética, la expresión del movimiento en el tercer caso no sugiere cinestesia con la misma intensidad que en los otros.

En Les douze travaux d'Astérix (Goscinny, Gruel y Watrin, 1976) y Astérix et la surprise de César (Gaëtan Brizzi y Paul Brizzi, 1985) se presentan dos escenas cuya composición es prácticamente igual; Se trata de una pelea entre los aldeanos galos contra las tropas romanas. A pesar de la similitud, contrasta la manera en que se ha representado el mismo acontecimiento: la batalla en segundo plano. En el primer caso, la batalla se representa como un fenómeno en el que es imposible distinguir las personas y sus acciones individuales (00:06:45) (Fig. 30). En el segundo caso, la acción de la masa se resume en una detallada silueta en la que se aprecian individuos y acciones concretas (00:21:27) (Fig. 31). A pesar de la especificación de las acciones de la batalla del segundo caso, la primera muestra confusión y velocidad, características peculiares de la batalla, por lo que el movimiento resulta vivenciado. 

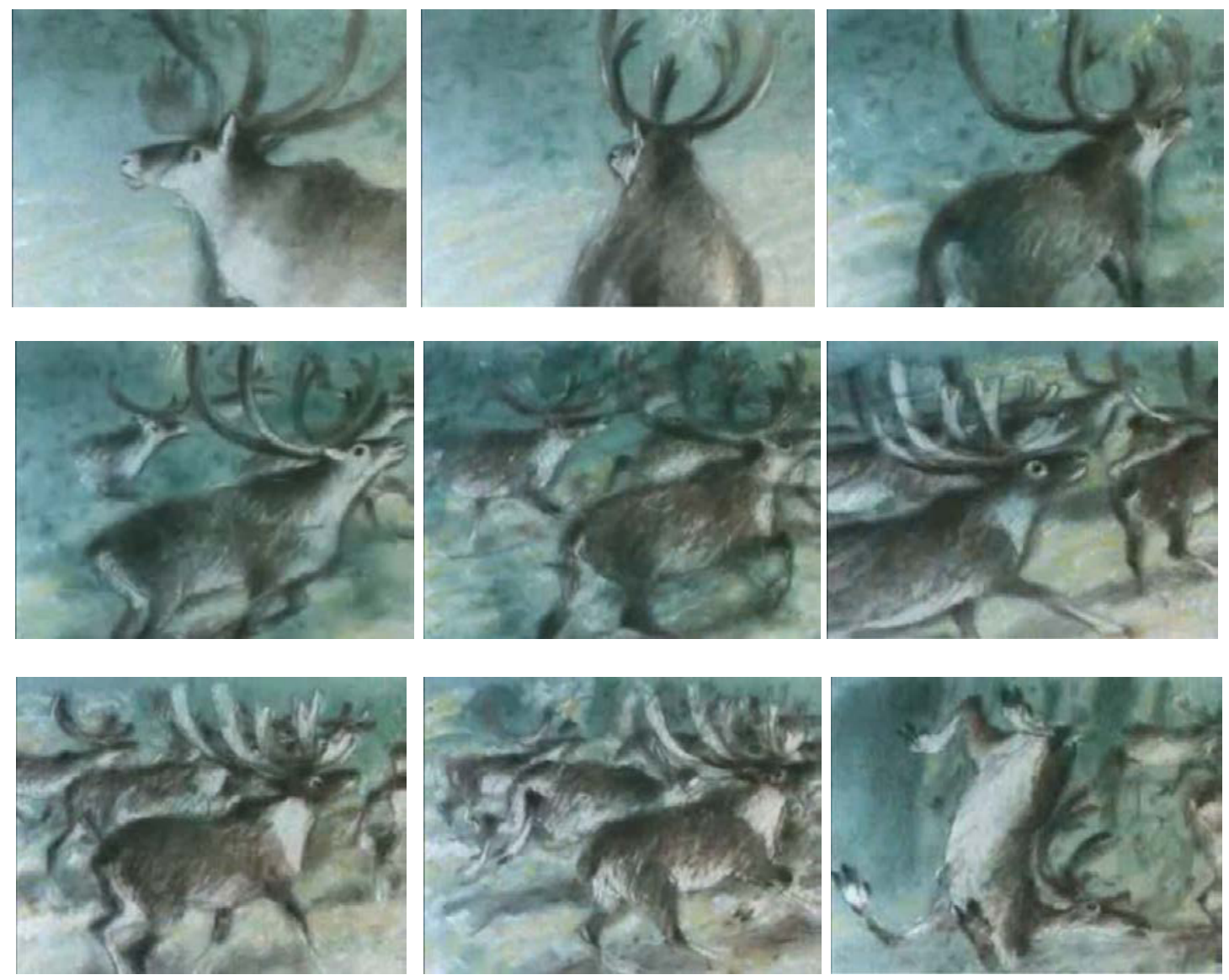

Fig. 25. Fréderic Back (1993). Le fleuve aux grandes eaux (El poderoso río). Serie de fotogramas.
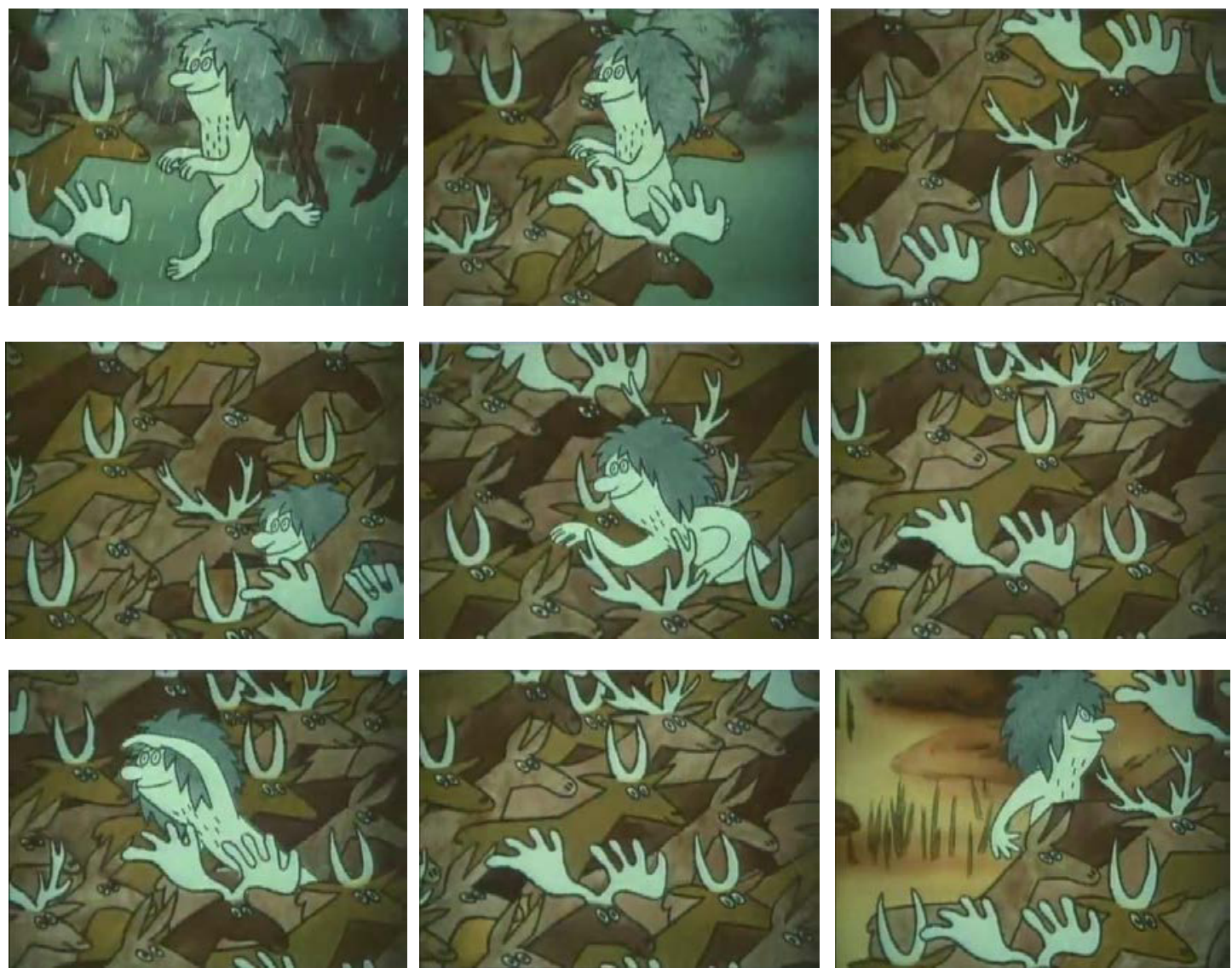

Fig. 26. Josef Lamka (1985). O Človičkovi (El hombrecito). Serie de fotogramas. 

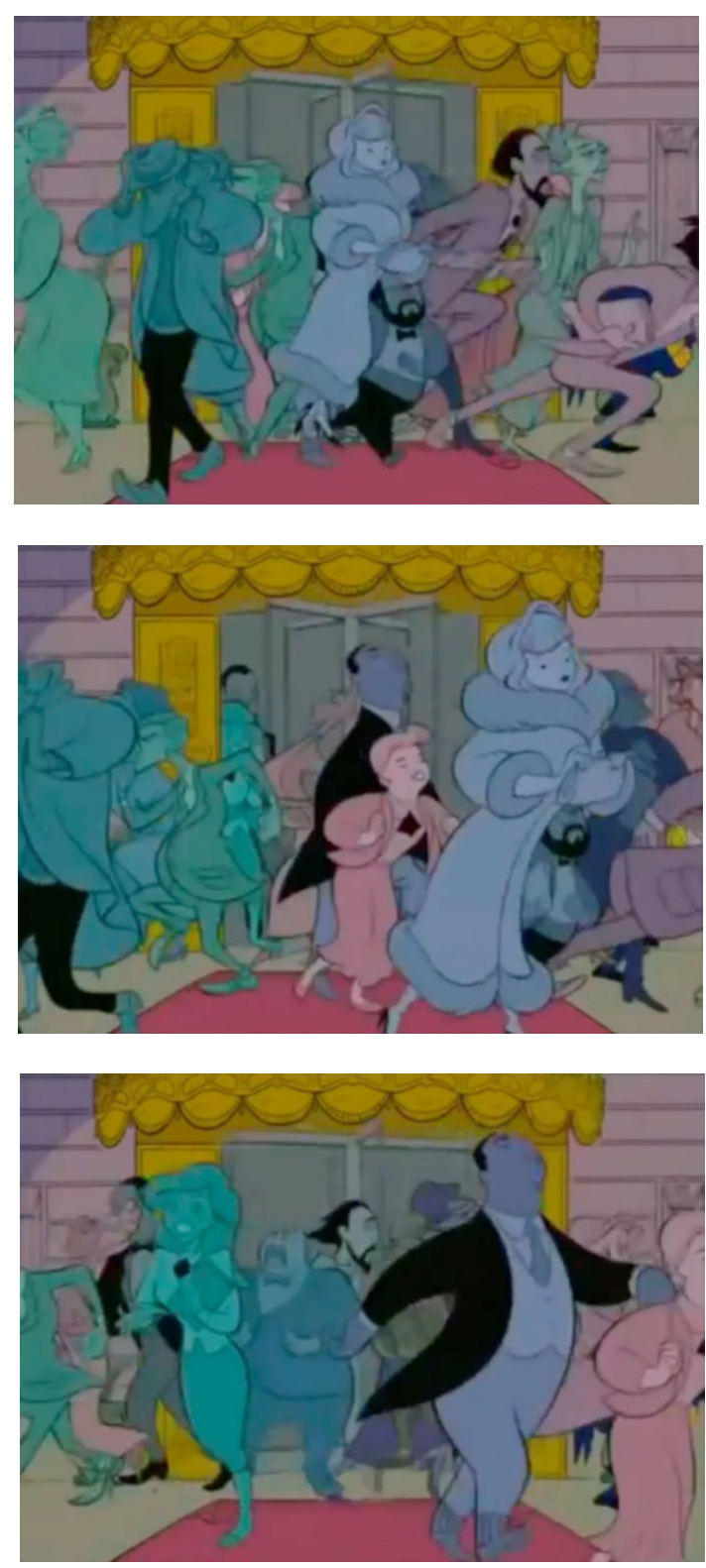

Fig. 27. Eric Goldberg (1999). Rhapsody in Blue; Fantasia 2000. Serie de fotogramas.

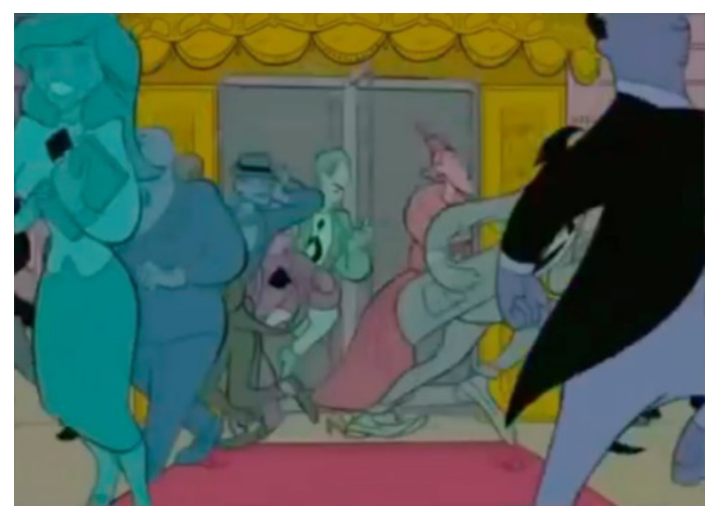



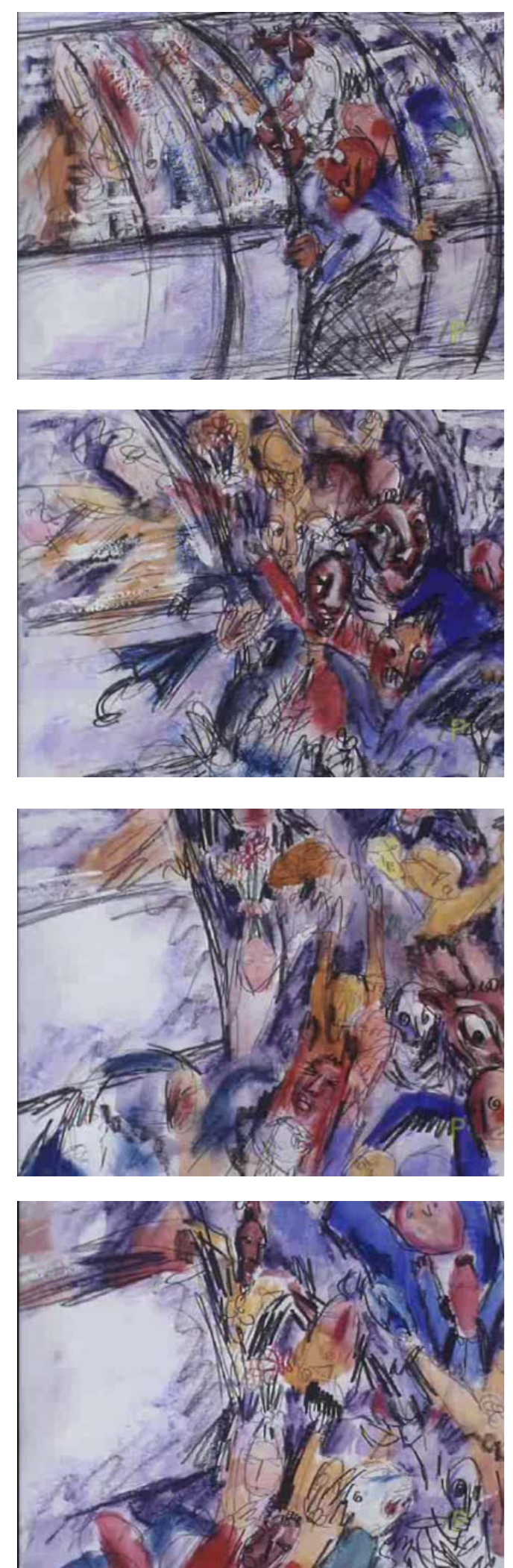

Fig. 28. Karen Kelly (1994). Stressed (Estresados). Fotogramas consecutivos.
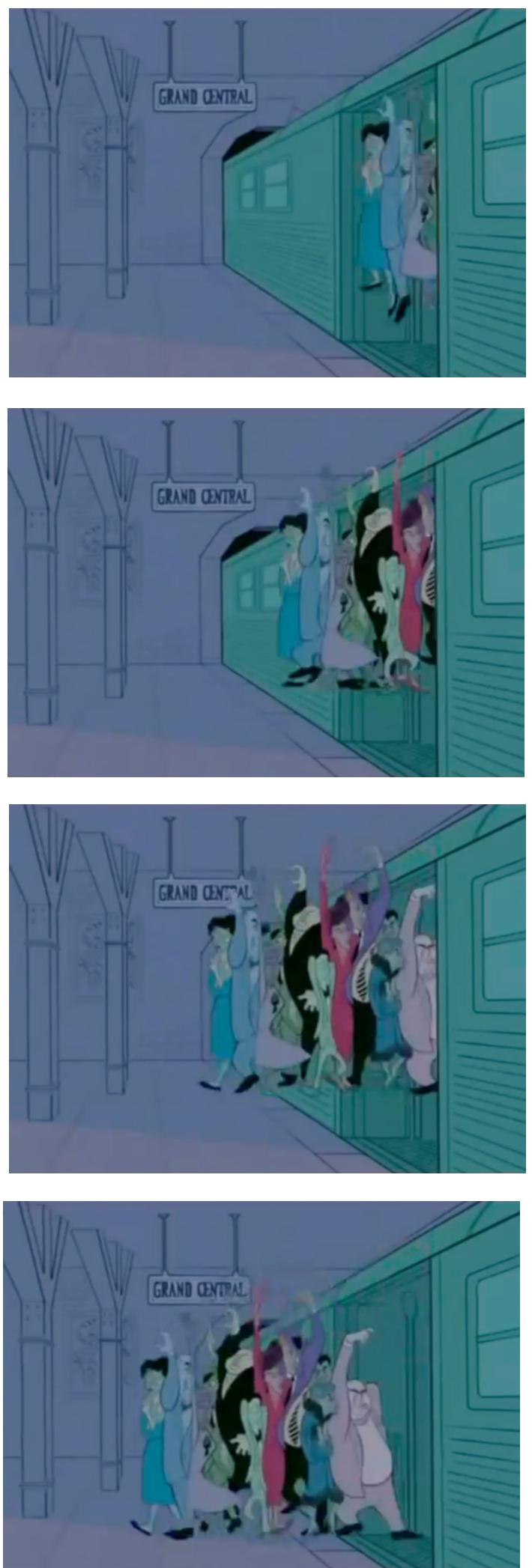

Fig. 29. Eric Goldberg (1999). Rhapsody in Blue; Fantasia 2000. Serie de fotogramas. 

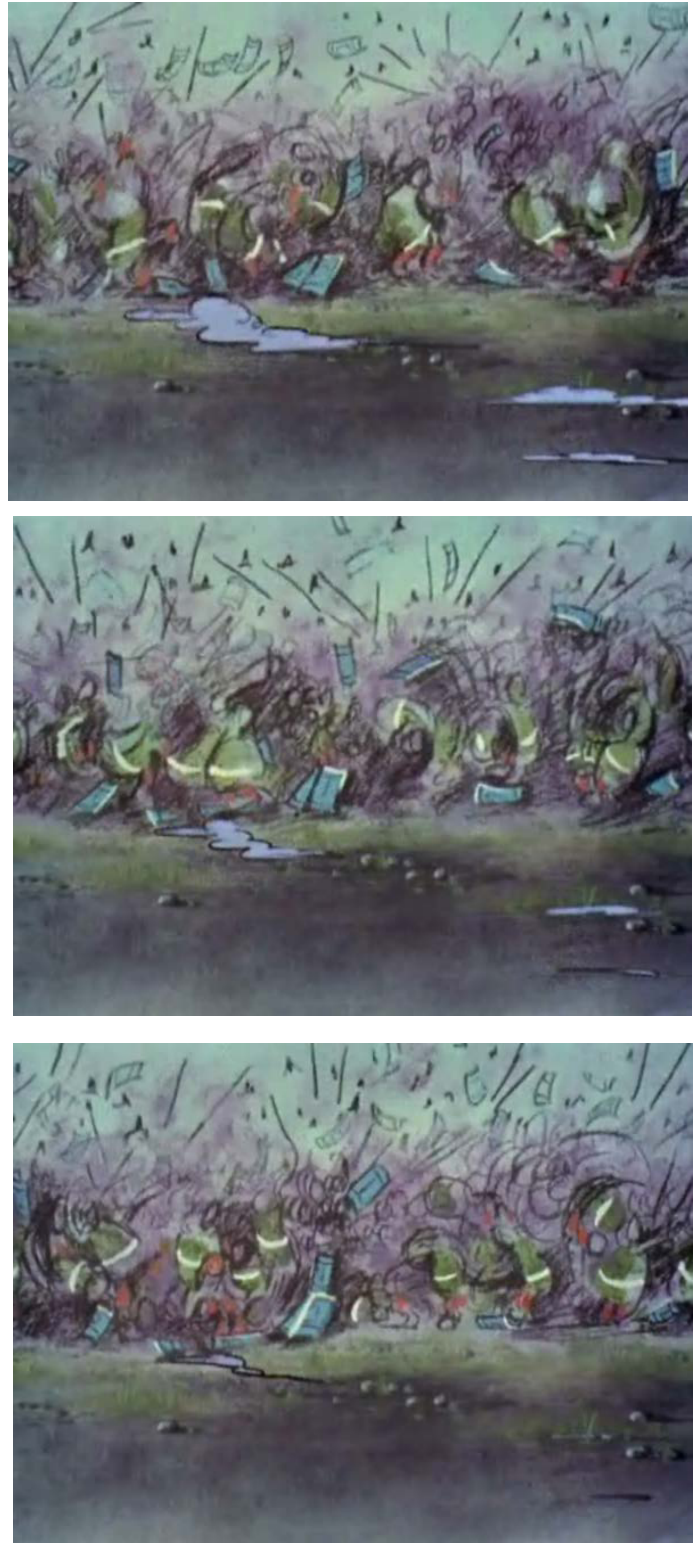

Fig. 30. René Goscinny; Henri Gruel; Albert Uderzo; Pierre Watrin (1976). Les douze travaux d'Astérix (Las doce pruebas de Asterix). Fotogramas consecutivos.
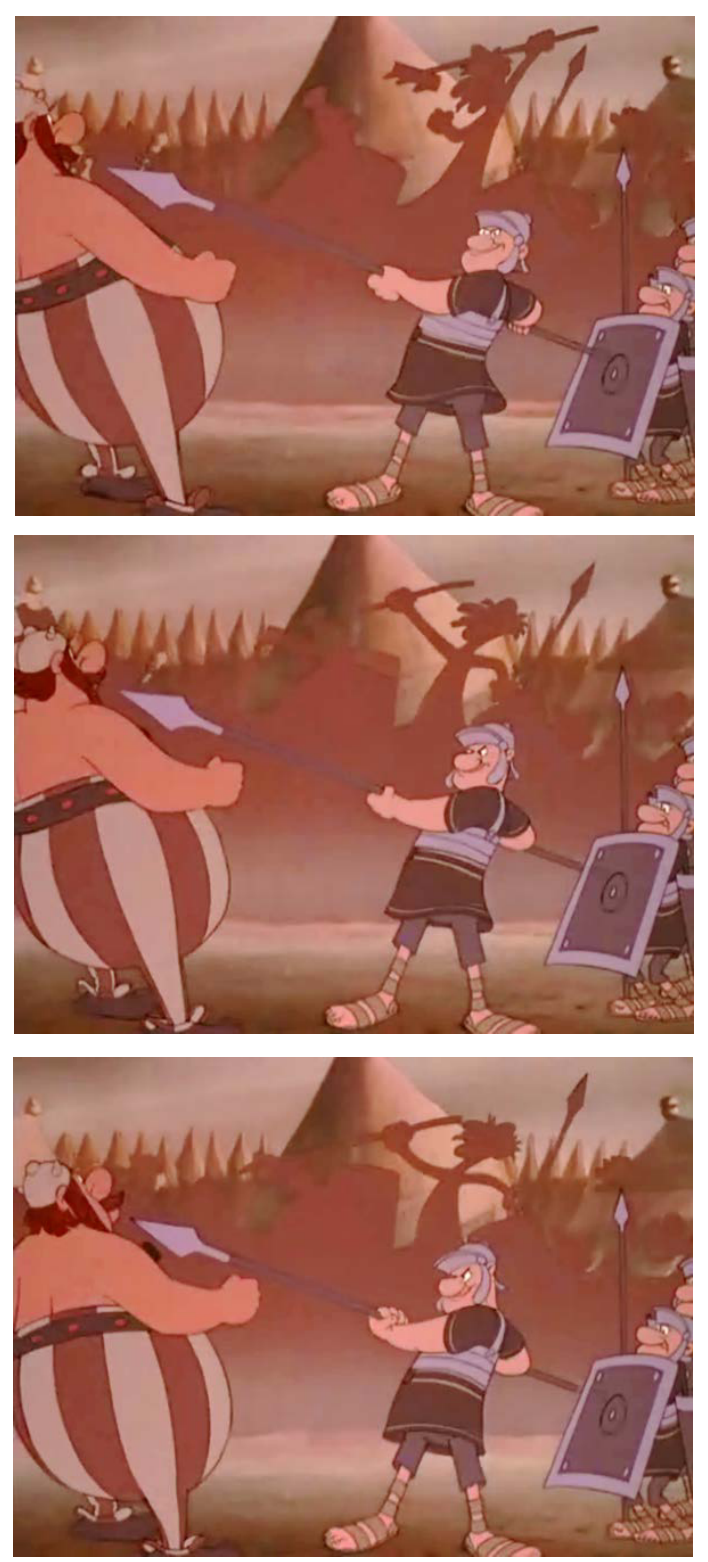

Fig. 31. Gaëtan Brizzi, Paul Brizzi (1985). Astérix et la surprise de César (Asterix y la sorpresa del César). Fotogramas consecutivos.

\section{LOS ACONTECIMIENTOS TIENEN LUGAR EN UN ESPACIO VIVENCIAL}

Las características anteriores implican que la acción acontezca, necesariamente, en un espacio acorde al movimiento: un espacio subjetivo cuya vivencia depende de la manera personal de relacionarse con el espacio. 
En A Little Routine (Una pequeña rutina) (George Griffin, 1994) hay representación del espacio vivencial a través de la imaginación de una niña. En la "ceremonia" de ir a dormir, un padre y su hija van desde el cuarto de baño al dormitorio. La secuencia de ellos dos en el cuarto de baño es sucedida por varios planos, por corte, en los que se les ve cómo caminan por un paisaje nocturno, atraviesan un río y ven una casita en la lejanía. Al llegar a la casia en medio de la naturaleza, y abrir la puerta, el interior de la casa es el dormitorio de la niña. Ir a la habitación, por la casa, es para ella como atravesar el bosque en la noche, es un camino hacia un lugar seguro (su habitación) rodeado de miedos (el bosque, que en compañía de su padre, está en calma, es un lugar tenebroso en potencia). Finalmente, cuando la niña se queda sola, todos esos miedos "entran" en su habitación. La representación metafórica del espacio da imagen, en este caso, al espacio vivencial como espacio de la experiencia humana y dotado de emociones. También vemos espacio vivencial en $\mathrm{Homer}^{3}$ (The Simpsons, temporada 7, capítulo 6) en el que Homer se interna en un espacio-tiempo paralelo que, por su descripción, podría ser un espacio-tiempo matemático (formado por una cuadrícula tridimensional sobre la nada negra), pero en el que se representa un espacio y un tiempo vivencial por la subjetividad que impera en este lugar aparentemente matemático; así, en este caso el espacio es vivencial sobre todo porque el conocimiento del espacio (la forma y las normas físicas de ese espacio concreto) se alcanzan por la experiencia directa (o experimentación). Así mismo encontramos una representación casi literal del espacio vivencial en L'Heure des Anges (Nightangel) (Drouin y Pojar, 1986) en la que los objetos y espacios aparecen cuando el personaje ciego los toca. Los objetos se mueven con vida propia e incluso atacan al hombre, que es lo que le parece al ciego cuando pierde la orientación; muy similar es la figuración del mundo para un niño sin vista en Private Eyes (Ojos privados) (Lemany, 2011).

En animación el espacio vivencial tampoco carece necesariamente del eje vertical y el plano horizontal que permiten reconocer lo que está arriba y lo que está abajo ${ }^{47}$; sin embargo, la descripción geométrica puede ser ineficaz para definir su cualidad vivencial. En animación podemos reconocer el espacio vivencial a primera vista en aquellas obras en las que la representación espacial está al margen de la geometría. Sin embargo, ésta no es su característica principal. Los acontecimientos que en él tienen lugar, por sus propiedades dinámicas, permiten recono-

\footnotetext{
47 "Pero por mucho que me vuelva y gire, el eje vertical permanecerá invariable y por él está determinado el plano horizontal. Lo que es delante, el punto de dirección en particular, es mutable, pero el plano como tal es invariable. De ese modo podemos definir, como primer y simplísimo principio estructural, que el eje vertical y el plano horizontal forman en común el esquema más simple del espacio humano concreto”. Bollnow, 1969, pág. 50
} 
cer el espacio vivencial. Por ejemplo, en Les tragèdies minuscules (Las tragedias minúsculas) (Felicioli \& Gagnol, 1999), el dibujo del espacio es abundante en líneas curvas en sustitución de las rectas, y la inclinación de los ejes vertical y horizontal es notable (Figs. 32-34). Pero además, al ver los móviles en acción, se comprende que el espacio tiene efecto sobre ellos y que no es un mero espacio aparentemente inestable en el que los personajes no sufren su naturaleza.

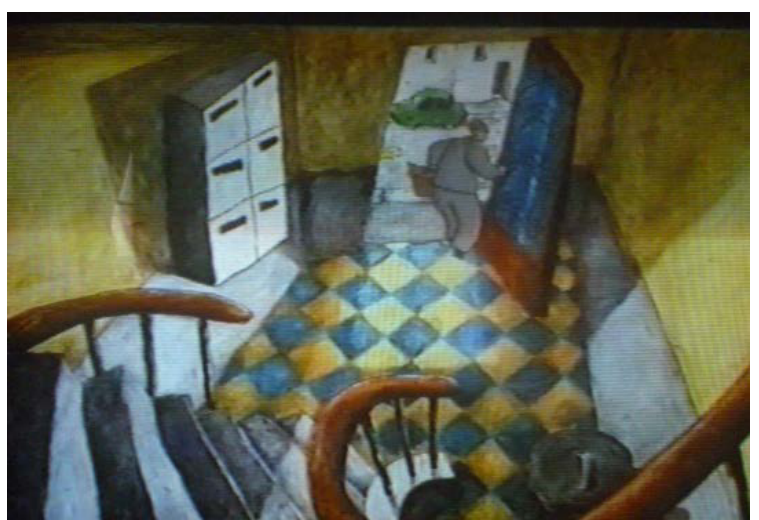

Fig. 32. Jean-Loup Felicioli y Alain Gagnol (1999). Ça aurait du être moi; Les tragédies minuscules (Debería haber sido yo; Las tragedias minúsculas).

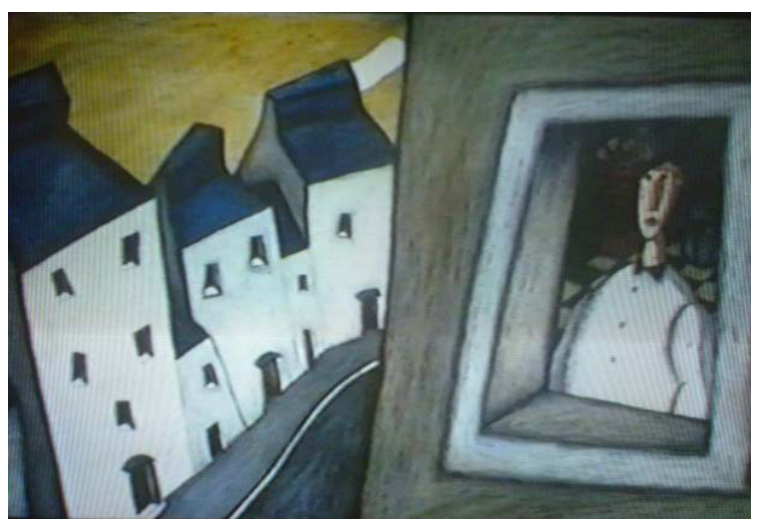

Fig. 33. Jean-Loup Felicioli y Alain Gagnol (1999). Un couteau dans les fourchettes: Les tragédies minuscules (Un cuchillo entre los tenedores: Las tragedias minúsculas).

Fig. 34. Jean-Loup Felicioli y Alain Gagnol (1999). Si tu savais ce que s'en pense; Les tragédies minuscules (Si supieras lo que pienso; Las tragedias minúsculas).

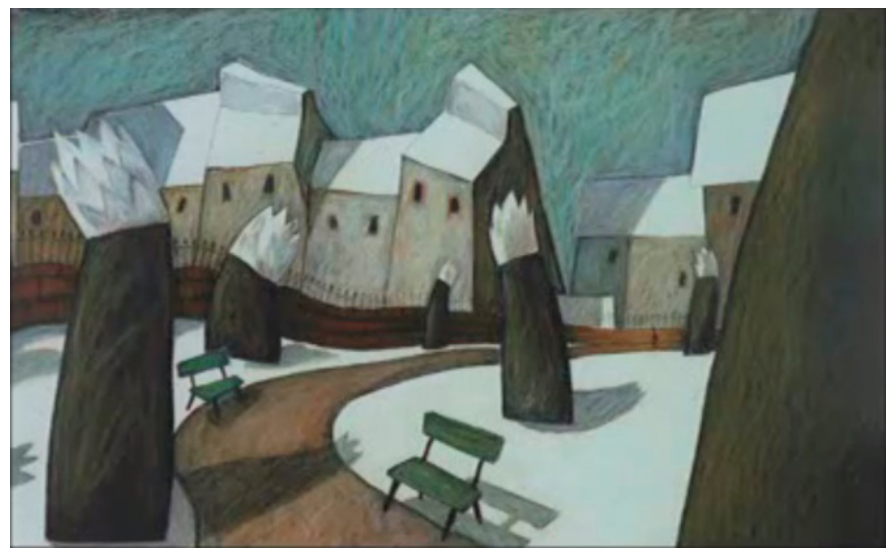

Así pues, puesto que en animación el movimiento es lo que, en última instancia, determina la naturaleza del espacio, éste puede ser aparentemente geométrico o estar representado de manera convencional, pero ser espacio vivencial debido a sus propiedades dinámicas. Por ejemplo en Alice (Svankmayer, 1987) el espacio experimenta transformaciones casi continuas, haciendo de éste un entorno sorprendente donde la geometría del espacio físico real adquiere propiedades subjetivas. Por ejemplo, la habitación de la niña se abre a un terreno solitario y desolado en medio del cual hay una mesa; la niña se introduce en el cajón de la mesa (demasiado pequeño para albergar a ningún niño), en cuyo interior se extiende el extraño mundo en el que se desarrolla la trama (0:07:00) (Fig. 35). Así 

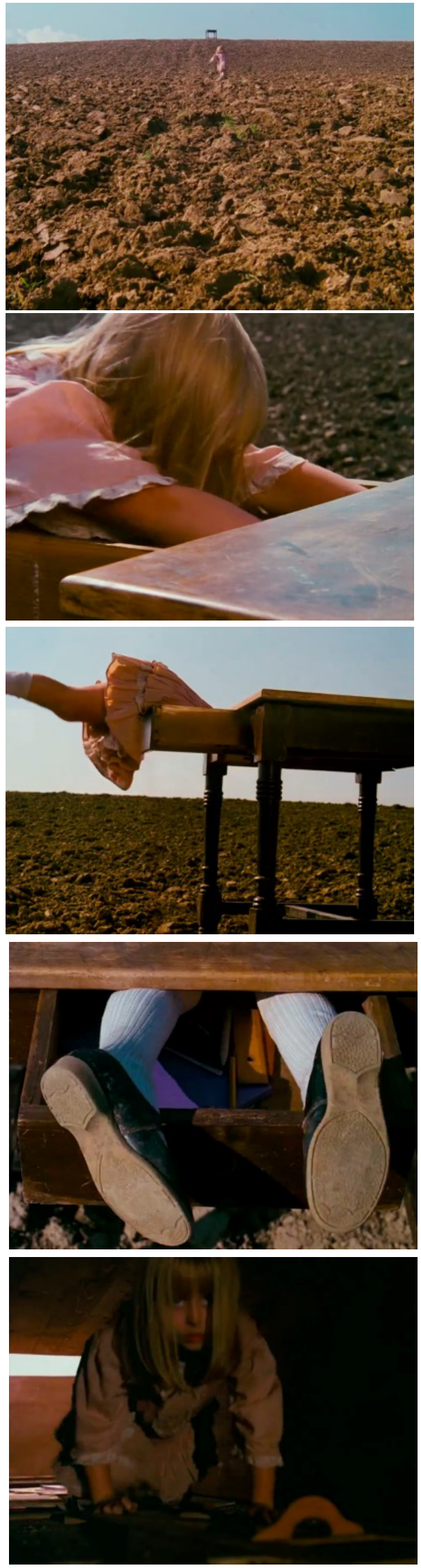

Fig. 35. Jan Švankmajer (1987). Alice (Alicia). Serie de fotogramas.
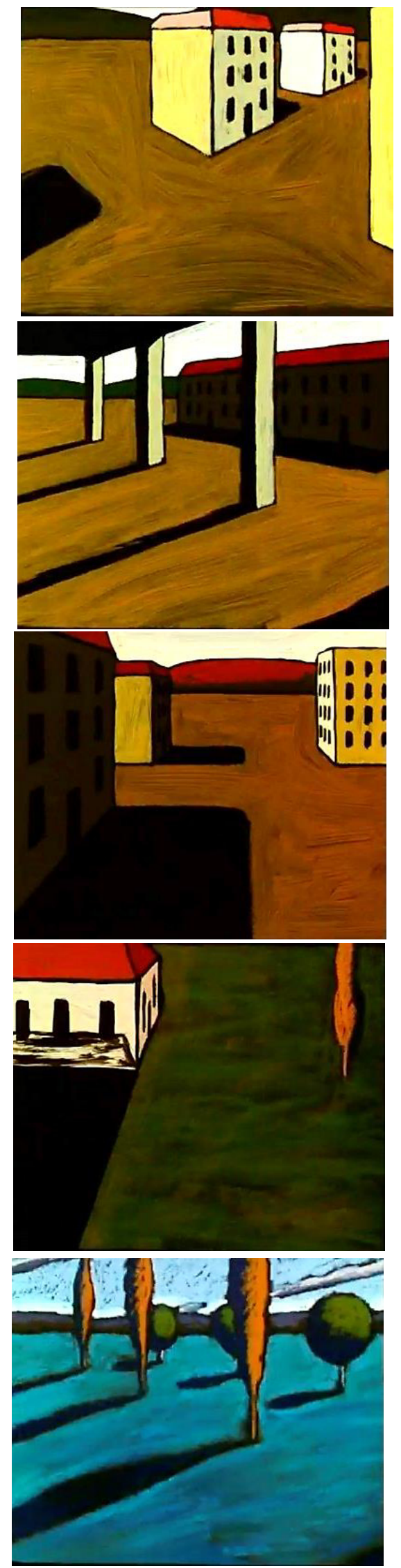

Fig. 36. Georges Schwizgebel (1998). Fugue (Fuga). Serie de fotogramas. 

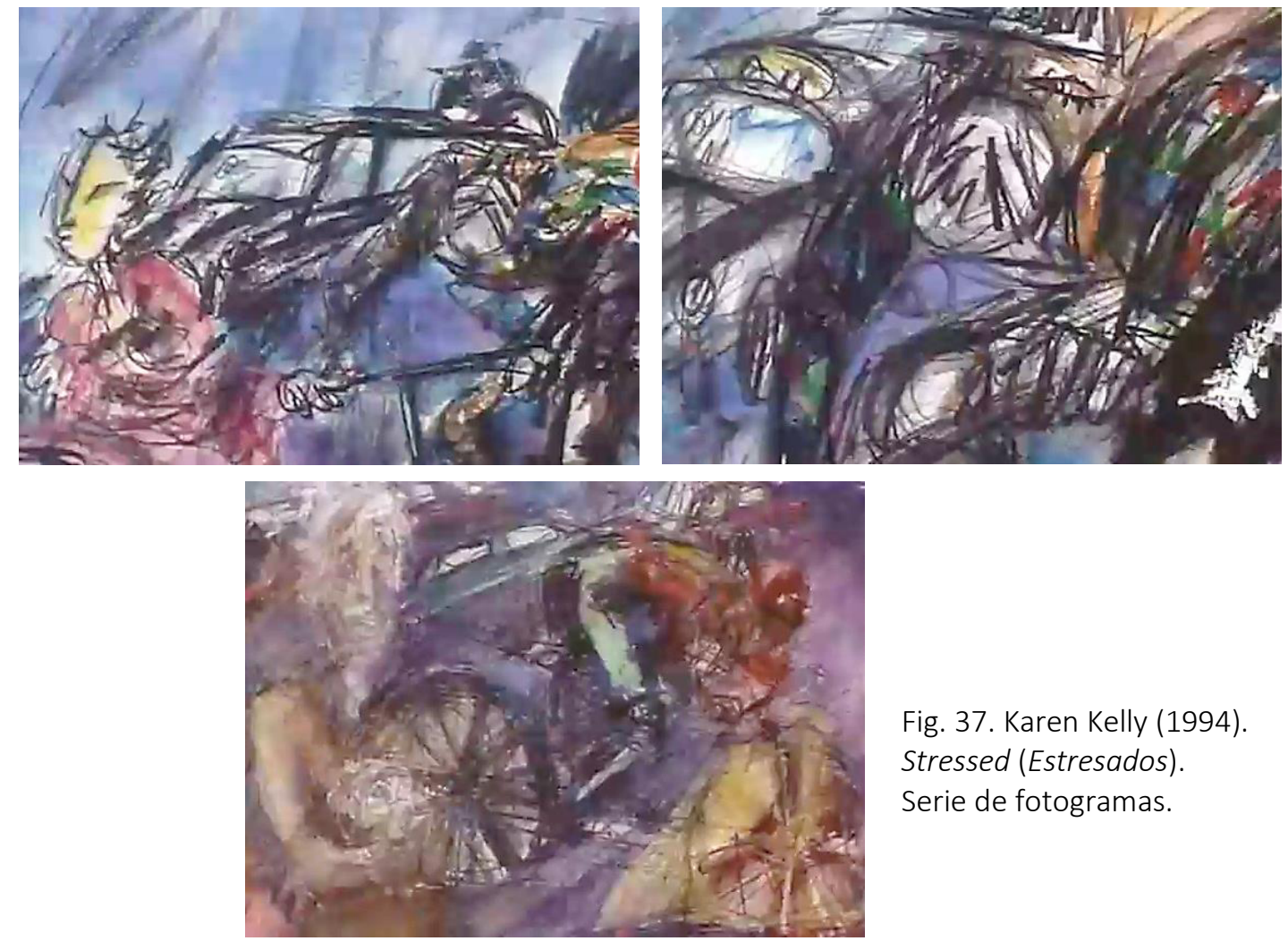

Fig. 37. Karen Kelly (1994). Stressed (Estresados). Serie de fotogramas.
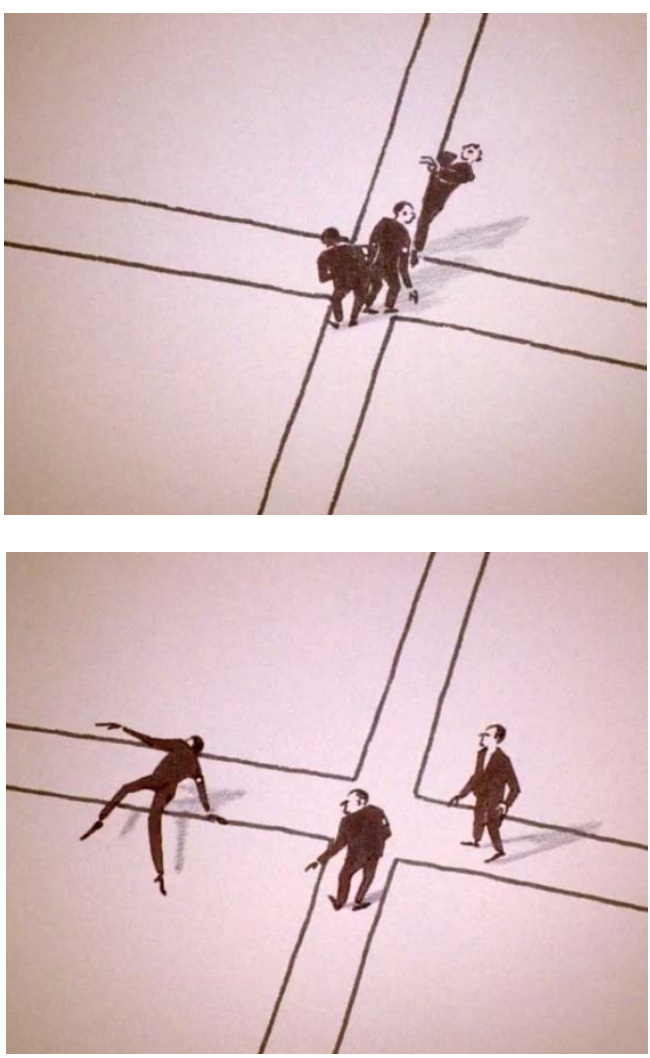

Fig. 38. Raimund Krumme (1991). Die Kreuzung (La encrucijada). Fotogramas.
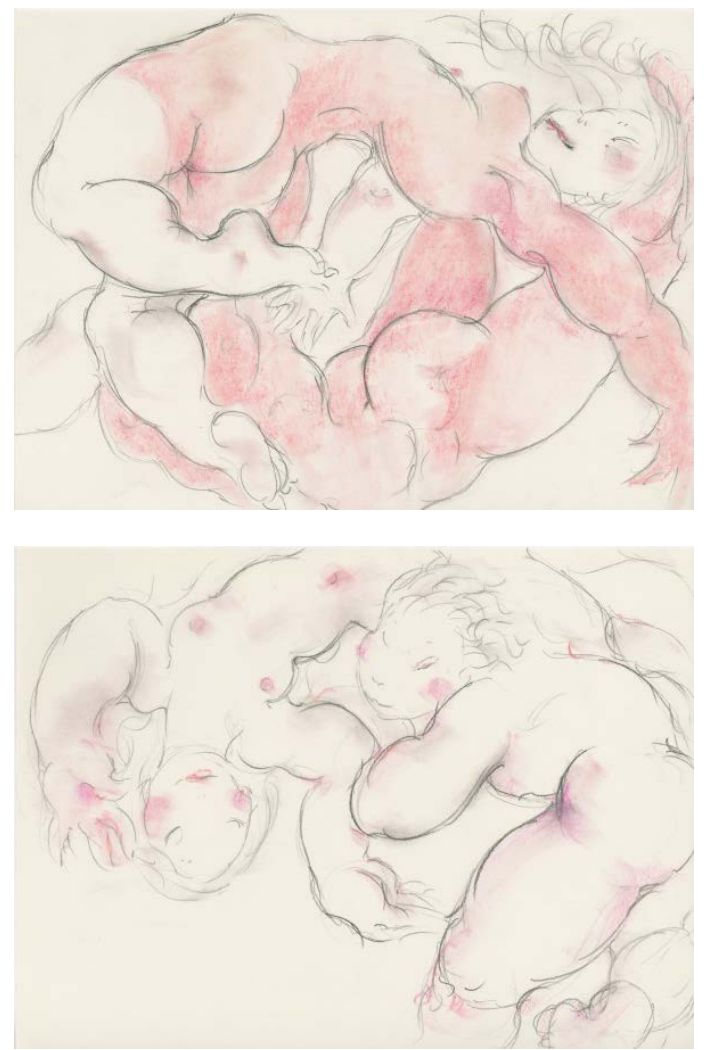

Fig. 39. Rosa Peris y Mercedes Peris (2011). Libidinis. Fotogramas. 

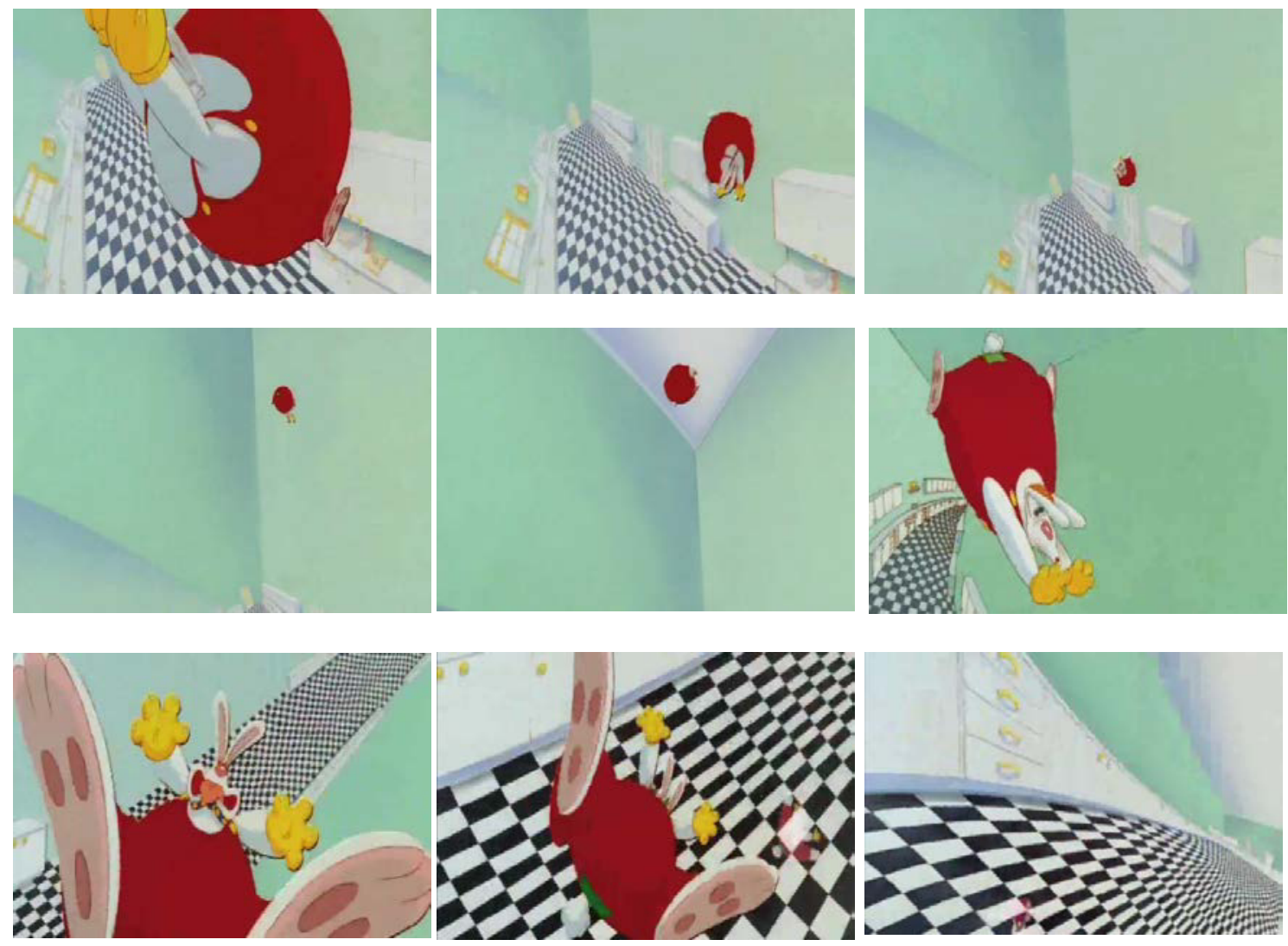

Fig. 40. Robert Zemeckis (1988). Who Framed Roger Rabbit? (¿Quién engañó a Roger Rabbit?). Serie de fotogramas.

mismo, en Jumping (Saltar) (Tezuka, 1984), el dibujo del espacio no es en sí una representación dinámica o que sugiera cualidades espacio-temporales especiales. Los dibujos individuales son representaciones del espacio en perspectiva, sin embargo, al verlo en movimiento, la acción se revela como vivenciada (Fig. 12). Lo mismo ocurre en la animación Fugue (Fuga) (Schwizgebel, 1998), donde el incesante desplazamiento de cámara por el espacio presenta la geometría de las arquitecturas y su entorno perspectivo como un lugar onírico, casi como si se tratase de un viaje astral (Fig. 36). En There Lived Kozyavin (Allí vivió Kozyavin) (Khrjanovsky, año) se muestra un espacio de geometría muy dura, un pasillo se extiende en perspectiva cónica, pero un movimiento de cámara deja ver la subdivisión del espacio en muchos más pasillos de los que un espacio geométrico coherente podría albergar; en este caso la ocultación inicial de esta característica da paso a la sorpresa, pero no es sólo el movimiento de cámara, sino también la alteración del dibujo perspectivo lo que genera el espacio vivencial.

Así mismo, el espacio vivencial puede ser representado sin ninguna referencia geométrica. El dinamismo de las calles de la ciudad en Stressed (Estresados) (Ke- 
Ily, 1994) queda plasmado sin mostrar en ningún momento referencias estructurales concretas: no hay perspectiva, no hay edificios, no se definen calzadas ni aceras por las que circulan vehículos y personas, y, sin embargo, transmite toda la sensación de las calles abarrotadas (00:01:41) (Fig. 37). E incluso la acción puede transcurrir en un espacio que se determina exclusivamente por la interacción de los personajes en éste, como en Anomalies (Cady, 2012) y en Libidinis (Peris \& Peris, 2011). En estas animaciones no hay ninguna referencia geométrica del espacio. En Anomalies, los elementos que ocupan el espacio (el suelo, las paredes, puertas y ventanas) se hacen visibles únicamente en el momento en que los personajes y objetos entran en contacto con ellos; el movimiento descubre la forma del espacio. Mientras que en Libidinis, éste revela más bien su naturaleza: de gravedad cambiante (un medio entre líquido y aéreo) (Fig. 39); esta característica se hace comprensible por el movimiento flotante de las figuras, que sólo eventualmente se apoyan en una superficie invisible. El espacio etéreo de este cortometraje tiene un carácter simbólico que acompaña al movimiento sensual de los personajes.

El cambio sustancial del espacio es otra característica del espacio vivencial en animación, ya que mantiene al espectador en un constante estado de descubrimiento espacial, tal y como ocurre al reconocer un lugar por primera vez. Las transformaciones evidencian la subjetividad de la representación del espacio y además provocan sorpresas sensoriales. En Estoria do Gato e da Lua (Historia del gato y la Luna) (Serrazina, 1995), el movimiento sustancial del espacio se produce a través de la metamorfosis de toda la imagen, mientras que en Die Kreuzung ( $L a$ encrucijada) (Krumme, 1991), el espacio se transforma continuamente, pero los cambios sólo son comprensibles por la interacción entre figura y espacio (Fig. 38). En Who framed Roger Rabbit? (¿Quién engañó a Roger Rabbit?) (Zemeckis, 1988), en la primera escena de la película se muestra una acentuada transformación del espacio. Esta escena contiene una interpretación del espacio vivencial de gran audacia, poco habitual en el lenguaje del cartoon. Mediante movimiento de cámara por animación, el espacio se muestra desde una perspectiva cambiante y muy exagerada, alterando la proporción del espacio original (el interior de una casa), en beneficio de la expresión del espacio y el movimiento subjetivo (00:03:50) (Fig. 40).

Así pues, la característica esencial de las animaciones en las que se representa el espacio vivencial es que, conforme el móvil actúa en él, se revela su naturaleza subjetiva, lo que genera la sensación de estar en o ante un espacio peculiar; o bien estimula el recuerdo de esta misma sensación que algunos espacios reales provocan en nosotros. 


\section{EL MOVIMIENTO TRANSMITE EL CONTENIDO EMOCIONAL}

Por medio del movimiento vivenciado se expresa el contenido emocional. Al igual que con las metáforas de movimiento, para calificar la expresión del movimiento como vivenciada no basta con transmitir el contenido de manera retórica a través de la imagen, sino que el movimiento representado debe sugerir las emociones del personaje por las otras cualidades anteriores (estimular las sensaciones cinética, expresar características particulares del movimiento y la ubicación de éste en un espacio vivencial). En realidad, al hablar de la expresión de características peculiares del movimiento (Punto B. en 1.2.2.) abarcamos las emociones, pero consideramos que éstas tienen a veces tal protagonismo en el movimiento vivenciado que cabe destacarlas como una cualidad con entidad propia. En Janguru Taitei (Kimba, el león blanco) (Takeuchi, 1997) encontramos un claro y hermoso ejemplo: el león corre y salta de alegría ante el nacimiento de sus hijos. La magnitud de los saltos (acentuada por el contraste con el silencio de la escena y la mudez natural del animal) transmiten su inconmensurable alegría por el acontecimiento. Los desmesurados saltos del león recuerdan a la tradición japonesa de los saltos fantásticos en escenas de combate (00:02:12) (Fig. 43), Así mismo, en Sientje (Moesker, 1997) la niña protagonista es regañada por los adultos. En esos momentos los adultos se hacen gigantes y se inclinan sobre ella, moviendo dedos amenazadores (00:02:47) (Fig. 42). Nuevamente, la metáfora está acompañada de la expresión de la sensación cinética: el movimiento resulta opresivo, acorde con lo que se representa. El largometraje Tekkonkinkret (Arias, 2006) tiene una narrativa muy simbólica; y presenta en varias ocasiones metáforas a través del movimiento, sobre todo mediante los increíbles saltos (tradicionales en el género de lucha del cine japonés), que se corresponden al estado de ánimo o emociones de los personajes: cuando los protagonistas se sienten poderosos realizan grandes desplazamientos por encima de edificios y aterrizan hábilmente; cuando se hayan en dificultades, los aparatosos aterrizajes hacen visual la miseria de su situación. Tras una sangrienta pelea, Negro (uno de los protagonistas) se deja caer de espaldas desde una ventana, simbolizando su propia caída moral (de 00:28:55) (Fig. 44); mientras que en otra escena, Blanco (el otro protagonista) cae ligero y balanceante, como una hoja que se desprende de un árbol (00:24:50) (Fig. 45): "Sé feliz... sé feliz..."

En L'Oeil du Cyclone (El ojo del huracán) (Bisaro, 2006) los hombre se derriten al paso de una mujer de fuego (00:02:44) (Fig. 41). Aquí la expresión móvil tiene cualidad cinestésica, sin embargo, la representación transmite más el hecho de "derretirse como la cera" que la acción que representa metafóricamente: el deseo 
de los hombres por la mujer. Algo similar ocurre en Juegos olímplicos - Nataçao (Ribeiro \& Bouchon, 1996), animación en la que se muestra un salto de natación en el que el nadador se transforma en ave y cae dulcemente. Aunque en estos dos casos la expresión de las emociones no es transmitida tanto por el movimiento como por la representación literal de la metáfora, ambos transmiten audazmente el mensaje.

Como vemos, a través de las metáforas se muestra de manera subjetiva la opinión o el punto de vista (no físico) o posicionamiento emocional o intelectual del personaje respecto a algo.
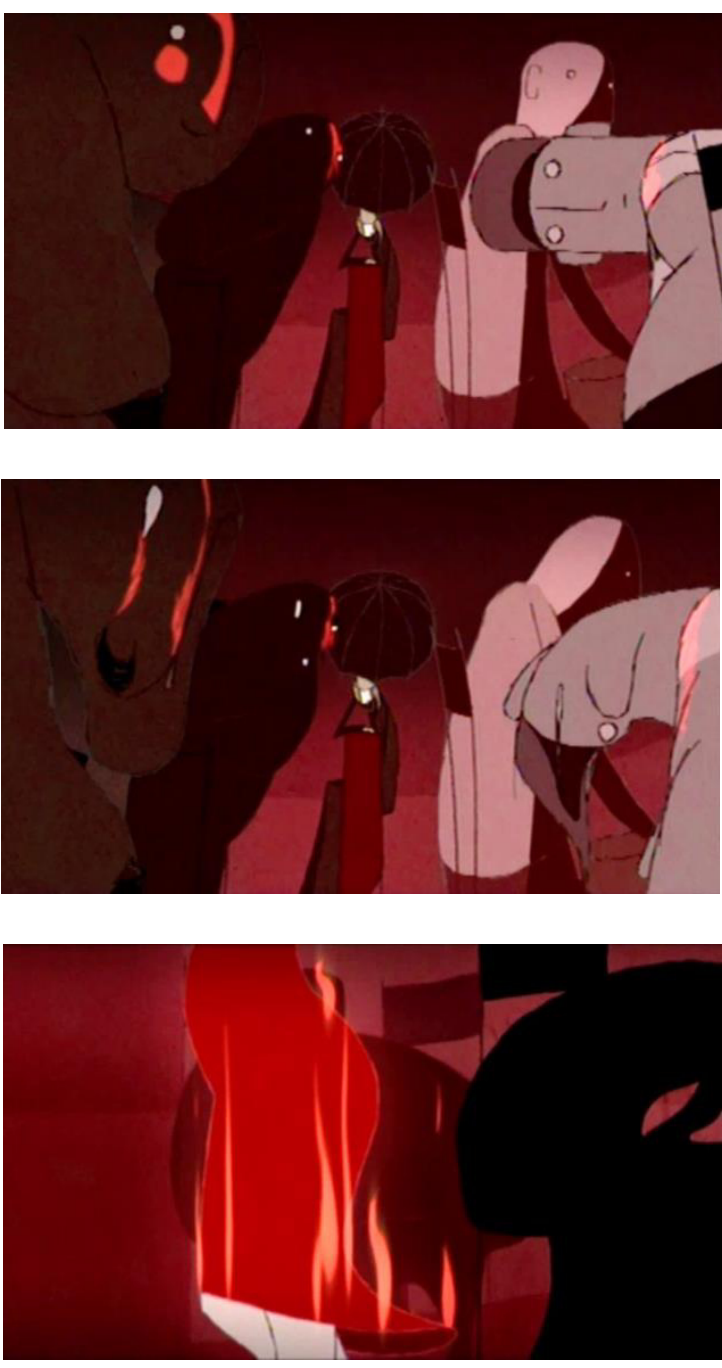

Fig. 41. Julien Bisaro (2006). L'Oeil du Cyclone (El ojo de la tormenta). Serie de fotogramas.

Fig. 42. Christa Moesker (1997). Sientje. Serie de fotogramas.
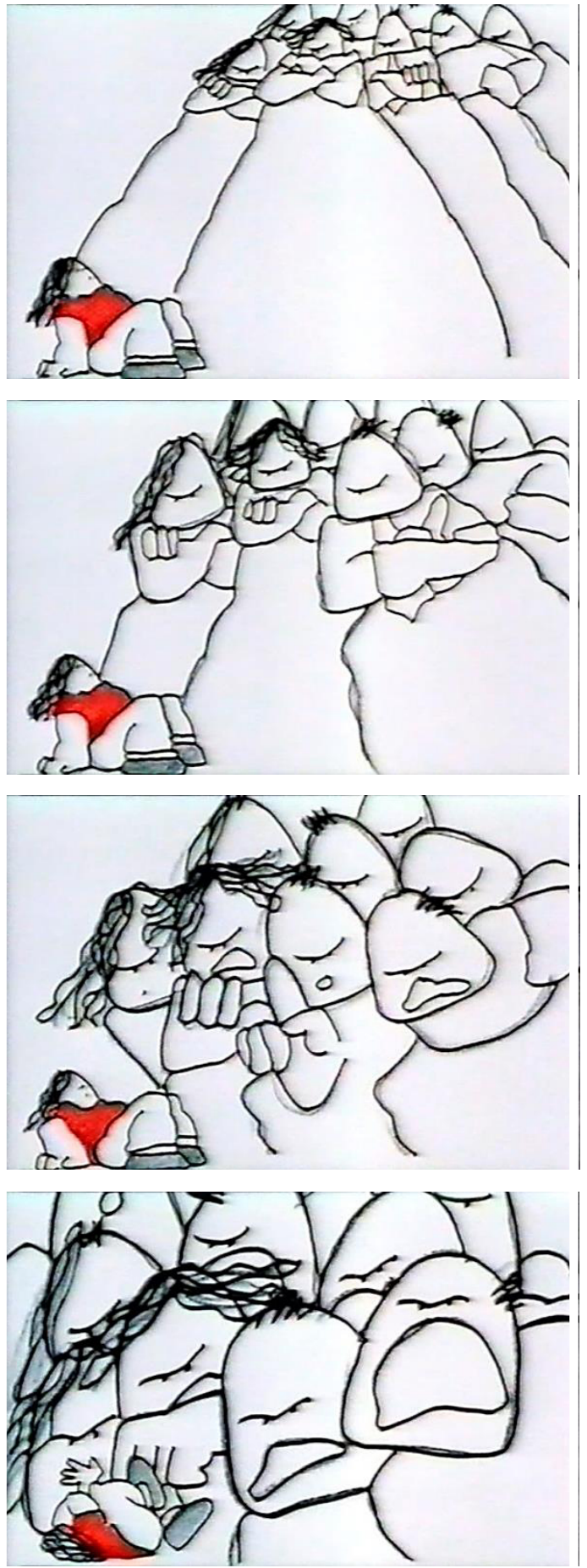

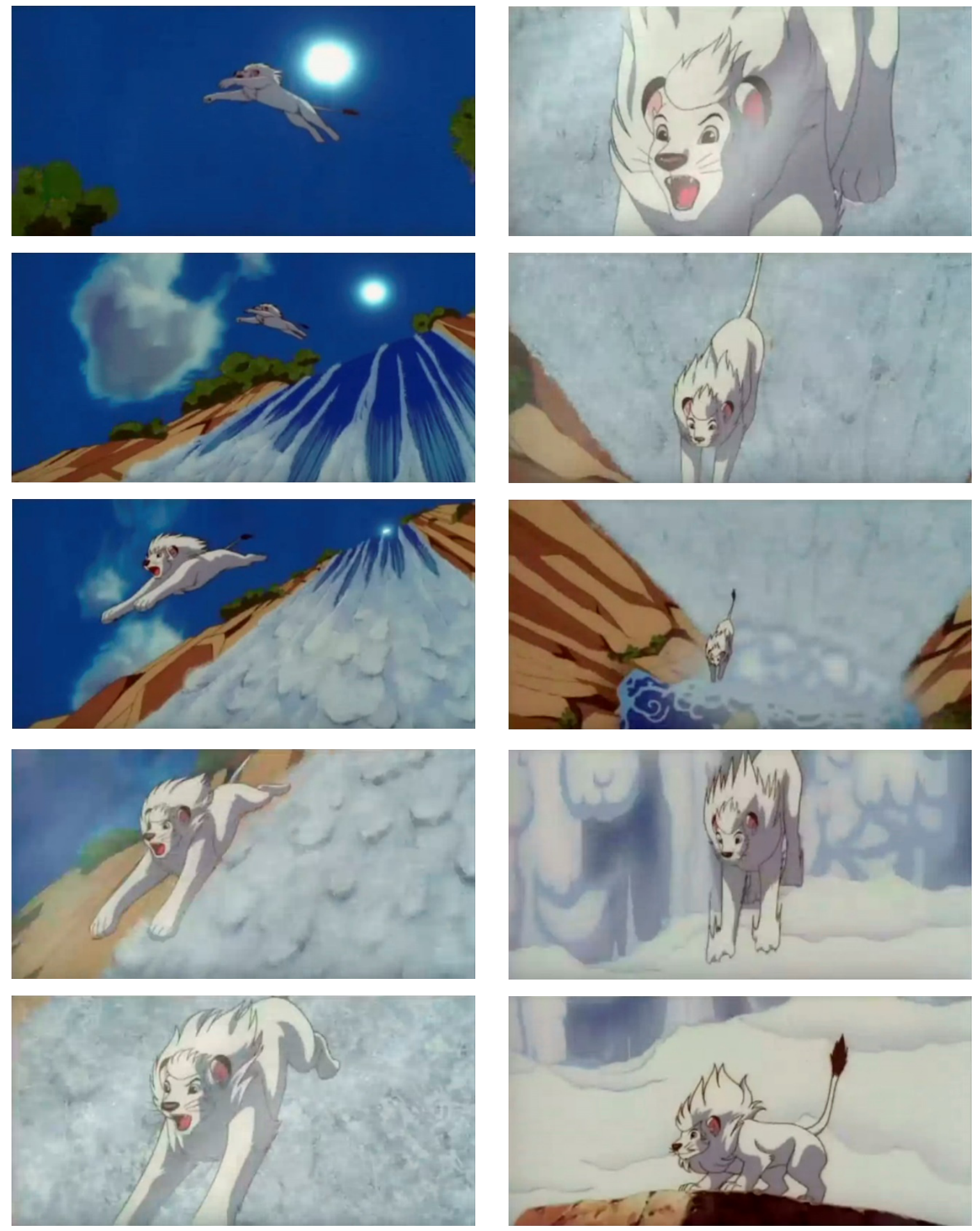

Fig. 43. Yoshio Takeuchi (1997). Janguru taitei (Kimba, el león blanco). Serie de fotogramas.

Las características mencionadas no se dan normalmente de manera aislada, por ejemplo en Passage (Krumme, 1994) [en DVD], la figuras que se deslizan sobre el hielo evocan la sensación que se experimenta al patinar sobre una superficie resbaladiza y al mismo tiempo se plasma cómo este movimiento se percibe vi- 

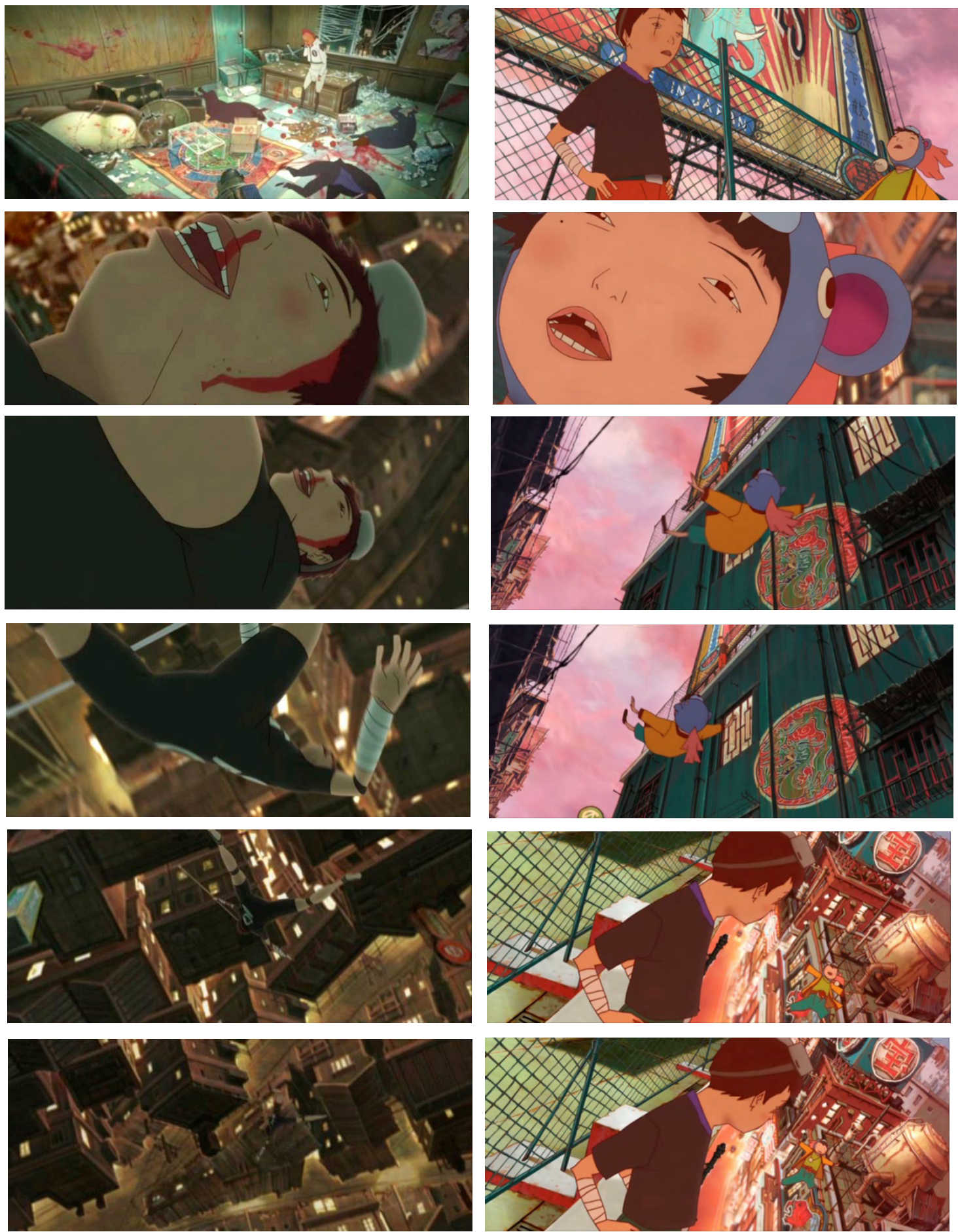

Fig. 44. Michael Arias (2006). Tekkonkinkret. Serie de fotogramas.

Fig. 44. Michael Arias (2006). Tekkonkinkret. Serie de fotogramas.

sualmente, por lo que podemos decir que transmite la particularidad de esta acción tanto al ser observada como al experimentarse. Además, el espacio es vivencial en cuanto a que se descubre gracias a la interacción de los personajes con el espacio. En Stressed (Kelly, 1995), también se combinan todas las cualidades que 
permiten identificar el movimiento vivenciado: los acontecimientos muestran características particulares (como el ejemplo del metro visto anteriormente, pág. 77), generan sensaciones cinéticas (como en la secuencia de imágenes relajantes - los caballos, el pez, la pareja entre las flores - transmiten una movimiento casi hipnótico que masajea el alma tras el sufrimiento de los personajes en las escenas anteriores), y representa el espacio vivencial, generado por el movimiento de las figuras antes que por la descripción geométrica de su forma. 


\subsection{EXPRESIÓN DEL MOVIMIENTO NEUTRO}

En el presente apartado plantearemos qué es el movimiento neutro en la plástica, identificando sus cualidades características (1.3.1.). Este apartado servirá de introducción para el siguiente (1.3.2.), en el que profundizaremos en cómo se presenta en animación el movimiento neutro.

\subsubsection{QUÉ ES EL MOVIMIENTO NEUTRO EN LA PLÁSTICA}

Para hablar de la representación del movimiento neutro extendemos el concepto de espacio matemático de Bollnow a la representación del movimiento. Como propusimos en el parágrafo 1.1.2., empleamos el término "movimiento neutro" y no "movimiento matemático" porque, aunque el conocimiento matemático sobre el movimiento en ocasiones se aplica a las artes, no pretendemos analizar cómo se manifiesta este conocimiento en la plástica, sino estudiar un tipo de representación móvil más o menos exento de expresividad, al cual nos referimos como "movimiento neutro".

Al trasladar el concepto de espacio matemático de Bollnow a la expresión del movimiento, hablamos de un tipo de representación del movimiento que, al igual que el espacio matemático, se realiza y se juzga objetivamente. Pero recordemos que Bollnow, al referirse al espacio matemático no sólo le atribuye la característica de ser medible objetivamente, sino también la de estar exento de cualidades emocionales y que, por ser creado bajo unos parámetros regulares, tiene como consecuencia la capacidad de homogeneizar el espacio. Por eso hemos llamado "movimiento neutro" a las representaciones que, por un lado, presentan la acción de manera fría y que, por otro lado, tienen la cualidad de igualar la expresión móvil (dando lugar a representaciones homogéneas). No incluimos en esta enunciación la representación matemática del movimiento ya que, como explicamos anteriormente (al final de 1.1.) el uso de las matemáticas no implica necesariamente que la obra posea las cualidades del movimiento neutro tal y como las vamos a definir a continuación. 
La representación del movimiento neutro queda definida sobre todo por la ausencia de cinestesia. La representación del movimiento neutro carece de capacidad para estimular de manera sinestésica las sensaciones que se experimentarían al vivir u observar el movimiento representado. Ya sea porque se dé prioridad a la exactitud mecánica, o por la ausencia de claridad o exageración en la representación, lo crucial es que la sensación móvil no se da o es muy leve, y no tiene presencia significativa. El paradigma de la representación neutra del movimiento son los dibujos explicativos de los manuales de instrucciones, por ejemplo sobre cómo ensamblar las piezas de un juguete desmontable o un mueble (incluso aunque no aparezcan flechas, el movimiento está implícito en la indicación de dónde encajar cada pieza) o las indicaciones para los pasajeros de un avión o cualquier otro tipo de instrucciones que implique movimiento (Fig. 46-47). A través de estas imágenes no percibimos ninguna sensación dinámica, su prioridad es la funcionalidad. Packard Jennings utiliza ex profeso este lenguaje en sus obras, no exentas de humor (Fig. 48).

\section{Ala española...}
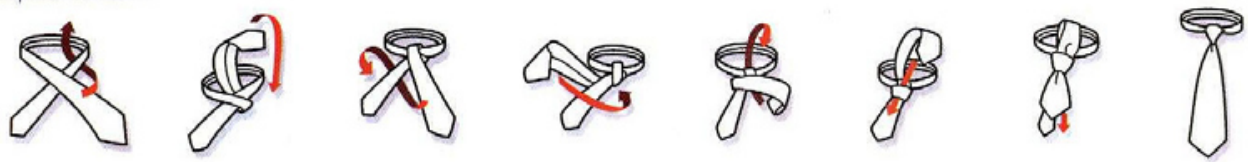

a la inglesa...
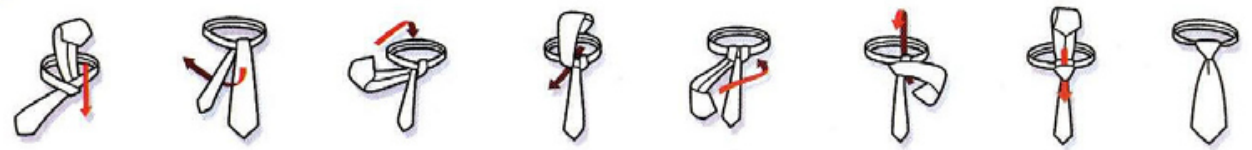

a la americana...
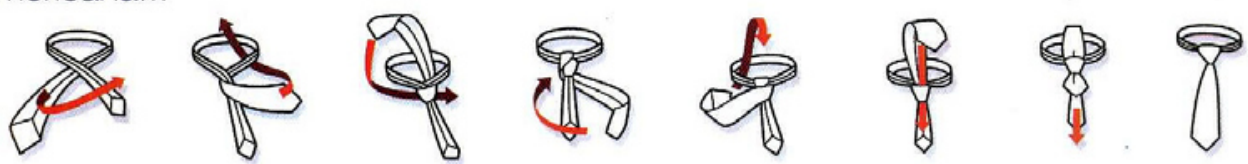

a la italiana...
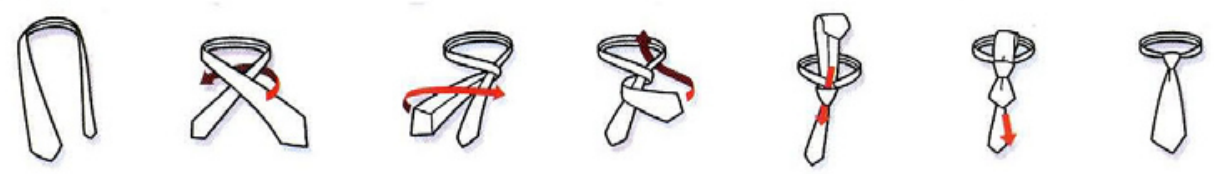

o hazle un lazo.
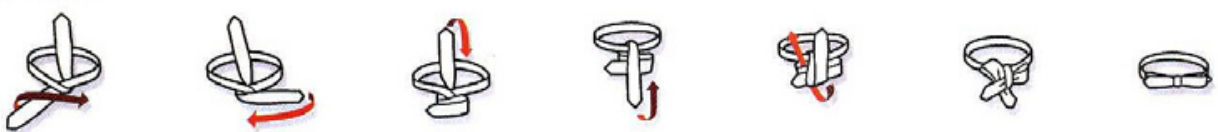

Fig. 46. Francesc Punsola (s/f). Cómo hacerse el nudo de la corbata: a la española, a la inglesa, a la americana, a la italiana o hazte un lazo. 
En el arte, la ausencia de cinestesia suele darse en las representaciones que tratan de estar más próximas a la mecánica tal y como la presenta la fotografía y el video, como las esculturas hiperrealistas de Duane Hanson. En éstas, la representación del movimiento se asemeja a una instantánea fotográfica, con más o menos inestabilidad visual, pero sin llegar a transmitir la sensación cinética de la acción (Fig. 49). Así mismo, el movimiento neutro también puede darse en representaciones de gran síntesis, como en las imágenes de Richard Uglik en las que recrea conocidas pinturas de la Historia del arte con figuras de Playmobil. La expresión móvil queda ahogada por la rigidez del click y las altamente limitadas (aunque variadas) posiciones que éste puede adoptar (Fig. 50-51); al igual que la obra de Packard Jennings, se prioriza la potencia de la imagen sobre la expresión del movimiento. Las instalaciones de neón de Bruce Nauman (como Marching Man, 1985) presentan una expresión móvil más o menos similar. Las imágenes con movimiento neutro pueden ser dinámicas gracias a la composición, a la cantidad de elementos, etc. porque este tipo de movimiento, a pesar de la ausencia de cinestesia que lo caracteriza, no es sinónimo de estatismo compositivo.

Otra de las características definitorias del movimiento neutro es la homogenización de la expresión móvil. Ésta es fruto de varios factores. Por un lado, el uso de técnicas que mecanizan el proceso de representación proporcionan resultados más o menos predecibles o repetibles; en este sentido, la fotografía es susceptible de captar el movimiento de manera similar, aunque no es modelo indiscutible de homogeneización. La homogenización también es debida al uso de lenguajes de representación móvil de estilo predeterminado que generan imágenes estandarizadas. Aunque éstas no estén hechas por medios mecánicos, por su carácter genérico, y por tanto despersonalizado, son comparables a la homogeneización de la carretera de la que habla Linschoten ${ }^{48}$. Uno de estos lenguajes está constituido por los signos gráficos del cómic. Se trata de signos que representan el movimiento, como las nubes de polvo al correr, líneas que representan vibración y líneas cinéticas que indican la trayectoria, entre otros (Fig. 52-54). El uso de signos gráficos no impide el movimiento vivenciado, ni significa que la expresión adolezca de capacidad para despertar sinestesia; los dibujos de la figura 55 son una muestra de que la sensibilidad gráfica no es en absoluto incompatible con el lenguaje del cómic. No obstante, los signos gráficos igualan la expresión. Que el movimiento sea neutro o vivenciado en obras de estas características depende de qué cualidades tengan mayor protagonismo.

La ubicación de los acontecimientos en un espacio matemático es otra ca-

\footnotetext{
${ }^{48}$ Bollnow, 1969, págs. 99-100
} 


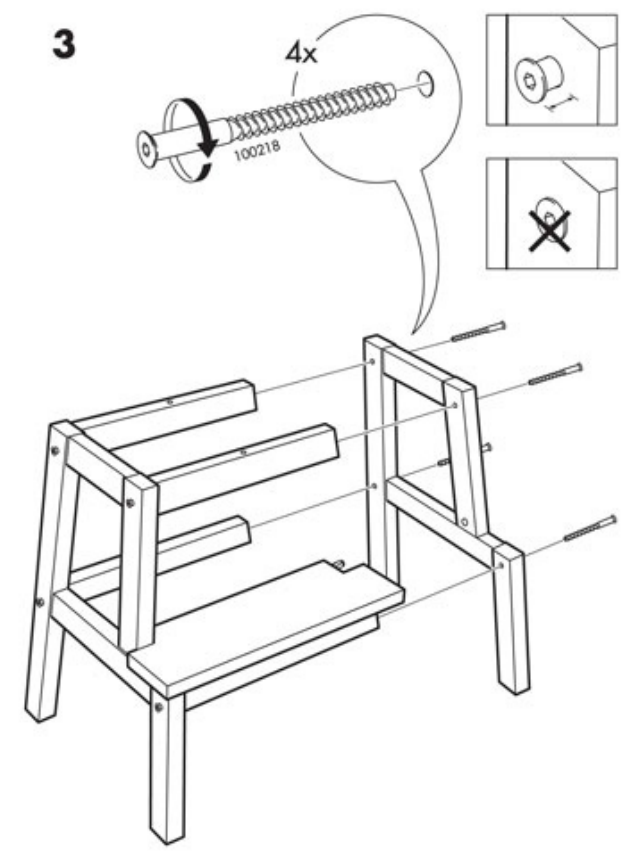

Fig. 47. IKEA (s/f). Instrucciones de montaje para la escalera-banco BECKVAM.

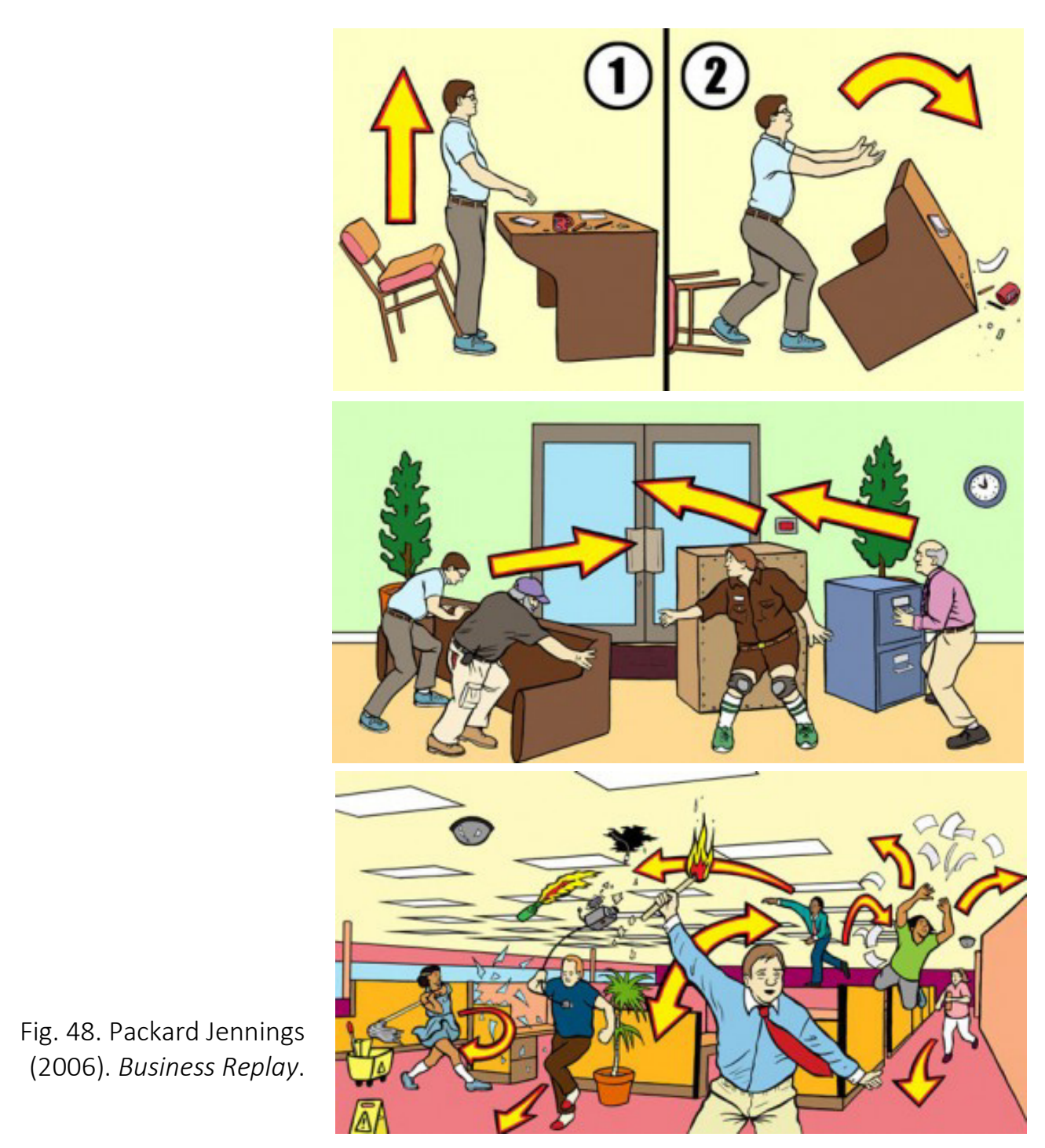




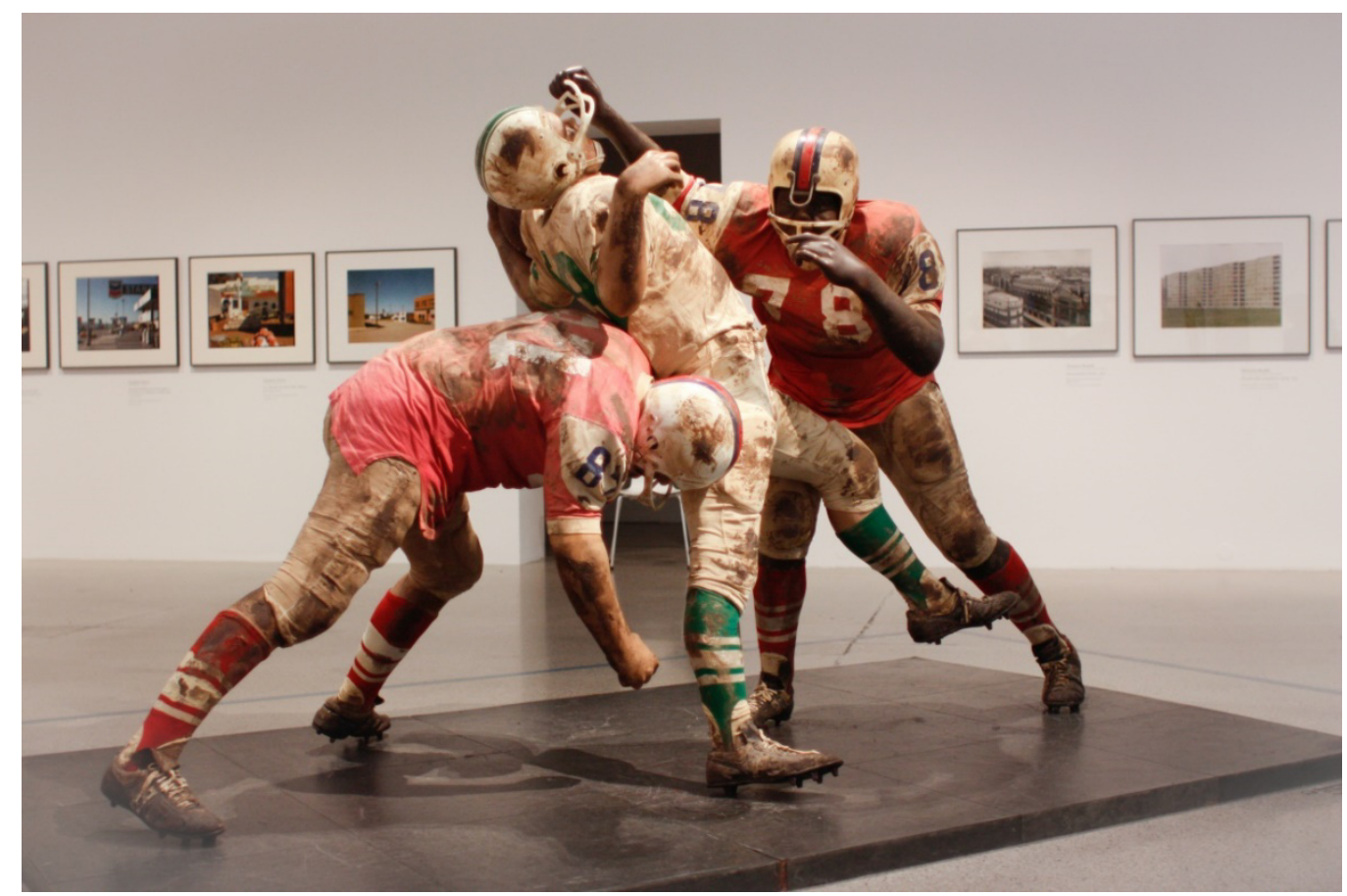

Fig. 49. Duane Hanson (1969). Footbah Vignette.

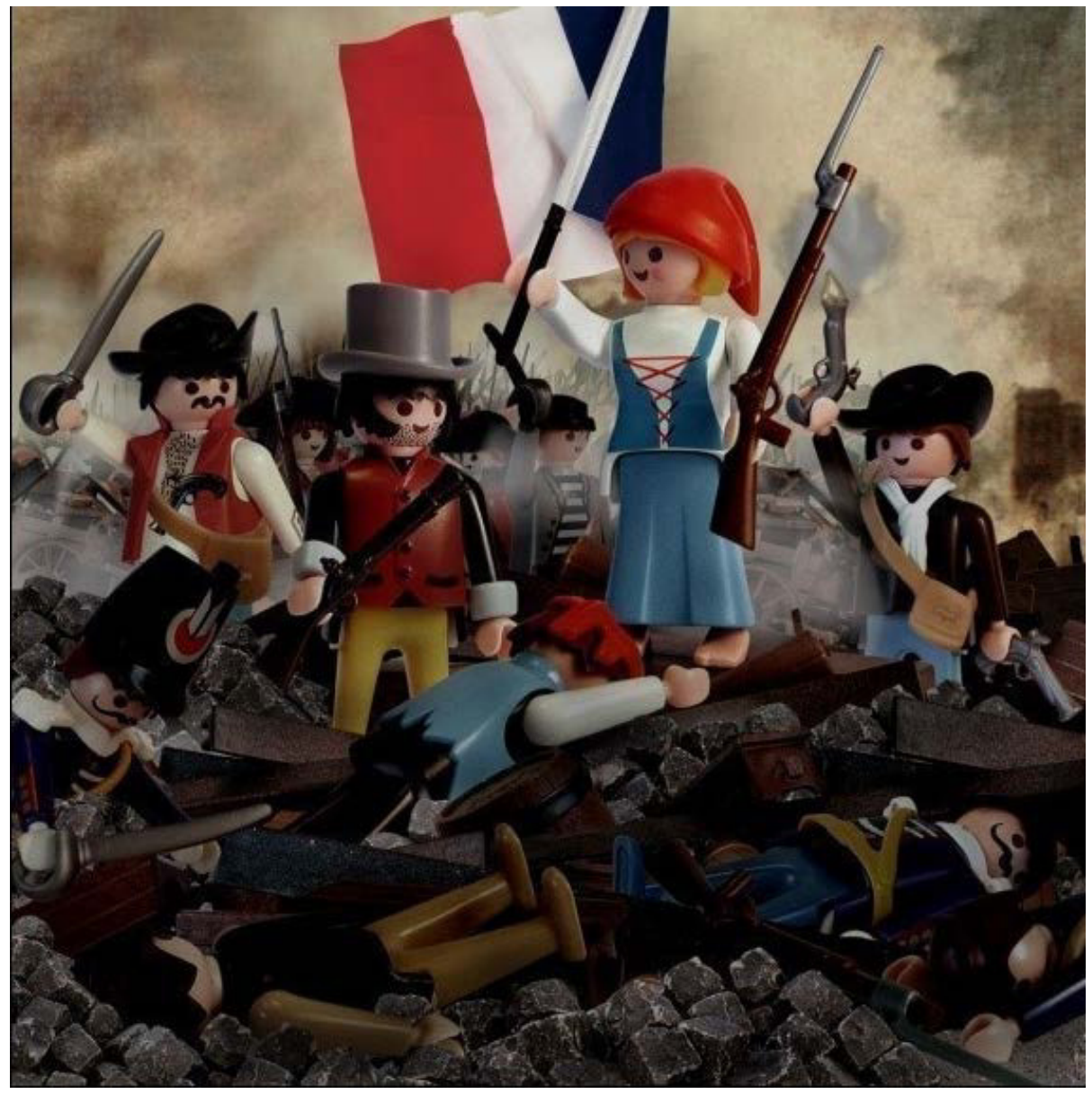

Fig. 50. Richard Uglik (h. 2000). La Libertad guiando al pueblo. 
Fig. 51. Richard Uglik

(h. 2000). La lechera.

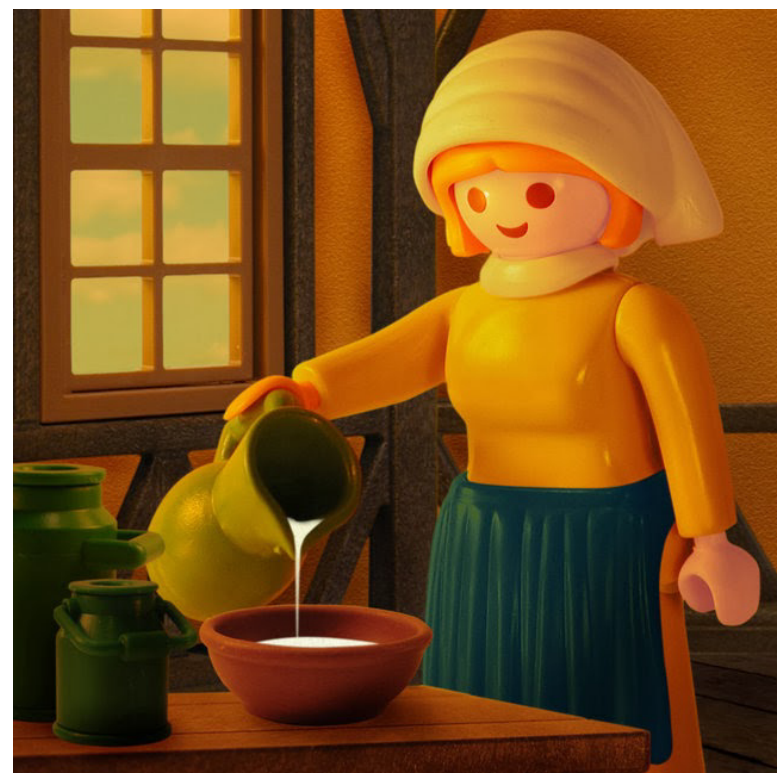

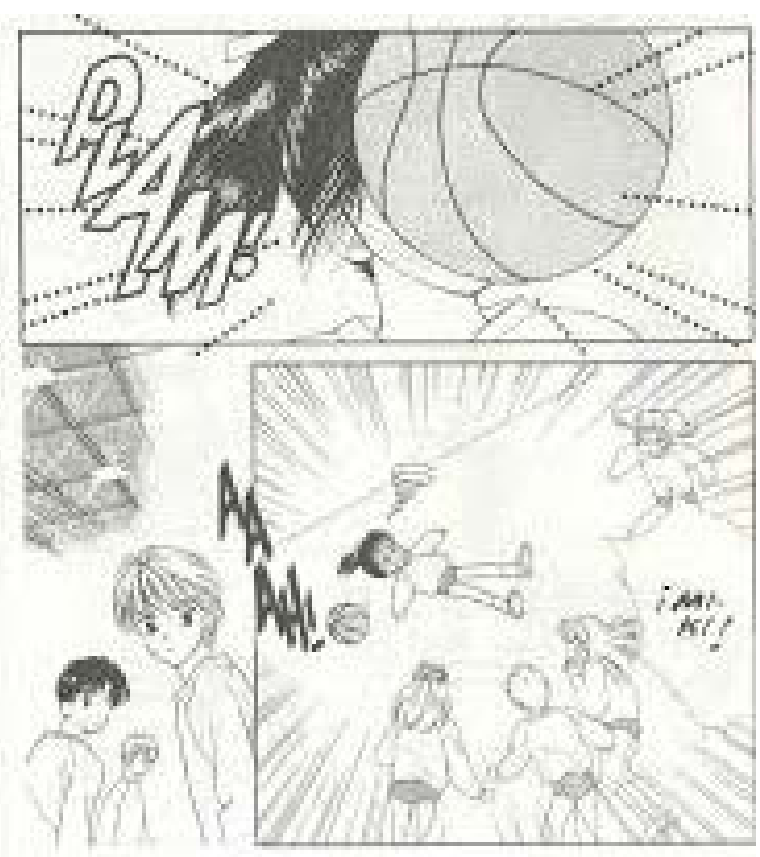

Fig. 52. Wataru Yoshizumi (1992-1995).

Mermelade Boy (La familia crece).

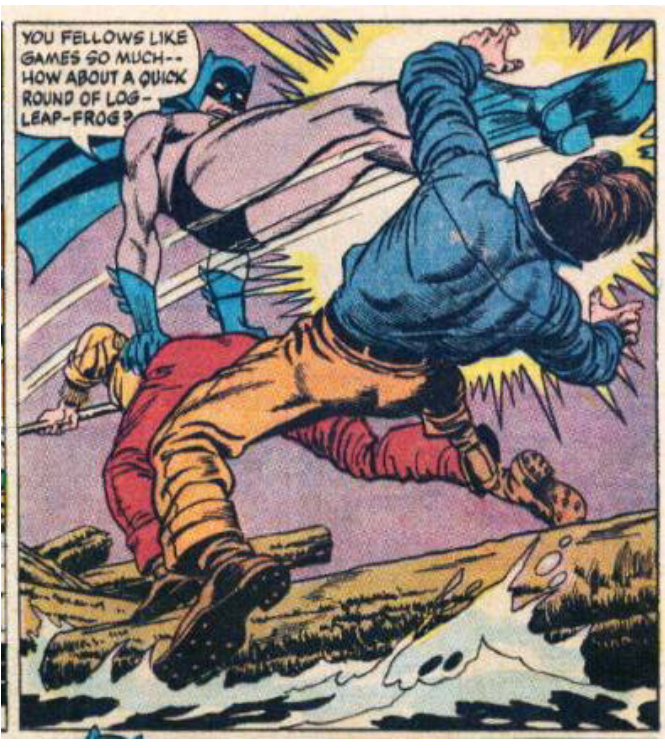

Fig. 53. Gardner Fox, Gil Kane y Sid Greene (1968). Batgirl's Costume Cut Ups (El traje de Batgirl se rompe) (detalle).
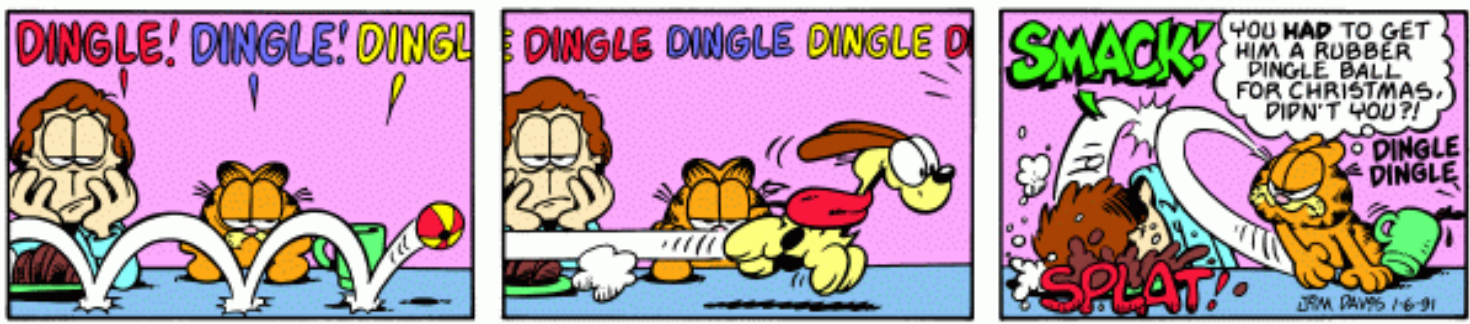

Fig. 54. Jim Davis (1991). Gardfield (detalle de la tira publicada el 6/1/1991) 


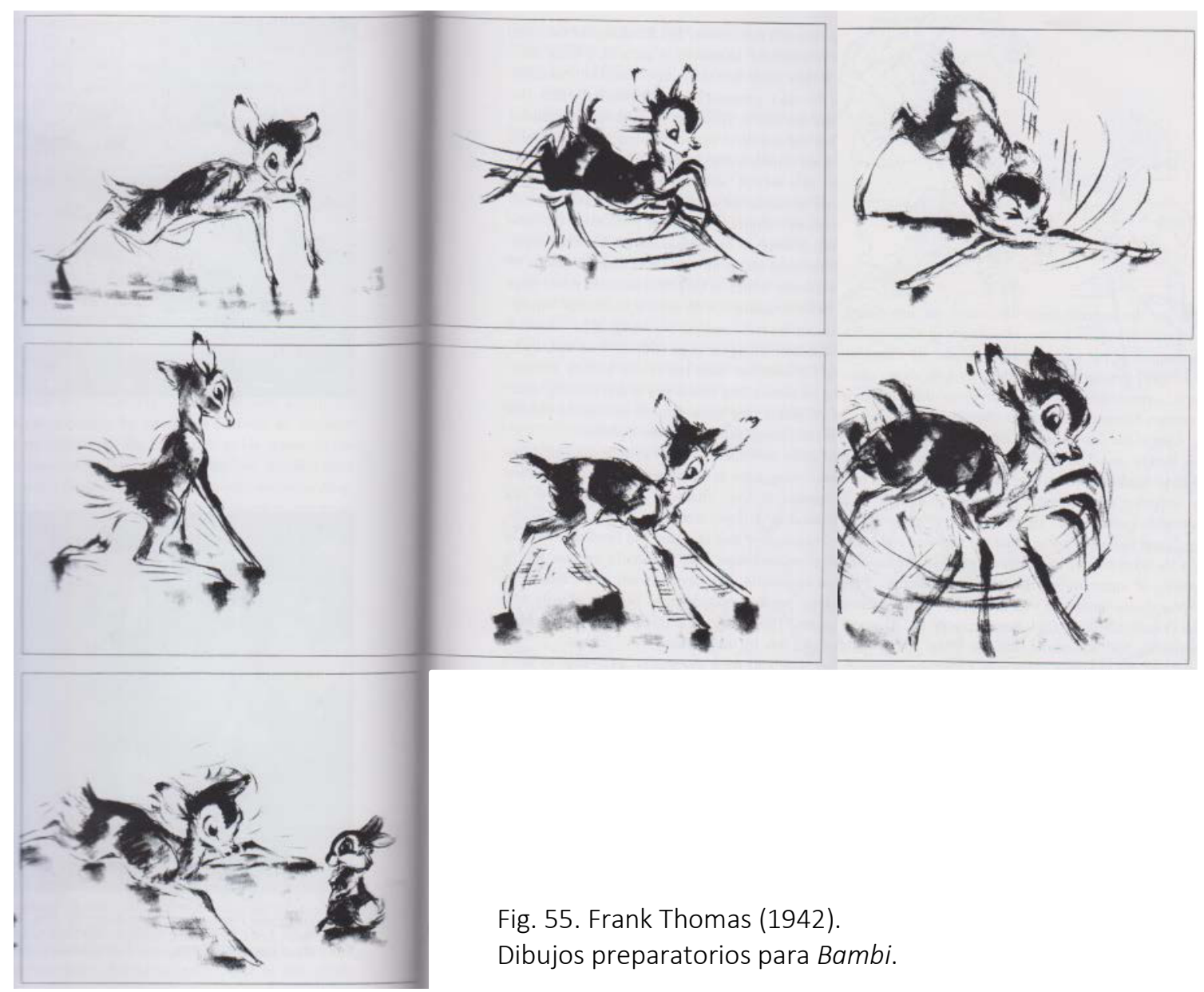

racterística que colabora a que el movimiento se represente como neutro; nos referimos a un espacio matemático según la definición de Bollnow, es decir, el espacio ortogonal triaxial concebido por las matemáticas y/o que posee un carácter homogéneo respecto a otros espacios. A este espacio plástico, por poseer las mismas cualidades no expresivas que la representación móvil de la que hablamos, lo llamaremos "espacio neutro". Así pues, el espacio neutro es aquel en el que la coherencia geométrica, mecánica y física, tiene prioridad frente a la transmisión de la experiencia móvil; abarca toda representación espacial que se mantenga, desde el punto de vista expresivo, en la frialdad y la homogenización visual.

Aunque el movimiento neutro suele darse por medio de la representación del movimiento según lo explica la mecánica clásica y las matemáticas, así como a través de cualquier método racional u objetivo y a través del uso de lenguajes codificados prestablecidos, el uso de estos medios no implica necesariamente expresión del movimiento neutro. Así, en la creación de una obra a través de sistemas más o menos matemáticos (como animación digital por interpolación), puede expresarse el movimiento como vivenciado, todo depende de que la ex- 
presión trascienda las limitaciones del medio. Observemos esta circunstancia en el dibujo del espacio geométrico (por ser fácilmente reconocible): la perspectiva geométrica, a pesar de ser un sistema matemático de representación, no es necesariamente escenario distante al espectador, ya que por el color, la composición, la luz, el diseño del espacio, la propia perspectiva, etc. se puede hacer que un espacio perspectivo presente cualidades propias del espacio vivencial. Las bodas de Alejandro y Roxana (Bazzi, 1517) (Fig. 56), es una muestra de cómo a través de la perspectiva se puede crear un espacio que provoca sensaciones que trascienden la representación de las tres dimensiones: despierta el deseo de caminar por la estancia y descubrir su geometría secreta ¿Qué sensaciones tan especiales pueden sentirse al atravesar el pasillo hipóstilo, o al estar en ese espacio que es interior y exterior a un tiempo? De la misma manera que el espacio neutro en las artes no se reduce a la representación geométrica, el movimiento neutro queda definido por su regularidad e inexpresividad, antes que por los métodos racionales por los que puede alcanzarse. De hecho, tanto la expresión del movimiento vivencial como del movimiento neutro se definen por sus características visuales o por cómo se perciben, no por las técnicas y mecanismos mentales a través de los cuales se realiza.

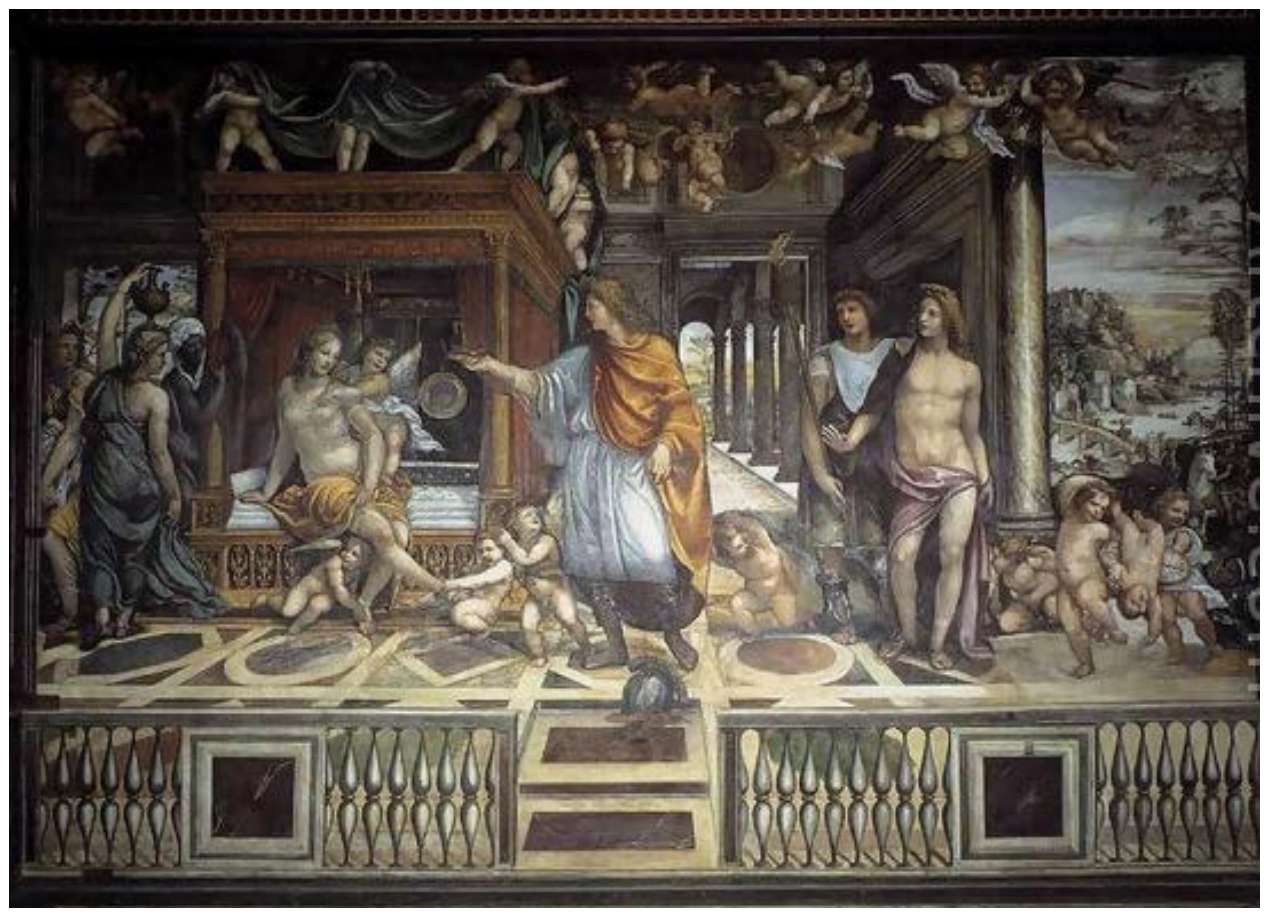

Fig. 56. Antonio Bazzi (1517). Bodas de Alejandro y Roxana.

El movimiento cien por cien neutro destaca, en definitiva, por su neutralidad expresiva (valga la redundancia). La ausencia de cinestesia, el espacio matemático y la 
homogenización de la representación del movimiento (características necesarias en algunos ámbitos, como el científico) pueden no resultar del todo interesantes en las artes. Pero aunque estas características, incluida la neutralidad expresiva, no suelen estar presentes en el arte, en ocasiones algunas de ellas ocupan un lugar predominante en determinadas obras.

\subsubsection{CARACTERÍSTICAS DEL MOVIMIENTO NEUTRO EN ANI- MACIÓN}

Las características que permiten detectar el movimiento neutro en animación son: la ausencia de cinestesia (el movimiento en la pantalla no sugiere emociones cinéticas), la homogeneización de la expresión móvil y la inserción de los acontecimientos en un espacio matemático. La consecuencia final de la priorización de estos valores es una cuarta característica: que la potencia expresiva del movimiento queda en segundo plano. Por ello el movimiento neutro, al contrario que el vivenciado, no suscita sensaciones dinámicas en el espectador ni transmite sentimiento o emociones. La implicación o emoción que el espectador siente ante la película proviene de elementos que no afectan directamente a la expresión móvil, como pueden ser las conexiones entre la historia narrada y su propia vida, o el interés personal por el contenido de la película.

\section{A. AUSENCIA DE CINESTESIA EN LA REPRESENTACIÓN DEL MO- VIMIENTO}

Una de las características de la representación del movimiento neutro en animación consiste en que carece de la capacidad de provocar cinestesia en el espectador, es decir, no sugiere sensación de movimiento. Los acontecimientos representados son identificables, pero su movimiento resulta contenido o poco claro. En estas obras el movimiento se representa sin llegar a transmitir su dinamismo. Esto es debido a la cualidad expresiva, independientemente de su calidad técnica. Esta característica es habitual en aquellas obras en las que el movimiento se representa bajo parámetros naturalistas muy fuertes que priman sobre la transmisión cinestésica del movimiento, por ejemplo en películas como Madame TutliPutli (Maciek \& Szczerbowski, 2007) (Fig. 57), The Separation (La separación) (Morgan, 2003) o L'Animateur (Adam and Eve) (Hilligoss, 2008). En estas películas el naturalismo es debido a otros factores además de la expresión misma de la ac- 
ción, como por ejemplo la planificación (sucesión de planos) de carácter cinematográfico. Aunque esta vinculación no es incondicional, y que la película sea naturalista no implica que el movimiento sea neutro (ver parágrafo 3.3. Vínculo entre movimiento matemático y representación mimética en animación).

Fig. 57. Chris Lavis y Maciek Szczerbowski (2007). Madame Tutli-Putli.

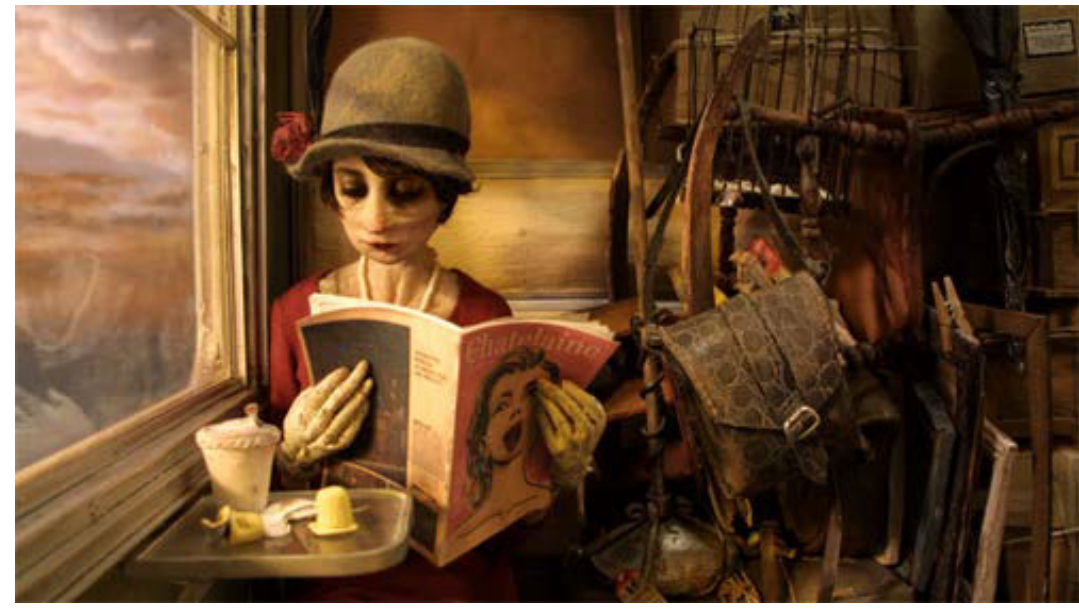

Otros factores que pueden provocar ausencia de sinestesia cinética son los movimientos breves y trayectorias cortas, así como la velocidad regular, aunque éstos no determinan que el movimiento sea neutro, como veremos detalladamente en el capítulo 2.

La ausencia de cinestesia se da en animaciones realizadas con cualquier técnica, pero son especialmente susceptibles de ello aquellas en las que la expresión móvil se fundamenta en la captura de movimiento (rotoscopia y captura por sensores). La dificultad de estos medios para excitar la emoción cinética de estos medios es debida a que la representación del movimiento resultante es anodina, sobre todo cuando se presentan en combinación con otras técnicas de animación. Por eso, un personaje hecho con rotoscopia inserto en una escena de animación de dibujo es reconocible por su movimiento sutil; sin embargo, la misma acción en un film de acción real puede ser muy expresiva. En Betty Boop's Bamboo Isle (Fleischer \& Culhane, 1932), Betty Boop baila como una hawaiana, acción conseguida rotoscopiando el movimiento de un film de acción real de una mujer de carne y hueso (fragmento que se incluye como introducción de la película). En la rotoscopia, las proporciones del cuerpo de la mujer real, así como su movimiento, no cambian respecto a la grabación original; pero la cabeza de la mujer ha sido reemplazada por la enorme cabeza de Betty Boop (Fig. 58). El movimiento de los ojos del personaje llama más la atención que el movimiento de cadera, en contraste con su protagonismo en el video de acción real. 
La transformación plástica de la imagen también contribuye a que el movimiento rotoscopiado evidencie sus carencias como animación; así, cuanto mayor es la transformación plástica de la imagen, menos se conserva la expresividad de la captura original. En Fire and Ice (Bakshi, 1983) (Fig. 59), con superficies de color planas perfiladas de negro (al estilo de la amplia mayoría de las animaciones industriales) el movimiento no provoca sensaciones cinéticas, ni siquiera las debidas al movimiento de los actores. Mientras que en A Snanner Darkly (Linklater, 2006) (Fig. 60), el movimiento del film de acción real base tiene tanta presencia que es difícil identificar el resultado como "animación", sino más bien como una película de acción real en la que se ha intervenido plásticamente y en la que se reconoce el trabajo dramático de los actores. Así pues, cuanta menos animación comparta plano con la rotoscopia y menos transformación plástica tenga el vídeo original, el movimiento rotoscopiado presenta mayor expresividad, pues sobresale el movimiento de la actuación del actor en lugar de quedar como "base" de la rotoscopia.

La animación por captura con sensores tampoco ofrece las mismas sensaciones perceptivas que la realidad, siendo difícil apreciar la expresividad del movimiento del actor, al contrario que la rotoscopia cuando en ésta se prioriza la imagen original capturada. A menudo la captura de movimiento se realiza repitiendo acciones susceptibles de ello, (como el caminado u otras acciones cíclicas), lo que contribuye a que los personajes tenga un movimiento "robótico". Habitualmente en las animaciones hechas con esta técnica, los movimientos capturados son enriquecidos con anticipaciones y retrocesos y con acciones secundarias al estilo de la animación industrial americana, que también son susceptibles de provocar movimiento neutro. De estos recursos hablaremos en el capítulo 3 (más sobre la captura de movimiento en el apartado B. de 3.2.5.). Animación por medios mecánicos). Cabe destacar que hacemos referencia directa a la rotoscopia y la captura de movimiento porque muchas veces son responsables de la ausencia de cinestesia; sin embargo, hay obras en las que se expresa el movimiento como vivenciado aunque estén hechas con estas técnicas.

También hay carencia de sensación dinámica en las obras audiovisuales en las que no hay representación del movimiento a través de la continuidad de los fotogramas, es decir, películas que se componen de dibujos estáticos sobre los que se hacen movimientos de cámara (zoom, tilt o paneo) o mediante el cambio de imagen con una frecuencia de al menos un dibujo o fotografía por segundo ( 1 imagen en 1 segundo, 1 imagen en 2 segundos, etc.). En estos casos, las imágenes se repiten en varios fotogramas con el fin de permanecer en pantalla un tiempo relativamente prolongado, el suficiente para que las imágenes individuales sean percibidas y, así, sean interpretadas como un conjunto de acciones. La representación 
móvil es mucho más intelectual, lo cual exige un esfuerzo perceptivo por parte del espectador. Cuando la ausencia de movimiento no tiene una intención expresiva clara, sino que dificulta la visualización de la película, decimos que se evita la representación del movimiento. Psyche and Eros, de Alison de Vere (1994) [en DVD] se caracteriza por usar diversos medios para resumir el movimiento, como la omisión del desarrollo de las acciones, tal y como se muestra en las imágenes de la Figura 61 (00:06:01). Esta sucesión de cinco imágenes transcurren en diez segundos, suprimiendo las fases intermedias. El movimiento se conforma por cambios sutiles (como entre la primera y la segunda imagen) o radicales, como entre la tercera y la cuarta.

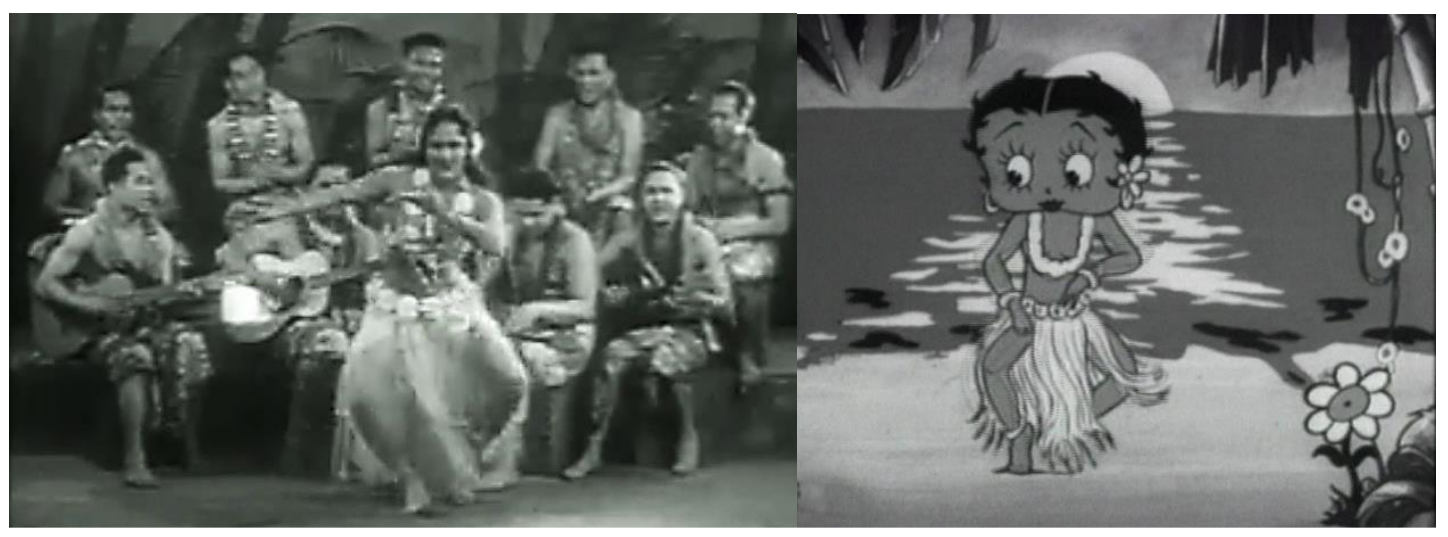

Fig. 58. Dave Fleischer y Shamus Culhane (1932).

Betty Boop's Bamboo Isle (Betty Boop's, la isla del bambú).

Fig. 59. Ralph Bakshi (1983). Fire and Ice

(Fuego y hielo).

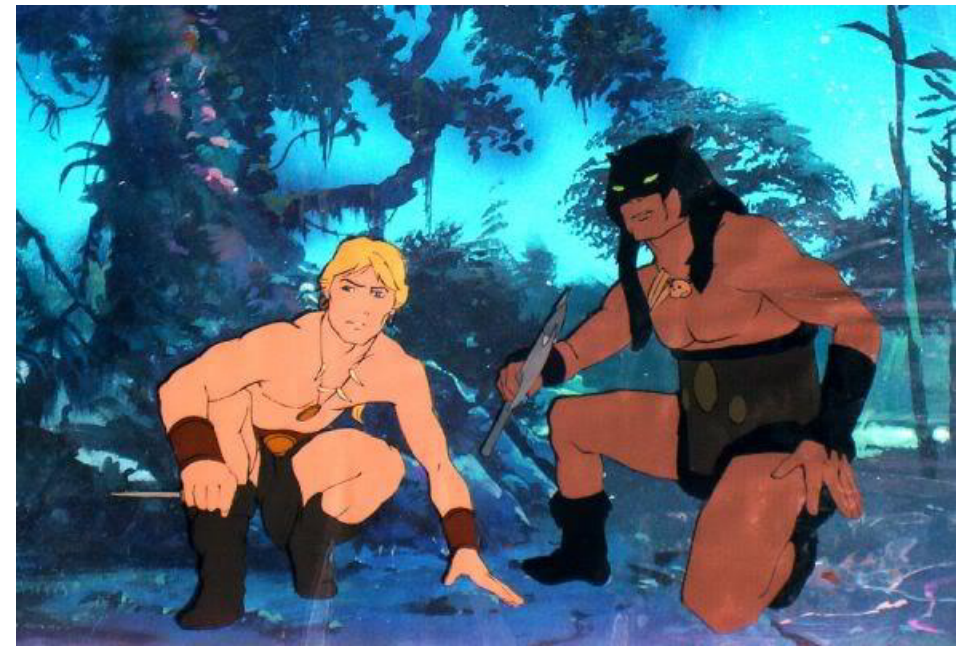

Fig. 60. Richard Linklater (2006). A Scanner Darkly.

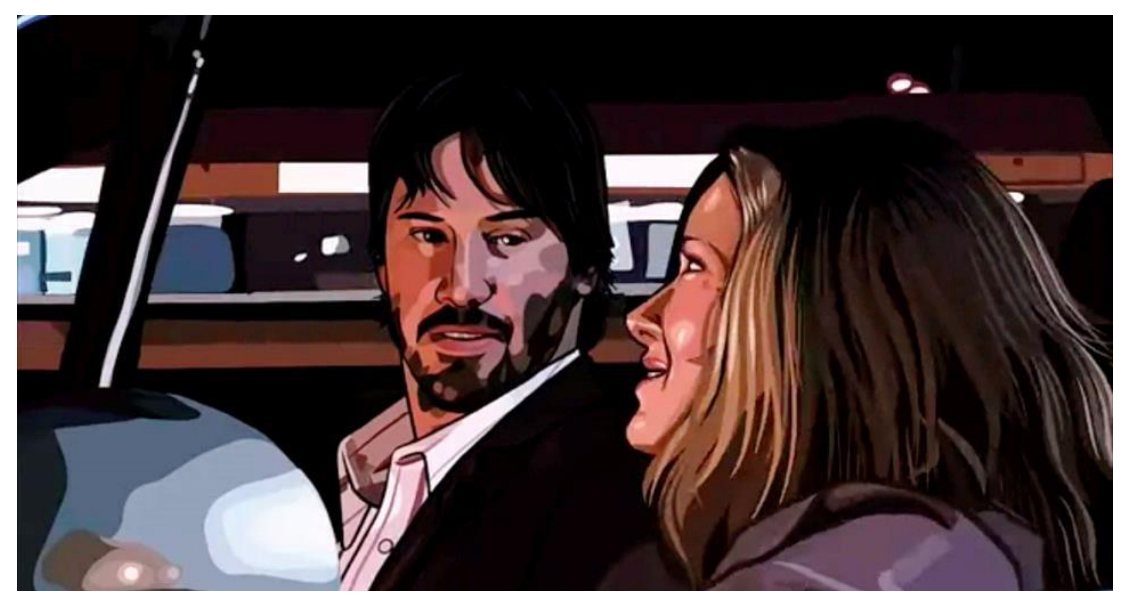


Fig. 61. Alison de Vere (1994).

Psyche and Eros (Pique y Eros). Serie de imágenes consecutivas.

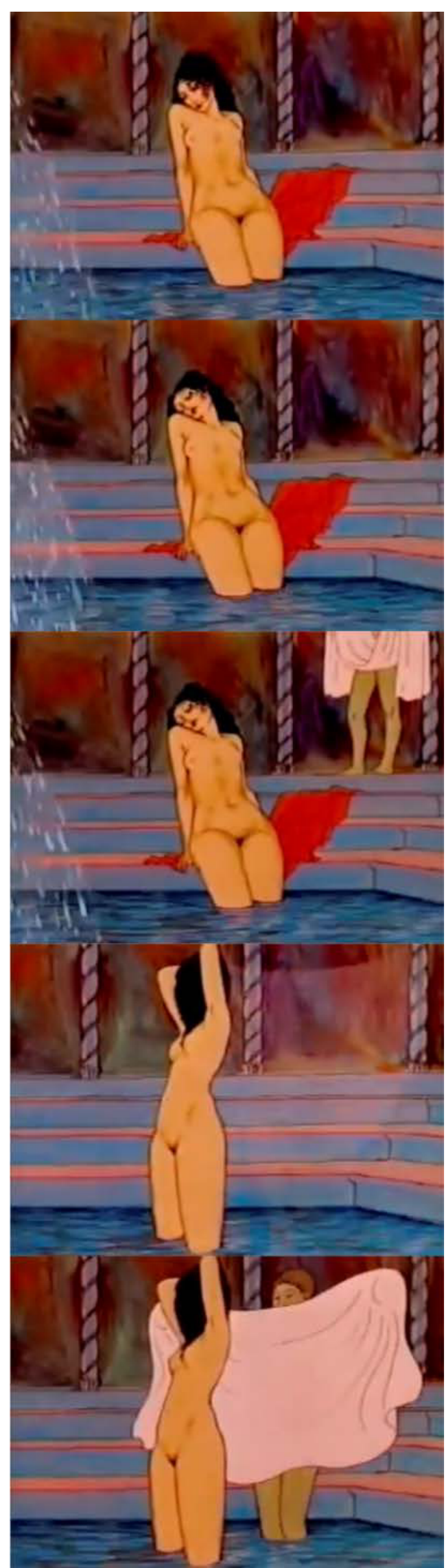



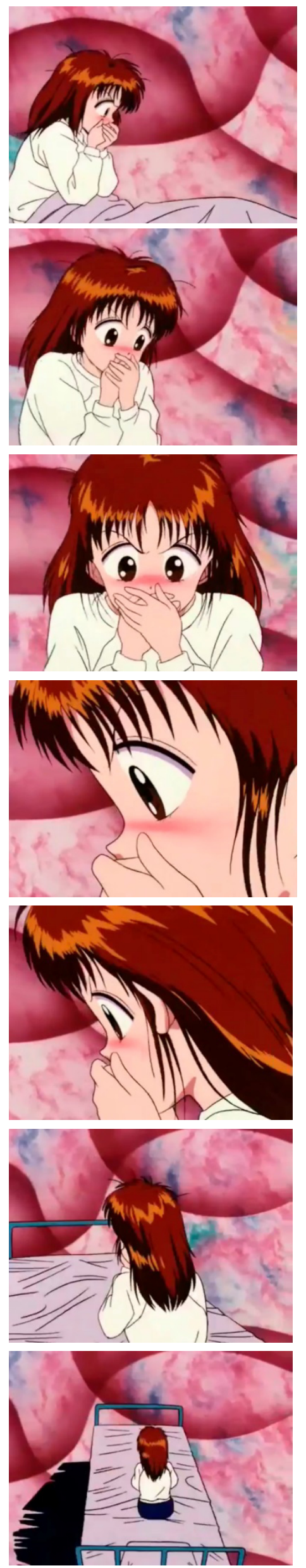
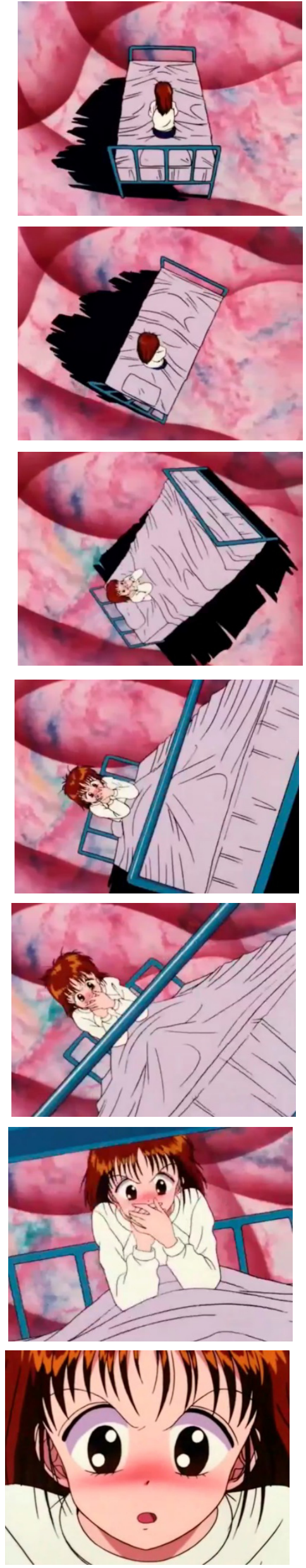

Fig. 62. Akinori Yabe (1994-1995). Mermelade Boy (La familia crece). Capítulo 1: Quiero enamorarme. Es guapo pero no le soporto. Serie de fotogramas. 
Las animaciones que no transmiten sensaciones cinéticas por el movimiento de los personajes y otros elementos requieren, para expresar el movimiento como vivenciado, potenciar otras cualidades como la creación de un espacio vivencial o la composición dinámica de la imagen (la sucesión de planos), como es el caso de muchos animes (animación japonesa), en los que la sucesión de los planos y los movimientos de cámara, antes que el movimiento de los personajes, tiene el peso expresivo. Por ejemplo, en Mermelade Boy (La Familia Crece) (Yabe, 1994-1995) la protagonista recibe un beso del chico que le gusta mientras ella finge estar dormida. La reacción emocional de la chica es transmitida por un movimiento de cámara en el que los elementos de la escena se ven desde puntos de vista poco habituales, mientras que ella se mantiene "congelada" en la misma posición (00:20:23) (Fig. 62) (Más sobre la composición móvil en el parágrafo 2.3.3 del capítulo 2).

\section{B. HOMOGENEIZACIÓN DEL MOVIMIENTO}

La primera manera en que se homogeniza el movimiento es por la objetividad, en el sentido en que el movimiento neutro transmite el movimiento con una claridad exenta de interpretaciones subjetivas; esto no significa que el movimiento sea naturalista, sino que plasma lo esencial para su comprensión es decir: dirección, sentido, velocidad y aceleración, libre de valoraciones subjetivas que hagan calificarlo como vertiginoso, impetuoso, brioso, extraño, simpático, suave, etc. En el vídeo El cuerpo humano para niño (s/a, s/f), la velocidad es absolutamente regular, tanto en la sucesión de planos como en los elementos móviles (partículas de oxígeno, líquidos, músculos, etc.). A los cambios de velocidad sutiles se suma la frialdad compositiva, supeditada a la claridad y objetividad de la explicación (Fig. 63).

También hay gran variedad de representaciones neutras, pues no todas derivan en un único modo de ser plasmadas, pero éstas despiertan sensaciones similares, por eso decimos que hay una tendencia a la homogenización de los resultados móviles. En este sentido, la representación del movimiento también puede tener una movilidad homogénea debido a otras circunstancias que no se ciñen a la representación básica de la dirección, sentido, velocidad y aceleración, sino por los recursos de representación dinámica o incluso por la técnica.

Los recursos de representación dinámica en animación son varios: los signos 


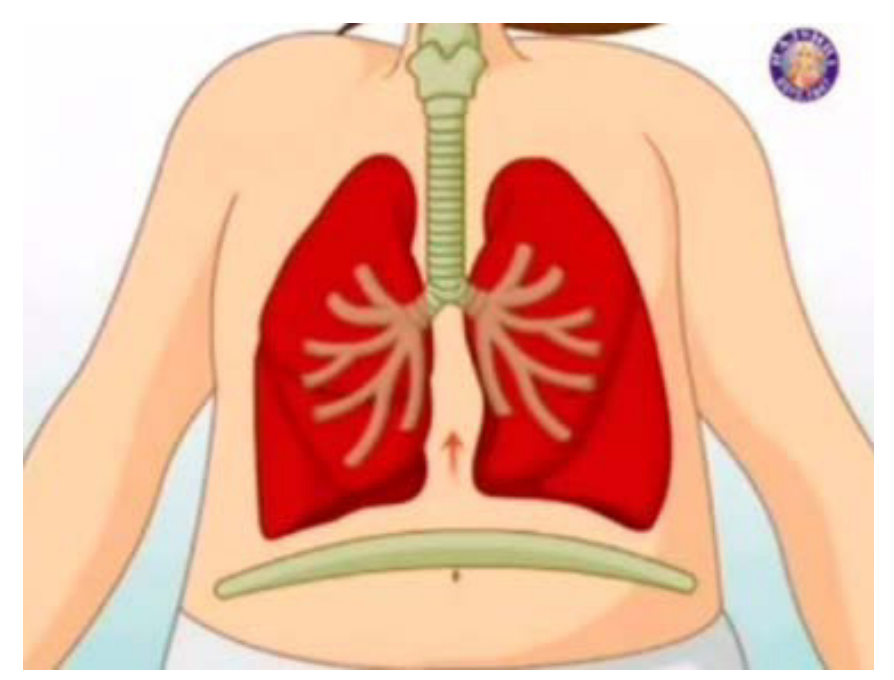

Fig. 63. s/a (s/f). El cuerpo humano para niños.

gráficos que provienen del cómic (como la multiplicación de la forma o las nubes de polvo para indicar velocidad), diversos compendios de recursos estilísticos, en los que se insertan los recursos dinámicos que han cobrado entidad propia en la animación (principalmente squash-stretch y anticipación-retroceso). Además, la movilidad característica de la técnica también puede proporcionar resultados dinámicos similares entre películas.

\section{B.1. Movilidad característica de la técnica}

Algunas técnicas presentan una movilidad muy característica que puede provocar cierta homogeneidad entre películas realizadas con la misma técnica. Nos referimos fundamentalmente al uso de acciones automatizadas por ordenador, a la rotoscopia y a la captura de movimiento por sensores. El amalgamiento de los resultados hace que el espectador identifique fácilmente las características móviles propias de estas técnicas. En el caso de la rotoscopia, como ya hemos comentado, se reconoce el movimiento de la acción real; en la captura por sensores, la digitalización de la acción real tiene una "pátina" también identificable, a medio camino entre la rotoscopia y las acciones por interpolación; y los programas de animación por interpolación proporcionan un cálculo predefinido para trayectorias fácilmente reconocible, a no ser que se introduzca una gran proporción de fotogramas clave que personalicen el movimiento. No obstante, aunque las animaciones hechas con estas técnicas por un lado presenten en mayor o menor grado movimiento neutro debido a este efecto de homogenización, a través de ellas también puede expresarse el movimiento como vivenciado. Por ejemplo, la video-escultura The Snail Trial (Artus, 2011), en el que la animación se realiza con ordenador, el atractivo movimiento resultante evoca el movimiento sinestésicamente y destaca por su belleza visual. (Fig. 64). 
Fig. 64. Philip Artus

(2011). Snail Trail.

Escultura láser.

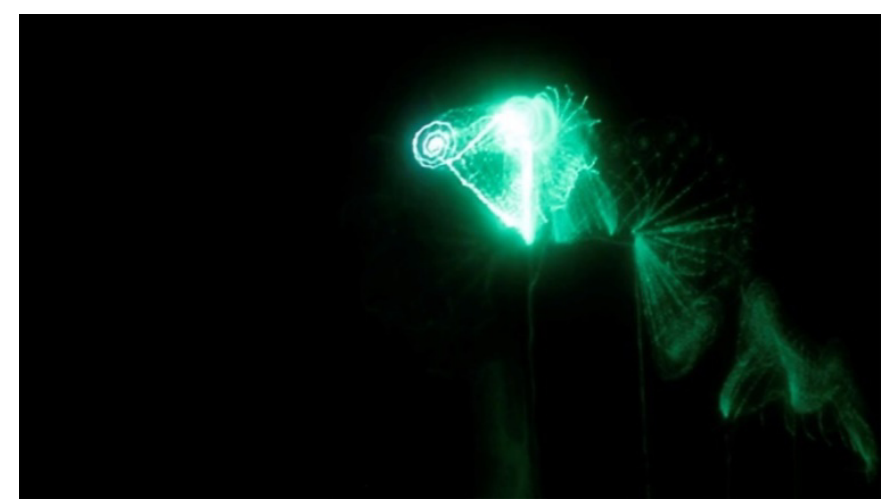

\section{B.2. Signos gráficos procedentes del cómic y recursos de repre- sentación móvil}

A veces, para reforzar el dinamismo, las imágenes se complementan con signos gráficos que indican movimiento, como los filajes y líneas cinéticas (líneas que indican la velocidad y la trayectoria); éstos son signos que abundan en el comic. Otros signos gráficos son las nubes de polvo para expresar velocidad, o estrellas cuando alguien se golpea en la cabeza, o el desdoblamiento del personaje para indicar velocidad, etc. En uno de los capítulos de Wile E. Coyote and the Road Runner (El coyote y el correcaminos) (Jones, 1951), los personajes levantan el polvo del camino tras ellos; cuando el coyote está apunto de atrapar al ave, ésta aumenta su velocidad, desapareciendo del plano y dejando en su lugar una nube circular, marca del drástico cambio de velocidad. A continuación el coyote se tropieza y todo su cuerpo se abalanza hacia delante dejando a su paso una estela que indica esta trayectoria. Finalmente, el animal agita la cabeza, movimiento para el cual se emplea la multiplicación de la forma, para indicar rapidez del movimiento (Fig. 65). Tales signos gráficos refuerzan el movimiento o compensan la ausencia de dinamismo en los dibujos, indicando, principalmente, las trayectorias y velocidad con un lenguaje conocido y aceptado por el espectador como propio del medio. Pero estos signos, que al igual que las metáforas de las que hablamos en el parágrafo anterior, no son necesariamente dinámicos, son prescindibles. En animación, medio en el que el movimiento se obtiene por la simple traslación del móvil, el reto trasciende a la mera indicación y comprensión de la acción.

La homogeneización del movimiento entre diferentes películas también puede resultar de la reunión de recursos de representación del movimiento más o menos extendidos que hacen que la expresión móvil en diferentes películas sea similar a pesar de estar hechas por diferentes autores y en distintas épocas. La representación consiste en un conjunto de recursos dinámicos que son fácilmente reconocibles debido a que su uso está notablemente popularizado, sobre todo en el 

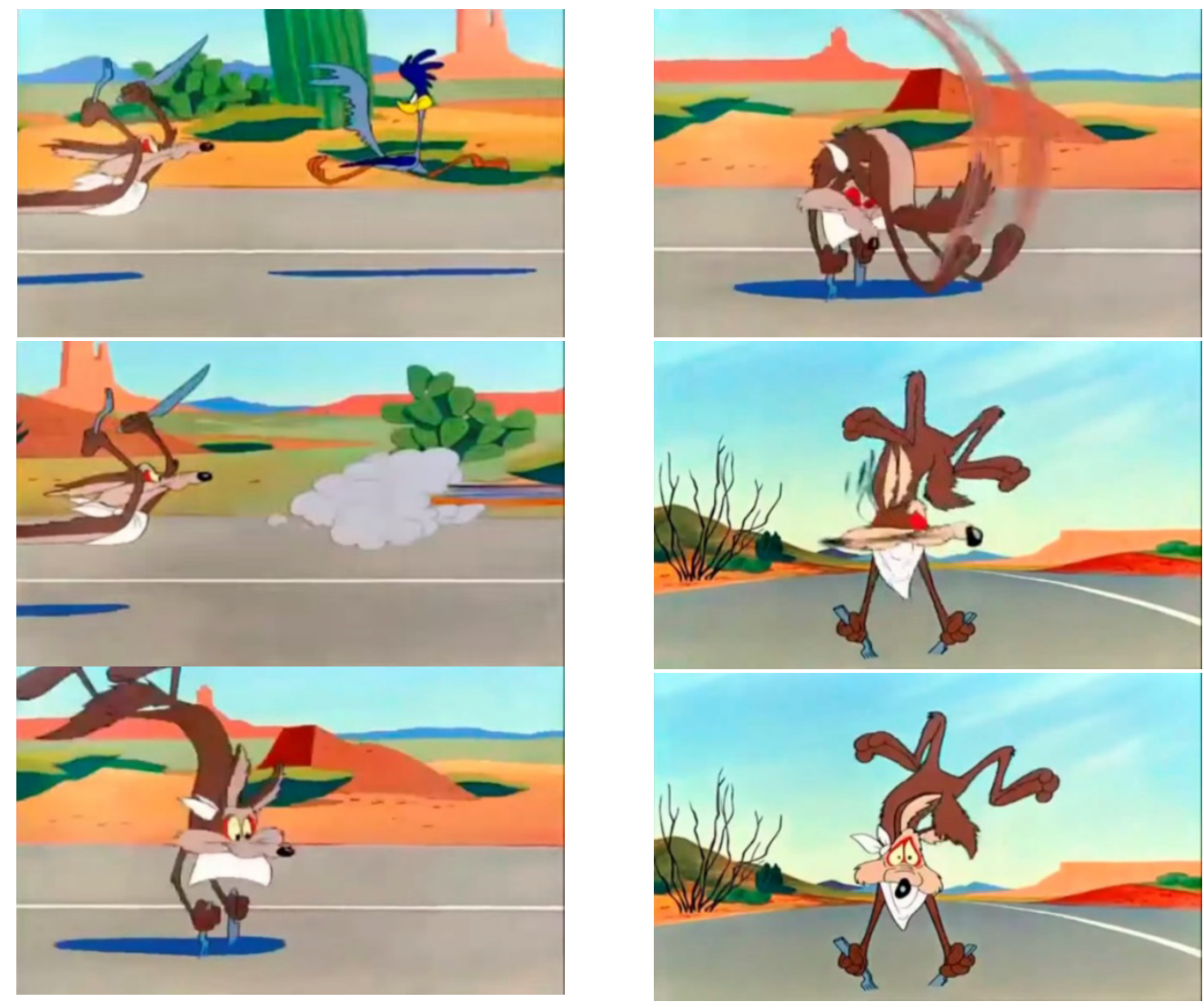

Fig. 65. Chuck Jones (1951). Wile E. Coyote and the Road Runner (E) coyote y el correcaminos). Serie de fotogramas.

ámbito industrial (el más accesible al gran público). La manera en que estos recursos de animación amalgaman la expresión del movimiento es similar al desvanecimiento de las peculiaridades del paisaje producido por las carreteras ${ }^{49}$ y también es resultado de la aplicación rígida de una serie de normas. Tanto si la codificación del movimiento bajo la que se crea una animación propone soluciones naturalistas como si no, convierte el movimiento en un elemento susceptible de homogenización.

El uso de códigos de representación móvil, a su vez, puede complicar la expresión de las características peculiares de cada movimiento porque normalmente éstos, al usar los mismos recursos para expresar diversos movimientos, aplanan la expresión. Además, lo característico de cada movimiento puede quedar velado tras el protagonismo de tales recursos. Así, por ejemplo, en Duet (Keane, 2014) los movimientos de cada personaje tienen prácticamente el mismo carácter, por ejemplo el chico, al correr, al trepar por un árbol o al escalar una montaña, transmite sensaciones cinéticas muy similares, en parte porque las tres acciones (de dificultad física diferente) se han representado con la misma intensidad cinética, a lo que se añade en todo momento el mismo efecto rebotante de la animación estilo Disney, muy sofisticado debido a la amplia experiencia del autor, pero

49 Bollnow, 1969, pág. 98 
que unifica el dinamismo. Las animaciones en las que no se recurre a un lenguaje preestablecido no corren el mismo riesgo de reiterar el mismo tipo de movimiento, por eso, los lenguajes al margen de los códigos pre-establecidos son más propicios para expresar el movimiento vivenciado.

\section{B.3. Compendio de recursos estilísticos}

Los estilos de animación con entidad propia, arraigada y popular están formados por un conjunto de recursos que forman las "recetas" para generar animaciones de estos determinados estilos. Los estilos más extendidos son el de Walt Disney Studios (que al inicio simplemente era el compendio de recursos de la animación de estudio que se hacía en América en los años 30 y que evolucionó hacia una manera de hacer exagerada pero "creíble" con entidad propia) y el anime (películas realizadas con el estilo gráfico del manga - cómic japonés - y que reúne los signos gráficos del cómic, parte de los recursos dinámicos de la animación americana y otros propios). Ambos son muy reconocibles y su aplicación dota de un mismo carácter a todas las producciones. El espectador sabe lo que puede esperar de ambos estilo en cuanto al movimiento, pero también en cuanto a otros elementos plásticos y de contenido (aunque en menor medida).

Hemos detectado que las características de la representación del movimiento que se mantienen en las películas realizadas según el "estilo Disney", desde Snow White and the Seven Dwarfs (Blanca Nieves y los siete enanitos) (Hand, Cottrell, Morey, Pearce, \& Sharpsteen, 1937) hasta Frozen, el Reino del Hielo (Buck \& Lee, 2013), son:

- Elasticidad acentuada de las formas al desplazarse, al iniciar un acción y al detenerse (efecto acordeón).

- Las anticipaciones y retrocesos (efecto rebote).

- Para expresar la emociones, los personajes adoptan sucesivas poses muy exageras y amaneradas, tanto con su cuerpo como con su rostro.

- La sucesión de planos y su composición imitan la planificación de una película de acción real.

- Los personajes son en gran medida independientes del fondo, aunque interactúan con éste y están perfectamente integrados visualmente.

- Los personajes están sujetos a arquetipos que siguen un diseño y un movimiento propio de cada tipo de personaje: mujer joven, delgada, inteligente y simpática; hombre joven, delgado y torpe; hombre corpulento bondadoso, etc.

- Etc. 
Algunas animaciones realizadas al margen de los estudios Disney en las que el movimiento presenta estas características son French roast (Fabrice O. Joubert, 2008), A Gentelmen's Duel (Duelo de caballeros) (McNally \& Ruiz, 2006), El vendedor de humo (Maestro, 2012), Francis (Hickey, 2013). En todas ellas se percibe que siguen el mismo patrón de movimiento y, habitualmente, también de diseño. (Fig. 66-70).

El otro estilo de animación más popular es el anime. Las producciones de Osamu Tezuka determinaron el estilo del anime; Tezuka era un apasionado de las películas de Hollywood y trataba de recrear en sus manga los encuadres y movimientos de cámara del cine occidental, lo que también quedó reflejado en sus películas. No obstante, a pesar de que la vinculación de Tezuka con la animación occidental determinó el camino del anime, la animación japonesa ha desarrollado un estilo de dinamismo con variantes propias. Aunque dentro del anime hay personalización del estilo y diferentes corrientes, algunas de las características habituales son:

- Cambios de velocidad muy acentuados.

- Composición de planos cinematográfica.

- Abundancia de movimientos de cámara por animación de notoria complejidad.

- Los personajes, al comunicarse, mantienen en estatismo total de todo el cuerpo a excepción de la boca, las pupilas y el efecto del viento en el cabello y la ropa.

- El cambio de pose es mucho menos frecuente que en la animación americana.

- La expresión de sentimientos y emociones se acompaña de signos gráficos a veces simbólicos, como una gotita de agua o sudor junto o sobre el personaje, que indica vergüenza o turbación; o un signo de exclamación o interrogación; también la forma de los ojos tiene una significación clara al adoptar la forma de líneas horizontales, líneas u óvalos verticales, puntos, espirales, etc. Este lenguaje procede directamente del manga.

Las producciones de este estilo son también incontables, y se realizan a nivel internacional, no restringiéndose a Japón. Algunos de los animes más populares en occidente son Berusaiyu no Bara (La rosa de Versalles) (Nagahama \& Dezaki, 1979-1980), Majingā Zetto (Mazinger Z) (Katsumata, 1972-1974), Ramma 1/2 (Mochizuki, Sawai, Nishimura, \& Shibiyama, 1989-1992) o Saint Seiya (Caballeros del zodiaco) (Morishita, 1972-1974) (Fig. 71-73). Hemos podido ver la influencia japonesa en la animación europea y americana en producciones más recientes 
como Pocoyo (Cantolla, Gallego, \& Garcia, 2005) y Big Hero 6 (Hall \& Williams, 2014).

Pese a la regularidad de los recursos, las sensaciones cinéticas pueden ser fuertes, porque la codificación del movimiento no tiene porqué ahogar la sensación cinética. Nos encontraríamos ante películas que tienen características del movimiento neutro, pero en las que también se expresa el movimiento vivenciado. Por ejemplo, en las series de animación japonesas la representación de combates está altamente codificada; dentro del código son infinitamente variadas, pero las semejanzas son evidentes. Así, el ritmo y la intensidad cinética varía de unos
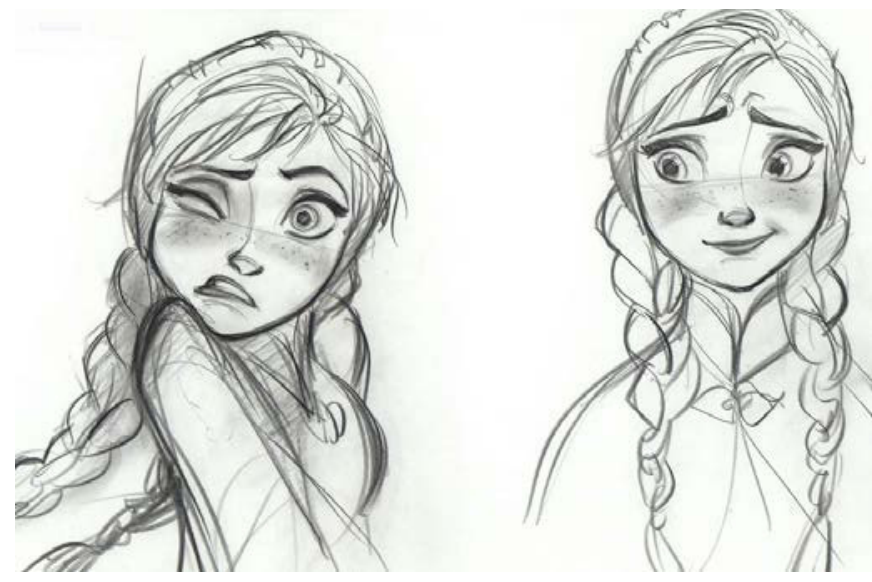

Fig. 66. Chris Buck y Jennifer Lee (2013), Frozen. Boceto.

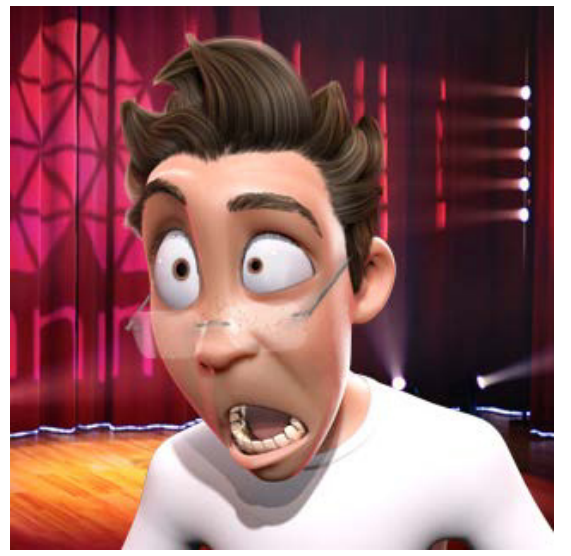

Fig. 68. David Plaza (2014). Mario Animum, el primer monologuista 3D.
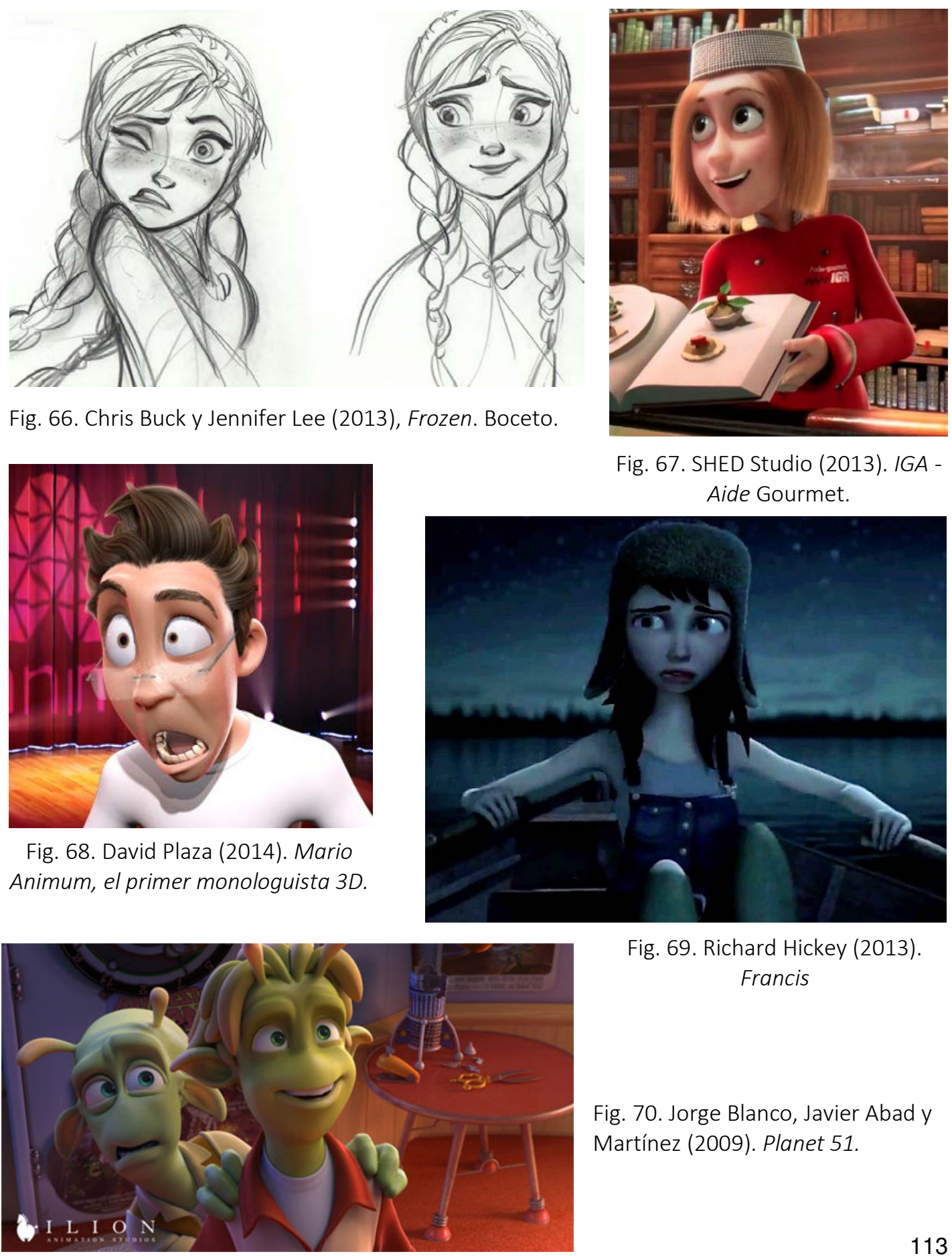

Fig. 67. SHED Studio (2013). IGA Aide Gourmet.

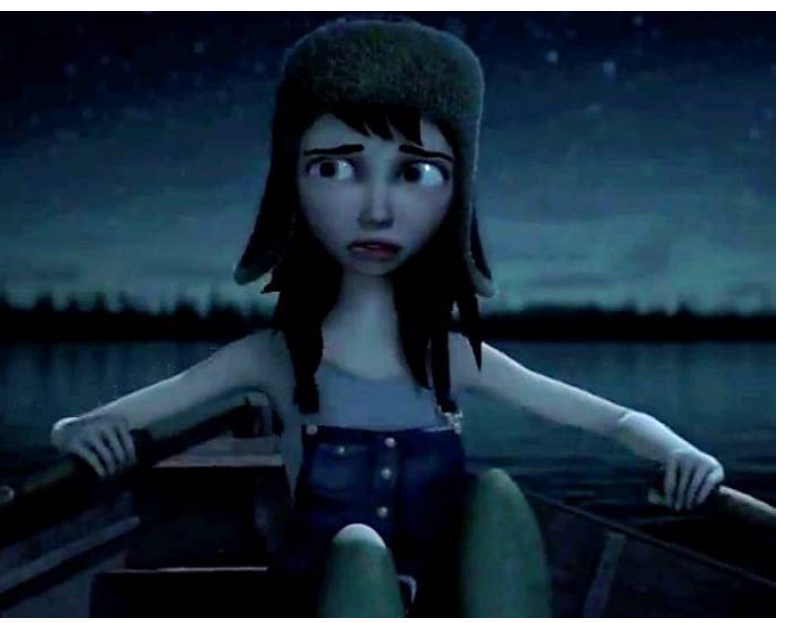

Fig. 69. Richard Hickey (2013). Francis

Fig. 70. Jorge Blanco, Javier Abad y Martínez (2009). Planet 51. 


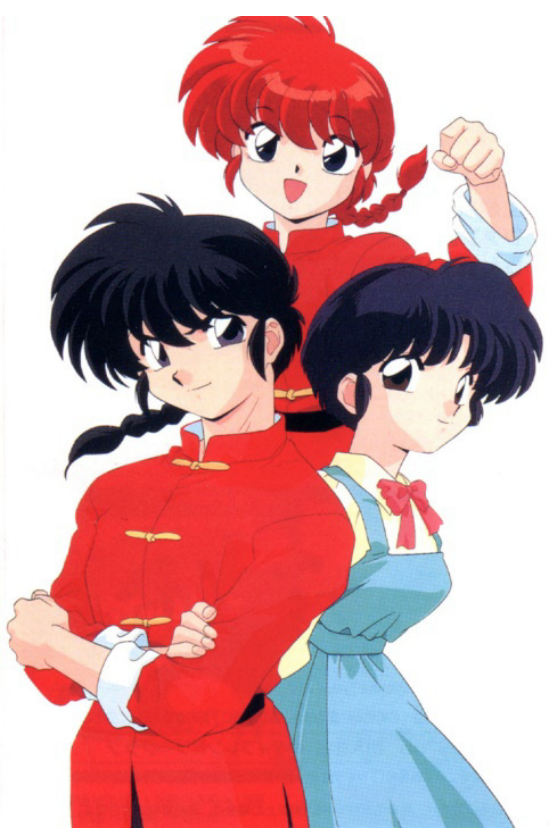

Fig. 71. Tomomi Mochizuki,, Koji Sawai, Junji Nishimura, Tsutomu Shibiyama (1989-1992). Ramma 1/2.

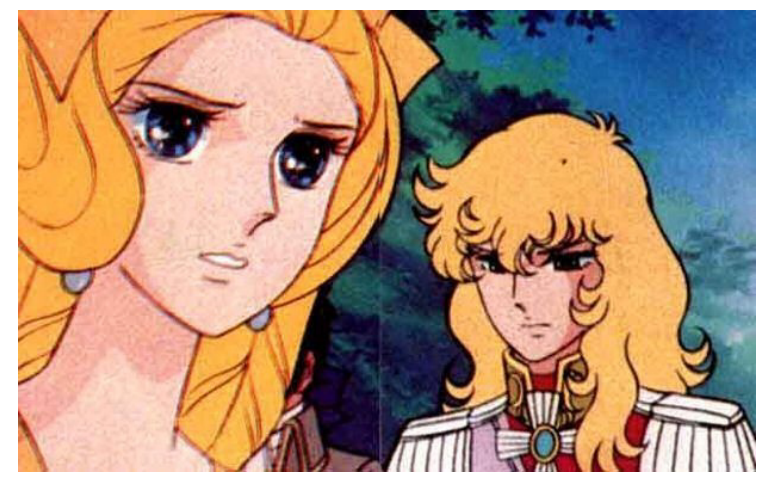

Fig. 73. Tadao Nagahama, Osamu Dezaki 19791980, Berusaiyu no Bara (La rosa de Versalles).

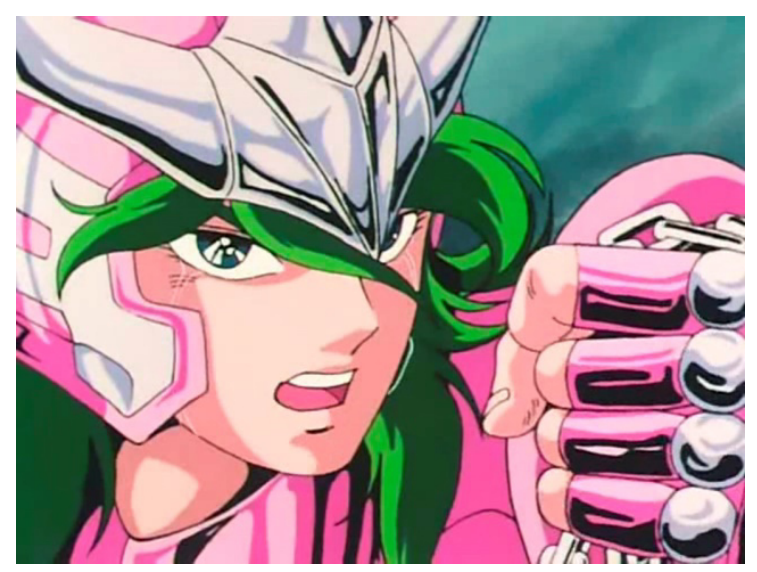

Fig. 72. Kōzō Morishita (1972-1974). Las cadenas de la anmistad; Saint Seiya (Caballeros del zodiaco).

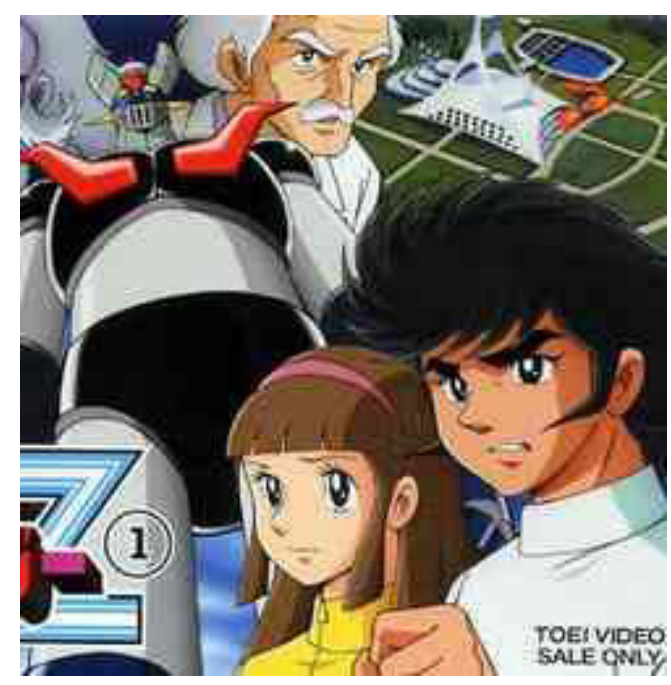

Fig. 74. Tomoharu Katsumata 1972-1974, Majingā Zetto (Mazinger Z).

combates a otros, pero permanece reconocible como cambio de intensidad propio del anime (alto contraste entre estatismo y dinamismo, velocidad extrema y cámara lenta, efectos abstractos como bolas de energía, haces de luz, fragmentos de roca también a alta velocidad, etc.). Sin embargo, hay pasajes que logran de manera notable transmitir sensaciones cinéticas que sorprenden al espectador pese al marco común de expresión, y por ello, en ellas identificamos el movimiento vivenciado. Esto nos lleva a concluir que la homogeneidad, cuando se refiere a la recreación de un estilo específico de animación no es incompatible con la expresión vivenciada. Así mismo, que el movimiento no siga un estilo preestablecido no implica que el movimiento se exprese como vivenciado, porque el movimiento vivenciado no se define por separarse de los lenguajes codificados, sino por su capacidad para transmitir dinamismo de manera sinestésica. 


\section{LOS ACONTECIMIENTOS TIENEN LUGAR EN UN ESPACIO MATEMÁTICO-NEUTRO}

Una manera de representar el movimiento neutro es por medio de la inserción de los acontecimientos en un espacio acorde a la definición del movimiento que presentamos en este trabajo, es decir, un "espacio neutro" que sería "matemático" acorde a la definición de Bollnow, ya sea por medio de la geometría (con la que se compone un espacio triaxial ortogonal medible de manera regular) o por su carácter homogéneo. Sin embargo, al igual que hicimos con la definición del movimiento neutro, destacamos que el lenguaje matemático no implica siempre espacio neutro, por lo que no constituye una característica definitoria de este espacio, sino que se define por su cualidad libre de connotaciones emocionales y su objetividad (como sistema objetivo, no como representación naturalista).

En animación, el espacio matemático estrictamente geométrico impide la flexibilidad necesaria para la representación de las cualidades cinéticas del movimiento, ya que determina en parte la interpretación del movimiento al concretar mediante un sistema regular el dónde de la acción. Así lo vemos en la figura 75 . En el cortometraje Delivery (Smith, 2002), la proximidad de los puntos de fuga acentúa las deformaciones del espacio y los elementos que se insertan en él. La regularidad geométrica de estas deformaciones hace que la distorsión de las proporciones deje de ser sorprendente tras los primeros momentos de visionado (Fig. 76). En A Gentelmen's Duel (Duelo de caballeros) ( McNally \& Ruiz, 2006) la representación del espacio es completamente geométrica y presenta características fotográficas como la profundidad de campo. La apariencia fotográfica de los escenarios, así como su papel restringido a simple localización de la historia que se narra, hacen de él un espacio matemático (Fig. 77). De la misma manera, la habitación en la que se desarrolla How to cope with Death (Cómo lidiar con la Muerte) (Ferreras, 2002) posee un diseño que prioriza la geometría y las proporciones de la representación naturalista del espacio (Fig. 78).

Pero de la misma manera que el espacio vivencial en animación puede representarse por medio del dibujo geométrico, el espacio neutro no queda definido por su aspecto geométrico, sino por sus cualidades espacio-temporales. Así, un espacio aparentemente matemático puede revelarse como vivenciado en su transcurso, y un espacio de diseño aparentemente dinámico, puede ser neutro. En Die Abenteur des Prinzen Achmed (Las aventuras del príncipe Ahmed) fotogramas de dos escenas (Reiniger, 1926) algunas escenas se desarrollan frente un fondo con el que las figuras no interactúan y que, pese a su belleza, se reconocen tras pocos segundos como "inaccesibles", fuera de la acción. No obstante, esto no 
merma las cualidades dinámicas de la película, de gran expresividad (Fig. 79). Otra manera de espacio neutro son los fondos "neutros" o espacio "inexistente", que además con los que además no hay ninguna interacción y ni si quiera ubican la acción (Fig. 63).

Bollnow hace énfasis en la cualidad regular y desvinculada de emociones personales del espacio matemático ${ }^{50}$. Por ello, hablamos de espacio neutro en toda representación que, del mismo modo que la representación geométrica estricta, homogenice las sensaciones que despierta en el espectador. En animación, encontramos lenguajes gráficos que poseen la cualidad de amalgamar espacios diferentes bajo las mismas características. En las imágenes 80 y 81 vemos diferentes escenarios que tienen en común la omisión sistemática del ángulo recto y que transmiten una sensación similar.

En definitiva, el espacio neutro en animación es aquel que carece de capacidad para transmitir sensaciones cinéticas, ya sea por su geometría o por su regularidad respecto a otras representaciones espaciales.

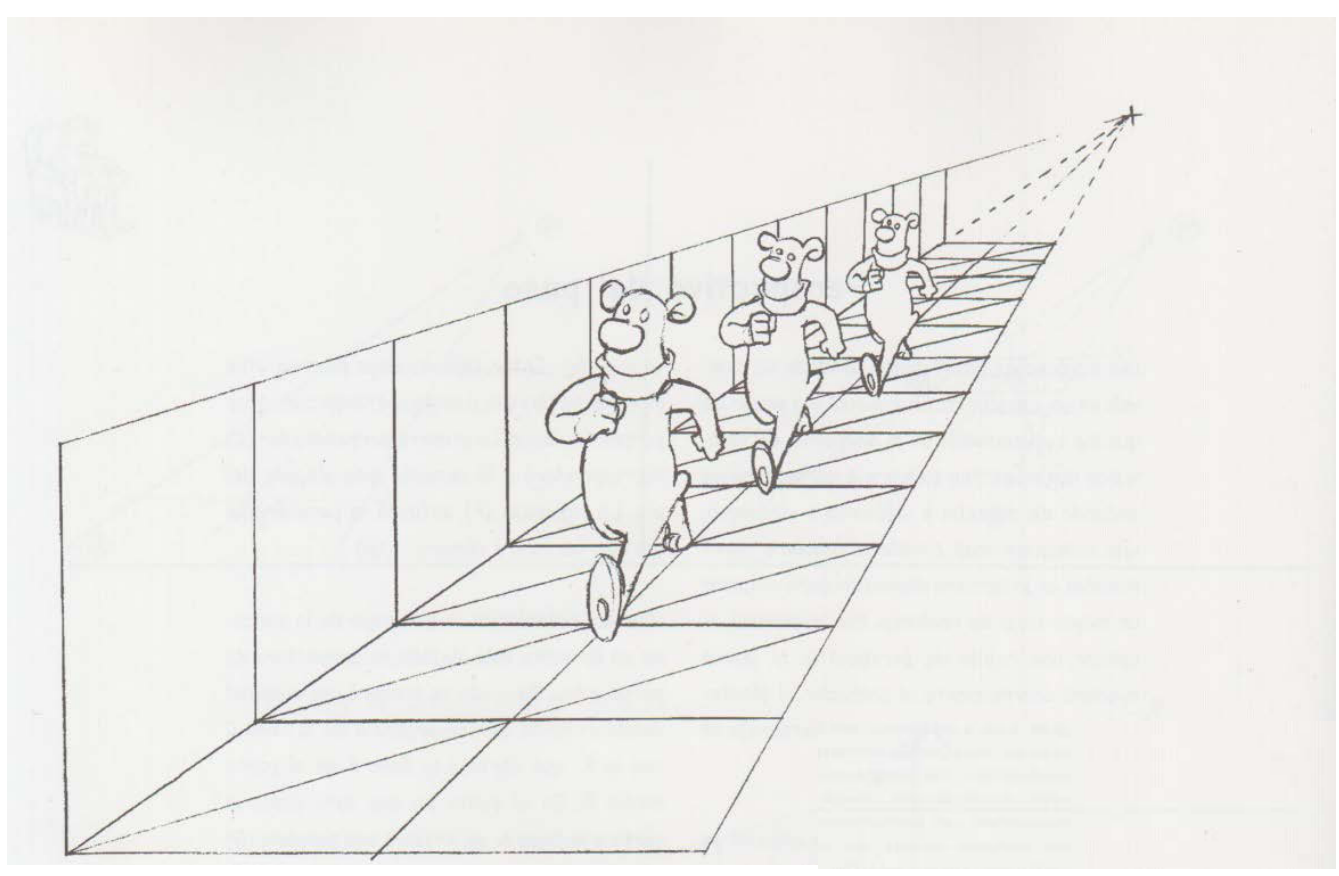

Fig. 75. Raul García (s/f). Dibujo en perspectiva.

\footnotetext{
${ }^{50}$ Bollnow, a partir de las reflexiones de Linschoten sobre el efecto homogeneizador que las carreteras tienen sobre el paisaje, atribuye al espacio matemático la cualidad de ser homogéneo. Bollnow, 1969, pág. 98
} 
Fig. 76. Patrick Smith (2002). Delivery (Entrega). Fotogramas de dos escenas.
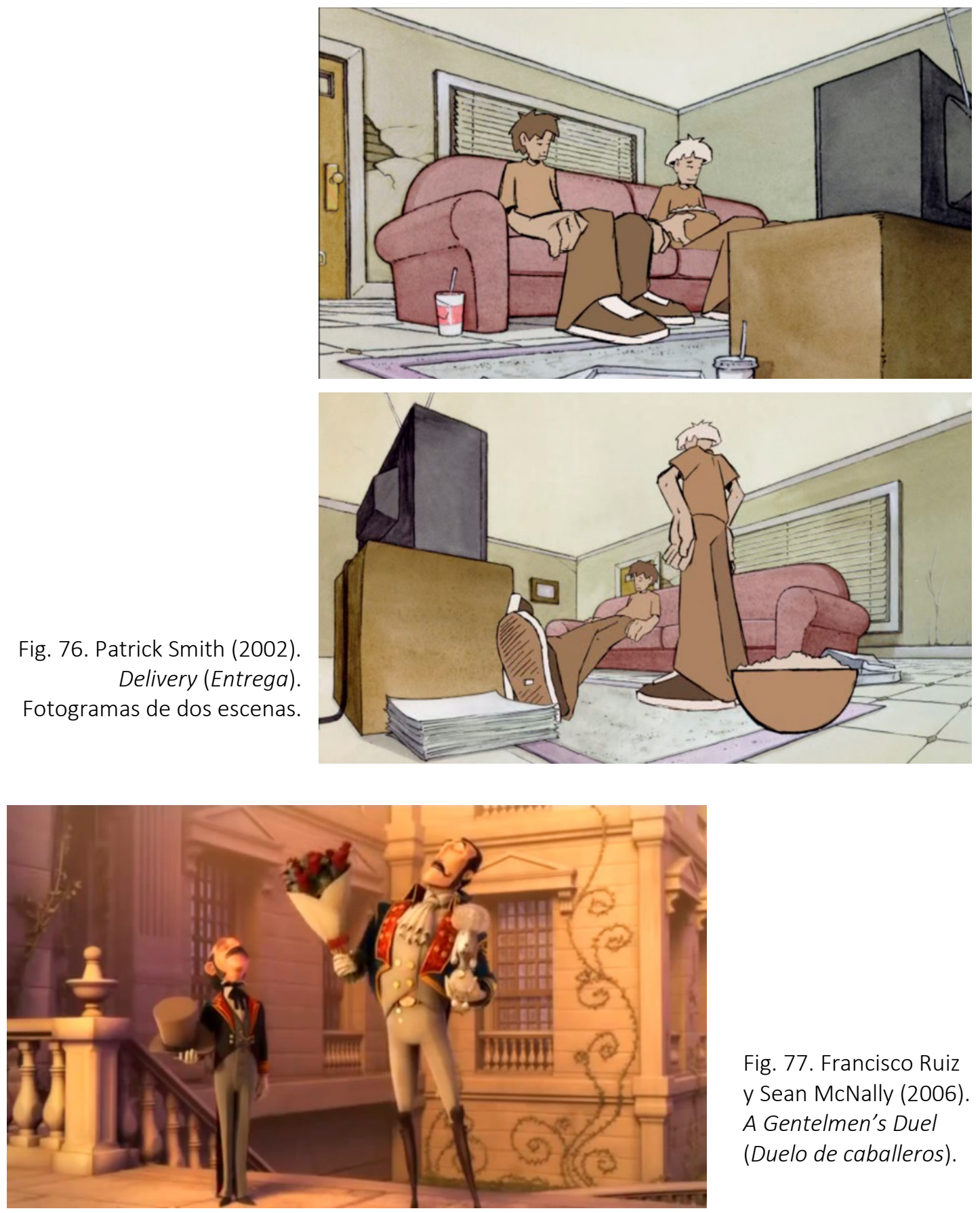

Fig. 77. Francisco Ruiz y Sean McNally (2006). A Gentelmen's Duel

(Duelo de caballeros).

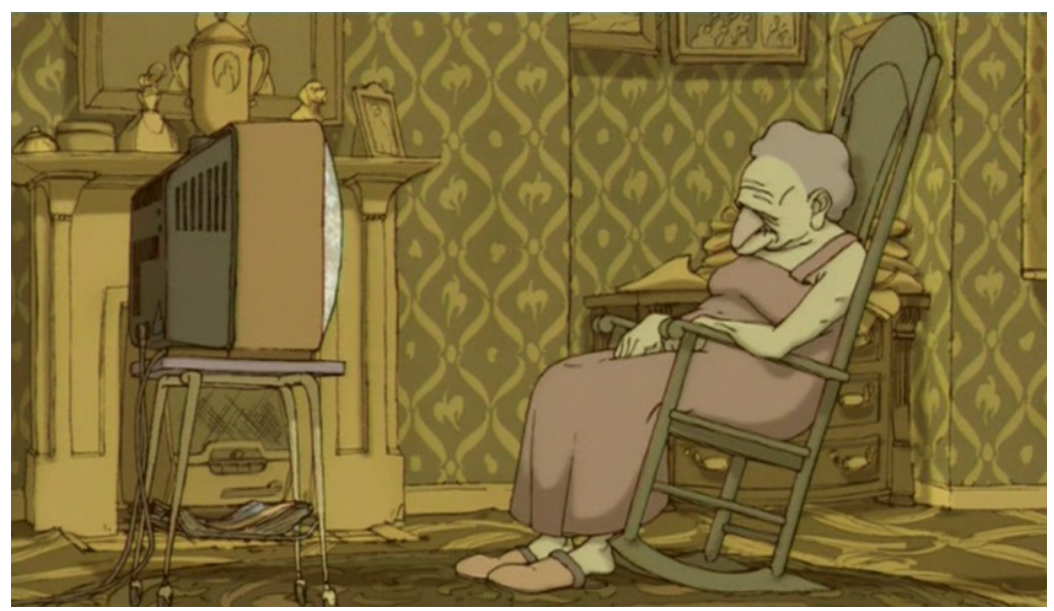

Fig. 78. Ignacio Ferreras (2002). How to Cope With Death (Cómo lidiar con la muerte). 

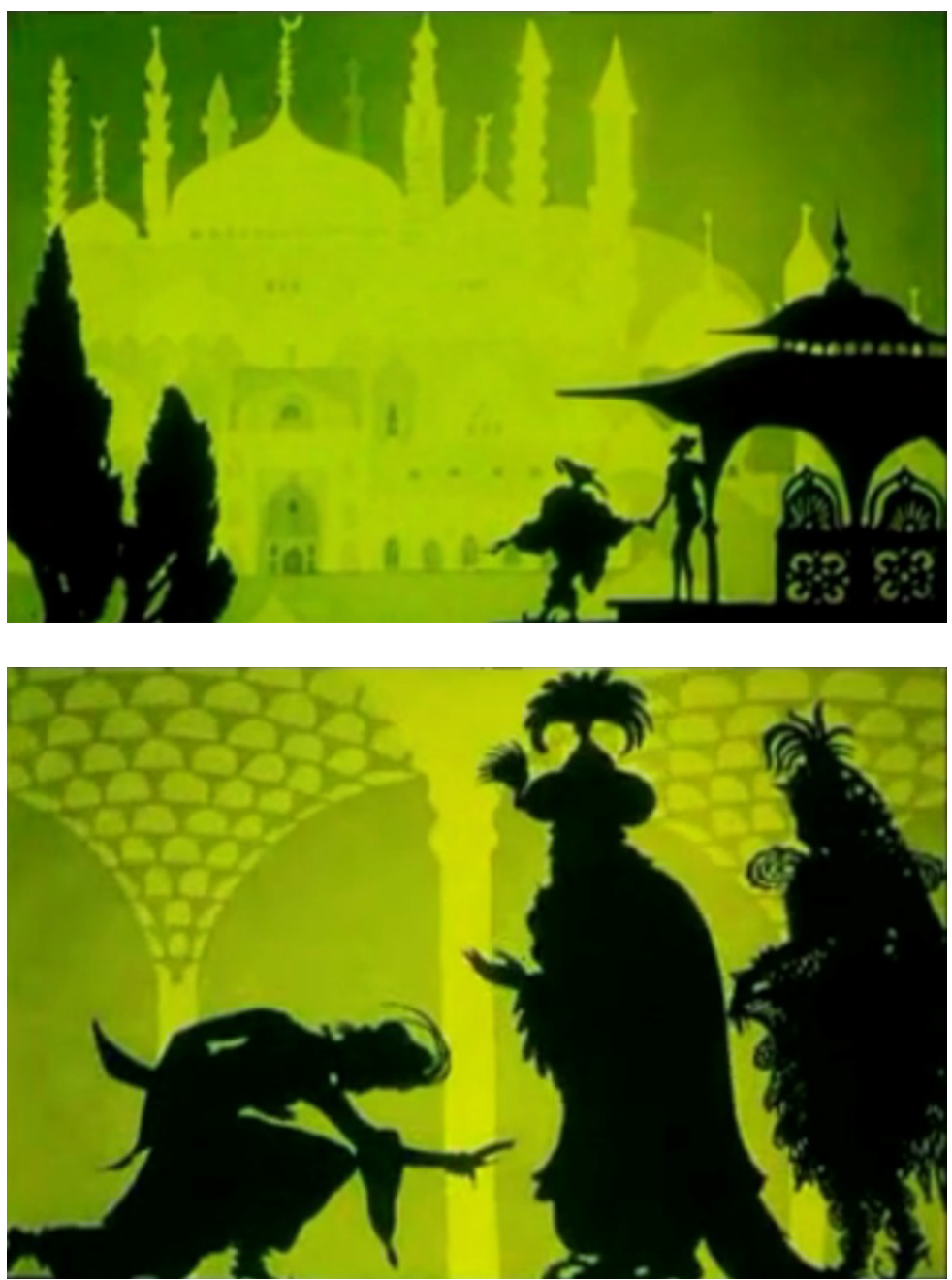

Fig. 79. Lotte Reiniger (1926). Die Abenteur des Prinzen Achmed (Las aventuras del príncipe Ahmed). Fotogramas de dos escenas.

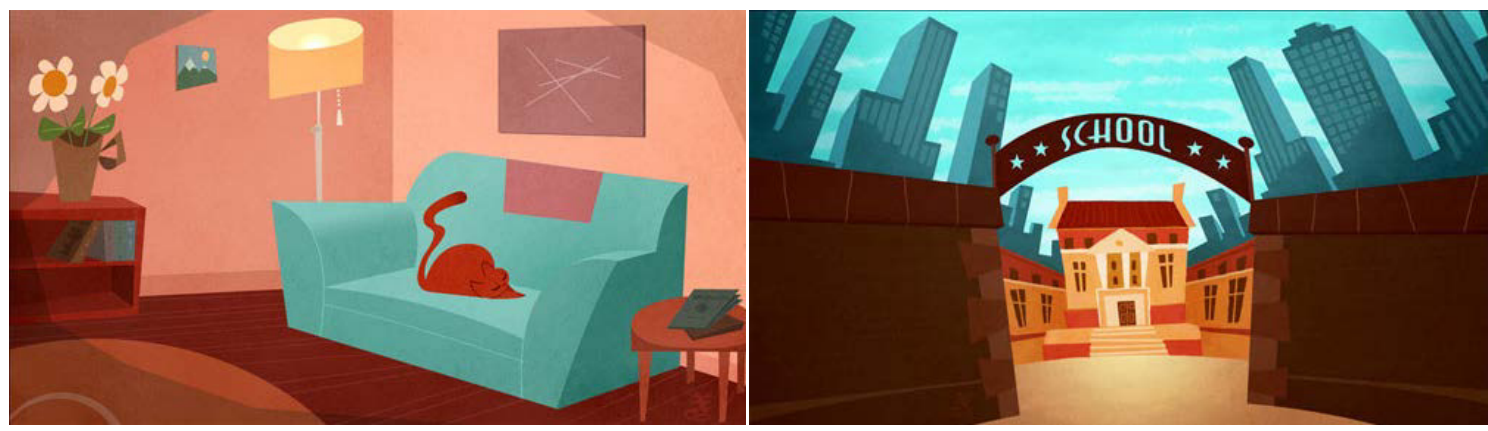

Fig. 80. Rafiq Elmansy (s/f). Fondos para animación.
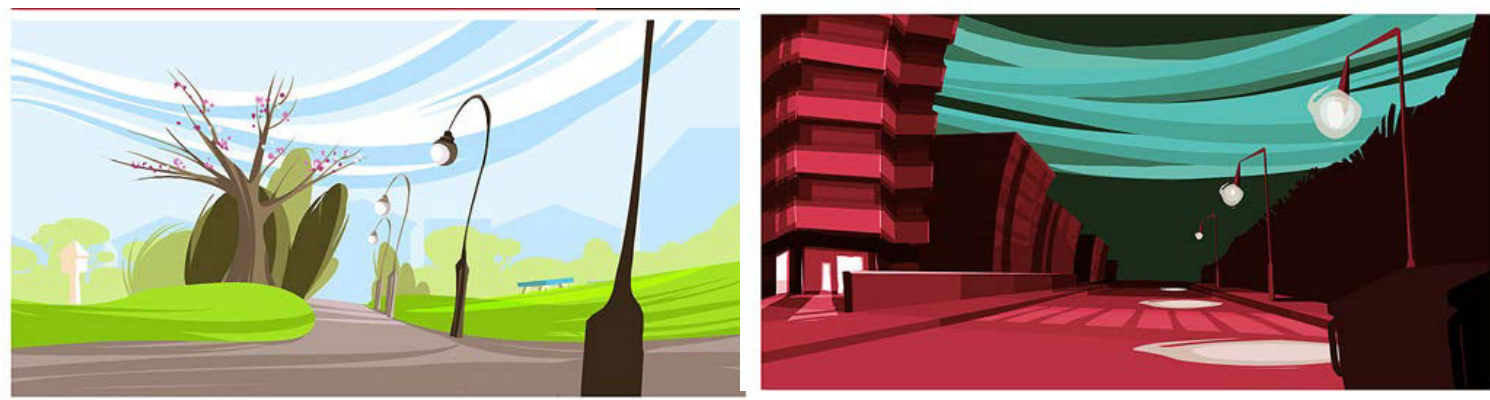

Fig. 81. Rafiq Elmansy (s/f). Fondos para animación. 


\section{EL MOVIMIENTO NO TRANSMITE EL CONTENIDO EMO- CIONAL}

La conjunción de los anteriores elementos da como resultado la neutralidad en la expresión del movimiento. Esta cualidad ya ha sido apuntada anteriormente al explicar en el apartado B. del presente parágrafo que en la representación neutra destaca sobre todo la identificación de la acción y principalmente las cualidades del movimiento: dirección, sentido, velocidad y aceleración. Al contrario que el movimiento vivenciado, en el que se transmite el contenido emocional, el movimiento neutro "puro" no expresa ninguna emoción, por lo que es difícil encontrar películas con movimiento totalmente neutro en el ámbito artístico, mientras que este tipo de representación dinámica es el más frecuente en videos de carácter científico, destinados al campo educativo, como vídeos sobre el funcionamiento del cuerpo humano, física, recreaciones virtuales de edificios o acontecimientos históricos, etc. En la simulación 3D de la casa del Fauno de Pompeya (Barragán, h. 2012), la prioridad reside en la fidelidad de la recreación histórica, realizada a partir del plano real de la ciudad, las medidas de los espacios y edificios, los colores (en unos casos los conocidos y en otros los posibles), etc. (Fig. 82). Los vídeos explicativos del protocolo de seguridad a bordo de un avión, como el de Airberlin (Airberli, s/f) y otras compañías, son modelo de ausencia de transmisión de emociones ya que, de hecho, es una de las características requeridas (Fig. 83). En estos ejemplos se concentra la ausencia de sinestesia, la representación del espacio neutro y la homogenización de la expresión móvil.

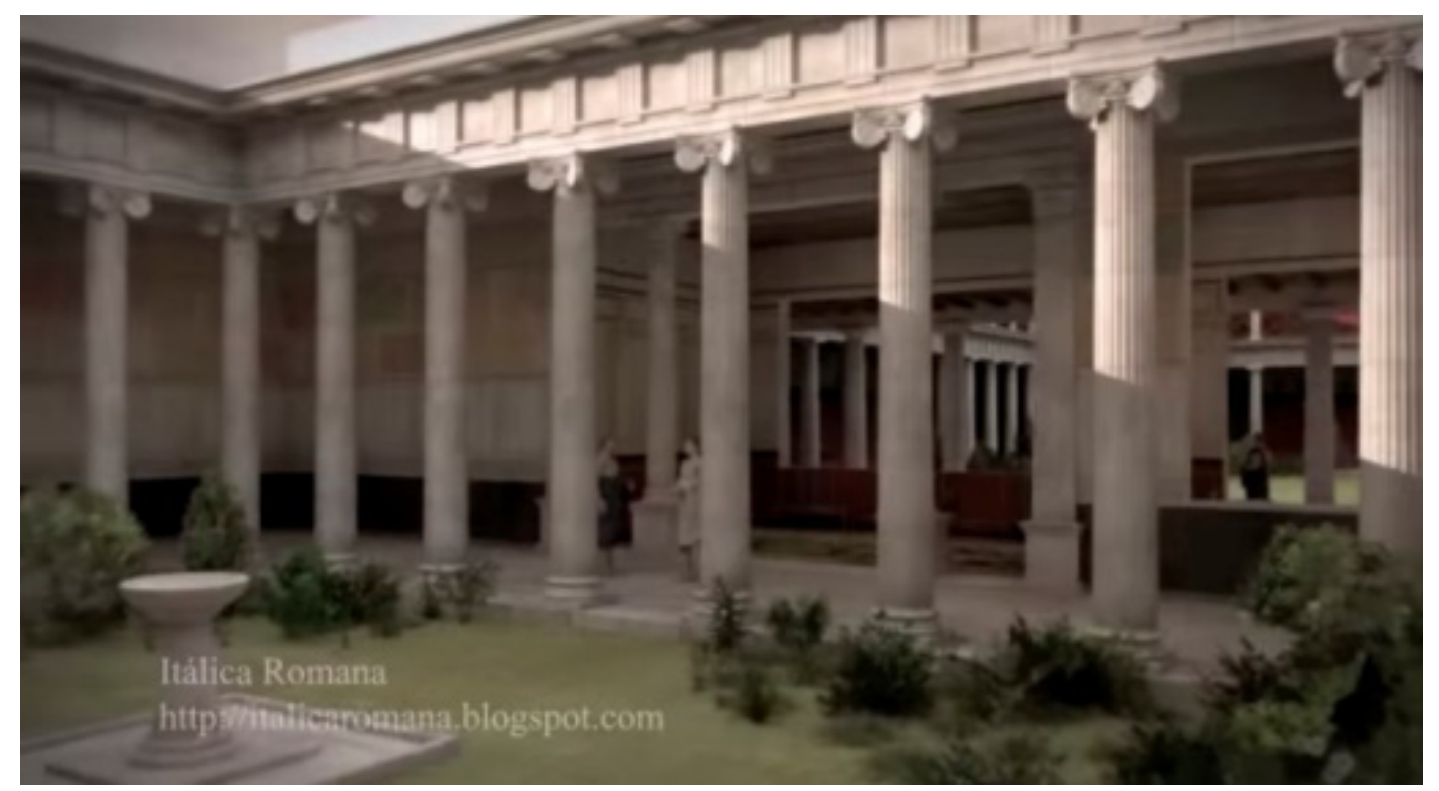

Fig. 82 . 
Movimiento vivenciado y movimiento neutro. Estudio sobre la expresividad

de la representación del movimiento en animación

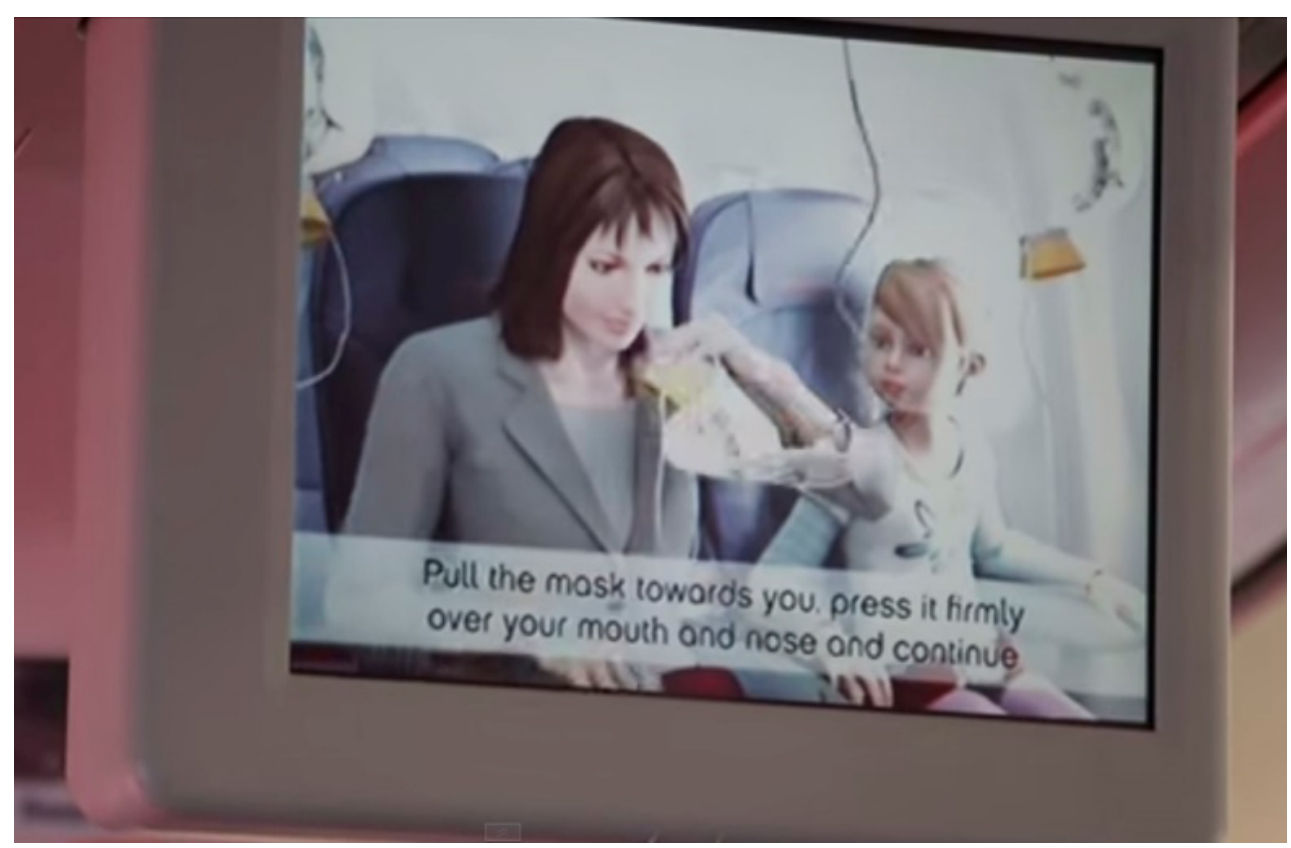

Fig. 83. Airberlin (s/f). Video de seguridad abordo. 


\section{CONCLUSIONES}

- En primer lugar, a modo de sumario, queremos recordar la línea principal del discurso en la primera parte de este capítulo: los conceptos de movimiento vivenciado y movimiento neutro son dos modos de denominar dos extremos de la intensidad expresiva de la representación del movimiento. Para definirlos nos hemos apoyado en los conceptos de espacio vivencial y espacio matemático de Bollnow; el primero es una comprensión del espacio a través de la experiencia humana, las posibilidades físicas de movimiento, conexiones emocionales y toda vivencia de estar y moverse en el espacio; y el espacio matemático es la interpretación matemática así como todo sistema objetivo de representación y gestión del espacio, al que Dürkheim atribuye también la homogeneidad del espacio.

- El concepto de espacio vivencial evoca cualidades de la vivencia subjetiva que se ven reflejadas en representaciones del movimiento de gran intensidad expresiva. Pero mientras que Bollnow se decanta por el término "vivencial" para hablar del espacio porque hace alusión a la trascendencia del concepto más allá de la vivencia subjetiva o personal, nosotros tomamos el término "vivenciado" porque la característica definitoria esencial de las representaciones móviles que denominamos con este término es la capacidad para evocar en el espectador la sensación de estar viviendo en primera persona el movimiento.

- En cuanto a la trasposición del concepto de espacio matemático al movimiento, aunque ciertamente el movimiento tal cual es explicado por las matemática y la física constituye movimiento neutro, su representación en el arte y la animación no se limita a la perspectiva proyectiva o a la representación geométrica, e incluso el movimiento vivenciado es posible a través de estos lenguajes. El movimiento al que nos referimos a partir del concepto de Bollnow se define como aquel que transmite un mensaje por medio de la desvinculación total de sensaciones cinestésicas o connotaciones particulares o emocionales, es un movimiento expresado con "frialdad"; por ello lo denominamos neutro.

- La expresión del movimiento vivenciado y neutro se identifica por las sensaciones que evoca en el espectador. La característica principal que tiene el movimiento vivenciado en el arte y en concreto en animación es la de evocar sensaciones 
cinestésicas, mientras que el movimiento neutro se destaca por lo contrario. También hay otras cualidades que permiten identificar la representación móvil como vivenciada o como neutra: la transmisión de características peculiares del movimiento o su ausencia, que es el punto de partida de la homogeneidad en la representación; la capacidad para transmitir o no el contenido emocional; y el tipo de espacio en el que se ubican los acontecimientos (neutro o vivencial, acorde con la definición del movimiento, y no determinado por si se trata de representación matemática o es independiente de ésta).

- Estas características se manifiestan de diversas maneras en animación. Para expresar el movimiento como vivenciado, uno de los recursos que normalmente conecta con la experiencia personal (pero no siempre) es el mostrar el punto de vista del personaje, su visión. También puede ayudar a evocar el movimiento vivenciado sin necesidad de coincidir con la ocularización, representar las emociones por medio del movimiento o de manera metafórica. La expresión de las peculiaridades del movimiento también están conectadas con la expresión subjetiva. $Y$ en cuanto al espacio, éste puede revelarse como vivenciado en el trascurso de la obra por cómo se da a conocer por medio del movimiento, tanto por cómo los personajes se relacionan con éste, como por cambios o acciones del espacio, aunque se trate de una representación matemática.

- En cuanto al movimiento neutro, ciertas técnicas y las representaciones más coincidentes con la realidad mecánica suelen carecer de la capacidad para evocar sensaciones cinestésicas, aunque el movimiento vivencial también es posible a través de ellas (como veremos en los capítulos 3 y 4 , se da en todas las técnicas y en todos los niveles de naturalismo). $Y$ respecto al espacio, por la interacción de los personajes y otros elementos móviles, éste se puede manifestar como neutro por su inaccesibilidad (funciona como fondo) o por la representación geométrica sin intervención de acontecimientos que lo revelen como vivenciado.

- La homogeneidad provine de la prioridad en la representación de los valores fundamentales del movimiento (dirección, sentido, velocidad y aceleración) manteniéndose al margen de otras cualidades del movimiento que responden a experiencias subjetivas; pero también se da por el uso de estilos específicos de animación o signos gráficos, aunque esta cualidad no impide otras características del movimiento vivenciado, como las sensaciones cinestésicas. Por lo que la homogeneidad, cuando proviene de la repetición de un estilo, no determina que el movimiento sea neutro. 
- Normalmente la transmisión de sensaciones cinestésicas tiene poder sobre las demás cualidades mencionadas, de modo que esta característica no requiere de las demás para expresar el movimiento vivenciado; pero su ausencia no avoca a la neutralidad expresiva, ya que las otras cualidades pueden conectar con vivencias, imágenes, etc. que evocan la sensación de vivir los acontecimientos representados sin ella. Pero cuando mayor impacto provocan éstos, es cuando vienen acompañados de impresiones cinestésicas.

- Las cualidades y características mencionadas se presentan en distintos grados de intensidad. Pueden darse aisladas, o en conjunción de todas o varias. También se dan en combinación características del movimiento vivenciado y del neutro, incluso cualidades opuestas, dentro de la misma película. La calificación de la expresión en estos casos depende de qué cualidades tengan mayor protagonismo expresivo. La expresión del movimiento absolutamente vivenciada o neutra ("pura") puede darse en toda la película o en sólo una parte, y a veces sólo en una acción o instante concreto. Cada obra es diferente. Pero mientras que es relativamente frecuente encontrar animaciones enteramente neutras (sobre todo en el campo científico y educativo), el movimiento vivenciado suele presentarse en su máxima expresión en fragmentos concretos de una película. 

2. REPRESENTACIÓN DEL MOVIMIENTO VIVENCIADO Y EL MOVIMIENTO NEUTRO EN ANIMACIÓN. COMPONENTES DINÁMICOS 

En este capítulo se analiza la expresión del movimiento vivenciado y el neutro en animación a través de diversos recursos técnicos y cinematográficos. La animación es un medio de expresión complejo en el que participan muchos elementos. Con el fin de delimitar en qué elementos de la animación "reside" la expresividad del movimiento, hemos considerado que este medio está formado por cinco componentes dinámicos que funcionan siempre a través de una inseparable conexión. Comenzamos el capítulo con una síntesis sobre aspectos técnicos fundamentales de la animación: el movimiento real y virtual que la hacen posible (2.1.1.) y se plantea el debate sobre la importancia de los fotogramas (2.1.2.). A continuación diferenciamos entre componentes plásticos y dinámicos de la animación (2.1.3.). De este modo, los tres apartados de 2.1. sirven como introducción al parágrafo 2.2. y al capítulo 3, en los que se estudian pormenorizadamente aspectos técnicos y cualidades cinematográficas que proporcionan los componentes dinámicos de la animación, así como el modo en que actúan sobre la representación del movimiento vivenciado y el neutro.

En este capítulo estudiamos detalladamente los siguientes componentes dinámicos: cambio de imagen (la sucesión de fotogramas), composición móvil, distribución de la intensidad cinética y presentación de la historia (relato). La valoración espacio-temporal se desarrolla en el capítulo 3 porque constituye el componente dinámico en el que más difieren la animación y el cine de acción real. No obstante, hemos considerado conveniente incluir en el presente capítulo un aparatado sobre dicho componente dinámico, apartado en el que se explica brevemente qué es y se anticipan los temas que se tratan en capítulo 3; con ello englobamos este componente en el discurso del presente capítulo y, así mismo, las conclusiones extraídas también se refieren a este elemento.

Para llevar a cabo este estudio se han realizado análisis de películas de animación, gracias a los cuales se ha llegado a las ideas que se exponen a lo largo de los capítulos 2 y 3 . Algunos de estos análisis figuran en el anexo 4 . Al final de 
los apartados en los que se trata cada componente espacio-temporal, hay un apartado (C.) en el que se sintetizan las ideas extraídas respecto a la influencia de los diversos recursos técnicos y cinematográficos sobre la expresividad de la representación del movimiento, y funcionan como conclusiones sobre cada componente dinámico. Veremos que en las representaciones más expresivas, así como en las neutras, aunque tienen algunos aspectos en común, casi todas las cualidades dinámicas (composición muy dinámica o menos, cadencia rápida o lenta, variedad de movimiento o no, etc.) existen tanto en películas con movimiento vivenciado como con movimiento neutro; así pues, no constituyen rasgos distintivos propios, por lo que no es posible determinar un modo de hacer para obtener determinado nivel expresivo. 


\subsection{REPRESENTACIÓN DEL MOVIMIENTO EN ANIMACIÓN. ASPECTOS TÉCNICOS}

El objetivo de este apartado es desgranar la complejidad de la animación como medio para representar el movimiento con el objetivo de aclarar conceptos que luego serán clave en el apartado 2.2. y en el capítulo 3. Los elementos físicos que generan la animación son muy pocos, pero su conjugación hace de éste un medio con muchísimas posibilidades expresivas. La característica distintiva principal de la animación es que es un medio en el que el movimiento existe físicamente, movimiento real que, por un fenómeno óptico, genera un movimiento virtual que constituye la materia prima sensible. En animación la representación dinámica tiene lugar través de esta ilusión de movimiento. En 2.1.1. se diferencia entre el movimiento presentado y representación del movimiento, y entre movimiento real y virtual; a continuación, en 2.1.2. estudiamos el debate sobre la relevancia de los fotogramas como imágenes individuales y su papel en el conjunto de la animación; y finalmente, en 2.1.3. diferenciamos entre componentes plásticos y componentes dinámicos de la animación.

\subsubsection{TIPOS DE MOVIMIENTO}

En este apartado se tratan conceptos bien conocidos por los profesionales de la animación y estudiosos del tema; los reunimos aquí para que sirvan de introducción antes de adentrarnos en los entresijos técnicos que se tratan en los siguientes apartados.

\section{A. MOVIMIENTO PRESENTADO Y MOVIMIENTO REPRESENTADO}

\section{Movimiento presentado}

En arte, el movimiento que se presenta es aquel que existe físicamente como parte de la obra; es un movimiento real. El movimiento real es la materia prima que configura las obras de arte cinético como los móviles de Alexander Calder y las "criaturas cinéticas" de Theo Jansen (en las que el viento acciona los mecanismos que las hacen "caminar"). En el arte cinético el movimiento real es la materia sensible para la creación de la obra. Las artes escénicas también se con- 
figuran a través del movimiento real. En el teatro y la danza el movimiento que se presenta es el de las personas, vestuarios y escenografías. Mientras que en el cine de acción real y la animación el movimiento presentado es el del cambio de imagen, aunque al ver $x$ imágenes por segundo, éstas se perciben como un movimiento continuo (según el número de fotogramas por segundo puede ser tan continuo como el movimiento real) y no como imágenes en sucesión debido al mecanismo perceptivo de la permanencia de la imagen en la retina y la incapacidad del ojo humano de diferenciar las imágenes individuales cuando se proyectan a tal velocidad. Así pues, en animación, al igual que en toda la cinematografía el movimiento presente es el cambio sucesivo de imagen, que genera la ilusión de movimiento. En éste medio el movimiento se expresa plásticamente por medio del transcurso de las imágenes.

\section{Representación del movimiento}

Representar el movimiento es traducir en imágenes (en el caso de las artes plásticas) o en acciones (en el caso del teatro) un movimiento existente en la realidad. En la representación existe una correspondencia entre la imagen o acción creada y el modelo del que parte. La representación es por tanto análoga al referente.

El movimiento que sirve de referencia también puede proceder del mundo de los sueños y la fantasía, es decir, no existente en la realidad física, pero sí en el mundo imaginario. Así, se representan hechos y acciones tanto reales como fantásticas: acciones imposibles (el vuelo del ser humano, la metamorfosis de un ser humano en otro animal, un retorcimiento del cuerpo anatómicamente imposible, etc.) y el movimiento de seres fantásticos (dragones, Pegaso, etc.). Por ejemplo, el movimiento de los personajes de The Sand Castle (El castillo de arena) (Hoedeman, 1977), no es análogo al de ningún ser vivo particular; aunque tengan rasgos similares a especies existentes (serpiente, pato, cerdo), el dinamismo de estos seres es tan singular como su forma (Fig. 1). En el capítulo 4 se trata más ampliamente la relación entre representación de movimientos fantásticos y el grado de expresividad (4.4.2., pág. 411).

Así mismo, existe expresión plástica del movimiento sin representación de movimiento análogo a la realidad. Éste sería el caso de imágenes no figurativas que no emulan ningún movimiento real o fantástico, sino que se enfocan en acciones "abstractas". En estas obras la expresión plástica tiene lugar a través del movimiento, pero no hay representación, como en Begon Dule Care (Fantasía en colores) (McLaren, 1949) y en Modern No. 2 (Mizue, 2011), donde líneas y 
formas geométricas se mueven en pantalla en un juego visual de gran dinamismo. También existen casos en los que se representan movimientos reales a través de formas abstractas; así lo vemos en Feuerhaus (Neubauer, 1998), en la que el título hace referencia al fuego, por lo que se entiende que el movimiento conseguido con la película pintada representa (o al menos muestra relación con) el movimiento del fuego, aunque formalmente no sea como éste; lo mismo ocurre en Estrella fugaz (Mercedes Peris, 2012): el flujo visual representa de manera abstracta la estrella errante; no hay estrella, pero se hace referencia a su movimiento deslizante y su fugacidad. Como explicamos en la introducción de esta memoria, en esta tesis no se aborda la expresión del movimiento abstracto, sólo la expresión del movimiento análogo a alguna acción real o imaginaria, y, salvo excepciones, nos restringiremos a la animación figurativa.

En animación el movimiento se representa por medio del movimiento presente, aunque no del mismo modo que en las artes escénica. En éstas el movimiento se representa por medio de la acción (la interpretación de los actores), por tanto, el movimiento que se presenta es al mismo tiempo interpretación de un movimiento real. Mientras que en la animación, como bien es sabido, el movimiento presente consiste en la sucesión de imágenes (la proyección de un fotograma tras otro), y el movimiento representado es la acción que vemos en la pantalla, (las acciones de los personajes y otros elementos móviles) que no se trata de movimiento real, sino de una ilusión ${ }^{1}$. Esto significa que en animación el movimiento que vemos en pantalla no existe físicamente (como el del actor); el único movimiento que se presenta ante nosotros, aunque no lo percibimos, es el cambio de imagen. En todo caso, el animador no "crea" el movimiento, sino que usa las imágenes en sucesión para representarlo. $Y$ es precisamente en este elemento en el que reside la gran flexibilidad de la representación del movimiento en animación y su capacidad para expresarlo de manera altamente expresiva.

\section{B. MOVIMIENTO REAL Y VIRTUAL}

El movimiento puede ser real o virtual. En animación, los dos tipos de movimiento tienen lugar simultáneamente, y la expresión del movimiento es posible gracias a su conjugación. A continuación hablaremos de ambos tipos de movimiento y de su papel en la animación.

1 Arnheim, 1957, pág. 131 


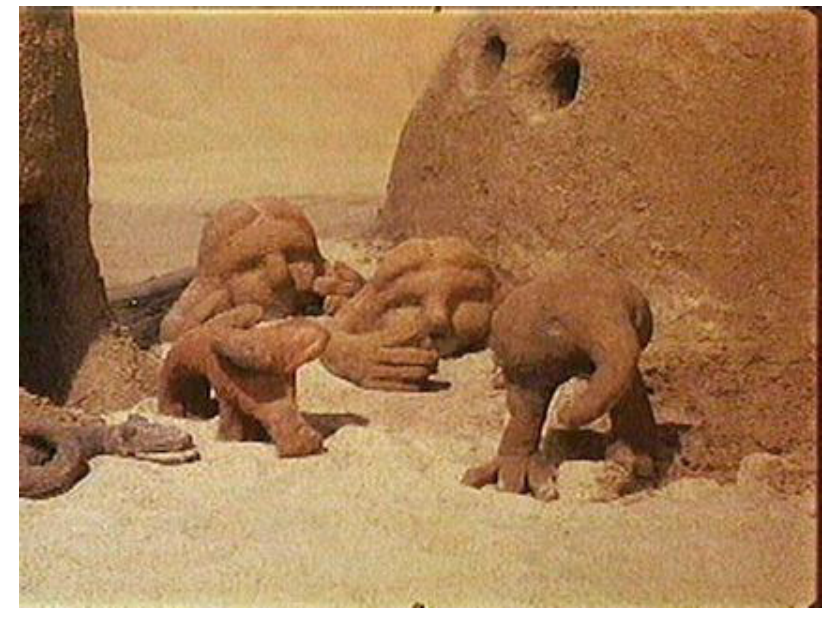

Fig. 1. Co Hoedeman

(1977). The Sand Castle

(El castillo de arena).

\section{Movimiento real}

El Movimiento real es aquel que tiene lugar en el espacio y el tiempo en que nos encontramos. El movimiento real de la animación es el cambio de imagen producido por el dispositivo (proyector, flipbook, archivo digital, etc.). El cambio de imagen es uno de los componentes dinámicos de este medio y puede utilizarse, como los demás, resaltando su plasticidad con fines expresivos (variando la frecuencia de imágenes por segundo, o el modo de transición de unas a otras, etc.). Así mismo, es relevante enfatizar que de las imágenes en transcurso (mientras no sean iguales y a partir de cierta velocidad de proyección) siempre resulta el movimiento, es decir, el movimiento existe por defecto, pero la cualidad expresiva de la representación sólo existe en potencia.

\section{Movimiento virtual}

El movimiento virtual es el efecto de movimiento que transmite una imagen estática que, por su diseño, nuestra visión no es capaz de percibir como estática sino en acción, por lo que, aunque la imagen es físicamente estática, produce la ilusión de movimiento real; se trata de un efecto óptico ${ }^{2}$. Así, en la figura 2 se perciben el giro de los discos, y en la figura 3 las forma parece expandirse como un líquido derramado.

\section{Ilusión de movimiento en animación}

En animación los efectos ópticos son esenciales. En animación el movimiento real del dispositivo (la proyección de una imagen tras otra a determinada velocidad) en conjugación con la permanencia de la imagen en la retina, produce el

\footnotetext{
${ }^{2}$ Arnheim, 1986
} 


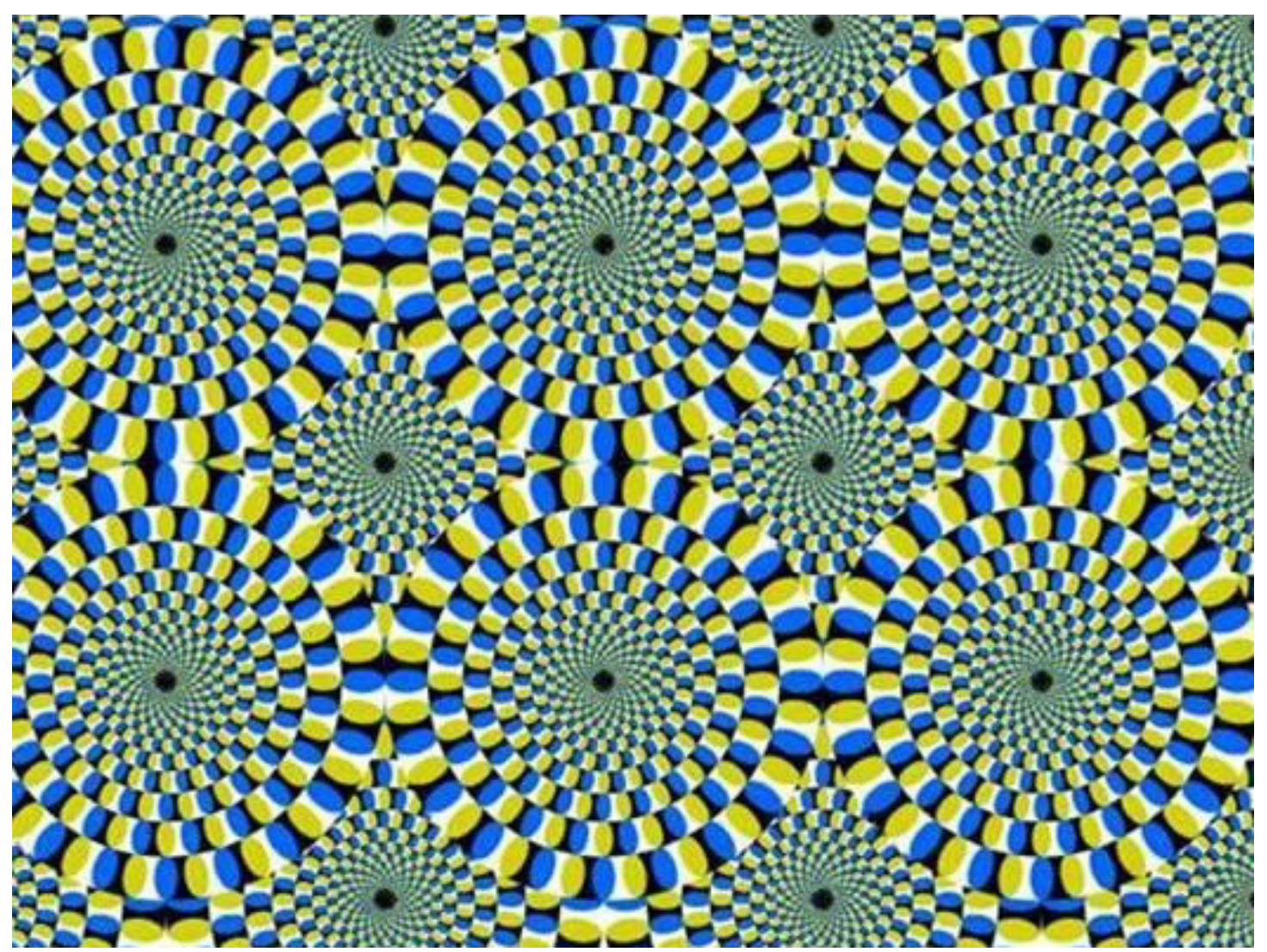

Fig. 2. s/a (s/f). Movimiento óptico.

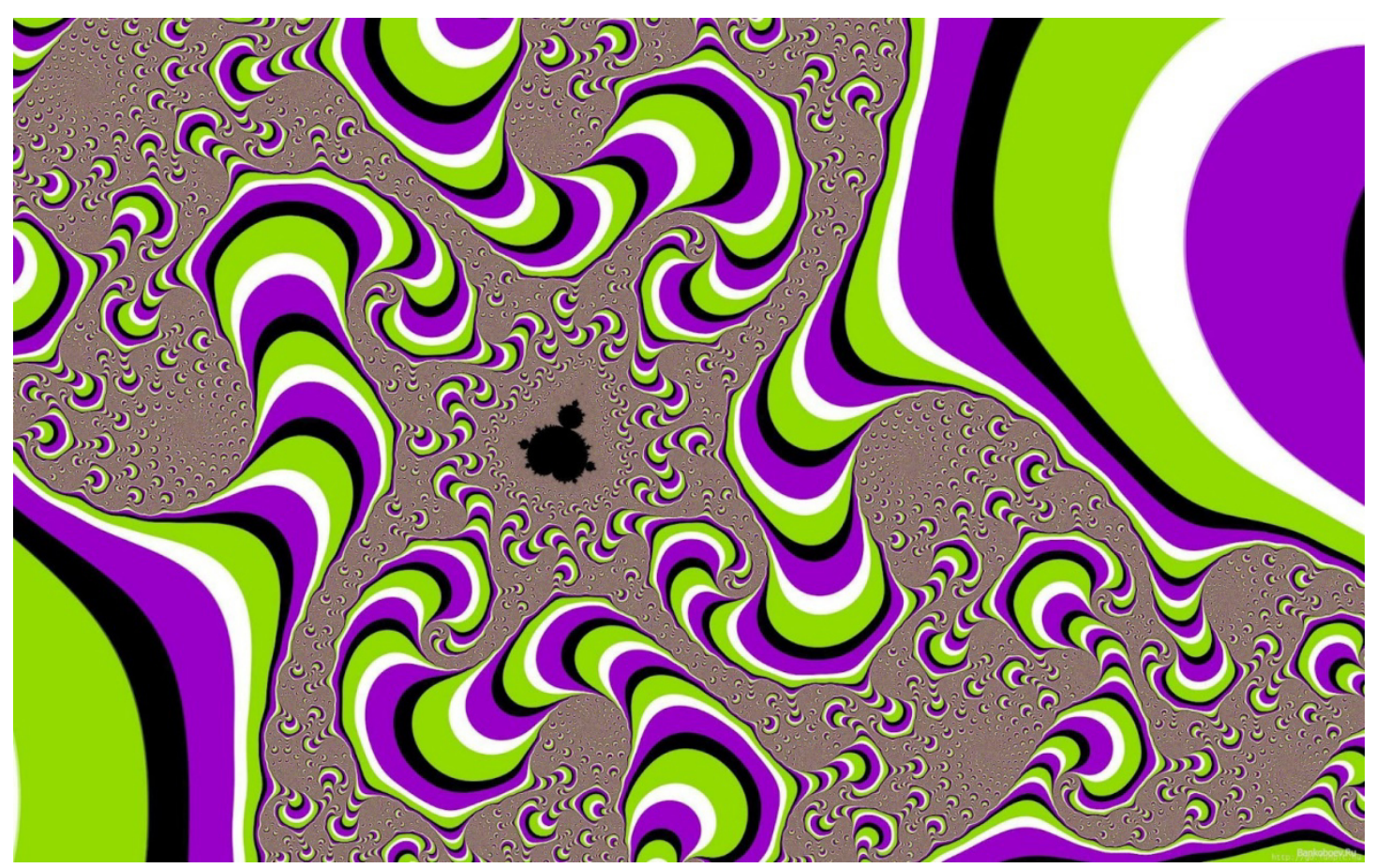

Fig. 3. s/a (s/f). Movimiento óptico. 
efecto óptico de la continuidad del movimiento, siendo imposible percibir los fotogramas como imágenes estáticas individuales. Esta sensación se debe al efecto estroboscópico, definido por Wertheimer a principios del siglo XX, consistente en la ilusión óptica de movimiento al observar imágenes fijas que se iluminan sucesivamente, debido a la identificación de las formas como una misma ${ }^{3}$. Pero Michotte apunta que la permanencia de las imágenes en la retina no es suficiente para obtener la impresión de movimiento ${ }^{4}$; Arnheim completa la explicación del fenómeno perceptivo del movimiento con otro fenómeno perceptivo: la agrupación y unificación de la información. ${ }^{5}$

La ilusión de movimiento constituye la materia prima de la animación, la cual es susceptible de ser manipulada de infinitas maneras. Aparte del efecto óptico de ilusión de movimiento, existen animaciones que utilizan los efectos ópticos como elemento plástico, a veces a partir de los mismos efectos que vemos en imágenes estáticas con movimiento virtual, pero expandiéndose a la cuarta dimensión. En Yellow Submarine (El submarino amarillo) (Dunning, 1968), en la escena del "mar de agujeros" vemos una trama de puntos negros sobre fondo blanco; con el desplazamiento de los puntos negros, se ven ondas circulares expansivas, a pesar de la disposición reticular rectangular de éstos; además, se producen pos-efectos que multiplican los puntos negros. En Begon Dull Care (Fantasía en colores) (McLaren, 1949) también hay pos-efectos, sobre todo en los fragmentos de mayor contraste lumínico y de color, en las que las líneas, al cambiar fugazmente de lugar, se multiplican ante nuestros ojos (00:03:18). En The Flight of Icarus (El vuelo de Ícaro) y La jeune fille et les nuages (La joven y las nubes) (Schwizgebel, 1974; 2000) se utilizan los fuertes contrastes de color y de luz entre fotogramas correlativos como elemento plástico; al verse de un fotograma a otro un cambio de color o de luz acentuado, se genera una fuerte vibración visual; parpadeos y destellos en estas películas tienen un fin eminentemente estético. En la segunda, además, la vibración de los puntos de color se puede comprender como una representación de los juegos lumínicos de una discoteca (00:02:45).

En Blinkity Blank (1955) Norman McLaren alterna las imágenes dibujadas con fotogramas en negro de modo que las imágenes se suceden en una frecuencia irregular: 1fotograma dibujado- 5fotogramas en negro - If dibujado - $5 f$ en negro - $1 f$ dibujado - $7 f$ en negro - $1 f$ dibujado - $8 f$ en negro - $1 f$ dibujado - $8 f$ en negro - $1 f$ dibujado - $1 f$ en negro - $1 f$ dibujado - $2 f$ en negro - $1 f$ dibujado, etc. De

\footnotetext{
${ }^{3}$ Guillaume, 1937, pág. 137

${ }_{5}^{4}$ Michotte en Sifianos, 2012, pág. 120

${ }^{5}$ Arnheim, 1979, pág. 502
} 
esta manera, al desaparecer la imagen tras proyectarse en un fotograma (la unidad mínima de tiempo), se genera un efecto óptico de pos-imagen; como la misma figura o forma similar reaparece tras varios fotogramas en negro, ésta se identifica como la misma; la alternancia irregular de la imagen con los fotogramas totalmente negros produce el parpadeo visual al que hace referencia el título.

Los efectos ópticos también pueden emplearse para representar el movimiento, como en Swamp nyz sumpf (Pantano) (Alkabetz, 1991): aquí el posefecto se emplea para simular un rápido movimiento de cámara (paneo) que corre paralelo a los guerreros, mostrando el ejército al espectador. Con el efecto óptico de multiplicación de la imagen (que al mismo tiempo genera ilusión de velocidad), se transmite la impresión de que el ejército es inmenso (00:03:38) (Fig. 4).
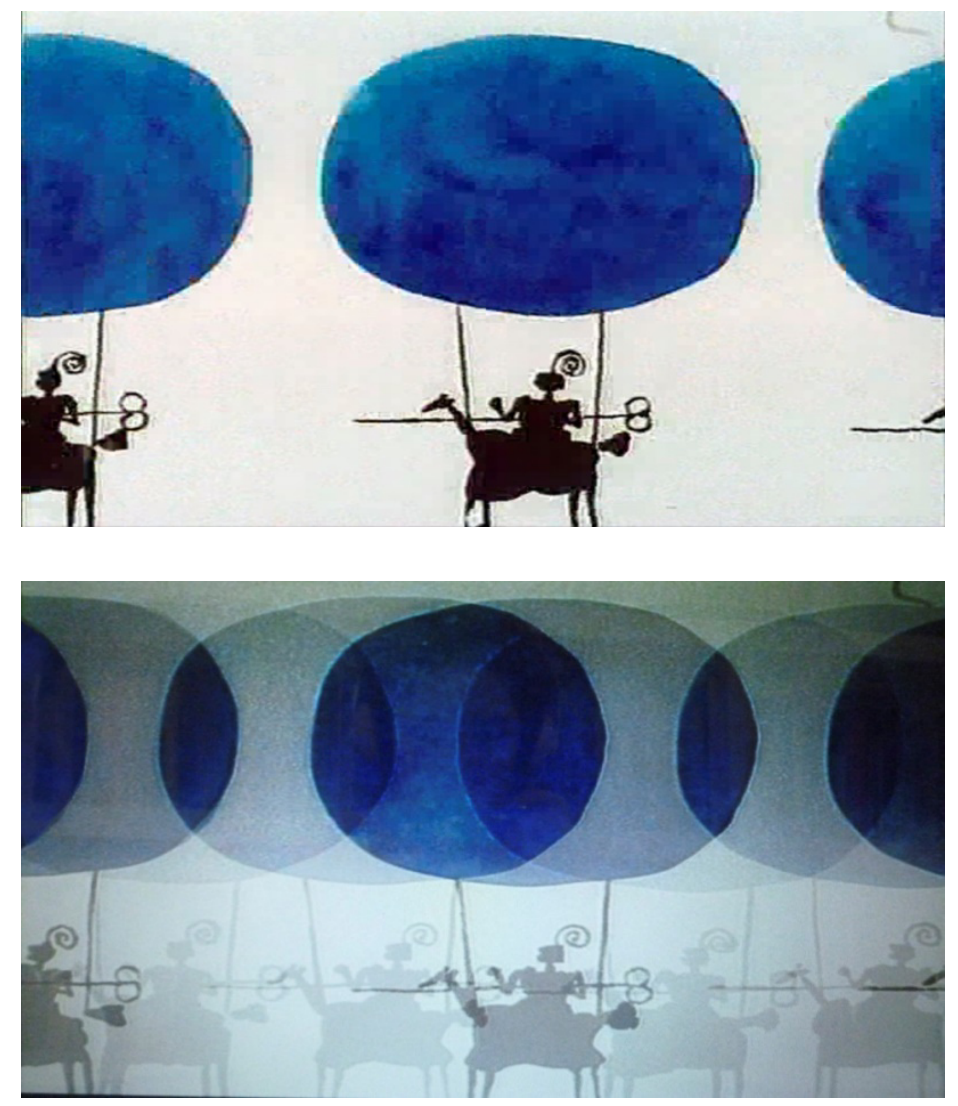

Fig. 4a. Gil Alkabetz (1991). Swamp nyz sumpf (Pantano). Fotograma.

Fig. 4b. Gil Alkabetz, (1991). Swamp nyz sumpf (Pantano). Efecto óptico de multiplicación. Así vemos la imagen en pantaIla, a pesar de estar compuesta de imágenes como la de la Fig. 4a.

Movimiento virtual y real se conjugan en animación, haciendo de éste un medio plástico complejo y a la vez muy versátil, cuyos componentes dinámicos ofrecen un rico abanico de posibilidades para la expresión móvil. 


\subsubsection{RELEVANCIA DE LOS FOTOGRAMAS}

La función de los fotogramas de una animación es harto conocida; sin ellos no existiría la película; pero la relevancia de "cómo" es cada uno de ellos es objeto de discusión, e incluso hay autores, como Pau Wells, que han minimizado su importancia a "factor no determinante" ${ }^{6}$. Indudablemente, a pesar de no ser percibidos individualmente, la conjunción de fotogramas crea en su sucesión el film; y puesto que todos ellos participan en el aspecto final de la obra, no se debería dejar de darles la importancia que merecen.

La idea de que es más importante lo que ocurre entre los fotogramas que las propias imágenes que los configuran procede de la famosa sentencia de Norman McLaren: "Lo que ocurre entre cada fotograma es más importante que lo que ocurre en cada fotograma. La animación es por tanto el arte de manipular los intersticios invisibles que hay entre los fotogramas" ${ }^{\prime 7}$. Normalmente se cita a McLaren para resaltar el factor "mágico" de la animación, otras veces para enfatizar que no importan las imágenes en su individualidad, y otras para restar importancia a las imágenes individuales y al cuidado que algunos autores ponen en cada fotograma (ya sea por su elaboración plástica como por cómo se expresa en ellos el movimiento). Sin embargo, el movimiento resultante de una animación pasa por la minuciosa atención a cada uno de los fotogramas, realización pormenorizada en la que también debe tenerse en cuenta la velocidad a la que serán visionadas las imágenes, que harán de ellas una unidad. A pesar de la popularidad que ha alcanzado esta aseveración, Georges Sifianos recoge en su obra Esthétique du cinéma d'animation la reflexión que el propio McLaren le comunicó personalmente en 1986 respecto a dicha definición:

PARA EL ANIMADOR, LA DIFERENCIA ENTRE CADA FOTOGRAMA SUCESIVO ES MÁS IMPORTANTE QUE LA IMAGEN EN CADA FOTOGRAMA INDIVIDUAL. ES EL CORAZÓN Y EL ALMA DE LA ANIMACIÓN. EL GRAFISMO, AUNQUE TAMBIÉN ES MUY IMPORTANTE, ES DE IMPORTANCIA SECUNDARIA. LA ANIMACIÓN ES POR TANTO EL ARTE DE MANIPULAR LA DIFERENCIA ENTRE FOTOGRAMAS SUCESIVOS, O LA IMAGEN EN CADA FOTOGRAMA: (y no debe confundirse con la excelencia del grafismo en sí mismo). ${ }^{8}$

\footnotetext{
${ }^{6}$ Wells P. , 2007, pág. 12, (trad. a.): The frame is no longer the determining factor in the measure of this movement.

${ }^{7}$ McLaren en Sifianos, 2012, pág. 20, (trad. a.): What happens between each frame is much more important than what exists on each frame. Animation is therefore the art of manipulating the invisible interstices that lie between frames.

${ }^{8}$ McLaren en Sifianos, 2012, pág. 25, (trad. a.): FOR THE ANIMATOR, THE DIFFERENCE BETWEEN EACH SUCCESSIVE FRAME IS MORE IMPORTANT THAN THE IMAGE ON EACH SINGLE FRAME. IT IS THE HEART \& THE SOUL OF ANIMATION. THE GRAPHISM, THOUGH VERY IMPORTANT TOO, IS OF SECONDARY IMPORTANCE. ANIMATION THEREFORE IS THE ART OF MANIPULATING THE DIFFERENCES BETWEEN SUCCESSIVE FRAMES, OR THE IMAGE ON EACH FRAME: (and should not be confused with the excellence of the graphism in itself).
} 
De esta manera McLaren matiza su propia definición de animación, aclarando que la relevancia reside en el cambio de unos fotogramas a otros y se reafirma en que la interacción entre fotogramas es más importante que una sola imagen.

El movimiento animado resultante depende directamente de las imágenes mismas, ya que lo que percibimos en el "intersticio entre fotogramas" es la imagen anterior, que permanece aún en la retina, enlazándose con la siguiente. Por ello en la valoración espacio-temporal (el dibujo pormenorizado del movimiento) las imágenes individuales cobran importancia en cuanto a su interconexión, la cual, a su vez, existe gracias a su composición individual, cuestión desarrollada extensamente en el parágrafo 3.2.4. Así pues, no se puede hacer caso omiso del hecho irrefutable de que los fotogramas componen la película y de que, desde su individualidad y por su relación con el resto, determinan el resultado. Y no sólo eso: casi todos los aspectos dinámicos de la película quedan definidos en ellos, porque los fotogramas no afectan exclusivamente a la valoración espaciotemporal, sino también a la composición móvil y al cambio de imagen (que también se configuran a través de los fotogramas); el único componente que queda fuera de esta consideración es la presentación de la historia (el relato).

Hemos visto que la animación es un medio que involucra diversas cuestiones técnicas. A pesar de ello, puede considerarse que su complejidad se reduce sencillamente a la ilusión de movimiento producida por el cambio de imagen. A través de esa imagen resultante que aparentemente se mueve, puede representarse el movimiento con mayor o menor expresividad. El nivel de expresividad, desde el neutro al vivenciado, se obtiene por la interacción de los componentes dinámicos, tema que se desarrolla a continuación.

\subsubsection{COMPONENTES PLÁSTICOS DE LA ANIMACIÓN; TÉCNICA DE ANIMACIÓN Y TÉCNICA PLÁSTICA}

En este apartado se presenta qué son y cuáles son los componentes dinámicos y su relación con la técnica plástica, y se plantea el dilema de cómo se obtienen el movimiento vivenciado y el neutro. 


\section{A. TÉCNICA PLÁSTICA Y TÉCNICA DE ANIMACIÓN}

Al hablar de técnica en animación se hace referencia a la técnica de animación (con la que se representa el movimiento) y a la técnica plástica (con la que se hacen las imágenes o formas volumétricas que se usan como elementos móviles).

La técnica de animación se refiere a cómo se realiza el cambio de imagen:

- Animación de dibujo: por dibujos sucesivos.

- Stop-motion o animación bajo cámara: fotografiando marionetas, objetos o elementos maleables (arena, barro, etc.) variando su posición, forma, color, etc. paulatinamente en cada fotografía, para que cada imagen sucesiva sea diferente, ya sea modificando la posición de objetos, o modificando un dibujo o pintura. El término "stop-motion" se utiliza normalmente para designar la técnica que utiliza marionetas volumétricas, pero la técnica recibe varios nombres según el elemento móvil: recortes, animación con arena, animación de pintura, animación con fotografías y animación de objetos.

- Pixilación: abarca desde métodos que se asemejan al stop-motion pero utilizando personas reales como móviles en lugar de objetos inanimados, hasta la filmación no convencional del movimiento real, modificando tanto la velocidad de grabación (frecuencia de fotografías por segundo) como el movimiento real (normalmente el modelo acelera o ralentizando la acción) de modo que altera el movimiento real.

- Animación por ordenador: los fotogramas se crean digitalmente, estableciendo fotogramas clave manualmente y fotogramas intermedios que se generan automáticamente. Pero si cada uno de los fotogramas se crea uno por uno en lugar de dejar que el programa los genere automáticamente, entonces la técnica de animación tiene más de animación baja cámara o stop-motion que de animación por ordenador. Grain coupon (Cupón de grano (Xi \& An, 2001) está hecha mucho más manualmente (editando las curvas automáticas y/o creando fotogramas clave más próximos) que Bird Boy (Rivero \& Vázquez, 2010) y el videoclip Spring isn't fair (Klein, 2004), en las que, a pesar de todo el trabajo y minuciosidad que haya conllevado su creación, destaca el reconocible movimiento de las acciones completadas por ordenador.

Cada técnica tiene una flexibilidad y unas delimitaciones que pueden determinar el tipo de acciones realizables, es decir, las acciones posibles no son las mismas en todas las técnicas. Por ejemplo, si se trabaja bajo cámara con recortes o marionetas, el movimiento está determinado por éstas, incluso aunque las piezas no tengas articulaciones fijas; mientras que en una animación de dibujo, 
las formas se pueden "deformar" con flexibilidad ilimitada, ya que el dibujo no impide físicamente el movimiento del personaje u objeto. Así mismo, los movimientos de cámara y la composición móvil en general (la evolución de la composición en cada plano o secuencia) es otro rango de acciones que pueden ser más o menos flexibles o posibles según la técnica de animación. Aunque el tipo de movimiento quede restringido por la técnica de animación, ésta generalmente no condiciona la expresión del movimiento como vivenciado o como neutro. No obstante, hay técnicas que propician el movimiento neutro (aunque no impiden el movimiento vivenciado), como la captura de video y de movimiento, y la animación CGI (en la que se completan acciones automáticas por medio de interpolación) ya que aportan unas características concretas a la valoración espaciotemporal (uno de los componentes espacio-temporales), como veremos extensamente en el capítulo 3.

La técnica plástica se refiere a la materialidad de los fotogramas: lápiz, acuarela, pastel, gouache, óleo, fotografía (en el caso de la animación de objetos y la pixilación), grabado, collage, modelado en de barro, plastilina, plástico etc. Todas las técnicas finalmente se muestran en pantalla como fotografías o digitalizaciones, que constituyen los fotogramas de la obra, ya sea en película cinematográfica, en archivo digital u otro formato de video.

En lo que a la expresión del movimiento se refiere, la técnica de animación es más relevante que la técnica plástica, ya que establece cómo se crea el transcurso de las imágenes que forman la película. A pesar de la influencia de la técnica plástica en el movimiento resultante, al comparar animaciones hechas con la mismas técnica de animación, observamos que la medida en que la técnica grafico-plástica influye en la expresión móvil es de menor impacto. Por ejemplo, en The Aristocats (Los Aristogatos) (Reitherman, 1970), en el cabello de la mujer y el boa de plumas (00:05:15) (Fig. 5) se aprecia la irregularidad del lápiz y del gouache aplicado a mano, la exhibición del material aporta cierta calidez a la expresión dinámica, pero sobre éste destaca el estilo concreto de animación, el mismo que en The Lion King (El rey león) (Minkoff \& Allers, 1994) (Fig. 6), pintada digitalmente, en la que no hay el menor rastro de la línea vibrante del lápiz o las irregularidades del gouache. Las diferencias plásticas no hacen que el movimiento difiera a penas. Por otro lado, En Des câlins dans les cuisines (Abrazos en la cocina) (Laudenbach, 2004), también dibujada a mano pero con un dibujo que vibra notablemente, los colores planos de la herramienta digital no aproximan la expresividad del movimiento a The lion King (Fig. 7). Pero Incluso a pesar de la diferencia dinámicas entre estas tres películas, el movimiento de las animaciones de dibujo es completamente diferente al que vemos en las animaciones de 


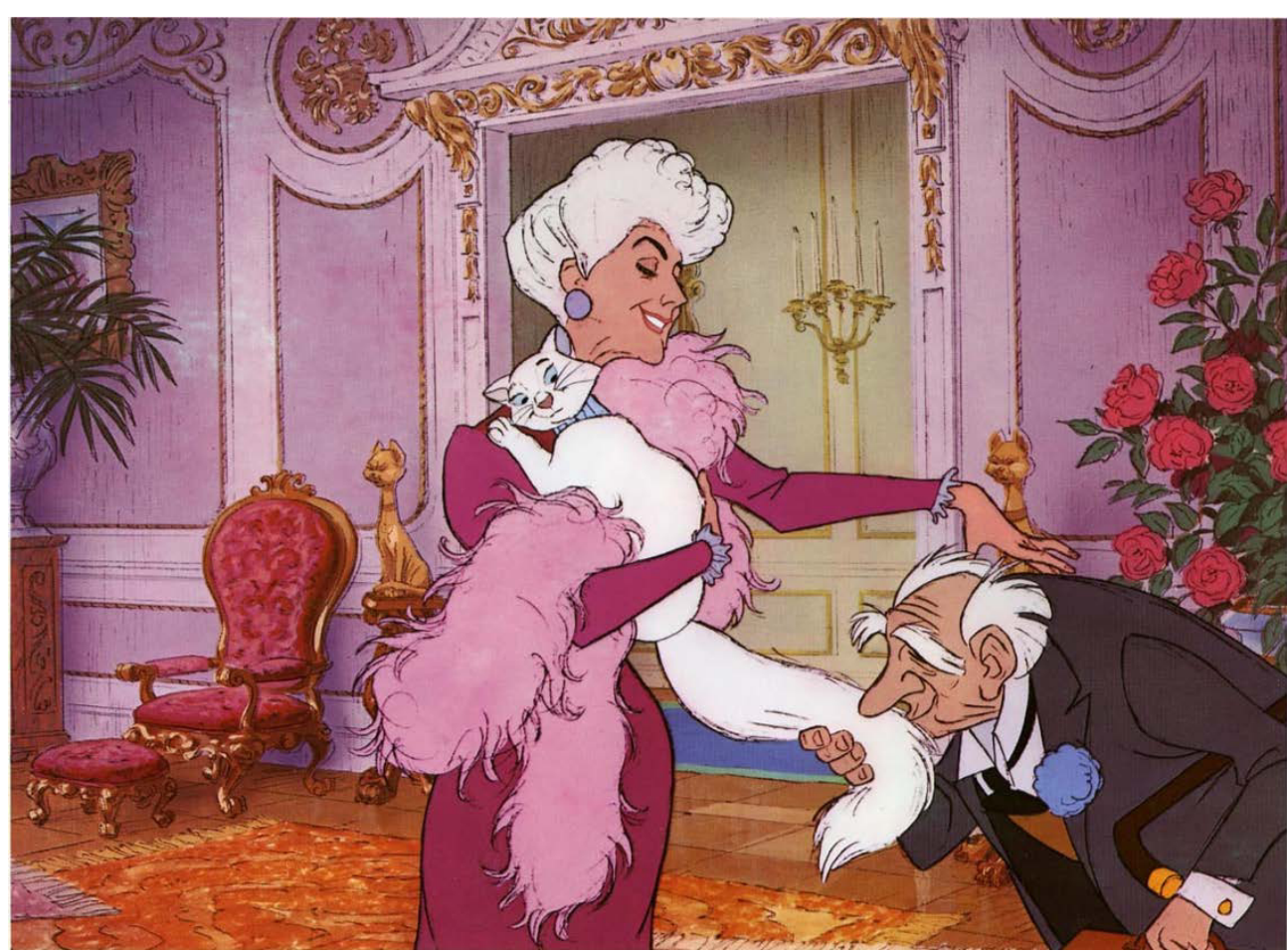

Fig. 5. Wolfgang Reitherman (1970). The Aristocats (Los Aristogatos).

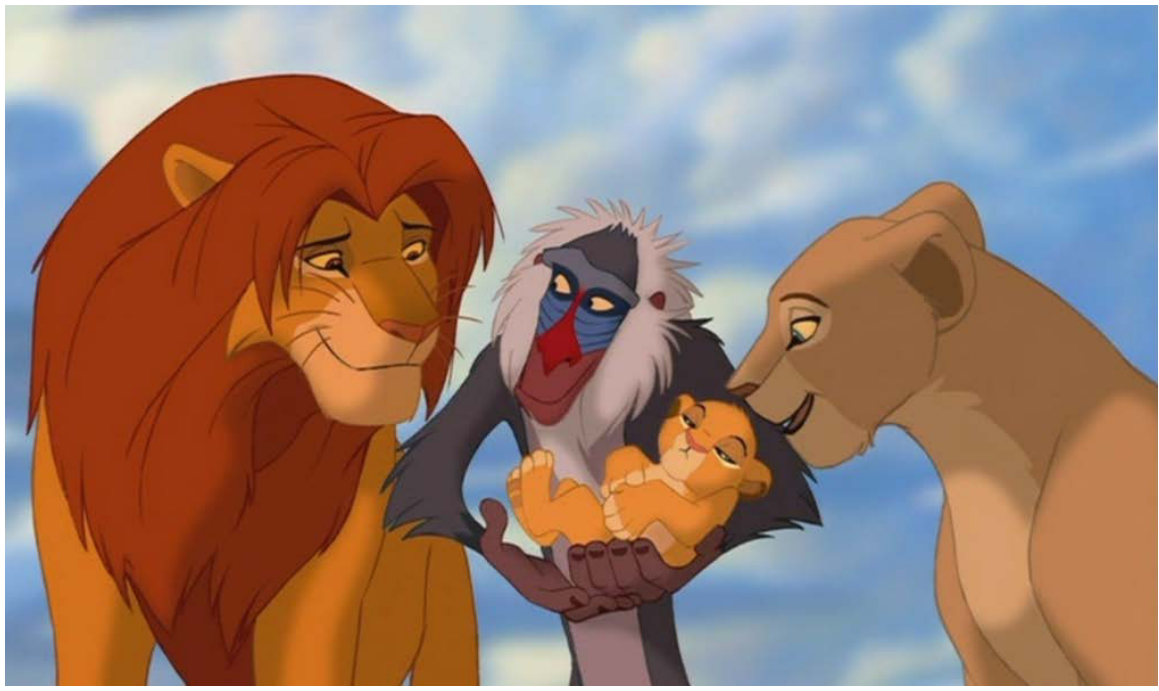

Fig. 6. Rob Minkoff, Roger Allers (1994). The Lion King (El rey león).

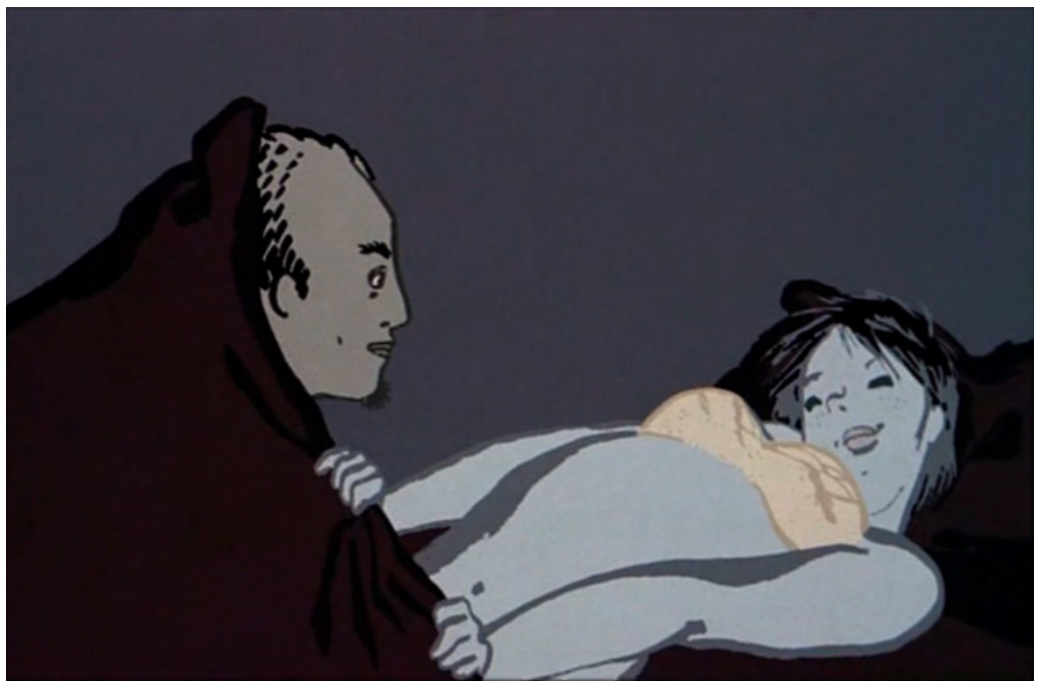

Fig. 7. Sébastien Laudenbach (2004). Des câlins dans les cuisines (Abrazos en la cocina). 
recortes y siluetas, como Die Abenteuer des Prinzen Achmed (Las aventuras del príncipe Ahmed) (Reiniger, 1926), realizada con siluetas, en la que los personajes se muestran de frente o de perfil, no son posibles los cambios de punto de vista (a no ser que se crearan marionetas específicas que representaran esto) y los movimiento de cámara se limitan a paneos, tilts y zooms. Así pues la técnica plástica empleada para la creación de los fotogramas de una animación no determina la cualidad de la expresión del movimiento, aunque ésta influye directamente en el movimiento animado.

A pesar de las restricciones de cada técnica plástica y de animación, el movimiento vivenciado y el neutro son factibles por medio de todas las técnicas de animación en combinación con cualquier técnica plástica, ya que su expresión depende de cómo éstas se apliquen y la interacción de todos los componentes espacio-temporales, como veremos en el parágrafo 2.2. y en el capítulo 3.

\section{B. COMPONENTES PLÁSTICOS}

La animación se compone de elementos espacio-temporales y plásticos. Hemos denominado "componentes espaciotemporales" a aquellos que se refieren exclusivamente al movimiento aunque estos también se emplean de manera plástica; son materia sensible (su papel en la expresión del movimiento vivenciado y neutro se desarrolla ampliamente en el parágrafo siguiente 2.2. y en el capítulo 3). Y hemos llamado "componentes plásticos" a los elementos que la animación tiene en común con el resto de artes plásticas: la técnica plástica, el color, la luz, el trazo, etc. y que, a su vez, también están en transcurso. Los componentes plásticos afectan directamente a uno de los componentes espacio-temporales: el cambio de imagen por lo que se puede considerar que los componentes plásticos se "funden" con éste componente espacio-temporal. Así pues, la expresión móvil depende de cómo se emplean tanto los componentes espacio-temporales como los componentes plásticos (los cuales influyen directamente sobre uno de los componentes espacio-temporales).

Como decíamos, los elementos plásticos como el color, la luz, la textura, el gesto gráfico, etc., al formar parte de la película, también se muestran en transcurso. Si su progresión es lenta, a lo largo de varios segundos o hasta a lo largo de toda una escena, o de una escena a otra, entonces se trata de cambio cualitativo o de alteración (siguiendo la clasificación aristotélica del movimiento). To- 


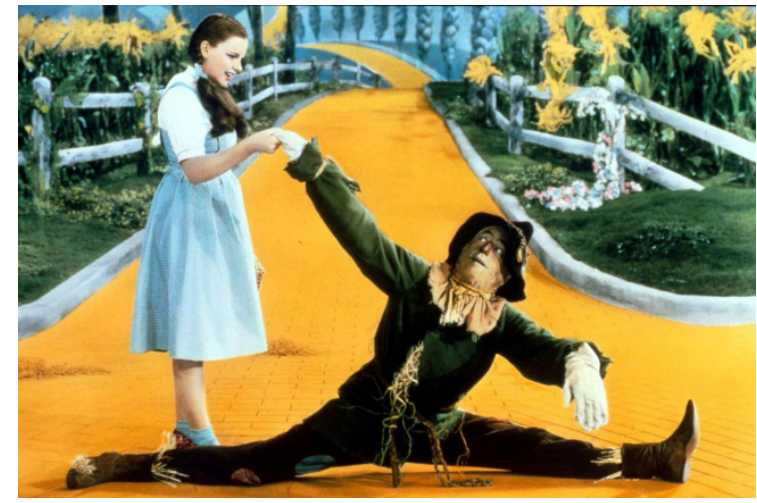

Fig. 8. Fleming, Le Roy, Thorpe y Vidor (1939). The Wizard of Oz (El mago de $\mathrm{Oz})$.

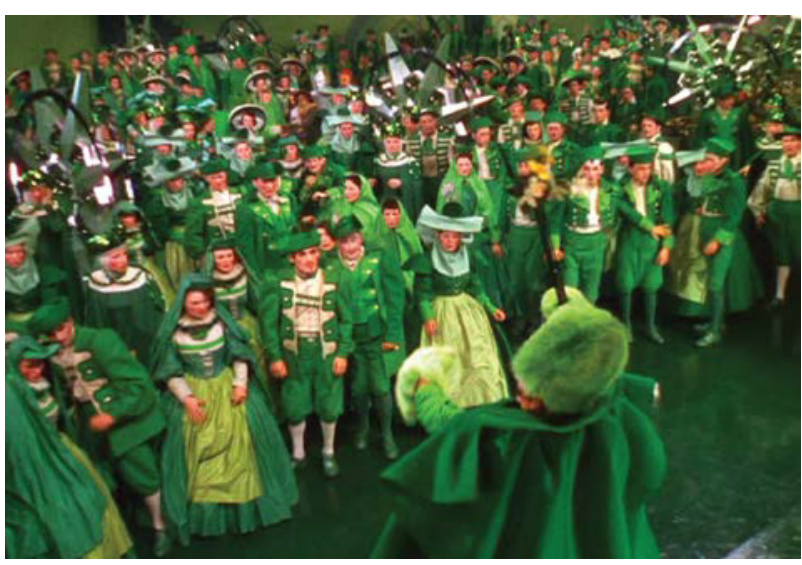

Fig. 9. Fleming, Le Roy, Thorpe y Vidor (1939). The Wizard of $\mathrm{Oz}(\mathrm{El}$ mago de Oz).

Fig. 10. Fleming, Le Roy, Thorpe y Vidor (1939). The Wizard of Oz (El mago de Oz).

memos por un momento un ejemplo de cine de acción real: en la película The Wizard of Oz (El mago de Oz) (Fleming, LeRoy, Thorpe, \& Vidor, 1939) el color cambia de unas escenas a otras; los decorados, vestuario y maquillaje generan distintos ambientes de color que se transforman a lo largo de la obra (Figs. 8, 9 y 10). En animación también es frecuente el cambio de color general para marcar el carácter de las escenas, o por otros motivos estéticos o narrativos.

Si el cambio plástico tiene lugar de un fotograma a otro (o varios fotogramas), se produce una vibración que sí podemos llamar movimiento, y es de esta manera como los elementos plásticos intervienen de manera directa en la expresión del movimiento. Unas veces, debido al gesto gráfico, el cambio de unos fotogramas a otros es muy notable; otras, es sutil cuando, como cuando se pintan áreas planas de color con gouache, lo que permite que se aprecia cierta variación entre fotogramas, lo que otorga mayor calidez a la animación); otras veces no hay cambio entre fotogramas, como cuando se pintan con áreas planas de color aplicado con la herramienta digital de rellenar en programas de pintura digital (en ese caso, la imagen no vibra nada). Así pues, la variación de color que tiene lugar de unas escenas a otras puede darse a distinta velocidad y frecuencia, siendo la máxima velocidad el cambio de unos fotogramas a otros, como 
vemos en la película Yellow Submarine en el fragmento dedicado a Lucy in the Sky with Diamonds (Dunning, 1968). En esta animación el fuerte cambio de color de unos fotogramas a otros genera una vibración de la imagen, que proporciona un movimiento singular que no tendría lugar si el color se mantuviera estable (Fig. 18). En el apartado 2.2.1. Cambio de imagen se trata extensamente la influencia de las cualidades plásticas de los fotogramas en la expresión del movimiento vivenciado y del neutro.

\section{QUÉ SON LOS COMPONENTES DINÁMICOS DE LA ANIMACIÓN}

Con el término "componentes dinámios visuales" nos referimos a aquellos elementos cinematográficos que tienen lugar en (y que al mismo tiempo conforman) la cuarta dimensión de la obra. Consideramos que los componentes espacio-temporales visuales de la animación son:

- El cambio de imagen, (producto del movimiento del dispositivo, que proyecta una imagen tras otra).

- La valoración espacio-temporal (conocida como timing, que corresponde al dibujo pormenorizado del movimiento).

- La composición móvil (que abarca el cambio de composición - al cambiar el plano -, el encuadre móvil - por movimiento de cámara - y la pantalla como superficie de composición en movimiento).

- La distribución de la intensidad cinética (que habitualmente es incluida en la definición de timing).

- La presentación de la historia (la manera en que se muestran los acontecimientos, el relato).

Los elementos dinámicos interactúan entre ellos y a veces es difícil determinar una frontera que los separe. Por ejemplo, en la distribución de la intensidad cinética intervienen, entre otros, la cantidad de elementos móviles y la velocidad del movimiento, que también participan directamente en la composición móvil.

Aún hay otro componente espacio-temporal, pero sonoro, no visual: el audio de la película, que comprende sonido, música y voz. Aunque también afecta a la expresión del movimiento y a veces con el mismo protagonismo que los componentes visuales, por ser un campo muy amplio y que requiere un estudio específico, no será tratado en esta investigación. Sus propiedades son merecedoras de un estudio aparte. 
Los componentes dinámicos son comunes a la animación y al cine de acción real, no obstante, de los componentes espacio-temporales del medio cinematográfico, uno queda totalmente a merced del movimiento real: la valoración espacio-temporal del movimiento. El cine de acción real requiere un movimiento real registrable, mientras que la animación no: en animación el movimiento se genera a por medio de imágenes plásticas creadas a partir de la nada, o bien la acción real es modificada (como en la técnica de pixilación). Esta diferencia esencial en la creación afecta al conjunto de la obra, implicando un tratamiento distinto de los componentes espacio-temporales. Al no requerir un movimiento real registrable, al crear plásticamente los fotogramas, el resto de componentes espacio-temporales se hacen altamente manipulables, en algunos casos con posibilidades que no existen en la acción real.

Tanto en cine de acción real como en animación, los componentes espaciotemporales son usados por el creador para expresar la idea o narrar la historia. La expresión del movimiento en animación también se da a través de estos. La intensidad con la que se transmiten sensaciones cinéticas y se hace sentir el movimiento como si se viviera en primera persona depende de cómo se conjugan estos elementos.

Así mismo, la expresividad de la obra en general no sólo depende del movimiento, sino de absolutamente todo lo que conforma la película, tanto elementos estéticos, como del contenido. Por supuesto, a veces entre las herramientas comunicativas más importantes de la película no está la animación. Por ejemplo, Thomas y Johnston explican que uno de las cualidades más interesantes de la película Snow White and the seven dworfs (Blanca Nieves y los siete enanitos) (Hand, Cottrell, Morey, Pearce, \& Sharpsteen, 1937) era las relaciones personales entre los enanitos, y éstas procedían del relato antes que de la animación ${ }^{9}$. La relación entre forma y contenido, por ser un campo de una complejidad específica, no será tratada directamente en esta investigación salvo en momentos concreto en los que es imposible separar el contenido de la obra de la representación del movimiento.

A continuación se expone La manera en la que se emplean los componentes espacio-temporales en los que se concentra la representación de la acción en animación (el cambio de imagen y la valoración espacio-temporal) y de qué manera cada elemento contribuye a que el movimiento se exprese como vivenciado o como neutro.

\footnotetext{
${ }^{9}$ Thomas \& Johnston, 1981, pág. 164
} 


\subsection{4. ¿CÓMO SE OBTIENEN EL MOVIMIENTO VIVENCIADO Y EL NEUTRO?}

En el capítulo 1, hemos establecido el movimiento vivenciado y el movimiento neutro como grados extremos de la expresividad de la representación del movimiento. Podemos reconocerlos por su visualidad y por las sensaciones cinéticas que producen en el espectador; sus características son enunciables. Pero definir los procesos creativos por los que se consigue un grado $u$ otro de expresividad en animación simplemente a través de sus características plásticas y cinematográficas es menos exacto, ya que ambos pueden presentar similitudes (por ejemplo, en ambos se usan tanto planos largos como planos cortos; o en ambos se muestra variedad o escasez de movimiento). Así pues, y a pesar de que se observa que algunas cualidades propician una u otra expresión dinámica, no es posible establecer cómo se obtienen el movimiento neutro y el vivenciado a partir de estas características. Aunque ésta investigación no se adentrará en la cuestión de la creatividad y en cómo a través de ésta se logra expresar el movimiento de manera vivenciada o neutra (esto correspondería al terreno de la psicología), haremos algunos apuntes a nivel de práctica artística.

Desde el punto de vista del artista, lo principal para expresar el movimiento vivenciado es tomar como referencia lo que se siente y se ve cuando se experimenta el movimiento, o cuando éste es observado desde fuera. Tomar las sensaciones físicas y emocionales como fuente de información para la creación artística es una idea muy arraigada, por ejemplos los aristas de los siglos XVI y XVII pensaban que el artista "para conmover al contemplador de su cuadro con las emociones humanas expresadas en él, debe sentir antes en sí mismo esas emociones" ${ }^{10}$ y la sabiduría zen aconseja al artista convertirse en bambú para dibujar el bambú; esta consigna poética transmite que el dibujo es expresión íntima que se logra desde la introspección. Así pues la principal fuente de información son las sensaciones cinestésicas que se experimentan, tanto en la realidad como por medio de la imaginación creadora; se alcanzan por medio de la experiencia personal y la ensoñación, por medio de la imaginación y los sentidos, tanto para acciones reales como fantásticas.

Lipps explica que "la percepción de la expresión contiene la actividad de fuerzas"; su teoría de la empatía explica en parte el tipo de observaciones que se realizan para expresar el movimiento vivenciado. El autor explica que la empatía

\footnotetext{
${ }^{10}$ Lee, 1940, pág. 45
} 
nos permite hallar expresión en objetos inanimados; Arnheim sintetiza su razonamiento de esta manera:

cuando miro las columnas conozco, por experiencia pasada, la especie de presión y contrapresión mecánica que en ellas tiene lugar. Igualmente por experiencia pasada sé cómo me sentiría si me encontrara en el lugar de las columnas y si estas fuerzas físicas actuaran sobre y dentro de mi cuerpo. Proyecto mis propios sentimientos kinestésicos sobre las columnas. Además, las presiones e impulsiones que la vista hace aparecer desde los depósitos de la memoria tienden a provocar respuestas también en otras áreas de la mente. ${ }^{11}$

Lo mismo ocurre con la expresión móvil en animación para crear el movimiento vivenciado. El animador Don Hahn recomienda: "Interpreta la escena... ¿qué se

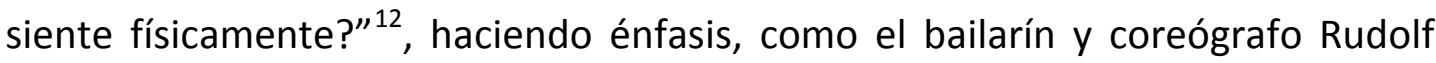
von Laban (capítulo 1, pág. 46), en la experiencia kinestésica como medio para aprender el movimiento.Thomas y Johnston también se refieren a la introspección, pero más dirigida a las emociones y sentimientos que al movimiento, fuera cual fuera la experiencia del personaje: "Tanto si era un Pinocchio aterrorizado encerrado en la jaula de Stromboli o un Bambi tímido en su primer encuentro con Faline, el animador tenía que vivir cada minuto de aquello o esto no estaría en sus dibujos" ${ }^{13}$.

En animación, al igual que en la plástica, por medio del movimiento vivenciado también se transmite cómo se ve, así, otra vía para acceder al conocimiento del mundo móvil es a través de lo visible. La siguiente descripción de Arnheim destaca el tipo de cosas que creemos que se observan para expresar el movimiento vivenciado:

Pero si me siento frente a un hogar y observo las llamas, normalmente no registro tonalidades de rojo, grados de claridad, formas geométricamente definidas que se mueven a cierta velocidad y a tal otra. Veo el gracioso juego de lenguas agresivas, un esforzarse flexible, un color vivaz. La cara de una persona se percibe y se recuerda con más inmediatez como alerta, tensa, concentrada, que como de forma triangular, de cejas oblicuas, de labios restos, etcétera. ${ }^{14}$

Para expresar el movimiento vivenciado también puede ser beneficioso que el artista, en el momento de realizar la obra, conduzca su cuerpo a "un estado kinestésico apropiado para la naturaleza del tema que ha de ser representado",

\footnotetext{
${ }^{11}$ Arnheim, 1979, pág. 364

${ }^{12}$ Hahn, 2008, pág. 63, (trad. a.): Act out the scene... what does it feel like physically?

${ }^{13}$ Thomas \& Johnston, 1981, pág. 147, (trad. a.): If it was a terrified Pinocchio locked in Stromboli's cage or a shy Bambi at his first meeting with Faline, the animator had to live every minute of it or it would not be in his drawings.

${ }^{14}$ Arnheim, 1979, pág. 367
} 
tal y como explica Arnheim sobre algunos artistas de la pintura japonesa ${ }^{15}$. Según Bowie, este estado es transmitido a la pincelada, de modo que el trazo expresa tales cualidades en su materialidad; es el principio del "movimiento vivo":

\begin{abstract}
Al representar un objeto que sugiere fuerza, por ejemplo un acantilado rocoso, el pico o las garras de un ave, las garras de un tigre o los troncos y ramas de un árbol, en el momento en que se aplica el pincel el sentimiento de fuerza debe der invocado y sentido a través de todo el sistema nervioso del artista e impartido por su brazo y mano al pincel, transmitiéndose así al objeto pintado ${ }^{16}$
\end{abstract}

Esto es lo único que unifica el proceso de creación de las animaciones en las que el movimiento se expresa como vivenciado. Respecto a cómo plasmarlo, pocas cosas se pueden afirmar con rotundidad, salvo que no hay una manera concreta que proporcione, de manera garantizada, la expresión de movimiento vivenciado, como veremos en el aparatado 2.2. y en el capítulo 3.

Podemos reconocer cuándo la animación se basa en la impresión visual que se tiene al observar el movimiento del natural o en la experiencia de vivirlo o en la ensoñación, porque destaca la impresión cinética, incluso aunque se dé la descripción mecánica y la representación de las leyes científicas. Así lo vemos en Crac! (Frèdèrick Back, 1981). En la escena de la celebración de la boda, uno de los fragmentos de mayor intensidad cinética del cortometraje, hombres y mujeres bailan taconeando al estilo folclórico. El movimiento de los pies es un ejemplo de cómo el conocimiento de la experiencia cinética o visual se materializa en animación. Las personas casi flotan sobre la vibración de sus pies y sin embargo no se identifican "pasos" que determinan este estilo de baile (00:03:05) (Fig. 11). En otro plano la pareja se funde en el grupo, y aunque es imposible distinguir las figuras individuales, se reconoce por su movimiento que todos ellos siguen bailando; nuevamente es la sensación cinética la que prima. En Triangle, de Erica Russell (1994) el movimiento es más vivenciado cuando la precisión técnica y coreográfica (00:02:45) se funden con la emoción cinética (00:04:22) (Fig. 12 y 13). La autora, con experiencia en la danza ${ }^{17}$, ha experimentado el movimiento representado; creemos que la vivencia se ha conjugado con el conocimiento técnico para alcanzar la expresión del movimiento vivenciado.

En cuanto al movimiento neutro, éste se obtiene priorizando y potenciando la claridad y objetividad en la transmisión del mensaje por encima de otros objetivos, por ejemplo, mostrar el punto de vista más claro para comprender el mo-

\footnotetext{
${ }^{15}$ Arnheim, 1979, pág. 419

${ }^{16}$ Bowie en Arnheim, 1979, pág. 419

${ }^{17}$ Dr. Grob's Animation Review. The animation film review site, 2013
} 
vimiento (sin servir a fines estéticos). Para representar el movimiento neutro, la animación debe mantenerse ajena a consideraciones particulares del movimiento, es decir, las percepciones personales del autor o sensaciones cinestésicas no deben quedar reflejadas. La vivencia personal del movimiento y las impresiones dinámicas que sugieren la observación de una u otra acción son datos que quedan a parte para crear el movimiento neutro, ya que pueden distorsionar el mensaje o cobrar protagonismo frente a éste.
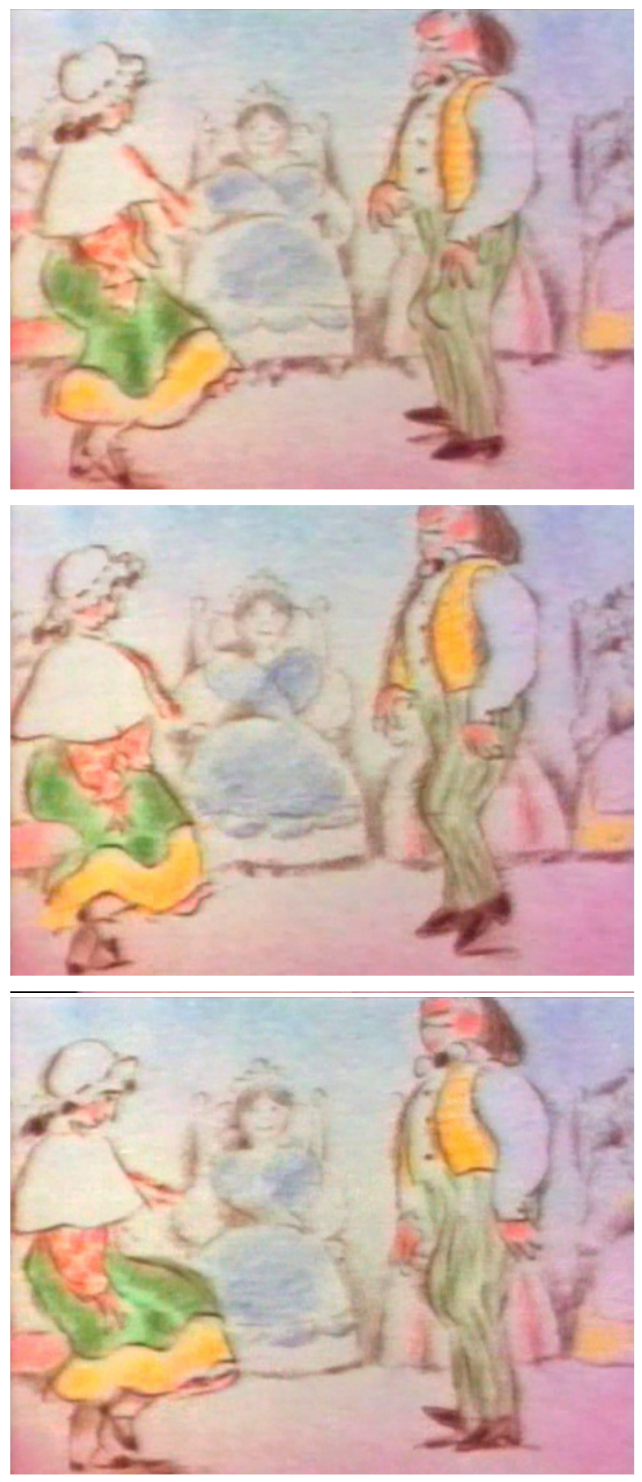

Fig. 11. Frédéric Back (1981). Crac!. Serie de fotogramas.

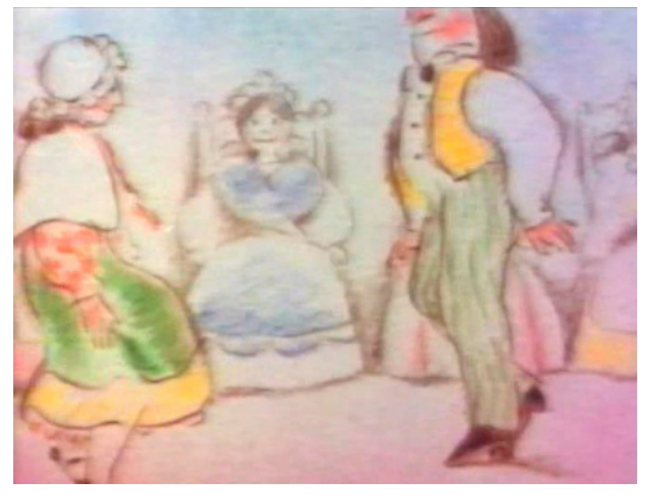



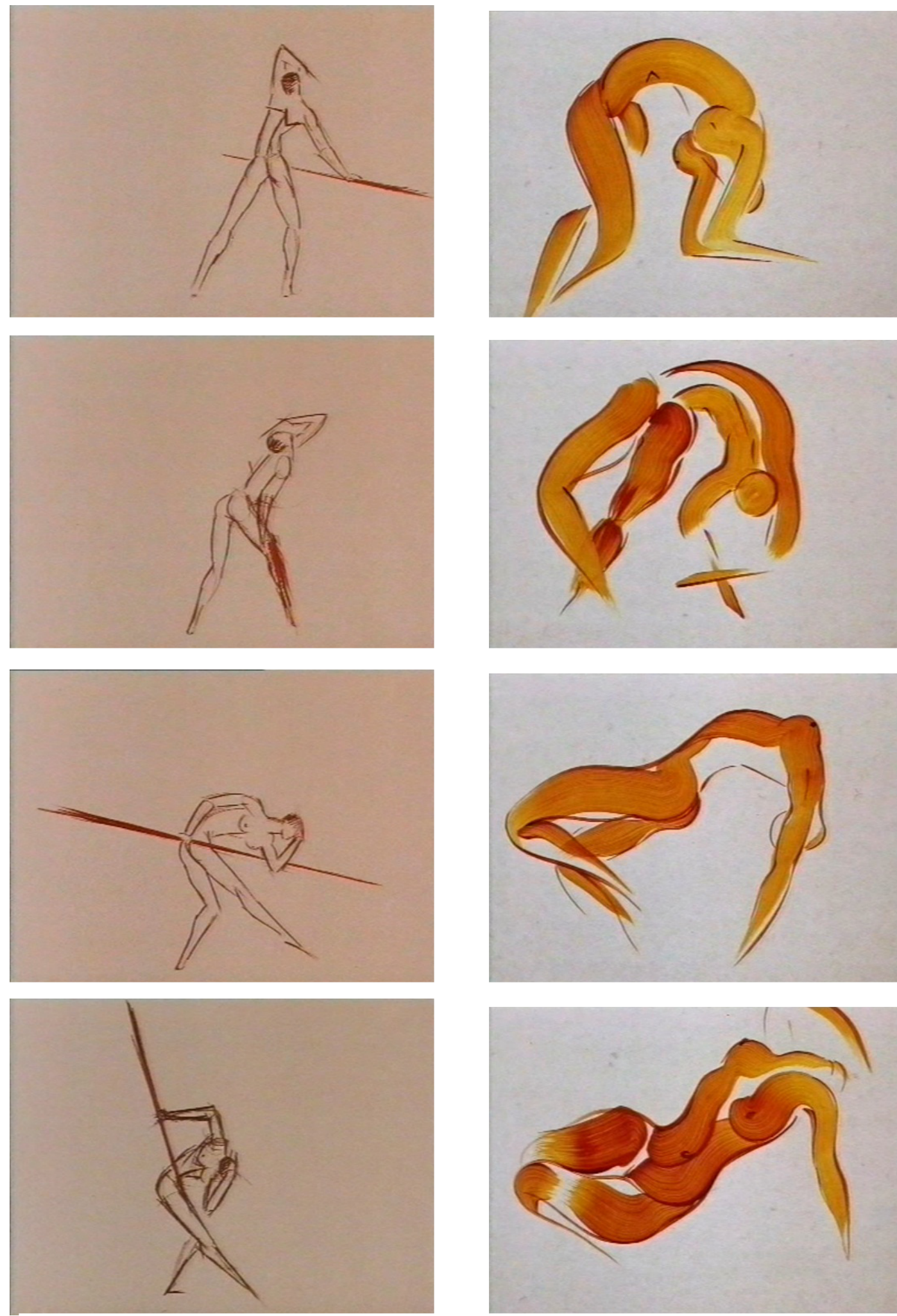

Fig. 12. Erica Russell (1994). Triangle (Triángulo). Serie de fotogramas.

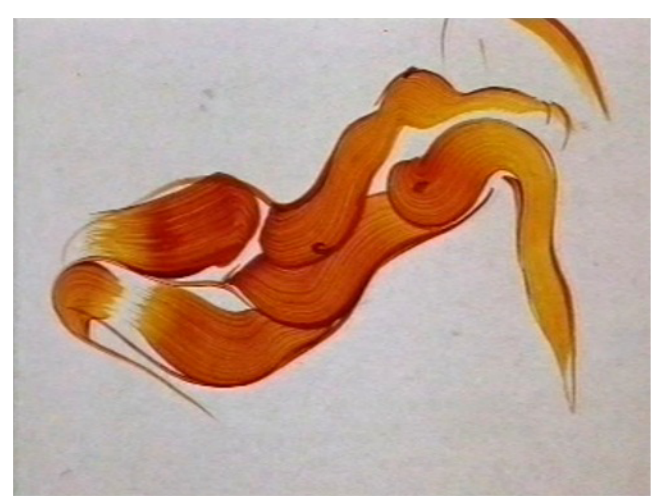

Fig. 13. Erica Russell (1994). Triangle (Triángulo). Serie de fotogramas. 
Respecto a la homogeneidad (homogeneidad entre animaciones, no la homogeneidad en el ritmo o la velocidad dentro de una obra particular), una de las características del movimiento neutro, ésta puede obtenerse al usar un estilo establecido de representación móvil o técnicas que unifican los resultados (como la captura de movimiento y la interpolación automática, o evitar la vibración de la imagen). Aunque esta característica aislada, si se acompaña de cualidades del movimiento vivenciado, no basta para representar el movimiento neutro.

En el parágrafo 2.2. y en el capítulo 3 se analizan pormenorizadamente diversas maneras de emplear los elementos dinámicos de la animación para expresar el movimiento vivenciado y el neutro. Hemos desglosado la animación en cinco componentes espacio-temporales visuales que presentamos a continuación. 


\subsection{COMPONENTES DINÁMICOS DE LA ANIMACIÓN}

Hemos reconocido cinco componentes dinámicos de la animación. Cada uno de cuales tiene elementos manipulables propios que los hacen complejos y muy versátiles plásticamente. En este capítulo se detalla la influencia de los componentes espacio-temporales en la expresión del movimiento vivenciado y neutro. Cada apartado está dedicado a uno de los componentes. En primer lugar se explica en qué consiste (A); por medio del análisis se desarrollan los elementos que los configuran y que incumben a la expresividad de la representación móvil (B); y finalmente, a modo de sumario, se resumen las ideas extraídas sobre cada componente (C). Como cometamos en la introducción del capítulo, nos extendemos sobre la valoración espacio-temporal en el capítulo 3, pero en el punto correspondiente a ésta, figura un planteamiento inicial de qué es, con el que entender el papel de este componente respecto a los demás.

\subsubsection{CAMBIO DE IMAGEN}

\section{A. QUE ÉS}

El cambio sucesivo de imagen es elemental en la representación del movimiento. Se trata de un movimiento, o más bien un cambio, real. El cambio de imagen tiene lugar por la proyección de la película o por procesos digitales de reproducción de video. Hay dos elementos manipulables de éste cambio real que pueden ser usados para la expresión plástica del movimiento: la frecuencia de imágenes por segundo (fips), es decir, la cantidad de imágenes que se proyectan por segundo - que puede ser variable o constante - y el paso entre fotogramas - instantáneo o por fundido -. El cambio instantáneo de imagen puede provocar, dependiendo de las características plásticas, una vibración que constituye otro de los elementos manipulables de este componente espacio-temporal. Como veremos a continuación, la vibración visual en animación es un elemento plástico más; su movimiento también participa en la representación del movimiento y la expresión vivenciada puede darse a través de ésta. La intensidad de la vibración depende de varios factores, aunque en su manejo también intervie- 
ne un poco, en cierto modo, "lo inesperado" como lo hace en la acuarela y otras técnicas al agua, por lo que siempre, por mucha experiencia que se tenga, el resultado puede ser sorprendente.

La frecuencia de fotogramas, la transición entre éstos y la vibración que proviene de ellos hacen del cambio de imagen un componente espacio-temporal muy flexible. Éste influye en el resto de componentes dinámicos, sobre todo en la valoración espacio-temporal y en la distribución de la intensidad cinética, pero también en la composición móvil.

\section{B. LA EXPRESIVIDAD DEL MOVIMIENTO A TRAVÉS DEL CAMBIO DE IMAGEN}

\section{B.1. Frecuencia de imágenes por segundo. Velocidad de pro- yección}

\section{- Imágenes / Fotogramas}

En animación cabe diferenciar entre imágenes por segundo (ips) y fotogramas por segundo (fps), cuya frecuencia no necesariamente es coincidente (Figs, 14 y 15). La frecuencia de fotogramas por segundo (ffps) indica la velocidad de proyección. La velocidad de proyección normalmente se mantiene constante, pero una misma imagen puede verse en dos o más fotogramas consecutivos (Fig. 15), lo que prolonga su tiempo en pantalla, (frecuencia de ips - fips -) y altera el movimiento resultante. Actualmente las películas de acción real se ruedan a una velocidad de 24 fotogramas (e incluso más). En animación esto está menos reglado, depende de las necesidades de cada película o la costumbre del realizador.

Como comentamos en 2.1. para que el movimiento sea percibido como continuo sin que el espectador se percate de los dibujos que lo conforman, la imagen en la retina debe concatenarse con otra antes de desaparecer. Para lo cual hace falta visualizar una frecuencia mínima de 12 ips. A partir de 12 o más ips percibimos un movimiento que asociamos a la velocidad de la acción real; a menor velocidad distinguimos el cambio de imagen. Sin embargo, en una animación con menor número de ips $(8,9$ o 10) se reconoce la continuidad del movimiento aunque éste sea entrecortado. 

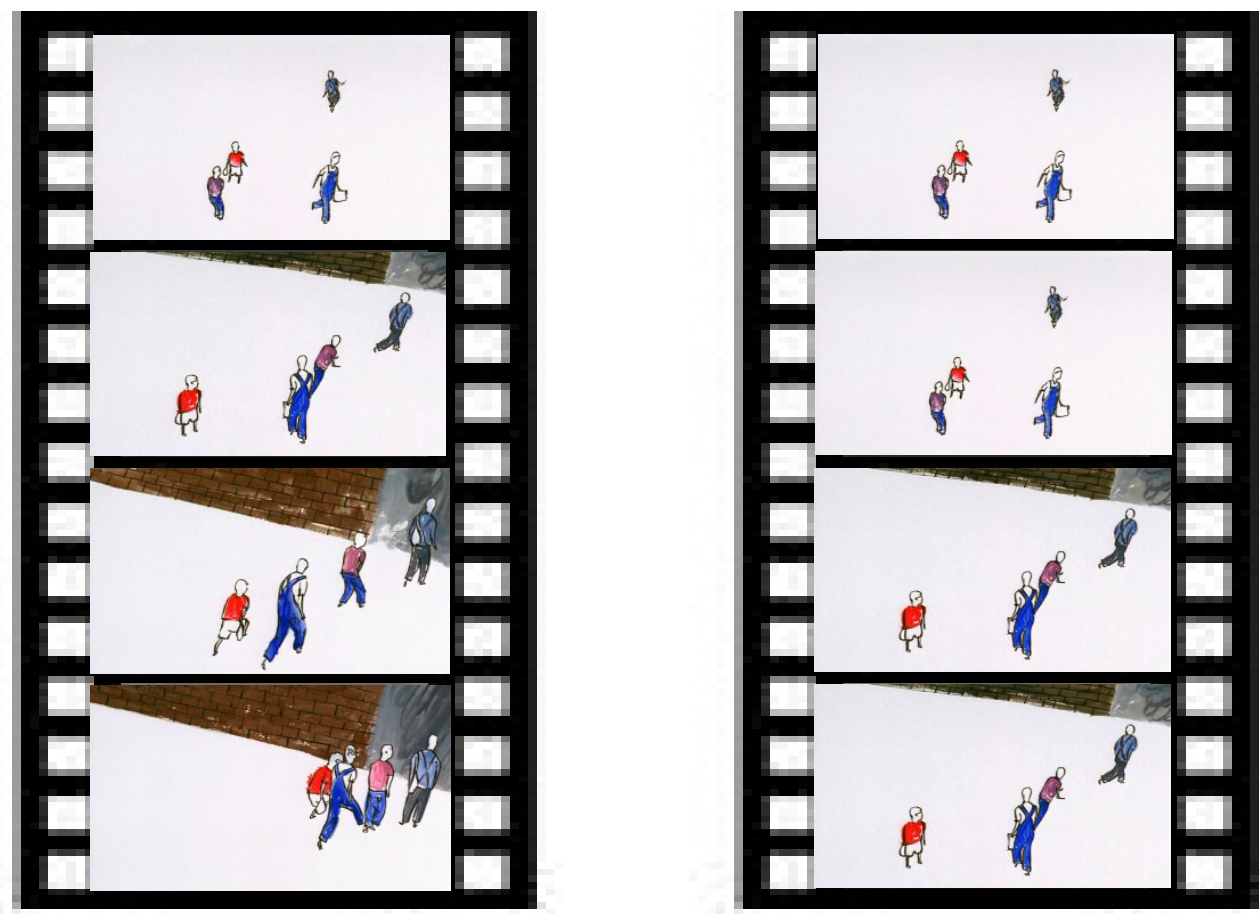

Figs. 14 y Fig. 15. Rosa Peris (2015), Simulación de película cinematográfica con imágenes de The man with the beautifull eyes, (Hogdson, 2000). En la primera, la imagen varía en cada fotograma; en la segunda, varía cada dos fotogramas. Aunque hoy en día no es frecuente la grabación analógica, sirva para clarificar la diferencia entre imágenes y fotogramas.

\section{- Variación de frecuencia de ips}

La alteración de la frecuencia de ips es otro elemento "maleable" de la animación que el artista emplea para expresar el movimiento. La frecuencia de imágenes por segundo o velocidad de cambio de imagen es constante en la amplia mayoría de películas. Las frecuencias más habituales en animación son de 12 y 24 ips, aunque es un elemento que varía de unas películas a otras e incluso dentro de la misma obra, dependiendo de la intención expresiva. La inclusión de distintas velocidades en una misma obra ha sido objeto de experimentación; por ejemplo, en ocasiones se hacen resúmenes del movimiento a través de las imágenes principales del desarrollo de la acción o incluso por medio de una única imagen para cada acción.

La frecuencia de ips es un potente elemento expresivo que puede pasar desapercibido. En los estudios Disney tradicionalmente utilizan frecuencia variable de 12 o 24 imágenes por segundo según la velocidad del movimiento a representar. La alternancia de 12 a 24 ips no es perceptible a simple vista para ojos inexpertos, pero los efectos que tiene sobre el resultado son aprovechados: 
Era conocido desde hacía mucho que para las acciones más normales no era necesario hacer un nuevo dibujo por cada fotograma de la película. Cada dibujo podía ocupar dos de los preciosos fotogramas, y la audiencia nunca lo detectaría a 24 fotogramas por segundo. Esto ahorraba inmensas cantidades de trabajo y en los movimientos lentos otorgaba una apariencia más suave a la acción. Más que eso, una acción rápida en "dos" [12fps] tiene más chispa y espíritu que la misma acción con intermedios, que tiende a hacer el timing demasiado uniforme y quita vitalidad. ${ }^{18}$

Por otro lado, la variación de la fips, lejos de pasar desapercibida, puede exhibirse notablemente, aunque no es muy común y, cuando se usa, la mayor parte de las veces es en breves fragmentos de la película. Raras veces es el elemento protagonista, como en La légende du pauvre bossu (La leyenda del pobre jorobado) (Ocelot, 1982) y Syrinx (Siringa) (Larkin, 1965). También lo es en Travel to China (Viaje a China) y The Da Vinci's Time Code (El código de tiempo de Da Vinci) (Alkabetz, 2002; 2002). En Travel to China, se muestran fragmentos de una única imagen con varias figuras, aislando partes de la imagen mediante el encuadre. Inicialmente, estos planos se mantienen un tiempo en pantalla. La duración de los planos se reduce progresivamente hasta que se reducen a $1 / 12$ de segundo, de modo que las imágenes cobran un movimiento que se reconoce como continuo. Manteniendo esta nueva velocidad, los planos varían en orden y encuadre, generando diversas trayectorias y cambiando la apariencia de la acción: correr, saltar, girar. etc. Algo parecido pasa en The Da Vinci's Time Code, en el que, por medio del encuadre de fragmentos la famosa obra de Leonardo, La Última Cena, se compone un movimiento continuo. En el ejemplo anterior los personajes tienen el mismo color, no así en este caso, en el que se parte de personajes mucho más individualizados, también con distintos colores, con lo que se hace patente que la configuración de la acción se impone sobre los otros elementos, de modo que se reconoce como una única forma en acción.

Encontramos frecuencia regular o cambiante tanto en películas con movimiento vivenciado como con neutro. En el caso de la expresión del movimiento neutro, la combinación de frecuencia de ips no tiene un fin expresivo o plástico, como en los ejemplos que acabamos de ver; los principales objetivo son la claridad y sencillez visual de la representación del movimiento, y transmitir con eficacia el mensaje.

\footnotetext{
18 Thomas \& Johnston, 1981, pág. 65, (trad. a.): It had long been know that for most normal action there was no needed to make a new drawing for every frame of the film. Each drawing could occupy two of the precious frames, and the audience would never detect it at 24 frames a second. This saved immense amounts of work and in the slower movements gave a smoother appearance to the action. More than that, a fast action on "twos" had more sparkle and spirit than the same action with inbetweens, which tended to make the Timing too even and removed the vitality.
} 


\section{B.2. El paso entre fotogramas}

\section{- Cambio instantáneo y fundidos encadenados}

El cambio de imagen puede ser instantáneo o por fundido. El cambio instantáneo consiste en que en un nuevo fotograma se presenta una imagen distinta a la del fotograma anterior. De este tipo de paso entre fotogramas se deriva la vibración de la imagen, cuyas cualidades, por presentar una gran variedad de efectos y constituir una problemática propia, lo trataremos en un punto aparte (B.3. de este parágrafo). En este apartado nos detendremos en los fundidos encadenados.

El cambio entre fotogramas también puede ser progresivo (una imagen desaparece progresivamente mientras aparece la siguiente). Los fundidos entre fotogramas continuos suavizan la vibración: "Los fundidos proporcionan un buen movimiento lento y la textura no parpadea a una frecuencia de 12 dibujos por segundo" ${ }^{19}$, lo que puede ser conveniente según el movimiento que se desee representar. Además de suavizar la vibración producida por la textura irregular de los fotogramas, los fundidos entre imágenes consecutivas pueden utilizarse para dotar a la acción de un carácter diferente, con significación especial; así, en The wife of Bath (La mujer de Bath) (Quinn, 1998), el caballero se encuentra con un grupo de doncellas danzantes que se transforman en una anciana. Las doncellas se representan por medio de imágenes que se suceden con fundidos encadenados (00:02:10). La sucesión de imágenes por corte y por fundidos encadenados reunidos en la misma escena marca la diferencia entre la naturaleza de la realidad y la fantasía: los fundidos proporcionan un ambiente de irrealidad acorde con la visión mágica.

Las cualidades dinámicas de los fundidos entre fotogramas también alteran la acción real y la animación de fotografías, y proporcionan el mismo efecto de movimiento "fantástico" que en la animación al otorgarle un dinamismo que difiere de la apariencia natural del movimiento. En How wings are attached to the back of the angels (Cómo las alas están unidas a la espalda de los ángeles) (Welch, 1996), las imágenes fotográficas se integran a la perfección con un dinamismo propio que no se parece a la animación de dibujo con la que se combina (fotografías en 00:05:44 y alteración de acción real en 00:06:43). Su dinamismo contribuye a la generación del ambiente enrarecido en el que transcurre la historia.

\footnotetext{
${ }^{19}$ Cotte, 2004, pág. 183, (trad. a.): Dissolves give a good slow movement and the texture doesn't flick at a rate of twelve drawings per second.
} 
Los fundidos encadenados son susceptibles de proporcionar tanto movimiento vivenciado como neutro, dependiendo de cómo se presenten. Los breves pero hipnóticos planos de How Wings are attached to the back of the Angels colaboran en la expresión del movimiento vivenciado, así como en Tántalo (Peris R. , 2010), en la que los fundidos entre imágenes sucesivas se extienden a toda la película. En este cortometraje la frecuencia de imágenes es variable, pero todas se suceden por fundidos encadenados, de modo que se muestran varias imágenes a un tiempo, de las cuales unas se ven con mayor definición que otras. La construcción de cada acción no es tan detallada como en una animación de 12 ips, pero gracias a la superposición de las imágenes y su sucesión se comprende la continuidad del movimiento. La vaporosidad de la imagen contribuye a la expresión de la idea por medio del movimiento: la imagen se escape a nuestros ojos de la misma manera que la mujer escapa del hombre (Fig. 16).
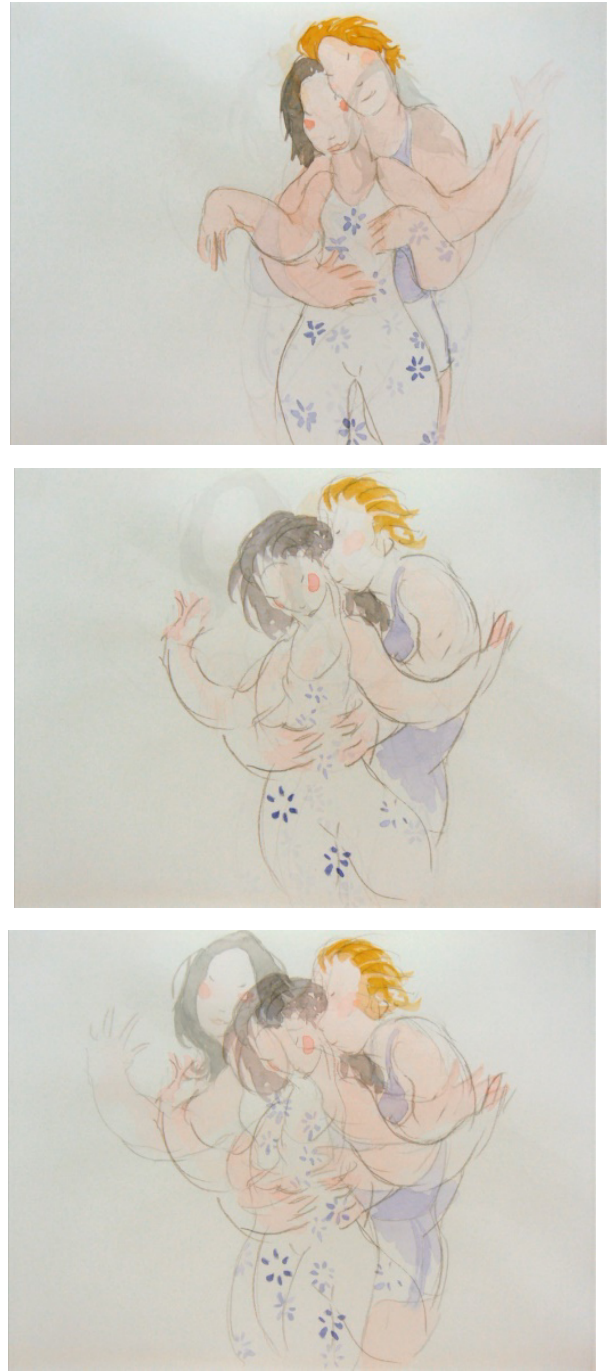
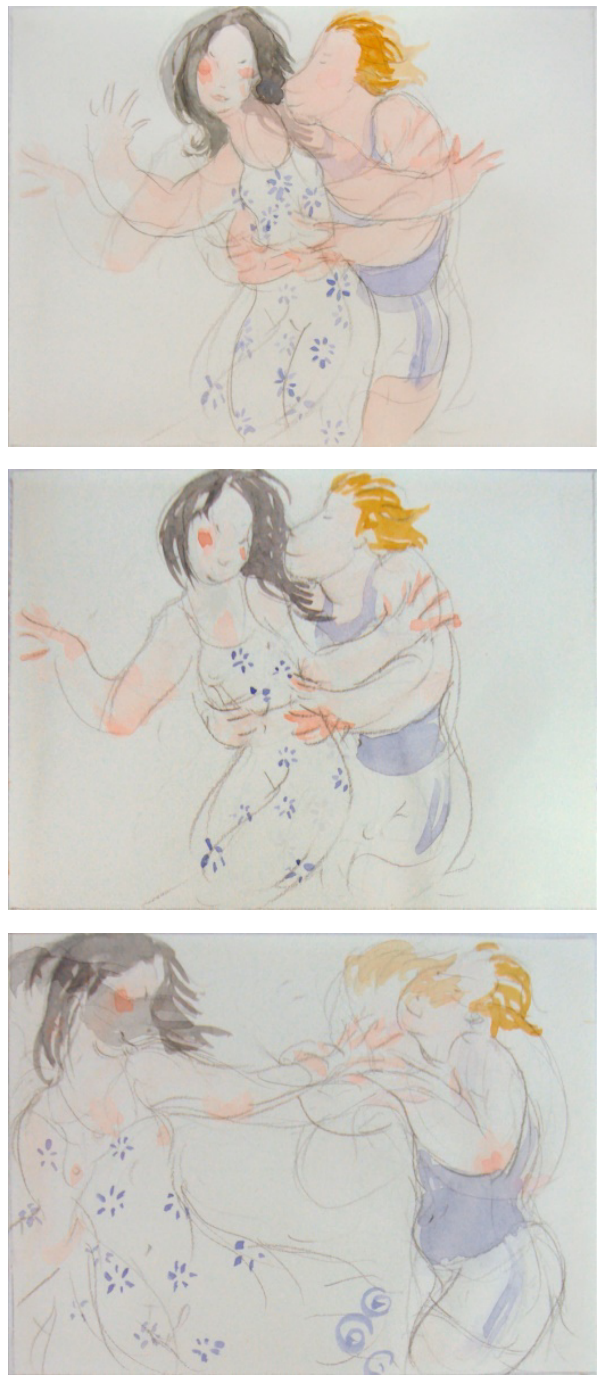

Fig. 16. Rosa Peris (2010). Tántalo. Fundidos encadenados. La superposición de imágenes en esta película es real, no un efecto óptico. 
De manera opuesta, en el video educativo de química Concepts in Science: Organic Chemistry 1. (Conceptos de ciencia: Química orgánica I) ${ }^{20}$ vemos un claro uso de los fundidos encadenados para representar el movimiento neutro. La fusión de dos elementos da como resultado una sustancia que aumenta de tamaño; el aumento de volumen se representa por fundidos encadenados. Aquí los fundidos no introducen ni un ambiente especial ni son vehículo para los sentimientos, simplemente resumen el paso del tiempo, un recurso largamente utilizado en el lenguaje cinematográfico.

\section{- Combinación de efectos}

La combinación de cambio de imagen por corte o por fundido y la variedad de frecuencia de ipf aporta riqueza dinámica a la animación; además puede aprovecharse para diferenciar entre los movimientos de los personajes, crear distintos ambientes, transmitir diferentes sensaciones, etc.

Entre otros, se combinan efectos en los cortometrajes Inon or the Conquest of Fire (Inon o la conquista del fuego) (Back, 1972) y La légende du pauvre bossu (La leyenda del pobre jorobado) (Ocelot, 1982). En ésta última, la frecuencia de imágenes es utilizada como principal elemento expresivo: el cortometraje tiene la mayor parte de su duración una frecuencia de imágenes por segundo muy baja, las imágenes permanecen estáticas en pantalla hasta varios segundos, de modo que la acción se compone de manera esquemática. A este movimiento se opone otro totalmente distinto, muy suave, obtenido con una fips mayor (12/1) en combinación con la permanencia de la imagen, es decir, queda en pantalla el rastro de la acción, un recuerdo visual de su transcurso. El movimiento es aquí vivenciado por transmitir sensaciones cinéticas y también porque el movimiento mismo expresa el contenido: la frecuencia menor en la presentación de los príncipes muestra su caminar orgulloso y un poco brusco (una imagen por cada paso), acorde con su personalidad. La frecuencia de imagen aumenta lentamente en las siguientes escenas, proporcionalmente al incremento de la violencia de la historia; hasta que, a partir del punto álgido (el apuñalamiento del joven en su espalda jorobada), la fips aumenta a 12; la frecuencia mayor en combinación con la permanencia de imagen otorga al vuelo del joven alado un movimiento hipnótico (00:06:07) (Fig. 17); la belleza visual de este movimiento representa también la belleza interior del joven, en el que la gente no veía más que un pauvre bossu.

${ }^{20}$ Arcadia Group SRL, h.2011 
En Syrinx (Siringa) (Larkin, 1965) la imagen se mantiene en pantalla un tiempo variable (a veces entre 10/12 ips, y otras permanece hasta 4 segundos) conectadas por transiciones por fundido, por lo que se diferencian cada una de la imágenes que componen la animación. El cambio de frecuencia de imágenes no tiene un significado tan obvio como en el ejemplo anterior, pero sin duda refleja la sensualidad de la ninfa y la bucólica persecución, y ofrece una visión romántica del fauno que sufre, con serena tristeza, por la pérdida de ésta.

La combinación de frecuencias y fundidos encadenados entre imágenes sucesivas puede aportar fuerza expresiva, aunque para representar el movimiento de manera vivenciada no es necesario combinar distintas velocidades de cambio de imagen. Así mismo, las representaciones más neutras del movimiento también presentan frecuencia constante o cambiante y cambio de fotogramas por fundidos o corte, pero tal variedad es para aportar claridad al mensaje, antes que para servir a fines expresivos.
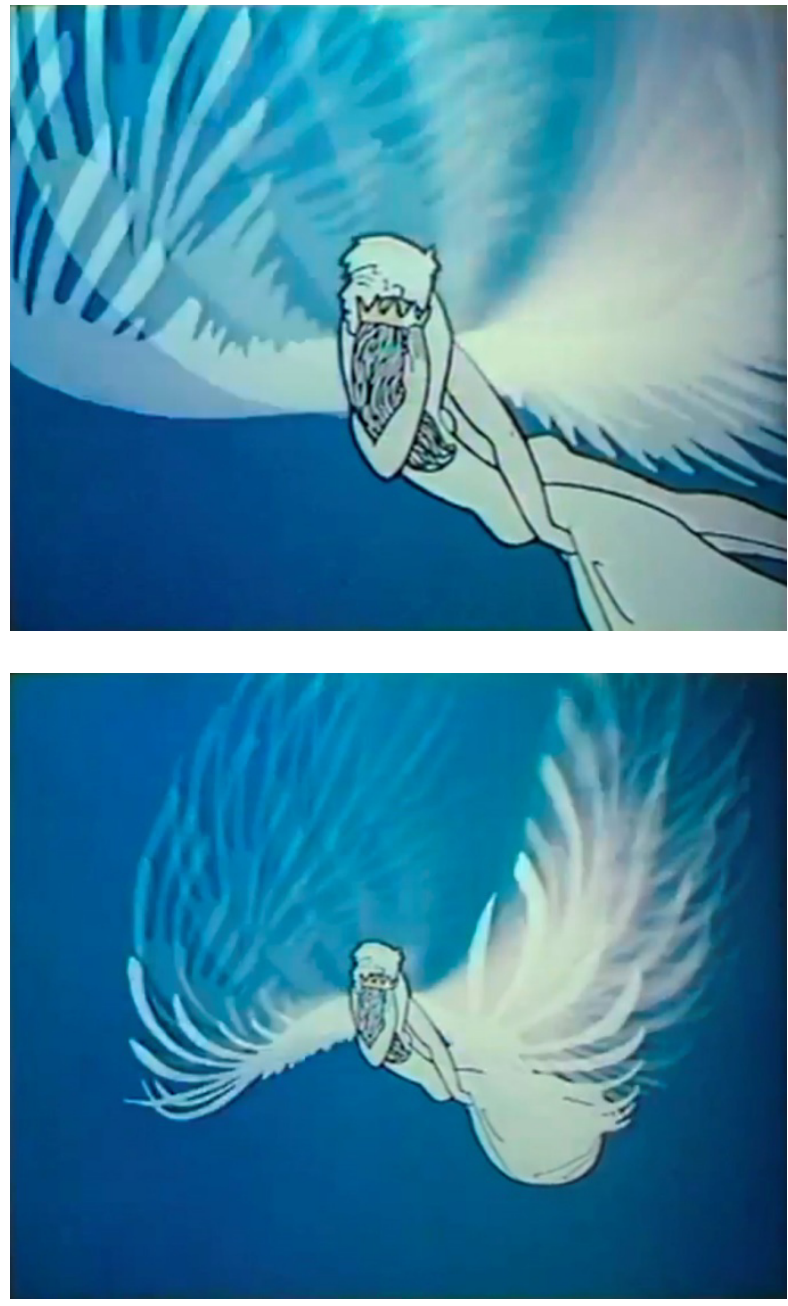

Fig. 17. Michel Ocelot (1982). La légende du pauvre bossu (La leyenda del pobre jorobado). Serie de fotogramas. 


\section{B.3. Vibración de la imagen}

\section{- A qué se debe. Usos y efectos}

De la sucesión de fotogramas cuyo trazo, textura o color es irregular se deriva la vibración de la imagen. Ésta tiene mayor o menor presencia dependiendo de la velocidad del cambio de imagen (frecuencia de ips), de la distancia física entre las formas que contienen las imágenes correlativas y de la semejanza plástica (trazo, color, textura, luz, etc.):

-La velocidad de sucesión de imágenes (fips) determina la velocidad de la vibración.

-A mayor distancia entre las formas representadas en fotogramas contiguos (lo que se traduce en un movimiento rápido en pantalla), menos percibimos la vibración. Cuando se representa un movimiento lento (las formas varían mucho más paulatinamente entre fotogramas consecutivos), se detectan más fácilmente las variaciones plásticas, aunque sean sutiles.

-A mayor diferencia de trazo/color/luz/textura entre fotogramas contiguos, mayor vibración.

En la animación de dibujo y de pintura, todos los elementos plásticos pueden vibrar, porque varían de un fotograma a otro (aunque tradicionalmente se mantiene estática una misma imagen para el fondo). En el caso de la pixilación o la animación stop-motion con elementos rígidos y no maleables (como los recortes, objetos, etc.), la vibración está relacionada con la continuidad de la forma del móvil y su posición en las imágenes correlativas. En el caso de la alteración de la acción real, cuantas menos imágenes se eliminen de la grabación original o a mayor velocidad de grabación, menor será la vibración.

Los efectos ópticos de los que hablamos en 2.1.1. se producen, como la vibración, por la irregularidad de la luz, el color o las formas entre fotogramas consecutivos, pero no son fruto simplemente de la irregularidad, sino del cambio brusco de unos fotogramas a otros. En estos casos la fuerte vibración provoca efectos ópticos, por ejemplo el cambio fuerte de color genera pos-imágenes, el cambio repentino de localización de la forma produce la ilusión de que ésta se multiplica, etc.

La vibración se presenta en diferentes grados de intensidad, puede ser imperceptible o altamente llamativa, e incluso insoportable para los ojos. Su protagonismo o "tensión" no sólo depende de la fuerza de la agitación, sino también del espacio que ocupa en pantalla: "La parte vibrante de una imagen Ilama, en prin- 
cipio, la atención como toda parte móvil. Por lo tanto la agitación de la textura puede entonces ser utilizada en esta dirección." ${ }^{21}$ La más mínima vibración puede enriquecer la plástica de la película, sencillamente porque aporta calidez al movimiento. Brad Hansen, autor de Lemonade (Limonada) (2006), opina que un valor de la rotoscopia es que, como la línea no se puede hacer exactamente en el mismo lugar, vibra, y ese efecto de vibración ya le da vida a la imagen, incluso en los planos en los que no se representa ninguna acción ${ }^{22}$. En otras películas, la vibración tiene mayor presencia plástica, como en Carnival (Carnaval) (Young, 1986) y The man with the beautiful eyes (El hombre de los ojos bonitos) (Hogdson, 2000). Hay mucha diferencia entre las imágenes correlativas de estas animaciones debido a la gestualidad del trazo y, obviamente, porque son fruto de la factura manual: la irregularidad de la línea, la ligera alteración de color por la distinta densidad de la pintura, el cambio de tono, etc.; se trata de efectos intencionados.

La vibración también puede ser un elemento expresivo con entidad propia. En la secuencia musical de Lucy in the Sky, en Yellow Submarine (Dunning, 1968), la vibración es fundamental; ésta es producida por el cambio drástico de color y la textura gráfica y crea un efecto psicodélico que acompaña visualmente el contenido de la canción, con referencias constantes al color ("[...] Con mandarinos y cielos de mermelada [...] Una chica de ojos caleidoscópicos / Flores de celofán amarillo y verde asoman sobre tu cabeza / Busca a la chica con el sol en los ojos que se ha ido..." ${ }^{23}$ ); el movimiento característico de la rotoscopia desaparece totalmente con la vibración del color y del trazo. (Fig. 18). En contraste con esta animación, vemos una vibración sutil pero con sentido expresivo en el cortometraje Light Forms (Formas de luz) (Light Forms (Formas de luz), 2010), en el que Malcolm Sutherland crea mecanismos fantásticos a partir de formas irregulares de aspecto orgánico. El movimiento rítmico de las acciones es acompañado por una constante y suave vibración que armoniza con la organicidad de estos seres.

Además de poseer cualidades plásticas, la vibración de la imagen puede participar activamente en la representación del movimiento. Así, encontramos animaciones en las que la vibración es el agente principal para representar algunas acciones. En el fragmento de la pieza musical All together now, en el film Yellow

\footnotetext{
${ }^{21}$ Sifianos, 2012, págs. 211-212, (trad. a.): La partie vibrante d'une image attire en principe l'attention, comme toute partie mobile. La mise en agitation d'une texture peut donc être utilisée dans cette direction.

${ }^{22}$ Hansen, Lemonade-Making Of the Rotoscoped Film.

${ }^{23}$ Lennon, Lucy in the Sky with diamonds, 1967, (trad. a.): With tangerine trees and marmalade skies [...] A girl with kaleidoscope eyes / Cellophane flowers of yellow and green / Towering into your head I Look for the girl with the sun in her eyes / And she's gone...
} 
submarine, la vibración producida por el abrupto cambio de color de un fotograma a otro en las aletas de los peces genera un movimiento óptico que representa el rápido aleteo de los animales. Y en Street Musique (Calle Musique) (Larkin, 1972)el cambio de color en fotogramas consecutivos es el único medio por el que se representa el movimiento de una moto: el dibujo es completamente estático en posición y forma, sólo el color cambia; simplemente por alternar dos fotogramas y repetirlos a lo largo de varios segundos, se produce una vibración que da vida a la imagen (00:05:25); se crea la ilusión de que la moto está en marcha y se desplaza al tiempo que la cámara la sigue (Fig. 19).

La vibración provocada por la textura de la imagen puede apoyar la narración y la evolución dramática de la película. G. Sifianos explica este fenómeno:

\begin{abstract}
Si la acción lo justifica, una vibración importante puede ser utilizada, pero sin tener efectos negativos. El suspense por ejemplo, en la narración, puede hacer invisible la vibración de la textura. Por el contrario, si a nivel narrativo no hay una acción importante para captar la atención del espectador, la vibración aumenta en importancia, se convierte en sujeto de la película, y si el efecto no se planificó, irá a la inversa del interés de la película. ${ }^{24}$
\end{abstract}

Una vibración sin una correspondencia tan literal entre suspense y tensión, pero que también forma parte del contenido de la película, es la que vemos en Flux (Hinton, 2002) [en DVD]. Los dibujos de esta animación, que recuerdan intencionadamente al trazo de un dibujo infantil y presentan gran variación entre fotogramas correlativos, generan un movimiento muy potente, una constante y fuerte palpitación. La vibración no refuerza la representación del movimiento, sino que forja el carácter de la película aportando, a través de la visualidad, un toque tragicómico acorde con la historia.

La capacidad de la vibración de la imagen para crear una textura dinámica que enriquece la plasticidad de la película, aportar información sobre el contenido o carácter de la historia e incluso para representar el movimiento puede colaborar en la expresión del movimiento vivenciado: en The Cat Come Back (EI gato volvió) (Barker, 1988) el temblor de la imagen crea la sensación cinética de tocar el instrumento de viento, cuya vibración parece extenderse a todo el cuerpo (Fig. 20). En The Metamorphosis of Mr. Samsa (La metamosfosis del señor Samsa) (Leaf, 1987) el movimiento de las patitas de la garrapata se acentúa gra-

\footnotetext{
${ }^{24}$ Sifianos, 2012, pág. 212, (trad. a.): Si l'action le justifie, une vibration importante peut être utilisée, mais sans avoir d'effets négatifs. Le suspense par exemple, dans la narration, peut rendre la vibration de la texture invisible. Par contre, si au niveau narratif, il n'y a pas une action importante pour capter l'attention du spectateur, les vibrations montent en importance, deviennent sujet pour le film, et si l'effet n'était pas prévu, il irait à l'inverse des intérêts du film.
} 
cias a la gráfica de la imagen, lo que plasma el movimiento nervioso del insecto al estar bocarriba (00:01:12). El movimiento vivenciado provocado por la vibración también se da en animaciones en las que por medio de este recurso se representan movimientos menos sutiles, como en Le Vent (Tunis, 1972), donde los efectos de las fuertes ráfagas de viento se hacen más evidentes gracias a la vibración del color.
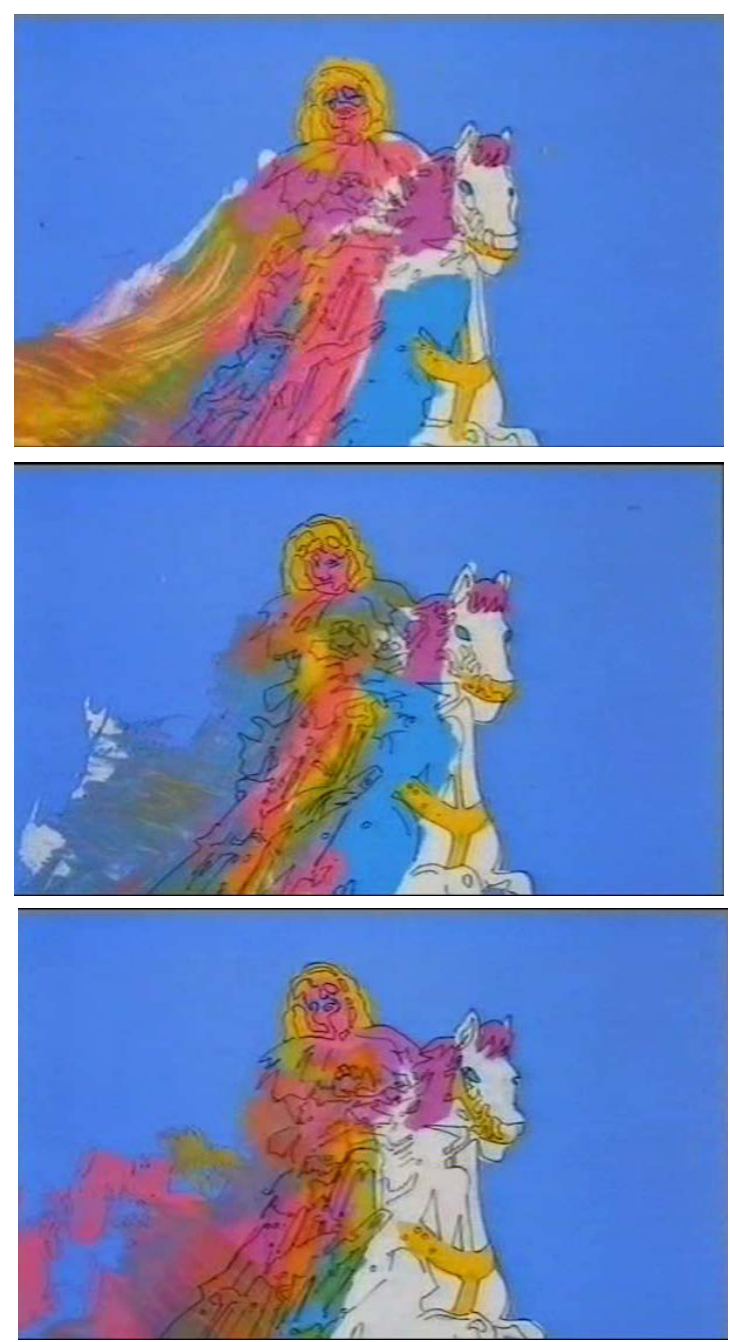

Fig. 18. George Dunning (1968). Lucy in the Sky with Diamonds. Yellow Submarine (El submarino amarillo). Fotogramas consecutivos.
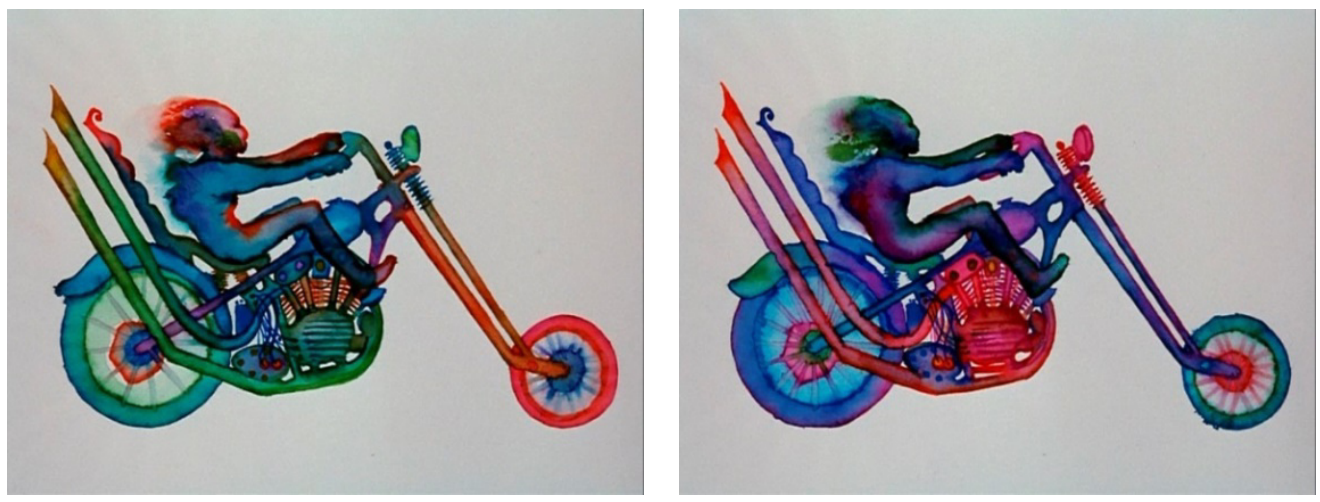

Fig. 19. Ryan Larkin (1972). Street Musique (Calle Música). Fotogramas consecutivos. 

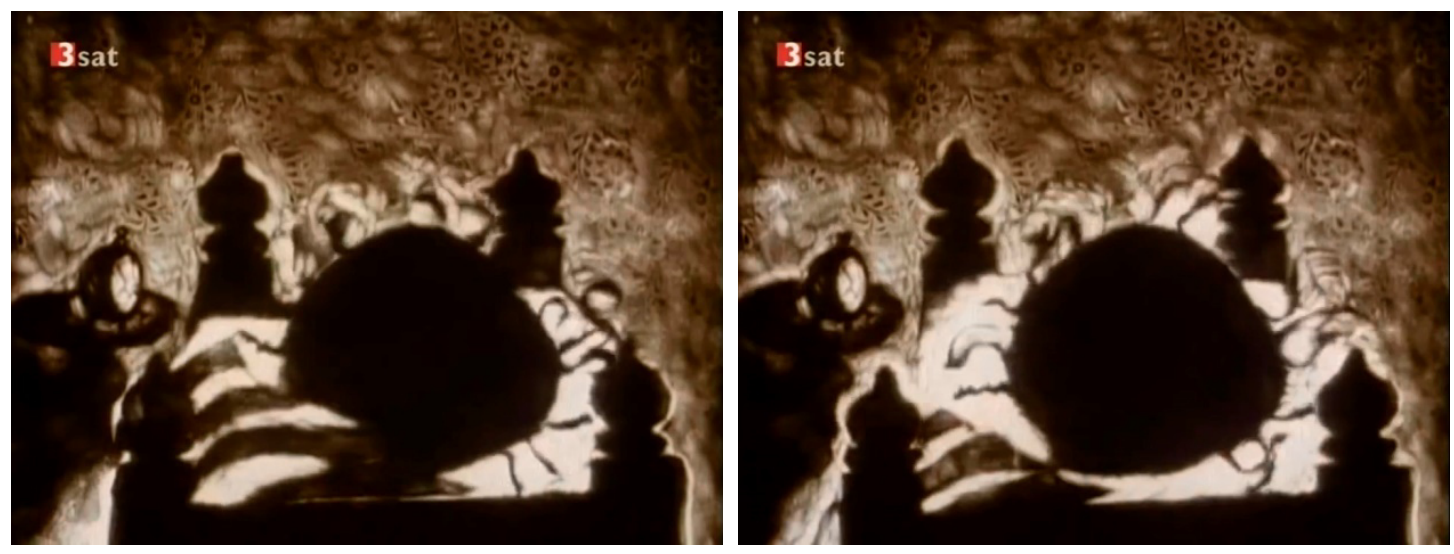

Fig. 20. Caroline Leaf (1987). The Metamorphosis of Mr. Samsa (La metamosfosis del señor Samsa). Serie de fotogramas.
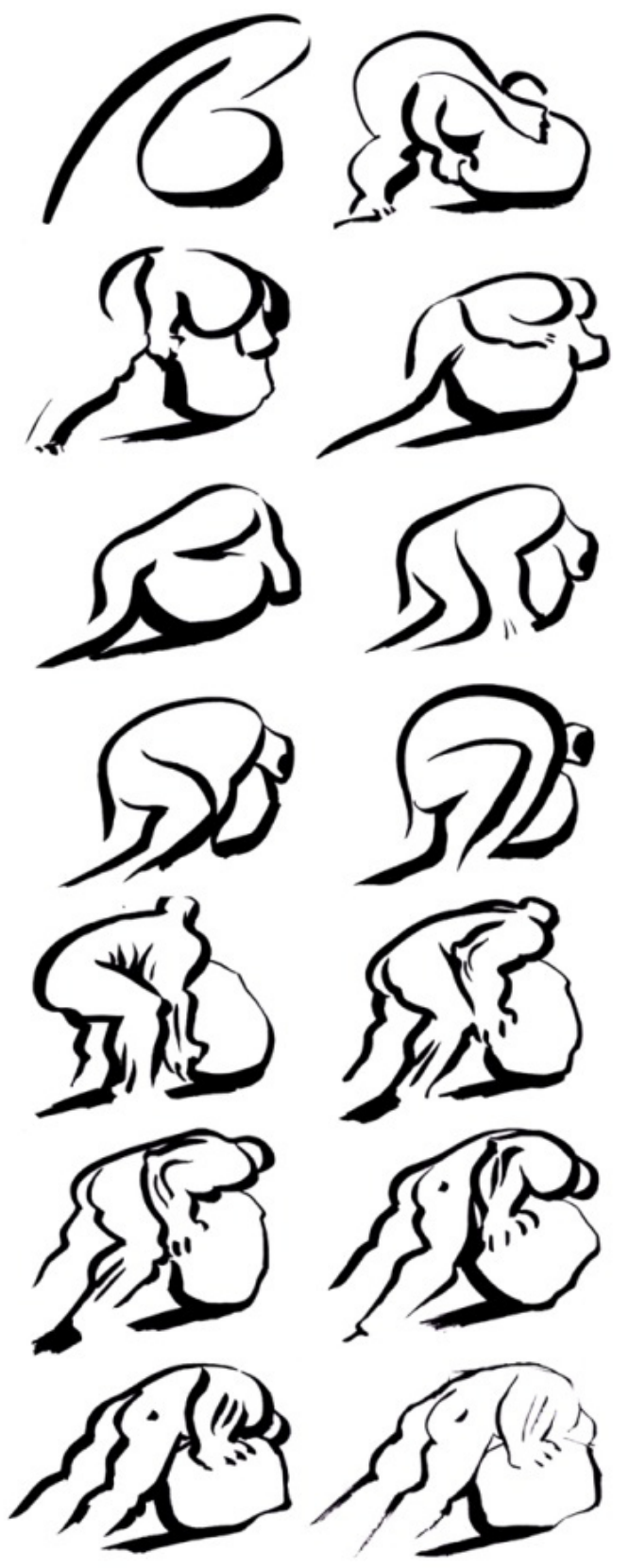

Fig. 21. Marcell Jankovics (1974).

Sisyphus (Sísifo). 
Así mismo, en Sisyphus (Jankovics, 1974) (Fig. 21) [en DVD], cortometraje en el que se interpreta el mito del hombre castigado a empujar una roca hasta la cima de una montaña, el movimiento se expresa como vivenciado gracias, sobre todo, a la vibración de la imagen. La línea y la forma del personaje varían notablemente entre fotogramas contiguos, lo que provoca el parpadeo de la figura de manera especial: a veces el cuerpo se resumen en pocas líneas, casi hasta la abstracción, otras los músculos se definen más, sobre todo en los momentos en que el hombre realiza más fuerza, es decir su esfuerzo físico se hace visual a través del cambio de definición de la musculatura, el cansancio es evidente; esto transmite una fuerte impresión cinética y despierta empatía hacia el personaje. Además del sufrimiento físico, el ahogo emocional que produce la tarea se transmite metafóricamente con el aumento paulatino de la roca. De esta manera, el sentido plástico de la vibración de la imagen expresa el movimiento y refuerza la narración (la vibración aumenta a la par que el dramatismo de la situación). En este cortometraje encontramos un compendio de las cualidades de la vibración gráfica en animación.

\section{- Cuando no hay vibración}

Para que no haya vibración o ésta sea imperceptible debe haber continuidad absoluta en el grafismo de las imágenes y la forma del móvil entre fotogramas contiguos; todos los elementos susceptibles de variar de un fotograma a otro deben permanecer estables excepto la posición o tamaño del móvil, que debe variar con precisión para que el movimiento resultante sea muy suave y fluido. El temblor, ya sea mayor o menor, es propio de la animación hecha a mano. En las técnicas de animación digital (Flash, Blender, etc.), la estabilidad de la imagen es fruto de la generación automática de fotogramas intermedios. En la sucesión de fotogramas el móvil mantiene exactamente el mismo color, sin variación de tono y con la misma calidad de línea. La precisión de la continuidad entre fotogramas es tan perfecta que el efecto de vibración no existe. Mientras que los fotogramas dibujados y pintados a mano, incluso aunque se compongan de áreas de colores planos, provocan un leve temblor que los distingue de la estabilidad total de aquellos generados o coloreados digitalmente; la suave fluidez de la imagen es producto de la precisión humana, no de la exactitud del ordenador. Así lo vemos en la mayoría de películas del Studio Ghibli: la animación de dibujo a mano, pese a la exactitud del trazo, confiere una cualidad diferente a la de la animación digital. 
Pero incluso aunque no haya vibración, la ausencia absoluta de movimiento sólo tiene lugar cuando se proyecta una imagen fija. Como explica Arnheim, "si en una secuencia cinematográfica se incluye un cuadro inmóvil, antes exhibirá un movimiento congelado que quietud" ${ }^{25}$. Del mismo modo, las imágenes fijas en animación producen la sensación de que la forma móvil está congelada y no tanto que es una forma "viva" en reposo. Arnheim observó con humor que esta inmovilidad viene a ser algo así como la maldición lanzada contra la mujer de $\operatorname{Lot}^{26}$.

La ausencia de vibración, además de ser un rasgo recurrente en las animaciones naturalistas (como veremos en el capítulo 3), es un elemento que homogeniza el resultado móvil que raramente falta en los videos educativos y videos de instrucciones, entre otros. Carecer por completo del parpadeo de la imagen es un recurso del movimiento neutro para obtener mayor inexpresividad o despersonalización, pues en este sentido es contraproducente un elemento en el que se vislumbra parte de la personalidad del artista. Aun así, también hay animaciones de movimiento neutro que presentan vibración.

De todos modos, la ausencia de vibración no sólo no es exclusiva de la animación de expresión neutra, sino que también se da en animaciones de muy diferentes grados de expresividad e incluso puede emplearse abiertamente con fines expresivos y retóricos e incluso para representar el movimiento (o más bien su ausencia). Por ejemplo, conscientes de la vida que esta vibración dota a la imagen, en Corps Bride (La Novia cadáver) (Burton, 2005), ante los invitados, el mayordomo se mantiene estático con la inmovilidad de la muerte. Para ello los animadores no han tocado la marioneta, como si se tratara de otro elemento más del set; así, la ausencia de vibración ha sido empleada de manera retórica (en esta historia, los muertos tienen más vitalidad que los vivos). También en Corre, caballito (Peris \& Peris, 2007) se usa este recurso: cuando el caballo protagonista de la historia está muriendo, la frecuencia de ips se reduce, lo que provoca que la vibración desaparezca progresivamente, hasta que, para representar el cese de la vida, la imagen se paraliza totalmente y un fotograma permanece en pantalla 5 segundos. Tras esos segundos, la vibración reaparece y el caballo resucita.

\footnotetext{
${ }^{25}$ Arnheim, 1979, pág. 314

${ }^{26}$ Arnheim, 1957, pág. 88
} 


\section{- Vibración o no vibración}

A veces la búsqueda de la estabilidad de la imagen en animación está motivada por el deseo de obtener mayor parecido con el movimiento cinematográfico, en el que, al registrar el movimiento real, al no haber irregularidad plástica entre fotogramas, tal vibración no existe. Algunos animadores simplemente lo consideran un error; Jonh Halas dice que si no se usan acetatos para combinar varios personajes en un mismo plano "los tonos y sombras vibrarán y estropearán el efecto en pantalla" ${ }^{27}$. Otras veces se evita el efecto parpadeante porque no apoya o dificulta la expresión del movimiento de la manera deseada, por ejemplo, para obtener un movimiento suave y fluido no necesariamente realista; En Malou ou I'hostilité mécanique (en Ut majeur) (Malou o la hostilidad mecánica (en Do mayor)) (De Roeck, 2011) vemos una animación muy refinada que no tiene vibración, ocurre también en Spring isn't fair (La primavera no es justa) (Klein, 2004), donde la ausencia de vibración es conseguida por animación digital 2D; ya sea por medios manuales o digitales, ninguna tiene vibración y ninguna representa el movimiento de manera naturalista, luego el uso o paliación de este elemento no siempre está relacionado con el nivel de naturalismo del movimiento.

El dinamismo de la imagen vibrante es, como hemos visto en este apartado, una herramienta de expresión en animación: como simple elemento estético, como medio para representar el movimiento o incluso como vehículo del contenido. Alexeieff observa otra cualidad de la vibración: la capacidad para hacer de la animación un medio independiente del arte producido hasta el momento (obras estáticas: pintura, escultura, etc.). Se refiere de la siguiente manera al uso intencionado y dirigido de la vibración de la línea en las películas Mail Early (Correo matutino) y Dollar Dance (El baile del dólar) (McLaren, 1941; 1943):

\footnotetext{
le daban la vuelta a la propia concepción de la animación de entonces, que aspiraba a vencer la inmovilidad consustancial del dibujo y la pintura, aun respetando la estabilidad de la imagen en su conjunto, hasta el punto que se hacía del repérage un criterio de competencia profesional. No se me había ocurrido, como tampoco a mis colegas, que se trataba de una superstición - de la herencia de los tiempos remotos en que el hombre sólo podía producir imágenes fijas. McLaren se atrevía a crear el dibujo trepidante, al que se propuso llenar de sentido, dirigiendo sus sobresaltos. $^{28}$
}

\footnotetext{
${ }^{27}$ Halas, The contemporary animator, 1990, pág. 18, (trad. a.): tones and shades will flicker and spoil the effect on the screen.

${ }^{28}$ Alexeieff en Bakedano, 1987, pág. 246
} 
Además, cuando la vibración procede de la irregularidad del trazo, frente a la estabilidad plástica de los medios digitales, trasluce la personalidad del autor. En este sentido, la vibración alejaría el movimiento resultante de la homogeneidad del movimiento, aunque, como ya hemos visto, la ausencia de vibración también puede tener intención expresiva, por lo que no es signo inequívoco de movimiento neutro. En todo caso, la vibración es un rasgo de la animación que denota que está hecha a mano. No sólo en las animaciones más gestuales, sino también en aquellas más fluidas, como Malou et l'hostiloté mecanique..., (mencionada anteriormente) o Kaguya-hime no Monogatari (El cuento de la princesa Kaguya) (Takahata, 2013). Curiosamente existen animaciones realizadas con pintura digital o con programas de animación que tratan de imitar la vibración propia de la animación hecha a mano. Esto se hace, con relativa frecuencia, para simular el efecto de película antigua. Para ello se introducen variantes de tono y matiz, y líneas adicionales (duplicando líneas de contorno, incluyendo líneas estructurales de la forma o líneas cinéticas); sin embargo la única manera de recrear este efecto consiste en producir manualmente cada imagen, prescindiendo de su generación automática. Apuntar simplemente (sin pretender entrar en un debate sobre qué es más conveniente en cada técnica) que simular un efecto natural de una técnica por medio de otra que se define precisamente por no presentar esa característica es una lucha contra el medio. Además esta operación supone una contradicción por imitar un efecto de componente azaroso mediante una operación absolutamente calculada. Plazaola sintetiza muy bien esta idea al decir que:

El material, se hace estético, no disimulándose, sino exhibiéndose, desplegando su riqueza sensible. Al mostrar sencillamente cómo es, deja de ser material muerto y se capacita para hacerse <<materia artística > a través de esa cualidad sensible que no ha intentado disimular, pero que tampoco necesita simular. ${ }^{29}$

A este respecto también son interesantes las palabras de Picasso sobre la búsqueda de la perfección.

Busca siempre la perfección. Por ejemplo, intenta dibujar un círculo perfecto; y como no puedes dibujar un círculo perfecto, el fallo involuntario revelará tu personalidad. Pero si quieres revelarla dibujando un círculo imperfecto, tu círculo, lo estropearás todo. ${ }^{30}$

${ }^{29}$ Plazaola, 2007, pág. 439

${ }^{30}$ Arnheim, 1979, pág. 145 
La vibración de la imagen en animación es un elemento maleable que puede presentarse en distintos grados; este elemento no determina la expresividad de la representación del movimiento, pues existen otros componentes dinámicos que también participan en ésta. Pero, según cómo se use, puede dotar de carácter vivenciado o neutro a la representación.

\section{CONCLUSIONES SOBRE LA INFLUENCIA DEL CAMBIO DE IMAGEN EN LA REPRESENTACIÓN DEL MOVIMIENTO VI- VENCIADO Y EL MOVIMIENTO NEUTRO}

Como hemos visto en este parágrafo, se puede influir en la expresión del movimiento a través de la intervención y alteración del cambio de imagen. Éstas son, en esencia, las posibilidades que ofrece (puntos observados en la tabla de análisis):

\section{- Variedad de frecuencia de imágenes por segundo.}

Se da tanto en animaciones con movimiento vivenciado como neutro. Es un elemento muy versátil con muchas posibilidades plásticas, sin embargo, su ausencia o presencia en una película no determina que el movimiento se exprese como neutro o como vivenciado.

- Vibración producida por la irregularidad de la gráfica en imágenes contiguas (trazo, mancha, textura, color, etc.).

Tanto la vibración como la ausencia de ésta pueden usarse para representar el movimiento como vivenciado. La vibración otorga "carácter" a la imagen, evidencia la factura manual y de ella se desprende la personalidad del autor. Por ello, en general, las películas con movimiento neutro evitan la vibración de la imagen. Es más, la ausencia absoluta de vibración puede ser un agente homogeneizador del movimiento, luego en ese sentido puede decirse que la ausencia de vibración es propia del movimiento neutro. Sin embargo, no es exclusiva de éste ni atenúa la expresividad, del mismo modo que la vibración no hace que la expresión sea vivenciada si no está dirigida a representar el movimiento o no genera sensación cinética.

- La vibración de la imagen, los efectos ópticos, los fundidos encadenados entre fotogramas y la fips se emplean para representar el movimiento o potencian las particularidades del movimiento.

Todos estos recursos pueden ser el medio principal para representar el movi- 
miento. Cuando esto transmite sensaciones cinéticas o particularidades de la acción, el movimiento se expresa como vivenciado.

\section{- Combinación de efectos producidos por el cambio de imagen (vibración,} efectos ópticos, fundidos encadenados, etc.).

Animaciones con diversos grados de expresividad combinan efectos visuales. Su uso u omisión no está relacionado con la expresión vivenciada del movimiento, ya que sirve tanto como elemento plástico como medio para transmitir el contenido, ya sea de manera expresiva o neutra. Según cómo se use, puede potenciar el atractivo plástico de la animación.

\subsubsection{VALORACIÓN ESPACIO-TEMPORAL}

Hemos denominado "valoración espacio-temporal" al desarrollo de la imagen a lo largo de los fotogramas sucesivos, lo que normalmente se conoce como timing. Determinando dónde está y cómo es la forma en las imágenes sucesivas (lo que implica cuánto cambia de un fotograma otro) se "construye" el movimiento o, dicho de otro modo, se dibuja la acción.

La factura de la valoración espacio-temporal depende de la técnica de animación (dibujando los fotogramas uno a uno, modificando progresivamente la posición o forma de una marioneta u objeto, alterando la velocidad de la captura de video, etc.). Pero de cualquier forma, la animación requiere la realización de todas las imágenes que forman la película (aunque algunas técnicas parten del registro de vídeo o de la generación automática de parte de los fotogramas). Ésta es la diferencia fundamental con el cine de acción real, en el que (como explicamos en el punto C. de 2.1.3.) la valoración espacio-temporal proviene de la captura de vídeo.

El hecho de crear una a una las imágenes de la película y determinar por medio de ellas cómo se desarrolla la acción involucra diversas cuestiones. Para empezar, su factura puede ser manual, mecánica o combinando ambos medios. También interviene el factor de la mecánica del movimiento; ya que éste se especifica pormenorizadamente, puede reproducir la mecánica tal y como la conocemos gracias al cine y a la cronofotografía o puede diferir notablemente de ésta. Además, la valoración espacio-temporal o timing es la clave de la animación 
más popular de la cultura occidental: la de Disney, y su expansión ha cobrado presencia en la animación de todo el mundo y de todos los ámbitos.

Aunque la manera en que se aborda la valoración espacio-temporal puede ser más o menos propicia para transmitir una gran expresividad o por el contrario para representar el movimiento de manera neutra, veremos que todos los métodos son susceptibles de expresar el movimiento como vivenciado o como neutro, dependiendo de la manera particular en que se usen los recursos de representación. Así mismo, debido a la interacción con el resto de componentes dinámicos, una valoración espacio-temporal vivenciada o neutra no determina la expresividad de la obra salvo que sea el componente dinámico protagonista de la representación.

Debido a la relevancia de este componente dinámico en la representación del movimiento, el capítulo 3 está dedicado enteramente a él, capítulo en el que explicaremos detenidamente qué es y profundizaremos en los temas que acabamos de plantear. Por el momento, sirva este apartado para aclarar el papel de la valoración espacio-temporal en el conjunto de componentes dinámicos.

\subsubsection{COMPOSICIÓN MÓVIL}

\section{A. QUÉ ES}

En este apartado analizamos el papel que la composición móvil en animación juega en la expresión del movimiento vivenciado y neutro. La composición móvil consiste en la evolución visual de la imagen a la largo de la película. La disposición de los elementos en la superficie de representación es móvil, en animación la composición está en transcurso; es pues otro de los elementos dinámicos de la animación. Lo que genera la composición móvil es el cambio mismo de la composición, ya sea por la sucesión de planos o por el desarrollo del movimiento en el plano; así pues, con composición móvil no nos referimos sólo a las diversas composiciones que se muestran a lo largo de la película (nuevo plano-nueva composición) o a la composición plástica de cada fotograma, sino también a la composición en transformación, lo que correspondería a la coreografía en danza o a la puesta en escena de un espectáculo. Así, el concepto de composición móvil abarca tanto la sucesión de planos (composición como encuadre) como el movimiento de personajes y otros móviles (que funciona como una coreografía). 
La composición en transformación está directamente relacionada con la distribución de la intensidad cinética, ya que la composición móvil de cada plano, el cambio de plano o la transformación de la imagen en los planos-secuencia generan ritmo, progresiones de intensidad, monotonía, etc. por eso, será imprescindible hacer referencia a este componente dinámico al hablar de los demás. A su vez, la composición de cada plano se ve influida o determinada por la valoración espacio-temporal de la acción, pues ésta es parte responsable de dónde están las formas en cada momento.

La composición móvil es uno de los componentes espacio-temporales que la animación y la acción real tienen en común. Es altamente maleable en ambos, aunque, claro está, de manera supeditada a la misma diferencia que también existe entre fotografía y pintura, sobre todo en las técnicas de dibujo, pintura, recortes, arena, etc. en las que la acción no transcurre en un espacio tridimensional real. Aunque, como veremos en el capítulo 3, a través de estas técnicas, puede imitarse la composición del cine de acción real, en cuanto a que se crea la ilusión de que una cámara filma en un espacio tridimensional.

La composición móvil es uno de los componentes dinámicos que soporta mayor parte de la expresividad en las películas en las que la valoración espaciotemporal no tiene protagonismo expresivo; en estas películas, la composición dinámica, en conjunción inseparable de la intensidad cinética, es en gran parte responsable de la representación del movimiento como vivenciado, como veíamos en la figura 62 del capítulo 1 (pág. 106). También el punto de vista que se muestra es responsabilidad de este componente dinámico. Como vimos en el capítulo 1, mostrar los acontecimientos en primera persona es uno de los mecanismos básicos para representar el movimiento vivenciado (aunque no siempre es efectivo). Se puede decir que la composición móvil puede tener gran poder expresivo, ya que "las emociones del espectador pueden ser influidas por el punto de vista, la dirección (de izquierda a derecha, o de derecha a izquierda), y la composición" ${ }^{31}$.

En la expresión del movimiento vivenciado a través de la composición móvil, ésta excede las consideraciones sobre dónde colocar la cámara para que se comprenda dónde están los personajes, o si es mejor comenzar una escena mostrando una vista general del escenario y acto seguido mostrar planos progresivamente más cercanos, etc. Para que la composición sea expresiva, requiere de

\footnotetext{
${ }^{31}$ Wright, 2005, pág. 156, (trad. a.): Viewers emotions can be influenced by point of view, direction (left to right, or right to left), and composition.
} 
un protagonismo mayor que el de ayudar a comprender la escena; por otra parte, evitar el aburrimiento del espectador (como se recomienda en diversos manuales) no parece ser la clave para hacer que la composición cumpla un papel expresivo. La composición móvil participa en la expresión del movimiento vivenciado cuando provoca sensaciones cinéticas gracias a la transformación de la imagen en la pantalla y al dinamismo visual que genera la sucesión de planos.

Mostrar variedad de acciones de diversas trayectorias, variedad de planos, diferentes composiciones, mostrar el movimiento a diferentes distancias, suceder los planos con variedad de transiciones, combinar cámara fija y movimientos de cámara, etc. sin duda genera una animación dinámica. Pero un gran dinamismo no implica movimiento vivenciado. La transformación de la composición debe ayudar a transmitir con intensidad el movimiento, sea cual sea el grado de dinamismo; a veces es necesaria una composición más estable o incluso monótona para expresar de manera vivenciada el movimiento.

No obstante la composición móvil que apoya la representación del movimiento neutro no genera las mismas sensaciones dinámicas, y esta ausencia de sensaciones dinámicas es normalmente propiciada por composiciones más bien estáticas o de movimientos de cámara lentos y largos planos de cámara estática, mediante los que se trata de mostrar el punto de vista más claro del elemento móvil y expresar un mensaje por medio de un dinamismo claro. Aunque, como acabamos de comentar, también hay animaciones que siguen esta descripción y que no pueden enmarcarse en el grupo de movimiento neutro.

Así mismo, la homogenización de la composición puede colaborar en la representación del movimiento neutro. Pedro Delgado hace la siguiente afirmación sobre el trabajo del dibujante de storyboard o guión gráfico:

Deberá convertir en planos todo el texto escrito, de manera que favorezca el avance, y el desarrollo del relato audiovisual, guiándose de dos ideas clave:

A. Planificar implica ir de lo general a lo particular.

B. El espectador siempre quiere tener mayor información acerca de los elementos que componen la obra.

Ambas ideas están interrelacionadas e implicadas. Por una parte, la cámara siempre va a arrancar con tomas muy abiertas, muy generales, para ir centrándose en áreas espaciales más reducida. Los planos muy abiertos ofrecerán más información, mientras que los planos más cerrados generalmente aportarán mayor significación, un mayor realce que conlleva información de aspectos más concretos. [...] Es por ello que casi todos los films responden a este criterio, aunque hay excepciones notables, como La pasión de Juana de Arco, de Dreyer (1928), elaborada fundamentalmente con planos muy cortos [...] En el dibujo animado apenas nos convendrán los planos muy cerrados, ya que el 
color plano y la ausencia de matices en los rostros hará que estos no se sostengan en la pantalla. ${ }^{32}$

Sin embargo, seguir estas directrices sistemáticamente, priorizando el cumplimiento de las mismas en lugar de atender al criterio expresivo que cada obra requiere, provoca que la composición móvil sea muy similar de unas películas a otras. Precisamente la mención de este autor al incumplimiento de las directrices que propone evidencia que atenerse a ellas no garantiza el éxito. Es más, por homogenizar la expresión móvil, tienen esta característica del movimiento neutro.

A continuación veremos los elementos que participan en la composición móvil: el formato, la composición del plano y la composición global de la película. Aunque la valoración espacio-temporal y el movimiento presente también determinan la composición dinámica, nos centramos en estos tres porque son específicos de este componente espacio-temporal.

\section{B. LA EXPRESVIDAD DEL MOVIMIENTO A TRAVÉS DE LA REPRE- SENTACIÓN DE LA COMPOSICIÓN MÓVIL}

La composición móvil es un componente dinámico muy maleable. Como en todo el arte bidimensional, la composición depende, en primer lugar, del formato (aspect ratio - relación de aspecto - en animación). En animación, a pesar de la expansión de los formatos estandarizados, se puede escoger la orientación del espacio compositivo (horizontal, vertical) o la cantidad de "superficies" que forman la obra (díptico, políptico, etc.), aunque es muy poco común. La movilidad de la composición "dentro" de los límites del formato depende a groso modo del movimiento en cada plano y de la sucesión de planos. Deleuze habla del movimiento relativo como aquel que se produce en cada plano por movimiento de cámara o movimiento de los personajes, y movimiento absoluto, el "sentido del todo"$^{\prime 33}$ :

lo que cuenta es que el plano, sea el que fuere, tiene algo así como dos polos: con respecto a los conjuntos en el espacio, donde introduce modificaciones relativas entre los elementos o subconjuntos; con respecto a un todo en cuya duración expresa un cambio absoluto. ${ }^{34}$

${ }^{32}$ Delgado, 2000, págs. 75-76

${ }^{33}$ Deleuze, 1983

${ }^{34}$ Deleuze, 1983, págs. 36-37 
La composición móvil depende de varios factores:

-El formato (proporción de pantalla o de la superficie en la que se proyecta).

-Todos los elementos compositivos de la imagen estática: distribución de los elementos, cantidad de elementos, punto de vista, color, luz, textura, etc.

- Todo movimiento que tiene lugar en el plano o cambio susceptible de modificarlo: movimientos por desplazamiento, la trayectoria que describe el móvil (incluyendo la trayectoria de la cámara en movimiento), la combinación de trayectorias (con la misma o diferente velocidad) cambios sustanciales, cambio de luz, de color, etc.

- Todo lo relativo a cómo se relacionan y cómo se conectan los planos (o composiciones) entre ellos: la duración del plano, la relación entre la acción que se desarrolla en cada uno, las transiciones entre los planos (por corte u otros recursos), etc.

- Cómo evoluciona compositivamente toda la película.

\section{B.1. El espacio compositivo. Formato y otras consideraciones}

Al hablar de espacio compositivo en animación nos referimos al formato de la superficie donde se visiona la obra: pantalla de cine, de televisión o cualquier otra pantalla y otras superficies de proyección. Éste espacio de representación es donde tiene lugar la composición del movimiento. Salvo en las animaciones de láser, en la animación y el cine de acción real lo que vemos es un video (digital o analógico) compuesto por fotografías o imágenes plásticas. Pero, a pesar de que la animación reúne diversidad de técnicas bidimensionales o tridimensionales, físicas o digitales, la mayor parte de las obras se visionan sobre una superficie bidimensional (incluido el cine estereoscópico). Existen formatos de proyección normalizados: 3:4, 16:9, cinemascope, etc. Estos formatos bidimensionales de proyección han sido estandarizados por la industria cinematográfica, con motivo de la distribución y exhibición de películas. Además existen pantallas de pequeño tamaño en teléfonos móviles y otros dispositivos portátiles de pequeñas dimensiones e internet; pueden visionarse a pantalla completa (de proporciones convencionales) o en espacios de proporciones menos habituales, como franjas horizontales y verticales de publicidad, encabezados de páginas web, etc. (Fig. 22).

El cineasta Eisenstein propuso la pantalla cuadrada como la superficie óptima, ya que en ésta, por medio de máscaras, podría establecerse cualquier rectángu- 
lo, e incluso cambiar el tamaño de la superficie compositiva. ${ }^{35}$ Aunque no sobre pantalla cuadrada, efectivamente el espacio convencional de proyección puede subdividirse o se pueden aislar zonas de la pantalla para crear "polípticos", áreas verticales, etc. En Triangle (Triángulo) (Russell, 1994), se usa el formato vertical en momentos muy localizados de la película, se aíslan zonas de la pantalla, "neutralizando" el resto de la pantalla con el color negro (en su visionado en una sala oscura, estas zonas "desaparecen"); esto produce el efecto de cambio de formato (00:05:04). En Damon the Mower (Damon la segadora) (Dunning, 1972) se utilizan dos papeles al mismo tiempo, uno vertical y otro horizontal. En un momento concreto, el movimiento del hombre con la guadaña se ve acentuado por el desplazamiento del formato acorde a la dirección de la acción. (00:02:30)

The Exciting Love Story (Una excitante historia de amor) (Dovnikovic-Bordo, 1989) y The Black Dog's progress) (Irwing, 2008) también son obras de animación "en políptico". The Exiting Love Story, presenta la pantalla dividida regularmente en 8 "casillas"; el espacio en cada fragmento de la pantalla y su accesibilidad se va descubriendo poco a poco; en cierto modo es espacio vivencial, en cuanto a cómo éste se conoce paulatinamente a través de la experiencia y cómo el ambiente de cada recuadro se distingue por sus propiedades sensoriales (frío, caluroso, abierto, cerrado), más que por sus características geométricas (Fig. 23). En estas dos composiciones se ocupa todo el espacio compositivo, mientras que en The End of The Wolrd in Four Seasons (El fin del mundo en cuatro estaciones) (Driessen, 1996), en cada escena la pantalla se organiza en 8 o 9 áreas cuadradas o rectangulares sobre fondo negro, a modo de "ventanas" o pequeñas pantallas visibles a lo largo de casi toda la película. En ellas se representan diferentes espacios. En algunas se trata del mismo espacio que en otra ventana, pero visto desde otro punto de vista. La composición transcurre en todas las ventanas de modo que la mirada se puede detener en cada sección sin que esto afecte a la comprensión de lo que ocurre. En un momento determinado la acción se coordina de manera evidente y dirige la mirada de una ventana a otra (Fig. 24).

Las consideraciones compositivas sobre el formato bidimensional, no obstante, pueden tener poca o ninguna autoridad en aquellas animaciones diseñadas para experiencias inmersivas y realidad virtual, así como para las instalaciones, en las que las animaciones se proyectan sobre superficies de otros materiales y proporciones, y sobre superficies no planas. En éstas la composición presenta una problemática especial según la obra, como ocurre por ejemplo en las proyecciones de Kathy Rose sobre cuerpo humano (como Oriental Interplay, 1991)

${ }^{35}$ Arnheim, 1957, pág. 60 
(Fig. 25) o The Snail Trial (Artus, 2011), escultura cilíndrica de material fosforescente sobre el que se proyecta una animación láser. En The Snail Trial, expuesta en una estancia a oscuras, la incidencia no continuada del láser (a ráfagas) es suficiente para visualizar la imagen, que permanece brillando y es reforzada por una nueva ráfaga de láser; el ser en movimiento, de láser continuo, recorre la superficie cilíndrica, dándole completamente la vuelta, lo que requiere unas necesidades compositivas muy específicas. También es de láser la animación de la instalación Anomalis - Near but blint (Anomalía - Cerca pero ciegos) (Menestrey, 2011). La animación se proyecta sobre cinco telas de tul separadas unas de otras. El láser atraviesa cada capa y se proyecta en profundidad, generando un efecto de "espejo interminable" y la imagen se multiplica (Fig. 26).

José Manuel Xavier, como Arnheim ${ }^{36}$, señala además la importancia de otro factor respecto al espacio de proyección: el "espacio relacional" (situado entre el espectador y la proyección). La percepción total de la obra depende de la interacción de éste y otros dos elementos espaciales: el "espacio de representación" (en el que se inscribe la imagen observada, la superficie de proyección) y el "espacio imaginario" (el espacio que se representa en la animación, sea o no análogo al espacio real). Éste puede estar situado más allá de la imagen, sugerir un espacio mayor del que vemos, un mundo más amplio a partir de un fragmento. ${ }^{37}$

En definitiva, el espacio compositivo varía dependiendo de la obra. Todos estos formatos amplían las posibilidades compositivas de la pantalla, algo que también puede utilizarse para potenciar la expresión del movimiento vivenciado. No obstante, la elección del formato no condiciona que el movimiento sea neutro o vivenciado, ya que ambos tienen lugar en todo tipo de formatos. Así pues, ningún formato es más propicio que otro para obtenerlo, ya que éste no determina la cualidad expresiva de la composición, sino la manera específica en que el movimiento se desarrolla en cada formato.

No obstante, a pesar de las diferentes posibilidades de formato en animación, gran parte de los animadores prefieren usar formatos de representación coincidentes con los formatos de pantalla estandarizados, pues esto supone el aprovechamiento total del espacio en el que la película podrá ser proyectada en salas de cine y pantallas de televisión y ordenador, que suponen el mayor medio de difusión de la animación. Precisamente la repetición de los formatos permite comprobar fácilmente que éste no determina la expresión del movimiento como

\footnotetext{
${ }^{36}$ Arnheim, 1957, pág. 26

${ }^{37}$ Xavier, 2007, pág. 32
} 


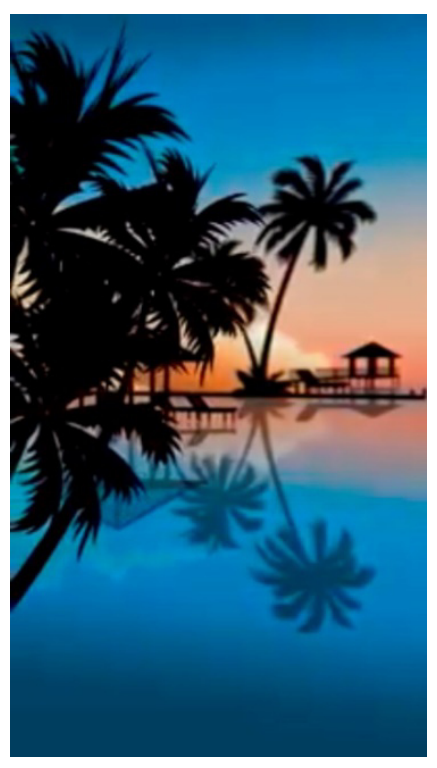

Fig. 22. Asignun $\mathrm{GmbH}$ (2014). Animación vertical en LCD Screen Asignun. Pantalla de smartphone.
Fig. 24. Paul Driessen (1996). The End of the World in Four Seasons (El fin del mundo en cuatro estaciones).

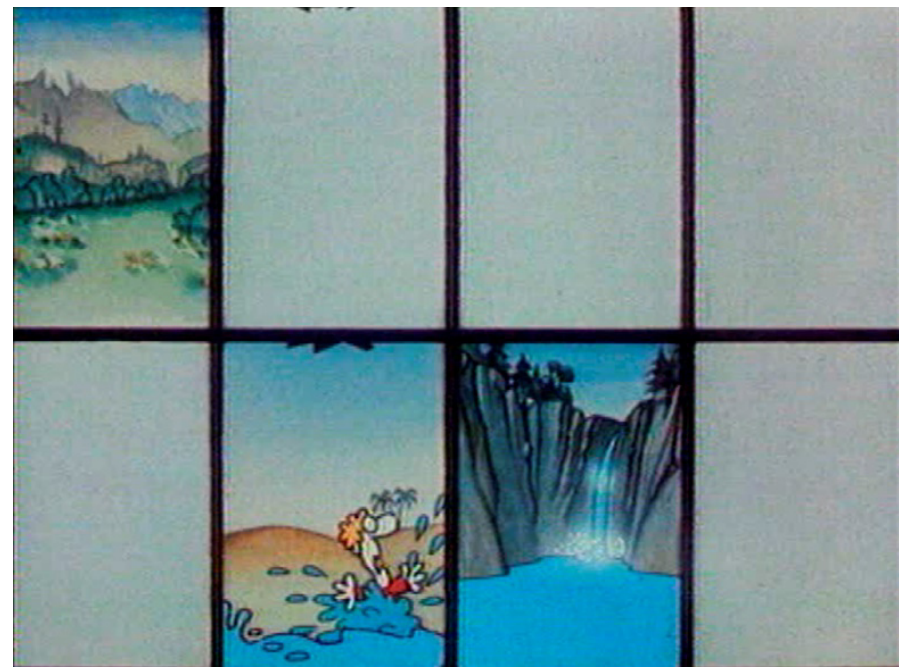

Fig. 23. Borivoj Dovnikovic-Bordo (1989).

The Exciting Love Story (Una excitante historia de amor).

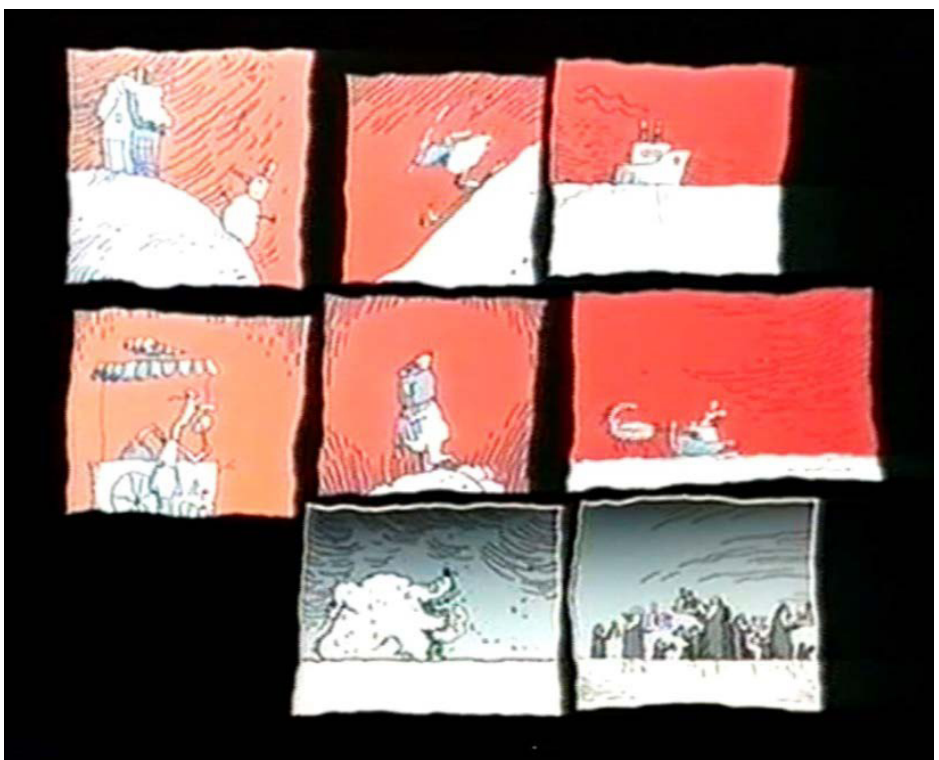

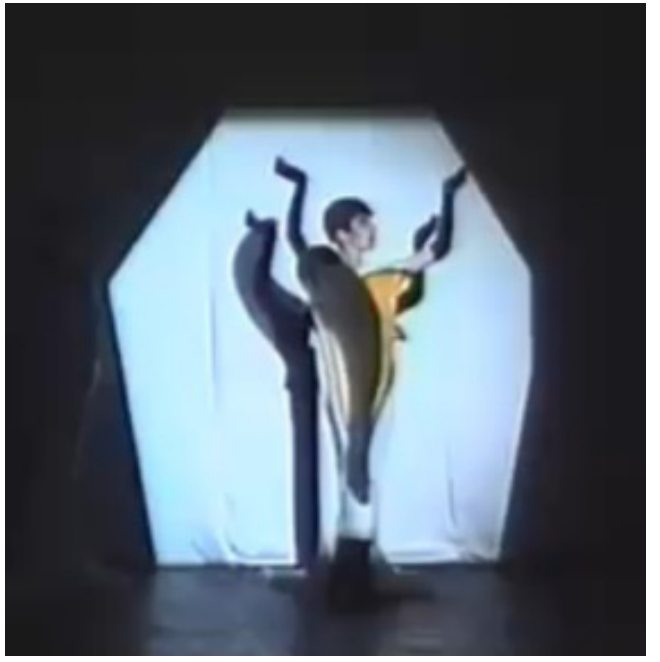

Fig. 25. Kathy Rose (1991). Oriental Interplay. Performance con animación.

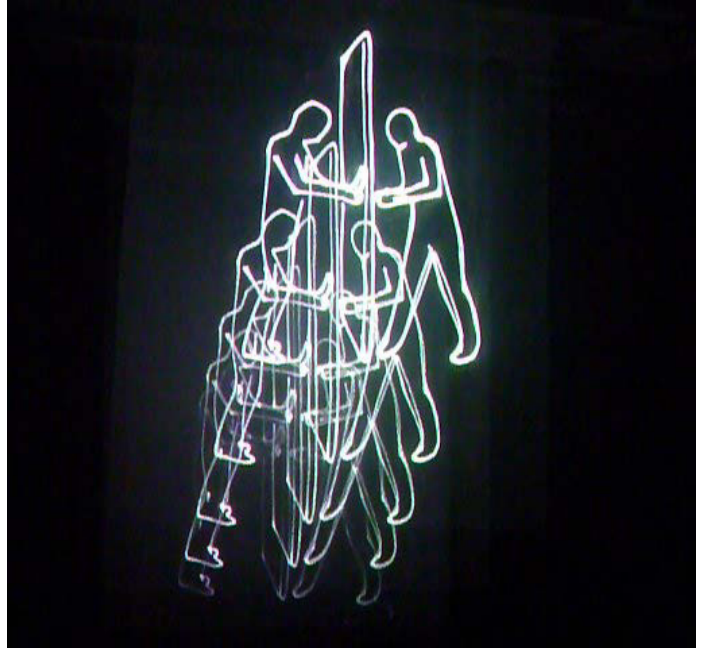

Fig. 26. Diana Menestrey (2011). Anomalis Near but blint (Anomalía-Cerca pero ciegos). Instalación con proyección láser. 
vivenciado o como neutro. Las posibilidades compositivas de un mismo formato son innumerables, como así se ve en diferentes animaciones. La amplia mayoría de animaciones a las que nos referimos en este apartado tiene formato 3:4 o 16:9.

\section{B.2. La composición móvil en el plano}

En animación, la composición en el plano es tan variada como en la pintura y la fotografía, cualidades compositivas que se combinan con las del cine, que ofrece la posibilidad de transformación por medio del movimiento. Esta "coreografía", dinamiza la composición de planos estáticos y enriquece la de los planos con movimiento de cámara.

Cabe destacar la importancia del punto de vista, ya sea estático (cámara fija) o dinámico (por movimiento de cámara). En el cine, el ángulo de encuadre da a conocer puntos de vista insólitos que muestran el espacio, las personas y las cosas desde perspectivas poco habituales ${ }^{38}$. Esta es una cualidad propia también de la animación, que se conjuga con las propiedades de la creación plástica para representar no sólo el punto de vista, sino también la forma y el movimiento de maneras sorprendentes.

Las posibilidades de la composición móvil en animación son ilimitadas en casi todas las técnicas (sobre todo el dibujo y la pintura), ya que la animación, por ser materia plástica, permite encuadres, puntos de vista y movimientos imposibles en el cine de acción real, porque no hay objetos, actores ni espacios reales a los que se supedite; aunque cada técnica tienen su propio margen de actuación. Este margen parece ilimitado en el dibujo y la pintura; para las marionetas, se ve determinado por éstas; la rotoscopia está mayormente determinada por la captura de video base, por lo que la composición móvil en esta técnica es plásticamente más cercana a la composición del cine de acción real que a la pintura o el dibujo. Los animadores de Disney se lamentaban precisamente de la dificultad para alterar la composición al animar una escena rodada previamente con actores, que además suponía una limitación de su creatividad:

Los animadores siempre se quedaban clavados en el suelo cuando todas sus secuencias eran rodadas en acción real de antemano. La imaginación de todos sobre cómo se podía hacer una puesta en escena era limitada por la ubicación

\footnotetext{
${ }^{38}$ Deleuze, 1983, pág. 31
} 
de la cámara, una vez que una escena había sido rodada era muy duro cambiar todo a un nuevo punto de vista. ${ }^{39}$

No obstante, esta limitación también puede considerarse como flexibilidad si tenemos en cuenta que la acción real, sólo cuando se transforma en rotoscopia, permite alteraciones compositivas como el cambio de ubicación del movimiento rodado. En Pas a deux (Van Dijk y Renault, 1988), cortometraje en el que las trayectorias varían respecto a la grabación original ${ }^{40}$, se acentuó la curva de las trayectorias, haciéndolas más circulares, de modo que la pareja de baile se desplaza sobre un suelo más "vertical", de modo que el desplazamiento se ve con mayor claridad que en el video base.

El movimiento en un solo plano puede ser muy variado. Gilles Deleuze se refiere así al movimiento dentro de cada plano en el cine:

el cuadro se concibe como una construcción dinámica en acto, que depende estrechamente de la escena, de la imagen, de los personajes y de los objetos que lo llenan. [...] El procedimiento del iris en Griffin, que aísla primero un rostro y después se abre y muestra el entorno; las investigaciones de Eisenstein inspiradas en el dibujo japonés, que adaptan el cuadro al tema; la pantalla variable de Gance, que se abre y se cierra <<según las necesidades dramáticas >> y como un <<acordeón visual >: tal fue desde el principio el intento de producir variaciones dinámicas del cuadro. $^{41}$

A continuación analizamos las "variaciones del cuadro" que incumben a la composición del plano en animación, las cuales dependen de:

- La cámara, que puede estar fija o en movimiento.

- El movimiento de los personajes y otros elementos móviles, que puede presentar cambio local o cambio sustancial. Esto incluye el movimiento de la superficie plástica (color, luz y materia) que puede ser fijo o estar en movimiento (si el cambio es de un fotograma a otro y no progresivo, la superficie plástica vibra).

- El espacio de composición, el formato (estable o en transformación).

Estudiaremos las posibilidades de movimiento según si hay o no movimiento de cámara, es decir, diferenciaremos entre planos fijos y planos con movimiento de cámara.

\footnotetext{
${ }^{39}$ Thomas \& Johnston, 1981, pág. 331, (trad. a.): Animators always had the feeling they were nailed to the floor when their whole sequences were shot ahead of time in live action. Everyone's imagination as to how a scene might be staged was limited by the placement of the camera, for once a scene had been shot it was very hard to switch to a whole new point of view.

${ }^{40}$ Masterclass de G. Van Dijk. Monstra Festival de Animación de Lisboa. 2011

${ }^{41}$ Deleuze, 1983, pág. 29
} 


\section{- Plano de cámara fija}

En este apartado nos referimos a aquellos planos de punto de vista estático (cámara fija) para centrarnos en el papel del movimiento de personajes y otros elementos móviles. Dentro del plano, la imagen puede tener más o menos dinamismo por la actividad de elementos móviles. Sus acciones pueden ser breves, prolongadas, rítmicas, etc. pueden desplazarse por toda la superficie compositiva o mantener su ubicación, ocupar mucho o poco espacio compositivo, etc. Según el movimiento de estos elementos, hay planos predominantemente estáticos (con cambio de luz, color o con movimiento simple de los personajes) y otros en los que el movimiento de los personajes es muy elaborado; así, la composición móvil de toda la película o de la secuencia cobra importancia como sucesión de encuadres o como sucesión de acciones. Esta distinción se disuelve cuando en el plano ambas cualidades compositivas tienen la misma relevancia. Las obras de animación pueden reunir todas estas opciones o hacer énfasis en una de ellas.

\section{Composición estática}

La composición tiene más importancia como encuadre en aquellos planos fijos en los que no hay ningún movimiento, la imagen es casi estática (de acciones breves), o presenta acciones localizadas en un punto concreto del espacio compositivo que ocupan poco lugar en éste. Arhheim destaca que "Mientras el marco de referencia dominante esté quieto, todo objeto inmóvil se percibirá como algo situado "fuera de tiempo», lo mismo que el propio marco." 42

A veces los movimientos no cambian sustancialmente la composición, ni configuran una sucesión de acciones más o menos continua, como algunos planos de Swamp nyz sumpf (Pantano) (Alkabetz, 1991) donde en un plano los guerreros cruzan las lanzas, pero no cambian de ubicación en la pantalla; o en Creature Comforts (Park, 1989) los personajes tienen una gesticulación muy variada que se concentra en los rostros y las extremidades superiores, mientras permanecen en el sitio, sin desplazarse, manteniendo absolutamente estático el resto del cuerpo (Fig. 27).

El cambio de color o de luz también provoca el cambio compositivo en aqueIlos planos que presentan mayor relevancia como encuadre. La película Japanesse (Kinoshita, 1977) comienza con un plano estático (sin movimiento de cámara)

\footnotetext{
${ }^{42}$ Arnheim, 1979, pág. 383
} 


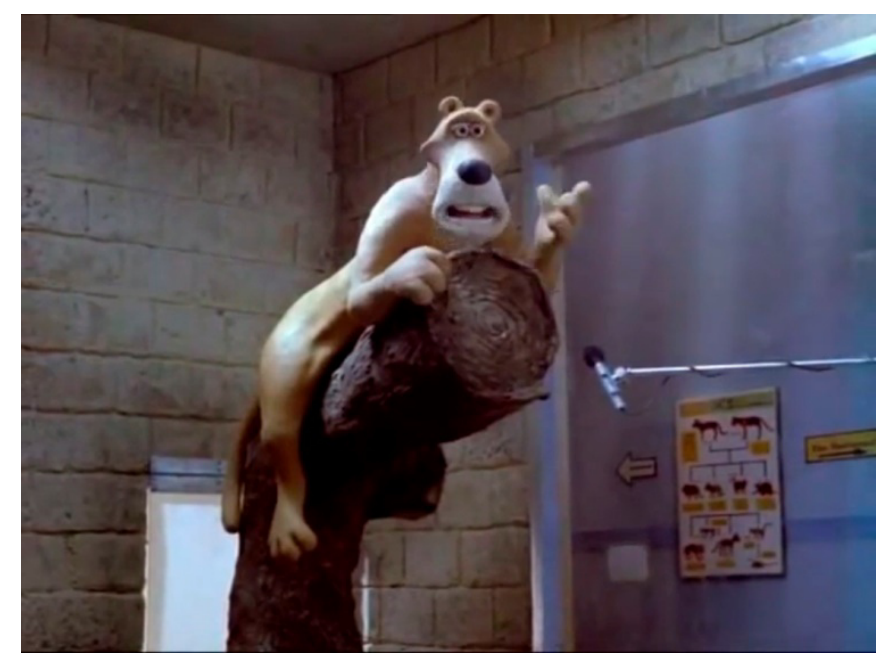

Fig. 27. Nick Park (1989).

Creature Comforts (Comodidades de la criatura).
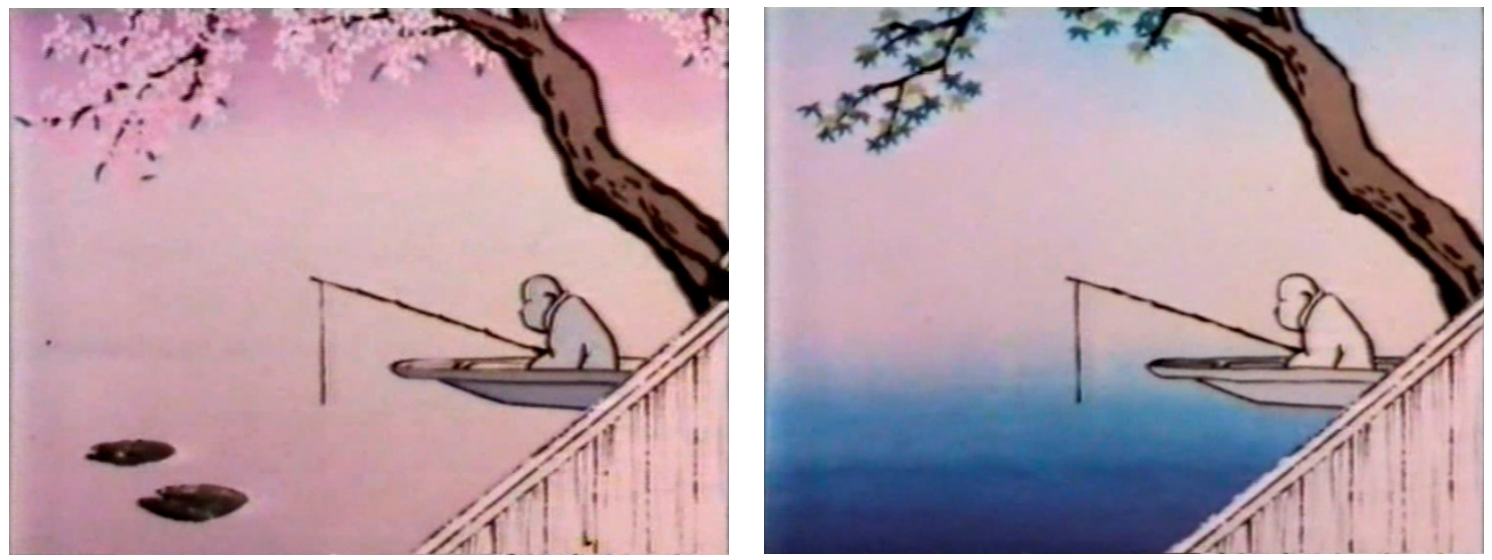

Fig. 28. Renzo Kinoshita (1977). Japonese.
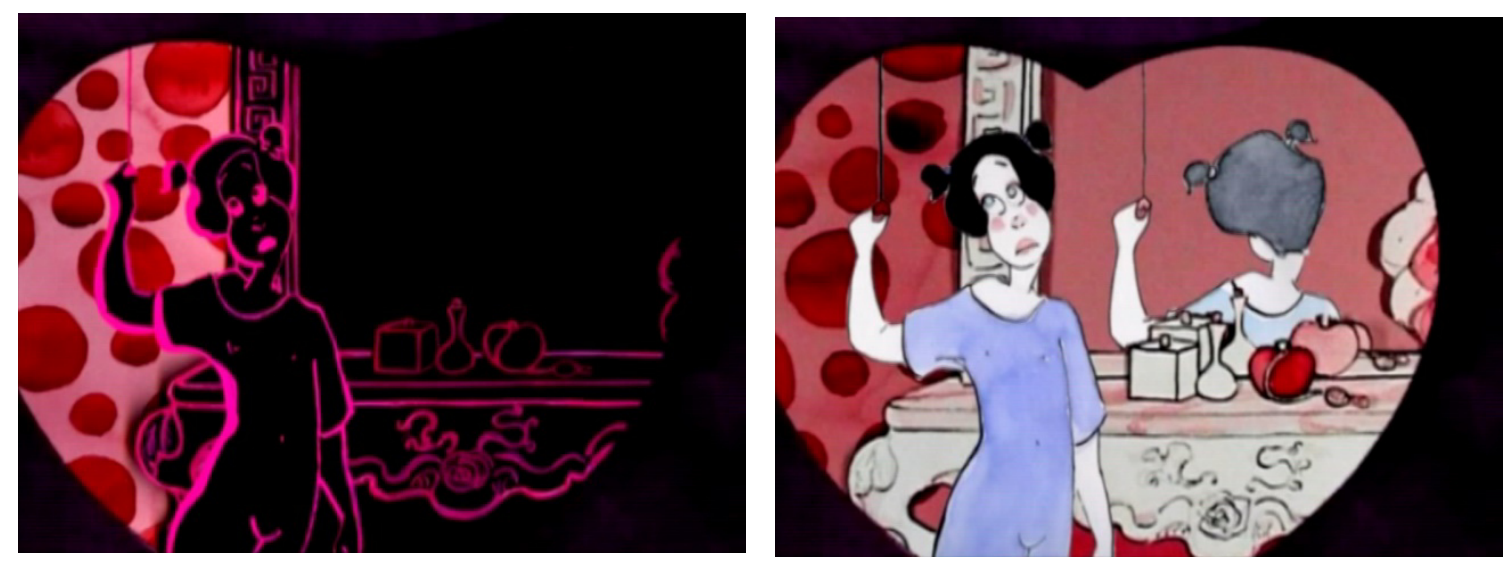

Fig. 29. Rosa Peris (2006). Prostitución infantil. Fotogramas consecutivos.

en el que se ve una escena tradicional japonesa: un hombre pescando en una barca en un río, un puente y un cerezo. Algunos elementos se desplazan eventualmente (una rana, una mariposa, gente en el puente), pero es el cambio progresivo de color del cielo y el agua lo que varía notablemente el paisaje (Fig. 28). En Prostitución infantil (Peris R. , 2006). La niña protagonista entra en una habi- 
tación oscura. Al encender la luz, el cambio de color y de luz cambian la composición: de una imagen de fondo negro con dibujo en rosa se pasa a una imagen de Ilamativos colores planos en la que la distribución lumínica es opuesta a la imagen anterior (Fig. 29).

Los principios compositivos en planos más o menos estáticos como los descritos son los mismos que en la pintura y el dibujo (la estructura compositiva, la cantidad de elementos, la distribución de los elementos en la superficie, la tensión dirigida, etc.). La composición plástica de estos planos, más parecida a la naturaleza de una imagen estática, influyen directamente en la composición total y también en la intensidad cinética, como veremos más adelante, en el punto B.3. de este parágrafo.

\section{Predominio del movimiento de personajes. Composición móvil como coreogra-} fía

En los planos sin movimiento de cámara el movimiento de los personajes u otros elementos móviles puede modificar la composición mediante movimientos más notables que los que hemos expuesto en el párrafo anterior, los cuales, ya sea al desplazarse o al mover partes concretas del móvil, provocan una alteración de la distribución de los elementos, del punto de vista, de la lejanía o cercanía respecto a la "cámara", del espacio que ocupan en pantalla, etc. Pero con composición móvil como coreografía no nos referimos a que los personajes y otros elementos móviles modifican su posición y, con ello, la composición de la imagen; nos referimos a la composición del movimiento, a la sucesión de acciones más o menos constantes que cobra carácter de "coreografía" y no de sucesión de composiciones estáticas (más próximas a las viñetas de un cómic, o a la sucesión de poses). Dicho de otro modo, predomina el movimiento de los personajes y el desplazamiento, antes que el cambio de encuadre.

A continuación apuntamos las propiedades principales que participan en la composición del movimiento:

- El tipo de movimiento. Qué acciones se representan, desplazamientos, rotaciones, flexión, extensión, movimiento rítmico, continuo, entrecortado, rápido, lento, etc. La composición del movimiento puede ser muy variada en acciones con desplazamiento: en Animation Dance Contemporaine 2010 (Guiol, 2010), el personaje se desplaza retorciéndose por el suelo, entra y sale de campo, se acerca a la cámara y se aleja exagerando la perspectiva. Éste es un plano estático (cámara fija) con mucha acción del personaje. 
El cambio sustancial de los personajes u otros elementos móviles es otra posibilidad del movimiento. Uno de los planos de Malou ou l'hostitilté mécanique (en Ut majeur) (Malou o la hostilidad mecánica (en Do mayor)) (De Roeck, 2011) consiste en un busto que se transforma en otro sucesivamente; en este plano, varía la "coreografía", pero el cambio compositivo (como se entiende en una imagen estática) es poco notable. Pero otras veces su característica más notable es que también provoca la redistribución de los elementos en el espacio compositivo (00:03:18). En esta misma película, sobre la cabeza de la protagonista aparecen diversas formas de colores que representan los pensamientos que acuden a su cabeza mientras trabaja; la generación continua de los diversos elementos móviles añade complejidad a la composición (00:01:10). En la película de Svankmayer Alice (1987), cuando Alicia bebe el contenido de una botellita, ésta se reduce de tamaño; la niña de carne y hueso es sustituida por una muñeca. El cambio de tamaño del personaje, mostrado en el plano estático, modifica la composición al tiempo que dirige la mirada de arriba (el rostro de la actriz) abajo (el rostro de la muñeca de porcelana) (00:20:00). Y en Tántalo (Peris R. , 2010), la mujer escapa nuevamente de los brazos del hombre al mismo tiempo que se desliza hacia arriba y se transforma en ave. La dirección de su trayectoria no cambia durante la metamorfosis, pero con el cambio sustancial se añade el elemento de las alas como principal forma que aporta nuevas posibilidades de movimiento (00:01:50). La metamorfosis no se usa siempre de manera que altera la composición del plano, sino también como medio para cambiar de plano; de esto hablaremos en el punto B.3. de este apartado.

- Cantidad de elementos en acción. Hemos visto planos con gran actividad, pero la acción también puede ser poco llamativa y ser determinante en la configuración del movimiento del plano. En Konyok-gorbunok (El caballito jorobado) (Ivanov-Vano, 1976) el plano muestra los dos caballos negros en el establo (00:20:45), los cuales se mantienen en el sitio pero mueven suavemente la patas, la cabeza, el cuello, la cola y las crines se balancean elegantemente. Por la coordinación de movimientos suaves de las diferentes partes del cuerpo, el plano resulta realmente complejo y atractivo sin necesitar rotaciones, ni torsiones ni desplazamientos. El carácter de la acción en el contexto de la película transmite la belleza excepcional de los corceles, haciendo honor a lo que se dice de ellos: "Nunca el mundo vio tan bellos caballos" (Fig. 30).

- Trayectorias. Las trayectorias, casi inseparables del tipo de acción, pueden ser rectas, curvas, en zigzag, según su posición respecto a la pantalla pueden ser paralelas, perpendiculares, oblicuas, etc. Todas las trayectorias producen cambios compositivos al variar de lugar los elementos móviles. A continuación nos 
detenemos en varios tipos de trayectorias, para ver cómo intervienen en el cambio compositivo y generan la coreografía.

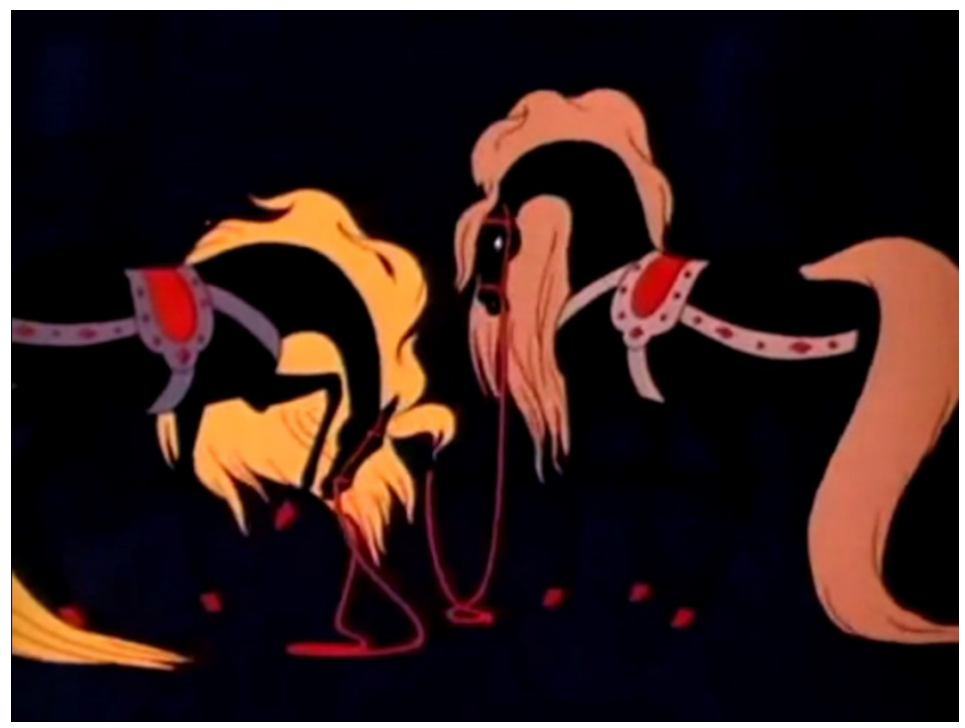

Fig. 30. Ivan Ivanov-Vano (1976). Konyok-gorbunok (El caballito jorobado).

Algunas películas enfatizan las trayectorias paralelas a la pantalla. En Rubicon (Alkabetz, 1997) el plano se mantiene estático en la mayor parte de la animación al tiempo que los elementos se desplazan en diferentes trayectorias horizontales, diagonales, curvas, girando sobre sí mismos, etc. y casi siempre en paralelo al plano de la pantalla.

Cuando las trayectorias tienen lugar en profundidad (se representan como oblicuas al plano de la pantalla), se producen cambios más o menos acentuados en el tamaño de los elementos, lo que modifica la composición. En Kuka kehtaa? (¿Quién osa?) (Lahtinen, 2010), el emperador irrumpe en la masa de súbditos que le rodea; su ropa se convierte en una franja azul y amarilla que aumenta de tamaño; a cada paso del personaje los elementos compositivos se redistribuyen. Cuando la casaca amarilla cubre toda la pantalla, el emperador se desvía a la izquierda y otro personaje vestido de verde le sigue desde la esquina inferior derecha; el verde se extiende por toda la pantalla y acaba el plano. (00:02:02) (Fig. 31). En Tonari no Totoro (Mi vecino Totoro) (Miyazaki, 1988) el "gatobús" se acerca a la pantalla rápidamente; al inicio del plano hay un par de puntos lejanos en el centro del espacio compositivo, pocos segundos después la pantalla se "Ilena" por los enormes ojos y sonrisa del insólito ser; los haces de luz que desprende dibujan líneas más o menos horizontales que atraviesan todo el espacio compositivo (00:50:54). Y en Happy Life (Vida feliz) (Sun \& Li, 2012), el protagonista baja unas escaleras de modo que, según el tramo de la escalera que desciende, se encuentra más o menos cercano al espectador (00:01:06). 
La combinación de trayectorias que suceden al mismo tiempo pueden producir composiciones muy dinámicas. Esto depende también de otros factores: el número de trayectorias, la velocidad, el tamaño de los elementos, etc. En Taratatá la parade (Back, 1977), en una de las escenas finales, numerosas figuras marchan en un desfile imaginario, cada una con una trayectoria particular: sus trayectorias no siguen exactamente la misma curva, unos rotan sobre sí mismos, otros mueven diferentes partes del cuerpo; uno de esos elementos (un caracol) dirige su trayectoria hacia el centro del espacio compositivo y desde ahí se expande en forma de espiral que ocupa toda la pantalla (00:06:55). En Tout rien (Todo nada) (Back, 1978) los humanos han sido dotados por Dios de un bello pelaje; alegres por su apariencia, hombre y mujer brincan, corren, ruedan por el suelo, giran. La combinación del movimiento de ambos personajes (variado en acciones y veloz, acercándose y alejándose del plano de la pantalla y entrando y saliendo de campo) transmite su júbilo (00:03:49) (Fig. 32).

Un elemento en movimiento cubre a otro también en movimiento, provocando la superposición de trayectorias. También en Tout rien (Back, 1978), el nacimiento sucesivo de las plantas se muestra de esta manera; cada nueva flor germina y se abre delante de la anterior (Fig. 33).

- Cantidad de espacio que ocupa la acción en pantalla. La acción puede transcurrir en una pequeña parte de la pantalla u ocuparla por completo y, por supuesto, puede variar el área que ocupa, como cuando un elemento se acerca o se aleja de la cámara. Hay planos en los que la acción se presenta en un área reducida de la pantalla, no sólo porque el elemento móvil sea pequeño, sino también porque el movimiento tiene una trayectoria muy corta, y al contrario, puede ocupar gran parte del espacio compositivo. Por supuesto la longitud de las trayectorias y el espacio que ocupan se percibirá como mayor o menor según la cercanía a la cámara, pero también según el tamaño de la pantalla y la distancia entre el espectador y ésta. Arheim reflexiona sobre cómo afectan estos factores a la percepción del movimiento, sobre todo respecto a la velocidad, y concluye que el tamaño de proyección es tenido en cuenta por el artista para obtener el efecto estético deseado ${ }^{43}$.

- Lugar de la pantalla en el que sucede la acción, lo que también incluye que ésta suceda en campo o fuera de campo. El lugar de la pantalla en que sucede la acción es fundamental, puede reforzar o dificultar la comprensión de la acción, pero también puede cambiar el sentido del movimiento: en The Flying Man (EI

${ }^{43}$ Arnheim, 1957, pág. 26 
hombre volador) (Dunning, 1962) el hombre se mueve en un movimiento perfecto de nado, pero lo realiza en la parte superior de la pantalla; la ausencia de referencias espaciales, salvo una línea de suelo que imaginamos gracias a que sus ropas descansan sobre éstas, hace que el hombre vuele en lugar nadar.

Otra posibilidad del movimiento de los personajes en el plano es que entren o salgan de éste, es decir, que la acción transcurra dentro o fuera de campo, de modo que la composición varía por la ausencia o presencia de elementos en el plano. Para Delueze la primera función del fuera de campo es añadir espacio al espacio ${ }^{44}$. "El fuera de campo remite a lo que no se oye ni se ve, y sin embargo está perfectamente presente" ${ }^{45}$. Éste es un recurso narrativo muy potente. Precisamente porque percibimos lo que está fuera de campo aunque no se vea, el movimiento que no ocurre en campo puede participar en la composición móvil. La acción fuera de campo tiene influencia compositiva cuando a partir de una acción conocida (lo que pasa en campo) se imagina o percibe la parte de la acción que ocurre fuera de la pantalla. En Tántalo (Peris R. , 2010) la mujer sale de la imagen, pero el hombre, que corre tras ella, permanece en pantalla; por su movimiento sabemos que continúa siguiéndola, y por la trayectoria circular que traza se comprende que la mujer también describe una curva fuera de campo, lo que queda confirmado por la dirección de ésta cuando vuelve a campo (00:01:24). Aunque también podemos suponer sucesos fuera de campo que no intervienen en absoluto en la composición dinámica, por ejemplo el sonido del tráfico indica la presencia de numerosos vehículos y personas en una ciudad pero el plano puede ser un detalle de un gato apaciblemente dormido en una ventana. Mostrar los elementos y acciones que comienzan fuera de campo puede provocar sorpresa u otras emociones, lo cual lo convierte en un recurso a tener en cuenta si se desea provocar este tipo de sensaciones en el espectador. En Rubicon (Alkabetz, 1997) el humor se sustenta en la sorpresa que produce ver a los personajes aparecer en pantalla con diverso aspecto y en diferentes combinaciones.

\section{- Movimientos de cámara. El punto de vista móvil}

Acabamos de ver posibilidades del plano con cámara fija, planos en los que la composición cambia por el movimiento de personajes u otros elementos móviles mientras el punto de vista permanece inmóvil. A continuación hablaremos de

\footnotetext{
${ }^{44}$ Deleuze, 1983 , pág. 35

${ }^{45}$ Deleuze, 1983, pág. 32
} 

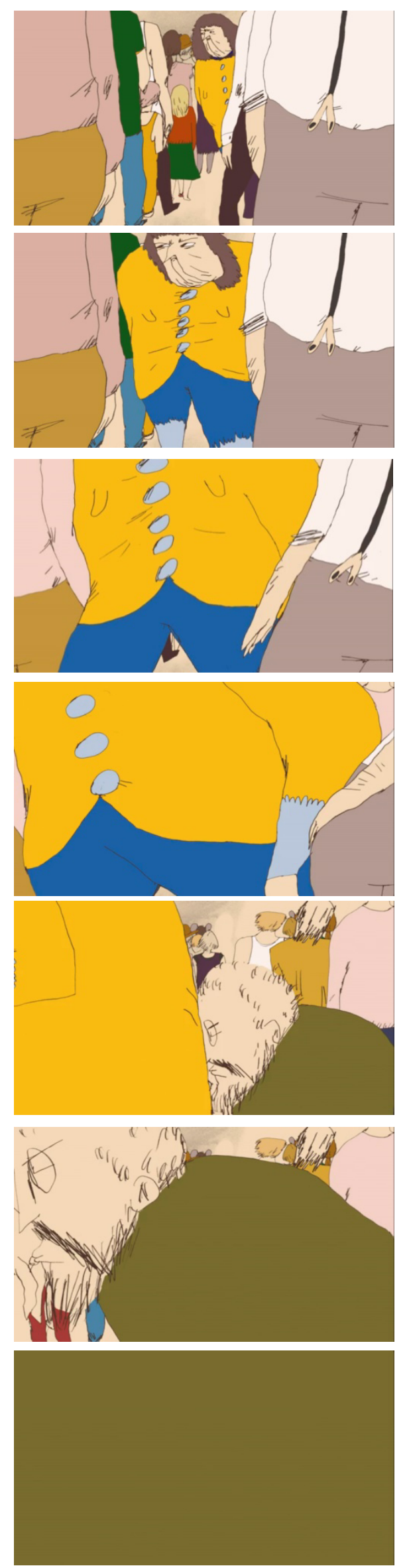

Fig. 31. Sanni Lahtinen (2010). Kuka kehtaa? (¿Quién osa?). Serie de fotogramas. 
Movimiento vivenciado y movimiento neutro. Estudio sobre la expresividad

de la representación del movimiento en animación

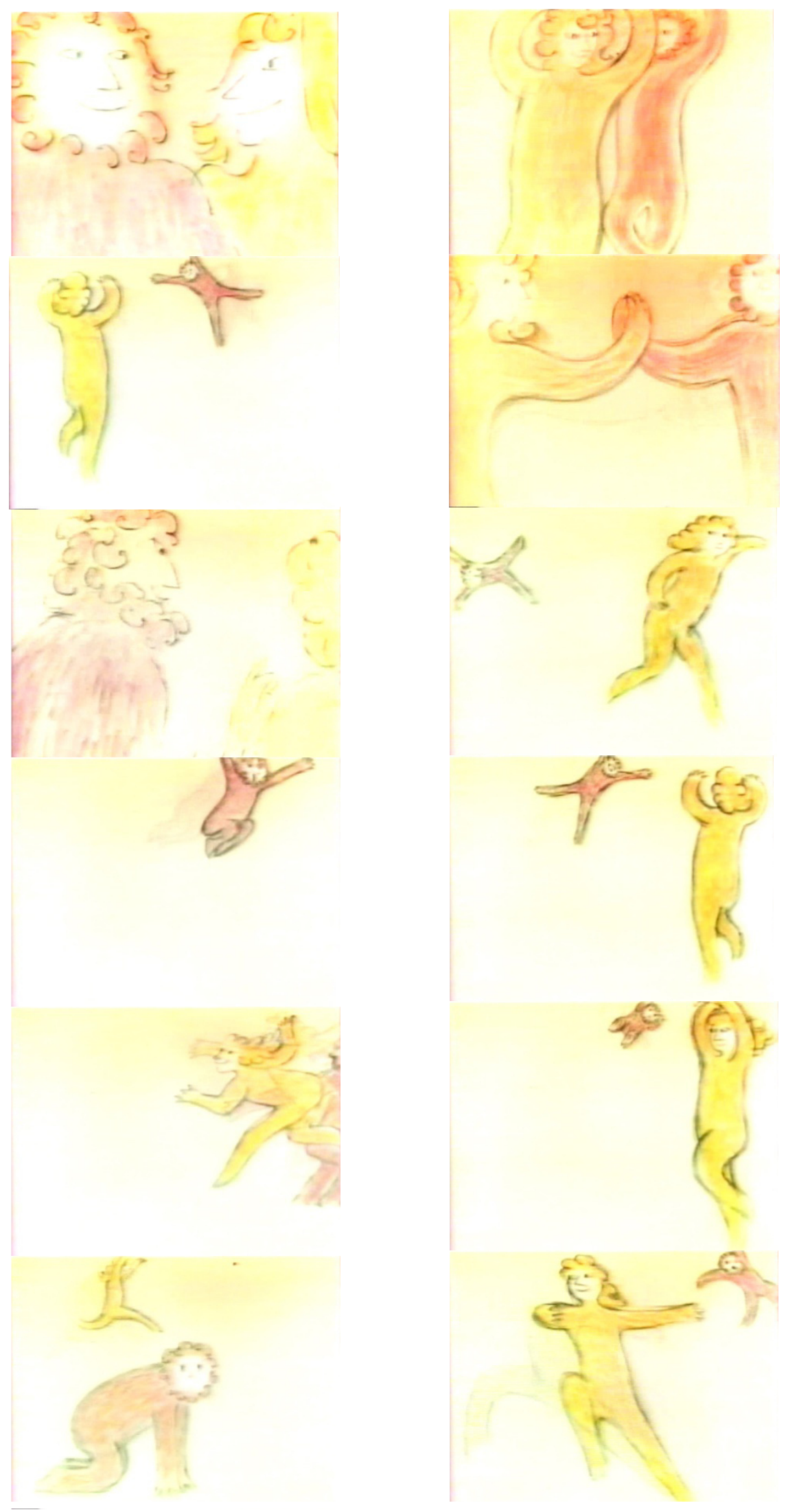

Fig. 32. Frédéric Back (1978). Tout rien (Todo nada). Serie de fotogramas. 

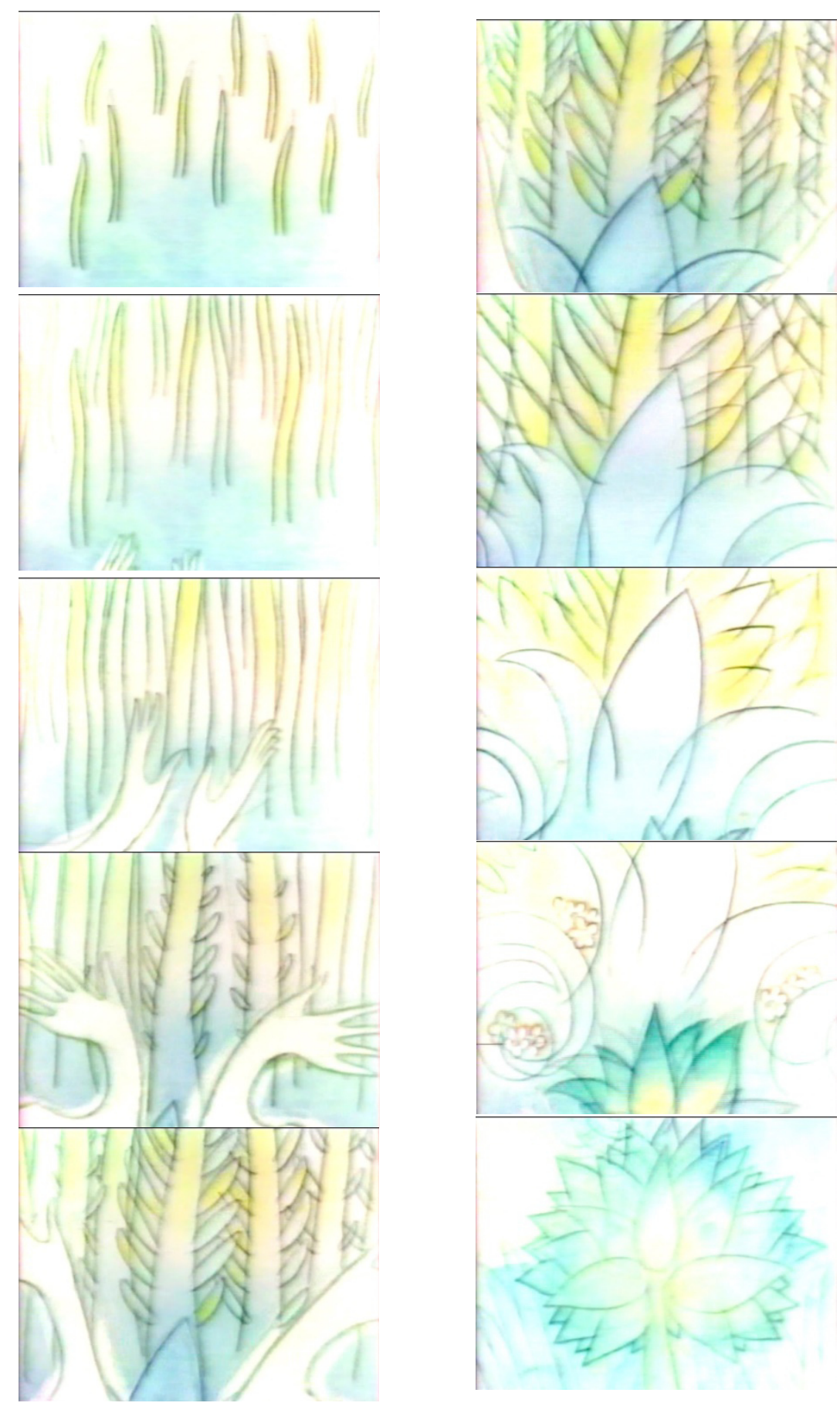

Fig. 33. Frédéric Back (1978). Tout rien (Todo nada). Serie de fotogramas.

los planos móviles, es decir, aquellos que tienen movimientos de cámara. En estos planos, la composición cambia al desplazar el punto de vista, se muevan o no los personajes y el resto de elementos.

Los movimientos de cámara en animación son:

- Zoom in - zoom out: el encuadre se acerca o se aleja (en cine y en aquellas técnicas de animación que usan cámara, se llaman movimientos ópti- 
cos, porque la cámara no se desplaza, sólo las lentes).

- Paneo (deplazamiento horizontal paralelo a la pantalla) y tilt (desplazamiento vertical paralelo a la pantalla) y cualquier desplazamiento diagonal paralelo a la pantalla.

- Panorámica: rotación sobre el eje de la cámara, que puede ser simulada en animación.

- Traveling: cualquier trayectoria curva, recta o mixta que describe la cámara.

Todos estos cambios del punto de vista se realizan desplazando realmente la cámara o el zoom en las técnicas que utilizan cámara para grabar, y se realizan manualmente (o asistidos por ordenador) en las técnicas que no requieren cámara cinematográfica real. Los movimientos de cámara animados manualmente pueden llegar a ser incluso más complejos que con cámara de cine debido a que no existen limitaciones físicas reales para mover la cámara ni deben atenerse a ninguna necesidad física de ésta o del set de rodaje.

Arnheim atribuyó a la cámara móvil la cualidad de "presentar el mundo desde el punto de vista de un individuo, tomar al hombre como centro de su cosmos; esto es, hacer accesible una experiencia muy subjetiva a los ojos de $\operatorname{todos}^{\prime 46} \mathrm{y}$ así representar "estados subjetivos, como pueden ser caída, subida, tambaleo, mareo, etcétera" y "actitudes subjetivas, como el caso del individuo que siempre es el centro de la escena (es decir, de la trama)" ${ }^{47}$. Como vemos, concedió al movimiento de cámara una gran capacidad para comunicar estados subjetivos (como ya comentamos en el capítulo 1, esta es una manera de transmitir el movimiento vivenciado). Además de esta cualidad, el movimiento de cámara dinamiza los planos en los que no hay movimiento de otros elementos y enriquece aquellos en los que sí hay, como vemos a continuación.

\section{Movimiento de cámara sin acción de otros elementos}

El movimiento de cámara dinamiza la imagen en planos sin acción de personajes u objetos, como explica Arnheim: "un marco móvil comunica una acción a todo el entorno y los objetos que contiene" ${ }^{48}$. Así lo vemos en Jumping (Saltar) (Tezuka, 1984) [en DVD], cortometraje que consiste en un continuo punto de vista móvil (apenas hay algunas acciones aparte del desplazamiento de la cámara) (Fig. 12 del cap. 1 pág. 66). De manera parecida, en una secuencia de The Fellowship of the Ring (La comunidad del anillo) (Jackson, 2001) el principal movimiento es un desplazamiento de cámara (a veces el único) íntegramente reali-

\footnotetext{
${ }^{46}$ Arnheim, 1957, pág. 84

${ }^{47}$ Arnheim, 1957, pág. 97

${ }^{48}$ Arnheim, 1979, pág. 383
} 
zado con animación (01:12:09); el plano sobrevuela Isengard, mostrando el nuevo aspecto del lugar, una mariposa nocturna vuela delante del objetivo hasta llegar a lo alto de la torre; aquí, con un par de cortes se deja ver que el mago atrapa al insecto y lo suelta; a continuación un nuevo movimiento de cámara, esta vez más intrépido, desciende rápidamente; aunque la trayectoria no se corresponda con la de la mariposa nocturna y ésta esté delante de la cámara en algunos momentos, se puede interpretar que ambos movimientos de cámara son la perspectiva de la mariposa, lo que da respuesta a la sensación de vuelo que transmite. Y el cortometraje Fiumana (Inundación) (Gromskaya, 2012) consiste en un largo y continuo movimiento de cámara en el que las metamorfosis, la vibración de la textura, y los cambios de luz y de color hacen que el espectador no se percate de que apenas hay acciones de los personajes. En estos planos se comprende cómo el movimiento de cámara otorga vida a todo el entorno.

\section{Movimiento de cámara más acción de otros elementos}

La composición de los planos móviles no sólo depende, claro está, del cambio del punto de vista, sino también de si al mismo tiempo acontece algo y cómo, de este modo, la multitud de posibilidades de movimiento de un plano se multiplica al combinar los movimientos de cámara con la acción de los personajes y otros elementos móviles. Puede tratarse de acciones no relevantes o poco llamativas, de modo que no participan significativamente en la composición durante el recorrido de la cámara. En The Message (El mensaje) (Krumme, 2000) los largos y complejos movimientos de cámara que se producen la mayor parte del tiempo sin que ocurran otras acciones llamativas a su paso provocan una gran intensidad cinética: la trayectoria de la cámara muestra el espacio de arriba abajo, gira en una amplia trayectoria curva, se desplaza hacia abajo y muestra el espacio de abajo arriba, se eleva mientras sigue avanzando, y en un movimiento curvo se desplaza nuevamente hacia abajo (00:04:00). Este tipo de plano nos recuerda al concepto de cámara con entidad, que no representa lo que ve uno de los personajes, ni tampoco representa al cameraman, pero tiene personalidad, como si fuera un "punto de vista anónimo de alguien no-identificado entre los personajes". ${ }^{49}$ Este tipo de planos subjetivos transmiten el movimiento como si se viviera en primera persona.

Otras veces un elemento se desplaza al mismo tiempo que la cámara, de modo que el personaje se mantiene en el mismo sitio compositivo pero el movimiento del espacio genera la sensación de que se desplaza, así, el personaje y

${ }^{49}$ Deleuze, 1983 , págs. $110-111$ 
otros elementos móviles están en acción pero su trayectoria no participa activamente, ya que aunque ésta se comprende, no "dibuja" ninguna línea de desplazamiento. En The Owl Who Married a Goose (El búho que se casó con una gansa) (Leaf, 1974) los gansos vuelan en migración hasta que se posan en un lago (00:04:55) (Fig. 34); las aves surgen del fondo blanco, se acercan al plano de la pantalla y giran a la izquierda, se mantienen volando en el mismo lugar de la pantalla (por lo que se entiende que el punto de vista se desplaza con ellos). Como tiene poco protagonismo y los gansos tienen mucha importancia en la imagen, aunque se comprende que los gansos se acercan al lago, este cambio en el fondo (el acercamiento al lago circular) tiene una segunda lectura más abstracta: como círculo que se hace grande. Es notable la inversión del color: los gansos marrones sobre fondo blanco se vuelven blancos al superponerse al lago marrón. Y en Tagebuch (Diario) (Jevremovic, 2000), en los primeros planos dentro de la casa, prácticamente sólo cambia el punto de vista; la mano de una persona y las acciones que realiza (lavar, poner el café, acariciar al periquito, etc.) ocurren en el centro de la pantalla y apenas sin movimiento, como si permaneciera inmóvil en un entorno que se desplaza; es más relevante el cambio del punto de vista que el resto de elementos.

Otras veces la acción de los elementos móviles participa notablemente en la composición móvil durante los desplazamientos de cámara. Uno de los planos de Taratatá la parade (Back, 1977) consiste en un desplazamiento horizontal de cámara que muestra un campo de molinos de viento de fantásticos colores; las aspas de los molinos, de distintos tamaños, giran, lo que proporciona una gran riqueza de movimiento; la composición móvil de este plano sería muy distinta si las aspas permanecieran estáticas (00:07:23). En The man with the beautifull eyes (El hombre de los ojos bonitos) (Hogdson, 2000), un paneo recorre una calle en la que circulan coches y otras personas que se interponen entre el espectador y los niños que protagonizan el cortometraje; el cruce de trayectorias en combinación con el desplazamiento del punto de vista proporciona un dinamismo muy atractivo, incluso aunque todas las trayectorias son horizontales y paralelas a la pantalla (Fig. 35). Y en Dreams And Desires. Family Ties (Sueños y deseos. Lazos familiares) (Quinn, 2006), la videocámara a través de la que se ve la historia escapa de las manos de la protagonista y sale volando por los aires: el punto de vista giratorio se combina con trayectorias curvas descritas por los personajes, que pasan, también por los aires, delante del objetivo.

El punto de vista evoca la presenta invisible de un personaje anónimo en Tekkonkinkreet (Arias M. , 2006) [en DVD]: la secuencia del título consiste en un complejo y prolongado traveling que enseña la ciudad a vista de pájaro, y nunca 
mejor dicho, porque el punto de vista se desplaza junto a un cuervo que unas veces está fuera de campo y otras a la vista. Tanto el desplazamiento de la cámara como el del ave son muy variados, siempre hacia delante: hacia arriba, hacia abajo, a los lados, se desplazan paralelos al suelo u oblicuamente, en línea recta o curva; el cuervo cruza en diagonal el espacio compositivo, se aleja al ir hacia delante más deprisa que la cámara, se queda atrás y deja de verse, se le ve desde abajo o desde arriba, etc. El espectador tiene la sensación de moverse con la cámara entre y por encima de los edificios de la ciudad (no es una imagen fija que se desplaza para generar la ilusión de movimiento de cámara).

La combinación de movimiento de cámara y movimiento de personajes y otros elementos no sólo puede generar composiciones móviles muy dinámicas, sino que, dependiendo de cómo se haga, propicia una representación del movimiento muy expresiva. Arnheim destaca la capacidad del movimiento de cámara para acentuar el movimiento de aquello que se graba y de este modo "El cine da al mundo de las cosas la oportunidad de manifestar sus poderes intrínsecos e irrumpir en medio de los hombres" ${ }^{50}$. En Crac! (Back, 1981), en el baile de la boda, el movimiento de las parejas se potencia gracias al desplazamiento del punto de vista, el espectador se ve envuelto por las parejas de baile, como si él mismo participara de la fiesta; a esto también contribuyen otros factores, como la plástica: la textura del trazo varía en cuestión de segundos, definiendo o indefiniendo las figuras, las cuales a veces sobrepasan de tal manera el espacio compositivo que sólo se ve parte de ellas, lo que acerca la imagen a la abstracción (Fig. 36) (00:03:31).

Konyok-gorbunok (El caballito jorobado) (Ivanov-Vano, 1976) presenta mucha riqueza de movimiento y en planos bastante más largos que los habituales en la animación comercial actual. En uno de ellos vemos cómo el niño protagonista doma a la yegua mágica que se come su cosecha. El movimiento se desarrolla de manera compleja: el caballo brinca por los pastos, se revuelca y a continuación vuela por los aires con el niño en su lomo, se acerca y aleja de la cámara (es decir, en profundidad), se retuerce en curvas cerradas, corre en diagonales paralelas a la pantalla (ascendiendo y descendiendo), agita sus crines y su cola, cambia de velocidad, etc. Toda esta riqueza de movimiento tiene lugar a través de cinco planos que duran un total de 1 minuto 44 segundos (de 00:03:14 a 00:04:53) (Fig. 37). El movimiento de cámara no sigue con exactitud al animal, sino que se adelanta o atrasa respecto a su avance, de modo que la yegua a veces está en el centro del plano, otras a un lado, otras sale de campo, etc. En definitiva, se trata

\footnotetext{
${ }^{50}$ Arnheim, 1979, pág. 313
} 

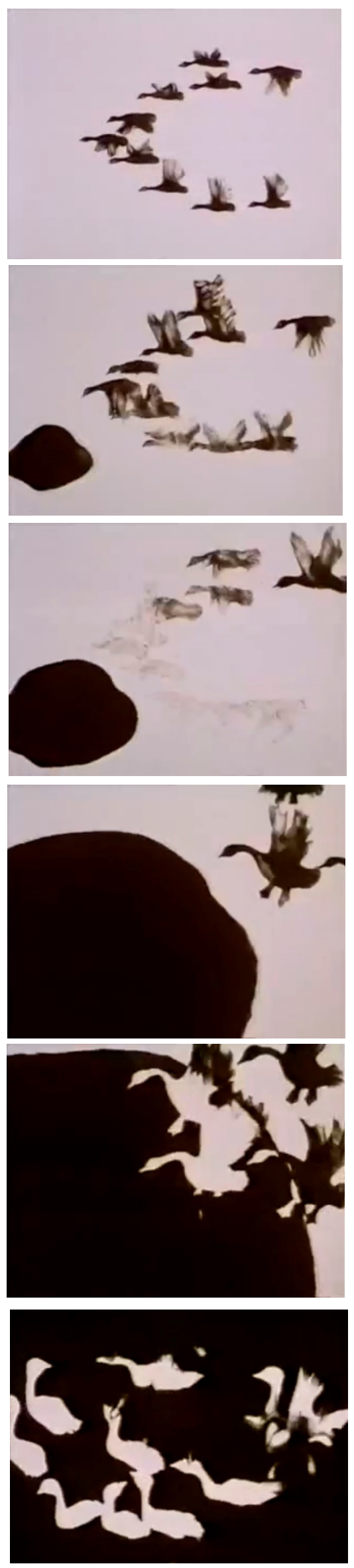

Fig. 34. Caroline Leaf (1974). The Ow/ Who Married a Goose (La lechuza que se casó con una gansa). Serie de fotogramas.
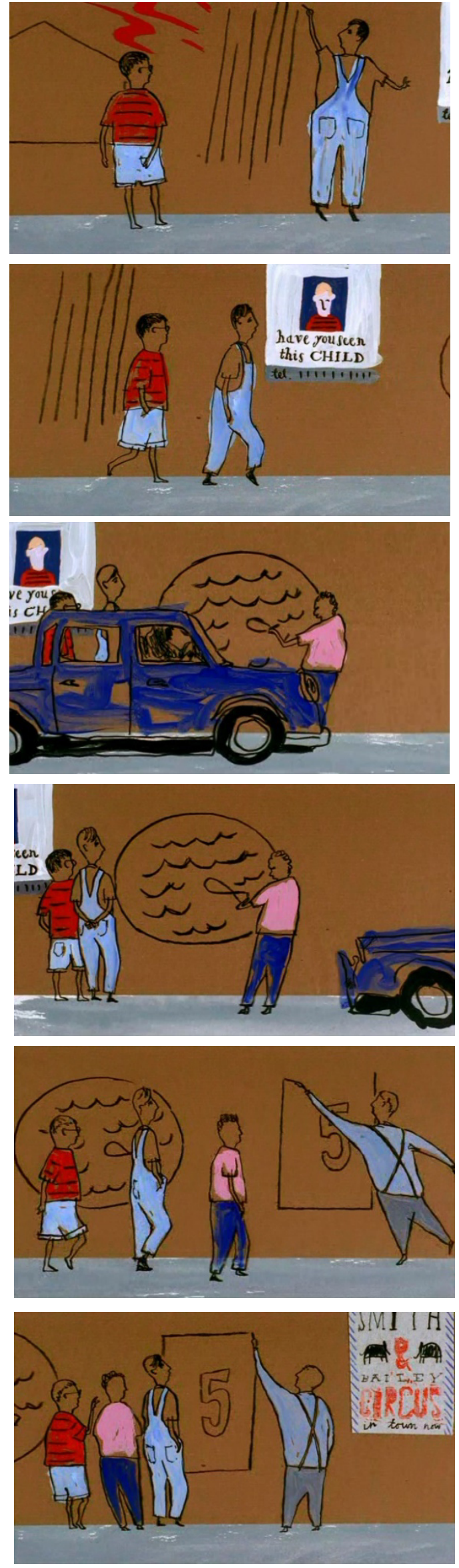

Fig. 35. Jonathan Hogdson (2000). The man with the beautifull eyes (El hombre de los ojos bonitos). Serie de fotogramas. 

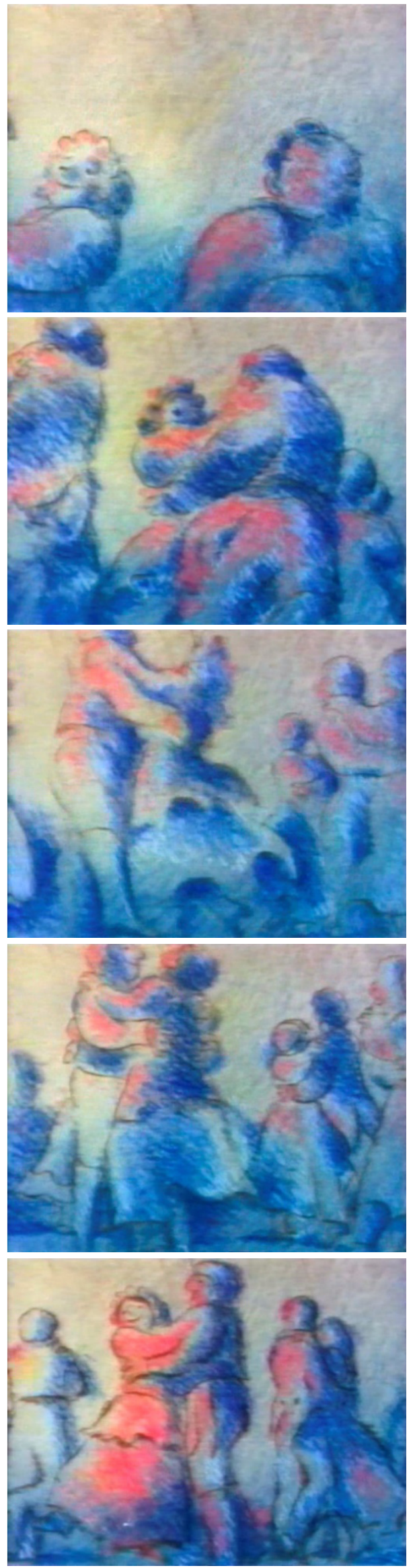
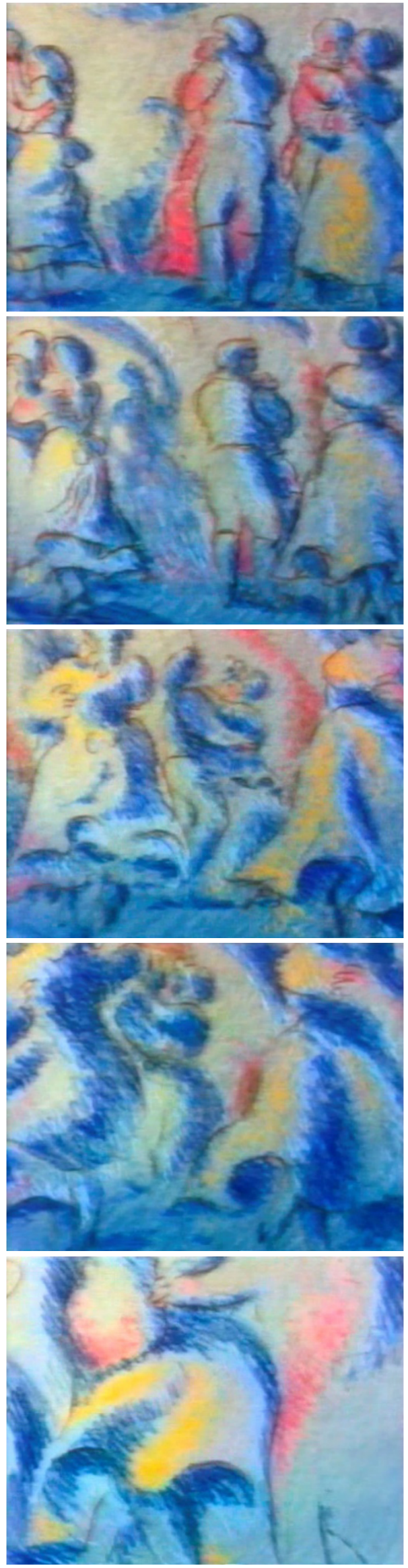

Fig. 36. Frédéric Back (1981). Crac! Serie de fotogramas. 

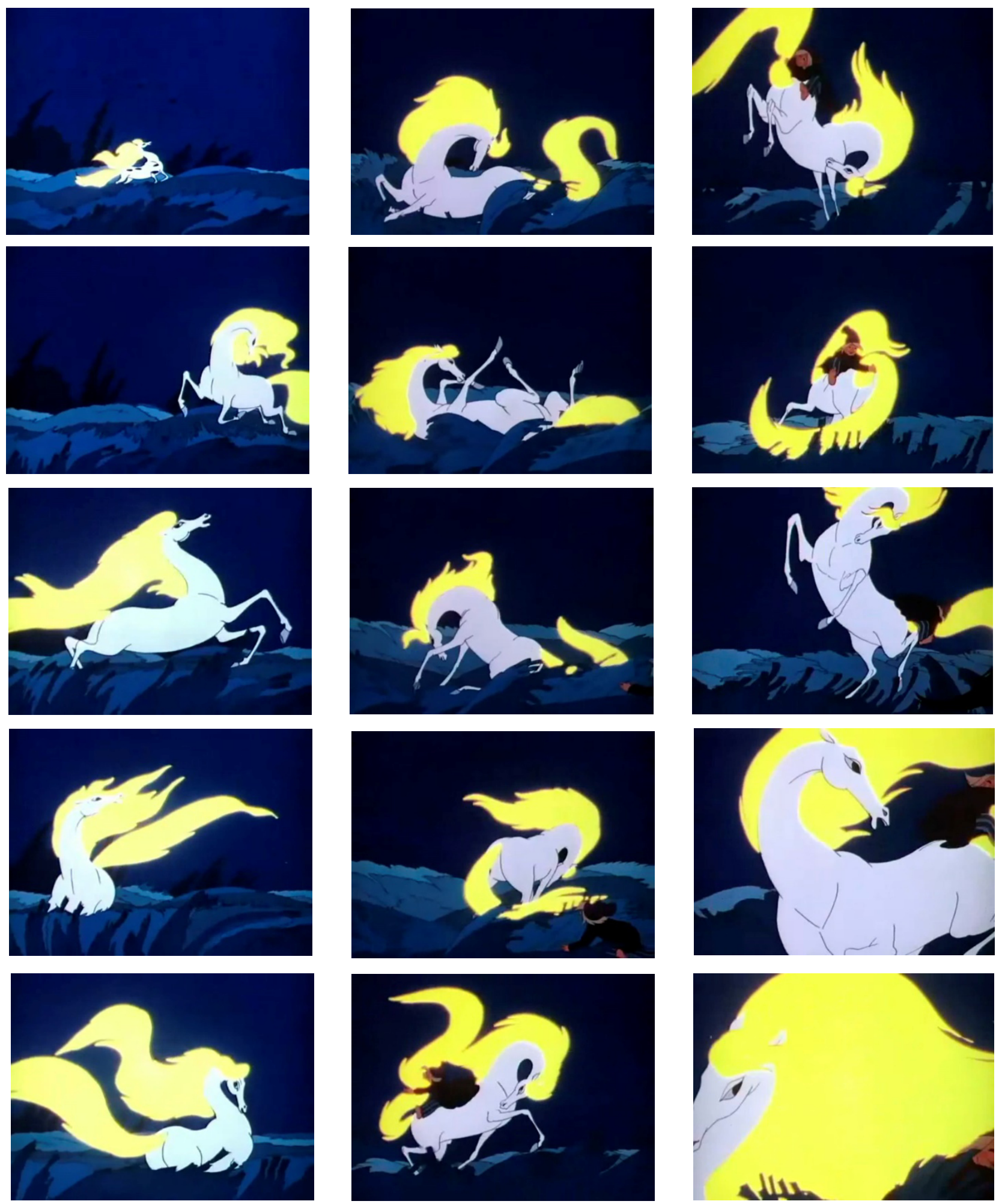

Fig. 37. Ivan Ivanov-Vano (1976). Konyok-gorbunok (El caballito jorobado). Serie de fotogramas.

de un caso en el que la composición móvil (como encuadre y como coreografía) acompaña el movimiento de la escena y refuerza las acciones del caballo (de valoración espacio-temporal también muy expresiva), lo que provoca sensaciones cinéticas de gran intensidad. Es un caso claro de movimiento vivenciado. 
La combinación de movimiento de personajes y punto de vista móvil también puede emplearse de manera más expositiva que expresiva, ya que los recursos, aunque proporcionan mayor o menor dinamismo, pueden servir para distintos fines. En un render que representa las calles de la antigua ciudad de Pompeya ${ }^{51}$, los ciudadanos pasean por el centro social de la ciudad al tiempo que la cámara realiza un traveling (00:01:30); esto proporciona una experiencia muy diferente a la de los ejemplos anteriores.

\section{- Cambio de formato}

El cambio de formato es otro de los posibles movimientos en la composición del plano. El formato puede cambiar dentro de una misma obra de un plano a otro, lo cual no es muy frecuente, como tampoco lo es el cambio de formato en el mismo plano. El formato del espacio compositivo influye de manera esencial en la obra audiovisual, ya que se convierte en el espacio en el que tiene lugar el desarrollo del movimiento y la distribución de los elementos. Si el formato también se muestra en evolución por medio del cambio de proporción o de forma, esto interviene indiscutiblemente en la composición móvil.

Una de las alteraciones del formato más frecuente es la subdivisión del espacio compositivo. Las subdivisiones de la pantalla son muy variadas y no sólo en horizontal o vertical, también pueden ser en diagonal o en sección curva. Este recurso habitualmente sirve para mostrar acontecimientos simultáneos. En Grain coupon (Cupón de grano) (Xi \& An, 2001), en momentos concretos, la pantalla se divide en dos secciones para mostrar detalles de la acción (la división de la pantalla tiene lugar en el mismo plano, no de un plano a otro). Por ejemplo, en un lado de la pantalla se mantiene el punto de vista habitual de la película, un plano general frontal en el que vemos al anciano trabajado en la mesa $y$, al mismo tiempo, en la otra sección de la pantalla, un plano de detalle deja ver cómo el hombre pinta una miniatura Fig. 38 (00:05:58). Mostrar acciones que suceden a la vez también se emplea para establecer comparación, como en el capítulo 41 de la temporada 1 de Saint Seiya (Caballeros del zodiaco), donde la tensión previa al enfrentamiento entre el caballero de Virgo y el caballero de Leo se representa mostrando simultáneamente la expresión de sus rostros; la pantalla se divide en vertical (Fig. 39). Este recurso no sólo se da en animación, existe prácticamente desde los inicios del cine y se usó recurrentemente para representar, normalmente en una sección ovalada de la pantalla, los pensamientos y deseos

${ }^{51}$ Yersin, y otros, 2007 
de un personaje, así "Dos cosas relacionadas conceptualmente se sitúan visualmente de lado y de este modo se da una representación gráfica comprensible del tema" ${ }^{52}$; como vemos, se trata de un recurso tomado del cómic.

El cambio de formato menos habitual es aquel en el que el espacio compositivo cambia de proporción progresivamente mediante el recurso de dejar en negro el espacio que queda "fuera" del nuevo formato; de ese modo, en la proyección, el espacio negro se considera neutro, no participante de la composición, como el marco de una ventana. En Triangle (Triángulo) (Russell, 1994), la mayor parte de la película se desarrolla en formato 3:4 y planos muy aislados de formato vertical (como vimos en B1. de 2.2.3.) vertical, pero en un momento determinado cambia progresivamente de orientación, transformando el formato de 2:1 a 1:2, pasando por rectángulos de proporciones intermedias (00:05:34); el formato es aquí otro elemento en acción. La composición se adapta también progresivamente al formato, expandiéndose y encogiéndose a medida que el formato lo hace Fig. 40. Instantes antes, el formato alterna su orientación de horizontal a vertical alternativamente (00:05:04).

Otros cambios de formato son el que vemos en The End of the World in Four Seasons (El fin del mundo en cuatro estaciones) (Driessen, 1996). En esta película la pantalla muestra varias "ventanas" a modo de políptico. Al final de cada secuencia, las ventanas desaparecen de diferente manera, unas se arrugan como una hoja de papel, o salen de campo llevadas por el viento, alterando el políptico. Y en Prostitución infantil (Rosa Peris, 2007), por el recurso de oscurecer el espacio alrededor de unas mirillas a través de las que se ve la historia, el espacio compositivo deja de ser 3:4 y adopta forma de corazones. El formato varía de unos planos a otros: 3:4 - un corazón - 3:4 - dos corazones - 3:4, etc. (Fig. 41) En este caso el cambio de formato ubica al espectador detrás de una pared en la que unos agujeros dejan mirar el interior de una habitación, por lo que los planos de las mirillas son planos subjetivos de la mirada de un personaje al que no vemos en ningún momento de la película pero que tiene un papel activo y decisivo: un voyeur espía a una niña en su intimidad. De esta manera el formato evidencia la presencia del personaje y convierte los planos en su mirada e incluso, en cierto modo, pone al espectador en su lugar, lo que lo acerca al movimiento vivenciado.

Los cambios de formato más frecuentes son aquellos con sentido retórico o estético. Pero todo rasgo de la composición colabora estrechamente en la ex-

\footnotetext{
${ }^{52}$ Arnheim, 1957, pág. 91
} 
presión del movimiento, por ello, siguiendo las observaciones anteriores, creemos que la movilidad del formato puede ser un elemento activo en la expresión del movimiento vivenciado o neutro. Aunque en el caso anterior se puede hablar de movimiento vivenciado por plano subjetivo, permítasenos ejemplificar a través de un caso hipotético cómo podría el formato provocar sensaciones cinestésicas: en el film Tunnel (túnel) (Kashkoolinia, 2012) con el oscurecimiento de todo el espacio compositivo excepto una franja curva que representa un túnel, la película transmite la claustrofobia del personaje ante las dificultades de atravesar el estrecho pasadizo. Aquí, sin embargo no podemos hablar de cambio de formato porque, aunque el espacio practicable se delimita al oscurecer el espacio circundante, éste sigue participando en la composición. Pero si el espacio alrededor del túnel desapareciera por completo cuando el hombre se introduce en él, dejando que se percibiera el túnel como el formato, entonces el cambio de formato colaboraría en la representación del movimiento vivenciado.

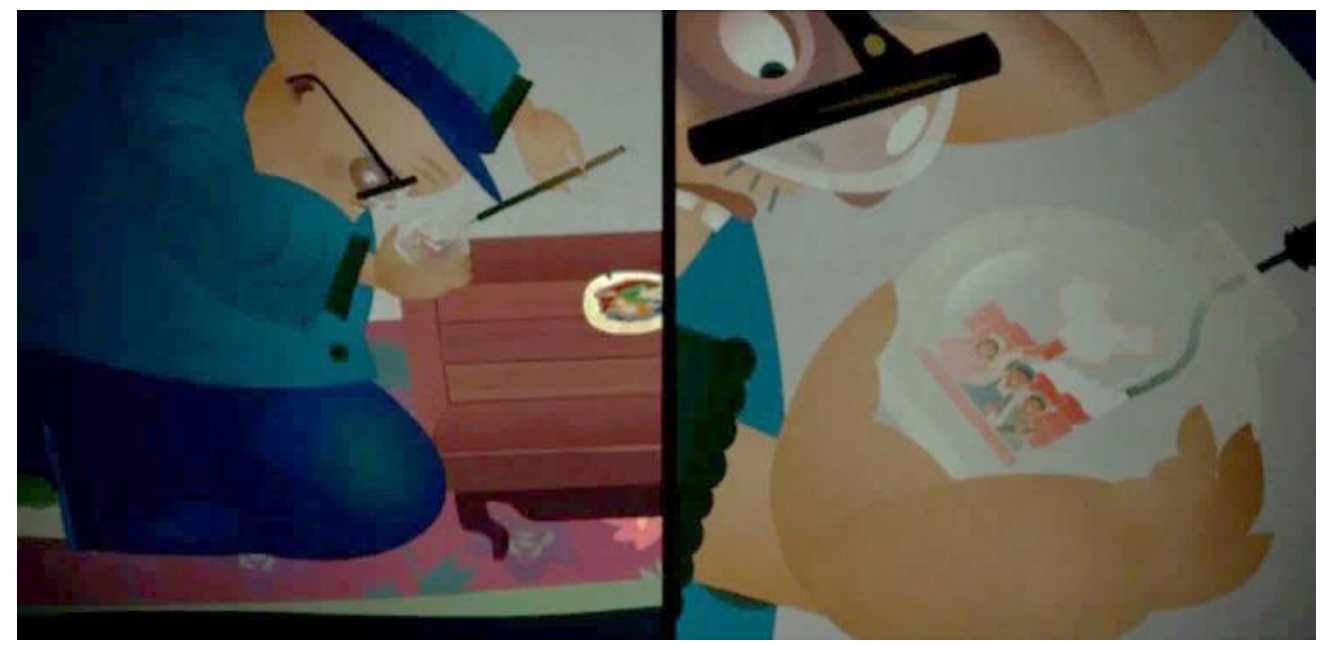

Fig. 38. Chen Xi y Xu An(2001). Grain coupon (El cupón de grano).

Fig. 39. Kōzō Morishita y Kazuhito Kikuchi (19861988).Sancturay daikessen! Atena saidai no kiki (La gran batalla del Santuario) capítulo 41 tempora 1 El santuario. Saint Seiya (Caballeros del zodiaco).

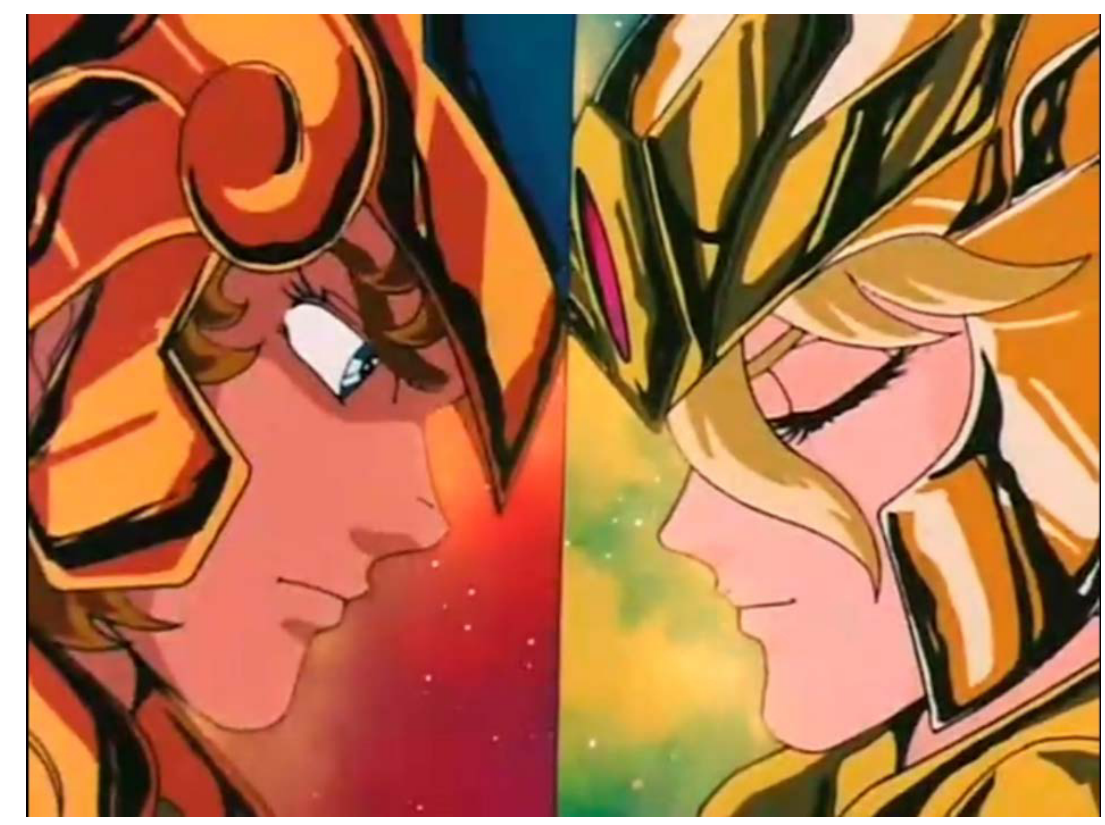


El cambio de formato puede dar mayor dinamismo. No obstante, el formato estable (que no cambia a lo largo de la película) no hace que el movimiento de la animación sea neutro, pues todos los demás acontecimientos pueden ser lo suficientemente expresivos.

La composición del movimiento en cada plano participa en la expresividad del movimiento, pero ningún tipo de movimiento, trayectoria o encuadre es más adecuado para expresar el movimiento vivenciado o neutro, ni tampoco la variedad o regularidad de las acciones. Aunque la variedad en principio es más atractiva y estimulante, ya hemos visto que no implica necesariamente movimiento vivenciado, ni la regularidad, movimiento neutro; tanto la redundancia, o incluso pocas acciones, pueden crear movimiento vivenciado, dependiendo de la sensación que se desee expresar (el cansancio físico, por ejemplo, puede exagerarse por medio de la ausencia de movimiento).

En el caso de la composición móvil ocurre lo mismo; es más relevante qué y cómo se dice con la combinación y sucesión del movimiento. Podemos identificarla como expresión vivenciada o neutra según su cualidad expresiva antes que por sus características formales: podemos analizar si transmite sensaciones cinéticas, si está comunicando el contenido emocional mediante la composición, si ayuda o no a transmitir las peculiaridades del movimiento o si colabora en la generación de un espacio vivenciado o neutro. A continuación presentamos algunos casos de animaciones en las que la composición dinámica sustenta la carga expresiva:

En Tántalo (Peris R., 2010) lo la composición dinámica es el principal agente que provoca el movimiento vivenciado: colabora en la expresión de la idea que se representa (la trayectoria interminable con curvas, rotaciones, el salir y entrar en campo es acorde con la persecución y la huida como juego, pero también como frustración - la mujer siempre se escapa -). En Libidinis (Peris \& Peris, 2011) los ángeles-niño también se desplazan por la pantalla dibujando variedad de curvas, la amenidad de sus trayectorias en un mismo plano transmite su carácter juguetón, ya que, además de las acciones que realizan (se abrazan, se tiran de la piel, giran, etc.), ante todo las variaciones compositivas que provocan son una manera de visualizar sus ganas de jugar. En Stressed (Estresados) (Kelly, 1994) un hombre se desploma en la calle, muerto por un ataque al corazón. Su cuerpo yace boca abajo, como una forma más o menos recta; entonces comienza a elevarse, primero se acerca a la cámara, dos criaturas celestiales acuden a por él y los tres juntos se alejan del plano de la pantalla. En su ascenso, describen trayectorias curvas y en espiral, como aves felices, alegres de encontrarse. 

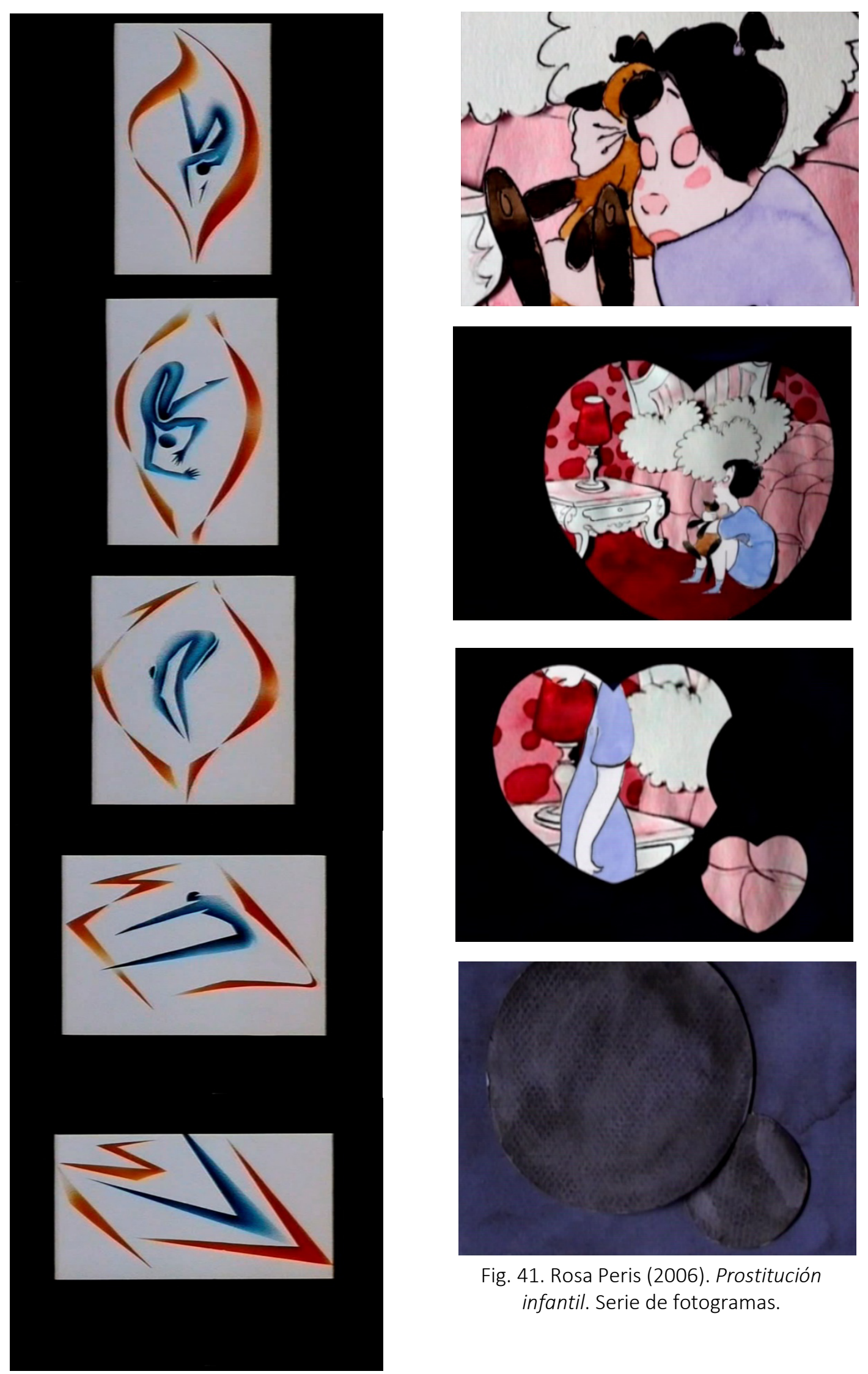

Fig. 40. Erica Russell (1994). Triangle (Triángulo). Serie de fotogramas. 


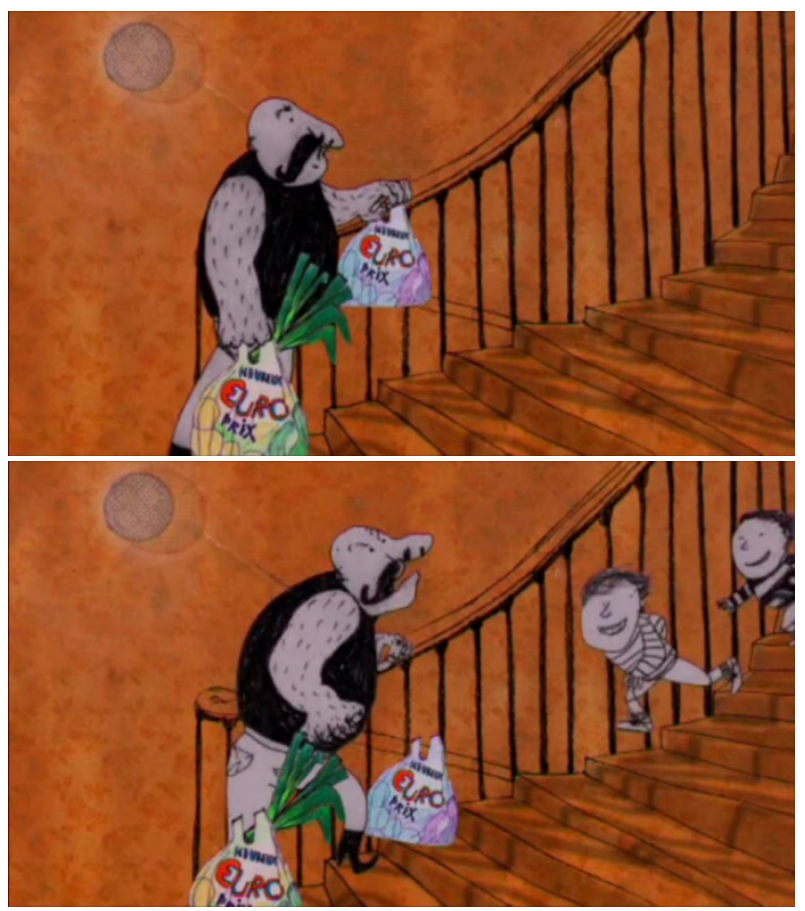

Fig. 42. Annelaure Daffis y Léo Marchand (2007). La Saint-Festin. Serie de fotogramas.
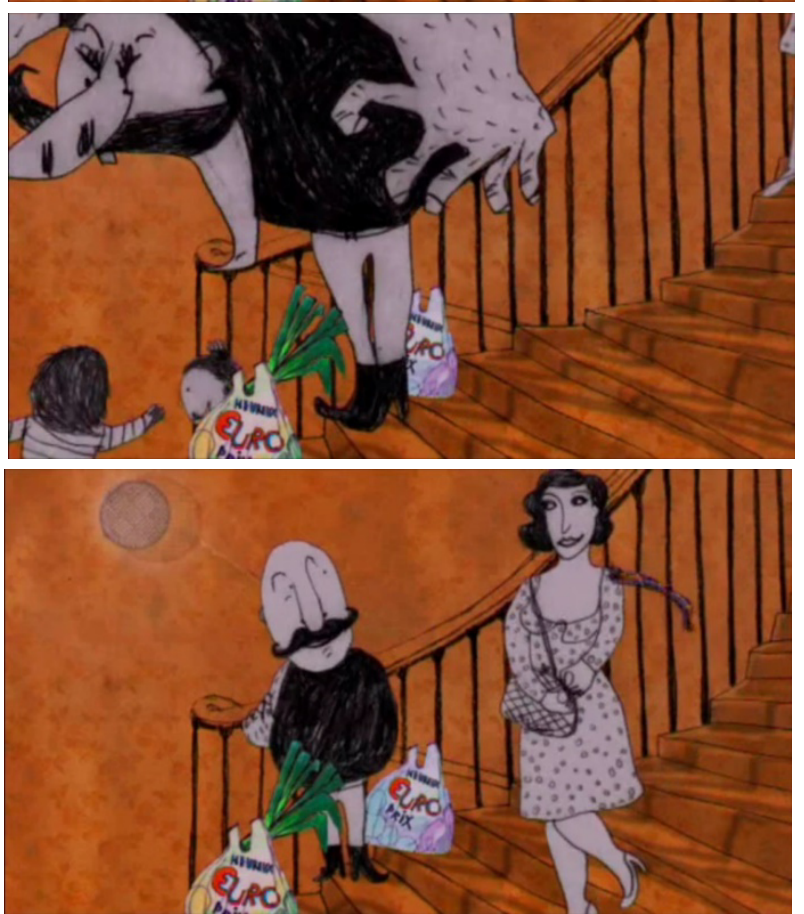

También en La Saint Festin (Daffis \& Marchand, 2007) [en DVD] la composición móvil trasmite el carácter de los personajes: cuando el protagonista sube la escalera, dos niños bajan correteando (trayectorias que se cruzan), él se molesta y su agresividad se representa mediante el aumento de su tamaño (rostro y torso se hacen grandes, ocupando más espacio de la pantalla); a continuación vuelve a la proporción original, porque baja la hermosa madre de los niños, que recorre una trayectoria simple que encarna su elegancia (00:03:45) (Fig. 42). 
La variedad compositiva o "coreográfica" por combinación de movimiento de cámara y movimiento de los personajes (u otros elementos), el cambio de formato y las combinaciones de todo tipo proporcionan gran dinamismo y tienen muchas posibilidades compositivas. No obstante, nuevamente, nos hallamos ante la misma situación que con otros recursos que proporcionan dinamismo a la animación o la hacen más atractiva: no implica expresión del movimiento vivenciado. Del mismo modo, una composición estática (por ejemplo, un personaje en el centro de la pantalla, sin desplazarse), aunque más propicia para el movimiento neutro como hemos visto en videos instructivos, no genera necesariamente animaciones de movimiento poco expresivo.

\section{B.3. Sucesión de planos y planos-secuencia. Evolución de la imagen}

La composición evoluciona a lo largo de la película a través de la sucesión de planos o por medio de planos-secuencia (un único plano que se transforma, ya sea un plano de cámara fija delante de la cual transcurren los hechos, ya sea un punto de vista móvil, o combinación de ambos). Unas películas se componen enteramente de una de estas dos posibilidades, en otras se combinan, y en otras se enfatiza una más que otra.

\section{- Sucesión de planos}

La sucesión de planos es la planificación más común en el arte cinematográfico, tanto de acción real como de animación. A través de la sucesión de planos y los movimientos que se representa en ellos, se genera el movimiento total de la obra. En la sucesión de planos se tiene en cuenta:

- La acción que transcurre en cada uno

- La duración

- La transición entre planos

\section{Duración de los planos}

La duración de un plano es relativa, depende de la duración total de la película y de los demás planos entre los que se encuentre. Arnheim ya observó que "El montaje influye en la velocidad porque el movimiento parece más veloz mientras más breve es el tiempo de su exposición. Cuando se suceden trozos breves rápidamente se tiene una dinámica intensa que puede ser adecuada para un 
episodio dramático". Los planos cortos generan un ritmo rápido y los largos, ritmo lento, pero esto depende directamente del movimiento que tiene lugar dentro de cada plano.

Los animes de lucha y deportes presentan con frecuencia ráfagas de planos cortos, unos con movimiento interno y otros estáticos. Su sucesión provoca ritmo. En Rurouni Kenshin (Furuhashi, 2011-2012), en la escena del duelo entre Kenshin y Saito, en momentos concretos los planos son muy breves. La ráfaga de planos muestra: acciones de alta velocidad, además de muy variadas (giros, saltos, diversidad de trayectorias, etc.), diversidad de movimientos de cámara en combinación con la acción de los personajes, lo que hace que el punto de vista cambie constantemente. Además, en general los personajes están vistos de cerca, lo que ubica al espectador "dentro" de la lucha, entre los contrincantes; así, la intensidad cinética que producen el movimiento de los planos y la sucesión de planos (que se refuerzan entre ellos) y la cercanía constante del punto de vista hacen que esta escena transmita fuertes sensaciones cinéticas implicando al espectador, por lo que el movimiento es altamente vivenciado.

Por el contrario, en Psique and Eros (de Vere, 1994) hay abundancia de planos largos muy estáticos, con poca o ninguna acción, lo que hace lenta la película. Sin embargo, la abundancia de planos largos no implica lentitud indefectiblemente, ya que las acciones que en ellos tienen lugar pueden aumentar la intensidad cinética, de modo que los planos largos con movimiento rápido aumentan la intensidad cinética. Así pues, la duración de los planos en conjunción con la composición móvil (composición más velocidad) configuran el tempo de la obra. En Hen, his wife (La gallina, su esposa) (Kovalyov, 1990), el hombre tiene una alucinación o recuerdo de su esposa-gallina al caerse una porcelana. Un instante antes, éste despierta de una pesadilla por el sonido del despertador (00:08:30), mira el despertador enojado y lo rompe de un manotazo contra la mesa; esta sucesión de 5 planos en 12 segundos tiene una narración clásica y se comprende como una continuidad. Pero la sucesión de planos que le sigue es un pequeño paréntesis temporal en la historia:

1. La mascota tira la figura. Sólo se ve la caer. 1,5 segs.

2. Por narración cinematográfica clásica, veríamos caer la figura en este segundo plano, pero en su lugar vemos otro plano de un plato que se rompe al estrellarse contra el suelo. 1 segs.

3. La esposa-gallina se gira y mira al espectador. $1 \mathrm{seg}$.

4. En el lugar exacto de la gallina se superpone, con fundido, un malévolo personaje de negro que aparece en escenas anteriores y que es el detonante de las preocupaciones actuales del hombre. 0,5 seg. 
5. En el lugar exacto del personaje de negro se superpone, con fundido, el hombre, imagen que se mantiene estática. 8 segs.

La sucesión de planos de la caída del plato y los tres personajes del cortometraje, pese a su breve duración en comparación con el contexto, supone una pausa, que sugiere la dilatación temporal cuando un recuerdo asalta nuestra mente: en breves segundos ( 2,5 segundos) el personaje recuerda a su esposa y al causante de su pérdida, además del dolor que le causa la situación (el plato que se rompe).

\section{Lo que sucede en cada plano. Nuevo plano-nueva composición}

La composición de cada plano interviene indiscutiblemente en la sucesión de planos, tanto si la relevancia recae sobre la composición por acción de los personajes como por encuadre. El cambio de imagen va generando la composición móvil y puede provocar tanto sensaciones cinestésicas como no. Puede consistir en una sucesión de variedad compositiva, o no mostrar grandes cambios sino una progresión visual paulatina. En los planos de How Wings are Attached to the Back of Angels (Cómo las alas están unidas a la espalda de los ángeles) (Welch, 1996), la composición tiene más protagonismo como encuadre, los planos son más bien estáticos en cuanto a que la acción de los personajes es breve o poco llamativa la mayor parte de las veces, pero se trata de acciones precisas, de trayectorias nunca azarosas que describen las mismas formas estáticas recurrentes de la composición: la línea vertical y horizontal, la circunferencia y el ángulo de 45o: la mujer entra del jardín; se ve una puerta, entramos por la puerta; se ve una línea vertical que es el hueco entre unas cortinas; la cortina se entreabre (ángulos de $45^{\circ}$ ) y se descorre; el hombre toca la espalda de la mujer describiendo una línea vertical en zigzag y la piel se abre (similar a la cortina, también en ángulo de $45^{\circ}$ ); la mujer se desvanece y el hombre queda frente al espejo; la línea vertical del cigarrillo y la circunferencia de humo se conectan un poco más adelante, pero no inmediatamente, con el contorno horizontal del piano y una urna de cristal vista desde arriba (00:05:53 - 00:06:55) (Fig. 43).

Los planos que se suceden pueden presentar más acciones, de modo que el movimiento de los elementos, antes que el encuadre, lleva el peso compositivo (como comentamos anteriormente). En Tout rien (Todo nada) (Back, 1978), como ya vimos, cada plano muestra una serie de acciones con una trayectoria y unas características específicas, pero siempre en movimiento; los movimientos se alternan o continúan. En otras películas los planos son más largos o la acción que acontece en cada uno no está tan conectada con el plano anterior o posterior, pero siguen un principio de riqueza de movimiento y variedad de trayectorias, como en general las películas de Miyazaki. 

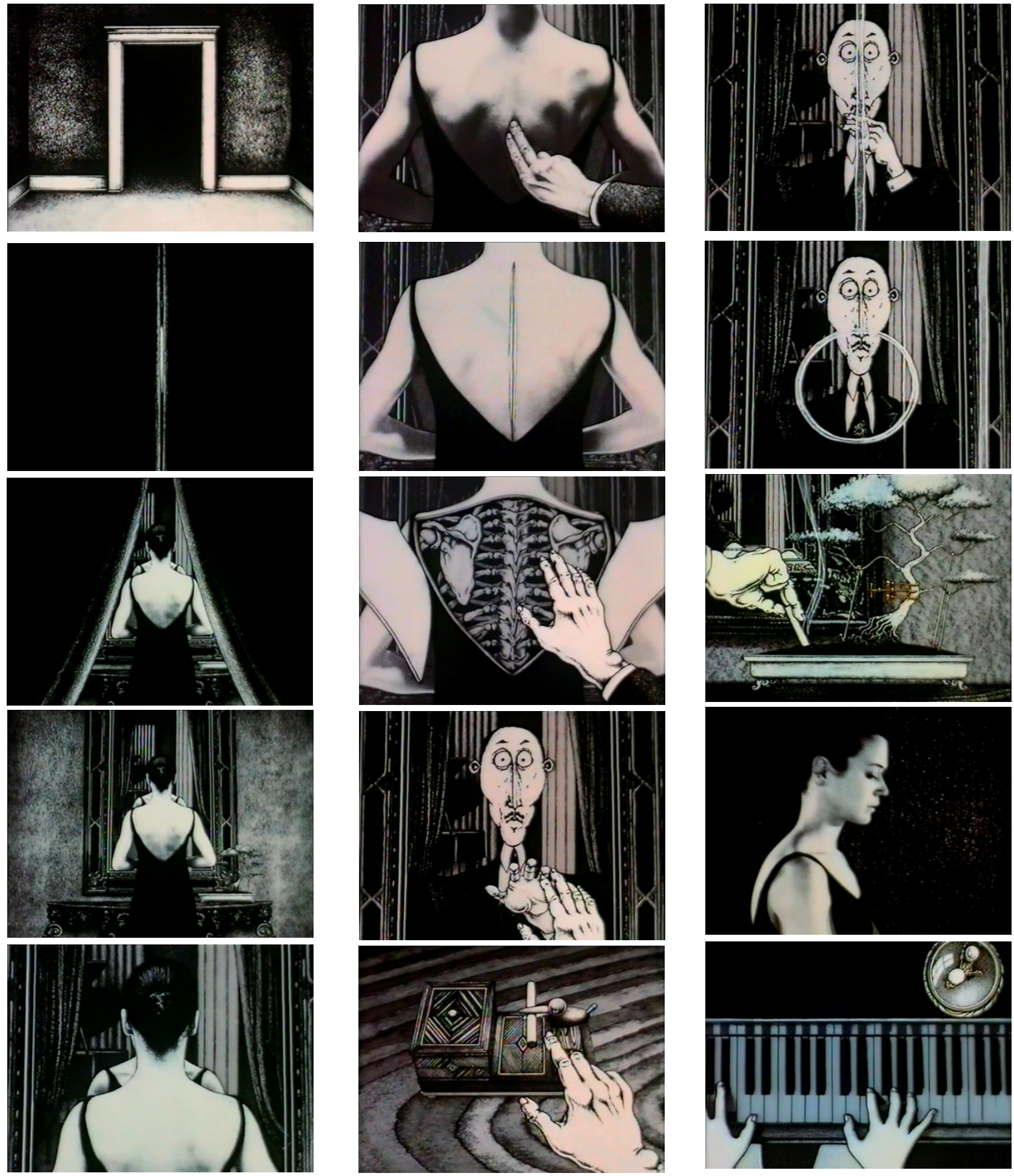

Fig. 43. Craig Welch (1996). How Wings are Attached to the Back of Angels

(Cómo las alas están unidas a la espalda de los ángeles). Serie de fotogramas.

\section{Conexión entre planos}

Cuando la composición cambia, se habla de cambio de plano. En la sucesión de planos, además del encuadre y movimiento que sucede en cada uno, influye la conexión entre ellos. El paso de unos planos a otros puede realizarse de distin- 
tas maneras:

- cortes (la que más fácilmente permite identificar el cambio de plano),

- fundidos

- movimientos de cámara

- entrada y salida de campo

- metamorfosis

Todos los recursos para cambiar de plano, aunque nos referimos a ellos como "transiciones", tienen tanto protagonismo como los planos mismos. Participan directamente de la visualidad y ritmo de la animación. La medida en que colaboran en la expresividad del movimiento depende de su influencia dentro de una obra para transmitir sensaciones cinéticas, para transmitir el contenido emocional o para exponer algo mediante un movimiento libre de connotaciones emocionales.

\section{- $\quad$ Corte cinematográfico}

El cambio de composición por corte y por fundido son los más habituales en el cine de acción real. Pero esto no significa que el corte sea un medio que homogenice el lenguaje cinematográfico y que, por tanto, se acerque al movimiento neutro; todo depende de cómo se use. El corte entre planos puede provocar tanto movimiento neutro como movimiento vivenciado si sus cualidades potenciales se usan con este fin. Como vimos en el apartado "Duración de los planos", el corte, al ser un cambio de imagen no progresivo sino de un fotograma a otro, supone un cambio más o menos drástico según los planos que conecte. El corte cinematográfico, al cambiar la totalidad de la imagen de un fotograma a otro, puede generar o romper el ritmo dinámico (incluso aunque no rompa la continuidad de la narración).

El corte cinematográfico puede intervenir en la composición móvil de modo que transmita ritmo y genere continuidad visual (no nos referimos a la continuidad del racord, que genera la sensación de que lo que acontece en cada plano tiene lugar en el mismo espacio-tiempo, sino a la continuidad visual). La sucesión de planos unidos por cortes supone la yuxtaposición de fragmentos de mayor o menor duración en los que se representa uno u otro movimiento; el movimiento que en ellos se muestra puede producir la interconexión entre los planos. La conexión por medio del movimiento puede ser por continuidad u oposición de trayectorias, por reiteración o contraste de acciones.

En La création des oiseaux (La creación de los pájaros) (Back, 1973) encontramos un modelo de continuidad visual y ritmo entre planos unidos por corte; 
cada plano muestra una acción de los niños indios jugando en el bosque (00:00:10): los cuatro corren colina abajo de izquierda a derecha. Corte. Dos ranas saltan en un estanque y a continuación uno de los niños salta sobre el agua con una caña como pértiga, de derecha a izquierda. Corte. Dos niños saltan al potro sobre otros dos, de izquierda a derecha. Corte. Uno de los niños gira suavemente (trayectoria muy breve) desde la esquina inferior derecha de la pantaIla. Corte. Hasta aquí las trayectorias son opuestas, y a continuación siguen la misma dirección de izquierda a derecha: un niño gira en sentido opuesto a las agujas del reloj. Corte. Dos niñas hacen la voltereta lateral en el mismo sentido; una de ellas pierde la corona de hoja, que recoge a continuación. Corte. La niña se coloca la corona de hojas también en dirección izquierda-derecha (Fig. 44). La secuencia se compone, pues, por continuación de la trayectoria y direcciones opuestas, creando un efecto de "contra-curvas" y "curvas concatenadas". Las rotaciones de las marionetas de recortes evidencian la simplicidad de la mecánica de la acción, lo que da mayor protagonismo a la composición móvil es, que en esta secuencia, es responsable principal de las sensaciones cinética y de la expresión del movimiento como vivenciado.

Arnheim justifica la alternancia o similitud de direcciones entre planos a una cuestión de equilibrio y como medio para establecer comparación o contraste. ${ }^{53}$ Para ver esto, permítasenos detenernos en un caso de acción real: los primeros planos de The Fellowship of the Ring (La comunidad del anillo) (Jackson, 2001). Los primeros planos de la película, separados por corte, ya presentan los rasgos fundamentales de las razas de este mundo:

1 y 2 - Fundición de los anillos.

3 - Las manos de tres elfos con anillos se unen en el centro de la pantalla (dirección concéntrica).

4 - Tilt para mostrar el rostro de los elfos, es un plano cercano, enfatiza su sabiduría e intuición.

5, 6 y 7 - Puntos de vista giratorios mostrando detalles de los siete anillos dispuestos en círculo y a los enanos, también en círculo, elevando los anillos. Es una presentación de su carácter heroico.

8 - Zoom out que muestra a los hombres en disposición de flecha, bajando las manos en las que sostienen los anillos (movimiento contrario al del plano anterior). Su disposición habla de una sociedad jerárquica, en la que rigen leyes.

La transición es tan relevante como la duración del plano y lo que sucede en él. Cuando los planos son breves y se suceden uno tras otro con presteza por

\footnotetext{
${ }^{53}$ Arnheim, 1957, pág. 134
} 
corte cinematográfico, la composición y el movimiento de cada plano pueden generar ritmo, como en los ejemplos del apartado "Duración de los planos". Otras veces, sin embargo, el corte no genera ningún ritmo, ni supone una conexión entre el movimiento de cada plano; en estos casos el corte no participa en la generación de sensaciones dinámicas, no obstante, que se represente el movimiento como neutro depende también del resto de factores (la composición en cada plano, la valoración espacio-temporal, el movimiento del dispositivo y el relato).

En 2.2.1. hemos hablamos de los fundidos como parte de los recursos visuales del cambio de imagen, como transición de una imagen a otra; aquí nos referimos a este mismo recurso pero como cambio de plano. Los fundidos permiten que ambos planos se vean a la vez por transparencia, hasta que el antiguo, al disolverse, deja paso al nuevo, que se define totalmente. Tradicionalmente en el cine los fundidos representan el paso del tiempo (entre otras cosas); un fundido entre dos planos da a entender que el nuevo plano representa un tiempo posterior no inmediato al plano anterior.

\section{- Fundidos}

"El fading in y el fading out pueden utilizarse para demostrar la percepción subjetiva de los seres humanos; por ejemplo, cuando una persona se despierta o va quedando dormida." ${ }^{54}$ Ésta es, sin duda, una cualidad de los fundidos que ayuda a representar el movimiento como vivenciado. Pero aparte de esto, la transición por fundido, como el corte, no es ni más propia del movimiento vivenciado ni del neutro. Aunque por su capacidad para expresar el paso del tiempo y para generar ambiente o un ritmo sosegado (los fundidos para conectar planos cortos pueden aminorar la velocidad ${ }^{55}$ ), la transición por fundido puede usarse para potenciar el movimiento vivenciado, así como para representar el movimiento de manera neutra. En Le fleuve aux grandes eaux (El poderoso río) (Back, 1993), hay abundancia de fundidos encadenados entre planos. El movimiento de los personajes y los movimientos de cámara son lentos, al unirlos mediante fundidos (unos más progresivos que otros) se genera una cadencia ralentizada. Estos fundidos a veces provocan una comparación: en un plano se muestra una de las aguas de un tejado; éste plano se funde con otro en el que se representan las olas llegando suavemente a la playa. Por un momento vemos los dos elementos, que presentan cualidades similares: la dirección de la superficie y las ondas del agua y de las tejas. Arnheim ya apuntaba esta cualidad comparativa que se establece en la superposición de imágenes en el cine y dice que tam-

\footnotetext{
${ }^{54}$ Arnheim, 1957, pág. 89

${ }^{55}$ Arnheim, 1957, pág. 135
} 
bién puede establecerse contraste por el mismo medio. ${ }^{56}$ No obstante, los fundidos no siempre colaboran positivamente, a veces simplemente hacen la animación más pausada sin un claro propósito expresivo.
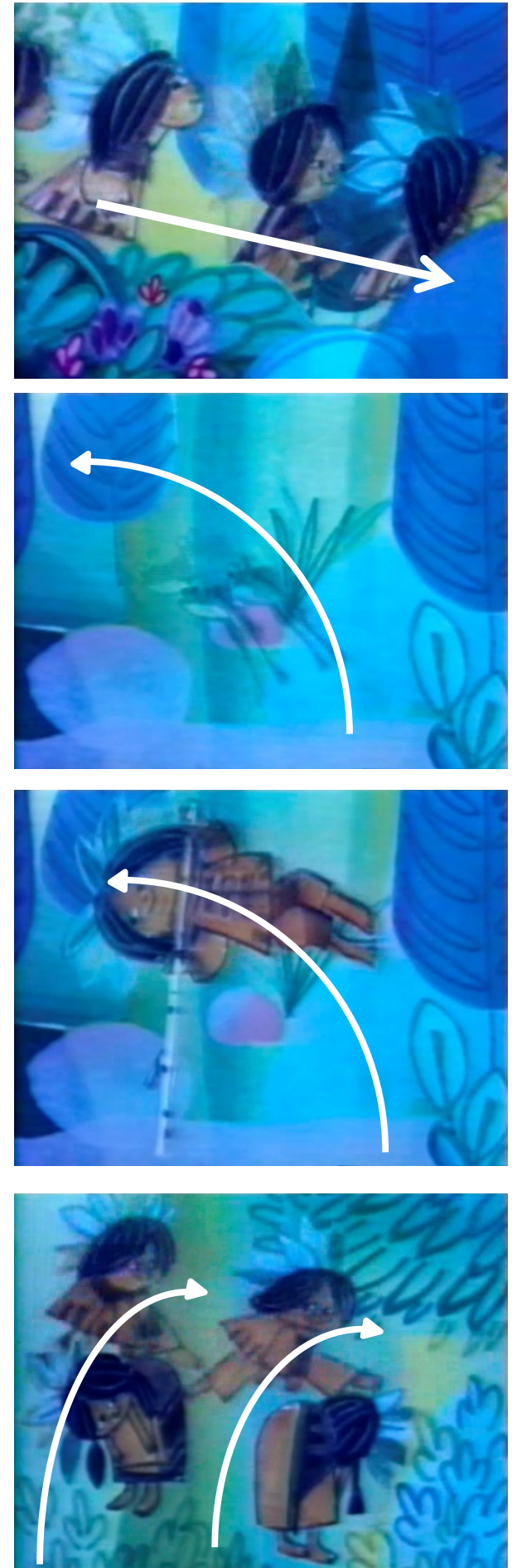
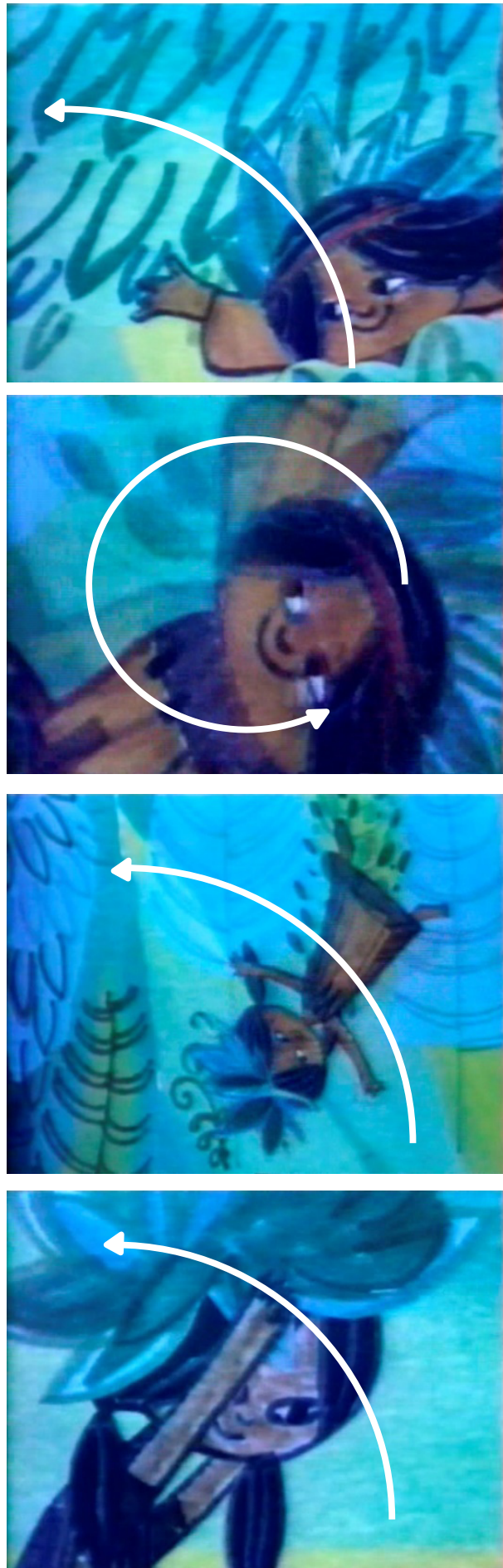

Fig. 44. Frédéric Back (1973). La création des oiseaux (La creación de los pájaros). Serie de fotorramas

\footnotetext{
${ }^{56}$ Arnheim, 1957, pág. 89
} 


\section{- Movimiento de cámara, entrada y salida de campo}

Los movimientos de cámara a veces funcionan como transición de un plano a otro al hacer un recorrido hasta llegar al nuevo centro de atención: el nuevo encuadre. Los cambios de plano por movimiento de cámara, sobre todo los que siguen trayectorias curvas y son oblicuos, resultan muy dinámicos y generan sorpresa (en general, mostrar por movimiento de cámara algo que estaba fuera de campo crea este efecto), cualidades ambas que colaboran en la expresión del movimiento vivenciado. Aunque sean transiciones, pueden cobrar protagonismo, como pasa en el cortometraje Yankale (Alkabetz, Yankale, 1995), donde el encuadre que "enmarca" frontalmente una carretera cambia mediante un giro de cámara (incluso se podría decir que lo que gira es el espacio más que la cámara) hasta mostrar el nuevo plano: una vista frontal de una señal (00:02:54).

La velocidad de los movimientos de cámara también influye en la expresividad. Por ejemplo, en Cavallette (Bozzetto, 1990) vemos una pirámide, a continuación, hay un rápido movimiento de cámara a la derecha con paneo para encuadrar el nuevo plano: un hombre adorando un ídolo. Exactamente igual, del plano del templo griego se pasa al plano siguiente con otro paneo a la derecha: un hombre tocando la flauta y una mujer bailando. La rapidez de estos movimientos y otros que salen en el cortometraje son acordes al tono cómico del relato. Un movimiento lento, en este caso, tendría menos temperamento.

Pero el desplazamiento del punto de vista para encuadrar el siguiente plano no siempre proporciona resultados tan expresivos. En los videos expositivos los movimientos de cámara no proporcionan sorpresas, sino que, ante todo, aclaran o amplían la información. En el documental educativo sobre la invasión de Numancia (Jimeno Martínez \& de la Torre Echávarri, 2009) [en DVD] se ve en detalle la llegada de las galeras romanas a la costa de Tarraco, a continuación, un movimiento de cámara amplía y aleja el punto de vista hasta ver la mayor parte de la Península Ibérica, para ver el territorio bajo dominio romano en esa época (Hispania Citerior e Hispania Ulterior); a continuación se acerca de nuevo para mostrar la ubicación de Numancia (00:00:26). Éste es un movimiento absolutamente neutro en el sentido en que se definió en el capítulo 1: no provoca sensaciones cinéticas ni expresa contenido emocional. La velocidad lenta es la más común en estos movimientos de cámara, aunque no es una norma.

- Metamorfosis

El cambio sustancial para conectar dos planos es considerado como elemento distintivo que define la animación: 
La habilidad para metamorfosear imágenes significa que es posible crear una conexión fluida de imágenes a través del proceso de la animación misma más que a través de la edición, aunque, por supuesto, la edición puede ser usada en la misma película. La metamorfosis en animación consigue el más alto grado de economía en continuidad narrativa, y añade una dimensión al estilo visual de la película de animación al definir el abstracto fluir de la puesta en escena entre las propiedades fijas de las imágenes antes y después de la transición. ${ }^{57}$

Esto ocurre en Cavallette (Bozzetto, 1990), donde la transición entre planos tiene lugar la mayor parte de las veces por cambio sustancial, principalmente generación y corrupción (los personajes aparecen y se desintegran en pantalla), narrando en clave cómica, aunque no exenta de pesimismo, el inicio y el fin de diversas civilizaciones en unos pocos segundos.

Las cualidades narrativas de la metamorfosis no son suficientes para expresar el movimiento vivenciado, ya que la simple eficacia narrativa no es la clave que sostiene la expresividad de la representación del movimiento en animación. Para expresar el movimiento vivenciado por medio de la metamorfosis ésta debe ser el agente principal que proporcione sensaciones cinéticas y transmita el acontecimiento como vivido en primera persona. La metamorfosis, aunque casi siempre tiene mucha potencia visual, en realidad no está vinculada directamente con el movimiento vivenciado; como las metáforas, debe usarse con este fin, ya que por sí mismo no tienen un nivel de expresión dinámica concreto (no es ni vivenciado ni neutro). Un ejemplo de movimiento vivenciado propiciado por la metamorfosis como cambio de plano lo encontramos en 78 Tours (78 vueltas) (Schwizgebel, 1985); en este cortometraje la metamorfosis se combina con el desplazamiento del punto de vista, de manera que la composición móvil se crea en conjunción con las trayectorias de la cámara, los personajes y otros elementos dinámicos, lo que proporciona sensaciones dinámicas intensas, además de ser una representación del espacio vivencial, ya que se establecen conexiones entre el espacio, la actividad social y el ocio por medio de la transformación de diversas imágenes, creando un mapa imaginario de lo que podrían ser las actividades de ocio de una persona.

En Corre, caballito (Peris \& Peris, 2007) no hay ni un solo corte para cambiar de plano. Los métodos para modificar el encuadre son por metamorfosis de los

\footnotetext{
${ }^{57}$ Wells P. , 2007, pág. 69, (trad. a.): The ability to metamorphose images means that it is possible to create a fluid linkage of images through the process of animation itself rather than through editing, although, of course, editing may also be employed in the same film. Metamorphosis in animation achieves the highest degree of economy in narrative continuity, and adds a dimension to the visual style of the animated film in defining the fluid abstract stage between the fixed properties of the images before and after transition.
} 
personajes y del espacio, por entrada y salida de campo de los elementos y por movimiento de cámara. La metamorfosis se emplea incluso en la representación de hechos que tienen lugar simultáneamente: el caballo está ascendiendo para superar un obstáculo interminablemente alto; por metamorfosis se pasa a un plano medio de dos espectadores que prestan atención; nueva metamorfosis; vista del caballo derribando una barra de la valla; metamorfosis; plano de otros dos espectadores, éstos decepcionados. El cambio de un plano a otro sigue la trayectoria del movimiento, lo que conecta el movimiento de los planos provocando sensaciones cinéticas (00:02:03).

La metamorfosis no siempre funciona como cambio de plano, como en Britannia (Quinn, 1993). La metamorfosis en esta película sólo hace de transición entre planos en un momento concreto: cuando la bola del mundo se reduce y se
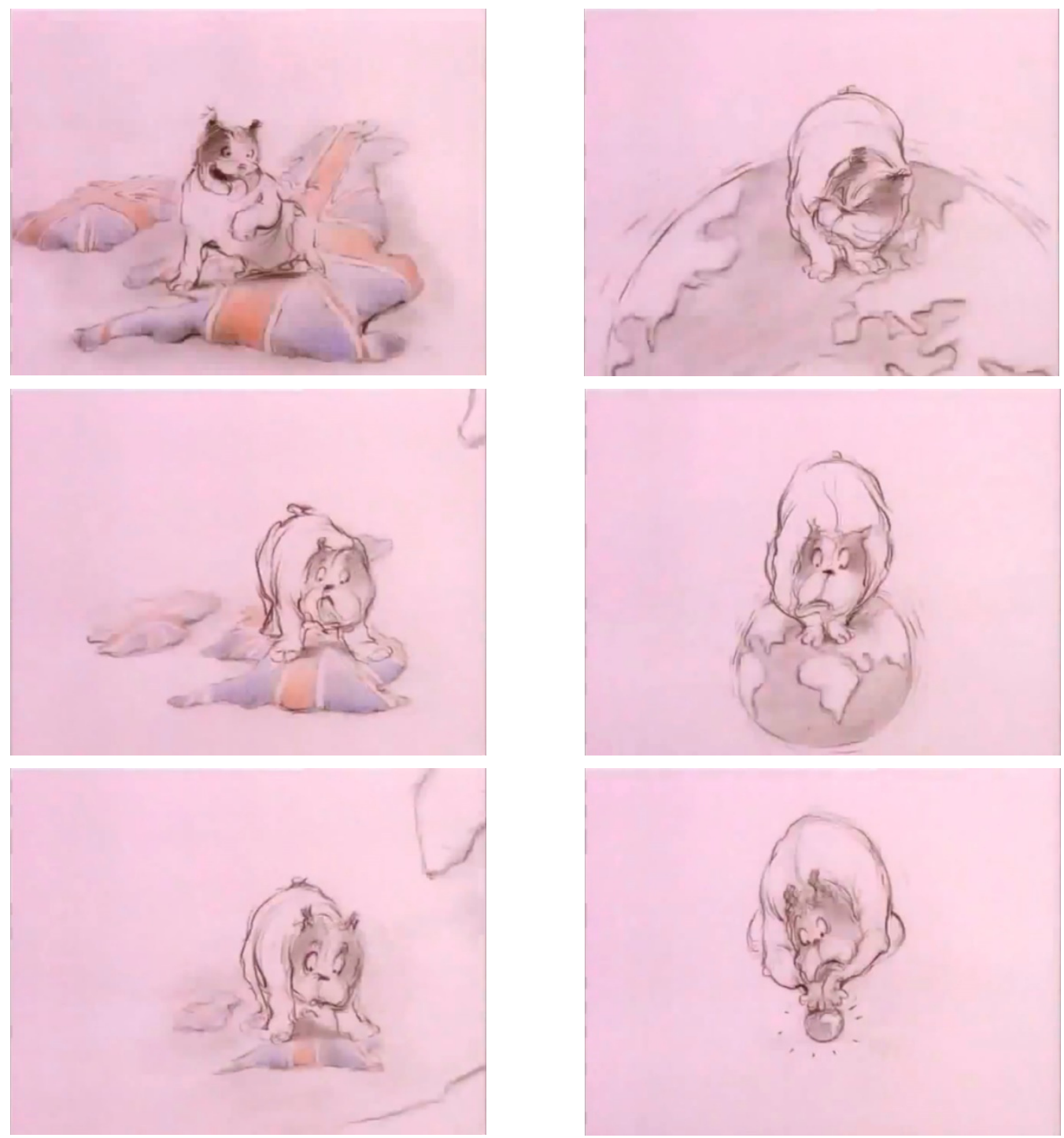

Fig. 45. Joanna Quinn (1993). Britannia. Serie de fotogramas. 
convierte en pelotita para jugar (00:00:53) (Fig. 45); e incluso aquí tiene un contenido narrativo: establece comparaciones y conecta ideas (el collar de personas-la esclavitud, la transformación del bulldog en perrito-la pérdida del poder colonial de Gran Bretaña). El movimiento sustancial puede tener tal frecuencia que no se distinguen planos ni secuencias, sino que la película se compone de un único plano-secuencia en constante transformación (de los que hablaremos a continuación).

La metamorfosis tiene normalmente un sentido explicativo en los videos didácticos. Las transformaciones con sentido estético o con significado no se encuentran en estos videos, porque éstas corresponden a un terreno más personal y de expresión artística. Aunque, como hemos dicho antes, esto no hace de la metamorfosis una herramienta para crear el movimiento vivenciado infaliblemente.

\section{- Planos-secuencia. Desarrollo de la composición de la imagen}

Los planos-secuencia son más prolongados; en éstos se muestran varias composiciones o bien la composición está en continuo cambio, sin ser posible diferenciar planos. La continua transformación del plano-secuencia se da por los mismos recursos de transición enunciados, excepto el corte. No obstante, utilizar todas las transiciones excepto el corte no da lugar al plano-secuencia, ya que éste no consiste, por ejemplo, en dos planos muy diferentes unidos por una metamorfosis; para ser plano-secuencia debe reconocerse como unidad compositiva. En When the Wind blows (Cuando el viento sopla) (Murakami, 1996) un plano-secuencia hace de paréntesis en la historia para enseñarnos los pensamientos de una mujer; la imagen fluye sin interrupción en este plano que, al finalizar, vuelve a dar paso a la historia principal narrada.

Las características de las que hablamos en B.2. La composición móvil en el plano, tienen lugar aquí a lo largo de un tiempo mayor, por lo que esas características se ven en mayor evolución. Pero como tienen una duración mayor, suele tener más importancia en ellos la composición móvil como sucesión de acciones. Otras veces el movimiento se desarrolla en el plano sin utilizar estos recursos, con una puesta en escena "teatral", en el sentido en que el punto de vista está fijo y la escena se desarrolla desde ese punto de vista. Aunque el punto de vista es estático, las posibilidades de movimiento son infinitas, como vimos en el punto B.2. La composición móvil en el plano; así pues, en un plano-secuencia de cá- 
mara fija, la capacidad para expresar el movimiento vivenciado se centra en la composición móvil como coreografía y en el timing.

Seiltänzer (El baile de la cuerda) (Krumme, 1986) y Bitz-Butz (Alkabetz, 1984) son cortometrajes que consisten en un único plano-secuencia y en ambos la continuidad visual resulta estimulante, cualidad que puede ayudar a propiciar el movimiento vivenciado. Este tipo de planos normalmente atrapan la mirada. No obstante, los planos-secuencia no implican ni expresión del movimiento vivenciado ni del neutro, ya que, al igual que pasa con la sucesión de planos conectados por corte, la expresión del movimiento por medio del plano-secuencia depende de cómo se usa éste recurso.

Los planos-secuencia se complican visualmente todavía más al contener los recursos para cambiar de plano sin corte. En éstos, la metamorfosis, el movimiento de cámara y la entrada y salida de campo de elementos móviles, alcanzan su máxima expresión. Hay películas que son enteramente un único planosecuencia. La combinación de todos estos recursos, además del movimiento de los personajes, proporciona resultados muy dinámicos, por lo que pueden propiciar representaciones del movimiento expresivas. Al igual que los dos ejemplos anteriores, también La curse à l'abîme (La maldición del abismo) (Schwizgebel, 1992), Los niños tienen derecho a la protección durante los conflictos armados (RMUSL Animation India, 1999) y Le chapeau (El sombreo) (Cournoyer, 1999) consisten en un único plano-secuencia, pero en éstas los recursos para cambiar la composición están dominados por el movimiento de cámara y la metamorfosis. En los planos-secuencia como los que vemos en Le chapeau, la conexión de ideas se hace visual a través de la continua transformación de varios elementos, pero ninguno permanece el tiempo suficiente para hablar de transiciones entre planos; la metamorfosis no funciona como transición entre planos, sino que es el contenido del plano.

Todo influye y al mismo tiempo no determina que el movimiento sea vivenciado o neutro. Los elementos principales que intervienen en la sucesión de planos (la duración, el movimiento que en ellos acontece y las transiciones) pueden configurar movimiento neutro o vivenciado. Como ya hemos dicho varias veces, ni el mayor dinamismo ni la mayor velocidad o complejidad dinámica son la clave para obtener movimiento vivenciado. En los planos-secuencia, por su mayor duración, igual que ocurre en los planos largos, la expresión del movimiento vivenciado puede darse por la continuidad compositiva (no exclusiva del plano- 
secuencia, como veremos en B.4. en el apartado Continuidad compositiva) y por las cualidades de otros componentes espacio-temporales (la valoración espaciotemporal y el cambio de imagen). El movimiento vivenciado así como el neutro se obtienen tanto por medio de la sucesión de planos como por medio de planos-secuencia.

\section{B.4. Evolución total de la película}

La composición móvil se desarrolla a lo largo de la película. Aunque cada plano y cada secuencia sean una unidad compositiva, todo se entrelaza en una evolución única. Los temas que tratamos en este aparatado son: cómo la composición móvil está relacionada íntimamente con la distribución de la intensidad cinética; que la composición puede mantenerse más o menos estable a lo largo de toda la obra, o puede variar; algunas características compositivas recurrentes; y el último punto de este apartado está dedicado a la continuidad visual.

\section{- Relación entre la composición móvil y la intensidad cinética}

En la evolución de la imagen a lo largo de la película se tiene en cuenta la composición de cada plano dentro de la totalidad de la película, cómo se relacionan y conectan los planos, la relación entre los planos (por similitud, por contraste o por progresión dinámica; por ejemplo, cada vez planos con más elementos, o cada vez direcciones más oblicuas y menos paralelas, etc.); y, en definitiva, el sentido de la composición en el transcurso total de la obra.

La evolución de la composición móvil es el punto de máximo encuentro con el componente dinámico "distribución de la intensidad cinética", es decir, con el timing global de la película. En el apartado 2.1.1., veremos que una de las acepciones de timing se refiere a la velocidad y a la intensidad cinética que ésta genera. A esta faceta del timing la hemos llamado "distribución de la intensidad cinética", y "composición móvil" a cómo evoluciona la imagen en el espacio compositivo (en la cual también participa la intensidad cinética).

Un cambio en la composición móvil implica normalmente un cambio en la intensidad cinética. Por ejemplo, el aumento de elementos móviles implica una alteración compositiva y aumenta la intensidad móvil. En el apartado 2.2.4 se trata extensamente este otro componente espacio-temporal. 


\section{- Cambio de composición o composición constante}

Normalmente la composición evoluciona a lo largo de toda la película, ya sea por encuadre o por sucesión de acciones. El cambio de composición tiene lugar por los recursos antes tratados: movimiento de personajes y otros elementos, movimientos de cámara, corte, metamorfosis, etc. Pero también hay animaciones en las que la composición se mantiene más o menos invariable, como la primera mitad de Killing of an Egg (Asesinato de un huevo) (Driessen, 1977), en la que, pese a la actuación del personaje, el encuadre y la disposición de los elementos permanecen casi sin variación (Fig. 46).

La evolución de la composición participa en la expresividad del movimiento y, por tanto, la alteración del cambio compositivo en relación a la evolución total puede ser responsable de que el movimiento sea vivenciado o neutro. Esto ocurre, por ejemplo, en Stressed (Estresados) (Kelly, 1994): la escena de la muerte del hombre (de la que hablamos anteriormente) no es más dinámica que otras de la película, ya que todo este cortometraje es abundante en trayectorias curvas y tiene mucha riqueza de movimiento; pero las escenas anteriores presentan una intensidad narrativa creciente (muestran la vida estresante de las personas, sus miedos, frustraciones, irritaciones y tristezas); hasta que la muerte de este personaje (anónimo dentro de la película) supone una pausa visual (primero la figura permanece estática y sobre ella desfilan en una capa transparente las personas de la ciudad) y, a continuación, significa un alivio en cuanto al contenido (un personaje ha alcanzado la paz) que se representa por medio de tres figuras angelicales de trayectorias muy fluidas y variadas en movimiento.

Otro ejemplo de expresión del movimiento vivenciado por medio del cambio compositivo en el conjunto de la película lo encontramos en L'homme qui plantait des arbres (El hombre que plantaba árboles) (Back, 1987), cuando se refiere a la irrupción de la guerra, se amplía el número de personajes, las trayectorias se cruzan y aumenta su velocidad. En este caso se da imagen a la situación sin representar literalmente los hechos; es principalmente la composición móvil compleja, por medio de la combinación de movimiento de cámara y de los personajes, la que transmite la agitación y confusión emocional de los hechos narrados (00:06:34). Además, se amplía la gama cromática y los colores se vuelven más saturados, factor que también participa en la representación del caos reinante.

La composición móvil total como neutra sería aquella que determina este carácter en la película. Aquellas composiciones globales más estáticas son susceptibles de provocar movimiento neutro, como en las animaciones instructivas que 
hay en la zona de seguridad de los aeropuertos. En estas animaciones, el cambio compositivo, si lo hay, no despierta sensaciones cinéticas, ni transmite el contenido de manera sensorial. No obstante, las composiciones estables también pueden proporcionar el movimiento vivenciado. Los capítulos de Moustique (Mosquito) (Marsily \& Roosens, 2014) presentan composiciones sencillas y que no cambian constantemente; en uno de los capítulos piloto, el mosquito se posa en la axila de un hombre que sostiene unas pesas (00:00:35). La necesidad del hombre de permanecer quieto se traduce en el mantenimiento del plano; esto produce tensión en el espectador (por empatía podemos imaginar el pinchazo del picotazo y la creciente necesidad de rascarse); ese aguantar sin moverse es acentuado por la composición estable; se trata de un caso en el que la composición estática acentúa el movimiento vivenciado (Fig. 47).
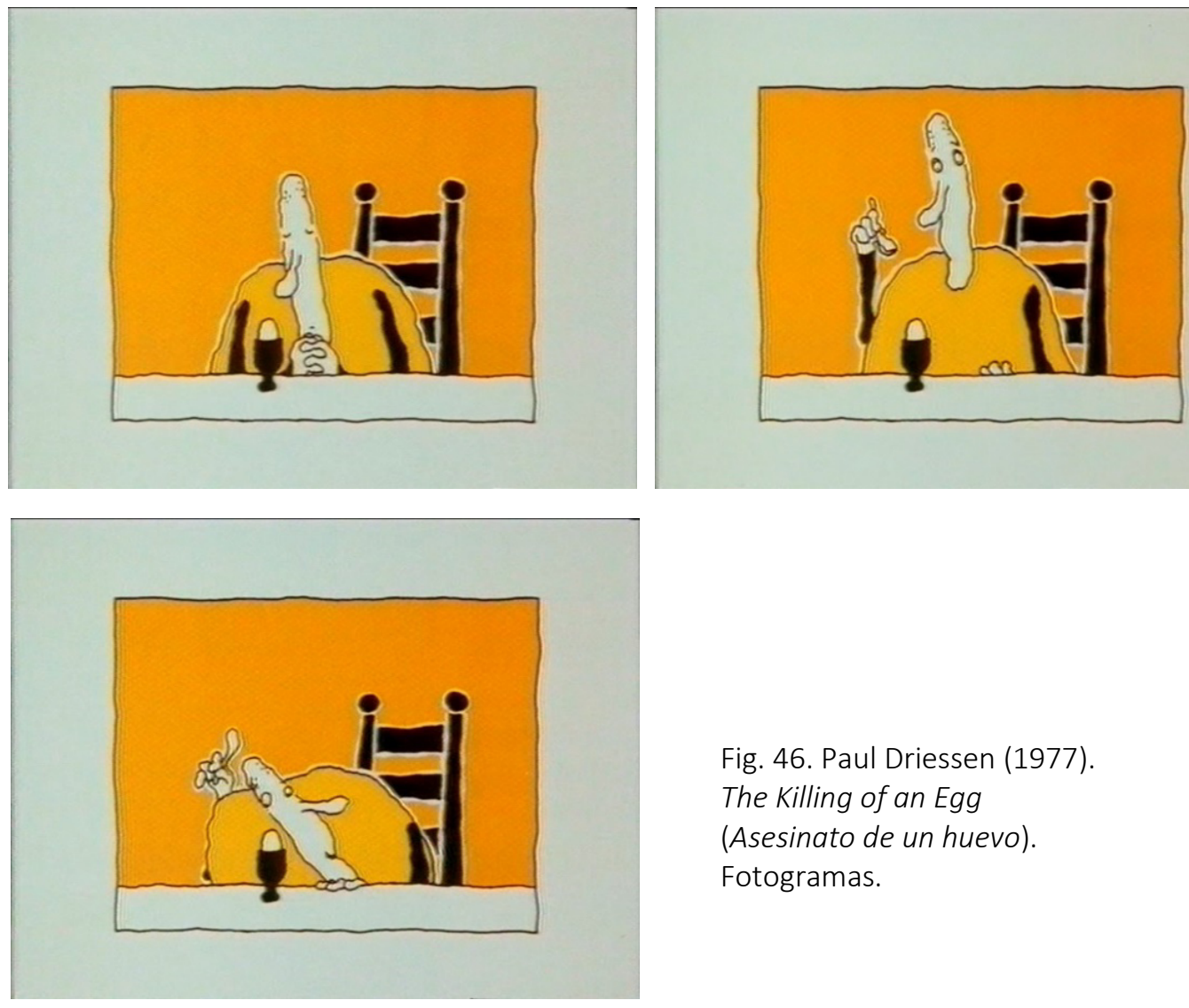

Fig. 46. Paul Driessen (1977).

The Killing of an Egg

(Asesinato de un huevo).

Fotogramas.

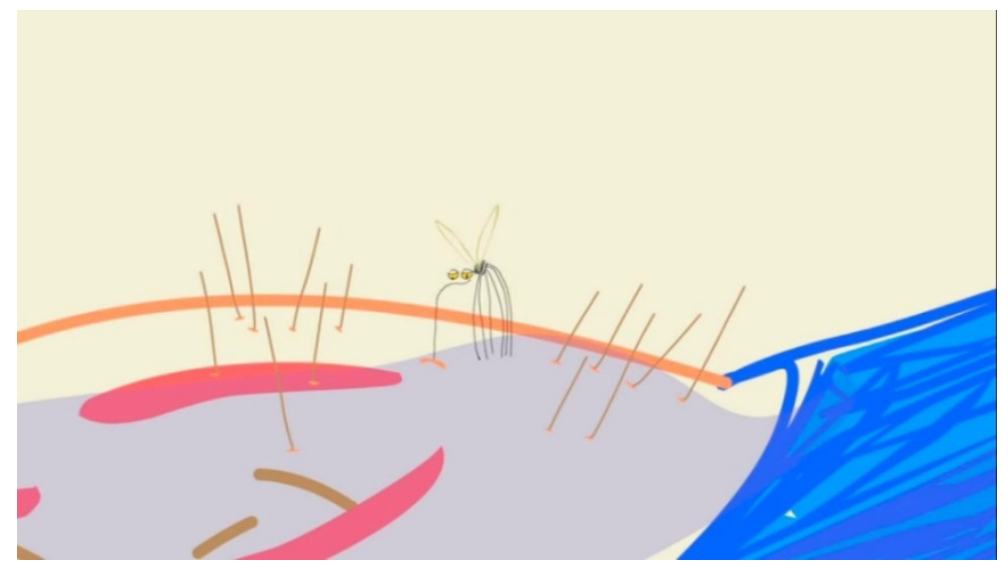

Fig. 47. Noémie Marsily et Carl Roosens (2014). Moustique (Mosquito). 
Los cambios compositivos tienen la capacidad de transmitir sensaciones cinéticas, depende de cómo se presenten, por eso, una composición variada puede propiciar el movimiento vivenciado, aunque la riqueza de puntos de vista, movimientos de cámara, diferentes velocidades y ritmo, etc. no es imprescindible para expresar el movimiento vivenciado, puesto que, como se está recogiendo a lo largo de este capítulo, hay animaciones sin estas cualidades dinámicas que expresan el movimiento de manera muy intensa. Por eso, de poco sirven las fórmulas sobre cómo construir el guión gráfico de una película, como ésta en la que se aconseja la variedad sin justificación:

\begin{abstract}
Cada escena encaja en el ritmo del conjunto. Para un ritmo general excitante en escenas de acción puede ser necesario romper con una escena tranquila de construcción de personaje o una escena cómica. Varíe la localización. Varíe sus planos. Corte entre acción y visión del personaje, comedia y acción, lo negativo y lo positivo. Varíe la duración de las escenas. Varíe las transiciones. ${ }^{58}$
\end{abstract}

\title{
- Composición total
}

La totalidad de la composición, es decir, desde el comienzo de la película hasta que acaba, normalmente sigue un criterio dirigido a cumplir el objetivo de la obra, sea cual sea. Este criterio puede ser una forma o movimiento recurrente, o una estructura, también puede ser una estructura organizada según la intensidad cinética, ya que estos componentes dinámicos están muy interrelacionados (pero en este apartado no hablaremos de la distribución de la intensidad cinética). Una composición que sigue un criterio formal puede reforzar el dinamismo de la película o transmitir o apoyar una idea.

Hay películas en las que la composición dinámica se construye a través de una forma específica, una estructura perceptible para el espectador que organiza el movimiento. Por ejemplo, Travel to China (Viaje a China) (Alkabetz, 2002) tiene un esquema fundamentalmente circular, la planificación a partir de la imagen única sobre la que se realizan tomas describe un círculo al encuadrar partes concretas de la imagen; también el movimiento del espacio que se genera, aunque bastante abstracto, parece seguir esta misma forma circular. Así mismo, el marco cuadrado de Bitz Butz (Alkabetz, 1984)dirige la trayectoria fundamental sobre

\footnotetext{
${ }^{58}$ Wright, 2005, pág. 177, (trad. a.): Every scene fits into the rhythm of the whole. For overall pacing action scenes may need to be broken up with a quiet character-building scene or a comedy scene, especially early in the script. Vary your scenes and your sequences. Vary locations. Vary shots. Cut between action and character insight, comedy and action, the negative and the positive. Vary scene lengths. Vary paces.
} 
este armazón, el cual determina la composición en todo momento. 78 tours (Schwizgebel, 1985) se basa en el giro, como indica el título, e incluso la música es un vals (baile en el que el giro es fundamental). Una estructura de composición global muy poco habitual es la composición en espiral sobre la que se mueve la cámara en La course a l'abîme (La maldición del abismo) (Schwizgebel, 1992) (Fig. 48). Esta estructura general marca la composición de toda la película, ya que determina el desplazamiento de la cámara pero además las trayectorias de los personajes también se adaptan a la misma.

Otras veces, pueden haber rasgos compositivos recurrentes, haya o no una estructura evidente. El predominio de un tipo de movimiento u otro rasgo compositivo dinámico a veces es fácilmente reconocible, como en Libidinis (Peris \& Peris, 2011) donde hay trayectorias curvas en casi todo momento; o la Introducción de Honey, I Shrunk the Kids (Cariño, he encogido a los niños) (Pompian, 1989) en la que, para transmitir que los niños son pequeños, los planos suelen tener un ángulo bastante acentuado, tanto desde arriba como desde abajo. Taratatá la parade (Back, 1977) presenta trayectorias rectas y paralelas al plano de la pantalla en la primera parte del cortometraje, mientras que la segunda parte es abundante en trayectorias circulares y también tiene algunos movimientos en profundidad; esta diferencia compositiva entre la primera y la segunda parte forma parte de la transmisión visual del mensaje de la película: el mundo construido por los adultos se asocia a la trayectoria recta y el de la infancia a la trayectoria curva.

Tanto con estructura compositiva como con reiteración de movimientos, direcciones, etc. no nos referimos al espacio en el que se desarrolla la historia; por ejemplo Quest (Quest, 1996) se desarrolla en diversos escenarios dispuestos uno debajo de otro en vertical, pero en el movimiento del personaje y los objetos móviles no predomina la dirección de arriba abajo. O en Sisyphus (Jankovics, 1974), sabemos que el personaje se desplaza sobre una superficie ascendente, pero la composición móvil no marca esta dirección más que por la inclinación de la línea de tierra, mientras el personaje permanece en el centro de la pantalla. El esquema global al que nos referimos es pues el compositivo dinámico, no necesariamente coincidente, como vemos, con el del escenario.

La forma también es un criterio que otorga un sentido global a la composición móvil. En Triangle (Triángulo) (Russell, 1994) esta forma es el triángulo, representación gráfica del "triángulo amoroso" que protagoniza el cortometraje; pero los personajes no describen trayectorias triangulares, sino que esta forma está pre- 
Fig. 48. Georges Schwizgebel (1992). La curse à l'abîme (La maldición del abismo).

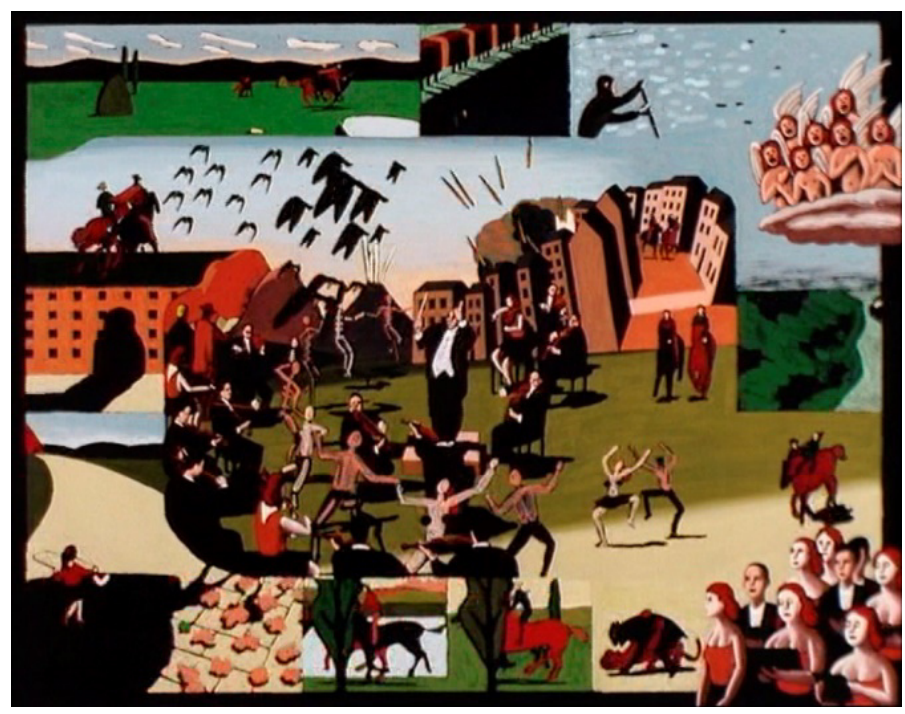

sente en casi todos los planos. En Les trois inventeurs (Los tres inventores)(Ocelot, 1980) son los círculos (casi siempre giratorios) (Fig. 49). Y en How Wings

are Attached to the Back of Angels (Cómo las alas están unidas a la espalda de los ángeles) (Welch, 1996), como vimos en B.3. de este apartado, las formas recurrentes son la línea horizontal, la línea vertical, la línea inclinada $45^{\circ}$ y el círculo, líneas que también se dibujan como trayectorias. Como se observa, la forma recurrente puede ir acompañada o no de un movimiento similar.

La evolución global de la composición participa en la expresión del movimiento y puede, como todos los recursos, apoyar la expresión del movimiento vivenciado y la del neutro. Hemos observado que ni la reiteración de formas, ni la reiteración de acciones o características dinámicas, ni una estructuración específica determina que el movimiento sea neutro o vivenciado.

\section{- Continuidad compositiva}

La composición en animación, como hemos visto, está en transformación. En su desarrollo a lo largo de la obra, puede evolucionar de tal manera que transmita continuidad visual.

En animación se pueden entender varias cosas por continuidad:

- Por un lado está la continuidad como visionado en sucesión de los fotogramas. Al visualizar en sucesión los fotogramas de una animación, percibimos las formas 

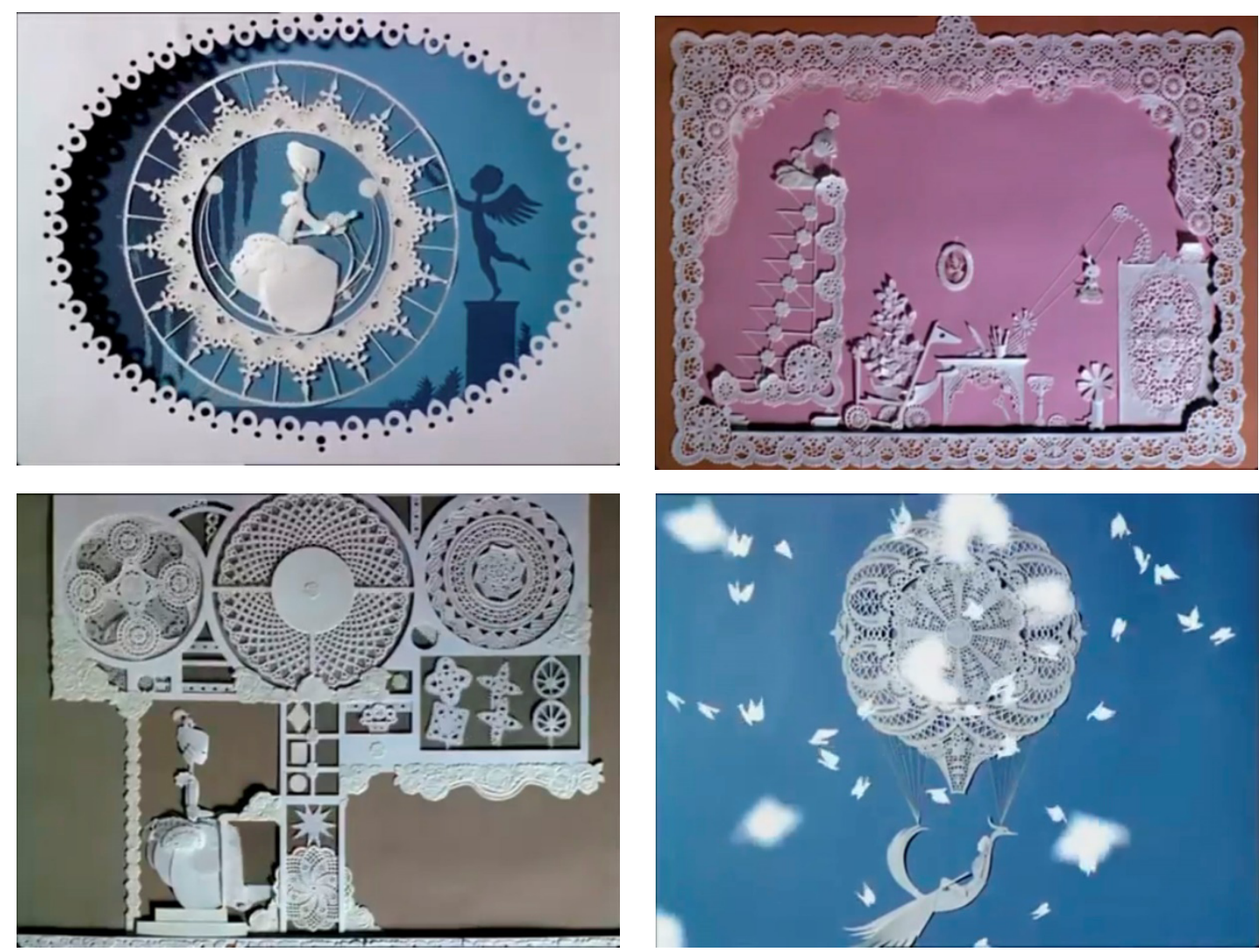

Fig. 49. Michel Ocelot (1980). Les trois inventeurs (Los tres inventores).

Fotogramas de diversas escenas.

representadas en esas imágenes como si correspondieran a una única forma en movimiento. Este fenómeno genera continuidad entre imágenes fijas, consecuencia del movimiento real del dispositivo y el fenómeno óptico de la persistencia de la imagen en la retina. Esta continuidad, como ya hemos visto, existe por defecto.

- Cuando se habla de continuidad también se remite al racord. Éste se refiere a la continuidad espacio-temporal representada por medio del montaje, de modo que una secuencia hecha a partir de diferentes tomas parece acontecer en el mismo espacio-tiempo. El término se extiende a la animación para referirse a la representación coherente de un plano a otro, que da a entender si lo que se muestra entre planos es o no el mismo espacio-tiempo. Así, si los personajes permanecen en un sitio, aunque el punto de vista cambie, se sigue entendiendo la comprensión del espacio-tiempo representado y la entidad de los sujetos. Esto es lo que Arnheim Ilama "movimiento dirigido" y, según él, es el factor perceptual más fuerte del cine. ${ }^{59}$

\footnotetext{
${ }^{59}$ Arnheim, 1979, pág. 394
} 
- Sin embargo ninguna de éstas es la continuidad visual compositiva a la que nos referimos. Con continuidad compositiva nos referimos a la fluidez de la imagen y a la constante transformación de la composición. Transmitir esto depende de mucho más que de la visualización de los fotogramas uno tras otro a determinada velocidad, sino del desarrollo de la composición, del cambio o constancia de la intensidad cinética y de la valoración espacio-temporal.

\section{Elementos que intervienen:}

La continuidad visual reside principalmente en la composición móvil, pero también se debe a la valoración espacio-temporal y a la distribución de la intensidad cinética. No existe método por el cual se obtenga indiscutiblemente, aunque sabemos que hay características que la propician, principalmente aquellas que no interrumpen la imagen: los planos largos, los planos-secuencia y la sucesión de acciones.

Cada película que presenta continuidad visual compositiva lo hace de diferentes maneras: Las animaciones de Georges Schwizgebel tienen una gran continuidad visual plástica por predominancia del plano-secuencia, sin corte. Las películas The Street (Leaf, The Street (La calle), 1976) (La calle) y Le chapeau (El sombrero) (Cournoyer, 1999) tienen continuidad visual por cambio sustancial para pasar de unos planos a otros en la primera y plano-secuencia compuesto por metamorfosis en la segunda. Otras películas tienen continuidad visual por una conjunción de varias características, como The Message (El mensaje) (Krumme, 2000) y Stressed (Estresados) (Kelly, 1994), en las que se produce principalmente por los movimientos de cámara y la sucesión de acciones de los personajes. Todas ellas tienen en común que el ritmo visual "atrapa" la mirada.

Pero también hay secuencias de planos cortos que generan ritmo y simples montajes por cortes que transmiten continuidad, ya que el corte como paso de unos planos a otros, aun suponiendo un abrupto cambio de imagen, no tiene porqué detener la lectura de los acontecimientos mostrados en pantalla; de hecho, por medio de la planificación con corte se pueden componer escenas de gran dinamismo y fluidez en las que la yuxtaposición o continuación de trayectorias puede colaborar activamente en la expresión dinámica. Cuando el corte se da entre planos que no se relacionan dinámicamente ni compositivamente aunque correspondan a la misma secuencia (sean largos o cortos), entonces sí que entrecortan la visualidad de la película y a veces incluso pueden provocar confusión visual, como en Velocity (Glusiec, 2012). También hay planos largos y planos-secuencia en los que, por la ausencia de acciones, se detiene la continuidad compositiva, como ocurre con los largos planos de Anomalies (Cady, 2012), que 
no se relacionan visualmente. Así pues no hay una norma infalible por la que se obtenga continuidad compositiva.

Un ejemplo de continuidad compositiva es Tántalo (Peris R. , 2010). En este cortometraje la composición está en movimiento de principio a fin; visto prácticamente todo desde el mismo punto de vista, la sucesión de acciones y el modo de desplazamiento son variados, pero con las trayectoria curvas y las rotaciones como constante, como se ve desde la primera secuencia: una parra crece desde la esquina inferior derecha, se extiende por el margen del espacio compositivo y al alcanzar más o menos el punto de inicio es relevada por unas adelfas que emergen del lado inferior. Éstas describen una trayectoria en espiral que ocupa la mayor parte de la pantalla, hasta desenrollarse y desplazarse a la izquierda, movimiento que se concatena con la trayectoria, también curva, que describen un hombre y una mujer que se desplazan corriendo; la mujer, al llegar al centro de la pantalla, da un giro completo sobre sí misma, lo que se conecta con un cambio de dirección que la lleva a salir del plano "acercándose" a la cámara; el hombre extiende los brazos pero permanece en el centro de la pantalla. Éste es sólo un ejemplo; las variantes compositivas por desplazamientos y acciones de los elementos móviles (personajes, objetos, formas abstractas, etc.) son muy variadas.

La continuidad visual mece al espectador, lo transporta en un flujo de movimientos; cuando hay continuidad visual, esta sucesión incesante de acontecimientos atrapa la mirada y, de alguna manera, excita la sensación de vivir un viaje visual que, cuanto más dura, más excita la sensación cinética. En este sentido la continuidad visual contribuye a que el movimiento sea vivenciado. Pero una composición por planos unidos por cortes, también colabora a que el movimiento sea vivenciado cuando el cambio de plano, por conectarse con el siguiente, o por cambiar de velocidad, o por el ritmo dinámico que genera, provoca sensaciones cinéticas.

Hemos observado que con frecuencia las animaciones con movimiento neutro tienen planos más largos, con pocos y poco llamativos movimientos y pueden sucederse tanto por fundidos como por corte; pero también hay movimiento neutro en sucesiones de planos más cortos y con movimiento llamativo. Un ejemplo es la representación de los jinetes de Massinissa corriendo a la carga en la animación documental Numancia (Jimeno Martínez \& de la Torre Echávarri, 2009): la velocidad de la acción en combinación con el movimiento de cámara 
Fig. 50. Alfredo Jimeno Martínez y Jose Ignacio de la Torre Echávarri (2009).

Numancia. Serie de fotogramas.
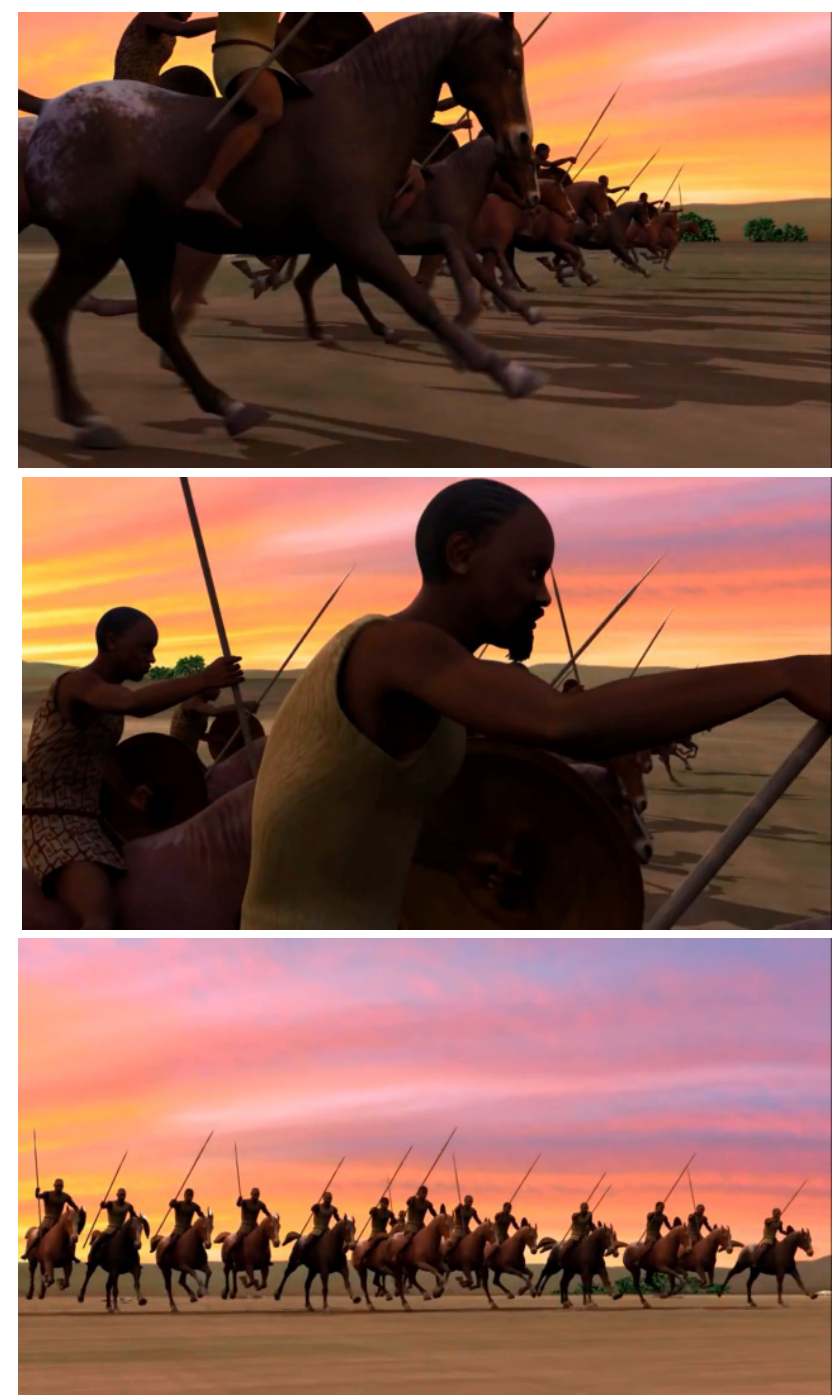

sin duda hace de ésta una escena muy dinámica, no obstante, el movimiento "robótico" de los personajes y el movimiento regular de la cámara proporcionan una expresión más próxima al movimiento neutro que al movimiento vivenciado (00:08:27) (Fig. 50). También correspondería a una sucesión de planos neutra aquella que se ajustara a un modo de hacer que correspondiera a un estilo de animación específico, no obstante, si tal modo de hacer, aunque con fórmulas repetidas que garantizan el éxito, despertara sensaciones cinéticas, esta cualidad se impondría sobre su lenguaje estándar.

La sucesión de planos que provoca movimiento vivenciado es aquella que por medio del transcurso de planos despierta sensaciones cinéticas o presenta otras cualidades del movimiento vivenciado. De los ejemplos que hemos visto, la escena de Rurroini Kenshi presenta movimiento vivenciado potenciado por la sucesión de planos (caso en el que las cualidades del movimiento vivenciado sobresalen respecto a la homogeneidad que caracteriza al neutro); en otras animaciones la composición es vivenciada por otros valores compositivos tan diversos 
que no podemos catalogar recursos compositivos que la proporcionan, sólo podemos afirmar que la continuidad visual, los cambios de velocidad y las sucesiones de planos cortos suelen ser estimulantes y atractivos, pero esto no proporciona movimiento vivenciado de manera asegurada y estas características, como hemos visto, también pueden darse en la animación de movimiento neutro.

\section{CONCLUSIONES SOBRE LA INFLUENCIA DE LA COMPOSICIÓN MÓVIL EN LA REPRESENTACIÓN DEL MOVIMIENTO VIVEN- CIADO Y EL MOVIMIENTO NEUTRO.}

A partir de lo expuesto anteriormente y de los análisis realizados, extraemos las siguiente ideas respecto a qué elementos de la composición móvil influyen y cómo en la expresión del movimiento vivenciado y neutro.

\section{- Forma y proporción del formato}

\section{- Cambio de formato}

Ningún formato determina en absoluto que la expresión del movimiento sea vivenciada o sea neutra; lo determinante es cómo se desarrolla la composición en el formato de cada obra. Lo mismo ocurre con el cambio de formato.

\section{- Corte cinematográfico}

- Cortes entre acciones que interrumpen el movimiento

- Cortes entre acciones concatenadas

El corte es uno de los métodos más habituales de conexión entre planos. Dependiendo de cómo se use, puede apoyar la expresión del movimiento o perjudicarla. Los cortes entre acciones que interrumpen el movimiento pueden crear confusión visual o romper el ritmo dinámico cuando ocurren entre planos breves; pero aunque esto no ayuda mucho a la creación del movimiento vivenciado, esto no los convierte en medio para representar el movimiento neutro. Cuando los cortes que interrumpen la acción suceden entre planos más prolongados, tienen todavía menor influencia. Por el contrario, los cortes también pueden darse entre planos cuyo movimiento se entrelaza o genera un ritmo visual; esta cualidad del montaje sí puede propiciar el movimiento vivenciado, ya que puede transmitir sensaciones dinámicas.

\section{- Continuidad compositiva}

En animación, la continuidad compositiva atrapa la mirada y es visualmente atractiva, por eso la continuidad compositiva puede ayudar a expresar las sensa- 
ciones de la vivencia del movimiento. No obstante, a pesar de propiciar el movimiento vivenciado, su presencia o ausencia en la obra no implica ni indica si el movimiento se expresa como neutro o como vivenciado.

\section{- Fundidos entre planos}

- Metamorfosis y movimiento de cámara para cambiar el plano

Estos recursos sirven para generar continuidad compositiva (aunque no siempre la transmiten). En sí mismos no son recursos que impliquen expresión de movimiento vivenciado ni neutro.

\section{- Planos-secuencia}

- Sucesión de acciones

\section{- Continuidad de trayectorias}

Estos recursos colaboran en la creación de una composición visual fluida, lo cual puede evocar sensaciones cinestésica, por tanto, colabora positivamente en la expresión del movimiento vivenciado, pero no lo proporcionan indiscutiblemente.

\section{- Abundancia de planos largos}

- Abundancia de planos cortos

La duración de los planos influye en la composición global y por tanto en que el movimiento sea vivenciado o neutro. Según el movimiento que se desee expresar o la sensación que se desee transmitir, los planos largos o los cortos serán indicados para crear movimiento vivenciado. El movimiento neutro tampoco se obtiene por el uso de planos de mayor o menor duración, aunque las animaciones de videos educativos o de contenido científico suelen usar planos largos (aunque también se pude conseguir movimiento neutro con planos cortos), preferencia que propicia la presentación del contenido de manera expositiva más que sensorial.

\section{- Las trayectorias generan el cambio compositivo}

El cambio de composición de un plano a otro, así como por el movimiento de los elementos dentro del plano puede provocar sensaciones cinéticas $y$, por tanto, puede ayudar a expresar el movimiento vivenciado, pero todo depende de cómo se use.

\section{- Movimientos de cámara por animación.}

- Planos subjetivos (mirada del personaje)

Los movimientos de cámara por animación con frecuencia sugieren la mirada en primera persona, aunque no representen planos subjetivos. Como vimos en 
el capítulo 1, mostrar el movimiento como si se viviera en primera persona es un recurso para expresar el movimiento vivenciado, no obstante, para expresarlo así no basta con encuadrar lo que vería el personaje, si no que el movimiento de cámara debe ayudar a transmitir el movimiento.

Además hemos observado la influencia de estas otras características:

- Se muestran diferentes composiciones

- Variedad de acontecimientos.

- Variedad de trayectorias y velocidad.

- Variedad de movimiento de los personajes y otros elementos, del espacio y de cámara.

- Hay cambio sustancial de los personajes y otros elementos y/o del espacio.

Ninguna de estas características influye en la representación del movimiento como vivenciado o como neutro. La variedad del movimiento que se muestra en pantalla no implica de qué manera se expresa éste; tampoco si se trata de cambio local o sustancial.

\subsubsection{DISTRIBUCIÓN DE LA INTENSIDAD CINÉTICA}

\section{A. QUÉ ES}

La distribución de la intensidad cinética es la evolución de la intensidad del movimiento a lo largo de toda la película. Al abarcar la totalidad de la obra, en ella participan directamente la valoración espacio-temporal de cada acción y la composición móvil. Como veremos en el capítulo 3. Representación del movimiento vivenciado y neutro a través de la valoración espacio-temporal, el concepto de "timing" normalmente abarca tanto las acciones individuales como toda la película. Al englobar el dinamismo de toda la película, consideramos que esta acepción de timing adquiere cualidades distintivas como componente dinámico que es necesario estudiar separadamente de lo que concierne al dibujo de cada acción individual (la representación pormenorizada de acciones), que es el punto central de la valoración espacio-temporal. La distribución de la intensidad cinética es por tanto la valoración espacio-temporal del conjunto de la obra.

Algunos autores, como Pedro Delgado, incluyen todos los elementos de una película en la definición de "timing": 
Cada cartoon va a transmitir al espectador humor, inquietud por su personaje preferido, tensión si éste representa a su héroe, etc., junto a la satisfacción posible por el disfrute estético a través del color, el silencio o el sonido, el recreo visual por la puesta en escena y la manera en la que se ha animado. Un cúmulo de aspectos que también favorecerá que se produzca una sensación global, única, la del timing. Que no se trata de la duración, sino del efecto general que ese o aquel dibujo animado van a producir en el espectador: la sensación que van a transmitir. ${ }^{60}$

Respecto a lo que no hay duda es que esta definición de "timing" afecta tanto a la totalidad de la película como a elementos concretos. En esta investigación delimitaremos toda esa inmensidad de elementos a la intensidad de movimiento y al ritmo que genera la distribución temporal de esa intensidad. No incluimos en esta consideración la composición móvil, así como ningún otro elemento grafico-plástico (tratamiento de la superficie) o de audio. Lo hemos denominado "distribución de la intensidad cinética" porque consideramos que con este nombre se recogen los dos elementos que la forman y que son inseparables. También nos referiremos a este componente dinámico como tempo ${ }^{61}$.

Además de ayudar a plasmar lo característico de cada acción, la intensidad cinética también puede reforzar el mensaje, la idea o emoción representada. Esto puede ser por medio de la concordancia o contraste entre la intensidad cinética con la intensidad de otros elementos: el relato, el sonido, etc.

La figura 51 representa un plan de sincronización entre música y movimiento. Evidencia la similitud entre ambos elementos. En esta gráfica los acentos del movimiento parecen estar representado por los círculos oscuros en contacto con la línea inferior de la banda. En este apartado presentamos los gráficos de la distribución de la intensidad cinética de varias películas; en ellas hemos marcado más alto los momentos de mayor intensidad (al contrario que en la fig. 51); Los gráficos son orientativos; la intensidad cinética no se ha medido cuantitativamente, sino que simplemente se trata de dar imagen a la impresión que produce el ritmo dinámico.

La distribución de la intensidad cinética juega un papel importante en la expresión del movimiento vivenciado y neutro. La evolución de la intensidad a lo largo de la película puede transmitir sensaciones cinéticas, puede usarse para representar o reforzar las características peculiares de cada acción, pero también es clave en la transmisión de las emociones e ideas. Cada cadencia e

\footnotetext{
${ }^{60}$ Delgado, 2000, pág. 88

61 "Tempo" es el término usado aisladamente en The Illusion Of Life: Disney Animation (Thomas \& Johnston, 1981, pág. 368) para referirse a lo que creemos es la distribución de la intensidad cinética.
} 
Fig. 51. s/a. Sincronización entre música y movimiento para una animación (s/f).
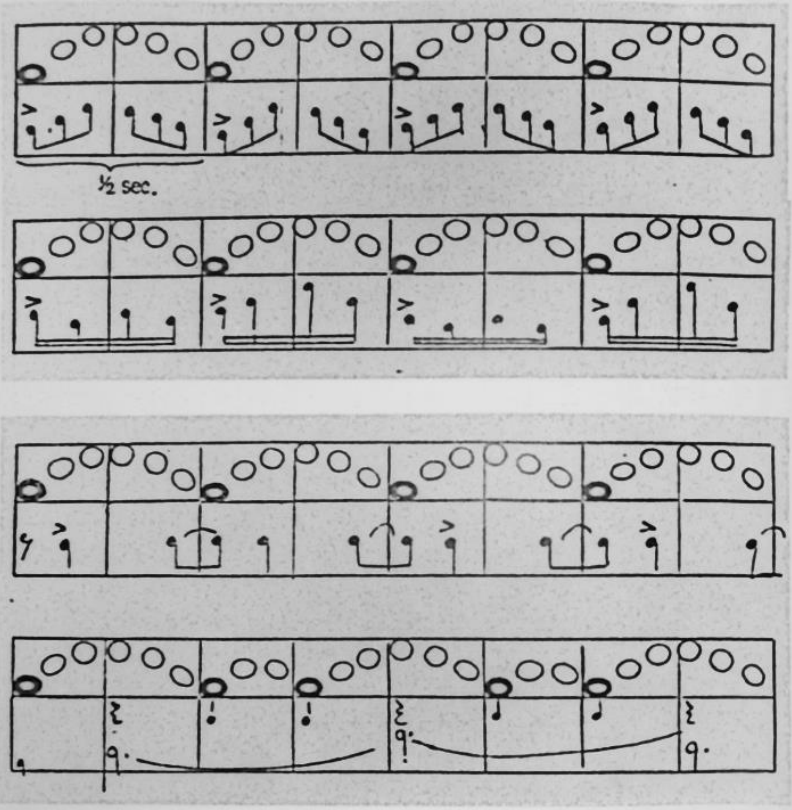

intensidad pueden ser valiosas para producir diferentes efectos, no corresponden necesariamente a una única significación, por ejemplo, un ritmo rápido puede ser frenesí, euforia, alegría, nerviosismo, acoso, etc. Y un ritmo regular puede transmitir monotonía, aburrimiento, opresión, comicidad, etc.

Una distribución de la intensidad cinética vivenciada o neutra sería aquella que presentara cualidades que propusimos en el capítulo 1 como propias de estos tipos de expresión. Así, la intensidad cinética vivenciada es aquella que sugiere sensaciones cinéticas como si se viviera (o contemplara) el movimiento personalmente. En el caso del movimiento neutro, la intensidad del movimiento se presentaría de manera tal que no transmita sensaciones cinéticas. En cuanto a la cualidad uniformadora del movimiento neutro, hay tempos que repiten la estructura de la misma manera y con la misma intención expresiva, de manera que, en cierto modo su evolución es predecible. Por ejemplo, hay películas que repiten algunas estructuras de intensidad cinética, como una gran intensidad seguida de quietud y silencio absoluto para el título. No obstante, hemos observado que la repetición de estructuras de intensidad cinética no impide que se transmitan sensaciones cinéticas $y$, por otro lado, no hay tempos claramente codificados, por lo que, la homogeneidad no es un valor significativo de la distribución de la intensidad cinética.

La distribución de la intensidad cinética puede expresar las características del movimiento y potenciarlo, puede transmitir parte del contenido, provocar sensaciones cinestésicas o puede tener un objetivo eminentemente plástico. La intensidad del movimiento tiene tanto poder visual que puede ser el agente 
principal de las cualidades del movimiento vivenciado en animaciones en las que otros componentes dinámicos no son particularmente expresivos.

\section{B. LA EXPRESIVIDAD DEL MOVIMIENTO A TRAVÉS DE LA DIS- TRIBUCIÓN DE LA INTENSIDAD CINÉTICA}

A continuación se plantean varios aspectos de la distribución de la intensidad cinética: las propiedades de la intensidad alta o baja, la distribución regular e irregular de la intensidad cinética y la intensidad creciente y decreciente.

\section{B.1. La intensidad}

La intensidad de una animación se genera por todos los elementos visuales, de audio y contenido que la forman. Pero en lo que respecta al movimiento, la intensidad cinética depende básicamente de la velocidad y la cantidad de elementos en movimiento. Una intensidad suave se da cuando hay pocos elementos móviles en pantalla, éstos tienen velocidad más o menos lenta, no realizan cambios bruscos, los planos son largos o se suceden con fundidos encadenados, etc. Hay más intensidad cinética cuando hay muchos elementos móviles a la vez, el movimiento es rápido, los planos son cortos, etc. También los efectos ópticos de vibración y post-efectos aumentan la intensidad cinética. Toda intensidad es eficaz para transmitir diversas sensaciones.

La intensidad cinética puede colaborar en la expresión del movimiento al acentuar las características dinámicas de la acción representada. En The Owl Who Married a Goose (El búho que se casó con una gansa) (Leaf, 1974), vemos muy bien la intervención de la intensidad cinética en la representación del movimiento característico de los personajes. En esta animación, ningún personaje se mueve más rápido que otro, tanto el búho como los gansos presentan un movimiento sereno. Sin embargo, los gansos se muestran siempre en grupo, por lo que a pesar de su movimiento lento, todos juntos aumentan la intensidad cinética y transmiten la algarabía de la bandada; mientras que el búho sólo tiene una intensidad cinética menor. Esta diferencia en la intensidad genera un ritmo según se muestran en pantalla uno u otros personajes y acentúa la diferencia entre el búho y los gansos, donde radica el hilo conductor de la historia.

La expresión del movimiento vivenciado y neutro puede sustentarse o ser re- 
forzada por este componente dinámico, ya sea mediante intensidad alta o baja, y haya o no equivalencia entre la intensidad cinética y el momento narrativo.

\section{- Intensidad alta o baja para expresar el movimiento}

Existen todos los gradientes imaginables de intensidad cinética, desde los más altos a los más bajos. La intensidad cinética alta implica mayor dinamismo y una baja intensidad cinética proporciona escenas menos dinámicas. The wind subsides (El viento se calma) (Jevremovic, 1997) presenta intensidad progresivamente creciente. La primera parte del cortometraje es un plano de un paisaje, los dibujos se suceden con fundidos encadenados, y transmiten el ambiente tórrido de la Savannah africana. La intensidad cinética aumenta con la entrada en escena de un ñu, y se hace aún más intensa con la aparición de un guepardo, que transmite cada vez más velocidad gracias al aumento de la intensidad cinética, provocado por la velocidad de la acción, el cambio de técnica y los efectos ópticos por alternancia del color del fondo. Finalmente el guepardo atrapa a su presa (la cual ha estado fuera de plano en casi todo momento), precisamente este instante no es tan dinámico. Por el contrario en L'homme qui plantait des arbres (El hombre que plantaba árboles) (Back, 1987), el ritmo monótono y lento de la animación apoya la generación de un ambiente de vida sosegada. Los movimientos de cámara son complejos y muestran al mismo tiempo a los personajes en acción, sin embargo en este caso, la baja velocidad y la regularidad de éstos (sin evidentes cambios de velocidad) baja la intensidad cinética.

La intensidad cinética alta es propicia para despertar sensaciones cinéticas, pero no proporciona incondicionalmente movimiento vivenciado. De la misma manera, la intensidad cinética baja es propicia para el movimiento neutro. No obstante, esto no siempre implica este tipo de expresividad; a veces es necesaria suavidad cinética para expresar el movimiento como vivenciado. En definitiva, puede requerirse cualquier grado de intensidad cinética, según el movimiento representado o la sensación cinética que se desea transmitir.

La batalla entre Clouds y Sephiroths en Final Fantasy VII. Advent Children (Nomura \& Takeshi, 2005) (Fig. 52) transmite gran intensidad cinética. En esta animación la acción es todavía más veloz que en The wind subsides, y son otros factores los que aumentan la intensidad cinética: sucesiones de planos cortos y movimientos de cámara complejos (también rápidos), cambios de velocidad bruscos, acciones complicadas (los personajes realizan giros en el aire al tiempo 
que se desplaza la cámara), también se muestran explosiones, llamaradas y relámpagos que cambian la luz de la escena con flashazos. En este caso, la conjunción de elementos provoca sensaciones dinámicas, lo que acerca esta animación a la expresión del movimiento vivenciado. Una animación con intensidad cinética opuesta a la de esta escena de combate es Sr. Trapo (Díez, 2002), aquí la lentitud tal vez excede la expresión de un ambiente deprimente (llega incluso a resultar difícil seguir el hilo de la historia), pero la baja intensidad de movimiento contribuye sin duda al ambiente lúgubre y, al llegar el momento de mayor intensidad cinética (el Sr. Trapo tiene que coger un tren pero se le ha enganchado la maleta), la lentitud del personaje (en contraste con la intensidad del sonido) transmite impotencia.
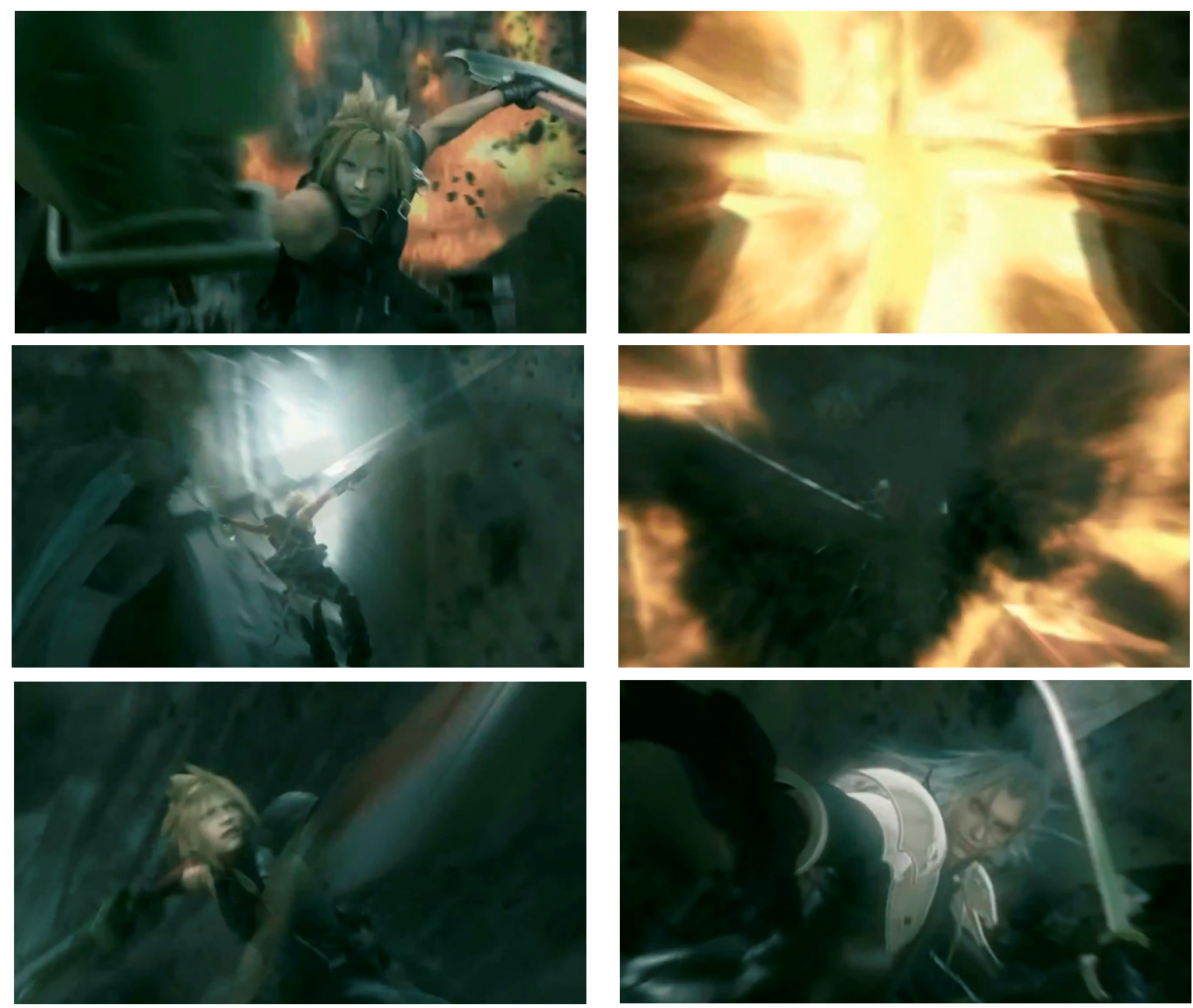

Fig. 52. Tetsuya Nomura y Takeshi Nozue (2005). Final Fantasy VII. Advent Children (Fantasía final VII. Los hijos del advenimiento). Serie de fotogramas.

Detengámonos en un caso curioso. Una animación realmente morosa es la de los títulos de crédito de Those Magnificent Men in Their Flying machines or How I Flew from London to Paris in 25 hours 11 minutes (Esos chalados en sus locos 
cacharros o cómo volé de Londres a Paris en 25 horas y 11minutos) (Searle, 1965). La animación de los aviones no tiene un sentido muy protagonista, ya que son simples, aunque decorativos, portadores de los créditos (Fig. 53) (no como en Honey, I Shrunk the Kids - Cariño, he encogido a los niños - , en la que veíamos cómo la animación previa anuncia claramente el tono de la película). A primera vista puede considerase que en estos otros títulos de crédito se representa el movimiento neutro. $Y$ en cierto modo es muy cierto, sobre todo por su lentitud y movimiento regular, y por la ausencia de expresividad. No obstante, tras ver la película se comprueba que la animación ya era heraldo de la historia que antecede, en la que la lentitud, morosidad y repetición acaban siendo los elementos cómicos. Por lo que, en este sentido, no se puede considerar neutro, aunque llamarlo vivenciado fuera tal vez demasiado, sí al menos se comprende que su lentitud y monotonía es más expresiva de lo que parece en un principio. Además, la exagerada lentitud de los aviones es una burla a las velocidades que alcanzaban en la época en que se ubica la historia.

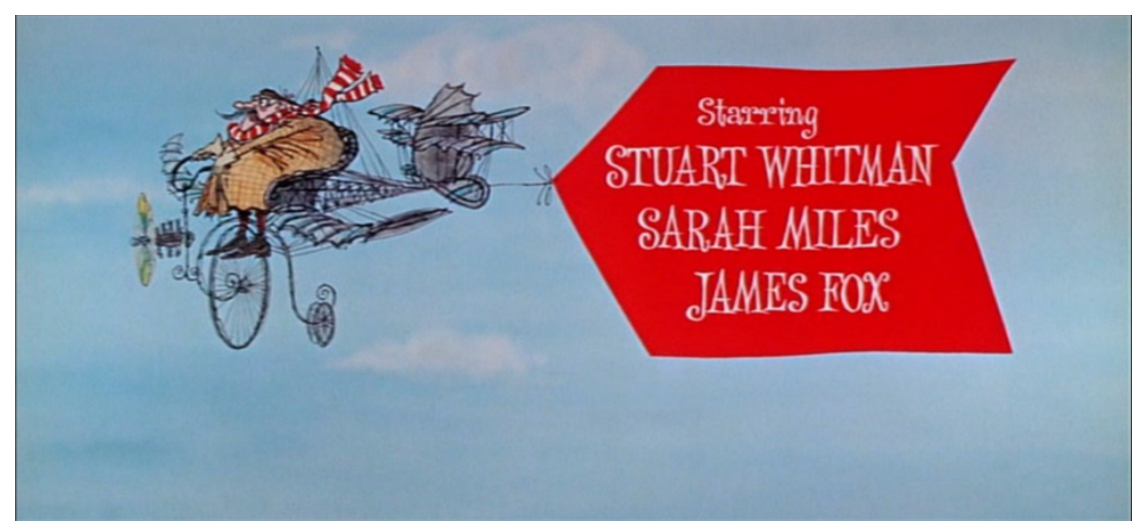

Fig. 53. Ronald Searle (1965). Créditos animados de Those Magnificent Men in Their Flying machines or How I Flew from London to Paris in 25 hours 11minutes (Esos chalados en sus locos cacharros o cómo volé de Londres a Paris en 25 horas y 11 minutos).

\section{B.2. Distribución de la intensidad}

Cualquier manera de distribuir la intensidad cinética a lo largo de la película puede apoyar la expresión del movimiento como vivenciado o neutro, todo depende de la manera en que se use para representar los acontecimientos. Este componente dinámico puede presentar especial protagonismo o simplemente tener presencia como un elemento expresivo más. El ritmo dinámico de la película es muchas veces crucial para la comunicación de sentimientos e ideas, así como en la expresión del movimiento vivenciado. A continuación analizamos, a 
través de varios tipos de distribución cinética, cómo el movimiento vivenciado y el neutro se potencian o generan gracias a este componente dinámico.

- Intensidad regular o irregular, por contraste y rítmica. Variedades y uso expresivo

La intensidad cinética puede ser regular o irregular a lo largo de la película. Aunque una distribución irregular de la intensidad (con cambios de velocidad, alternancia de intensidades, etc.) es más dinámica que la distribución regular, ambas posibilidades pueden ser adecuadas para expresar el movimiento vivenciado, dependiendo de cómo se presenten. Analizaremos pormenorizadamente varias animaciones con distinta distribución cinética.

La intensidad irregular es frecuente en muchas películas y tiene infinidad de variaciones. En la anteriormente mencionada Tout Rien (Todo nada) (Back, 1978) hemos visto que la intensidad del movimiento cambia a lo largo de la animación, presentando tres partes diferenciadas que mantienen una intensidad irregular pero dentro de unos límites. En otras películas la intensidad evoluciona progresivamente de suave a fuerte, o incluso sin grandes cambios. Otras presentan ritmo cambiante por contraste. En los Walt Disney Studios prestaban especial atención al ritmo variado. Según Thomas y Johnston:

Según nuestra experiencia, una imagen que pretenda excitación continua y tensión dramática nunca mantenía la atención de la audiencia. Parecía embotar sus sentidos. Podía haber un tema fuerte subyacente, pero la historia tenía que ser contada con un equilibrio de tempos e ideas frescas. ${ }^{62}$

Para estos animadores la clave está en un rimo variado y en la originalidad. Y dicen que no hay un método de trabajo automático que dote a la película de estas cualidades ${ }^{63}$.

La variedad de intensidades puede tener diversos fines. Puede tener presencia principalmente plástica: en Rubicon (Alkabetz, 1997), la intensidad cinética aumenta progresivamente, decrece, aumenta de nuevo más rápidamente y decrece una vez más en la última parte de la película (de esta última parte se po-

\footnotetext{
${ }^{62}$ Thomas \& Johnston, 1981, pág. 368, (trad. a.): In our experience, a picture that attempt continuous excitement and dramatic tension never held the attention of the audience. It seemed to dull their senses. There could be a strong underlying theme, but the story had to be told with a balance of tempos and fresh ideas.

${ }^{63}$ Thomas \& Johnston, 1981, pág. 367
} 
dría decir que el ritmo decae, como separándose del resto de la película). En esta animación la distribución de la intensidad es el componente fundamental de la película, que se presenta como un juego estético más que como expresión de emociones o ideas. No obstante, es la cadencia de la intensidad cinética la que provoca sensaciones dinámicas. Ciertamente la evolución de la intensidad cinética de esta obra es comparable a una pieza musical.

El cambio de ritmo puede usarse para expresar el contenido emocional, como en Swamp nyz sumpf (Pantano) (Alkabetz, 1991) (Fig. 54). En esta animación dos ejércitos de caballería se mantienen a flote en un cenagal gracias a los globos que contrarrestan el peso de sus armaduras. En la lucha por los globos, se descubre el delicado equilibrio del sistema que los mantiene a flote. El ritmo alterno de la intensidad del movimiento, marcado por altos contrastes (estatismo-dinamismo, movimientos lentos-movimientos rápidos y acciones cortasacciones prolongadas) colabora en la creación del ambiente agresivo y silencioso en el que viven estos seres. Los personajes se mantienen en espera, quietos (siempre con la vibración que produce la materia plástica) y acto seguido comienza una contienda de alto dinamismo y relativamente larga, tras la cual se recupera la quietud anterior.

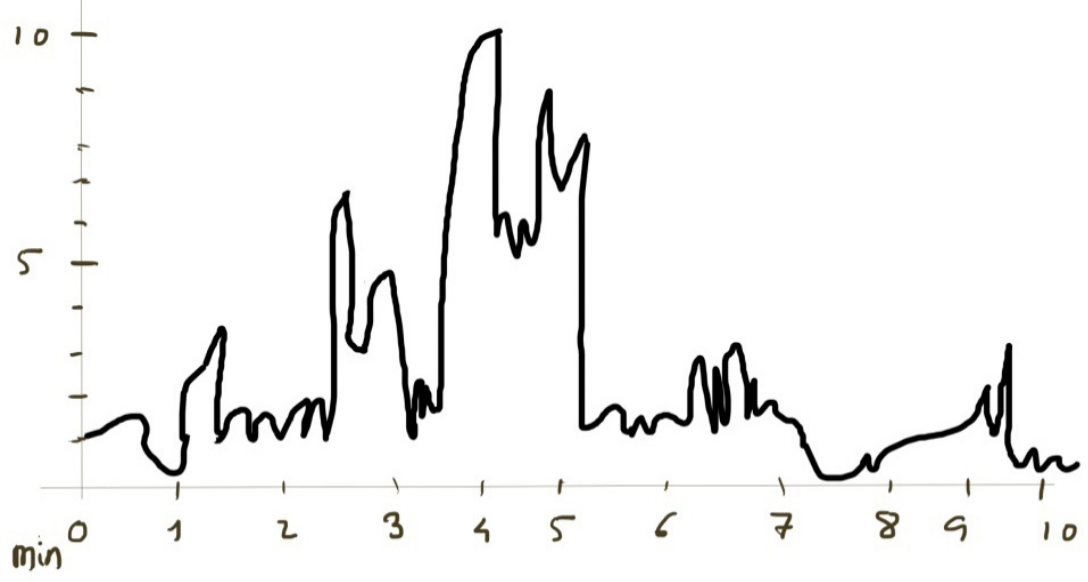

Fig. 54. Rosa Peris (2015). Gráfico de intensidad cinética de la película Swamp nyz sumpf (Alkabetz, 1991).

El cambio de intensidad provoca una cadencia que puede caracterizarse por el ritmo, como en Yankale (Alkabetz, 1995), donde en varias secuencias la intensidad es determinada por la acción: la gente caminando marca la dirección arriba-abajo que se prolonga en varios planos (00:04:12). También presenta este ritmo Bitz-Butz (Alkabetz, 1984), pero en este caso la intensidad rítmica es constante, se extiende a todo el cortometraje, como si estuviera marcada por un 
diapasón. La acción crece y decrece en ritmo debido a la acción misma. Otra manera de generar ritmo es mediante la duración de los planos y por el movimiento que en ellos tiene lugar. En Illusion? (¿llusión)? (Back, 1975), se repite dos veces una misma estructura (00:06:47) (Fig. 55):

- Forma geométrica vibrando.

- Niños trabajando en cadena de montaje (distribución reticular, movimiento rítmico).

- El plano se cubre paso a paso por formas geométricas.
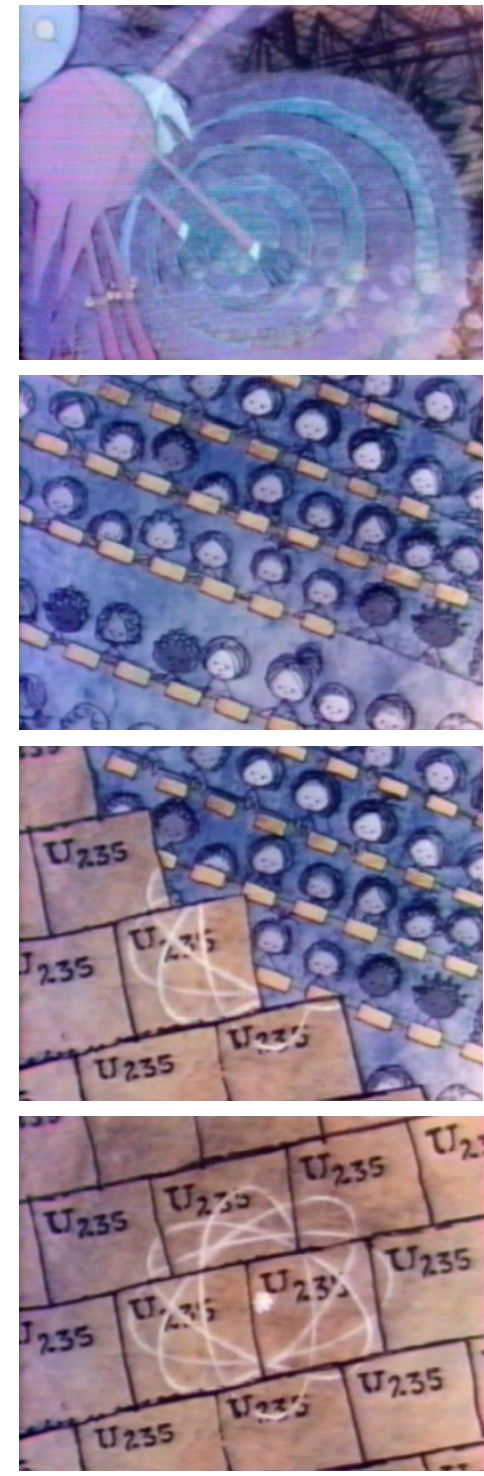
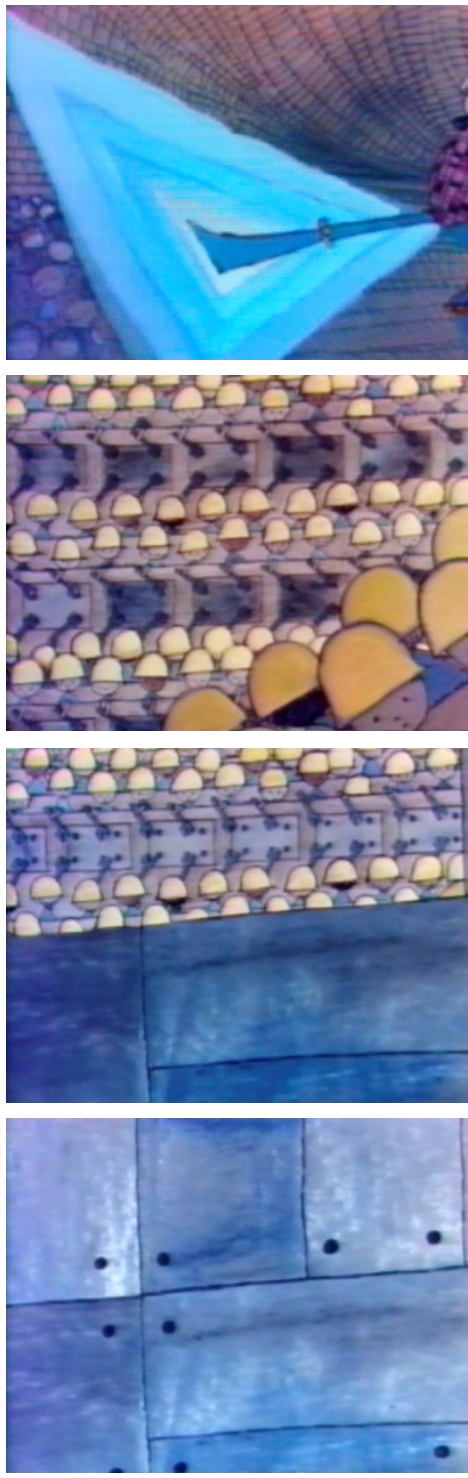

Fig. 55. Frédéric Back (1975). Illusion? (¿llusión?). Dos series de fotogramas.

La distribución irregular de la intensidad no siempre colabora tan evidentemente en la expresividad de la película. Hay animaciones en las que la distribución cinética no es tan significativa para la representación del movimiento o no participa activamente en la expresión del mensaje. En Carnival (Carnaval) 
(Young, 1986), la intensidad sube y baja, pero no genera una estructura o unos cambios que potencien el movimiento; no es el elemento central de la expresividad de la obra, en la que es mucho más relevante la valoración espaciotemporal.

La distribución regular puede colaborar igualmente en la expresión del movimiento vivenciado. La monotonía puede ser la característica principal de algunas acciones, y hay animaciones en las que es prioritaria la creación de monotonía visual, como en La revissement de Frank N. Stein (El encanto de Frank N. Stein) (Schwizgebel, 1982) (Fig. 56) [en DVD]. Se trata de una animación no narrativa en la que, por medio de un plano subjetivo, se atraviesa en primera persona un espacio geométrico de sucesivas habitaciones, con un movimiento balanceante que indica los pasos. El movimiento balanceante se asocia finalmente con la criatura de Frankstein, a la que vemos en la escena final rechazada por un grito de espanto. El ritmo al que se atraviesan las estancias es altamente regular. Pero es precisamente en esa monotonía donde reside parte importante del peso expresivo de la película. Se transmite un ambiente de opresión, el espectador se adentra en un estado de ánimo cada vez más profundo; cada repetición, cada introducción a través de una nueva puerta aumenta esta sensación hipnótica. La intensidad regular del movimiento y el ritmo que genera el balanceo son muy importantes, ya que el largo plano del caminado en primera persona por este espacio psicológico (no real) ayuda en cierto modo a empatizar con la criatura cuando es abiertamente rechazada.

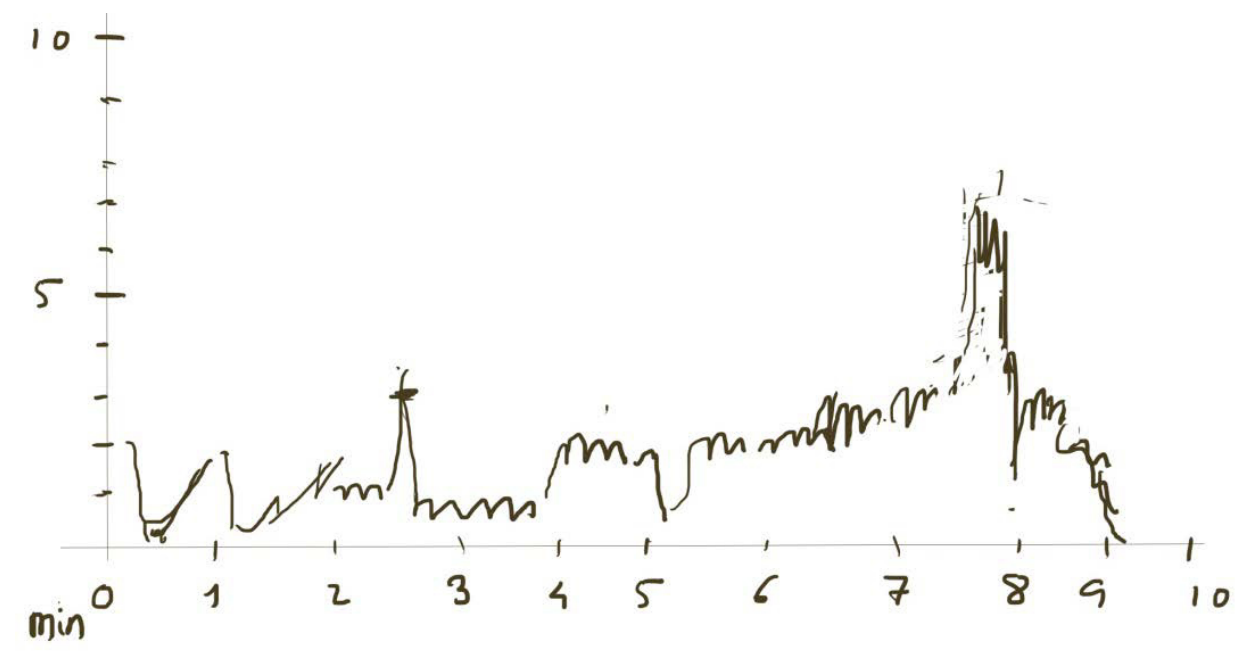

Fig. 56. Rosa Peris (2015). Gráfico de intensidad cinética de la película La ravissement de Frank N. Stein (Schwizgebel, 1982).

La poulette grisse (La gallina gris) (McLaren, 1947) (Fig. 57) da imagen a una canción de cuna. Esta animación se desarrolla con intensidad cinética muy suave 
y regular. Se presenta el mínimo de movimiento. Los pocos movimientos que se muestran son lentos desplazamientos de cámara, fundidos encadenados de progresión lenta (la imagen cambia a baja velocidad) y transformaciones de una imagen a otra (el dibujo de una gallina incubando se convierte poco a poco en una imagen con siete huevos), es decir, no se representa ninguna acción, sólo cambios de imagen. La lenta evolución de la nana está precedida y seguida de una introducción y un cierre muy parecidos: en la cabecera, la cámara avanza hacia el fondo del paisaje, siguiendo una trayectoria de arriba abajo, como los saltos de un ciervo o conejo; en el cierre, se muestra el mismo movimiento en sentido contrario, "hacia afuera". Esto concede a la película una estructura simétrica. La mayor intensidad de movimiento de estos fragmentos sirve de transición hacia la parsimonia del cuerpo de la película. El ritmo monótono y suave es fundamental para provocar relajación y serenidad, características acordes con la canción a la que da imagen.

Una distribución de intensidad cinética regular mantiene un "tono" específico a lo largo de la escena (o incluso de la obra completa, por lo que tiene la capacidad de generar una atmósfera, un ambiente. En los primeros 2 minutos y 20 segundos (los primeros planos de la película) de Le fleuve aux Grandes Eaux (EI poderoso río) (Back, 1993), no todas las acciones tienen la misma velocidad (la forma humana que representa el mar se mueve lentamente; las aves son veloces en su aleteo y desplazamiento), pero todas mantienen una velocidad constante, además utiliza largos fundidos encadenados entre imágenes (como el movimiento del mar y el plano de las ballenas) y entre planos (el cambio del mar al plano del continente visto desde arriba, y luego de nuevo al mar). La sucesión de planos de timing regular, y muchos de ellos lentos, provoca un ritmo que mece la mirada, es hipnótico.

Así mismo, la distribución regular de la intensidad cinética es propia del movimiento neutro, ya que a través de ésta es más sencillo mantenerse en la imparcialidad. En el render de la recreación de la catedral de Santiago de Compostela ${ }^{64}$, se ofrecen diversas perspectivas que permiten imaginar el aspecto que el edificio tendría en la época en que se construyó. Se compone sencillamente de desplazamientos de cámara, y la intensidad cinética es regular en todo el video. La ausencia de ritmo es típica de estas presentaciones, con las que se pretende mostrar un espacio de manera objetiva y sin ninguna implicación expresiva. Así, el espectador es, en primer lugar, informado y puede juzgar por sí mismo el contenido de la animación.

${ }^{64}$ TVE, 2013 


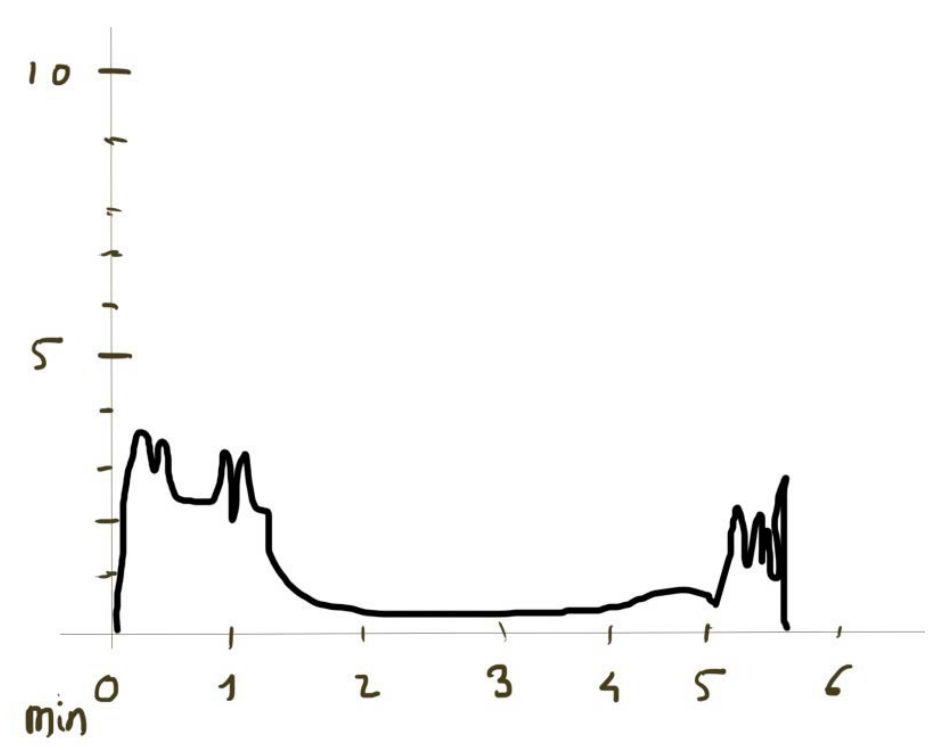

Fig. 57. Rosa Peris (2015). Gráfico de intensidad cinética de la película La poulette grisse (McLaren, 1947).

La distribución regular de la intensidad cinética también puede truncar el ritmo visual en algunos casos. Puede producir monotonía al margen de la línea expresiva de la película, es decir, que la ausencia de cambios de intensidad cinética no colabore en la expresión del movimiento y, por tanto, transmita una regularidad más parecida a la de los videos expositivos. Este tipo de regularidad de la distribución cinética aporta a la animación cualidades del movimiento neutro. Así, encontramos obras en las que, pese a la riqueza de movimientos y la abundancia de movimientos de cámara, parece que el ritmo regular resta relevancia al dinamismo, la hace lenta sin razón aparente.

\section{- Cambio de intensidad creciente-decreciente. Variedades y uso expresivo}

Cuando la intensidad es irregular, ésta puede tener una cadencia creciente o decreciente, lo que también puede usarse para expresar el contenido de la película. Para el animador, tener en cuenta la distribución de la intensidad cinética ayuda a dirigir este elemento hacia lo que se desea expresar. El aumento o descenso de la intensidad puede ayudar a expresar la evolución de la situación. Y puede ser responsable del movimiento vivenciado, porque los cambios son propicios a despertar sensaciones dinámicas. Los cambios de intensidad pueden ser progresivos o inmediatos, y ambos dinamizan la distribución de la intensidad cinética (Fig. 58). 


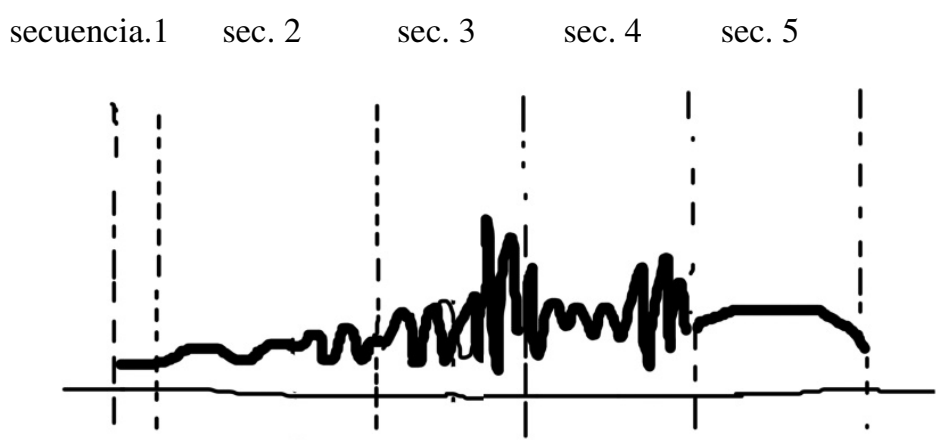

Fig. 58. Rosa Peris (2015). Gráfico de intensidad cinética de la película Tututú (Rosa Peris, 2012).

\section{Cambio de intensidad progresivo}

El cambio de intensidad progresivo, sobre todo si se prolonga en el tiempo, enfatiza la idea de evolución que representa, por ejemplo, Los niños tienen derecho al descanso (Unicef, 1979), es fundamental la ralentización del niño cuando se va a dormir y el frenetismo de las actividades del día; ambas velocidades se acentúan progresivamente mediante un montaje en el que se resume cada vez más la actividad del niño. La alta velocidad potencia la representación del estrés y la lenta, el cansancio. La subjetividad del tiempo mediante los resúmenes y dilataciones temporales, más el contraste de la velocidad, muestran la historia desde el punto de vista del niño, el protagonista, por lo que empatizamos con él e incluso podemos sentirnos identificados.

\section{Cambio de intensidad inmediato}

Cuando la intensidad cinética aumenta o disminuye drásticamente, pueden provocarse sensaciones dinámicas debido al contraste de velocidad, de cantidad de elementos, etc. El cambio repentino puede resultar estimulante, como vemos en Schlaf (Dormir) (Gentinetta \& y Braun, 2011), donde la distribución de la intensidad cinética se organiza por alternancia de fuerte-suave: a pasajes con muchos elementos y movimiento progresivamente rápido (en el mismo plano) se contraponen pasajes de composición más sencilla, con menos elementos y de movimiento lento, de menor intensidad. En esta película se ve claramente cómo la distribución de la intensidad cinética está en relación absoluta con la composición móvil (Fig. 59). Además, en este cortometraje la intensidad del sonido es acorde con el movimiento, lo que clarifica todavía más la estructura compositiva. Se trata también de un juego visual por ritmo.

Las posibilidades de distribución de la intensidad cinética son tan variadas como películas hay. La introducción de Who Framed Roger Rabbit? (¿Quién engañó a Roger Rabbit?) (Zemeckis, 1988) presenta tanto aumento progresivo de 
Fig. 59. Claudius Gentinetta y Frank Braun (2011). Schlaf (Dormir). Fotogramas de varios planos.
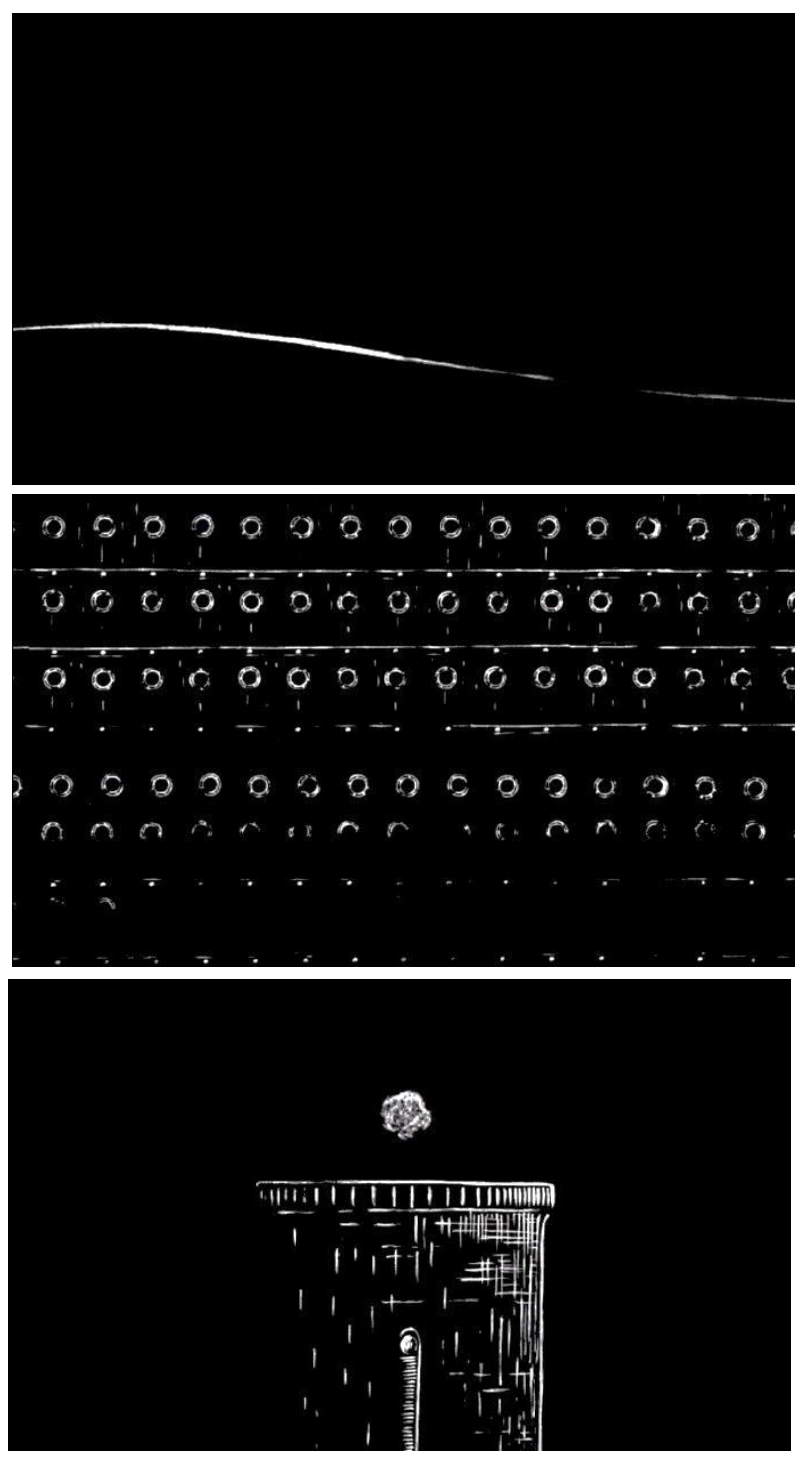

la intensidad como cambios inmediatos. Los movimientos delicados del niño se suceden de planos de dinamismo cada vez mayor.

Todo cambio en la intensidad cinética, ya sea por progresión o inmediato, por medio de las cualidades que ofrece, puede aprovecharse para expresar las característica de la acción representada o transmitir parte del contenido de la película. En Seiltänzer (El baile de la cuerda) (Krumme, 1986), la relación de los personajes evoluciona de una relación de poder a una de dependencia del antiguamente poderoso hacia su víctima; este cambio de situación se acompaña de la reducción de la intensidad cinética. El cambio en la intensidad del movimiento ayuda a comprender que el cambio de situación del personaje de opresor a dependiente se representa aquí como algo digno de compasión. En Le moine et le poisson (El monje y el pez) (Dudok de Wit, 1994), tras el creciente frenetismo del monje por hacerse con un pez, el progresivo aumento de la intensidad cinética decrece en la última secuencia, simbolizando que los personajes han hallado la 
serenidad: la obsesión del monje por el pez ha trascendido hasta convertirse en parte integrante de él y no conflictiva.

La conclusión es que no hay una intensidad ni una manera de distribuirla que proporcione incuestionablemente la expresión del movimiento como vivenciado o como neutro. Depende de cómo se use y de lo que se desee transmitir con ello.

\section{CONCLUSIONES SOBRE LA INFLUENCIA DE LA DISTRIBUCIÓN DE LA INTENSIDAD CINÉTICA EN LA REPRESENTACIÓN DEL MOVIMIENTO VIVENCIADO Y EL MOVIMIENTO NEUTRO}

De los elementos que intervienen en la configuración de la distribución cinética y los análisis realizados, extraemos las siguientes conclusiones respecto a si influyen o no y cómo en la expresión del movimiento vivenciado y neutro.

\section{- Intensidad cinética alta o baja.}

La alta intensidad cinética puede propiciar la transmisión de sensaciones dinámicas y, por tanto, puede ayudar a expresar el movimiento vivenciado. Por el contrario, el movimiento neutro parece darse con frecuencia en animaciones de intensidad cinética baja. No obstante, toda intensidad es apta para expresar el movimiento vivenciado, ya que las sensaciones cinéticas no se limitan a la movilidad más fuerte; y puede expresarse con viveza todo movimiento, ya sea lento o rápido, con mayor cantidad de elementos o menos, etc.

\section{- Intensidad cinética discontinua.}

Aunque esto dota de mayor dinamismo a la película, no determina que el movimiento sea vivenciado ni neutro. Dependiendo de cómo se utilice, la intensidad irregular puede provocar sensaciones cinestésicas debido al cambio de velocidad o puede comunicar el contenido de la película, o por el contrario puede generar movimiento neutro.

\section{- Intensidad cinética uniforme.}

Aunque proporciona menor dinamismo, no determina que el movimiento sea vivenciado o neutro, ya que puede ser precisamente un ritmo regular lo que proporcione movimiento vivenciado, según lo que se represente. No obstante, el ritmo regular es frecuente en las animaciones deliberadamente objetivas (como videos de contenido científico). 


\section{- Cambio de intensidad cinética por contraste.}

Cualquier contraste visual puede provocar dinamismo. Así ocurre en el caso de la distribución de la intensidad, por lo que una animación con contrastes de intensidad de movimiento puede provocar sensaciones dinámicas con más facilidad que una sin contrastes, aunque, como siempre, esto depende de cómo se presente esta característica. La presencia de esta propiedad en una animación no es signo unívoco de que el movimiento se exprese como vivenciado.

\section{- Cambio de intensidad cinética progresivo.}

Aunque provoque menor intensidad cinética, puede ser altamente expresivo y puede provocar o potenciar sensaciones cinestésicas. Su presencia o ausencia no determina que el movimiento se exprese como vivenciado o como neutro.

\section{- Intensidad cinética creciente, decreciente o rítmica.}

Cualquier intensidad cinética y cualquier distribución de la misma en el conjunto de la película es susceptible de provocar sensaciones cinéticas dependiendo de cómo se use. No hay una manera de distribuir la intensidad dinámica de modo que proporcione movimiento vivenciado o neutro de manera garantizada.

\subsubsection{PRESENTACIÓN DE LA HISTORIA. EL RELATO}

\section{A. QUÉ ES}

La narración o manera en que se presenta una historia, también propio de los medios orales y escritos, tiene herramientas particulares en el campo audiovisual. El relato se manifiesta a través de los otros componentes dinámicos. La manera en que se presentan los acontecimiento que ocurren en un espaciotiempo no está íntimamente relacionado con la representación del movimiento entendido como la acción; la presentación de la historia afecta más al tiempo y a lo que se ve o se sabe sobre lo que le ocurre a los personajes, que con la representación del movimiento. Pero la alteración del tiempo y el punto de vista, así como los giros narrativos, pueden afectar a la representación del movimiento como acción. Además, la relación entre el relato y la distribución cinética también puede propiciar el movimiento vivenciado y el neutro.

La narración es un campo muy amplio que no podemos abarcar en este estudio, por lo que en este apartado no nos adentraremos en cómo la manera en que se organiza el relato supone una presentación alterada del espacio-tiempo 
(entendido como plano de la existencia) y la creación de un mundo diegético que se da a conocer a través del relato, sino que nos centraremos exclusivamente en aquellos puntos del relato que creemos que afectan directamente a la representación del movimiento como acción. Además, abarcamos tanto las animaciones narrativas como las nos narrativa. Respecto al relato narrativo o no narrativo, la animación, como obra plástica audio-visual, puede preponderar su cualidad de obra plástica en transcurso o como narración. Esta cualidad la hará para unos autores el medio idóneo para narrar un relato, para otros, el medio ideal para expresar ideas en transcurso sin componer una narración.

Un relato que potencia el movimiento vivenciado es aquel que, por la manera en que presenta los acontecimientos (el orden, la duración y la frecuencia de los hechos, los giros y sorpresas narrativas, y el punto de vista desde el que se narra) ayuda a transmitir el movimiento como si se vivieran en primera persona, o acentúa las sensaciones cinéticas o la transmisión del contenido emocional recae en el movimiento. Torre Bawher y Glory Voctory (Gloria Victoria) (Usev, 2013; 2006), por su ritmo e intensidad, despiertan pasión y visceralidad, en este caso dirigido a una finalidad política. Por el contrario, un relato neutro es aquel en el que los acontecimientos se presentan de la manera más objetiva y fría posible (como los videos explicativos que ya hemos mencionado). Además, un relato homogéneo a otros ( $\mathrm{y}$ por tanto que tuviera esta cualidad del movimiento neutro) es aquel que adopta un particular modo de contar extendido en el campo audiovisual, más allá de los recursos que nuestra percepción requiere para interpretar correctamente la narración. Como ocurre con los otros componentes espacio-temporales, la industria ha generalizado unas pautas para construir el relato. Luis Martín Arias se refiere a la independencia de las convenciones narrativas como un riesgo a través del cual puede lograrse la creación de una obra estética. Por la similitud con lo que ocurre en la animación, detengámonos en su comparación entre Vértigo y Falcon Crest:

Ahora bien, frente al telefilme, $<<$ Vértigo $>>$ se dilata en exceso, se hace $<<$ lenta $>>$
y reiterativa; hay incluso secuencias enteras, cuando no escenas y planos que
$<<$ sobran $\gg>$, desde el punto de vista de una estricta y pragmática comunicación
del argumento al espectador. Pero, precisamente, en esa $<<$ lentitud $>>$, en ese dis-
pendio absurdo, visto desde la lógica puramente narrativa y comunicacional de un
telefilm, estriba el posible valor $<<$ estético $>>$ de la película, en tanto que supone
un riesgo: de ser rechazada, de ser incomprendida o mal interpretada; o interpre-
tada en exceso, más allá de las intenciones argumentales de su $<<$ autor $>>$ o auto-
res. En la escena de $<<$ Falcon Crest $>>$ es muy difícil que el telespectador añada al-
go, pues el producto está perfectamente acabado; mientras que en la secuencia de 
$<<$ Vértigo >>, el desajuste entre representación y argumento deja la fisura por la que el exceso interpretativo puede desplegarse. ${ }^{65}$

A continuación veremos los principales elementos del relato que influyen en la representación del movimiento como acción: el punto de vista desde el que se presentan los hechos (no nos referimos al campo visual de un personaje, al plano como ocularización), la representación del tiempo, los giros narrativos y la concordancia entre relato e intensidad cinética.

\section{B. LA EXPRESIVIDAD DEL MOVIMIENTO A TRAVÉS DE LA PRE- SENTACIÓN DE LA HISTORIA}

\section{B.1. El punto de vista desde el que se presenta la historia}

El punto de vista desde el que se presentan los acontecimientos puede ser el de uno o varios personajes y puede mostrarse tanto por medio de una narración en primera persona, como por medio de un narración en tercera persona o de un narrador omnisciente, pero que por el contenido se da a entender que se muestran las opiniones o impresiones de un personaje (ver comentario del capítulo 1 sobre Vértigo, pág. 68). Esto puede influir en que el movimiento sea vivenciado, ya que, como vimos en el capítulo 1, este tipo de representación se caracteriza por inspirar la vivencia personal de la acción, y una narración en primera persona, o que facilite la identificación o conexión emocional del espectador con los personajes, ya es un paso hacia el movimiento vivenciado, incluso aunque no coincida con el campo visual, es decir, lo que ve el personaje. Aunque, como ya también observamos en el capítulo 1, la representación de lo que ve el personaje no implica necesariamente movimiento vivenciado; así mismo, la narración en primera persona tampoco tiene necesariamente esta capacidad.

En The Killing of an Egg (Driessen, 1977), se narra la misma historia dos veces, cada vez desde un punto de vista. La primera secuencia consiste en un personaje que rompe la cáscara de un huevo para comérselo, al tiempo que una voz pide auxilio desde el interior del huevo. La secuencia culmina con la muerte del habitante del huevo; a partir de aquí el personaje que rompió el huevo se ve en el papel del ser que pedía ayuda, repitiéndose la historia pasa a paso, cíclicamente. Como nota todavía más irónica, la voz que pide ayuda desde el interior del pri-

${ }^{65}$ Martín Árias, 1997, págs. 88-90 
mer huevo es la misma que la del personaje que lo rompió (el audio es el mismo repetido), por lo que el espectador comprende inmediatamente que la historia está a punto de repetirse. Encontramos la misma estructura en el cortometraje Umbra (Sombra) (Sutherland, 2010) en el que el autor también muestra la misma historia dos veces, narrada desde dos puntos de vista (tampoco es exactamente una repetición, sino una situación que evoluciona cíclicamente). Primero unos pequeños seres se precipitan a la nada al caer en la sombra que proyecta el protagonista (la sombra arrojada se convierte en agujero). El protagonista no quiere ser responsable de la desaparición de más de estos seres, por lo que se tumba en el suelo, haciendo que su cuerpo no proyecte sombra. Más adelante, por el desarrollo de la historia, el protagonista vive la misma situación que los serecillos del principio (su papel, y así su punto de vista, se ha cambiado por el de estos personajes); en esta escena se da a entender el drama de los personajes diminutos y su necesidad apremiante por arrojarse a la nada. El autor consigue que el espectador se implique con el personaje, tanto bajo la primera perspectiva de la historia como bajo la segunda, en definitiva, hace que se comprenda el drama de todos los personajes. El punto de vista junto al tipo de movimientos y expresiones de los personajes, así como la valoración espacio-temporal ayudan a comunicar la problemática de la historia, a empatizar con los personajes, lo que acentúa el movimiento vivenciado.

\section{B.2. La representación del tiempo}

La representación del tiempo es uno de los elementos que tienen en común todos los medios narrativos, literatura, teatro, cine, cómics y novelas gráficas, animación... En todos estos medios el espacio-tiempo se presenta en transcurso. La presentación de la historia es uno de los componentes dinámicos de la animación y, como tal, participa en la expresión del movimiento vivenciado o neutro. Una de sus influencias sobre el movimiento se realiza sobre todo a través de la alteración del tiempo. Pero no nos referimos a la alteración temporal que tiene lugar en la valoración espacio-temporal (ver apartado 3.2.2. Alteración del espacio y el tiempo.), es decir, el dibujo de las acciones particulares, sino al transcurso de los acontecimientos. Pero para que la alteración temporal que supone el relato participe activamente en que la expresión móvil sea vivenciada, la representación del tiempo debe exceder la eficacia del lenguaje cinematográfico, ya que en este medio toda película es una presentación alterada del tiempo que aceptamos y comprendemos, forma parte de la contemplación estética, pero sin que afecte necesariamente a la representación de las acciones. 
Hablaremos de recursos que influyen en el relato a partir de los conceptos que Gerard Genette emplea en la literatura ${ }^{66}$ (habitualmente aplicados al cine): orden, duración y frecuencia. El orden, duración y frecuencia del relato configuran una sensación temporal particular en cada animación.

\section{- Orden}

El orden de los acontecimientos puede influir en la representación del movimiento. Tanto si es lineal como no lineal, el relato puede ser estimulante. El orden de los acontecimientos puede mostrar cómo vive un personaje la historia, lo que sería un primer acercamiento a la expresión vivenciada de los hechos. Hay casos en los que la alteración del orden afecta directamente a la representación de la acción, como en Ex-enfants (Ex-niños) (Drouin, 1994), donde se representa cómo el pensamiento del joven retrocede hasta alcanzar en su memoria el punto de inflexión en su vida, un momento en el que era feliz previamente al inicio de la serie de acontecimientos que lo llevan a la situación actual: herido de muerte en la guerra. Es evidente que en esta obra el orden del tiempo afecta a la representación del movimiento, ya que cada acción se representa al revés (de atrás hacia delante, invirtiendo el orden de los fotogramas). Además, es fundamental la inversión del tiempo para transmitir el dramatismo de los hechos y conmover al espectador; aunque la inversión del orden de las acciones no las hace vivenciadas.

Aunque un orden anacrónico, inverso o no lineal puede dinamizar el relato y hacerlo estimulante, no afecta a la expresividad del movimiento a no ser que esté dirigido precisamente a ver la historia desde la perspectiva de un personaje, como en el caso de Ex-enfants; por ejemplo, un relato anacrónico podría expresar el movimiento vivenciado si representara un personaje mareado o desorientado. Por el contrario, 78 Tours (78 vueltas) (Schwizgebel, año) presenta también orden anacrónico y la expresión del movimiento vivenciado en esta película recae en la composición móvil (por las abundantes trayectorias curvas y la continuidad visual que cautiva la mirada). Un orden lineal tampoco afecta negativamente a la expresión del movimiento vivenciado ni propicia el movimiento neutro, así lo creemos dada la existencia de numerosas animaciones de orden lineal en las que el movimiento se expresa como vivenciado, por lo que entendemos que no lo impide: Seiltänzer (El baile de la cuerda) (Krumme, 1986), Tout rien (Todo nada) (Back, 1978), Private eyes (Ojos privados) (Lemany, 2011), Tántalo (Peris R. , 2010), etc. son lineales. En estas animaciones el movimiento es viven-

\footnotetext{
${ }^{66}$ Genette, 1972
} 
ciado debido a cómo son los otros componentes dinámicos, y el orden lineal del relato no resta expresividad a su movimiento.

En la animación con movimiento neutro también hay relatos con orden lineal o no lineal, anacrónico, inverso, etc. pero esto tampoco determina que la representación del movimiento sea más o menos neutra. Por ejemplo, el documental sobre Numancia (Jimeno Martínez \& de la Torre Echávarri, 2009) presenta los acontecimientos históricos en orden cronológico, lineal, mientras que el video de instrucciones de seguridad de la compañía aérea LAN (LAN Airlines, s/f) [en DVD], no tiene orden cronológico, sino que muestra en sucesión situaciones aisladas unas de otras (uso del cinturón de seguridad, cómo ponerse el chaleco salvavidas, qué hacer en caso de despresurización, etc.) (Fig. 60).
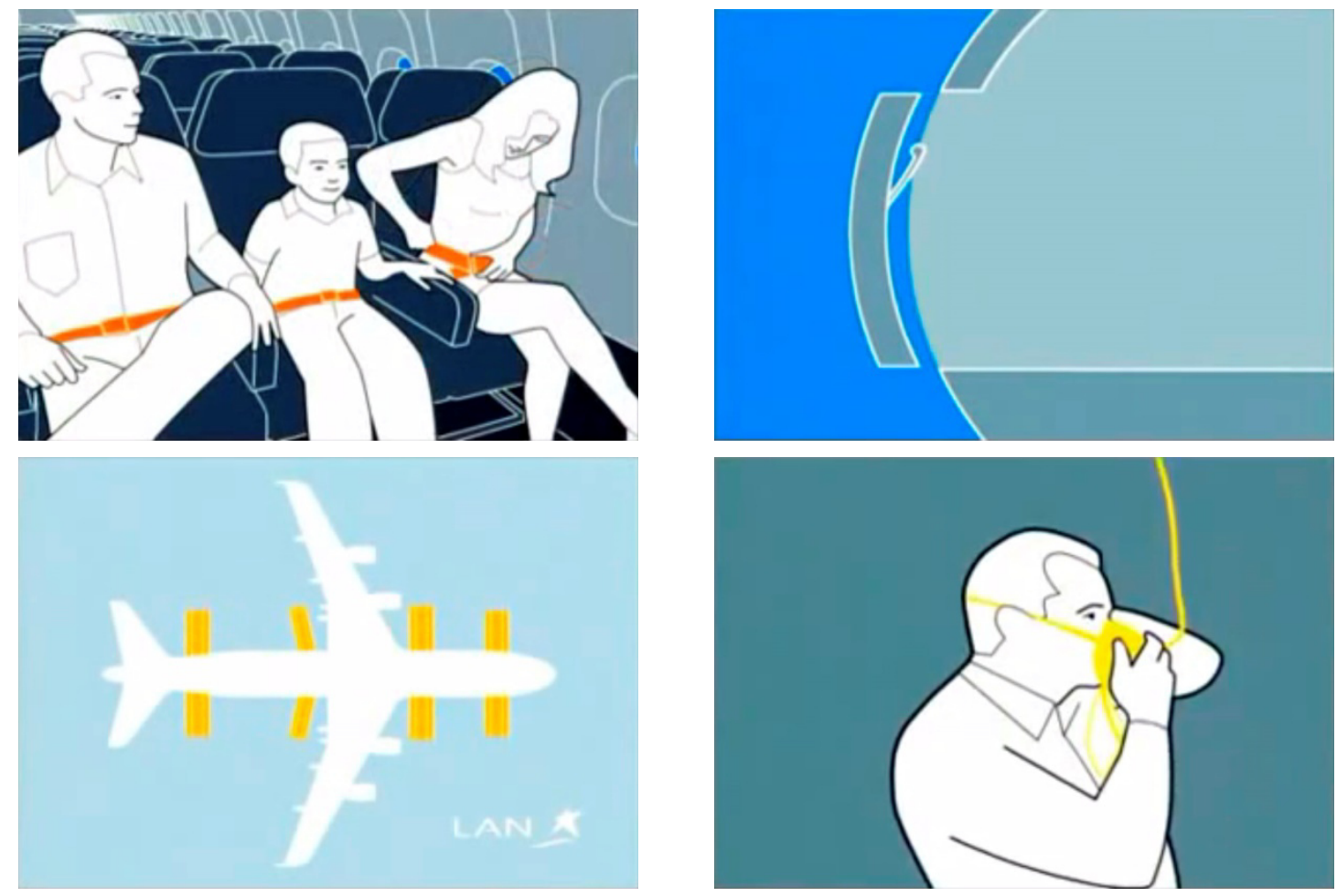

Fig. 60. LAN Airlines (h.2007). LAN Airlines: Safety Video Airbus 320, instrucciones de seguridad de la compañía aérea LAN Airlines. Fotogramas de varios planos.

\section{- Duración}

La duración de los acontecimientos puede ser normal, rápida o lenta (por medio de la dilatación o contracción del tiempo, de modo que los acontecimientos ocurren en un tiempo mayor o menor al real). Estamos acostumbrados a los resúmenes de tiempo y a las elipsis en el cine; casi todas las películas, tanto de animación como de acción real, contraen el tiempo en el que transcurre la histo- 
ria (horas, días, meses, años) a unos cuantos minutos. Aunque se trata de una cuestión de percepción personal, la dilatación del tiempo real en el relato y la contracción, cuando éstas exceden de lo habitual e incluso necesario para la narración cinematográfica, dan paso a la expresión de sensaciones personales. En Hen, his wife (Gallina, su esposa) (Kovalyov, 1990) hay una dilatación temporal en la que el hombre recuerda a su gallina-esposa. Los recuerdos se suceden en la mente del hombre con tan sólo oír el sonido del plato que se rompe contra el suelo. Una serie de planos muy breves sintetizan lo ocurrido anteriormente (pág. 202). Así mismo, el inserto de When the wind blows (Cuando el viento sopla) (Murakami, 1996) representa la ensoñación de una mujer, que tiene un momento de dispersión agradable al hacer soplar las semillas de un diente de león. La historia se detiene unos segundos para mostrar la fantasía del personaje; en ambos casos se transmite esa sensación, que tenemos al internarnos en los nuestros propios pensamientos, de que el tiempo se detiene o se prolonga.

Ex-enfants (Ex-niños) (Drouin, 1994) presenta dilatación del tiempo y, al mismo tiempo, orden invertido de la acción. Se muestra cómo la vida pacífica de un pueblo se rompe con el comienzo de la guerra. El niño protagonista va al frente y en las trincheras cae por un disparo, momento en que el tiempo se dilata mostrando de nuevo, a modo de recuerdos del niño, los mismos acontecimiento hacia atrás (de manera resumida), al llegar al que era el plano inicial de la película; en ese momento se "sale" del pensamiento del niño y se le ve caer. Esta dilatación temporal representa el momento de "ver pasar la vida delante de los ojos" pero con los últimos acontecimientos de la vida.

\section{- Frecuencia}

Con la frecuencia ocurre como con la duración, que algunos tipos son aceptados como normales en el cine sin que produzcan extrañeza por la manera en que alteran el espacio-tiempo. Éste es el caso de los acontecimientos únicos (se representa una vez lo que ocurre una vez), que no tienen un efecto particular en lo que a la representación del tiempo se refiere; y la frecuencia frecuentativa, al representar una vez lo que sucede más de una, supone una manera de contraer el tiempo, que, como dijimos, se reconoce sin asombro por ser habitual e incluso necesario en la representación espacio-temporal del lenguaje audiovisual. Ambos recursos influyen en la presentación del tiempo, en el relato, pero tampoco tienen relevancia en la representación de la acción. Sin embargo, la repetición y la reiteración, pueden tener mayores efectos en la expresión del movimiento, e incluso pueden colaborar a obtener movimiento vivenciado; además, pueden 
generar ritmo. Por ejemplo en Revolver (Bergqvist, Ekstrand, Odell, \& Ohlson, 1993), la representación del movimiento tiene lugar por medio de loops (serie de dibujos que se repite cíclicamente y que tradicionalmente se usa para ahorrar trabajo en la animación de acciones cíclicas, como el caminado), aquí la repetición comunica la frustración de los personajes, que se ven en situaciones patéticas o incómodas. En el cortometraje Hors-jeu (Fuera de juego) (Schwizgebel, 1977) los jugadores de baloncesto también se representan por medio de ciclos de fotogramas, lo que transmite la insistencia y dificultad de las jugadas, del intentar quitar el balón sin conseguirlo (00:02:18).

La animación de los derechos de los niños Los niños tienen derechos al descanso (de la que también hablamos en B.2. de 2.2.4.) muestra el día a día del niño protagonista, un horario completo de actividades sin descanso. La representación reiterada de las actividades incide en el estrés que provocan al menor. La reiteración (y la progresiva aceleración de las escenas), en este caso, transmite el cansancio del niño. Es un claro ejemplo de que la frecuencia reiterativa puede ser vehículo de la expresión del movimiento vivenciado. Sin embargo, en Les trois inventeurs (Los tres inventores) (Ocelot, 1980), una historia con la misma estructura se repite cuatro veces; aunque esto colabora en la comprensión del drama de los personajes, no influye en que el movimiento sea vivenciado, expresividad que recae en este caso mayormente en la valoración espaciotemporal. También tiene una frecuencia así la animación explicativa de la zona de seguridad emitida en el aeropuerto de Lisboa ${ }^{67}$, en la que se representa una misma escena más o menos similar con diferentes personajes y con variación de detalles (un hombre pasa el control de seguridad, pone sus objetos personales en la bandeja, pita el control; a continuación ocurre lo mismo con una pasajera), con lo que claramente se pretende que el mensaje llegue con eficacia; pero la representación del movimiento se mantiene neutra. Así pues, encontramos frecuencia reiterativa tanto en animaciones con movimiento vivenciado como en animaciones con movimiento neutro.

En general la representación del tiempo en la sucesión de acontecimientos afecta a la representación del espacio-tiempo de manera amplia y no siempre directamente a la representación de acciones concretas, las cuales están determinadas más por el cambio de imagen y la valoración espacio-temporal antes que por el orden, duración y frecuencia de una serie de sucesos. No obstante la manipulación de estas tres características del tiempo puede hacer que la expre-

${ }^{67}$ Emisión: 22/03/2015 
sión del movimiento sea vivenciada, como hemos visto a través de varios ejemplos.

Otra cuestión también de interés es que en las obras que tienen menor atractivo visual, las cuestiones referidas al tiempo pueden convertirse en un elemento expresivo crucial. Thomas y Johnston recalcan la importancia de "Además de una presentación visualmente excitante del material, debe haber un desarrollo cuidadoso del drama inherente en cada situación", con el fin de "mantener a la audiencia encantada, pero también excitada y preocupada, especialmente deseando saber qué va a ocurrir a continuación" ${ }^{68}$. Éste es el caso de cortometrajes como Revolver (Bergqvist, Ekstrand, Odell, \& Ohlson, 1993) y Los niños tienen derecho al descanso (Unicef, 1979); tanto la valoración espacio-temporal como la apariencia plástica no son los elementos centrales de la expresión; en ambos casos es el relato, y en concreto la representación temporal, el elemento comunicativo principal y, además en estos dos casos, hasta tal punto que se convierte en la herramienta a través de la cual tiene lugar el movimiento vivenciado.

\section{B.3. Giros narrativos}

Un giro narrativo es un cambio repentino en la historia que cambia la situación de los personajes y que complica o simplifica la situación anterior. El cambio inesperado resulta estimulante y despierta mayor interés en la historia y en saber qué va a pasar. Son propios de los relatos narrativos aunque también pueden darse en animaciones no narrativas, ya que éstas también presentan la evolución de acontecimientos. Su influencia consiste en que pueden causar impresión estética en el espectador y dar sentido a otros elementos de la película, como el movimiento. Pero los giros narrativos no determinan en absoluto que el movimiento sea vivenciado o neutro, ya que éstos se dan tanto en películas que destacan por los giros narrativos como en las que no.

Kuka kehtaa? (¿Quién osa?) (Lahtinen, 2010) relata, a través de la experiencia de una niña, la adoración de los vasallos a su emperador. Los ciudadanos rinden

\footnotetext{
${ }^{68}$ Thomas \& Johnston, 1981, pág. 370, (trad. a.): Our goal must be to keep the audience pleased, but also excited, concerned, and, especially, wondering what is going to happen next. This will take place only if the audience is involved with the characters and what there are doing. In addition to an exciting visual presentation of the material, there should be a careful development of the drama inherent in each situation.
} 
homenaje al monarca besando su mano. En el silencioso acto, un silbido importuna al emperador que, furioso, busca al culpable; entonces la niña descubre que el silbido proviene del propio emperador: un pequeño orifico en su pierna da a entender que está lleno de aire y que el sonido es producido por un escape; los vasallos en lugar de besar su mano lo que hacen es soplar por un agujero a modo de flotador. Esta sorpresa hace comprender todo lo anterior de otra manera. También un descubrimiento final hace que el espectador comprenda la primera escena de otra manera en Father and Daughter (Padre e hija) (Dudok de Wit, 2000): la marcha del padre en la barca en la primera secuencia de la película simbolizaba su muerte, lo cual se entiende así cuando la hija, ya anciana, inicia la marcha por el lago seco y se reencuentra con su padre.

En Seiltänzer (El baile de la cuerda) (Krumme, 1986) no hay giro narrativo por comprensión repentina, sino un cambio de situación: mediante la reiteración y variaciones para profundizar en la historia, cada escena refuerza la idea y muestra un poco más de la relación de poder entre los dos personajes y la rebelión contenida de la víctima, hasta que a partir de determinado punto, y de forma natural, sin lucha, tiene lugar la inversión de los roles de los personajes; el fuerte depende ahora de su víctima, quien lo acoge. En Rubicon (Alkabetz, 1997) el giro narrativo también consiste en una sorpresa, aunque no de inversión de la situación ni de comprensión repentina que cambia el concepto de lo ocurrido anteriormente; aquí, el giro narrativo consiste en que, a partir de una historia conocida (un hombre tiene que pasar al otro lado del río una col, una oveja y un lobo sin que ninguno devore a otro), en lugar de continuar la historia como la conocemos, empieza a cambiar de manera absurda.

En las dos películas del apartado anterior The Killing of an Egg y Umbra, el cambio de punto de vista provoca un giro narrativo. El cambio del punto de vista cambia por completo la situación y completa la historia. En ambas la historia ocurre de nuevo en otro nivel, los protagonistas la viven desde otra perspectiva.

Sin embargo, aunque los giros narrativos hacen estimulante el relato, la expresión del movimiento vivenciado no depende de ellos. Existen numerosas películas con narraciones menos interesantes e incluso no narrativas en las que el movimiento es vivenciado, como Flux (Hinton, 2002), Stressed (Estresados) (Kelly, 1994), Malou ou l'hostitilté mécanique (en Ut majeur) (Malou o la hostilidad mecánica (en Do mayor)) (De Roeck, 2011), Báladi (Peris, 2010), etc. En Báladi una mujer baila entre el público, no hay siquiera una evolución gráfica, sin embargo por el movimiento de la mujer y del propio espacio, se transmite la flexibilidad y potencia de la bailarina, sensaciones destacables al observar el bai- 
le, por lo que se puede calificar como movimiento vivenciado. En estas películas la expresividad del movimiento se basa principalmente en la valoración espaciotemporal y, en menor medida, en el cambio de imagen; la ausencia de un relato más dinámico o complejo no afecta a la expresión del movimiento vivenciado.

Los giros narrativos no existen en animaciones de representación neutra del movimiento, ya que, por definición, el movimiento neutro es objetivo y con él se pretende expresar un mensaje de la manera más clara desde el primer momento. No obstante, hay algunas animaciones que pueden usar el relato precisamente para, aun transmitiendo el mensaje con claridad, resultar amenas; éste es el caso de la animación explicativa de la zona de seguridad emitido en el aeropuerto de Lisboa (de la que hemos hablado pocas páginas atrás): un pasajero deja los objetos metálicos en una bandeja, pero al pasar el control, pita porque tiene las llaves en el bolsillo; al dejar las llaves y volver a pasar el control, vuelve a sonar, dejando al pasajero sorprendido y molesto. De esta manera el video muestra con sentido del humor un hecho que agota e irrita al pasajero, así, deja claras las instrucciones a seguir y al mismo tiempo ameniza la espera en el control de seguridad.

Hemos visto varios ejemplos de relatos con diversas estructuras; aunque la expresión del movimiento como vivenciado o neutro no depende de la manera en que se narre la historia, puede acentuar la identificación del espectador con los personajes y puede resaltar las sensaciones cinéticas. Su presencia en la película, tiene un atractivo especial: si de dos obras audiovisuales con el mismo relato una de ellas tiene movimiento vivenciado, ésta conecta más íntimamente con el espectador que aquella que no lo tiene.

\section{B.4. Relación con la intensidad cinética}

Sin duda el relato influye en la transmisión global de las ideas, sensaciones o emociones que se desean comunicar con la animación. La idea que se desea expresar puede sugerir la dinámica de la animación y tener relevancia para el autor como motivación. En este sentido el relato está relacionado con la intensidad cinética, por lo que, para expresar lo deseado, ambos deben reforzarse y apoyarse mutuamente por medio de la concordancia o el contraste. Así pues, el relato y la cadencia cinética no necesariamente tienen la misma intensidad. Por lo tanto para ser acordes, podrían tanto ser de intensidad paralela o no, de este 
modo, un relato podría tener una tensión que fuera in crescendo a lo largo de la película, pero una intensidad cinética que fuera decreciendo. Pero mientras que la distribución cinética es específica de la intensidad del movimiento, el relato está relacionado con el tempo en cuanto a que afecta a la percepción del total de la obra, abarca toda la espacio-temporalidad de la historia y la manera de presentarla al espectador (no sólo a su visualidad).

Primero pongamos dos ejemplos de cine de acción real. En Psycho (Psicosis) (Hitchcock, Psycho (Psicosis), 1960) el clímax narrativo tiene lugar cuando Lila Crane descubre que la madre de Norman Bates está efectivamente muerta, y que éste la suplanta. La fuerza del descubrimiento viene acompañada de uno de los momentos de mayor intensidad cinética: la lámpara se balancea, provocando el movimiento frenético de la luz y la sombra sobre el cadáver, expresando el horror de los hechos. Mientras que en The Third Man (El tercer hombre) (Reed, 1949) el punto de mayor emoción de la historia se sitúa en el descubrimiento de que Harry Lime está vivo. La manera en que se da imagen a la escena acentúa la intensidad de la narración, pero cinéticamente tiene una intensidad baja.

A continuación exponemos varios ejemplos en los que la intensidad cinética y del relato son coincidentes:

-En Sen to Chihiro no Kamikakushi (El viaje de Chihiro) (Miyazaki, 2001) cuando se revela la auténtica identidad de Haku y su verdadero nombre (olvidado hasta entonces), así como su relación con la protagonista, los personajes están descenciendo en caída libre durante largos segundos. Sus ropas y cabellos son sacudidos fuertemente por el aire, un momento de intensidad cinética, sobre todo por la velocidad más que por la cantidad de elementos.

- En los primeros minutos de Kimba, el león blanco (Janguru Taite) (Takeuchi, 1997), el león, tras conocer a sus cachorros, sale corriendo de alegría (ver pág. 88, y fig. 43 del cap. 1); aunque el audio es absolutamente discreto, la imagen es muy potente, la velocidad y la intensidad de los saltos del animal, los movimientos de cámara y los alejamientos y acercamientos a primer plano del león hacen de ésta una escena de intensidad cinética acorde a la intensidad del hecho relatado.

- Le Grain coupon (Cupón de grano) (Xi \& An, 2001) es un cortometraje que se desarrolla en su gran mayoría con una intensidad suave, sin trayectorias muy largas, acciones breves y que abarcan poco espacio compositivo. La máxima intensidad de la película se alcanza en una de las últimas escenas: la pelea entre la mujer y el militar (00:14:22). La rebelión de la mujer, el punto de mayor intensidad narrativa, corresponde al pasaje de mayor intensidad cinética: las trayectorias se alargan, las acciones se suceden sin pausas, los personajes abarcan con su 
movimiento la mayor parte del espacio compositivo y también aumenta la velocidad.

- En Les trois inventeurs (Los tres inventores) (Ocelot, 1980) el descenso del globo que fabrica el padre y en el que vuela es uno de los pasajes de mayor intensidad cinética de la película. El acento en esta parte del relato no parece coincidir con ningún clímax de la historia, sin embargo, visualmente cobra mucha importancia debido a la complejidad del movimiento: las capas de profundidad se multiplican de modo que multitud de aves vuelan en diferentes trayectorias alrededor del globo, que ocupa la mayor parte de la pantalla, mientras desciende lentamente. La combinación de trayectorias y la multitud de elementos móviles de este plano hacen que sea el de mayor intensidad cinética; se trata de un énfasis visual que hace destacar un hecho aparentemente sin importancia como uno de los más bellos de la película. En la escena siguiente el globo es destrozado por tres hombres. En realidad el clímax tiene sentido como los últimos momentos de la corta vida del globo; la intensidad cinética revela la importancia dramática, que se comprende en su totalidad en los planos siguientes (00:03:47).

En otras animaciones, por el contrario, encontramos que la intensidad cinética baja se presenta en los momentos de mayor tensión o impacto narrativo:

- Woman who stole fingers (La mujer que robaba dedos) (Shiroki, 2001), es un cortometraje de terror de intensidad cinética suave mantenida a lo largo de toda la obra. El horror del niño al ver que la mujer hace desaparecer sus dedos se transmite precisamente en su parálisis, quietud que se refleja en toda la escena, no sólo en la reacción de los personajes (00:01:24).

- En Anomalies (Anomalías) (Cady, 2012) se cuenta la aparición de unas anomalías espaciales ante diferentes personas. Tras una actitud más o menos pasiva ante tales fenómenos, un hombre es succionado por uno de los "agujeros". El descubrimiento del riesgo que representa la situación (de la que finalmente se percatan los personajes) es seguido de varios planos de quietud total, pero se trata de uno de los momentos de máxima intensidad del relato.

- Tout Rien (Todo nada) (Back, 1978) sigue un ritmo irregular en la primera parte (la creación del mundo y los sucesivos cambios en el hombre para satisfacer sus deseos). A partir de la revelación del ser humano, que decide actuar contra Dios y abusar de la naturaleza, la intensidad cinética se eleva: aumenta la velocidad del movimiento y la cantidad de planos, el tiempo se resume cada vez más, con lo que se muestra la evolución del hombre y su tecnología con acentuados resúmenes (por ejemplo, en un plano sale una central nuclear, un cohete, etc.). En este acto de la película, la intensidad del movimiento es coincidente con la intensidad de los acontecimientos (la capacidad del hombre para des- 
truir). Al llegar al punto álgido, y tras una pausa, el hombre repara su mal y se reconcilia con Dios. Esta tercera parte de la obra presenta movimientos suaves y lentos, fundidos encadenados, imágenes más sencillas, con menos elementos. En la escena de la reconciliación del hombre con la naturaleza, el movimiento es suave, pero narrativamente corresponde a una gran emoción.

En todos estos casos la intensidad narrativa no es coincidente con la intensidad cinética, pero precisamente la suavidad del movimiento acrecienta la importancia dramática de las escenas. Otras veces no se trata de que el clímax se exprese a través de una intensidad cinética baja, sino de que el movimiento mismo, que podría esperarse que fuera potente, se representa con intensidad contraria: en Swamp nyz sumpf (Pantano) (Alkabetz, 1991) la lucha final entre dos guerreros tiene lugar a través de acciones que ocupan poco espacio compositivo, es una escena de intensidad cinética moderada en comparación con el dinamismo en escenas anteriores de la película, pero de gran dramatismo.

Como vemos, tanto la coincidencia como el contraste entre relato e intensidad dinámica pueden ser apropiados para expresar el movimiento vivenciado; todo elemento que ayude a expresar las sensaciones de vivir el movimiento son propicias para representar así el movimiento y, por eso mismo, normalmente se evitará en las animaciones de movimiento neutro. En principio, en el movimiento neutro, al tratarse de una representación lo más libre posible de connotaciones personales, es propio que haya concordancia entre ambos componentes dinámicos, sin entrar en un juego de contrastes. No obstante, tanto la coincidencia como la diferencia entre estos dos componentes dinámicos existen también en animaciones de movimiento neutro, en las que la intensidad cinética baja puede ser el medio ideal para restar emoción a un relato dramático, o una intensidad mayor puede restar importancia a la gravedad de una acción extremadamente lenta.

\section{CONCLUSIONES SOBRE LA INFLUENCIA DE LA PRESENTA- CIÓN DE LA HISTORIA EN LA REPRESENTACIÓN DEL MOVI- MIENTO VIVENCIADO Y EL MOVIMIENTO NEUTRO}

Partiendo de lo dicho sobre los elementos del relato expuestos en el punto B. de este apartado y en conjunción con los análisis realizados, concluimos lo siguiente respecto a su influencia en la expresión del movimiento vivenciado y neutro: 


\section{- Punto de vista - Narración en primera persona}

Mostrar el mundo desde la perspectiva u opinión (no ocularización) de los personajes supone expresar los acontecimiento despertando las emociones que se tienen cuando se experimentan personalmente y es la manera más elemental de generar empatía, por lo que la narración en primera persona es una aproximación al movimiento vivenciado, aunque esto no hace necesariamente que la representación de las acciones sea vivenciada. Pero si la representación del movimiento es neutro, este componente espacio-temporal no puede imponerse sobre los que generan directamente la representación del movimiento (la valoración espacio-temporal, el cambio de imagen y la intensidad cinética).

\section{- Orden, duración y frecuencia.}

Encontramos alteraciones temporales tanto en animaciones con movimiento vivenciado como neutro. A parte de todo el juego narrativo que puede sostener la presentación del tiempo en el relato, esto no influye directamente en la expresión del movimiento vivenciado a no ser que se presente de manera que afecte directamente a la representación de las acciones acentuando sus cualidades distintivas, o acentuado la evocación de cinestesia. Además, no todas las alteraciones de tiempo tienen influencia en la expresión del movimiento vivenciado: las contracciones del tiempo y la frecuencia simple y frecuentativa son operaciones narrativas habitualmente utilizadas que normalmente tienen la función de resumir la historia, por lo que si estos recursos no sobrepasan su papel habitual, pueden no contribuir a transmitir el movimiento como vivido en primera persona; por otro lado, tampoco hacen que el movimiento sea neutro.

\section{- Giros narrativos.}

Los giros narrativos sin duda dinamizan el relato, generan sorpresa en el espectador al cambiar el significado de lo que se mostró con anterioridad, incluir nuevos elementos que complican la trama, invertir la situación, etc. Pero no están relacionados con la representación del movimiento vivenciado. No tienen influencia sobre la representación del movimiento, su ausencia no hace que el movimiento sea neutro ni su presencia hace que sea vivenciado.

\section{- Concordancia entre intensidad cinética e intensidad de los acontecimien-}

tos.

Puede favorecer la narrativa de los acontecimientos, emociones o ideas expresadas, y puede colaborar en la expresión del movimiento vivenciado tanto por concordancia como por contraste. La equivalencia o no de estos componentes dinámicos puede favorecer ambos niveles de expresividad, pero ni por contraste ni por equivalencia se obtiene con seguridad el movimiento vivenciado o neutro. 


\section{CONCLUSIONES}

- La expresividad del movimiento se consigue a través de los componentes dinámicos, los cuales están relacionados de una manera u otra con todos los elementos de la animación que conforman la obra: la plástica, la técnica, el contenido, etc.

- Cada componente dinámico, tiene un campo de actuación específico: la valoración espacio-temporal o timing (la evolución de la imagen a través de los fotogramas) afecta a la apariencia de las acciones concretas; el cambio de imagen (producido por el movimiento del dispositivo) y los efectos que produce afectan a la visualidad del movimiento (fluidez, vibración, etc.); la composición móvil y la distribución espacio-temporal están especialmente interrelacionadas y hay una influencia de doble dirección entre el desarrollo del movimiento en y a través de los planos y el ritmo general de la película; y la presentación de la historia (el relato) afecta al espacio-tiempo general de la película.

- De todos los componentes dinámicos, el relato es el que menor influencia tiene para hacer que el movimiento sea vivenciado o neutro, a no ser que se use de manera que afecte directamente a la representación de las acciones, o enfatice la distribución espacio-temporal por contraste o similitud entre la intensidad cinética y el relato, etc. Pero desde el relato se pueden presentar los acontecimientos desde la subjetividad de un personaje. Respecto a los otros componentes dinámicos, no es posible establecer una jerarquía entre ellos, porque ninguno tiene una supremacía incondicional sobre los demás en la expresión del movimiento. Es dentro de la película donde cada componente dinámico tiene determinada relevancia según cómo se use y cómo se relacione con los demás. Hay maneras de usarlos haciendo que sean muy notorios y lleven el peso expresivo, en ese caso compensan o se complementan con las cualidades menos expresivas o incluso neutras de los otros componentes. En definitiva, el nivel de expresividad del movimiento depende de la conjunción de todos los componentes espacio-temporales, no de uno sólo.

- Las películas pueden expresar el movimiento como vivenciado por cómo se 
usan todos sus componentes espacio-temporales o uno en concreto. Pero dado que todos los componentes dinámicos, tengan o no un papel muy activo en la plasticidad de la obra, actúan a la vez, para obtener movimiento vivenciado, el componente dinámico sobre el que recaiga la expresividad del movimiento debe tener la suficiente potencia expresiva.

- Sin embargo, para obtener movimiento neutro, normalmente no basta con que uno de los componentes no se emplee de manera "expresiva". Esto se debe a que en animación todos los componentes dinámicos tienen un gran potencial como materia plástica a través del cual expresar el movimiento, y para "anular" o adolecer de todo valor dinámico expresivo, todos los componentes, o la mayor parte, deben dirigirse a este fin de comunicación "neutra". Así pues, porque el tratamiento de uno de los componentes espacio-temporales sea neutro no podemos decir que el movimiento general lo sea. Para que el movimiento sea neutro, esta cualidad debe extenderse a varios elementos y predominar en la película.

- Tras el visionado y análisis de películas, y a través de las reflexiones que se recogen en este capítulo, hemos llegado a la conclusión de que no es posible asignar a ambos tipos de expresividad una serie de características cinematográficas ni técnicas. No existe una manera concreta de usar los componentes dinámicos que garantice la expresión del movimiento vivenciado o neutro; las ideas simplistas respecto a ambos tipos de movimiento son insostenibles ya que las características cinematográficas y técnicas que involucra cada componente dinámico existen en animaciones de diferentes grados de expresividad. Las amplísimas posibilidades que ofrece cada componente dinámico pueden emplearse tanto para expresar el movimiento vivenciado como el neutro, (la existencia de un solo caso contradice la afirmación de que se consigue de tal o cual manera) depende de cómo se usen y cómo se relacionen entre ellas. Además, cada película requiere unos recursos según su finalidad y objetivos. Así, no es posible afirmar, por ejemplo, que el dinamismo en cada fotograma hace que la representación sea vivenciada y que el estatismo hace que sea neutra; o que la alteración del orden del tiempo en el relato proporciona movimiento vivenciado, mientras que el orden lineal favorece el movimiento neutro.

Las dos creencias más consolidadas respecto a lo que da expresividad al movimiento son un mayor dinamismo visual (riqueza de movimiento, alta intensidad cinética, etc.) y un relato con alteración del orden de los acontecimiento y giros narrativos, mientras que a menor dinamismo u orden lineal, más neutra es la expresión. En cierto modo esta movilidad puede propiciar mayor expresividad, 
ya que, al haber más información dinámica se pueden provocar sensaciones cinestésicas con relativa facilidad. Pero la variedad de acciones se da en animaciones con distintos niveles expresivos (más o menos vivenciadas o neutras) lo que demuestra que no hay relación entre variedad de acciones y expresión del movimiento vivenciado o neutro; Lo mismo ocurre con la intensidad cinética: la alta intensidad no es exclusiva del movimiento más expresivo, y aunque dinamice la animación, no proporciona movimiento vivenciado de manera garantizada. En cuanto al relato, ni el orden de los acontecimientos, ni la presencia de giros narrativos determinan que la expresión del movimiento sea neutra o vivenciada. 

3. REPRESENTACIÓN DEL MOVIMIENTO VIVENCIADO Y NEUTRO A TRAVÉS DE LA VALORACIÓN ESPACIO-TEMPORAL 

En el presente parágrafo se trata el único componente dinámico que no presenta el cine de acción real. Su singularidad en animación reside en que el movimiento debe representarse mediante la creación uno a uno (normalmente) de todos los fotogramas, mientras que en el cine de acción real la valoración espaciotemporal corresponde al movimiento real que captura la cámara cinematográfica. Este hacer pormenorizado hace que en animación "todo sea posible". Por eso tratamos específicamente este componente dinámico en el presente capítulo. Primero definiremos a qué nos referimos con valoración espacio-temporal (3.1); luego hablaremos de varios aspectos que influyen en ésta (3.2.) y además nos detendremos en una experimentación plástica sobre este componente dinámico (3.2.3. B.). Finalmente determinaremos qué aspectos de la valoración espaciotemporal influyen y en qué grado en la representación del movimiento vivenciado y neutro (3.3.). 
Movimiento vivenciado y movimiento neutro. Estudio sobre la expresividad de la representación del movimiento en animación 


\subsection{QUÉ ES}

Hemos llamado valoración espacio-temporal al dónde y al cuándo de las formas en el espacio y el tiempo, lo que corresponde al dibujo o representación de la evolución de la acción a lo largo de los fotogramas. Se trata de un elemento muy flexible, objeto de interpretación, debido a que, como se comenta en la introducción, no procede de la captura del movimiento real (como en el cine de acción real), por lo que necesita ser creada. Este componente está directamente relacionado con la composición del movimiento en el plano (sobre todo si hay desplazamientos) y con el cambio de imagen (la frecuencia de imagen y la manera en que cambian los fotogramas - instantáneamente o por fundido - influye directamente en el dibujo detallado de la acción por determinar el número de imágenes necesarias por segundo y porque el paso de fotogramas puede provocar una vibración que formará parte de la acción.

La valoración o relación espacio-temporal es comúnmente conocida como timing, pero la definición de timing es amplia e incluso a veces un tanto confusa respecto a qué es. Normalmente abarca la valoración espacio-temporal y el ritmo e intensidad del movimiento a lo largo de toda la obra. Éste otro gran concepto, lo hemos denominado "distribución de la intensidad cinética" (es el tempo), y dado que en ésta participan elementos específicos, la consideramos como un componente-espacio temporal con entidad propia (parágrafo 2.2.4). Aunque timing engloba dos de los componentes dinámicos tal y como los presentamos en esta investigación, en ocasiones emplearemos también la palabra timing como sinónimo exclusivo de valoración espacio-temporal y no de distribución de la intensidad cinética (a la que hemos asignado el término alternativo tempo).

En animación, el movimiento que se ve en pantalla, como todo movimiento, tiene las siguientes cualidades básicas: dirección, sentido, velocidad y aceleración. Esto se representa a través de las imágenes estáticas que componen toda animación, y entre las cuales se establece una relación espacio-temporal (por eso, al hablar de valoración espacio-temporal nos referimos a la expresión del movimiento a través de las imágenes correlativas). Dirección, sentido, velocidad y aceleración responden al dónde y al cuándo de las formas en el espacio y el tiempo y se plasman a través de la distancia física entre las formas representadas de un fotograma a otro (de la cual se desprende la velocidad de tal movimiento) y depende 
directamente de la frecuencia de imágenes por segundo en la que se visionará la animación (cantidad de imágenes por segundo y constancia de la frecuencia: constante o cambiante).

La velocidad depende de la distancia entre las imágenes o, lo que es lo mismo, la cantidad de imágenes que se requiere para representar una acción: con una fips constante, a mayor distancia entre las formas representadas, mayor velocidad; a menor distancia, menor velocidad. Así, para un movimiento rápido se necesitan menos imágenes que para un movimiento lento. Pero aparte de esta evidencia técnica, es la valoración espacio-temporal la que determina el aspecto del movimiento resultante. Se puede decir que parte importante de la expresión del movimiento en animación se fundamenta en la valoración espacio-temporal.

El movimiento en pantalla siempre existe por la proyección sucesiva de imágenes que varían progresivamente. Anteriormente citamos la definición de McLaren en la que ubica la clave de la animación en la diferencia entre fotogramas. Para Harold Whitaker y John Halas para crear el timing no basta con variar la posición del móvil de un dibujo a otro, ya que:

El timing es la parte de la animación que da "sentido" al movimiento. El movimiento puede conseguirse fácilmente al dibujar la misma cosa en dos posiciones diferentes e insertando un número de dibujos entre los dos. El resultado en la pantalla será movimiento, pero no será animación. ${ }^{1}$

Así pues, el timing no sólo comprende el cambio del móvil en la cuarta dimensión, sino también qué se expresa con ese cambio. El timing es tan determinante en la significación del movimiento que dos acciones con la misma trayectoria pueden tener una apariencia muy diferente debido a su velocidad. Thomas y Johnston relatan la variedad de parecidos del ejercicio de la pelota botando con acciones distintas a ésta:

Este cambio en la parte inferior también daba la sensación de impulso para elevarse en el aire. Pero si hacíamos un dibujo extra o dos en ese punto para conseguir el máximo provecho de esta acción, la pelota permanecía demasiado tiempo en el suelo, creando extraños efectos de salto en lugar de botar (Algunas de estas pruebas parecían más frijoles saltando que ningún tipo de pelota). Si nosotros estimábamos

\footnotetext{
${ }^{1}$ Halas \& Whitaker, 1981, pág. 12, (trad. a.): Timing is the part of animation which gives meaning to movement. Movement can easily achieved by drawing the same thing in two different positions and inserting a number of other drawings between the two. The result on the screen will be movement, but it will not be animation.
} 
mal la manera de disponer los dibujos o la distancia entre ellos, creábamos extraños efectos que recordaban un conejo herido o una rana adormilada. ${ }^{2}$

Con las variaciones de velocidad también se modifica el carácter del movimiento representado, de modo que un movimiento similar varía de significado según la velocidad. ${ }^{3}$ Este fenómeno también se da en la acción real; en palabras de Arnheim, "Un cambio de velocidad no solo puede hacer expresivas las cualidades perceptuales, sino también modificarlas cualitativamente." $Y$ pone de ejemplo cómo al ralentizar los movimientos de deportistas y bailarines, éstos parecen “apagados y blandos" . Esto evidencia que la interpretación espacio-temporal está directamente relacionada con la expresión de emociones y sentimientos.

La relación espacio-temporal, al definir pormenorizadamente el desarrollo del movimiento, admite gran variedad de alteraciones, es decir, puede realizarse de infinitas maneras. A nivel técnico hay diferentes medios para abordar la valoración espacio-temporal, los principales son: la realización manual, métodos mecánicos (captura de movimiento) y métodos semi-mecánicos (en los que se realizan "manualmente" los fotogramas clave y los intermedios se obtienen automáticamente). En el siguiente apartado trataremos los efectos directos de estos tres métodos en la expresión móvil.

\footnotetext{
${ }^{2}$ Thomas \& Johnston, 1981, pág. 51, (trad. a.): This change at the bottom also gave the feeling of thrust for the spring back into the air, but if we made an extra drawing or two at that point to get the most out of this action, the ball stayed on the ground too long, creating weird effects of hopping instead of bouncing. (Some tests looked more like a jumping bean from Mexico than any kind of ball.) If we misjudged our arrangement of the drawings or the distance between them, we created apparitions reminiscent of an injured rabbit, or an angry grasshopper, or, most often, a sleepy frog.

${ }^{3}$ Thomas \& Johnston, 1981, págs. 64-65

${ }^{4}$ Arnheim, 1979, pág. 317
} 
Movimiento vivenciado y movimiento neutro. Estudio sobre la expresividad de la representación del movimiento en animación 


\subsection{ELEMENTOS QUE PARTICIPAN EN LA VALORACIÓN ESPACIO-TEMPORAL}

A continuación profundizaremos en los elementos que intervienen en la valoración espacio-temporal: diferentes maneras de seguir o interpretar la mecánica real; la alteración de velocidad y orden de la acción; qué ocurre cuando la valoración viene determinada por la técnica; y la influencia de los fotogramas individuales. Además, en el punto B. del apartado 3.2.3. se incluye la descripción y conclusiones de una experimentación plástica sobre una manera concreta de alterar la mecánica: por medio de fases no cronológicas de la acción. A lo largo del presente parágrafo se relata cómo cada uno de estos factores afecta a la expresividad de la representación del movimiento.

\subsubsection{MECÁNICA DEL MOVIMIENTO}

La mayoría de técnicas de animación (salvo la película pintada, según como se use) se basan en la sucesión de imágenes individuales. Esta característica técnica de representar el movimiento a lo largo de fotogramas consecutivos hace necesario definir pormenorizadamente el desarrollo de cada acción. Una de las cuestiones que afectan a la interpretación espacio-temporal es la medida en que el desarrollo imagen a imagen representa la mecánica real del movimiento.

Gracias al análisis de la mecánica, sin duda la valoración espacio-temporal constituye uno de los elementos dinámicos de la animación que se ha estudiado más detalladamente. Conocemos la mecánica gracias a la cronofotografía y al video, y aunque el artista no estudie estos medios, no podemos negar que existe un sustrato cultural, gracias a la fotografía y al cine, que nos da un conocimiento sobre la mecánica diferente al que se tenía con anterioridad a la aparición de estos medios. Por ejemplo, es un conocimiento bastante extendido que el caballo no extiende las cuatro patas en ningún momento del galope, y se ha popularizado la instantánea de la gotita que se eleva sobre el agua debido al impacto producido por otra gota al sumergirse. Pero ¿qué hacer con esta información, utilizarla o desecharla? 
Las soluciones plásticas a este planteamiento son muy diversas. Así, encontramos desde animaciones que guardan poco parecido con la mecánica real, hasta otras difíciles de diferenciar de la acción real, pasando por las infinitas posibilidades entre ambos extremos. Entre ellas algunas son creadas por medio de la captura de movimiento real, otras se basan en la información que ofrece el video, otras recurren a la mecánica clásica (la newtoniana), y otras no tienen ninguno de estos referentes.

A lo largo de los puntos 3.2.2., 3.2.3. y 3.2.4. de este capítulo trataremos diversas formas de alterar la mecánica real, y en el presente parágrafo, 3.2.1., nos centraremos en la valoración espacio-temporal que la sigue o la toma como referencia directa.

\section{A. REGISTRO DE LA MECÁNICA REAL}

Actualmente, el mayor grado de semejanza con la mecánica real se obtiene por los métodos de captura de movimiento. Tanto la rotoscopia como el motion capture se basan en el registro del movimiento real, cada uno desde sus especificidades técnicas. La rotoscopia consiste en dibujar sobre los fotogramas de acción real, que son transformados plásticamente en mayor o menor grado. En el motion capture el movimiento se obtiene por medio de sensores que se colocan sobre las personas y objetos móviles; la información sobre su posición en el espacio-tiempo es utilizada para recrear el movimiento en animación digital 3D. En ambos casos el movimiento resultante depende principalmente del movimiento real capturado, por eso en las animaciones de rotoscopia y por captura de movimiento en las que no se altera el movimiento registrado encontramos una interpretación de la relación espacio-temporal sólo proveniente del mecanismo de captura y que proporciona un movimiento anodino; incluso aunque se altere en cierta medida, se pude decir que la rotoscopia y en el motion capture son las técnicas en las que menor interpretación espacio-temporal se realiza. Sobre la influencia de estas técnicas en la interpretación espacio-temporal nos extenderemos un poco más en el punto 3.2.5. de este parágrafo, Cuando el movimiento viene dado por la técnica. 


\section{B. TOMAR INFORMACIÓN DETALLADA DE LA MECÁNICA REAL}

La mecánica puede utilizarse como referencia a partir de la cual interpretar el movimiento. La mecánica está al alcance de la mano hoy en día, ya que la fotografía y la grabación de video son fácilmente accesibles y con estos medios se puede estudiar con detalle el desarrollo mecánico del movimiento. Thomas y Johnston reflexionan sobre las virtudes de las cronofotografías de Muybirdge para traer a la memoria un movimiento visto tiempo atrás, pero concluyen que, pese a su utilidad, las imágenes estáticas no son una buena guía para los animadores que no estén familiarizados con el movimiento que se desarrolla en ellas, por lo que encuentran el análisis de filmaciones de acción real mucho más ventajoso ${ }^{5}$. Los Walt Disney Studios utilizaban referencias de video con frecuencia, pero la mayoría de las veces no para rotoscopiarla, sino para estudiar detalladamente el desarrollo del movimiento (Fig. 1). Anteriormente a la accesibilidad a las herramientas de edición de video mediante las cuales se puede analizar un video imagen a imagen, se utilizaban phostostats. Estos estaban compuestos por los fotogramas de acción real impresos y se visualizaban a modo de flipbook. Los photostats daban acceso al desarrollo de la acción real, información que se interpretaba según los intereses de la escena:

De los photostats, el animador escoge sólo aquellas acciones relacionadas con el tema central de su escena particular; entonces él los fortalece hasta que se convierten en la acción dominante, con todo lo demás eliminado o subordinado. Lo que aparece en la pantalla en una simple, fuerte, directa declaración que tiene claridad y vitalidad. El espíritu y vida han sido aumentados al adaptar la forma humana a los dibujos propios de un artista. ${ }^{6}$

Efectivamente encontramos los resultados de este modus operandi (en algunos casos de manera evidente) en animaciones tan separadas en el tiempo como The Jungle Boock (El libro de la selva) (Reitherman, 1967) y Brave (Andrews, Chapman, \& Purcell, 2012) [en DVD] (Fig. 2). El estudio de la mecánica real exagerada al modo que explicaban Thomas y Johnston se identifica por la sensación de naturalidad que transmite la animación, en la que, para ojos expertos, no es difícil reconoce la alteración temporal y exageración a partir de la cual ha sido creada. La pantera de The Jungle Book se mueve con la suavidad del felino, pero a una velo-

\footnotetext{
${ }^{5}$ Thomas \& Johnston, 1981, pág. 333

${ }^{6}$ Thomas \& Johnston, 1981, pág. 323, (trad. a.): From the photostats, the animator chooses only those actions that relate to the point of his particular scene; then he strengthens those until they become the dominant action, with everything else either eliminated or subordinated. What appears on the screen is a simple, strong, direct statement that has clarity and vitality. The spirit and life have been gained by adapting the human form to an artist's own designs.
} 
cidad y siguiendo unas trayectorias que se acomodan a las necesidades de los diálogos y la trama. Del mismo modo, el corcel de Brave sigue el desarrollo real del movimiento, pero la exageración de la flexibilidad del animal y del tiempo (en general acelerado) plasma la potencia y energía que caracterizan la acción.

En definitiva, la transformación de la mecánica real depende de cómo y en qué grado se use esa información: "La acción real puede dominar al animador, o puede enseñarle. Puede reprimir la animación, o puede inspirar grandes nuevas ideas. Todo depende de cómo la acción real sea concebida, filmada y usada". ${ }^{7}$

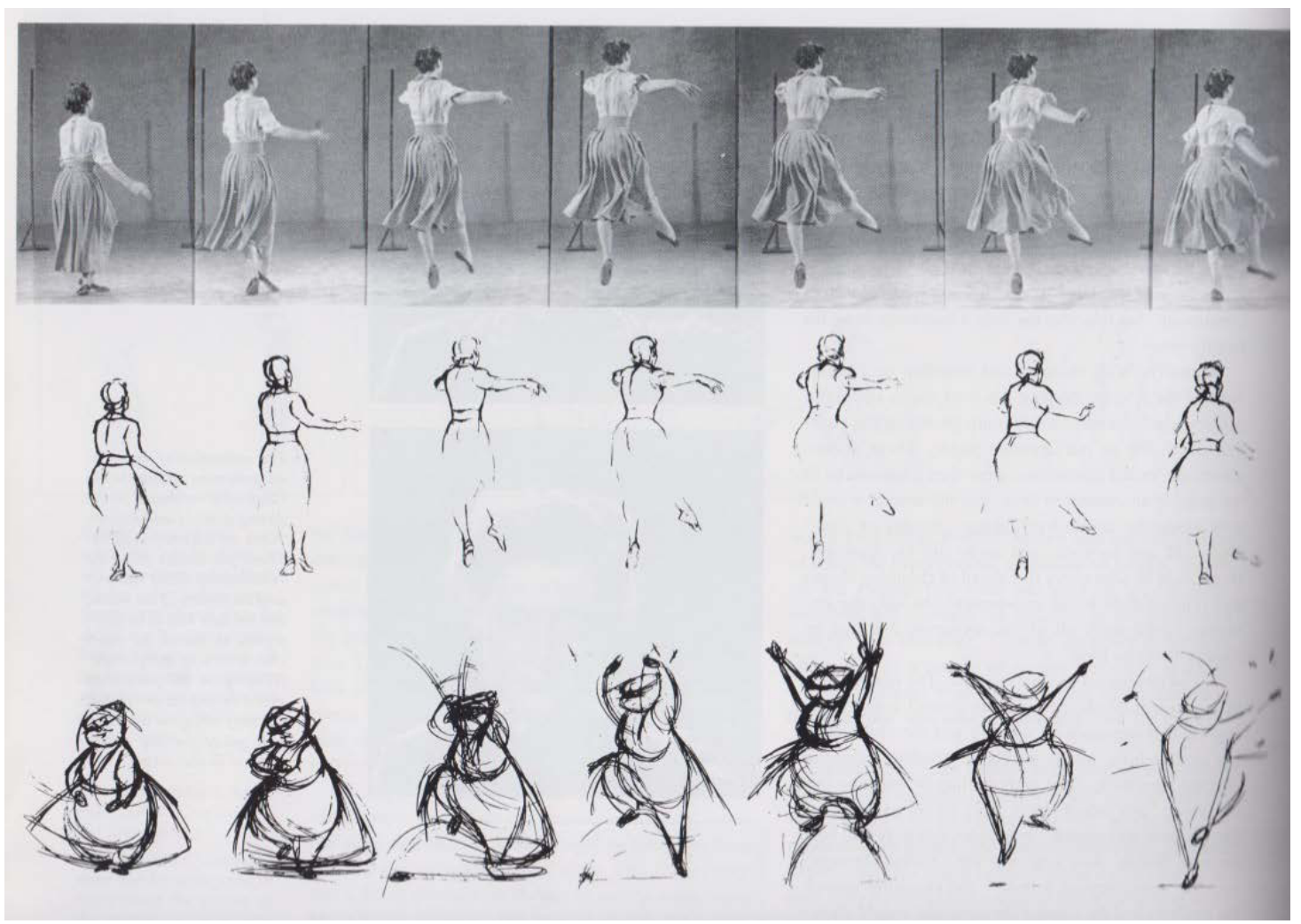

Fig. 1. Walt Disney Studios (1959). Sleeping Beauty (La bella durmiente).

\footnotetext{
${ }^{7}$ Thomas \& Johnston, 1981, pág. 319, (trad. a.): Live action could dominate the animator, or it could teach him. It could stifle animation, or inspire great new ideas. It all depended on how the live action was conceived and shot and used.
} 

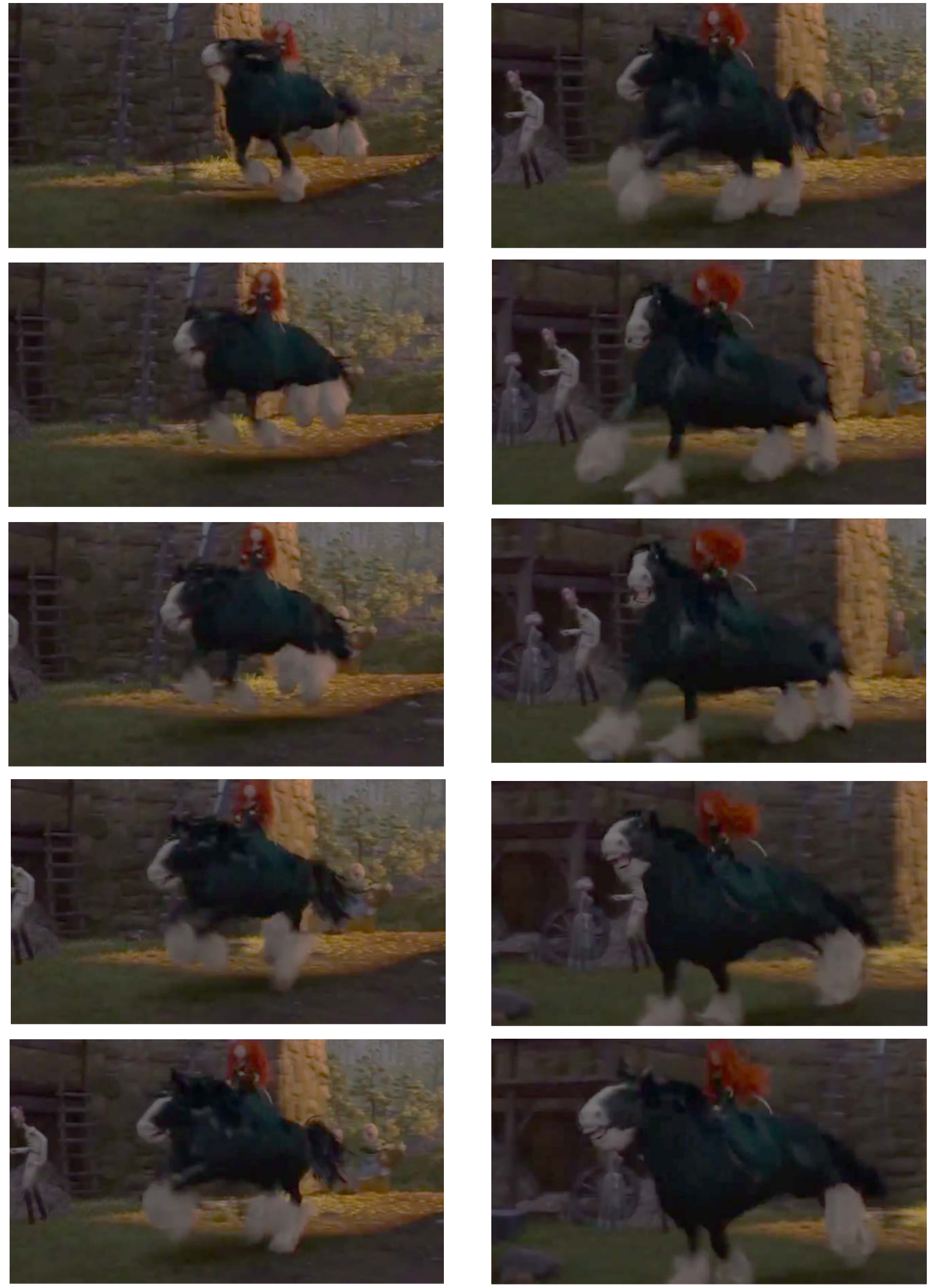

Fig. 2. Mark Andrews; Brenda Chapman y Steve Purcell. Brave (Brave. Indomable). Serie de fotogramas. 


\section{BASARSE EN LAS LEYES DE LA MECÁNICA CLÁSICA}

En animación una de las formas habituales de afrontar la representación del movimiento es a través de una conjunción de fenómenos que constituyen las causas y consecuencias de fuerzas físicas. Para explicar estos fenómenos se recurre a la ciencia, en concreto a las leyes físicas enunciadas por Newton, unas veces con objetivos naturalistas y otras para exagerar el movimiento conforme a esta pauta.

Sin duda, la interpretación de las leyes físicas más famosa es la que se ha creado para justificar la representación del movimiento que se realiza en los Walt Disney Stidios. En el punto D. de 3.2.2. hablaremos de los principales recursos del modus operandi de este estilo (surgido en los años 30 del siglo pasado, y ya afianzado en $1937^{8}$ ) que afectan a la valoración espacio-temporal, y veremos que no están basados en la mecánica clásica. Por el momento basta decir que las leyes de la física no les sirvieron de modelo, aunque posteriormente se les atribuyó esta explicación más o menos "científica" que ha alcanzado popularidad.

En animación la explicación del movimiento a través de las leyes físicas es más una intelectualización para explicar el desarrollo de la acción que una consecuencia de la observación del natural. En éstas se halló una explicación racional al squash y al stretch, al overlaping, etc. En realidad los principios aplicados son los mismos que en las animaciones de Disney, pero la manera de explicarlos varía, lo que evidencia que tal conocimiento científico no participa sino a posteriori, a modo de justificación. Un ejemplo de esto es el clásico ejercicio de la pelota botando. La pelota se representa comprimida al impactar contra el suelo. La interpretación de la flexibilidad de la pelota se argumenta de la siguiente manera (Fig. 5):

La pelota (posición A) cae siguiendo las leyes del movimiento de Newton. Cae atraída por la fuerza de la gravedad hasta que se ve detenida por la superficie del suelo. En ese momento se produce una compresión (posición B) ya que debido a la segunda ley del movimiento, la pelota tiende a continuar su descenso mientras que la fuerza externa del suelo se opone al mismo. Una vez comprimida, la pelota rebota intentando recuperar su forma inicial en reposo produciéndose una extensión de la pelota como reacción a la fuerza que el suelo ejercía en su contra (posición C). Esta fuerza pronto se ve neutralizada por la de la gravedad (posición D) que una vez más hace caer la pelota hacia el suelo. Debido al roce contra el aire, la fuerza de expansión será cada vez menor hasta que la pelota llegue a pararse hasta recuperar su posición en reposo (posición E). ${ }^{9}$

\footnotetext{
${ }^{8} 1937$ es el año del estreno de Snow White and the Seven Dwarf (Blanca Nieves y los siete enanitos) (Hand, Cottrell, Morey, Pearce, \& Sharpsteen), lo que confirma el refinamiento que se había conseguido ya a finales de los años 30 .

${ }^{9}$ García, 2000, pág. 24
} 


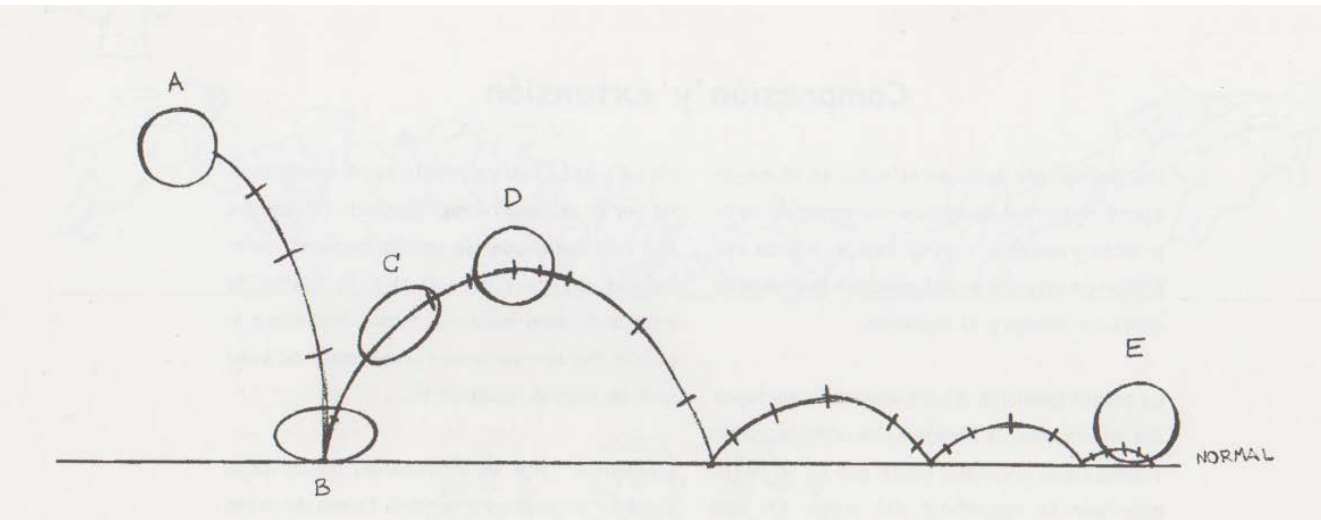

Fig. 3.

Raúl García

(2000).

Pelota

botando.

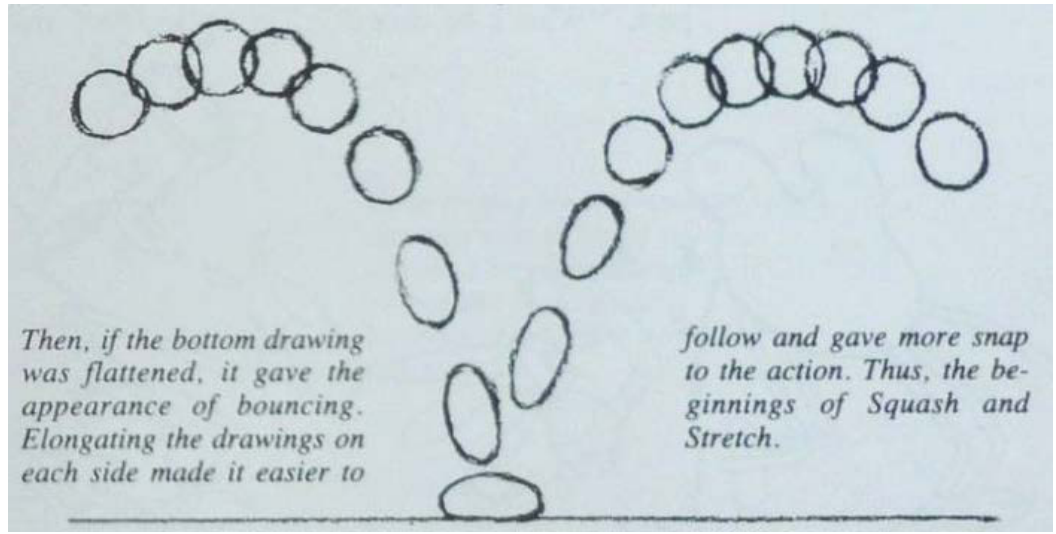

Fig. 4. Walt Disney

Studios (s/f).

Pelota botando.

(B)
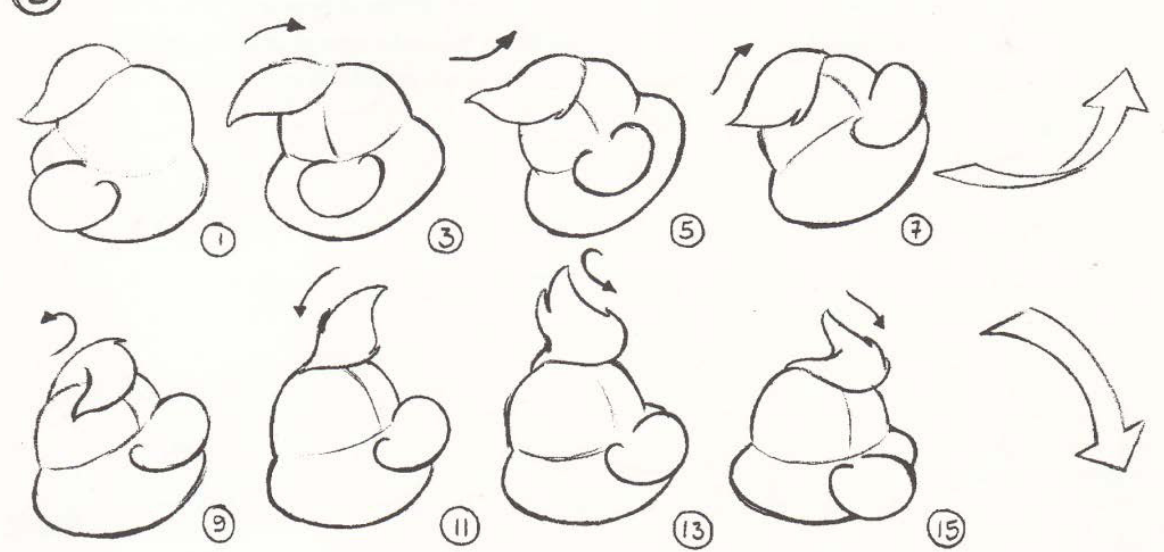

Fig. 5.

Raúl García

(2000).

Movimiento

del pelo.

Difícilmente podemos aceptar que este análisis sea el fruto de un examen visual del movimiento, sino al contrario, que la representación de la flexibilidad del objeto fue justificada a través de ésta. Dicha representación de la pelota, exenta de explicaciones científicas, procede de los estudios Disney, donde se explica a través 
del squash y el strech $^{10}$ (Fig. 3). De la misma manera, los movimientos en consecuencia de una acción (u overlaping) se pasan por el filtro newtoniano así (Fig. 4):

En la serie B, el movimiento principal es un giro de cabeza lateral y el pelo retrasa su animación secundaria hasta el dibujo 3. Cuando la cabeza completa el giro en la clave 9 , el pelo continúa su movimiento ascendente hasta que pierde su inercia en el dibujo 11, donde se doblega a la fuerza natural de la gravedad en el dibujo 13 para continuar su caída en el dibujo 15 hasta que llega a la posición de reposo. ${ }^{11}$

De esta manera, una serie de recursos que se crearon principalmente con intención de obtener movimientos de mayor flexibilidad y que se conjugaron con otros fenómenos observados en la naturaleza (como el overlaping) se complementaron con argumentaciones que aportaron una base científica a la representación plástica. La expansión de estos razonamientos ha llevado a afirmaciones tan tajantes como la de John Halas, quien presenta las leyes físicas como origen de los recursos de representación móvil:

Las fuerzas fundamentales que crean las leyes del movimiento - gravedad y fricción - no pueden ser cambiadas. Las leyes de movimiento newtonianas han sido siempre importantes en animación. Permanecen como puntos de origen para ser exagerados, distorsionados e incluso desafiados. ${ }^{12}$

Tal vez lo más desconcertante sean las explicaciones que combinan las razones físicas que provocan el movimiento y las razones psicológicas que motivan una acción, que más bien provocan confusión entre la representación del movimiento y lo que se cuenta con ese movimiento.

En la naturaleza, las cosas no simplemente se mueven. La primera ley del movimiento de Newton determinó que las cosas no se mueven al menos que una fuerza actúe sobre ellas. Así que el movimiento en animación es de importancia secundaria; el factor vital es cómo la acción expresa las causas subyacentes del movimiento. Con los objetos inanimados estas causas pueden ser fuerzas naturales, principalmente la gravedad. Con personajes vivos las mismas causas externas pueden causar movimiento, más la voluntad subyacente, estado de ánimo, instintos, etc. del personaje que se está moviendo. ${ }^{13}$

\footnotetext{
${ }^{10}$ Explicación original del ejercicio de la pelota en Thomas \& Johnston, 1981, pág. 51

${ }^{11}$ García, 2000, pág. 45

${ }^{12}$ Halas, 1990, pág. 15, (trad. a.): The fundamental forces which create the laws of movement - gravity and friction - cannot be changed. The Newtonian laws of motion have always been important in animation. They remain as starting points to be exaggerated, distorted, even defied.

${ }^{13}$ Halas \& Whitaker, 1981, pág. 12: In nature, things do not just move. Newton's first law of motion stated that things do not move unless a force acts upon them. So in animation the movement itself is of secondary importance; the vital factor is how the action expresses the underlying causes of movement. With inanimate objects these causes may be natural forces, mainly gravity. With living characters the same external forces can cause movement, plus the underlying will, mood, instincts and so on of the character who is moving.
} 
Así, la primera ley de Newton según la cual el movimiento es consecuencia de la aplicación de una fuerza (por ejemplo: un niño da una patada a un balón - causa-, la pelota sale disparada - consecuencia -) se combina con explicaciones más o menos psicológicas según las cuales el movimiento también pude ser consecuencia de un estado de ánimo o un deseo (por ejemplo: una persona tiene hambre causa - la persona come - consecuencia - ).

La valoración espacio-temporal en animación, cuanto más se ajusta a la mecánica real, menos sensaciones cinéticas transmite, lo que dificulta la expresión del movimiento vivenciado, al menos en lo que a este componente dinámico se refiere. Pero no hay una correspondencia fija entre expresividad "neutra" y movimiento animado basado en la mecánica, por lo que no se puede afirmar que se representa el movimiento neutro si se parte del desarrollo real de la acción. En cuanto a las explicaciones científicas, hemos visto que son un complemento a recursos de representación móvil, pero que no influyen en el resultado.

\subsubsection{ALTERACIÓN DE LA MECÁNICA: ALTERACIÓN DEL ESPA- CIO Y EL TIEMPO}

No hay una manera de interpretar la mecánica real de manera tal que con seguridad se obtenga expresión vivenciada o neutra del movimiento. Las posibilidades son muy amplias, desde modificar el tiempo o la mecánica de la acción hasta inventarla directamente. Los estilos de animación a veces surgen precisamente al establecer una manera concreta de abordar la valoración espacio-temporal. Ciertamente, en las representaciones del movimiento vivenciado normalmente este componente dinámico se separa de la relación espacio-temporal real, aunque no es una característica exclusiva de las animaciones más expresivas, sino que también se da en el movimiento neutro, y además de manera notable. En este apartado veremos varios ejemplos de animaciones que destacan por la alteración de la mecánica y de la velocidad.

\section{A. EXAGERACIÓN DEL TIEMPO}

El tiempo se comprime o se dilata en el conjunto de la narración en casi todas las películas de acción real y animación; muy pocas representan la duración real de los acontecimientos, ¿pero en qué medida se altera la duración de las acciones 
individuales (saltar, correr, rotar, etc.)? La exageración del tiempo en la valoración espacio-temporal puede realizarse por medio de la aceleración o deceleración de la acción total o parte de la acción (al dilatar o reducir la duración), o por medio de la acentuación del contraste entre rápido y lento (que se obtiene al exagerar o minimizar las trayectorias y el espacio recorrido en relación al tiempo y viceversa. Tiene diversas consecuencias dependiendo de cómo se lleve a cabo: puede mostrar el movimiento con más claridad que si se ajusta al espacio y al tiempo real (en sentido cinematográfico; es decir, que es comprensible visualmente); puede destacar cualidades propias del movimiento; y puede provocar o intensificar las sensaciones cinéticas que provoca en el espectador. Por otro lado, una distorsión extrema de la duración o de los cambios de velocidad puede hacer desaparecer el sentido del movimiento (dificultad para identificar la acción).

\section{A.1. Aumento o reducción de la velocidad total de la acción}

Una aceleración o deceleración de la acción total puede servir como resumen o análisis, lo que sirve tanto a fines expresivos como expositivos. Los movimientos lentos se asocian a animaciones educativas y del ámbito científico, pero el movimiento rápido también puede ser apropiado para videos instructivos cuando se requiere mostrar los efectos, por ejemplo, del tiempo, en unos pocos segundos ${ }^{14}$. En el video Life in the womb (9 months in 4 minutes) (La vida en el vientre materno (9 meses en 4 minutos)) (Medicine Forever, h. 2014) [en DVD] vemos la gestación de un bebé en pocos minutos. Es un ejemplo de combinación de las cualidades del movimiento vivenciado y el movimiento neutro. Por un lado los movimientos de cámara iniciales que muestran el recorrido de los espermatozoides hasta el óvulo lo representan como un viaje auténticamente veloz y estresante, transmite sensaciones cinestésicas a través de muy variados movimientos de cámara. A partir de esta fase, el movimiento es fundamentalmente neutro, ya que, aunque de manera amena debido a la velocidad y a que transcurren muchos cambios hasta que el bebé está totalmente formado, el movimiento presenta velocidad regular y sirve al propósito de mostrar un conocimiento objetivamente. El movimiento está exento de expresividad aunque luce la estética dinámica del cine actual, como otros videos científicos de hoy en día.

La aceleración y deceleración de la velocidad puede además cambiar el carácter de la acción, como se evidencia en el cine de acción real en la clásica aceleración que hace cómicas (o simplemente alegres) las acciones cotidianas y la dece-

\footnotetext{
${ }^{14}$ Halas, 1990, pág. 17
} 
leración que transmite pesadez y lentitud. Arnheim argumenta cómo la alteración de la velocidad real puede tener resultados muy expresivos, y pone el siguiente ejemplo (aunque se refiere al cine de acción real, estos efectos también se dan en animación):

En el film surrealista, Entreacto, se ve un coche fúnebre que se aleja velozmente del cortejo. El coche se precipita por las calles y el cortejo corre tras él en acción ralentizada. Las piernas se levantan muy lentamente como si se pegaran al suelo y los brazos se balancean con pesada lentitud. Una vez más se consigue un efecto cómico irresistible porque no se tiene la sensación de estar viendo una versión retardada de la acción normal de correr, sino una caricatura deliberada. ${ }^{15}$

Usualmente, tanto en animación como en cine de acción real, se asocia la exageración de la duración con la comedia, sobre todo los movimientos rápidos. John Halas afirma que "Ninguna comedia puede tener éxito sin exageración del tiempo, especialmente los asombrosos efectos de la acción rápida"16. Aunque de gran interés para la expresión móvil, el sentido cómico no influye en que el movimiento sea vivenciado o neutro (recuérdense las imágenes cómicas e irónicas de Packard Jennings que explotan el lenguaje de los manuales de instrucciones - Fig. 48 de cap. 1 -). No obstante, nos interesa la descripción Arnheim de Entreacto, ya que, por las sensaciones cinestésicas que sugieren el movimiento de brazos y piernas, se puede considerar movimiento vivenciado.

La distorsión de la duración también puede generar un ambiente. En Hen, his wife (Kovalyov, 1990) la psicología de los personajes es el elemento conductor de la historia. Pero el comportamiento de éstos se anticipa por la estética: a ojos vista se reconoce un ambiente extraño tanto por las peculiares formas y colores, como por la valoración espacio-temporal. Las acciones poco relevantes presentan alteraciones espacio-temporales que las hacen enigmáticas, por ejemplo, el bote de sal se acerca hacia la gallina cuando ésta extiende el brazo para cogerlo (no representa telekinesia, sino que, sencillamente, en la acción "coger algo" se ha introducido la variación "el bote se desplaza por sí sólo"). Una alteración eminentemente temporal es la que tiene lugar cuando un reloj despertador cae de la estantería: la escena transcurre a velocidad normal pero el reloj cae ralentizado, tanto que el plano acaba antes de ver el objeto impactar contra el suelo, impacto que se retrasa hasta varios segundos más tarde, ya empezado el siguiente plano. En esta película no todos los objetos y personajes se rigen por la misma pauta de

\footnotetext{
${ }^{15}$ Arnheim, 1957, pág. 88

${ }^{16}$ Halas, 1990, pág. 17, (trad. a.): No comedy can succeed without exaggeration of time, especially the amusing effect of speedy action.
} 
representación espacio-temporal, lo que acentúa el ambiente enrarecido de este mundo particular

\section{A.2. Exageración del tiempo y del espacio dentro de la acción}

El contraste de la velocidad dentro de cada acción puede provocar sensaciones cinéticas con mayor facilidad que un movimiento regular, por lo que esta característica puede ayudar a representar el movimiento como vivenciado. Aunque no se expresa el movimiento vivenciado así como así simplemente por emplear este recurso; para ello la acentuación del contraste debe provocar que el movimiento sea percibido como vivido en primera persona, transmitir rasgos peculiares del movimiento o provocar intensas sensaciones cinestésicas, como en Janguru Taitei (Kimba, el león blanco) (Takeuchi, 1997), en la que encontramos un claro empleo de la distorsión temporal y espacial como vehículo principal de la expresión del movimiento que, a su vez, es herramienta para transmitir el contenido emocional. Retomemos la escena comentada en el capítulo 1: el animal recorre grandísimas distancias al saltar, y el tiempo que se mantiene en el aire se prolonga, sin ser "cámara lenta", sino una mezcla de dilatación del tiempo y exageración del instante en que el animal está suspendido en el aire. El movimiento de cámara también colabora en el dinamismo de la escena y en transmitir la sensación que "siente" el león de surcar el aire.

No tan exagerada ni simbólica, pero también muy intensa, es la distorsión temporal en Rame Dames (Guiol, 2010). Aquí vemos acentuación del contraste rápido-lento dentro de cada acción; las acciones rápidas se aceleran y las lentas se ralentizan. Esto genera una intermitencia entre aceleración y lentitud que también saca de lo cotidiano todo movimiento para convertirlo en un hecho extraordinario. Parece que la obsesión del joven por la mujer hace que todo su cuerpo se convulsione, fuerza que transmite gracias a la exageración del tiempo y también, en gran medida, por los planos cercanos, que hacen que la escena que transcurre en un lugar público parezca más íntima.

\section{B. VALORACIÓN ESPACIO-TEMPORAL REGULAR}

La valoración espacio-temporal uniforme se obtiene mediante la separación espacial y temporal homogénea de las formas entre fotogramas contiguos; las 
formas en las imágenes correlativas cambian o se desplazan siempre la misma distancia física. Al proyectar la película a velocidad constante, la separación uniforme produce la velocidad regular del móvil. La valoración espacio-temporal de velocidad uniforme es también una distorsión, ya que pocos elementos móviles se mueven de esta manera en la naturaleza. Es la distorsión opuesta a la exageración del tiempo y el espacio de las acciones particulares. El amalgamiento del tiempo y el espacio en que transcurre una acción (y el ritmo regular, como vimos en 2.2.4.) genera diferentes resultados expresivos dependiendo de cómo se use: puede generar monotonía, cualidad aprovechable tanto para fines expresivos como expositivos; pero también puede restar claridad cinematográfica a la acción, o incluso puede variar el movimiento hasta cambiar su significado.

El timing regular, por tener velocidad constante, sin variaciones o sin variaciones notables, se asocia a la ausencia de expresividad y de emociones, las cuales, inicialmente, pueden ser más fácilmente estimuladas a través de los cambios y contrastes de velocidad. Esta cualidad convierte a la valoración espacio-temporal regular en un medio propicio para obtener movimiento neutro, apropiado para videos expositivos como la animación de LAN sobre cómo pilotar un avión a través de dibujos animados (LAN Airlines, 2010). En esta animación se marca muy bien la diferencia entre las escenas que muestran el funcionamiento del avión (en las que prima la claridad expositiva a través de las imágenes y que deliberadamente proporciona seriedad y objetividad) y las escenas en las que los niños reaccionan con sorpresa, risa, etc. ante los conocimientos (partes que no requieren mantenerse inexpresivas). Las primeras tienen una velocidad básicamente regular con algunos aumentos y disminuciones de velocidad, y en las segundas se usan anticipaciones y retrocesos muy suaves en contraste con algunos movimientos rápidos, los cuales, sin embargo, también se mantienen en un nivel bastantes neutro de expresividad.

No obstante, la velocidad regular del movimiento, al contrario que en el ejemplo anterior, es susceptible de dificultar la comprensión del movimiento representado. De hecho, el timing regular a veces evidencia que este componente dinámico no se ha tenido en cuenta en el diseño de la película, o incluso que hay falta de control sobre éste. Las primeras animaciones tenían un timing muy regular, como las animaciones de Émile Reynaud (1892-1900) proyectadas en su teatro óptico, como seguía pasando más adelante, en las películas de Windsor McCay. No obstante no podemos hablar de "falta de control" para referirnos a las animaciones de esta época, ya que se trataba de un momento de descubrimiento del medio y no se habían forjado todavía una cultura visual cinematográfica, es decir, estas obras en su contexto original no se podían calificar como "mal he- 
chas", todo lo contrario, eran auténticas proezas. Por otro lado, en Flip's Circus y en Little Nemo (McCay, 1921; 1911), ya fuera con o sin intención del autor, la distancia homogénea de desplazamiento o transformación de los dibujos de un fotograma a otro cobra interés visual; lo acontecido se vuelve atractivo precisamente por el timing regular, que altera la velocidad real del movimiento, lo que transforma la acción. En Flip's Circus el animal (una mezcla de hipopótamo y dinosaurio) salta repetidas veces. Esta acción la realiza a velocidad absolutamente constante, de modo que se mantienen en el aire un tiempo considerable, lo que hace desaparecer el sentido del salto: el salto se convierte en un movimiento de ingravidez y el animal parece flotar (00:03:45). Y en otro momento el domador, tumbado en el suelo, se incorpora de un salto cuando es pisado por el animal, salto con giro hacia atrás en el que se mantiene en el aire y aterriza exactamente a la misma velocidad, lo que hace del salto, nuevamente, un movimiento completamente fantástico, poco parecido a la acción de saltar salvo en la trayectoria, como si volara; a continuación, el domador golpea al animal, que cae también con la misma morosidad, añadiendo candidez a la escena (00:05:18). La valoración espacio-temporal regular, en este caso, otorga un valor cómico y crea movimientos fantásticos. Es un ejemplo de cómo el timing hace que la acción cobre un significado diferente sin actuar en detrimento de la expresión, sino al contrario, participando positivamente en ella.

La velocidad constante es menos dinámica que los cambios de velocidad, que resultan atractivos simplemente por la variación; sin embargo, la monotonía que otorga la velocidad regular al movimiento puede ser precisamente lo más adecuada para expresar ciertas acciones. Así, la velocidad regular también puede ser usada para acentuar esa característica particular del movimiento, lo que la aproximaría a una de las cualidades de la expresión vivenciada. En la primera escena de Revolver (Bergqvist, Ekstrand, Odell, \& Ohlson, 1993) un hombre está ahogándose, se mantiene a flote y se hunde alternativamente con una cadencia regular; al repetirse el mismo movimiento una y otra vez, sin variaciones y con una valoración espacio-temporal muy regular (la misma acción se repite cíclicamente), la monotonía persiste. En este caso la velocidad regular de la escena, contrariamente a lo que pudiera parecer inicialmente, hace más dramática la situación del personaje, que nunca está más cerca ni de la salvación ni de la muerte.

Las ballenas de Le fleuve aux Grandes Eauxes (El poderoso río) (Back, 1993) también presentan valoración espacio-temporal de velocidad constante. La monotonía del desplazamiento y del movimiento de las aletas (en lugar de marcados cambios de velocidad) transmite favorablemente la inmensidad y placidez de estos animales. En el fragmento dedicado a la obra musical Pinos de Roma en Fan- 
tasia 2000 (Hendel, 1999), en las que las ballenas tienen el protagonismo, encontramos planos en los que éstas se mueven con valoración espacio-temporal regular (como en la animación de Frédéric Back) y planos en los que hay aceleración y deceleración de la acción (el slow in-slow out propio de la compañía, recurso que veremos en el último punto de este parágrafo: Alteración espacio-temporal según un estilo de animación). Las primeras tiene el movimiento característico del enorme animal bajo el agua, mientras que las segundas presentan un movimiento rítmico que no resulta apropiado. Aquí se ve claramente que, según el movimiento representado, el timing regular tiene virtudes frente al irregular.

\section{ALTERACIÓN DE LA MECÁNICA}

En casi toda animación hay alteración de la velocidad de las acciones, pero en unas películas es más evidente la transformación de la mecánica que la alteración temporal y espacial. La modificación respecto al movimiento real puede tener lugar por varios medios: por síntesis, al reducir la información a lo más esencial; por invención de una mecánica "nueva", es decir, un desarrollo fantástico para una acción conocida; o bien por invención de una acción a propósito para expresar algo.

La alteración de la mecánica del movimiento mediante simplificación más sencilla es la que se hace en las pixilaciones realizadas por "sustracción" de fotogramas, eliminando imágenes de un video de acción real. Al eliminar información, aunque las acciones siguen identificándose, el movimiento resultante se percibe como extraño y suele cobrar interés estético. Al alterar la velocidad habitual de grabación de acción real, también se obtiene un movimiento cuya mecánica difiere de la natural; los cambios pueden ser sorprendentes, como vemos en $A$ Chairy Tale (Un cuento de sillas) (Jutra \& McLaren 1957). En este cortometraje los personajes (un hombre y una silla) se mueven por acción real y animación (la silla es movida por stop-motion y por el propio actor). En ocasiones la acción real se integra como si fuera otro tipo de movimiento que se suma a las posibilidades de la animación por pixilación. Los movimientos del hombre son interpretados de manera muy imaginativa por medio de la alteración de la velocidad de grabación, de modo que acciones habituales como andar, agacharse o bailar, se convierten en acciones totalmente extraordinarias; la sorpresa del hombre al ver que la silla tiene vida propia es un bello ejemplo de ello, en el que el sobresalto se comunica de manera más directa que por medio de la velocidad natural. 
Pero la mayor parte de las veces el movimiento se representa en síntesis por medio de la creación y no por sustracción de imágenes de una película de acción real; para ello se presenta lo elemental de la acción, aquello que necesita para ser reconocible. Esto se hace en infinitos grados de abstracción. En la película Luminaris (Zaramella, 2011) la valoración espacio-temporal se genera por movimientos de mecánica simplificada. Por ejemplo, la acción de mascar se presenta como un acto compuesto por unos pocos fotogramas en los que el rostro se deforma notablemente para acentuar los momentos en los que las mandíbulas se separan y en los que se cierran; la acentuación de las fases claves para describir el movimiento se presenta con una claridad no siempre fácil de ver en el movimiento natural del ser humano y que hacen atractivo el movimiento animado.

En otros casos la sencillez del movimiento queda determinada por el diseño del móvil; esto ocurre con las técnicas que emplean objetos, marionetas volumétricas y recortes. La simplicidad de la valoración espacio-temporal depende del diseño de las marionetas, de la flexibilidad del material, del tipo y cantidad de articulaciones y de las piezas de transición. Éste es el caso de l'italiana in Algeri (La italiana en Argelia) (Gianini \& Luzzati, 1968), animación en la que la síntesis de la acción está motivada y procurada por la forma de los recortes (Fig. 6). Por ejemplo, brazos y piernas, no tienen más que la articulación que las une al torso (en algunos personaje ni siquiera se determinan las piernas que, ocultas bajo falda o túnica, quedan unificadas en una pieza única), por lo que la acción de caminar se representa sin ninguna correspondencia con la mecánica real, pero manteniendo el ritmo de la acción. A través de estas acciones tan cotidianas ya se expresa la personalidad de los personajes.

En Jabberwooky (Svankmajer, 1971) se presenta gran variedad de objetos; a lo largo del cortometraje vemos las posibilidades de movimiento que ofrece cada uno. La sencillez de la mecánica depende del propio objeto: los soldaditos de

Fig. 6. Giulio Gianini y Emanuele Luzzati (1968). L'italiana in Algeri (La italiana en Argelia).

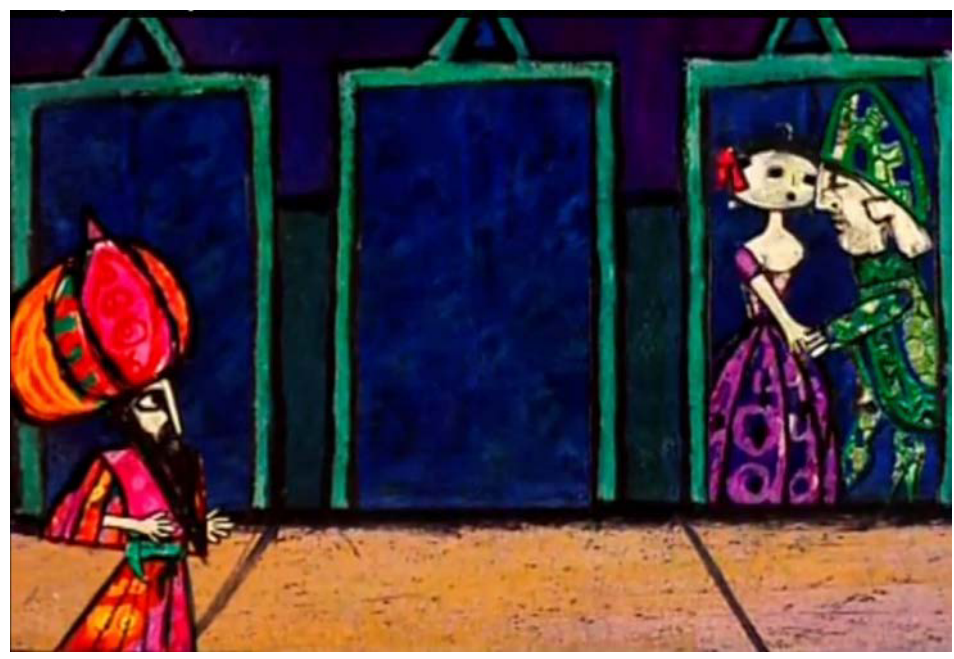


plomo, que son de una sola pieza, no tienen articulaciones, por lo que su movimiento consiste en desplazamientos y rotaciones (en ningún momento el objeto se deforma para obtener más posibilidades dinámicas) (00:07:40). Mientras que las muñecas, con articulaciones y partes flexibles, cobran un movimiento de asombrosa naturalidad a través de una gran riqueza dinámica, en parte por la suavidad del movimiento, y en parte también por el realismo de la escena: las muñeca grandes dan comidita a las pequeñas con movimientos maternales; una niña agita su manita porque no quiere comer, una muñeca grande limpia la boquita de otra pequeña, etc. (00:07:00).

Otras veces no se puede hablar de síntesis de movimiento, sino directamente de invención de la mecánica para acciones existentes. Aunque la exageración y la síntesis de la forma y el movimiento siempre implican imaginación e invención, en el fenómeno plástico al que nos referimos la acción representada se aleja tanto del desarrollo natural que cobra entidad como acción nueva. Así lo vemos en Les tragédies minuscules (Las tragedias minúsculas) (Felicioli \& Gagnol, 1999). Tal vez una de las más impactantes deformaciones de la acción la encontramos en el episodio titulado L'egoïste (El egoísta); cuando el protagonista, angustiado por la pérdida de la mitad de su rostro, se levanta de la cama, se lleva las manos a la cabeza y lo que sería un movimiento común de compresión se convierte en un retorcimiento imposible (el torso pasa entre las piernas y gira $360^{\circ}$ para volver a erguirse). No se trata tampoco de exageración del movimiento, sino de un movimiento cotidiano (contracción y expansión del torso) convertido en extraordinario. Esta reinvención del movimiento hace que las acciones cotidianas cobren protagonismo expresivo y configuren un lenguaje dinámico con contenido psicológico: al retorcer de tal manera su físico, el personaje hace visual su angustia emocional (Fig. 7) (00:01:52).

Algo parecido ocurre en Passage (El paso) (Krumme, 1994) [en DVD]. En algunos momentos de la película la exageración del movimiento alcanza un grado que no se puede identificar como simple síntesis de la acción, sino más bien como invención de la mecánica. Ésta exageración-fantasía tiene lugar principalmente en el dibujo del movimiento: los personajes se comprimen y extienden sin atender a la anatomía humana, sino priorizando la expresión de la acción por medio de la plástica, en la que cobra mucha relevancia el propio material: la tinta. En los momentos de mayor dramatismo, la pincelada se abre y el trazo se exhibe. De este modo, cuando un personaje apoya un pie en el lago, el peso de su cuerpo reposa sobre esa pierna, lo que se representa con una pincelada "amontonada"; cuando se sobresalta, su cuerpo se expande en pinceladas de trazo zigzagueante; otro personaje tira de éste para apartarlo, movimiento en el que el cuerpo se compor- 
ta casi como una tela (Fig. 8) (00:01:38). El autor inventa una mecánica alternativa a partir de la idea esencial de cada acción (expansión, contracción, torsión, flexión, etc.). Como en Les tragédies minúscules, la representación del movimiento deja ver las emociones de los personajes no sólo por el tipo de acciones representadas, sino por cómo éstas se modifican respecto a las acciones reales a las que corresponden.
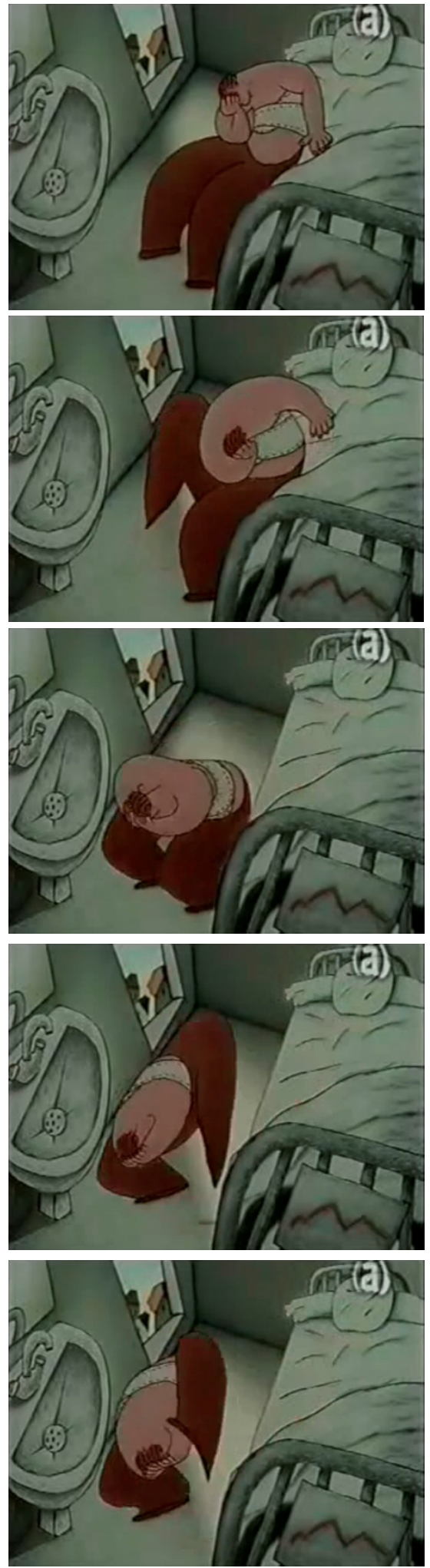
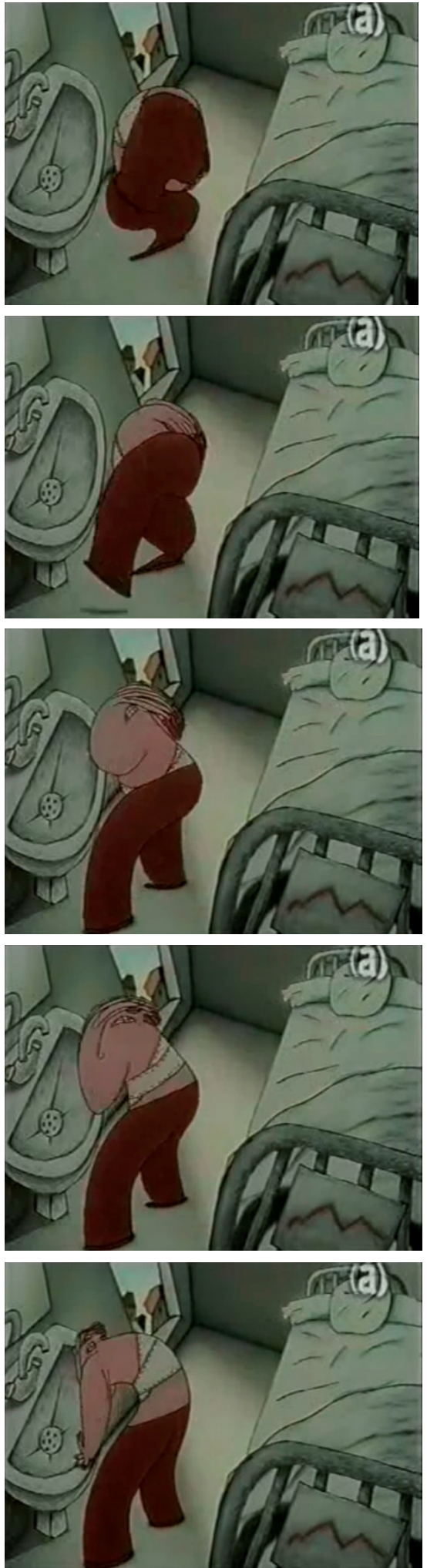

Fig. 7. Jean-Loup Felicioli y Alain Gagnol (1999). L'egoïste; Les tragédies minuscules (El egoista; Las tragedias minúsculas). Serie de fotogramas. 


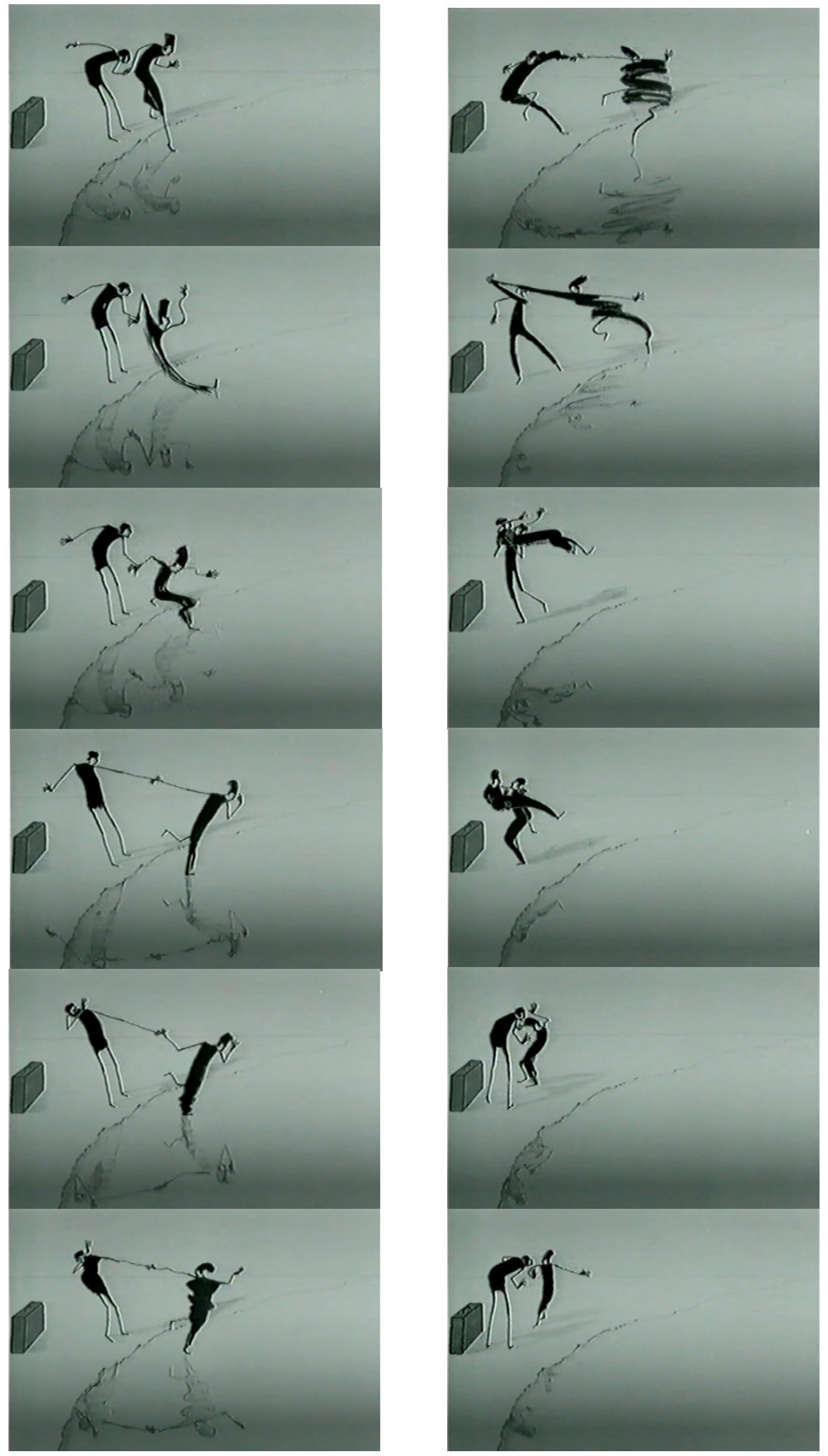

Fig. 8. Raimund Krumme (1994). Passage (El paso). Serie de fotogramas. 
En The wind subsides (El viento se calma) (Jevremovic, año) (Fig. 9), se ha prescindido totalmente de la mecánica real de las patas del ñu. Cuando éste empieza a correr, la acción se comprende por la velocidad y dirección. Además, el movimiento desencajado del animal se reconoce también porque, de alguna manera, el retorcimiento de las patas y el "desorden" del movimiento provocan sensación de urgencia, por lo que la representación es vivenciada a través de la valoración espacio-temporal. Así, vemos que la cualidad expresiva del movimiento de mecánica inventada es tan eficaz para identificar la acción como la correspondencia con la mecánica real.
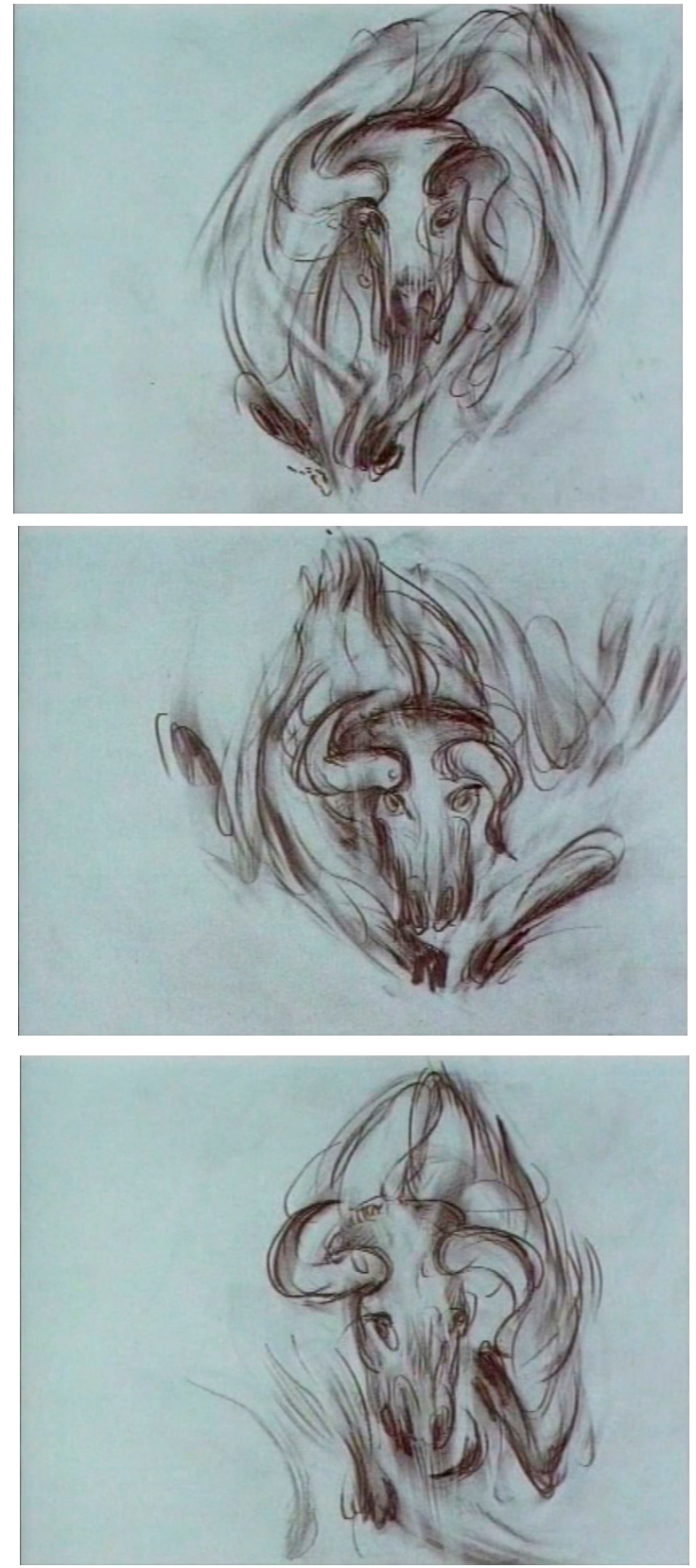
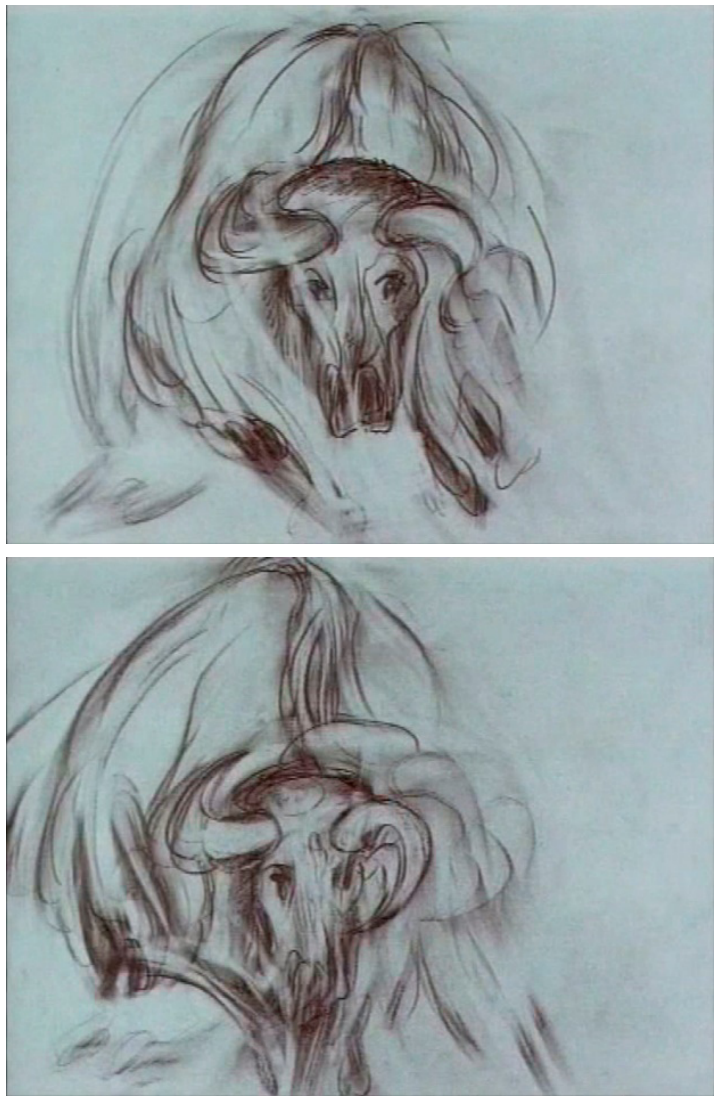

Fig. 9. Vuk Jevremovic (1997).

The wind subsides (El viento se calma).

Serie de fotogramas. 
La alteración de la mecánica también está presente en animaciones de movimiento neutro; a veces la simplificación de la mecánica e incluso la "invención" de una mecánica nueva es el medio idóneo para representar el movimiento dando preferencia a la claridad del mensaje frente a la subjetividad de las sensaciones que el movimiento suscita. En el video educativo Animación educativa: StudioHistoria (Serotonin Tech, 2013), los personajes con los que se ilustra la historia se desplazan en la pantalla con un simple movimiento de deslizamiento: el acto de caminar se ha reducido a la dirección y sentido del desplazamiento, sin reproducir el más mínimo movimiento de las piernas y ningún otro miembro del cuerpo (Fig. 10). Por lo que vemos que, a pesar de la gran potencia expresiva de la alteración de la mecánica, este recurso también representa satisfactoriamente el movimiento más neutro.
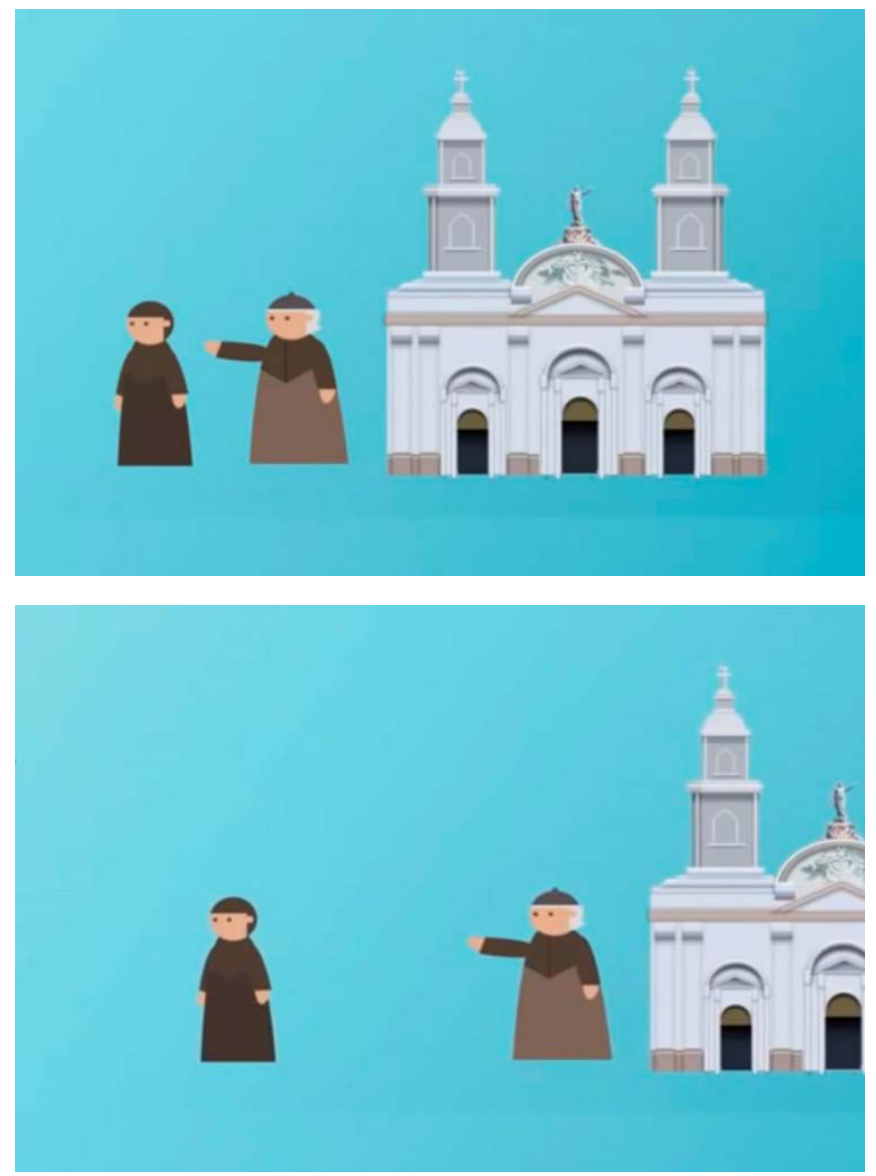

Fig. 10. Serotonin Tech (2013). Animación educativa: StudioHistoria. Serie de fotogramas.

Las técnicas de animación en las que se crean los elementos móviles (dibujo, recortes, etc.) ofrecen un rango infinito de flexibilidad en la definición del movimiento a lo largo de los fotogramas. Pero las técnicas hechas a partir de captura de movimiento también ofrecen un margen de posibilidades para distorsionar la 
valoración espacio-temporal. En la rotoscopia y el motion capture, las alteraciones de la valoración espacio-temporal más comunes son la eliminación y adición de fotogramas. Esta operación se concentra en prolongar o reducir el tiempo de las distintas fases de la acción para darle mayor claridad o hacer énfasis en algún punto. Cuanto más se altere la mecánica del movimiento capturado, el resultado se alejará más del dinamismo característico de estos medios de animación. A veces se añaden anticipaciones y retrocesos al estilo de la animación Disney (recursos de los que hablaremos en el punto siguiente), como en Thought of you... (Pensando en ti...) (Woodward, 2010). Aquí la apariencia del video de acción real que subyace a la animación es modificada por movimientos de fantasía que emergen a partir del movimiento natural de los dos bailarines (sobre todo metamorfosis en formas abstractas). La intercalación de acciones que mantienen el movimiento del video y otras que se desligan de él funciona por contraste entre el movimiento comedido de la rotoscopia y el movimiento dibujado, como mencionamos al principio de este apartado.

\section{VALORACIÓN ESPACIO-TEMPORAL SEGÚN UN ESTILO DE ANIMACIÓN}

La valoración espacio-temporal, como estamos viendo, puede hacerse de infinidad de maneras. Entre esas posibilidades hay métodos más o menos reglados que aseguran resultados específicos. Es el caso de los recursos de estilo de representación móvil. El más extendido es, sin duda, el que los Walt Disney Animation Studios crearon en los años 30 y perfeccionaron a lo largo del tiempo. El estilo Disney surgió hace ya más de 75 años. Tras el éxito de las películas de la compañía, su modo de hacer se desarrolló y difundió. Aunque ha variado a lo largo de los años, las características distintivas se mantienen. Lo que hace reconocible a este estilo es, por encima del diseño de los personajes, la valoración espaciotemporal. Los fundamentos de este estilo que están relacionados directamente con la interpretación espacio-temporal son: squash - stretch, anticipation, slow inslow out, arcs y overlaping. Éstos se arraigaron y extendieron como los "fundamentos de la animación", de hecho, constituyen el grueso de los conocimientos transmitidos en los manuales de animación (no sólo los publicados por Disney). Esta forma de abordar la relación espacio-temporal fue fruto de mucha experimentación en los estudios. Pocos estilos han determinado tan claramente la representación del movimiento en lo que a la valoración espacio-temporal se refiere. El manga, por ejemplo, aun presentando características distintivas entre los 
muchos estilos que reúne, no atañe concretamente a la valoración espaciotemporal de las acciones sino fundamentalmente a la planificación y la cadencia de la intensidad cinética (a parte del diseño de personajes).

Veamos en qué modo el famoso estilo de animación determina la valoración espacio-temporal:

El squash y el stretch es el aplastamiento (o compresión) y estiramiento de la forma en momentos determinados de la acción (Fig. 11 y 12). Este recurso surgió ante el deseo de plasmar la flexibilidad de los cuerpos que, anteriormente, resultaban bastante rígidos ${ }^{17}$. Exploraron la flexibilidad del cuerpo, por ejemplo el rostro al sonreír, masticar, soplar, etc. La clave reside en imaginar que no hay nada rígido y que en los dibujos principales (key frames), según la dirección del movimiento y el peso del objeto, prácticamente siempre se representa la fase extrema de un estiramiento (strech) o compresión o aplastamiento (squash) de la forma. ${ }^{18}$

Fig. 11. Walt

Disney Studios

(s/f). Squash

and Strech.
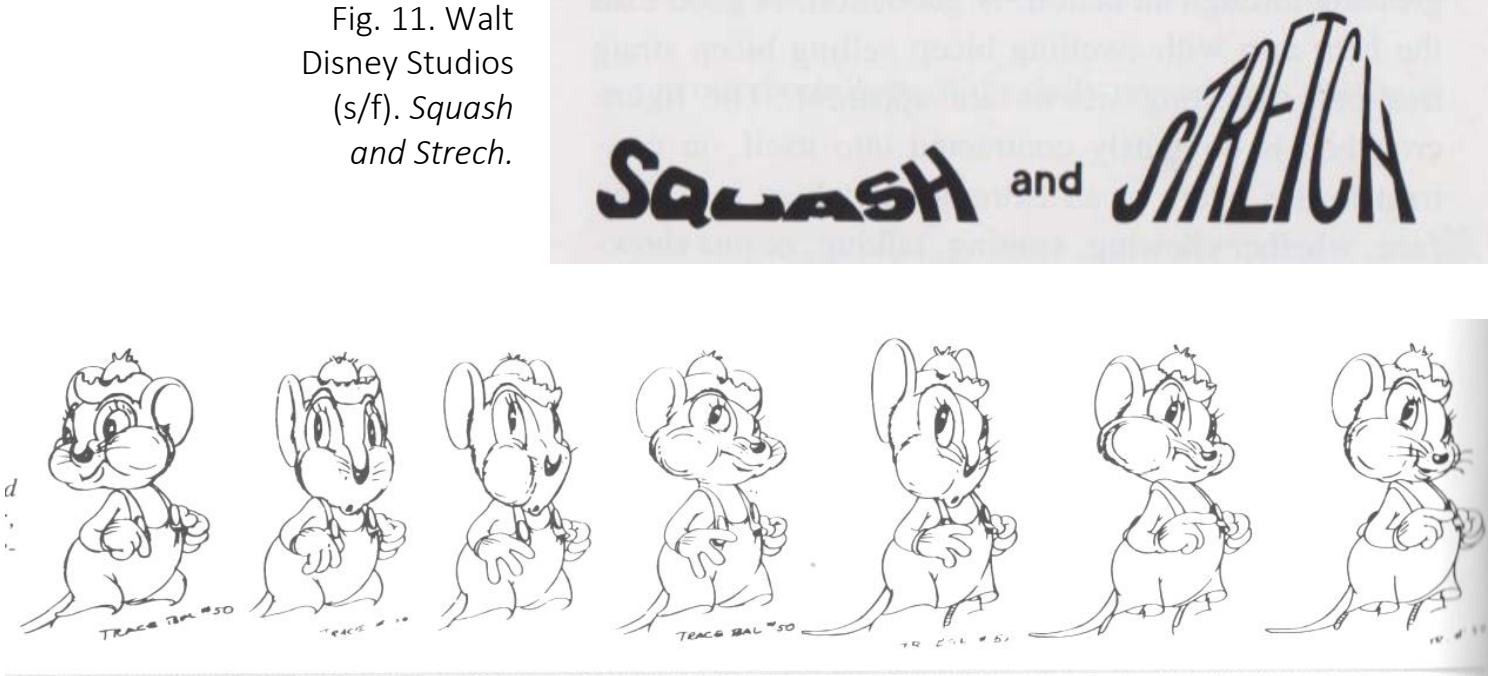

Fig. 12. Les Clark (1936). The Country Cousin (El primo de campo).

El overlaping (superposición) se refiere a cómo los elementos más flexibles o blandos del móvil (el pelo, la parte inferior de un abrigo largo, una capa, pero también las mejillas o un vientre voluminoso) se mueven "por detrás" o "con retraso" respecto a la parte motriz y rígida (que, al aplicar el squash y el stretch, no

\footnotetext{
17 Thomas \& Johnston, 1981, pág. 48

18 Thomas \& Johnston, 1981, págs. 47-51. Remitimos directamente al libro de Frank Thomas y Ollie Johnston porque es la fuente más original, aunque hay muchos libros en lo que se explican los "principios de la animación”, como los de John Halas, Preston Blair, Richard Williams, Raúl García, ect.
} 
se representa con rigidez) ${ }^{19}$ (Fig. 13). En realidad este fenómeno es fácilmente observable en la naturaleza (por ejemplo en el cabello y la ropa), pero al extenderlo sistemáticamente a todos los elementos blandos, la expresión se uniformiza.
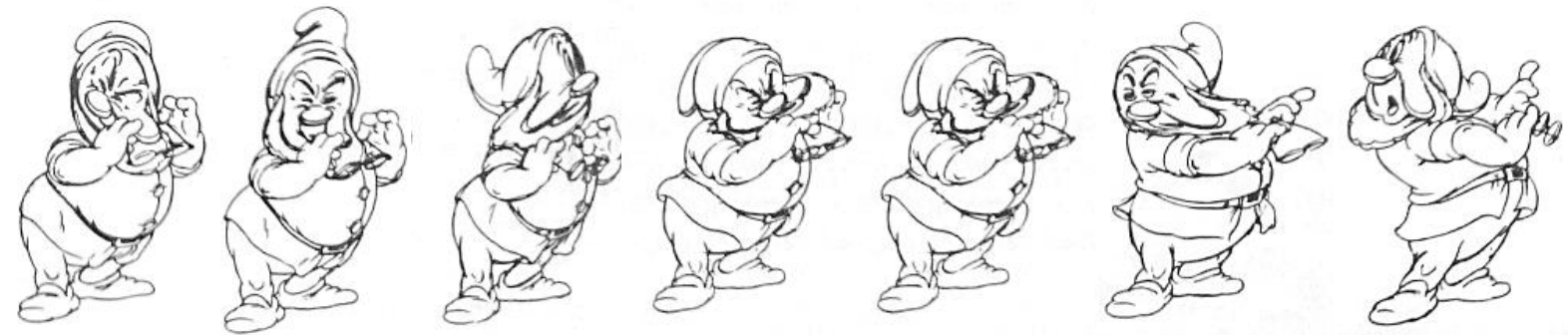

Fig. 13. Bill Tytla (1937). Snow White and the Seven Dwarfs (Blanca Nieves y los siete enanitos).

El Slow in - slow out (lento al entrar - lento al salir) consiste en distribuir los fotogramas intermedios (entre fotogramas clave) de modo que el movimiento sea más lento conforme se acerca a éstos ${ }^{20}$ (Fig. 14). Este recurso afecta directamente a la valoración espacio-temporal porque determina el espacio entre los dibujos. Aunque esta manera de distribuir el espacio entre fotogramas requiere adaptación según la acción representada, al presentase como norma base, la acción se ralentiza intermitentemente y se genera un ritmo dinámico concreto. Para Thomas y Johnston este recurso proporciona "un resultado muy vivaz, con el personaje saltando de una actitud a la siguiente." ${ }^{21}$

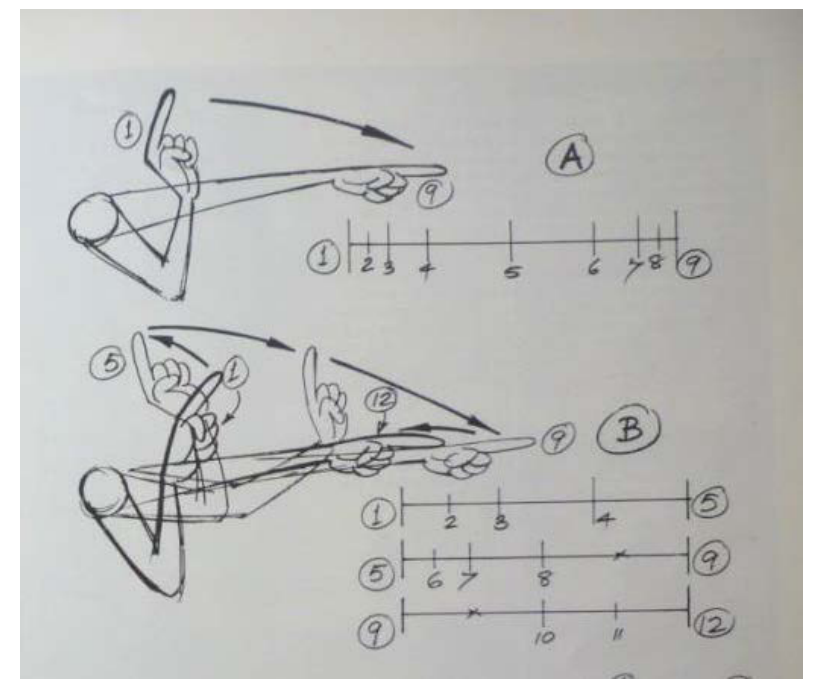

Fig. 14. John Halas y Harold Whitaker $(\mathrm{s} / \mathrm{f})$. Slow in - slow out.

\footnotetext{
19 Thomas \& Johnston, 1981, pág. 59

${ }^{20}$ Thomas \& Johnston, 1981, pág. 62

${ }^{21}$ Thomas \& Johnston, 1981, pág. 62, (trad. a.): The animator achieved a very spirited result, with the character zipping from one attitude to the next.
} 
El principio de los arcos define que casi todas las trayectorias son curvas ${ }^{22}$ (Fig. 15). Determinar la dirección del movimiento, y sobre todo la trayectoria de las partes móviles de un personaje u otros elementos, influye directamente en la valoración espacio-temporal. Mientras que slow in-slow out determina la distribución del tiempo de la acción, los arcos determinan la ubicación en el espacio.

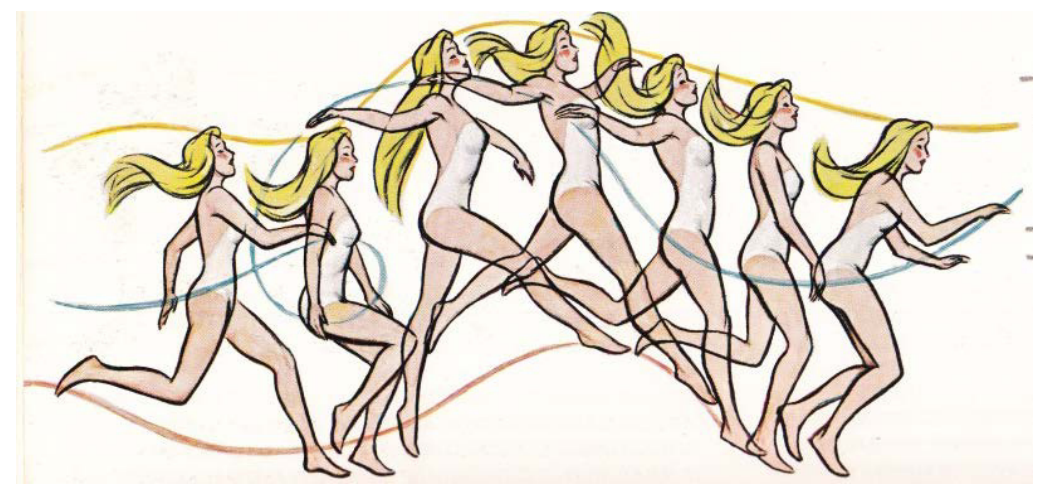

Fig. 15. Walt Disney Studios (s/f). Arcos de acción.

Otro recurso es el de anunciar toda acción con una anticipación. Aunque parece tener una justificación relacionada con la narración visual (el llamar la atención sobre lo que el espectador debe mirar en esos momentos) ${ }^{23}$, se ha convertido la mayor parte de las veces se ha convertido en un movimiento previo en dirección contraria al iniciar la acción y al acabarla (Figs. 16 y 17). Es el movimiento hacia atrás antes de avanzar, que se cierra con un movimiento hacia delante antes de parar (como la sensación que se tiene en un autobús cuando se pone en marcha y cuando frena); puede ser un ligero movimiento o estar llamativamente marcado. Esto, en conjunción con el squash - stretch y el slow in-slow out, cuando se aplica a toda acción, otorga a la animación un efecto rebotante que inicia y cierra cualquier acción (la forma se mueve de manera semejante a un acordeón).

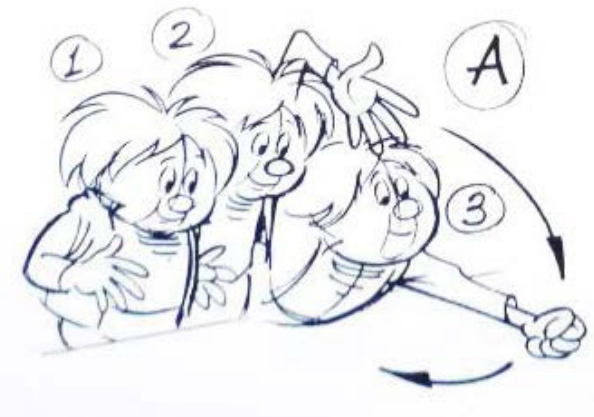

Fig. 16. John Halas y Harold Whitaker (s/f). Anticipación.

${ }^{22}$ Thomas \& Johnston, 1981, pág. 62
${ }^{23}$ Thomas \& Johnston, 1981, pág. 51

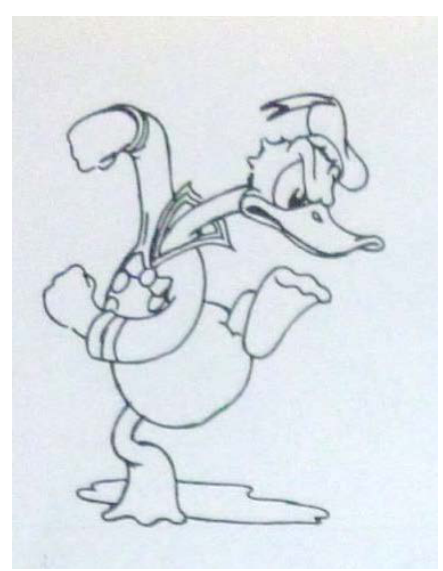

Fig. 17. Walt Disney Studios (s/f). Donald Duck. 
Estos fenómenos aislados parecen más o menos simples de aplicar, pero la realización de la animación se complica al tener que representarlos actuando todos a la vez, tal vez debido a la racionalización excesiva. Johnston y Thomas expresan simpáticamente el dilema: "Los caminados siempre se han vuelto problemáticos y complicados de animar. La acción puede involucrarse tanto con la distribución del peso y los movimiento secundarios que cada dibujo individual se convierte en un dolor de cabeza" 24.

La especificación de cuándo y cómo emplear los recursos de representación permitía al equipo de animación usarlos sistemáticamente y obtener resultados esperados. El modus operandi se afianzó y el lenguaje plástico cobró entidad propia. Desde muy pronto se convirtió en marca distintiva de este estilo, pero trascendió el contexto industrial de la animación americana y hoy en día se encuentra en animaciones de todo tipo, incluso en animaciones independientes. Encontramos este efecto de rebote y acordeón en películas de diversos estilos, por ejemplo en Cool World (Bakshi, 1992). En la figura 18 se muestran fotogramas de una escena que representa una persecución en coche; los vehículos se deforman llamativamente encogiéndose y estirándose según frenan o aceleran. Los mismos recursos también se emplean en animaciones de contexto no industrial con más o menos abundancia, como en la obra de Joanna Quinn, en la que son constantes las deformaciones que siguen este esquema (Fig. 19). Patrick Smith, animador independiente, resalta el slow in-slow out en sus películas como una elección personal para conseguir la alternancia de velocidad: "Cuando animo realmente pienso que el timing es importante y quiero que las emociones sean exactamente como quiero: rápido y lento, y rápido de nuevo" ${ }^{25}$. La determinación de cuándo y cómo se deforma el cuerpo en movimiento, su trayectoria o la distribución de la velocidad acotan bastante la valoración espacio-temporal, la cual adquiere un carácter muy reconocible y produce la uniformidad de la valoración espaciotemporal entre las animaciones en las que el movimiento se representa así. Por lo que, en este sentido se acerca a esta cualidad del movimiento neutro.

\footnotetext{
${ }^{24}$ Thomas \& Johnston, 1981, pág. 347, (trad. a.): Walks always have become troublesome and complicated to animate. The action can become so involved with weight distribution and balance and secondary movements that every single drawing becomes a headache.

${ }^{25}$ Smith 2002. Making of Delivery (00:01:17), (trad. a.): When I animate I really think the timing is important and I want emotions to be exactly right I want: Snap and slow and snap again.
} 

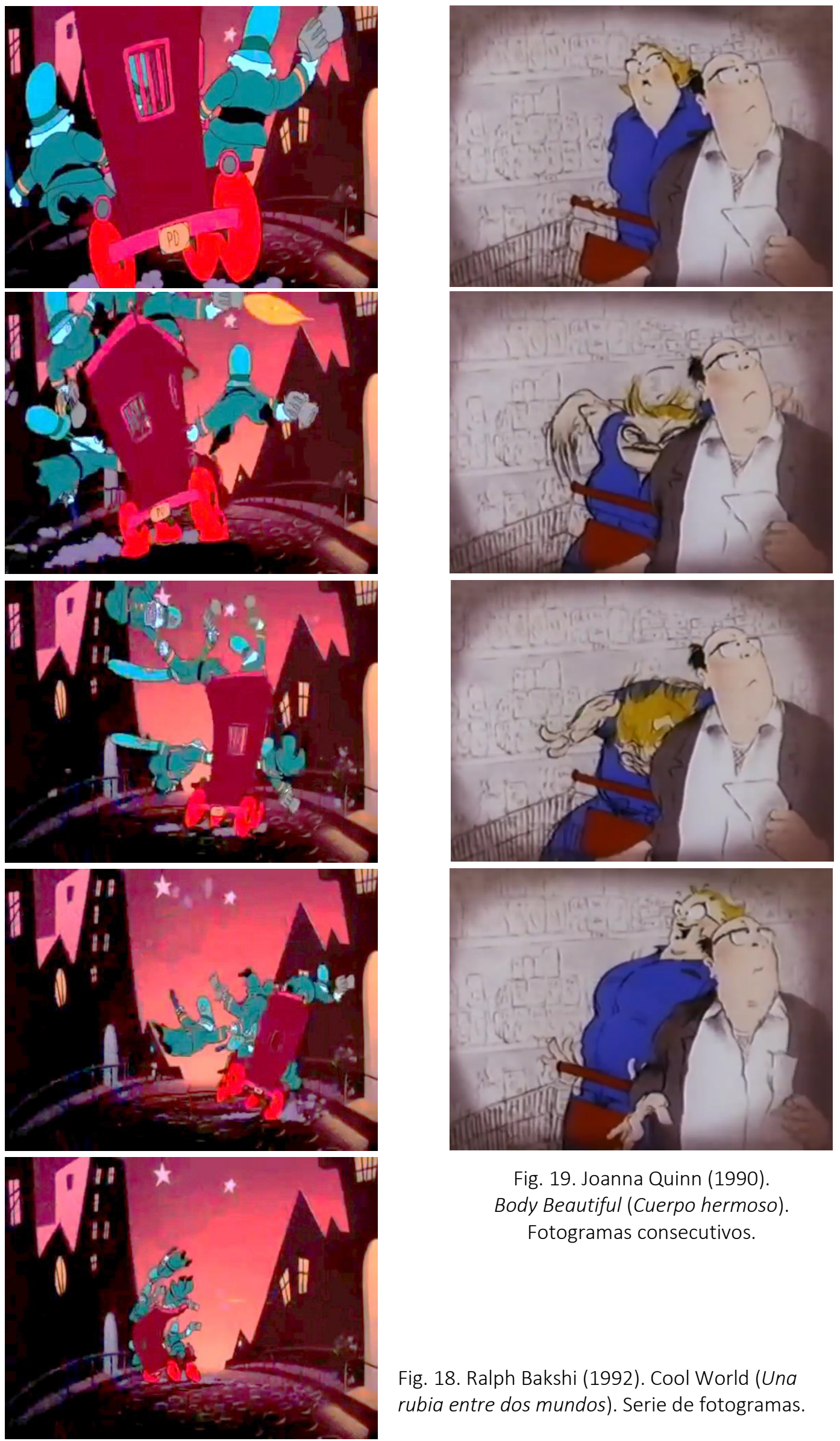

Fig. 19. Joanna Quinn (1990). Body Beautiful (Cuerpo hermoso). Fotogramas consecutivos.

Fig. 18. Ralph Bakshi (1992). Cool World (Una rubia entre dos mundos). Serie de fotogramas. 
Cabe destacar que la homogenización es sólo una cualidad del movimiento neutro y que las cualidades del movimiento vivenciado (generar sensaciones cinestésicas, expresar cualidades peculiares del movimiento, transcurrir en un espacio vivencial y transmitir el contenido emocional o ideológico) pueden darse no sólo en éste, sino en cualquier estilo de animación. En concreto en la animación de Disney, se evidencia la predilección por representar la flexibilidad y el peso, lo cual es un punto de partida para expresar cinestésicamente el movimiento. Un ejemplo de animaciones de este estilo que expresan el movimiento vivenciado es el gag de Pluto (Fig. 20) intentando empezar a correr, en el que, debido al terreno y a su propio estado emocional, el inicio de la carrera se retrasa; nos recuerda la misma impotencia que sentimos en esas pesadillas en las que no podemos correr cuando más falta hace. $Y$ recordemos el movimiento del caballo de Brave (Andrews, Chapman, \& Purcell, 2012), del que hablamos en el punto B. de 3.2.1., Tomar información detallada de la mecánica real.

Sin embargo, la simple reunión de las características de un estilo no proporciona una valoración espacio-temporal que se identifique necesariamente con el estilo en cuestión. Así, encontramos animaciones que presentan uno o varios de los recursos mencionados y que no corresponden al estilo de movimiento de películas que sí lo siguen, sino que tienen un dinamismo singular que no imita los recursos sino que los trasgrede y los personaliza. Por ejemplo Tanssi (Danza) (Lahtinen, h.2013) (Fig. 21), The cat come back (El gato volvió) (Barker, 1988) o Le moine et le poisson (El monje y el pez) son animaciones en las que los recursos de representación de Disney se emplean de manera tan personal que no existe vínculo estilístico entre éstas y la gran compañía. Las anticipaciones y retrocesos y el squashstretch se emplean en los tres casos de manera distinta entre ellas, pero tienen en común que otorga un carácter simpático, y hasta cómico, al movimiento. Esto evidencia que hace falta intención imitativa del estilo para que el resultado se enmarque dentro de éste.

Por otro lado se puede usar el estilo de animación de manera retórica. Esto no hace que el movimiento sea más o menos vivenciado o neutro, pero constituye otra forma de trasgredir el famoso estilo, por lo que nos detendremos en dos ejemplos. En Who framed Roger Rabbit? (¿Quién engañó a Roger Rabbit?) (Zemeckis, 1988), en la que actores de carne y hueso interactúan con personajes de dibujos animados, se presenta la animación tradicional americana representándose a sí misma, como un colectivo más de Hollywood, con sus intrigas y miserias. Mientras que Tráfico de órganos infantiles (Peris, 2006) remite al lenguaje del cartoon de manera irónica. Se trata una animación en blanco y negro que hace 
referencia al estilo de Tim Burton-Disney en el que un científico loco arquetípico utiliza una gran máquina para extraer los órganos de los niños y envasarlos en latas. El corto finaliza con el eslogan "Tráfico de órganos infantiles. No es una broma", lo que permite comprender el sentido crítico del cortometraje al representar tal abuso contra los niños utilizando un lenguaje tradicionalmente infantil.
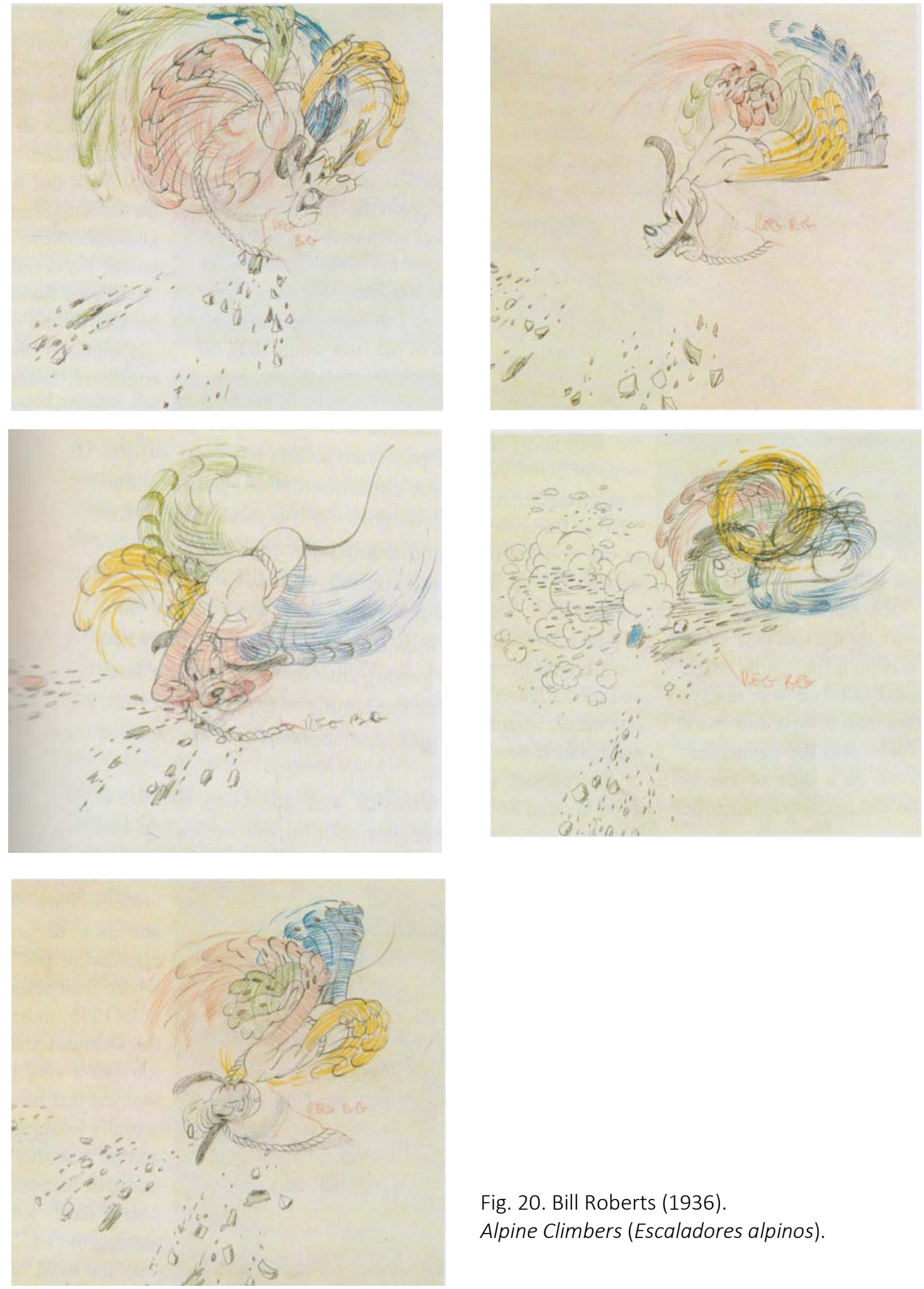

Fig. 20. Bill Roberts (1936).

Alpine Climbers (Escaladores alpinos). 

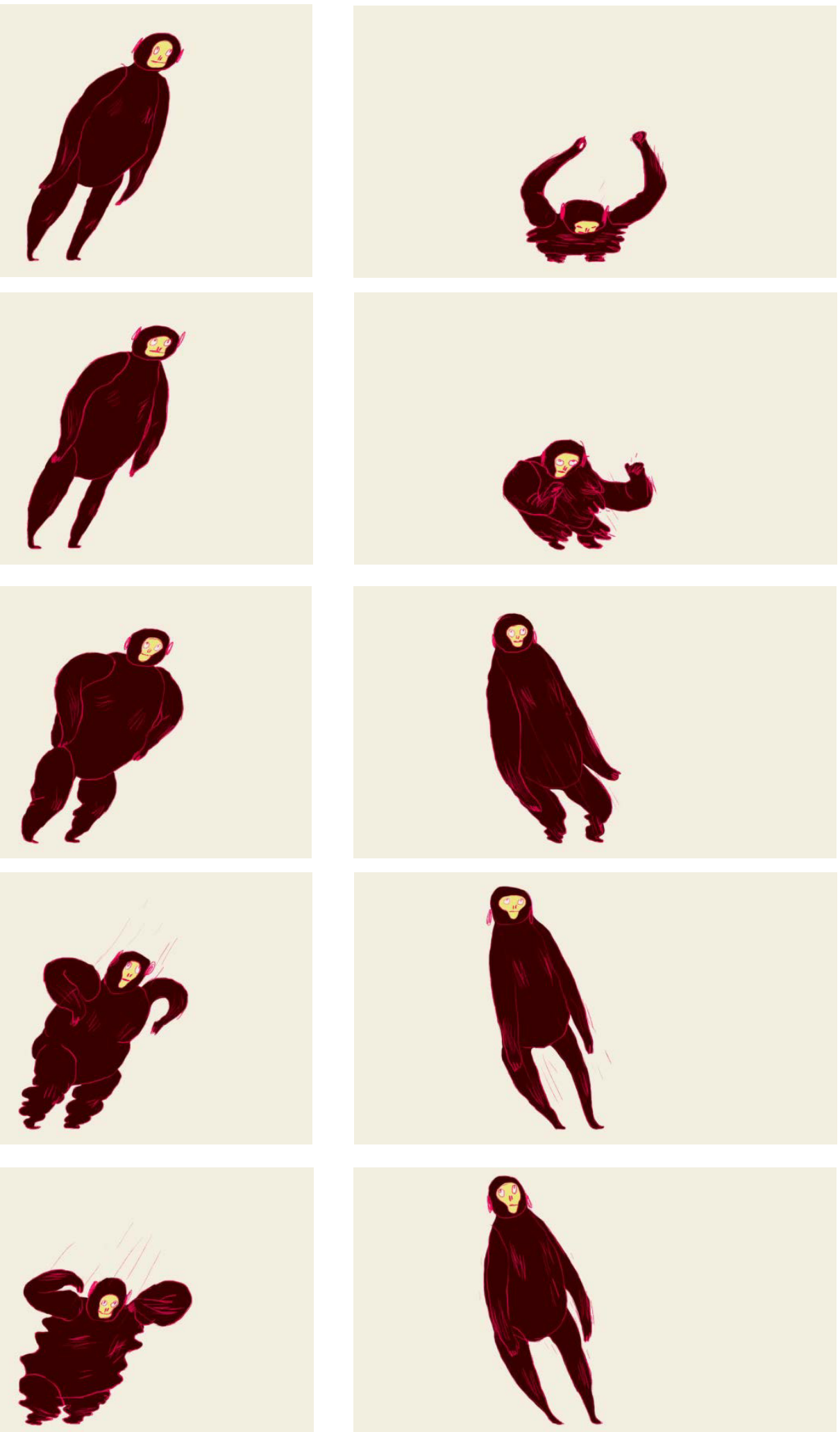

Fig. 21. Sanni Lahtinen (h.2013). Tanssi (Danza). Fotogramas consecutivos. 
La distorsión de la mecánica real puede ser de muchos tipos y no siempre colabora de manera expresiva en la animación. Pero esta intervención en la valoración espacio temporal, por afectar de manera directa, a la visualidad del movimiento, se convierte en un elemento altamente aprovechable para transmitir sensaciones, emociones e ideas. Esto, junto a su gran maleabilidad, la convierte en un medio ideal para la expresión del movimiento vivenciado.

\subsubsection{INTERPRETACIÓN ESPACIO-TEMPORAL POR ORDEN CRONOLÓGICO O YUXTAPOSICIÓN DE FASES}

Otro elemento que influye en la valoración espacio-temporal es el orden en que se presenta el desarrollo secuencial del movimiento. En animación el movimiento se representa por medio del desdoblamiento de la figura en varias imágenes sucesivas. Este estudio pormenorizado no tiene porqué corresponderse con la mecánica real, como acabamos de ver en 3.2.2. La desvinculación de la mecánica puede llegar a tal punto que no se siga el orden cronológico de la acción. En este apartado nos detenemos en esta manera de alterar la mecánica.

\section{A. OTRA MANERA DE ALTERAR LA MECÁNICA}

En animación lo más habitual es representar el movimiento de manera secuencial, siguiendo su orden cronológico. Pero si en los fotogramas contiguos se muestran fases del movimiento muy distanciadas entre ellas y estos se proyectan a una frecuencia de entre 12 y 24 ips, el movimiento cobra velocidad e intensidad $y$, sobre todo, una visualidad sorprendente. A continuación analizamos algunas obras en las que se expresa el movimiento de esta manera, la cual hemos denominado "yuxtaposición de fases no consecutivas o no cronológicas de la acción". En el cortometraje de animación La Saint-Festin (Daffis \& Marchand, 2007) [en DVD], en la escena de la bailadora de flamenco (00:12:50.), vemos que los fotogramas contiguos representan momentos extremos del movimiento del torso, los brazos y las piernas sin utilizar imágenes intermedias para alcanzar esos estadios de la acción, de modo que cada fotograma, visto por separado, representa una acción diferente (elevación de los brazos, extensión de un brazo y flexión del otro, brazos extendidos hacia atrás, etc.). La velocidad a la que se visionan estas imáge- 
nes (12 por segundo) hace que casi no se distingan tales acciones, sin embargo, transmiten el ágil y potente movimiento del flamenco. En la figura 22 vemos fotogramas contiguos, los cuales componen tan sólo medio segundo de película. Obsérvese la diferencia de cambio entre el hombre (de acción real) y la mujer. La sensación de movimiento que se transmite en cada dibujo, al clarificar y potenciar el dinamismo, sin duda contribuye a la expresión del movimiento de la mujer.

En Flux (Hinton, 2002) [en DVD], en el caótico movimiento de una niña llorando en brazos de su padre (00:00:46) y en la llama de una vela (00:03:50), vemos nuevamente que la acción está marcadamente resumida por medio de la supresión de las fases intermedias. Si el orden de los fotogramas se alterase, la acción seguiría percibiéndose de manera similar, como un movimiento de carácter continuo, a pesar de componerse por fases no consecutivas. En el caso de la vela (Fig. 23), la llama primero es negra y estrecha, a continuación es ancha y amarilla, etc. Si las imágenes se cambiaran de orden, el efecto percibido sería el mismo. Por lo tanto, al visualizar las imágenes en sucesión, se extrae el sentido secuencial de las mismas aunque la distancia temporal de las fases representadas contiguamente sea extrema. De hecho, si se estudian las imágenes individuales de la animación por yuxtaposición de fases no cronológicas, se advierte el parecido con los resúmenes marcados de tiempo en los que una imagen se mantiene varios fotogramas en pantallas (como en Psyche and Eros - de Vere, 1994 -, fig. 61, cap.1 - 00:06:01-) [en DVD]. Al no haber una evolución progresiva, dependiendo de la acción, las imágenes pueden interpretarse tanto como un resumen o como una alteración del orden. Al observar la animación de fases yuxtapuestas no se distinguen los fotogramas individuales, que cobran gran velocidad, y el movimiento no se percibe como desordenado, sino que se comprende con una nueva cronología.

También encontramos expresión dinámica por yuxtaposición de fases en la animación japonesa, a veces como resúmenes marcados de la acción y otras como representación intrépida de la velocidad. Las escenas de combate presentan con cierta frecuencia esta característica, en las que, en una combinación entre audacia de la representación y tal vez búsqueda de economía, en algunos casos se alcanzan niveles expresivos notables. Así lo vemos en La Pirámide de hielo (Saint Seiya, (Los Caballeros del Zodíaco) (Morishita, 1972-1974). Como las imágenes consecutivas representan momentos extremos de diversas acciones en lugar de fases progresivas, el cambio brusco de imagen produce un movimiento muy fuerte que transmite la extremada velocidad de los combatientes. La escena que vemos en la figura 24 (00:14:05.) se acompaña, además, de efectos intangibles: rayos luminosos que simulan explosiones eléctricas. Estos siguen el mismo principio de yuxtaposición y su principal efecto son los pos-efectos ópticos. 

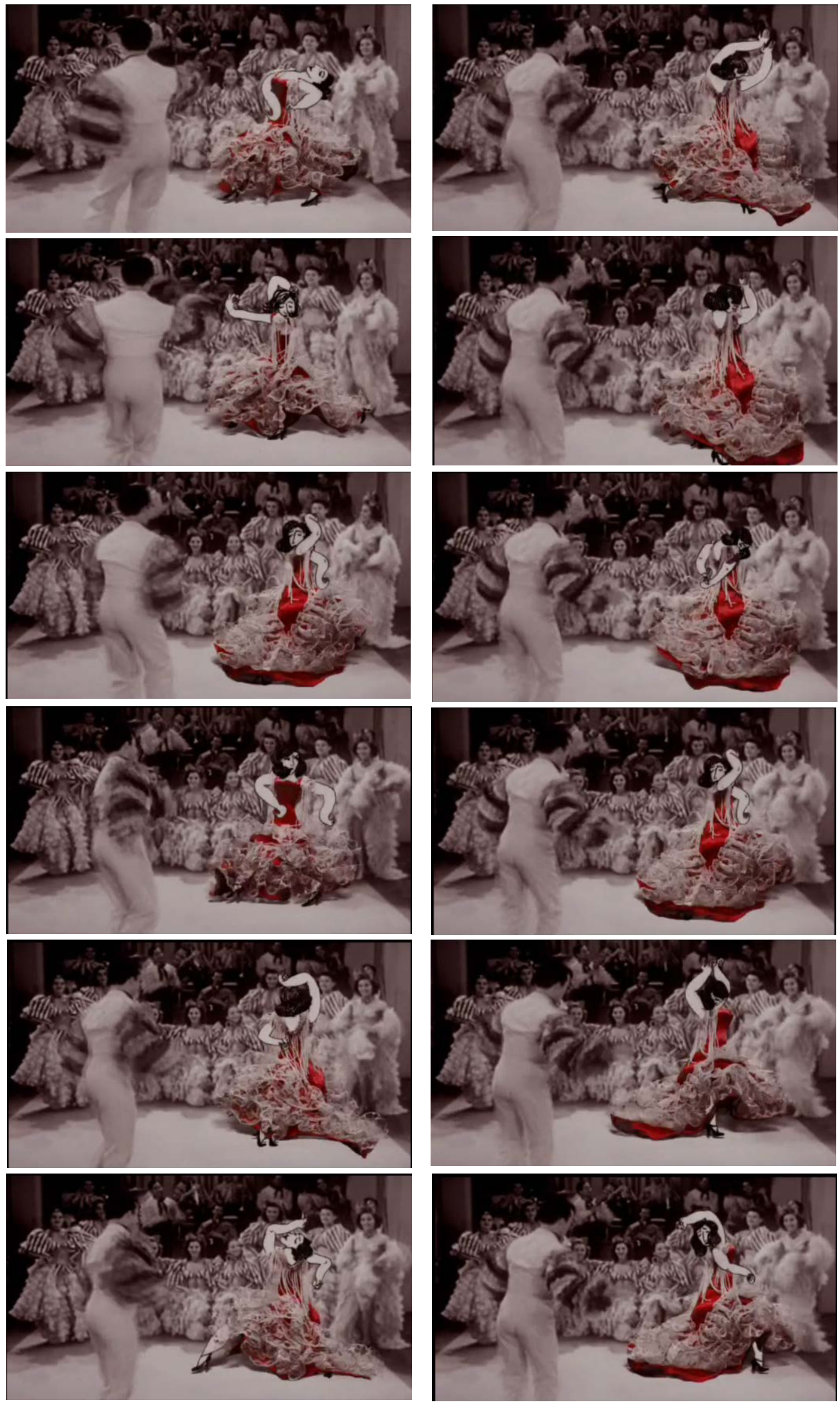

Fig. 22. Annelaure Daffis y Léo Marchand (2007). La Saint-Festin. Fotogramas consecutivos. 

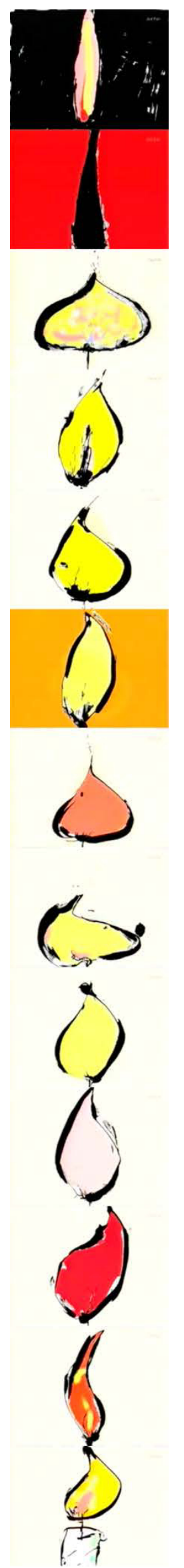

Fig. 23. Chris Hinton (2002).

Flux. Fotogramas consecutivos.

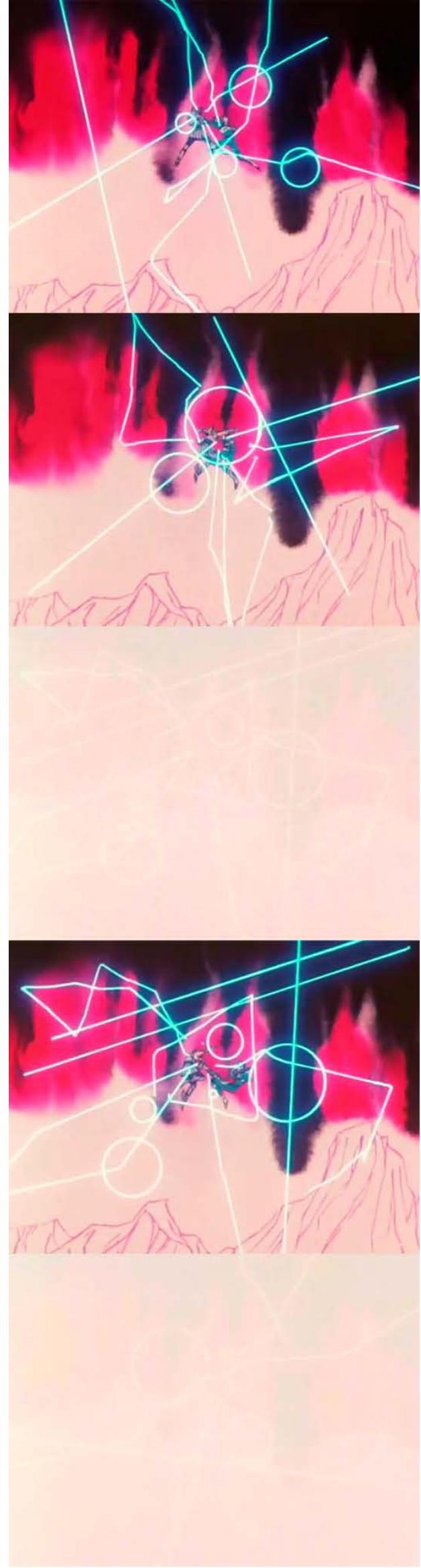

Fig. 24. Kōzō Morishita y Kazuhito Kikuchi (1986-1989). Saint Seiya (Caballeros del Zodiaco), Temporada 1, capítulo 21: La Pirámide de hielo. Fotogramas consecutivos. 
Finalmente, obsérvese que la representación de movimientos muy rápidos con trayectoria cambiante puede dar como resultado la disolución de la trayectoria, lo que visualmente es similar al efecto que produce la yuxtaposición de fases no cronológicas. En Možnosti dialogu (Dimensiones del diálogo) (Svankmajer, 1982) en las escenas en las que unos materiales se devoran entre ellos, hay una progresiva disolución de la dirección de las trayectorias hasta alcanzar gran intensidad cinética. En el punto máximo del fenómeno (papeles, metales y sustancias orgánicas se trituran unas a otras hasta ser imposibles de identificar -00:02:30 -), como consecuencia de la desaparición de la continuidad de las trayectorias, las imágenes contiguas dejan de mostrar el fenómeno en evolución, lo que da lugar a la yuxtaposición de imágenes no sucesivas.

En los ejemplos analizados, las imágenes que conforman las animaciones son más dinámicas en unos casos que en otros. Los dibujos de la bailadora de flamenco en La Saint-Festin evocan mucho más movimiento por sí mismas que las figuras de la escena de Saint Seiya. No obstante, la animación es audaz en ambos casos, ya que la yuxtaposición de fases otorga por sí misma una gran potencia al resultado, debido al llamativo movimiento parpadeante resultante de la gran diferencia entre fotogramas contiguos. Por ello se deduce que la expresión móvil por yuxtaposición de fases es por sí misma un recurso muy audaz, en el que el veloz cambio de pose es tan potente que otros elementos expresivos pierden protagonismo.

Por representar el movimiento priorizando la sensación visual global de la acción (por encima de la coherencia mecánica), la yuxtaposición de fases no cronológicas de la acción se aproxima en esta cualidad al movimiento vivenciado.

\section{B. EXPERIMENTACIÓN PLÁSTICA}

Hemos experimentado plásticamente a partir de las ideas expuestas con el propósito de conocer desde la práctica cómo expresar el movimiento vivenciado por medio de imágenes que no representan el desarrollo secuencial del movimiento. Las animaciones resultantes se incluyen en el DVD del anexo 2, en la carpeta 10. Animación por fases yuxtapuestas. 


\section{- Técnica}

La técnica empleada es una versión de película pintada que no requiere celuloide $^{26}$. En la técnica original el film cinematográfico se interviene directamente pintando, dibujando o esgrafiando. Es muy versátil: se puede trabajar manteniendo los fotogramas como unidad mínima, al igual que en la animación dibujo a dibujo o bajo cámara, es decir, transformando poco a poco la imagen; o se puede dibujar sobre el celuloide longitudinalmente, de modo que la película se compone de una imagen que se proyecta por secciones. En A Colour Box (Lye, 1935), una de las primeras obras sobre celuloide, vemos ambos tipos de intervención: manteniendo una forma que varía progresivamente de un fotograma a otro (por ejemplo círculos que cambian de tamaño) y formas que se extienden a lo largo de los planos (principalmente líneas). En la figura 25 se muestran extractos de la película Ere erera baleibu icik subua aruaren (Sastiaga, 1970), en la que también en unas partes se mantiene la entidad de los fotogramas y en otras no.
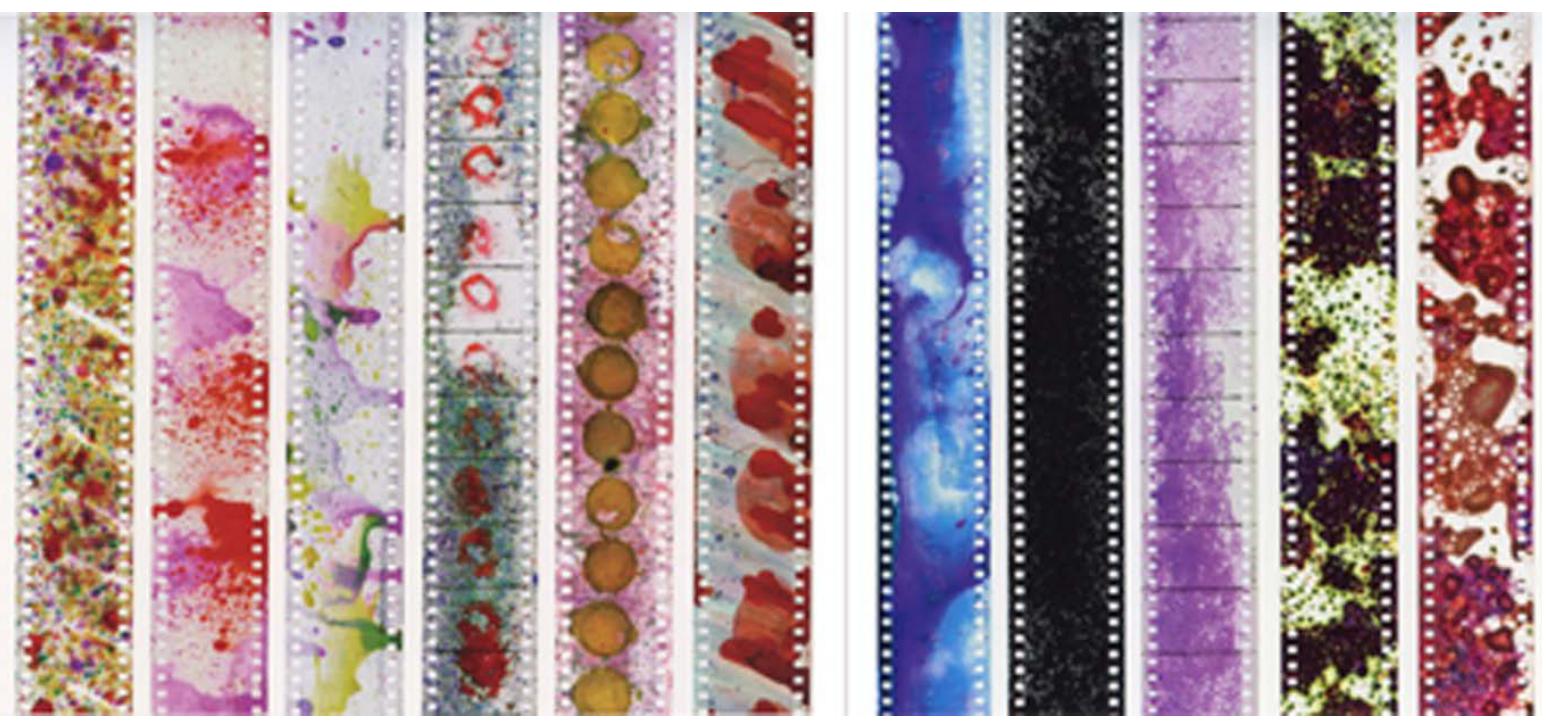

Fig. 25. José Antonio Sastiaga (1970). Ere erera baleibu icik subua aruaren. Celuloide pintado

Dado que la técnica se vale, como hemos visto, de trazados continuos que recorren la superficie de la película, y considerando que ésta es una de sus cualidades distintivas, lo que hicimos fue recortar largas tiras de papel de formato longitudinal que sirvieron de soporte alternativo al celuloide. Para este experimento se dibujó en sentido horizontal. Una vez dibujadas, las bandas se escanearon y se dividieron digitalmente en secciones. Las secciones corresponden a los fotogramas, con los que se realizó el montaje de video.

\footnotetext{
${ }^{26}$ Hemos empleado esta adaptación de la técnica de película pintada con anterioridad en las películas $A l$ ritmo del color (López Martín, Peris y Peris, 2007) y Libidinis (Peris \& Peris, Libidinis, 2011).
} 

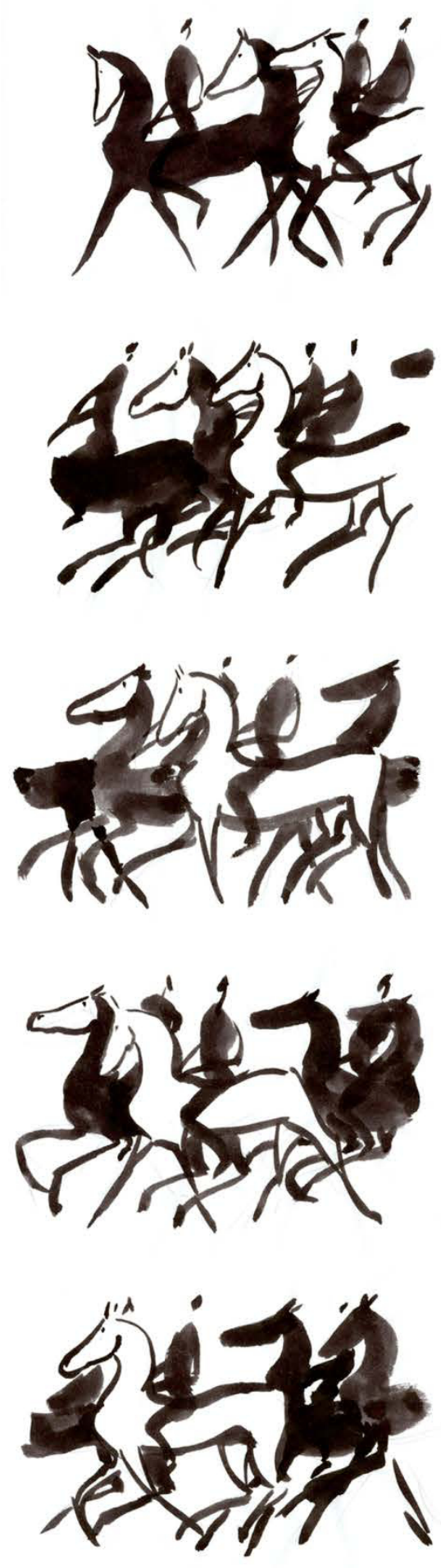

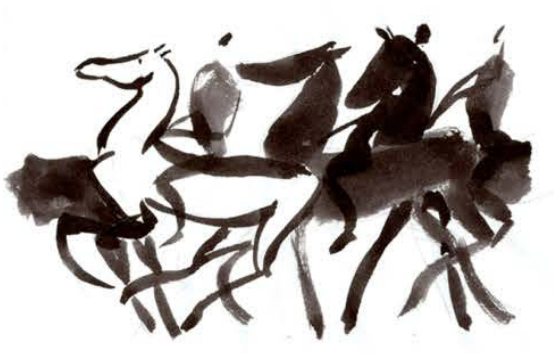

Fig. 26. Rosa Peris (2011). Fotogramas consecutivos de la animación dibujo a dibujo. Animación 1. Experimentación plástica de animación por fases yuxtapuestas.

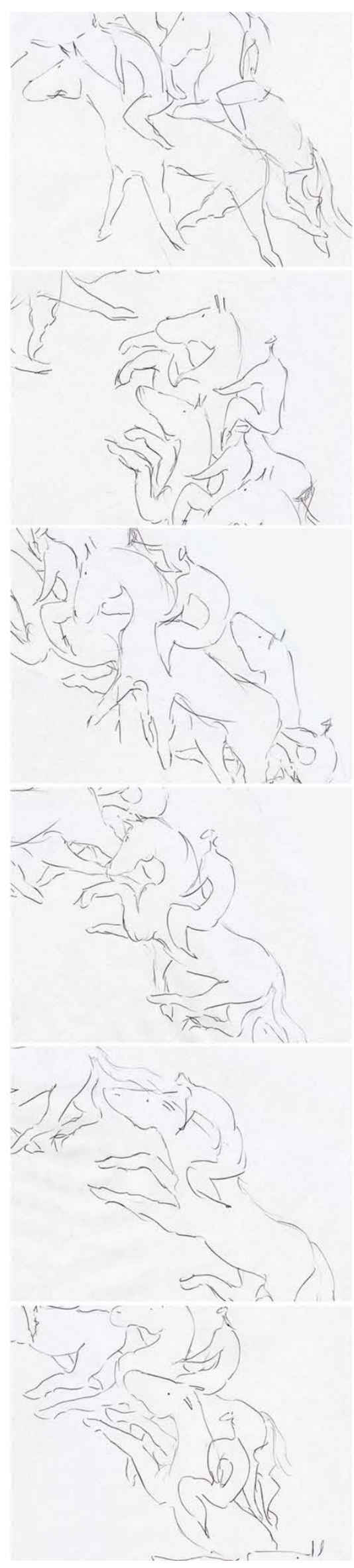

Fig. 27. Rosa Peris (2014). Fotogramas consecutivos de la animación 6. Experimentación plástica de animación por fases yuxtapuestas. 


\section{- Elección del motivo a representar}

Como motivo a representar se escogió un acontecimiento que poseyera una naturaleza próxima a la abstracción, pues se consideró adecuado para la técnica; no obstante, cabe recalcar que la intención no ha sido conseguir resultados similares a las abstracciones de películas como A Color Box o Begon Dull Care (Fantasía en Colores) (McLaren, 1949), sino que predominara la entidad del movimiento representado. El acontecimiento en cuestión es un grupo de jinetes desplazándose. La técnica de película pintada ha sido usada para animar elementos figurativos, no exclusivamente abstractos, pero esto se ha hecho manteniendo la entidad de los fotogramas como en Hen Hop (McLaren, 1942), película en la que la gallina aparece en pantalla como un elemento individual que se reconoce como el mismo gracias a la correlación entre fotogramas. Por ello destacamos que los fragmentos de animación que presentamos suponen una novedad por ser una técnica derivada de la película pintada mediante la que se representa el movimiento de elementos figurativos sin mostrar su evolución cronológica entre fotogramas correlativos, pero que mantienen el sentido del movimiento representado (hasta la fecha no tenemos conocimiento de que se haya utilizado esta técnica con este propósito).

\section{- Variaciones gráficas y de animación}

Con la intención de comparar los resultados, se realizó previamente una secuencia de animación dibujo a dibujo en la que se describe pormenorizadamente el movimiento (animación 1). Los dibujos correlativos corresponden a fases consecutivas de la acción. En la figura 26, el caballo blanco permite comprender la progresión de la misma. En las siguientes secuencias (animaciones 2 - 6) hemos prescindido precisamente de la relación cronológica entre fotogramas (Fig. 27). Para ello se ha dibujado en formato longitudinal (no dividido en secciones que correspondan a los fotogramas) un único dibujo formado por numerosas figuras de caballos y jinetes cuya trayectoria es paralela al plano de representación. Se ha procurado que estos dibujos transmitan dinamismo por sí mismos por medio de las propiedades compositivas habituales de las secuencias: dirección-sentido, continuidad visual de la forma, relación de semejanza y proximidad, abanicos de diagonales, etc. Cabe destacar que aunque los dibujos representen secuencias, al dividir la imagen en secciones no se obtiene en absoluto el desarrollo minucioso del movimiento, sino que hay saltos abruptos entre los fotogramas resultantes.

Se realizaron variaciones gráficas de dibujos con tinta para comprobar en qué medida esto podía afectar al movimiento. Estas variaciones son: 
- Dibujo de mancha de densidad más o menos uniforme. Aunque las manchas no son regulares, la silueta del conjunto destaca por encima de las figuras individuales. (Fig. 28)

- Dibujo en el que se individualizan caballos negros y blancos con línea y mancha. (Fig. 29 y 30 )

- Dibujos con mayor grado de análisis de la forma. (Fig. 27, 31 34)

- Dibujos de línea. (Fig. 27, 33 y 34)

Finalmente se realizaron variaciones de dirección y del punto de vista. Para ello se dibujó la sucesión de jinetes siguiendo una trayectoria compuesta por varias curvas. En este dibujo la acción no es estrictamente paralela a la pantalla (Fig. 32). Pero el "recorrido" era corto y de él se extrajeron pocos fotogramas, por lo que los cambios de dirección resultan bruscos. No obstante, nos permitió entrever que es posible variar la dirección de nuestro "celuloide" particular de manera que se añaden a la vertical y a la horizontal todas las trayectorias posibles. En vista a estos resultados, y con el fin de conseguir cambios de dirección menos abruptos, se creó un soporte con forma especial. Está compuesto por dos grupos de tres círculos cada uno (que se visionan como dos curvas constantes) y dos bandas curvas que se unen tangencialmente a éstos (Fig. 33). El conjunto forma un ciclo de 6 segundos. Ésta adaptación del soporte mantiene las características de la película pintada, pues los fotogramas se extraen de la misma manera que de las bandas horizontales, pero adaptándose a la curva.

\section{- Digitalización de la imagen y extracción de fotogramas}

En la técnica original se realiza una copia del celuloide plásticamente intervenido para así evitar el deterioro que se produciría al proyectar la película repetidas veces. Pero en este caso ni existe celuloide ni proyector cinematográfico. Los programas de edición de video utilizados muestran una imagen tras otra a la velocidad escogida; es decir, funcionan por imágenes independientes (archivos de imagen) no "bandas" de imagen. Así pues, con el fin de emular el efecto de proyección de la cinta, es preciso, previa digitalización de los dibujos, dividirlos en secciones que correspondan a los fotogramas. En los dibujos longitudinales la división fue sencilla de realizar (Fig. 28), mientras que esta labor fue más delicada en aquellos dibujos en los que varía la trayectoria (Figs. 32 y 33) ya que en estos es necesario mantener la línea de trayectoria coherente a lo largo de los fotogramas. 


\section{- Edición de video}

Se crearon seis secuencias de animación correspondientes a las variaciones gráficas y de trayectoria:

- Animación 1: Animación dibujo a dibujo. 12fps. Trayectoria rectilínea. Movimiento paralelo al plano de representación. Figuras negras y blancas (Fig. 26).

- Animación 2.1 y 2.1: Animaciones por fases yuxtapuestas. 12fps. Trayectoria rectilínea. Movimiento paralelo al plano de representación. Figuras negras (Fig. 28). Son dos animaciones hechas con tiras diferentes pero con las mismas carcaterísticas.

- Animación 3: Animación por fases yuxtapuestas. 12fps. Trayectoria rectilínea. Movimiento paralelo al plano de representación. Figuras blancas, grises y negras (Figs. 29 y 30).

- Animación 4.1 y 4.2: Animación por fases yuxtapuestas. 12fps (animación 4.1) y 10 fps (animación 4.2). Trayectoria rectilínea. Movimiento paralelo al plano de representación. Figuras en tonos grises (Fig. 31).

- Animación 5: Animación por fases yuxtapuestas. 12fps. Trayectoria curvilínea cambiante. Acción oblicua al plano de representación. Figuras de gráfica variada (Fig. 31).

- Animación 6: Animación por fases yuxtapuestas. 12fps. Trayectoria curvilínea cambiante. Acción oblicua al plano de representación. Figuras de línea. (Fig. 27, 33 y 34$)$.

Cada animación se editó en dos versiones, a 12 fps y 10 fps, para comprobar las diferencias entre ambas. Se utilizaron los programas Adobe After Effects y Adobe Premier.

\section{- Resultados}

Las variaciones plásticas influyen en el resultado. Las figuras completamente negras (animación 2) no llegan a transmitir la sensación de traslación del grupo de jinetes y caballos, aunque se percibe su movimiento tumultuoso. Las que combinan figuras blancas y negras (animación 3) o de diferentes grises (animaciones 4 y 5) expresan con eficacia el avance y el movimiento global del suceso. Esto incluye los dibujos de línea en los que no se individualizan las figuras por tonos (animación 6). De ello se deduce que la distinción entre figuras es determinante para dar a entender el desplazamiento del grupo, ya sea una diferencia por áreas de mancha o por línea. 
Las animaciones a $10 \mathrm{fps}$ y a $12 \mathrm{fps}$ proporcionaron efectos dinámicos ligeramente diferentes. Aunque el movimiento en ambos es frenético, la velocidad menor no aporta más claridad a la expresión del suceso, ya que se produce la sensación de que la animación se detiene constantemente, de modo que interrumpe la continuidad que se obtiene a $12 \mathrm{fps}$. La frecuencia de $10 \mathrm{fps}$ no impide la fluidez del movimiento expresado cuando en los fotogramas contiguos se muestra la evolución cronológica y pormenorizada del movimiento, pero en el presente caso, al proyectar imágenes sin relación cronológica directa, la diferencia de 2 fotogramas en la frecuencia de las imágenes afecta significativamente a la comprensión de la continuidad.

La animación 5, la primera prueba de cambio de dirección, es muy breve, pero vemos cómo la alteración gráfica no impide percibir la trayectoria. Pero es en la segunda prueba (animación 6) en la que se representa satisfactoriamente la trayectoria curva y el cambio de dirección.

Las animaciones resultantes poseen una gran intensidad cinética, mayor que la que se expresa en las imágenes que las conforman. Para que la velocidad de la animación fuera equivalente a la velocidad transmitida en el dibujo, los caballos deberían representarse en un avance más estrepitoso en las bandas de imágenes. Pero a pesar de la diferencia de intensidad cinética entre las imágenes y los videos, esto no supone un inconveniente, ya que están acorde (no representan velocidades opuestas), por lo que el movimiento resultante es coherente. Es más, en las animaciones 2, 3, 4 y 6, por evocar el característico tumulto de un gran grupo de jinetes y caballos, y por la sensación cinética que sugieren, el movimiento resultante tiene estas cualidades de la expresión vivenciada.

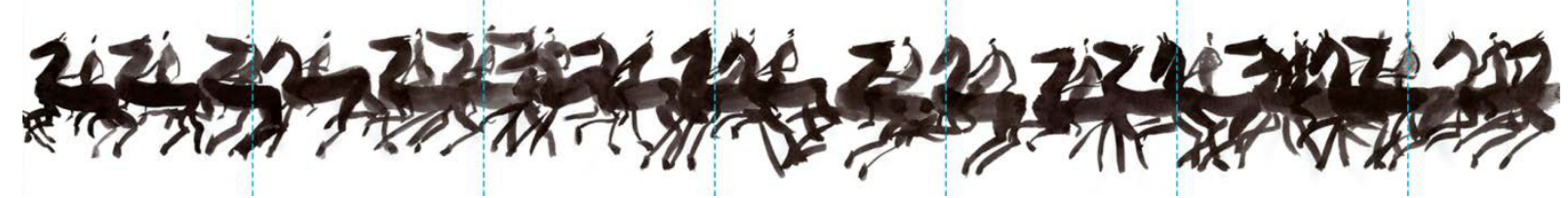

Fig. 28. Rosa Peris (2011). Fragmento de banda de imagen de la animación 2 con líneas verticales que indican la división entre fotogramas. Experimentación plástica de animación por fases yuxtapuestas.

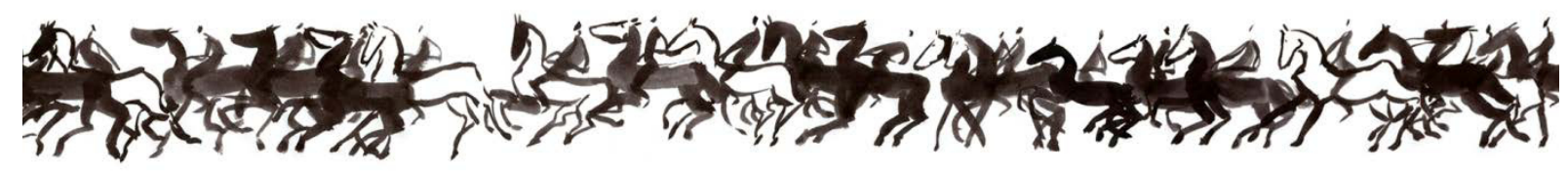

Fig. 29. (Rosa Peris (2011). Fragmento de banda de imagen de la animación 3. Experimentación plástica de animación por fases yuxtapuestas. 

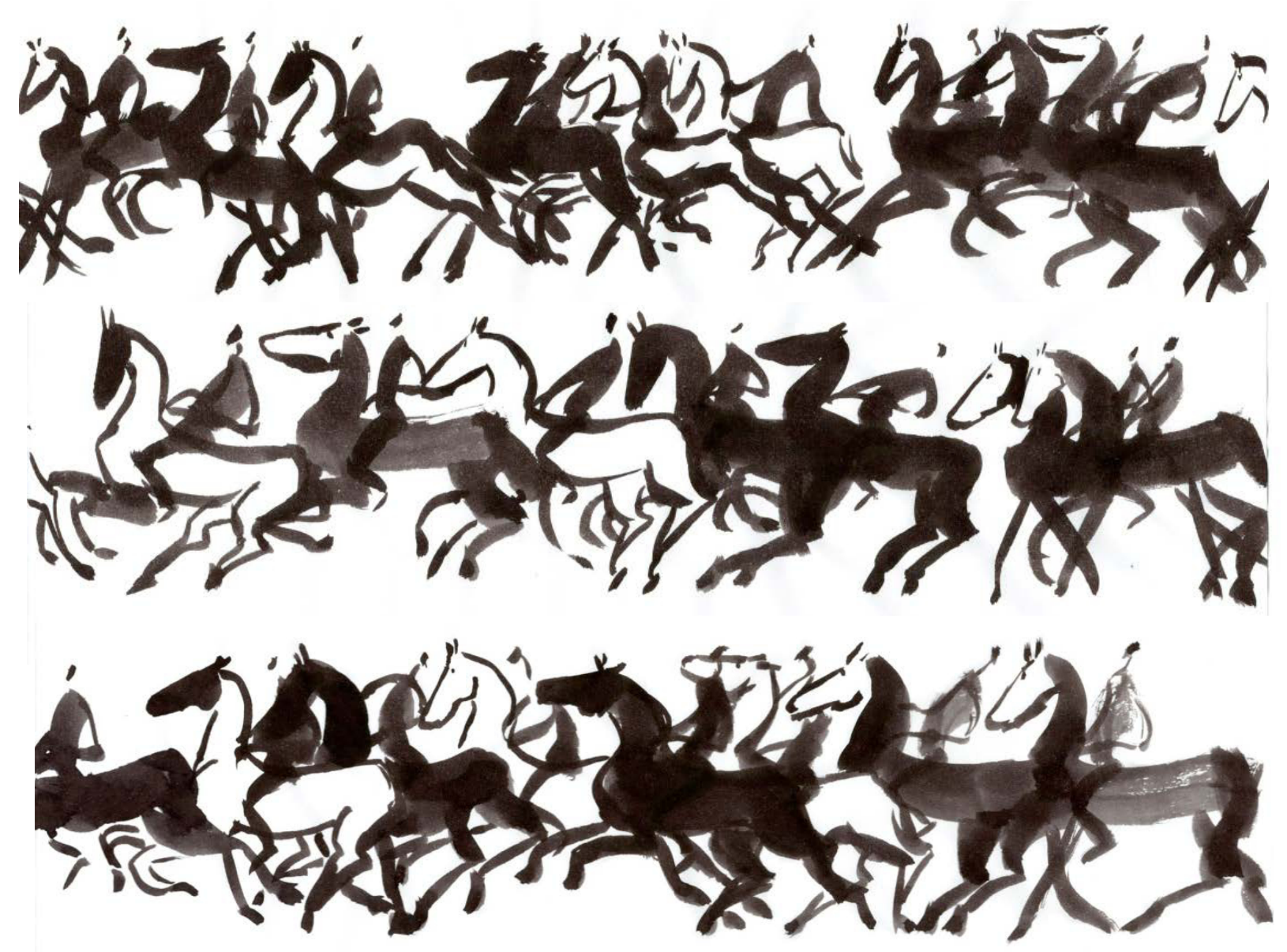

Fig. 30. Rosa Peris (2011). Detalle de banda de imagen de la animación 3.

Experimentación plástica de animación por fases yuxtapuestas.

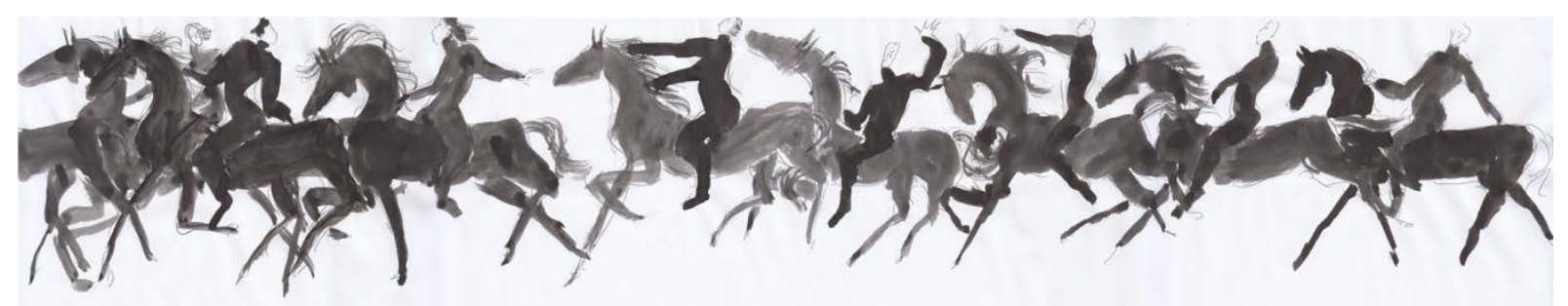

Fig. 31. Rosa Peris (2011). Fragmento de banda de imagen de la animación 4.

Experimentación plástica de animación por fases yuxtapuestas.

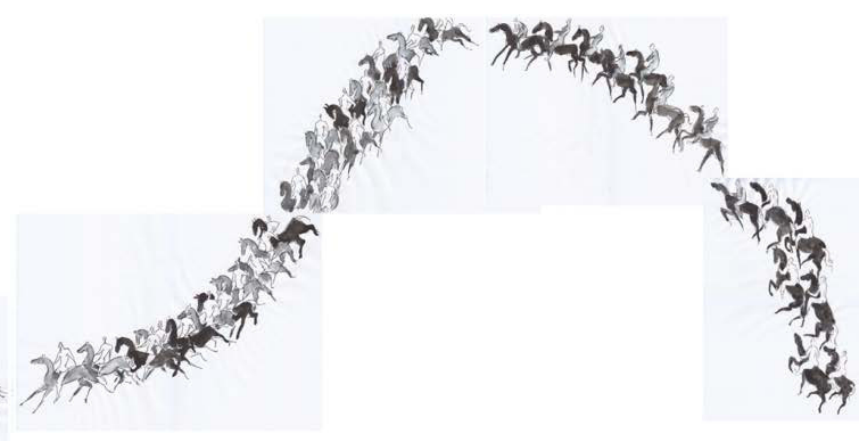

Fig. 32. Rosa Peris (2011). Banda de imagen de la animación 5. Experimentación plástica de animación por fases yuxtapuestas. 


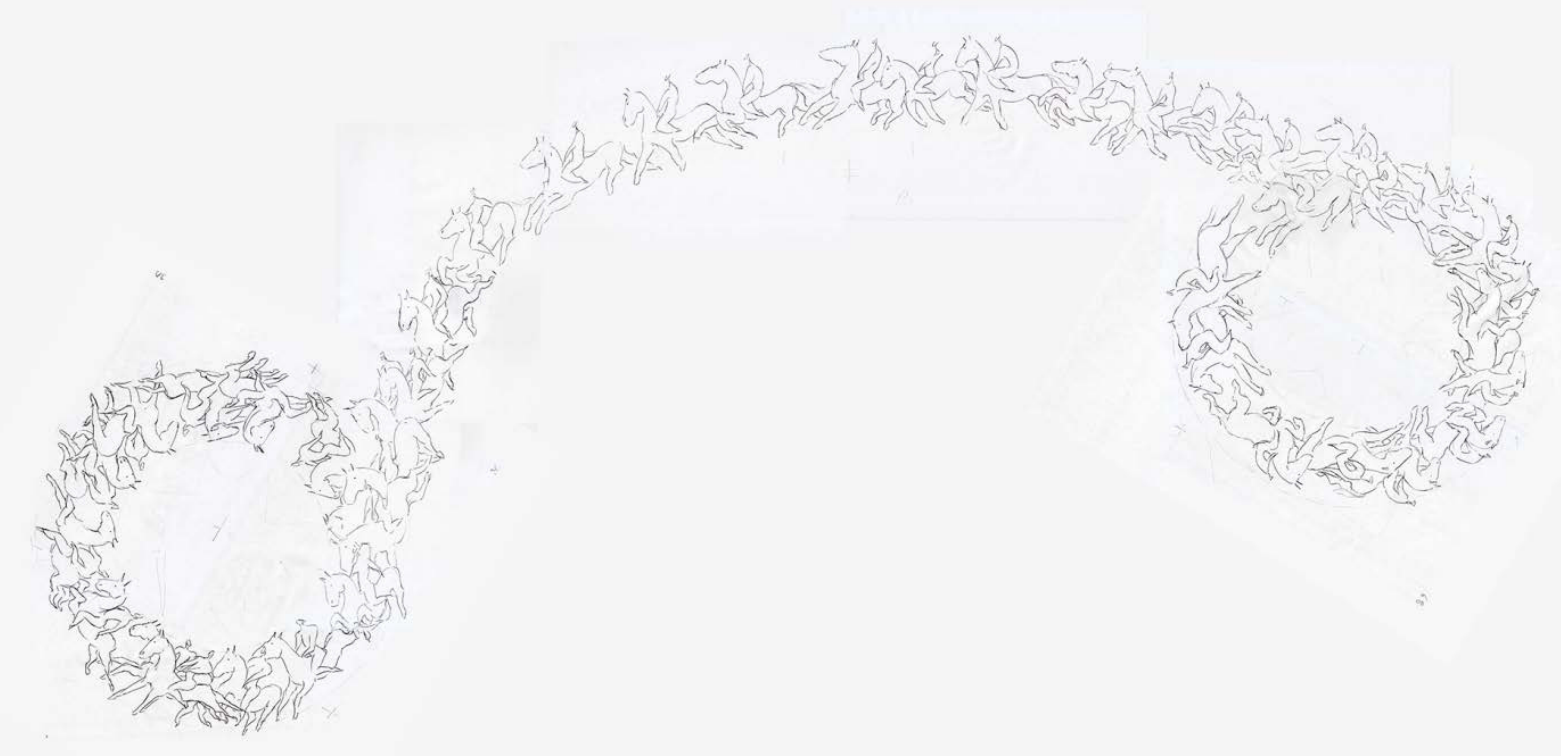

Fig. 33. Rosa Peris (2014). Una de las bandas curvas y dos de los círculos de la animación 6 . Los esquemas lineales que determinan el recorrido se dibujaron a mano alzada, pero su descripción geométrica es la siguiente: a la izquierda y a la derecha hay sendos pares de circunferencias concéntricas unidas tangencialmente por dos líneas curvas paralelas a modo de camino. La línea superior une la circunferencia interior del par izquierdo con la línea exterior del par derecho. Y la línea inferior de dicha banda une la circunferencia exterior del par izquierdo con la interior del par derecho.

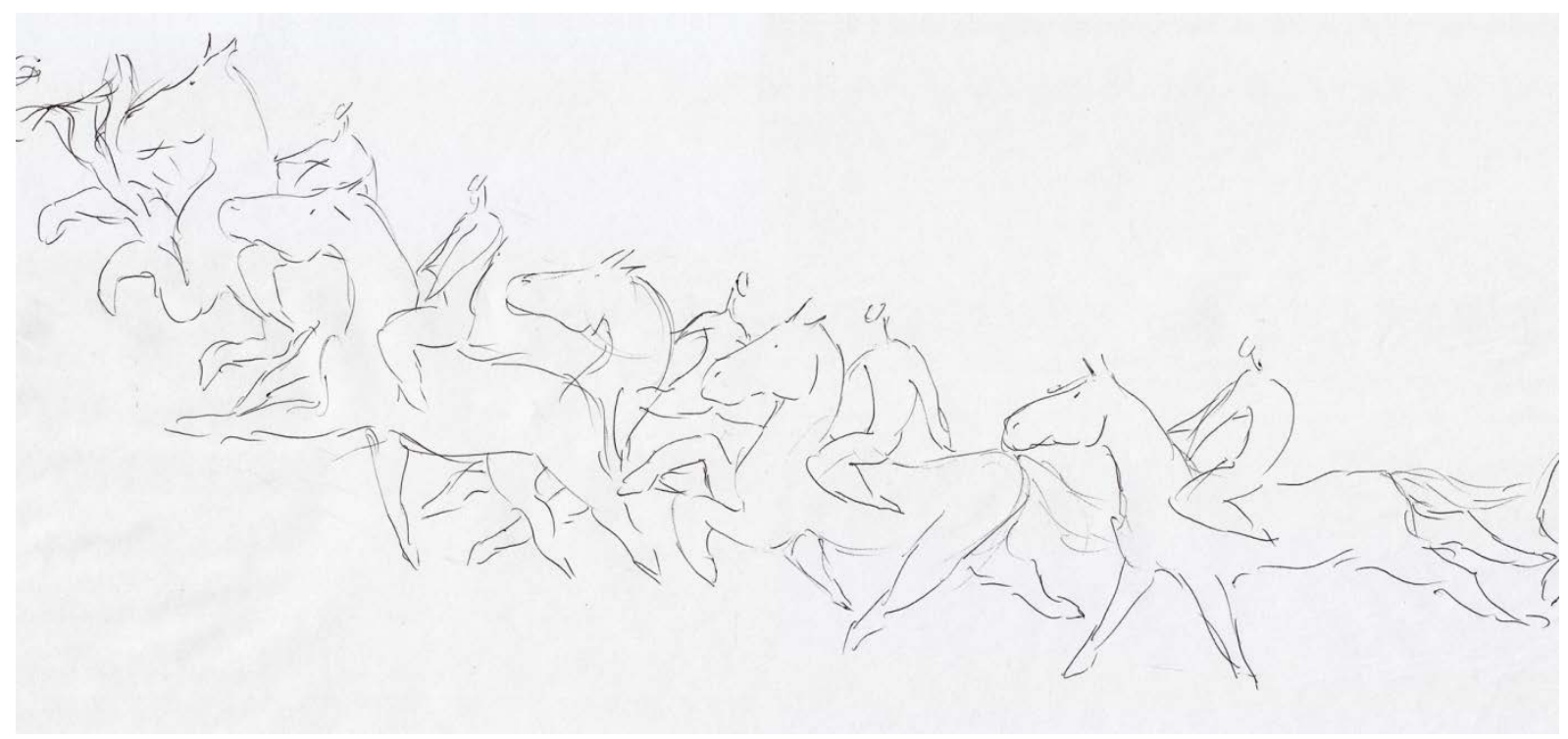

Fig. 34. Rosa Peris (2011). Detalle de banda de imagen de la animación 6. Experimentación plástica de animación por fases yuxtapuestas.

\section{- Conclusiones}

Las pruebas de expresión móvil por yuxtaposición de fases no sucesivas, así como la secuencia previa de animación dibujo a dibujo con las que se comparan, nos han servido para comprobar desde la propia experiencia que ambos son medios efectivos para expresar el movimiento. Al representar el mismo movimiento 
con ambos métodos, hemos podido observamos que la representación por yuxtaposición de fases no cronológicas transmite el dinamismo con un grado de abstracción mayor que la secuencia lineal.

Hemos trabajado con el potente transcurso de las imágenes propio de la película pintada, asumiendo que esta técnica siempre tiene un cierto grado de imprevisibilidad. Sin embargo, a pesar de la apariencia de sencillez y espontaneidad, la expresión móvil por fases no progresivas de la acción requiere una planificación detallada. Es precisamente su característica más propia, el abrupto cambio entre fotogramas, lo que exige un gran control sobre lo que se desea transmitir.

Así mismo, comprobamos que en ambos métodos, el dinamismo de los dibujos individuales que componen la animación colabora en la expresión del movimiento. Pero al igual que en la animación lineal, esta característica no es imprescindible en la representación por fases yuxtapuestas, ya que el notable cambio de imagen provoca un efecto visual de por sí muy audaz. Debido a esta intensidad dinámica, la continuidad del movimiento predomina sobre la discontinuidad gráfica; por ello, en uno de los videos realizados (animación 5), las variaciones de tono y nivel de síntesis de la forma no han afectado a la comprensión del movimiento global animado.

Finalmente, llegamos a la conclusión de que este método de expresión móvil requiere concordancia entre la velocidad de la acción representada y la velocidad resultante de la sucesión de fotogramas drásticamente diferenciados. Es decir, esta manera de intervenir sobre la valoración espacio-temporal exige la expresión de un movimiento de alta intensidad cinética, acorde con las virtudes del medio. Por su capacidad para transmitir velocidad (de la que a su vez se desprende una tendencia a sugerir sensaciones cinestésicas), esta técnica es un medio propicio para expresar de manera vivenciada acontecimientos con esta característica.

\subsubsection{SENSACIÓN DEL MOVIMIENTO EN CADA FOTOGRAMA}

La ilusión de movimiento existe en toda animación debido a que por la similitud y proximidad de las formas en imágenes contiguas vistas en sucesión, éstas son reconocidas como una sola en movimiento (efecto estroboscópico). Al contemplar la animación en transcurso, tal ilusión de movimiento se percibe independientemente del dinamismo visual de las imágenes que la forman. En este apartado se estudia qué influencia tiene sobre el movimiento animado que los fotogramas transmitan movimiento por sí mismos. 


\section{A. QUÉ ES EL DINAMISMO EN IMÁGENES ESTÁTICAS}

Cada una de la multitud de imágenes que forman la animación puede albergar una representación del movimiento que transmita dinamismo al observarla por separado, fuera del transcurso de la película. En ella no se produce el efecto óptico de ilusión de movimiento real, sino que la imagen se reconoce como estática. En palabras de Marcolli, la comunicación visual del movimiento ocurre "cuando las formas se presentan estructuradas dinámicamente, aunque en su colocación estén inmóviles" ${ }^{27}$. A través de la forma y la composición se comprende la dirección, sentido y velocidad de la acción como si se vislumbrara su evolución, es decir, una prolongación espacio-temporal de la acción representada, y todo esto sin necesidad de indicaciones adicionales como flechas o líneas de acción que indiquen esquemáticamente la trayectoria y dirección del objeto móvil. Esta sensación se debe a la dinámica de la forma y a cómo se dirige la tensión visual que produce $^{28}$. Arnheim habla de que estas imágenes están "fuera de la dimensión temporal", de modo que la imagen puede representar varias fases de un acontecimiento $^{29}$; y Rodin explica cómo ocurre esto mismo sobre figuras individuales en lugar de toda la escena: "es frecuente que el artista, para expresarlo [el movimiento], represente fases sucesivas de la acción en diferentes partes de la figura." $^{30}$

Encontramos sensación de movimiento en muchas obras plásticas a lo largo de la historia del arte, como en las esculturas de Gianlorenzo Bernini: en su David (1623-1624), la torsión del cuerpo y la dirección de la mirada anticipan la acción; o los dibujos de Toulouse Lautrec, como Baile en el Moulin Rouge (1889-1890), en el que las figuras de la Goulue y Martin Désossé sugieren la acción del baile y permiten imaginar cómo se desarrolla. El dinamismo visual depende de todos los elementos de la imagen, pero éste puede quedar reflejado tanto por medio del análisis formal como por medio de la síntesis. De este modo, si comparamos Diana y sus ninfas sorprendidas por sátiros (Pieter Paul Rubens, 1639 - 1640) (Fig. 35) y Daphnis y Cloe (Chagal, 1969) (Fig. 36) en ambos observamos dinamismo, pero el nivel de síntesis y análisis de la forma es muy distinto: en el primero hay un alto grado de descripción formal y en el segundo, formas muy sencillas resumen el cuerpo humano.

En animación la sensación de movimiento en imágenes estáticas se puede encontrar en los fotogramas que componen películas como Crac! (Back, 1981), Feet of song (Russell, 1988) y la serie de TV Les Tragédies Minuscules (Las tragedias minúsculas) (Felicioli y Gagnol, 1999) entre muchas otras. También en las animaciones realizadas en el contexto de esta investigación (Libidinis, Báladi, proyectos y animaciones para la experimentación que se explica en el apartado B de 3.2.3.)

\footnotetext{
${ }^{27}$ Marcolli, 1978, pág. 36

${ }^{28}$ Arnheim, 1979, págs. 423-425

${ }^{29}$ Arnheim, 1979, pág. 425

${ }^{30}$ Arnheim, 1979, pág. 436
} 

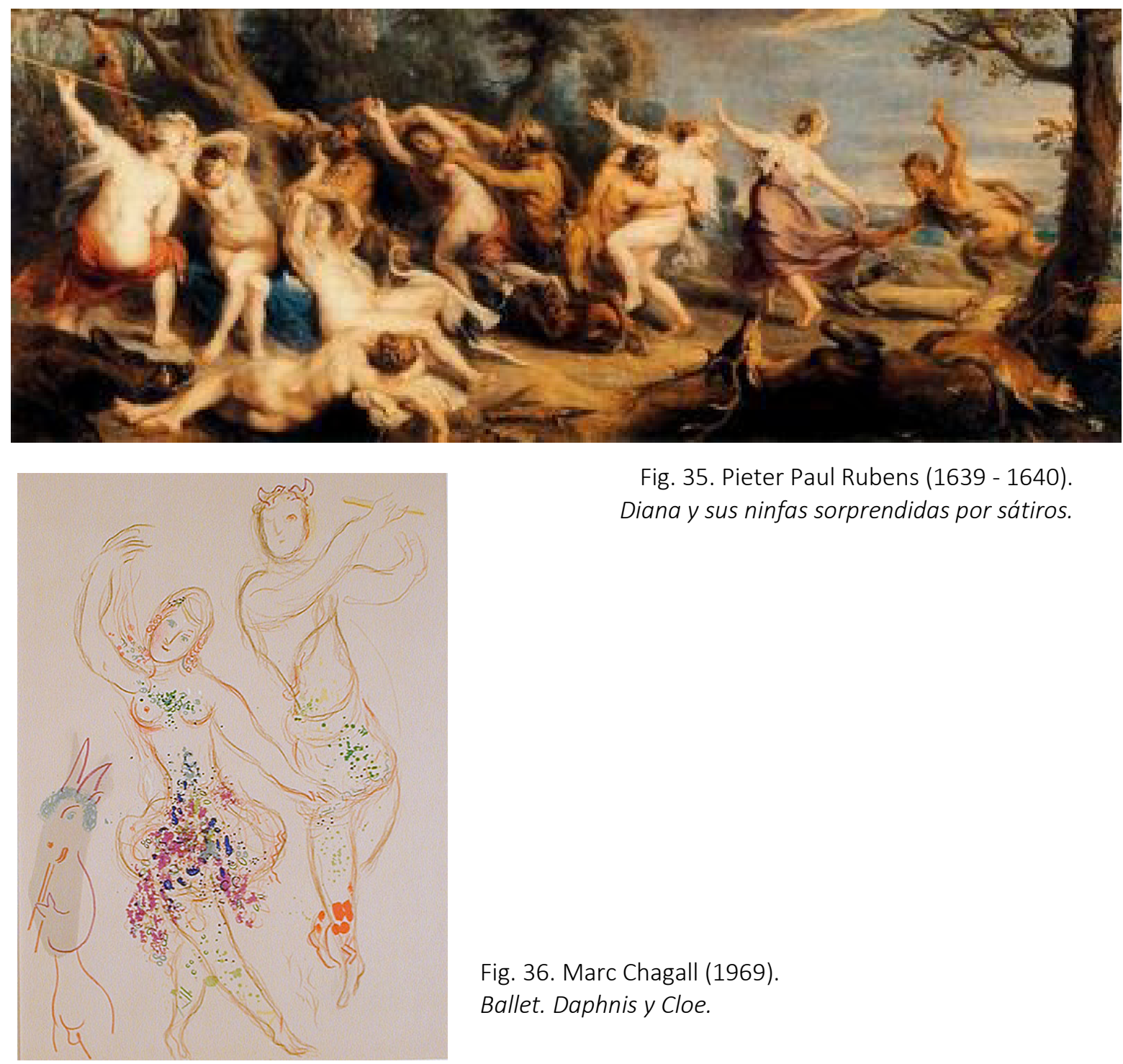

Fig. 35. Pieter Paul Rubens (1639 - 1640). Diana y sus ninfas sorprendidas por sátiros.

Fig. 36. Marc Chagall (1969).

Ballet. Daphnis y Cloe.

el dinamismo en los dibujos individuales ha sido un objetivo constante (Figs. 3739). Al estudiar los fotogramas individuales, vemos que el dinamismo de las figuras invita a imaginar lo ocurrido anteriormente así como su futura evolución. El dibujo del movimiento en los fotogramas influye en la contemplación de la película. Las animaciones con esta característica presentan distintos niveles de síntesis formal. Por ejemplo, si comparamos The Message (Krumme, 2000) (Fig. 40) y Body Beautifull (Quinn, 1990) (Fig. 41) comprobamos que el nivel de análisis de la figura humana es distinto: en la primera los personajes son simples formas casi rectangulares con cabeza redonda y brazos y piernas filiformes, y en la segunda, tanto la anatomía como el atuendo están más determinados; pero ambos presentan un potente dinamismo.

Como en todo el arte plástico, también en animación la dinámica visual se da en representaciones de movimiento no análogas a la realidad, como la escena de Triangle (Russell, 1994) en la que se produce una transformación de la figuración a la abstracción: los cuerpos humanos se transforman en manchas naranjas y azu- 
les que se cruzan y descruzan de modo que sugieren el suave roce de la piel. En este caso la abstracción sirve para expresar la sensación cinética de una acción existente en la realidad; aunque la forma humana de los personajes se ha diluido, continúan siendo identificables gracias al movimiento y al color. Esto evidencia la relevancia que tienen en la representación del movimiento la dirección y el sentido de la acción, la continuidad y el carácter del movimiento, más que el parecido del móvil con la forma real. Así pues, la insinuación de movimiento en imágenes estáticas no reside en el análisis o en la síntesis formal, como tampoco en la figuración o en la abstracción, porque como dijo Arnheim: "La tensión dirigida es una propiedad tan genuina de los objetos visuales como el tamaño, la forma y el color." ${ }^{31}$

Fig. 37.

Rosa Peris

(2012). Tututú.

Dibujos

preparatorios.
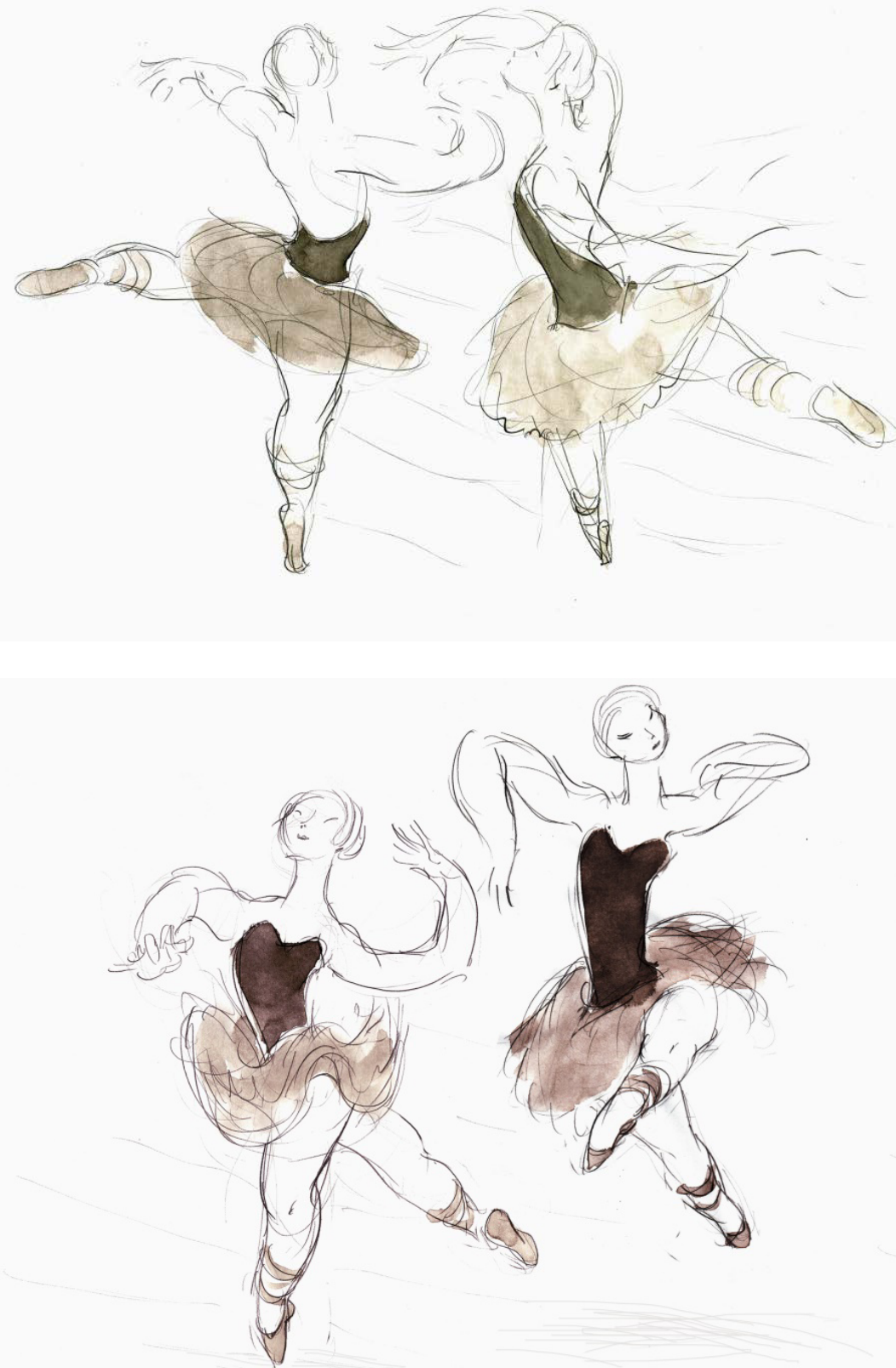

Fig. 38.

Rosa Peris

(2012). Tututú.

Dibujos

preparatorios.

${ }^{31}$ Arnheim, 1979, pág. 423 


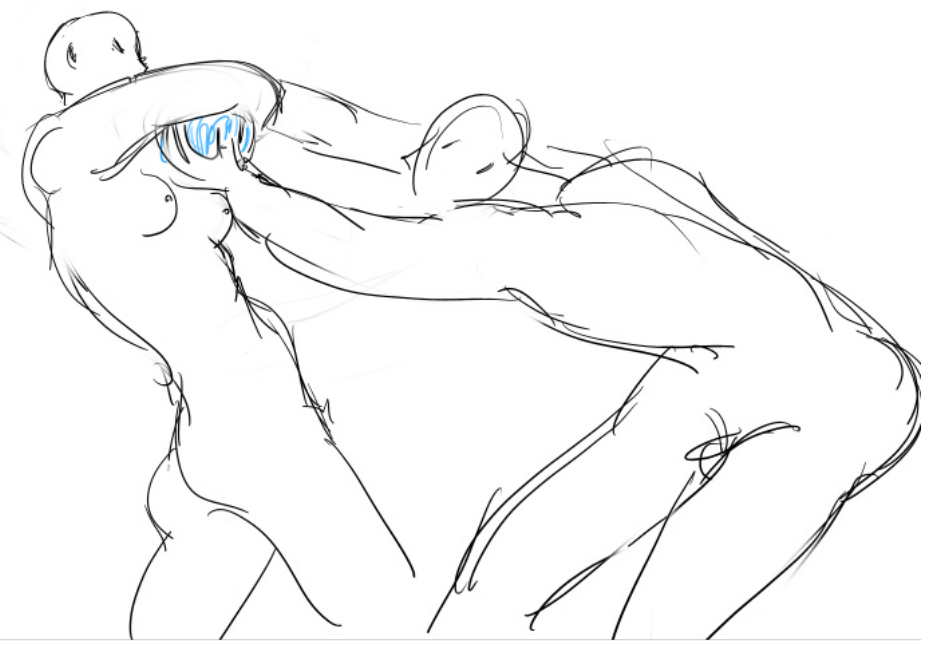

Fig. 39. Rosa Peris (2011). Mío, tuyo, nuestro.

Dibujos preparatorios.

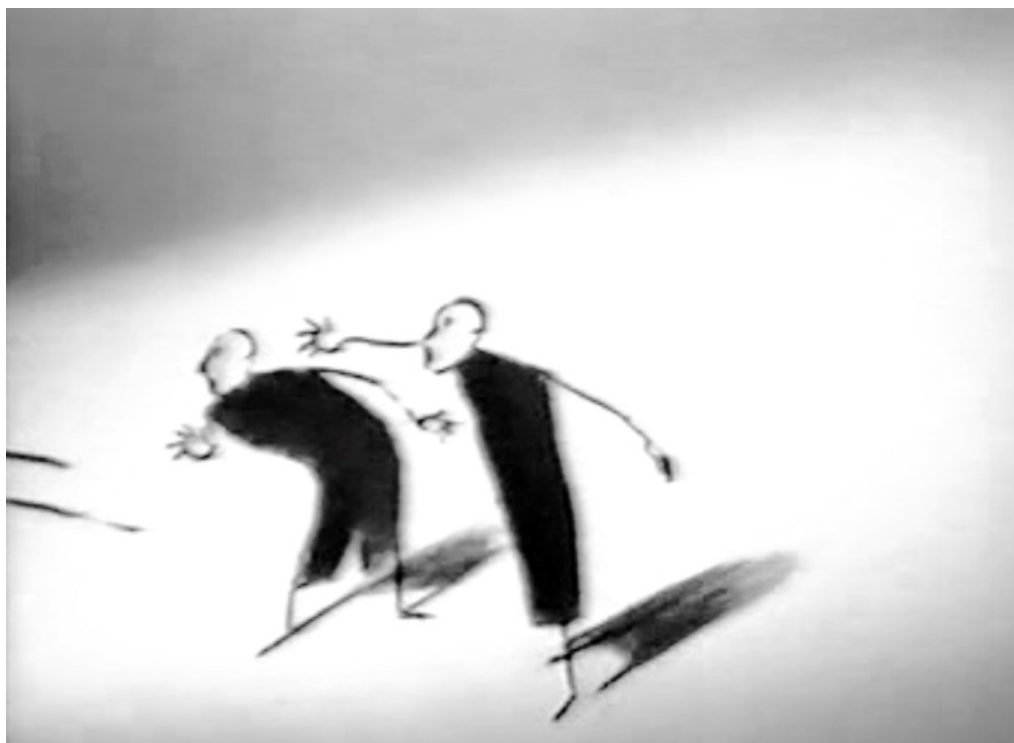

Fig. 40. Raimund Krumme (2000). The Message (El mensaje).

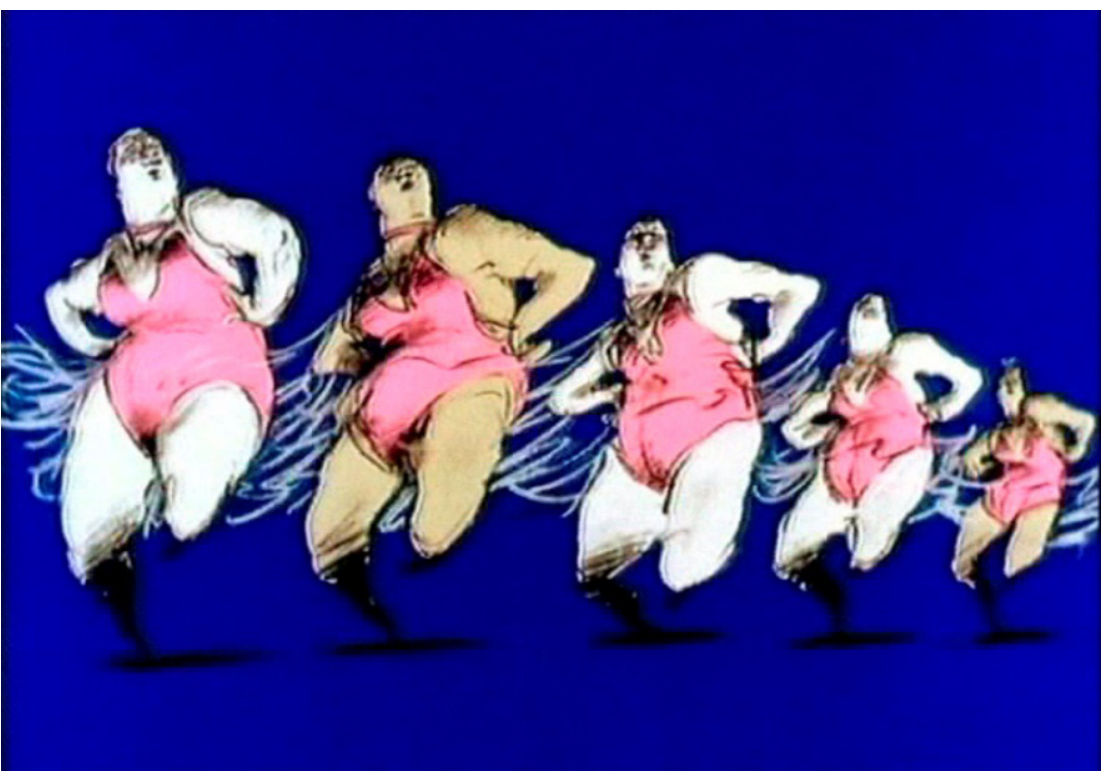

Fig. 41. Joanna Quinn (1990). Body Beautiful (Cuerpo hermoso). 


\section{B. EFECTOS QUE PRODUCE EN LA ANIMACIÓN}

El resultado de una animación depende en parte de la manera en que se expresa el movimiento en las imágenes que la forman y en la relación espaciotemporal entre éstas (el dónde y el cuándo de las fases de cada acción). Frank Thomas y Ollie Johnston, animadores de los Walt Disney Studios, reclamaron la relevancia de los dibujos que componen la animación, ya que "para una escenificación clara de la acción, cada dibujo en la escena debe mostrar la actitud y el acting $^{\prime 32}$. Aunque esta cualidad varía de unas escenas a otras y entre películas, es un objetivo perpetuo en casi toda la historia de la compañía, que persiguieron por medio de recursos de representación móvil más o menos racionalizados (como el squash y el stretch entre otros, cuestión que tratamos en el punto D. Valoración espacio-temporal según un estilo de animación en el apartado 3.2.2.). La afirmación de Thomas y Johnston evidencia la consciencia de que el resultado final depende de los fotogramas que conforman la película y que consideran que expresar movimiento en cada fotograma hace que la animación sea más clara y comprensible. La idea de la claridad persiste hoy en día en estos estudios. Don Hahn lo resume así: "El público solo tiene una vigesimocuarta parte de segundo para leer cada fotograma individual de la animación, así que tiene que leerlo realmente con claridad." ${ }^{33}$

El dinamismo en las imágenes individuales juega, efectivamente, un papel influyente en la valoración espacio-temporal. La expresión dinámica proporciona una fluidez especial que no proviene sólo del visionado de las imágenes en continuidad. Veamos más detalladamente porqué se produce este efecto:

La conexión compositiva de las imágenes que forman una animación es comparable a las secuencias de figuras que vemos en muchas obras plásticas en las que, por la dirección y situación de las formas en el espacio, se representa el desarrollo de una acción (Fig. 35 y 36). Encontramos esto en numerosas obras a lo largo de la historia del arte; una de las más famosas es el friso del Partenón que representa la procesión de las Panateneas. Toda representación de una acción a través de una secuencia de figuras funciona por los mismos principios: semejanza, proximidad y continuidad ${ }^{34}$. Detengámonos por un momento en Diana y Acteón (Cavaliere d'Arpino, 1603-1606) (Fig. 42). Aquí, la disposición lineal de las mujeres, cercanas unas a las otras a distintas distancias en variedad de posiciones y actitudes,

\footnotetext{
${ }^{32}$ Thomas \& Johnston, 1981, pág. 179, (trad. a.): For clear staging and clarity of action, every drawing in the scène must show the attitude and the acting.

${ }^{33}$ Hahn, 2008, pág. 65, (trad. a.): The audience only has one twenty-fourth of a second to read an individual frame of animation, so it has to read really clearly.

${ }^{34}$ Coheler, h. 1930, pág. 27
} 
crea continuidad visual; forman abanicos de diagonales y, sin desaparecer la entidad de los personajes, se podría entender la evolución del movimiento como si representara una única mujer. Arnheim señala que algunas de estas imágenes son un "equivalente inmóvil del movimiento estroboscópico" ${ }^{35}$. Con esto no pretendemos decir que este tipo de imagen sean el origen (tantas veces buscado) de la animación, ya que, como dice George Sifianos: "La yuxtaposición de dos o más posturas sucesivas es muy diferente a la búsqueda de una ilusión, a pesar de que en ellas haya una clara intención de crear un «flujo dinámico»" "36. Sin embargo la comparación es pertinente para comprender el modo en que la sensación dinámica en cada fotograma afecta a las imágenes secuenciales.

En las imágenes secuenciales se establece una relación de concatenación debida a las fuerzas dinámicas que emanan de cada figura, a su semejanza y distancia, por las cuales quedan visualmente enlazadas ${ }^{37}$. En animación tiene lugar el mismo principio: cuando cada fotograma transmite movimiento, cada imagen "lleva" a la siguiente; esto provoca una continuidad peculiar en la valoración espaciotemporal. Esta fluidez no se consigue sólamente por la sucesión de las imágenes una tras otra; sino que proviene de la concatenación visual o entrelazamiento profundo entre imágenes.

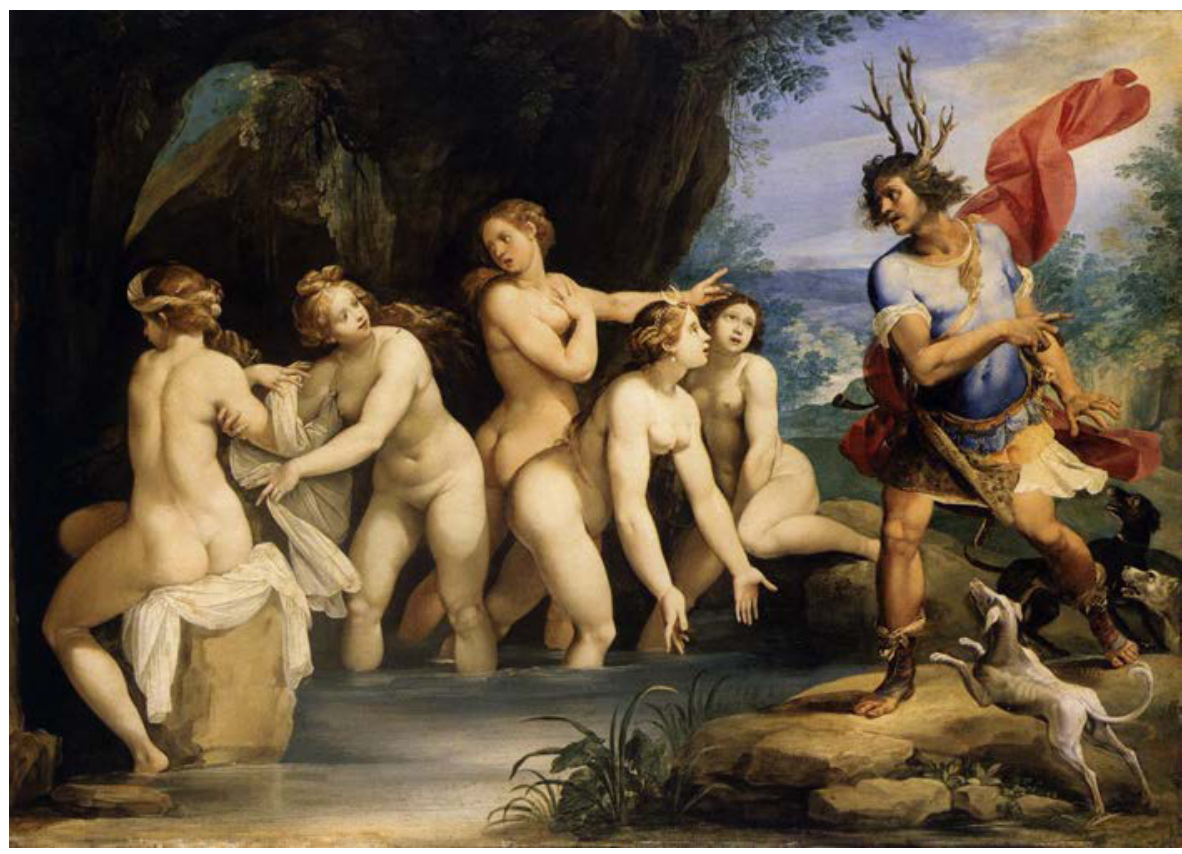

Fig. 42. Cavaliere d'Arpino (16031606). Diana y Acteón.

\footnotetext{
${ }^{35}$ Arnheim, 1979, pág. 435

${ }^{36}$ Sifianos, 2012, págs. 90-91, (trad. a.): La juxtaposition de deux ou plusieurs postures successives est très différente de la recherche d'une illusion, en essayant de dessiner un «flou cinétique».

${ }^{37}$ Arnheim, 1979, págs. 97-98
} 
En los flipbooks y animáticas se aprecia muy bien la relevancia de la expresión dinámica en las imágenes individuales y cómo su interconexión favorece la comprensión del movimiento animado. Los flipbooks son libros normalmente de tamaño pequeño (10 x 7cm. aproximadamente) en los que cada hoja que los compone contiene una imagen que tiene el mismo papel de los fotogramas en una película. Con una mano se toma el total de las páginas y se pasan rápidamente (to flip), lo que permite ver las imágenes en sucesión. El método manual de pasar las páginas de un flipbook provoca que la frecuencia de imágenes por segundo sea irregular y que la animación se fragmente (y se rompa así la continuidad del movimiento). Al aumentar el tiempo de visionado de cada imagen y, por tanto, retrasar el cambio a la siguiente, se hace más necesario que cada una transmita la dirección y sentido de la acción y así, del mismo modo que en composiciones con secuencias de movimiento, la tensión dirigida interconecte las imágenes. De este modo, a pesar de la lentitud del paso de las páginas, no se pierde la comprensión del acontecimiento representado.

Si comparamos dos flipbooks en los que se muestra una escena de Estória do gato e da lua (Serrazina, 1996) ${ }^{2}$ (Fig. 43) y de Clandestino (Feijó, 2000) ${ }^{3}$ (Fig. 44), observamos que la primera (en la que se ve al gato contemplando la luna y emergiendo del oscuro interior de una casa) posee un diseño más dinámico por el movimiento de cámara y las llamativas metamorfosis. No obstante, el estatismo de los fotogramas que lo componen dificulta la visualización del flipbook. Sin embargo, la escena de Clandestino, cuyos dibujos son visualmente dinámicos, es perfectamente comprensible incluso en su visionado por flipbook (el hombre nadando transmite la fuerza del movimiento del cuerpo contra el agua). Así mismo, las cualidades de las imágenes dinámicas se manifiestan también en las animáticas (videos previos a la animación completa en los que el movimiento se presenta esquemáticamente por medio de los fotogramas clave). En las animáticas para Senrasine y Mío, tuyo, nuestro (Rosa Peris, 2010; 2011) [en DVD] se intuye la futura fluidez de la acción gracias a la expresión del movimiento en los dibujos que las forman. Así pues, ante una frecuencia de imágenes por segundo menor a 12 ips, la tensión dirigida en cada imagen facilita la continuidad y comprensión de la acción representada, efecto que en la animación con una frecuencia de 12 fps puede afectar positivamente a su expresividad.

No obstante, la expresividad del movimiento resultante no depende únicamente del dinamismo en las imágenes individuales (ésta es sólo una característica que interviene en la valoración-espacio temporal), sino de cómo se conjuga con el desplazamiento o alteración progresiva de las formas de un fotograma a otro (la esencia de la relación espacio-temporal) que puede ser más o menos irregular, 
como vimos en los punto A. y B. de 3.2.2. La obra de Florence Miailhe en general y Psyque y Eros (de Vere, 1994) están formadas por imágenes dinámicas que, sin embargo, vistas en sucesión proporcionan un movimiento moroso y poco expresivo debido a la valoración espacio-temporal regular, es decir, porque la distancia entre formas de una imagen a otra es la misma o muy parecida y también por la dilatación sistemática de casi todas las acciones. En estas películas las imágenes estáticas anuncian un dinamismo que no queda reflejado en la animación. Por ejemplo, en Histoire d'un prince devenu borgne et mendiant (Historia de un príncipe que se convirtió en tuerto y mendigo) (Miailhe, 1996) [en DVD], el barco zozobra y el personaje se agita de un lado a otro mientras se ase de cabos para no caer (00:00:42); pero la combinación de la frecuencia de 8 ips (a veces algo más; que genera pequeñas interrupciones del movimiento), la relación espaciotemporal regular y la ralentización de la acción generan una animación más neutra que vivenciada. Así pues, la dinámica visual no proporciona por sí sola altos niveles de expresividad en animación, sino que debe darse en conjunción con una valoración espacio-temporal que apoye el movimiento.

La coordinación de la relación espacio-temporal en fotogramas contiguos y el dinamismo de éstos suele estimular sensaciones cinéticas que colaboran en la expresión del movimiento vivenciado, y otorga potencia y atractivo visual a la representación de los acontecimientos. Veamos algunos ejemplos: En el cortometraje Stressed (Estresado) (Kelly, 1994) (Fig. 45), tras la muerte de un hombre, dos criaturas celestiales descienden y lo acompañan en un bello movimiento ascendente. Las tres figuras vuelan siguiendo trayectorias curvas cruzadas. El fluir del movimiento se debe tanto a la disposición de las formas en el espacio compositivo como al dinamismo de los fotogramas. Si analizamos las imágenes individuales, comprobamos que éstas sugieren por sí mismas la fluidez de la acción de las figuras flotantes (00:03:00); del mismo modo, el dinamismo de la niña de Nadando en el aire (Mercedes Peris, 2010) es transmitido tanto por su trayectoria exenta del contacto con el suelo como por el dinamismo visual del dibujo, que genera una mayor sensación de ligereza (Fig. 46). También en el cortometraje Báladi (Rosa Peris, 2011), en la que se muestra a una mujer bailando, esta cualidad participa activamente en la expresión del movimiento de la bailarina, lo hace llamativo y ayuda a transmitir la voluptuosidad del cuerpo en acción, pero además facilita su lectura: algunos movimientos complejos se resuelven en muy pocos fotogramas, pero, pese a la velocidad de las imágenes en transcurso, la acción es comprensible. En la figura 47 se muestran fotogramas consecutivos en los que representa una elevación y extensión del brazo al tiempo que el torso pasa de estar plegado a extendido en tan sólo 5 imágenes (que se visionan a 12 ips, es decir, en 0,5 segundos). En estas tres animaciones la tensión dirigida en los fotogramas funciona 
en conjunción con una valoración espacio-temporal irregular. La unión de estos elementos crea el movimiento que vemos en pantalla.

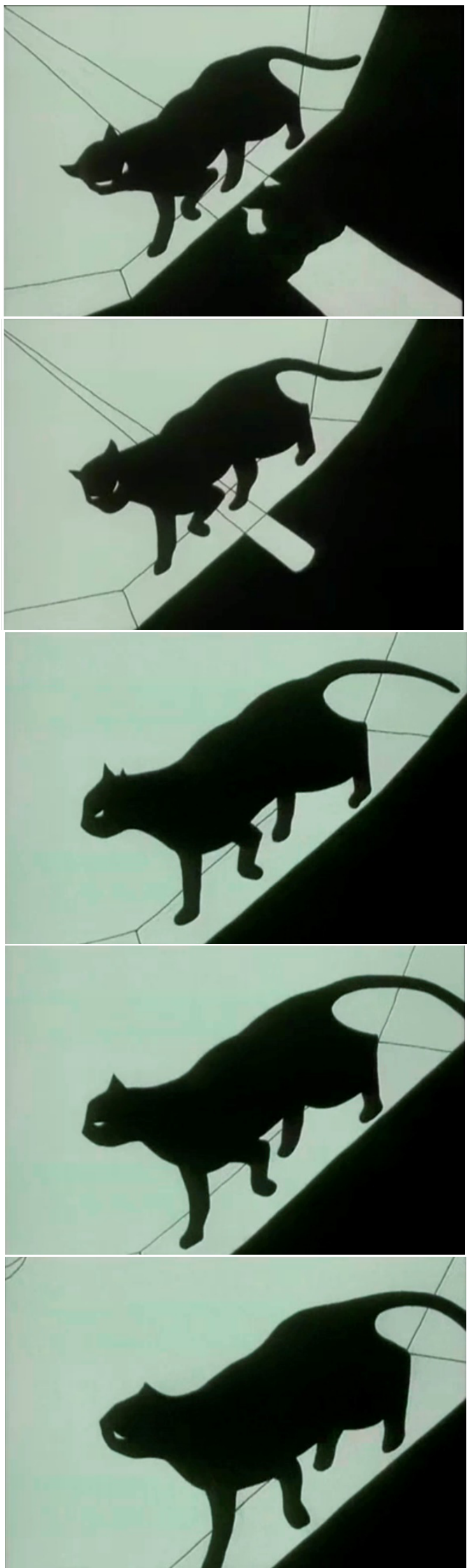

Fig. 43. Pedro Serrazina (1996). Estória do gato e da lua (Historia del gato y la luna). Páginas de flipbook.
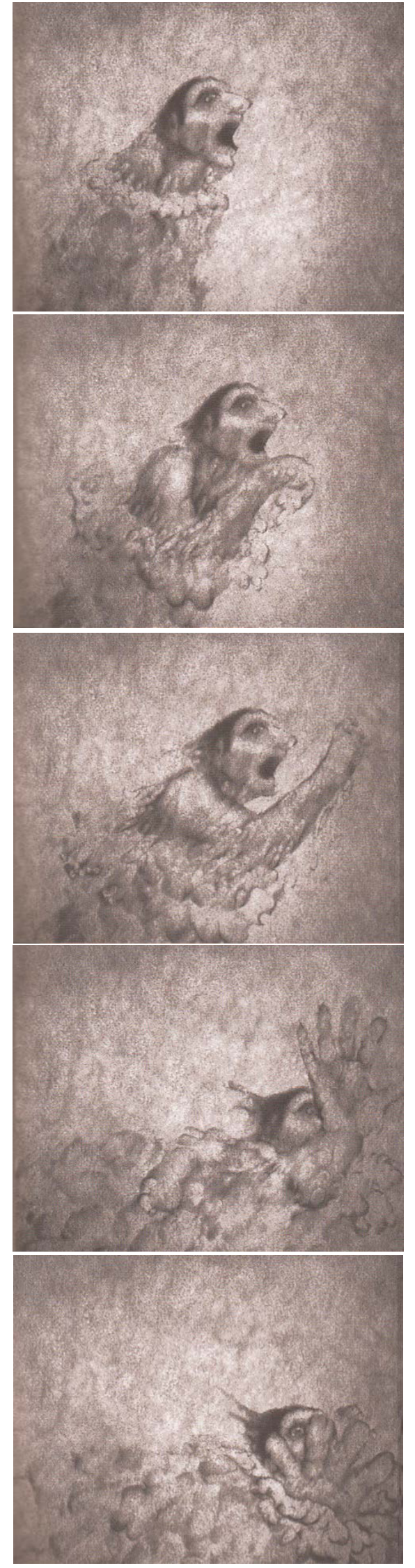

Fig. 44. Abi Feijó (2000). Clandestino. Páginas de flipbook. 

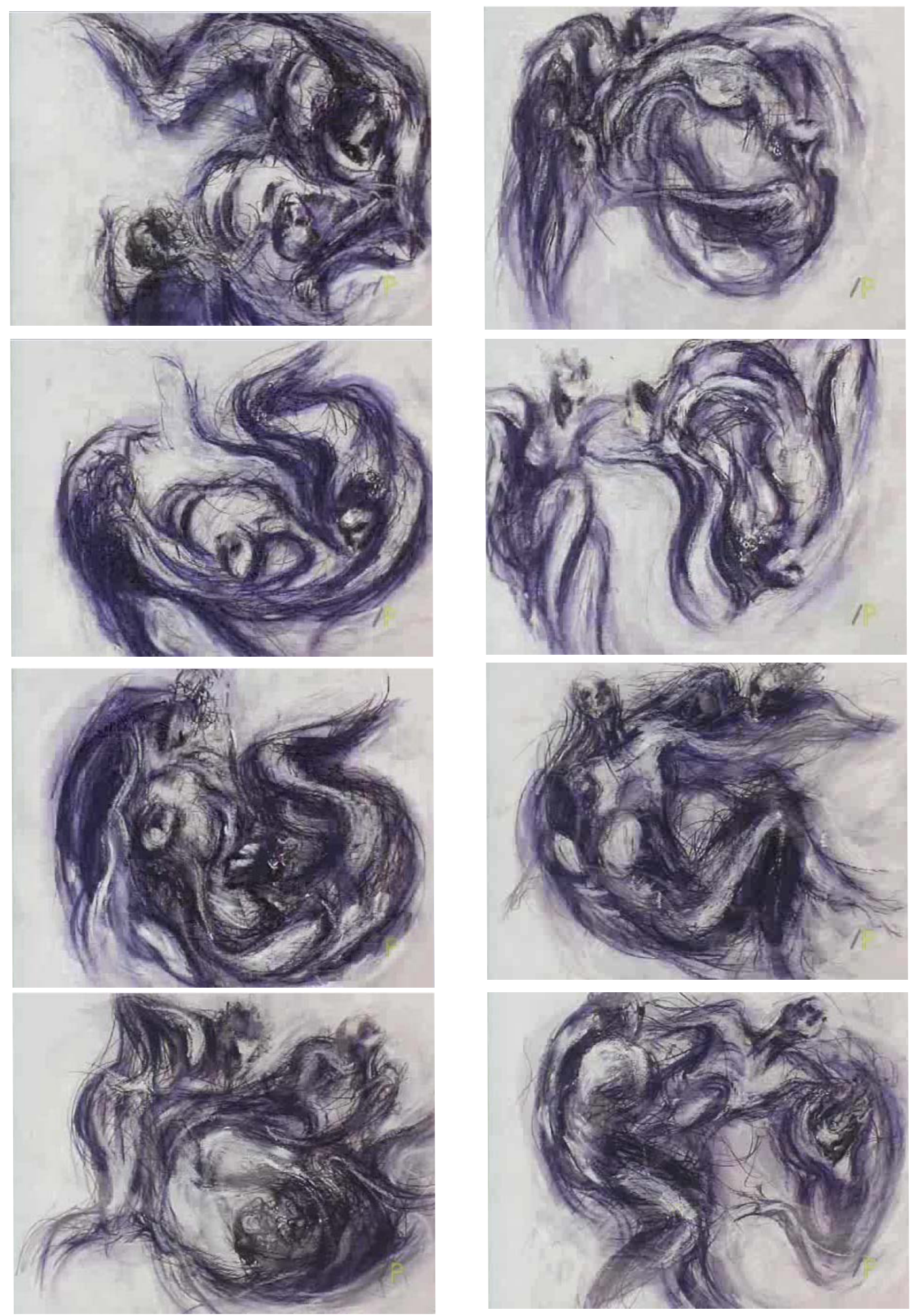

Fig. 45. Karen Kelly (1994). Stressed (Estresados). Serie de fotogramas. 

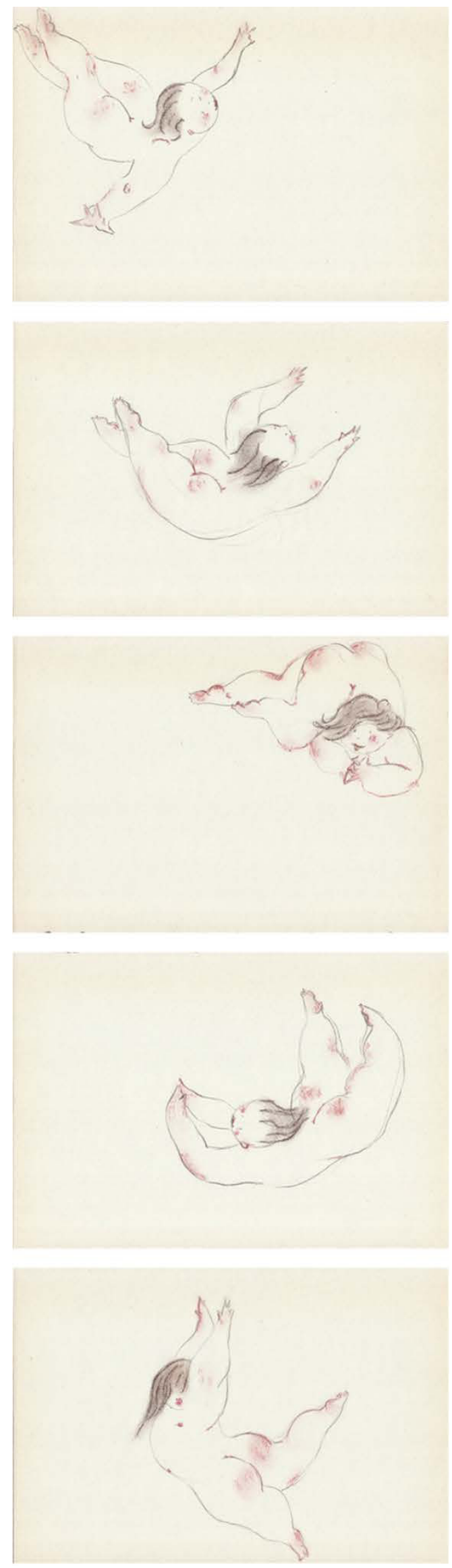

Fig. 46. Mercedes Peris (2010). Nadando en el aire. Serie de fotogramas.
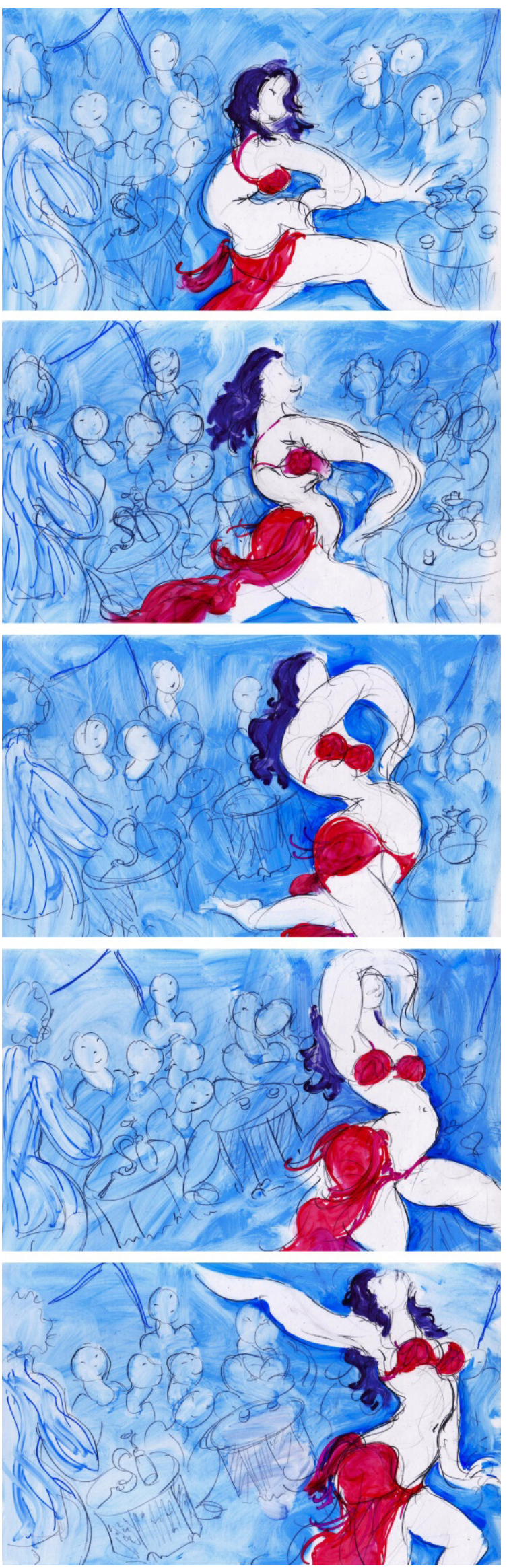

Fig. 47. Rosa Peris (2011). Báladi. Fotogramas consecutivos. 


\section{CUANDO NO HAY SENSACIÓN DE MOVIMIENTO EN LOS FOTOGRAMAS INDIVIDUALES}

Las imágenes que componen la animación pueden no expresar dinamismo individualmente. Se trata de imágenes estáticas en las que "entendemos que lo que se representa es un movimiento; pero no sólo no lo vemos, sino que lo encontramos dolorosamente ausente" ${ }^{38}$. Cuando una animación está formada por imágenes así, no produce el mismo efecto de fluidez que aquellas en cuyos fotogramas ya se expresa dinamismo, sino que tiene otros resultados: por un lado puede presentar un movimiento anodino e incluso neutro, pero, por otro lado, puede ofrecer movimiento de gran simplicidad y hasta generar sensaciones dinámicas de expresión vivenciada. El movimiento vivenciado por medio de la valoración espacio-temporal no basada en el dinamismo de cada imagen no se fundamenta en la interconexión entre fotogramas, sino en un mayor protagonismo de la distancia espacial y temporal entre las formas de un fotograma a otro.

A continuación confrontamos dos películas con el fin de observar la influencia del dinamismo en los fotogramas sobre la expresividad de la valoración espaciotemporal. Se analizan dos acciones de películas diferentes: el movimiento de Puck en Sueño de una noche de verano (Trnka, 1959) (Fig. 48) en la escena en que descubre las propiedades mágicas de la flor del amor y el movimiento del protagonista de Next! (Purves, 1990), un actor que trata de demostrar sus cualidades en un casting (Fig. 49). Si comparamos los fotogramas que configuran dos acciones de similar dirección y velocidad, se aprecia que la película de Trnka cuenta con imágenes dinámicas en los fotogramas: la marioneta de Puck transmite el cambio de dirección con claridad, a pesar de que las líneas que recorren su cuerpo no se corresponden a la mecánica que esa acción mostraría en fotogramas de una película de acción real. Mientras que la animación de Purves carece de este dinamismo: el estatismo de la figura impide conocer siquiera la dirección de la acción; en esta película el sentido del movimiento (adelante y atrás, en la acción que vemos en el ejemplo) sólo se aprecia al observar la película. Al ver ambas animaciones en transcurso, se aprecia que la carencia de dinamismo en los fotogramas de Next! provoca que el cambio de sentido se amalgame en movimientos regulares de trayectorias poco definidas; la acción se representa con expresividad moderada (aunque no es completamente neutra). Mientras que la animación de Trnka, por medio de un claro dinamismo en cada imagen, genera un movimiento ondulante que transmite el equilibrio y esfuerzo de Puck por no caer a tierra; y precisamente por plasmar estas sensaciones corporales, expresa el movimiento vivenciado.

\footnotetext{
${ }^{38}$ Arnheim, 1979, pág. 415
} 

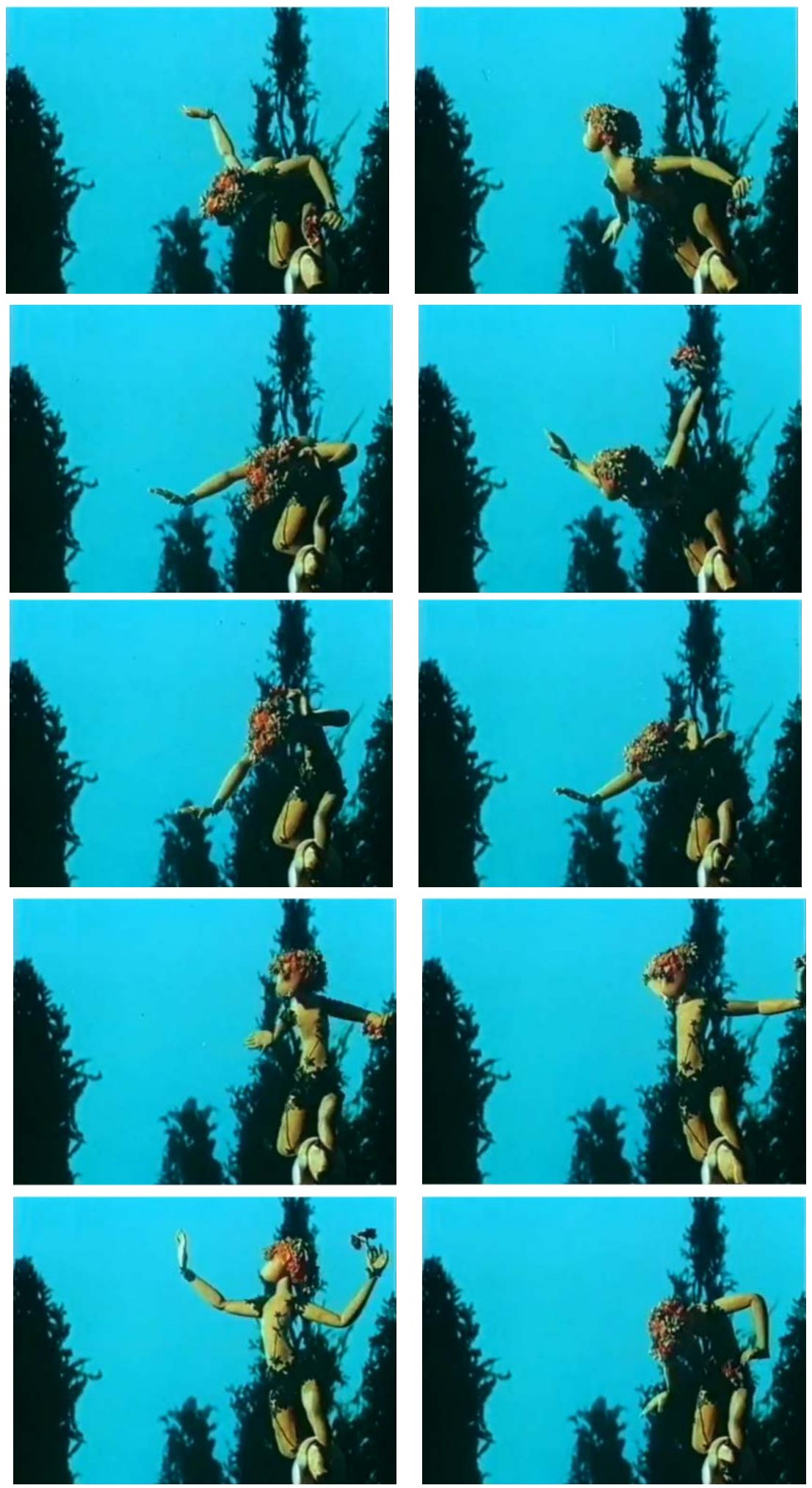

Fig. 48.

Jiri Trnka

(1912-1959).
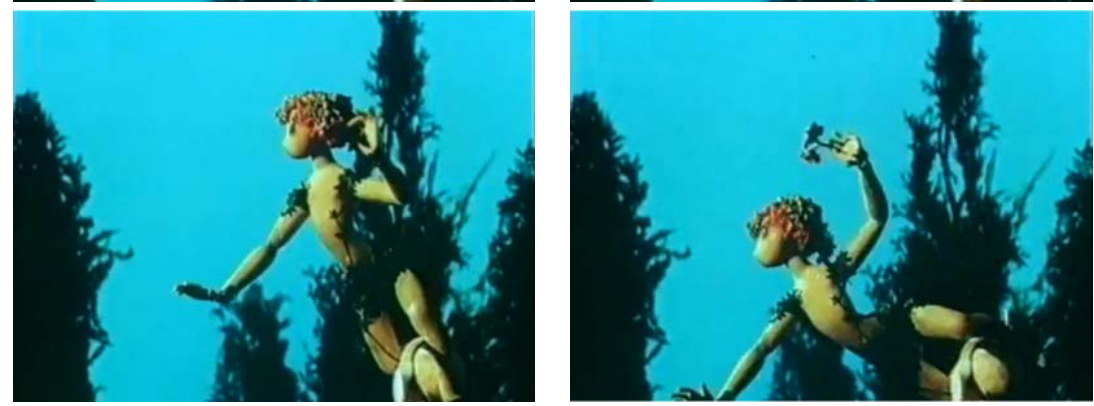

Sen noci

svatojanske

(Sueño de una noche de

verano). Serie

de fotogramas. 

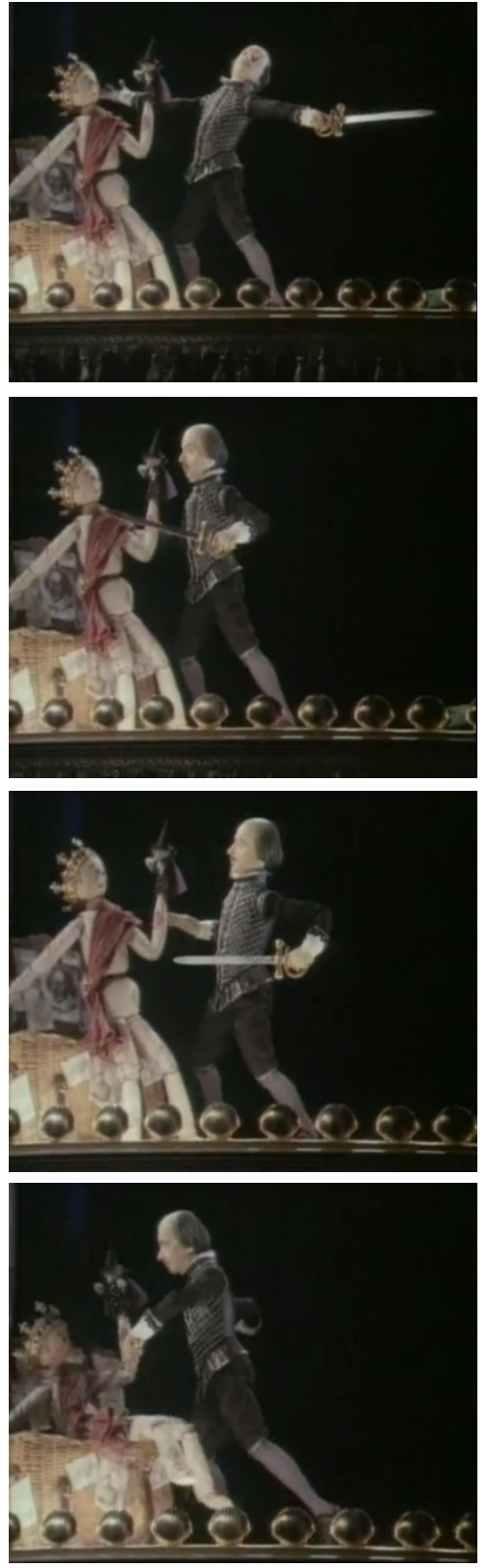

Fig. 49.

Barry Purves

(1990). Next! (iSiguiente!). Serie de foto-

gramas.

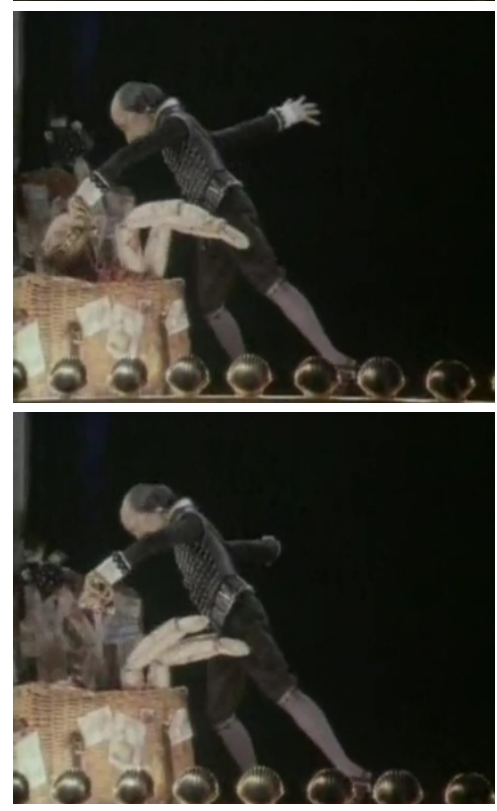

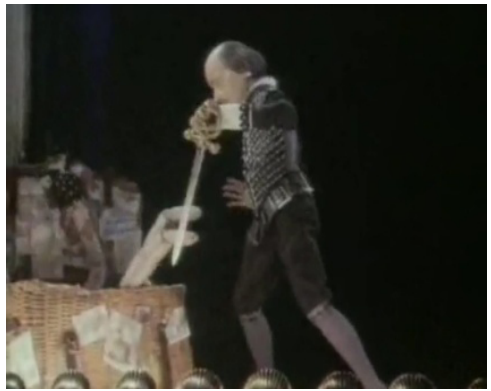
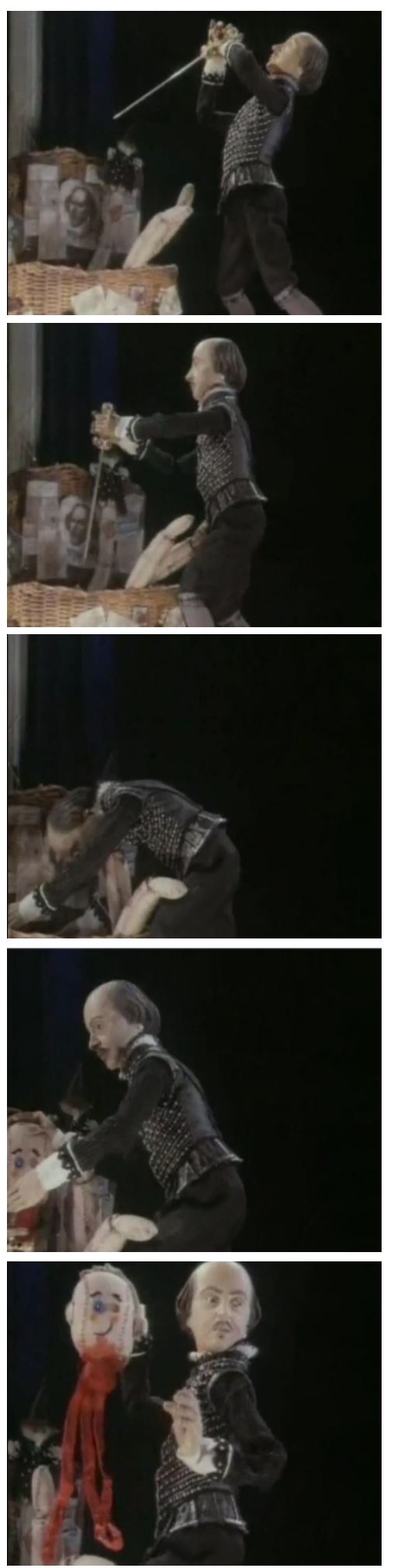
La fluidez que aporta a la animación el dinamismo de imágenes estáticas y la potencia expresiva de su combinación con la relación espacio-temporal entre fotogramas no es siempre lo más deseable; su pertinencia y eficacia dependen del contexto. El efecto poco expresivo que a veces produce la ausencia de dinamismo en los fotogramas es aprovechado en las animaciones que requieren movimiento neutro. Así lo vemos en videos científicos y explicativos en general (como los videos de protocolos de seguridad dentro del avión [en DVD]) o incluso en el caminar de hombrecito de la luz verde del semáforo. En estos casos se busca la claridad de la representación precisamente a través de la ausencia de dinamismo en los fotogramas, ya que las distorsiones de la forma e incluso de la propia acción, afectarían a la exactitud o simplicidad que requieren.

Pero la ausencia de sensación de movimiento en las imágenes individuales no indica que el movimiento sea neutro; hay películas en las que, aunque las imágenes que las componen no son dinámicas, el movimiento en pantalla evoca sensaciones cinéticas o cualidades peculiares de la acción gracias al tratamiento de la valoración espacio-temporal. Por ejemplo, el cortometraje Todos los niños tienen derecho a una familia (Repiso, 1999) carece de esta cualidad en las imágenes, pero el movimiento es vivenciado. El movimiento del niño al gatear transmite las características del desplazamiento a esta edad: a trompicones, pero con delicadeza.

Además, tanto en el caso de que los fotogramas contengan imágenes dinámicas como en los que no, este hecho sólo atañe a uno de los componentes-espacio temporales de la animación, por lo que no determina que el movimiento se exprese como vivenciado o como neutro. La expresividad del movimiento puede fundamentarse en otros componentes dinámicos, como la composición o el cambio de imagen, como ocurre en Jumping (Saltar) (Tezuka, 1984) [en DVD], La curse à l'abîme (La maldición del abismo) (Schwizgebel, 1992) o Memelade Boy (Yabe, 1994-1995) (películas de las que hablamos en el capítulo 1), todas sin fotogramas dinámicos, en las que la valoración espacio-temporal pasa a segundo plano y el movimiento destaca como vivenciado en algunos fragmentos, escenas o en toda la película.

El dinamismo en los fotogramas que componen una animación tiene la cualidad de crear una fluidez especial en el movimiento resultante gracias a la interco- 
nexión que crean las fuerzas dinámicas y aporta claridad cinematográfica al movimiento. Pero la tensión dirigida no garantiza la expresividad de la animación, ya que ésta es sólo una cualidad de los fotogramas y la valoración espacio-temporal depende también de la distancia o diferencia entre las formas de un fotograma a otro (como vimos en 3.2.2.). La comunión de estos dos elementos puede potenciar la expresividad de la representación del movimiento y evocar sensaciones dinámicas. Pero la valoración espacio-temporal también puede tener cualidades cinestésicas sin necesidad del dinamismo en las imágenes individuales; e incluso sin esta cualidad, la animación puede expresar el movimiento vivenciado a través de otros componentes dinámicos. Por otro lado, la ausencia de dinamismo en los fotogramas puede proporcionar un movimiento menos llamativo, esencial en contextos en los que se requiere el movimiento neutro.

\subsubsection{CUANDO EL MOVIMIENTO VIENE DADO POR LA TÉCNICA}

La manera en que se aborda la relación espacio-temporal puede ser creándola a partir de la nada, es decir, a mano, o por medios mecánicos o semi-mecánicos. Los medios mecánicos incluyen aquellas técnicas por las que la relación espaciotemporal viene dada principalmente por la técnica misma, como la captura de movimiento y la rotoscopia. Con medios semi-mecánicos nos referimos a aquellos en los que la valoración espacio-temporal en parte viene dada por la técnica pero también está hecha a mano (programas de animación CG). De la misma manera que algunos estilos de animación delimitan la manera en que se aborda la valoración espacio-temporal, en estas técnicas de animación es el propio medio de creación de los fotogramas lo que la determina Pero el movimiento capturado y el generado por ordenador pueden alterarse, con lo que se amplía el margen de interpretación y con él el grado de expresividad que puede alcanzarse.

\section{A. Rotoscopia}

La rotoscopia consiste en la transformación plástica de las fotografías que componen una película de acción real grabada previamente. La rotoscopia se ha empleado en la animación con una amplia variedad de objetivos:

El uso directo de la acción real ha sido parte de la industria de la animación durante años - como una ayuda para la animación, como compañero de la animación, e incluso como un sustituto de la animación. De vez en cuando, casi todos los estudios han 
dado con una tira de acción real para perfeccionar una acción específica que los animadores no eran capaces de captar. ${ }^{39}$

Efectivamente, algunas películas usan la rotoscopia como una transformación plástica en la que tiene prioridad el lenguaje y las características cinematográficas del cine de acción real, como Chico y Rita (Errando, Mariscal y Trueba, 2010) o Chainsaw (Motosierra) (Tupicoff, 2007). Otras veces se emplea para facilitar la compleja tarea de estudiar y dibujar pormenorizadamente el movimiento.

En la rotoscopia la valoración espacio-temporal queda determinada por el video base. En el proceso de captura de movimiento real, con la cámara de cine se encuadra, el punto de vista se desplaza, se acerca, se aleja, la imagen se enfoca y se desenfoca, etc. Esta manipulación supone un modo de ver y un modo de mostrar; no es objetiva. Pero la captura de video en sí es un proceso mecánico que tiene lugar en la cámara y que da como resultado una valoración espaciotemporal dada por la máquina. Así pues, la interpretación de la valoración espacio-temporal (no de otros componentes) no existe en la fase de captura. Para algunos directores el atractivo de la rotoscopia reside en esto mismo. Brad Hansen, director de Limonade (Limonada) (2006), afirma que de la rotoscopia le gusta precisamente que se reconoce el movimiento de los actores, y destaca la flexibilidad de los fondos, ya que aun estando toda la acción rodada en el mismo espacio, el plano puede ubicarse en cualquier escenario ${ }^{40}$.

No obstante, el video base admite cierta flexibilidad al ser transformado en rotoscopia. Además de modificar plásticamente los fotogramas, es posible intervenir en la valoración espacio-temporal: como vimos en 3.2.2. se pueden añadir o eliminar fotogramas, lo que altera el timing del video original; asimismo, se puede modificar la posición del elemento grabado. Aun así es uno de los métodos en los que la mecánica se interpreta en menor grado (3.2.1.). Y a pesar de las modificaciones de velocidad, ubicación en el espacio respecto al video original y otros factores referidos al espacio y al tiempo, normalmente estas intervenciones no afectan al carácter general del movimiento capturado. Por eso la rotoscopia proporciona a la valoración espacio-temporal un tono común a las películas realizadas con esta técnica; se trata de un dinamismo más bien contenido que pocas veces genera sensaciones cinéticas en el espectador. En este sentido, la rotoscopia tiene una valoración espacio-temporal de expresividad neutra.

\footnotetext{
${ }^{39}$ Thomas \& Johnston, 1981, pág. 319, (trad. a.): The direct use of live action film has been part of the animation industry for years - as an aid to animation, a companion to animation, and even as a replacement for animation. From time to time, almost every studio has fallen back on a strip of live film to perfect a specific action animators were not able to capture.

${ }^{40}$ Hansen, 2005
} 
Nadie sabe a ciencia cierta porqué el trazado a lápiz de una figura de acción real suele parecer tan estática e innatural en la pantalla, a menos que, simplemente, no es una copia de la realidad [...] Ciertamente la cámara graba lo que está ahí con una imparcial falta de énfasis. ${ }^{41}$

La imparcialidad de la que hablan Thomas y Johnston es idónea en videos que buscan la austeridad expresiva del movimiento neutro. El movimiento también puede llegar a ser vivenciado en las animaciones de rotoscopia, pero la expresividad no se da a través de la valoración espacio-temporal, sino por medio de otros componentes dinámicos.

\section{B. Captura de movimiento}

En la técnica de animación motion capture (captura de movimiento por medio de sensores), la valoración espacio-temporal también procede del movimiento real, pero éste no es capturado por una cámara cinematográfica, sino que consiste en los siguiente: por medio de sensores adheridos al cuerpo de los actores y objetos (en las articulaciones y diversos puntos de la superficie dependiendo del nivel de detalle que se desea registrar), queda registrada la posición de estos puntos concretos en un espacio tridimensional virtual definido por coordenadas (altura, anchura y profundidad) más su dimensión temporal. De esta manera el movimiento es registrado como información matemática a partir de la cual se reconstruye virtualmente el móvil (sobre ese esqueleto de puntos móviles) (Figs. 50 y 51). De esta manera la valoración espacio-temporal de la animación resultante se corresponde a la de la acción capturada; la valoración espacio-temporal es determina por la técnica. Sin embargo esta información sólo consiste en el cambio de posición de unos puntos, es decir, sólo queda registrado el desplazamiento, y no características peculiares respecto a las sensaciones que despierta tal movimiento, que corresponden a la percepción y experiencia personales. En este sentido la captura pura (sin alteración de la información original) es movimiento neutro, ya que registra las características básicas del movimiento: dirección, sentido, velocidad y aceleración, sin reflejar connotaciones personales de su experiencia ni de su observación (como se observó en capítulo 1).

El movimiento capturado en esta técnica, como en la rotoscopia, es susceptible de ser modificado. La manipulación del movimiento capturado depende de la

\footnotetext{
${ }^{41}$ Thomas \& Johnston, 1981, pág. 323, (trad. a.): No one knows for sure why a pencil tracing of a live action figure should look so stiff and unnatural on the screen, unless there simply is no reality in a copy. [...] The camera certainly records what is there, but it records everything that is there, with an impartial lack of emphasis.
} 


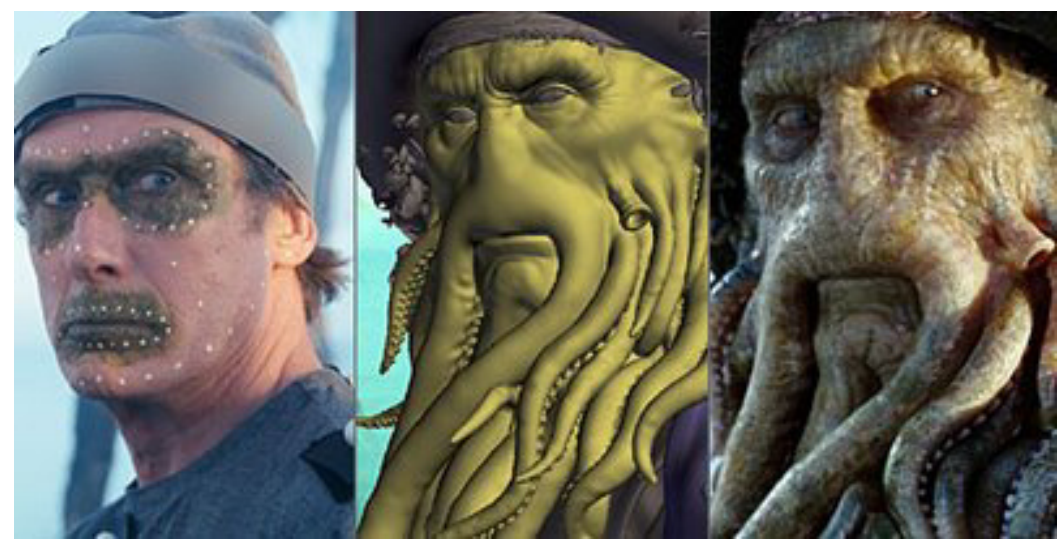

Fig. 50. Captura del movimiento del rostro en Pirates of the Caribbean: Dead Man's Chest (Piratas del Caribe: el cofre del hombre muerto).

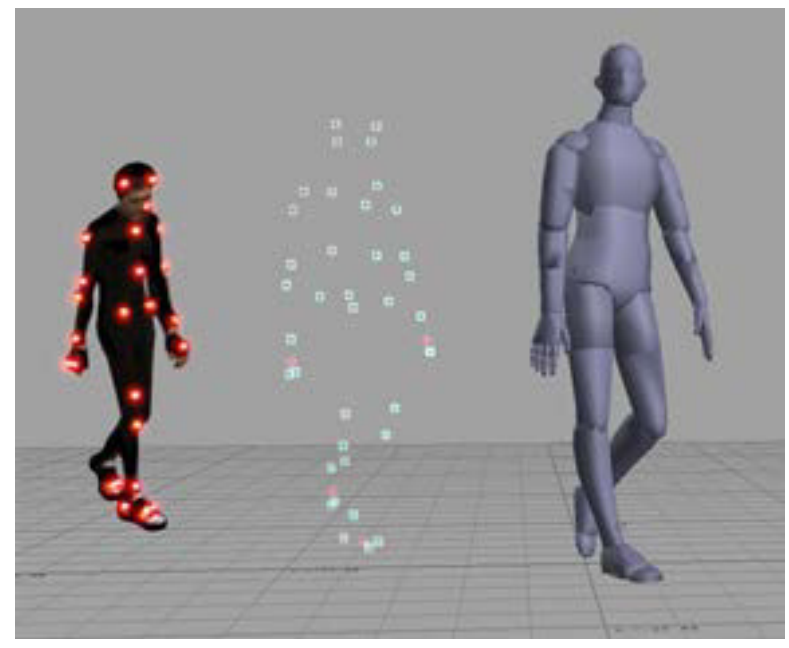

Fig. 51. s/a (s/f) Estadios de producción de captura de movimiento.

sustracción y adición de fotogramas para hacer énfasis en momentos concretos de la acción, y la modificación de la dimensión temporal de acciones o acontecimientos completos. También se podría alterar el orden cronológico y así representar el movimiento por fases yuxtapuestas, entre otras intervenciones. Pero a pesar de las modificaciones, se reconoce el movimiento distintivo de la técnica, que, al igual que la rotoscopia, tiene un carácter contenido. Por proporcionar representaciones móviles de valoración espacio-temporal homogénea, la captura de movimiento también presenta esta cualidad del movimiento neutro.

Pero el dinamismo anodino del motion cature puede desvanecerse en otras cualidades cinematográficas, como ya apuntamos en el capítulo 1. Para empezar, la alteración del movimiento capturado puede ser tal que la valoración espaciotemporal devenga en un agente más expresivo, aunque es poco común. Por ejemplo, cuando el protagonista de Avatar (Cameron, 2010) está por primera vez 
conectado a su avatar, al levantarse se tambalea, no tiene control de su cuerpo; parte de ese mareo se transmite por el movimiento de cámara, pero también por cómo se mueve el personaje. Asimismo, en la manera de correr de los na'vi, hay alteración de la acción capturada, en parte también por el alargamiento de las proporciones, que otorga un carácter más mágico a estos extraterrestres. Pero normalmente las cualidades expresivas del motion capture provienen de los otros componentes espacio-temporales, que dejan en segundo plano la valoración espacio-temporal. La película Avatar también es un ejemplo de animación por captura de movimiento en la que la planificación (especialmente los movimientos de cámara) es tan potente que transmite el movimiento como vivenciado sin que la valoración espacio-temporal propia de la técnica actúe en detrimento de la expresividad.

\section{Animación CG (animación generada por ordenador)}

La animación CG, tanto 2D como 3D, puede considerarse una técnica en la que la valoración espacio-temporal se obtiene semi-mecánicamente, porque a través de estos programas al animador determina los fotogramas clave (punto de inicio y de fin para trayectorias o cambios sustanciales) y el programa crea los fotogramas intermedios. Por un lado, al establecer los fotogramas principales que definen la acción, se tiene dominio sobre la representación del movimiento (no viene dada principalmente por la técnica, como en la captura de movimiento). Por otro lado, la generación automatizada de fotogramas intermedios proporciona un movimiento de aspecto mecánico, prefabricado. Esto ocurre porque el software genera el movimiento acorde a los parámetros para los que ha sido programado, es decir, sigue unos patrones que adapta según los fotogramas clave que el animador establece.

Aunque en la animación CG la valoración espacio-temporal es proporcionada por el software, la técnica permite mayor flexibilidad que aquellas que se basan en la captura de vídeo y movimiento. No obstante, por muchos puntos calve que se introduzcan, las imágenes intermedias generadas entre esos puntos clave siempre serán realizadas automáticamente. Para Mullen es importante hallar el equilibro entre acciones automáticas y hechas a mano. El autor opina que:

Las interpolaciones hacen que la tarea de animación sea mucho más fácil al automatizar gran parte del trabajo laborioso. Sin embargo, es importante recordar que se debe encontrar un equilibrio entre hacer las cosas a mano y utilizar herramientas automatizadas. [...] Crear claves y editar curvas en exceso puede generar un movi- 
miento intermitente, irregular, mientras que simplemente dejar que las interpolaciones hagan todo el trabajo genera movimientos suavizados poco convincentes. ${ }^{42}$

Dejando a un lado las cuestiones sobre el verismo del movimiento, el timing automático homogeniza, sin ninguna duda, el movimiento. Cuantos más fotogramas clave se establezcan y más se modifiquen las curvas que se trazan por defecto entre éstos (es decir, cuanto menos protagonismo se deje a la interpolación automática), la animación resultante tendrá un movimiento más personalizado.

En las animaciones CG menos sofisticadas y en algunas ya consideradas antiguas, como Sr. Trapo , La Faim (Hambre) (Foldes, 1974) (Fig. 52) o Sink (Inmersión) (Tomioka, 1999) las acciones automatizadas se reconocen fácilmente; en animaciones de movimiento mucho más sofisticado, como Elephant Dream (Kurdali, 2006), o Box Factory (Krause, 2003), vemos menos el efecto de las acciones automatizadas; y en otras como Ratatouille (Bird, 2007) y Brave (Andrews, Chapman, \& Purcell, 2012) es imperceptible a simple vista, probablemente debido a una animación más detallada de puntos clave y edición de curvas de interpolación.

A veces el aspecto prefabricado de la animación generada por ordenador es precisamente el más adecuado. Por ejemplo, para transmitir un mensaje de la manera más aséptica posible o incluso para exhibir que la animación se realizó con esa tecnología y no a mano, acorde con una apariencia de avance tecnológico. En animación, la apariencia artificial de la técnica también ha sido aprovechada: la primeras animaciones de Pixar Animation Studios evitaban la representación de seres humanos ya que la animación CG proporcionaba movimientos y formas muy mecánicos, por eso el primer largometraje de la compañía fue Toy Story (Unkrich, 2010) (Fig. 53), en la que los protagonistas son juguetes, y los personajes humanos (aunque participan en la historia de manera crucial) tienen poca presencia visual; el movimiento mecánico y las texturas artificiales resultan muy apropiados para mostrar un mudo de plástico compuesto por juguetes industriales.

Realicemos una breve comparación entre dos animaciones que representan un acontecimiento similar: el movimiento de los espectadores en un cine en Zuschauer (Espectadores) (Krumme, 1989) (Fig. 54) y el movimiento de una masa de gente en Grain Coupon (Cupón de grano) (Chi, 2001) (Fig. 55). La primera es una animación de dibujo en la que destaca la gran diversidad de acciones del grupo, los cambios de velocidad, la coordinación de los individuos y el movimiento desordenado, etc. en la que por medio del movimiento se representan metafóri-

${ }^{42}$ Mullen, 2007, pág. 305 
camente actitudes sociales. Y en la segunda, realizada con animación digital, vemos el movimiento ordenado de la multitud; en ésta el movimiento automático de apariencia deslizante de la animación digital es aprovechado para transmitir mediante el movimiento una idea: el pueblo uniformado por las ideas políticas.

Las técnicas mecánicas y semi-mecánicas tienden a homogenizar la representación del movimiento. Además, aquellas basadas en la captura de video y movimiento presentan una valoración espacio-temporal que, salvo excepciones, no transmite sensaciones cinéticas. Esto las hace propicias para el movimiento neutro, pero ésta característica no tiene porqué impedir la expresión del movimiento vivenciado, ya que "la capacidad creativa es independiente del mayor o menor espectro de posibilidades técnicas. Ella depende de la capacidad y el talento de

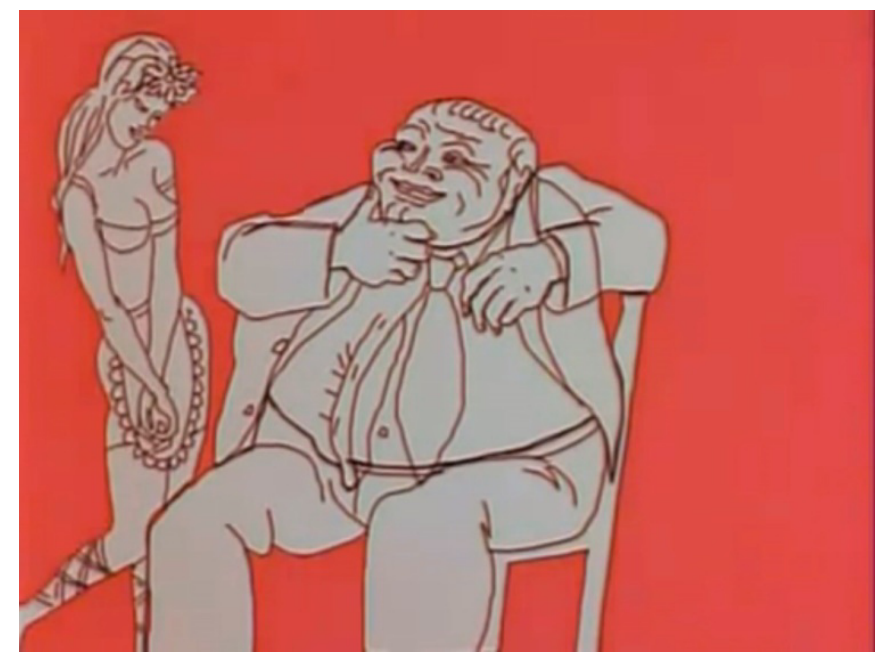

Fig. 52. Peter Foldes (1974). La Faim (Hambre).

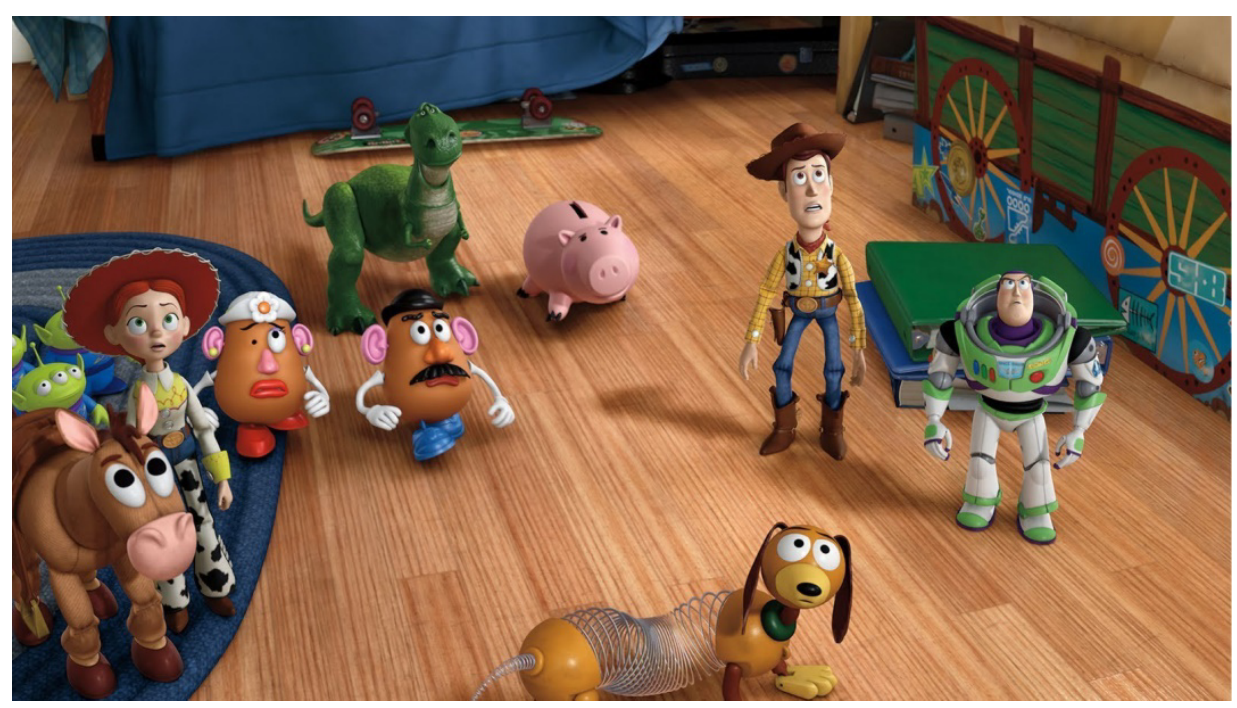

Fig. 53. Lee Unkrich (2010). Toy Story 3. 
quienes las utilizan" ${ }^{43}$. Esta afirmación de Feldman sobre la tecnología en el cine de acción real es aplicable a la animación CG y las técnicas de captura, en las que otros componentes dinámicos pueden tomar el protagonismo expresivo.

De este modo, en cada animación destacan unos componentes dinámicos u otros: por ejemplo, L'année du daim (El año del ciervo) (Schwizgebel, 1995) no tiene una valoración espacio-temporal expresiva, no hay alteración evidente y las imágenes individuales son muy estáticas, pero el movimiento es vivenciado debi-

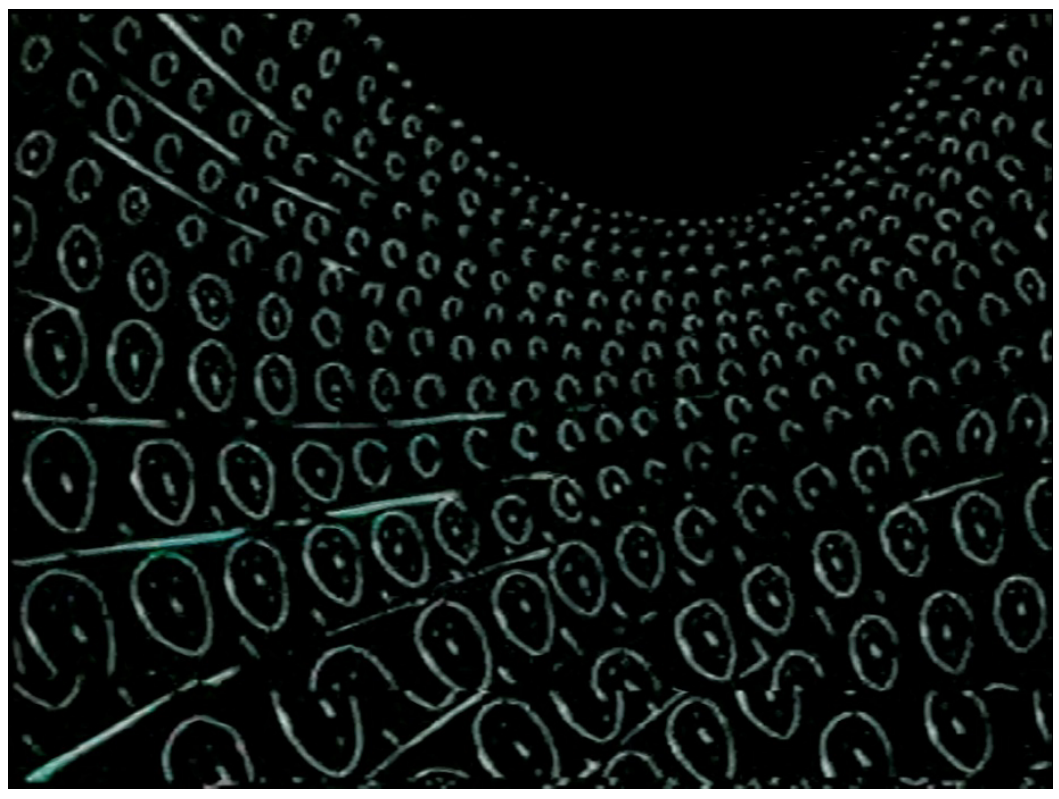

Fig. 54. Raimund Krumme (1989). Zuschauer (Espectadores).

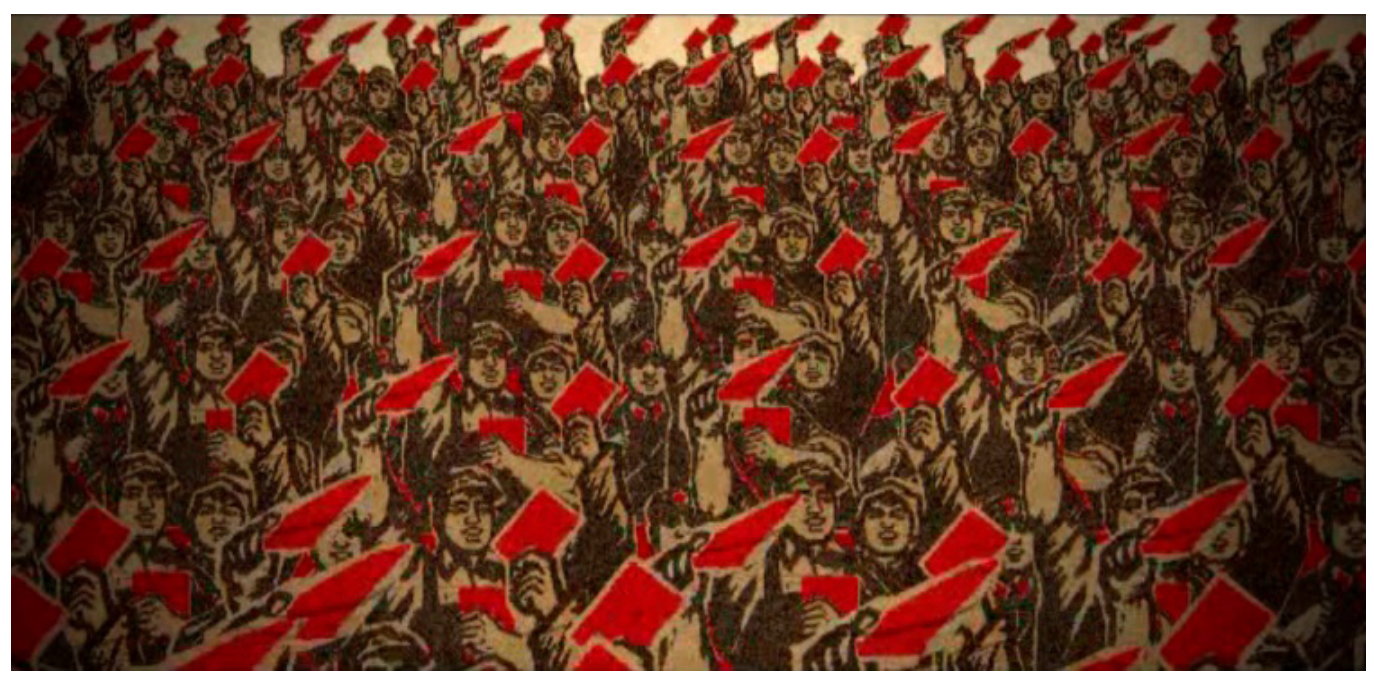

Fig. 55. Chen Xi y Xu An (2001). Grain coupon (El cupón de grano).

${ }^{43}$ Feldman, 2001, pág. 84 
do a la composición móvil; sin embargo, el video con las directrices de seguridad de la compañía aérea Lan Chile es neutro por la conjunción de todos los elementos (el relato anacrónico no lo hace ni vivenciado ni neutro). Y en Rame Dames (Guiol, 2010) el movimiento es vivenciado, sobre todo por la valoración espaciotemporal, con grandes exageraciones del tiempo, velocidad y lentitud de las acciones; en esta obra el peso expresivo no recae sobre otros componentes dinámicos, aunque también colaboran a ello, como la planificación (con planos inclinados, movimientos de cámara, etc.) y el cambio de imagen (hay vibración por uso plástico de la técnica de dibujo). Y La ravissement de Frank N. Stein (El encanto de Frank N. Stein) (Schwizgebel, 1982) [en DVD] tiene movimiento vivenciado por la distribución de la intensidad cinética; no requiere de todos los componentes encauzados a la expresividad máxima. 


\subsection{CONCLUSIONES: INFLUENCIA DE LA VALORACIÓN ESPACIO-TEMPORAL EN LA REPRESENTACIÓN DEL MOVIMIENTO VIVENCIADO Y EL MOVIMIENTO NEUTRO}

A partir de los elementos de la valoración espacio-temporal estudiados y los análisis realizados, extraemos las siguientes conclusiones respecto al papel de la valoración espacio-temporal en la expresión del movimiento vivenciado y neutro en animación:

- La valoración espacio-temporal es regular o irregular

Ambos recursos pueden proporcionar movimiento expresivo o neutro.

- Modificación evidente de la mecánica o invención de una mecánica nueva (fases no cronológicas de la acción inclusive)

Esta característica suele estar presente en las animaciones en las que el movimiento es vivenciado, pero su uso no es sinónimo de esto. La alteración de la mecánica puede estar igualmente enfocada a la representación del movimiento neutro como del movimiento vivenciado; dependiendo de cómo se realice, puede proporcionar movimientos de diferente grado de expresividad.

- La representación del movimiento se fundamenta en la mecánica real.

Colabora en la expresión del movimiento vivenciado o neutro dependiendo de en qué medida se represente la mecánica real. Si se enfatizan aspectos concretos de la mecánica por medio de la exageración de la trayectoria o la velocidad o se acentúan aspectos particulares de la acción, la valoración espacio-temporal puede dar paso al movimiento vivenciado. Si por el contrario no se introduce ninguna variación o interpretación de la mecánica real, de esto se puede derivar una valoración espacio-temporal que no transmita sensaciones cinéticas, por lo que correspondería a movimiento neutro.

- El movimiento se obtiene por captura de video.

- El movimiento se obtiene por captura de movimiento.

- La animación se genera con técnicas CG.

El uso de estas técnicas homogeniza la interpretación espacio-temporal y ade- 
más, la captura de vídeo y de movimiento normalmente carecen de capacidad para generar sensaciones cinéticas. Cuanto más se modifique el movimiento y el video capturado y cuanto más se edite el movimiento en animación CG (es decir, cuanto más se modifique el movimiento que proporcionan las técnicas) el movimiento resultante se puede alejar más de la homogeneidad que proporcionan. La expresión del movimiento vivenciado por estos medios proviene sobre todo del resto de componentes dinámicos.

\section{- Dinamismo en las imágenes estáticas que forman la animación.}

Puede potenciar la transmisión de sensaciones cinéticas, ya que si la animación se compone de dibujos que transmiten movimiento por sí mismos, con mayor facilidad inspirará sensaciones cinéticas y por tanto puede derivar de ella la expresión del movimiento vivenciado, pero depende directamente de cómo se conjugue con la separación de las formas entre fotogramas, esto es, de la relación espacio-temporal. Pero no es una característica necesaria para expresar el movimiento con expresividad.

\section{- La representación del movimiento corresponde a un estilo de animación.}

Cuando la interpretación espacio-temporal sigue un estilo de animación, la representación se homogeniza, ya que unifica la expresión del movimiento. No obstante, esta característica no tiene por qué impedir la expresión móvil vivenciada. Tanto por medio de un estilo específico como por medio de su trasgresión, se pude representar el movimiento como vivido en primera persona, expresar cualidades peculiares de la acción o generar sensaciones cinestésicas. 


\section{CONCLUSIONES}

- La valoración espacio-temporal se manifiesta en la representación detallada de la acción a lo largo de los fotogramas. Esta representación pormenorizada puede ajustarse a la mecánica real, basarse en ella, interpretarse notablemente, o bien ser totalmente independiente de la mecánica real y constituir una mecánica inventada.

- La recreación exacta del desarrollo real del movimiento (sin ninguna alteración) genera una valoración espacio-temporal que raras veces despierta sensaciones cinestésica y que proporciona un dinamismo neutro; mientras que la alteración de la mecánica, al modificar el movimiento real, ofrece un amplio margen de posibilidades expresivas, desde movimiento totalmente neutro que por medio de una síntesis de la mecánica despersonalice la acción, hasta movimiento vivenciado, ya sea por síntesis (extrayendo una característica particular de la acción), por análisis (mediante una mecánica descriptiva pero con alteración o exageración espaciotemporal) o por invención (creando un desarrollo nada relacionado con la realidad mecánica y que a su vez puede ser sintético o analítico).

- Una de las manera de alterar la mecánica es rompiendo el orden cronológico de las fases de una acción. Esto proporciona una animación caótica pero de potente dinamismo que se puede aprovechar para expresar el movimiento vivenciado en los casos en los que se quiera destacar estas cualidades de la acción: velocidad y caos; por lo tanto, no es apropiada para representa cualquier movimiento ni para crear movimiento neutro.

- La valoración espacio-temporal consiste en cómo se relacionan espaciotemporalmente las imágenes contenidas en los fotogramas, lo que depende sobre todo de cómo cambia progresivamente la imagen. Que cada fotograma contenga imágenes dinámicas, es decir, que sugieren movimiento por sí mismas, puede colaborar en la expresión del movimiento generando una fluidez particular en la animación que puede ser propicia para transmitir sensaciones cinestésicas; no obstante, no es independiente de la relación espacio-temporal entre imágenes. Además hay animaciones sin dinamismo en cada uno en sus fotogramas que transmiten sensaciones cinestésicas, por lo que evocar movimiento en los foto- 
gramas individuales no es sinónimo de expresión del movimiento vivenciado, ni su ausencia indica expresión neutra.

- Respecto a la cualidad homogénea del movimiento neutro, en la valoración espacio-temporal ésta proviene principalmente de la rotoscopia, el motion capture y los programas de animación CG (computer generated); todas, debido a sus peculiaridades técnicas, proporcionan una valoración espacio-temporal con un carácter similar; no obstante, este efecto puede paliarse por medio de la intervención en el timing en aquellas que parten de la captura y editando las acciones automáticas que generan los programas CG.

- Otro factor que homogeniza la expresión móvil es el uso de estilos específicos de animación, aunque la trasgresión del estilo personaliza el movimiento. Además, el movimiento vivenciado no es incompatible con la adopción de un lenguaje plástico preestablecido, de hecho los estilos más extendidos de animación (Disney y la mayor parte del anime) tienen cualidades dinámicas por las que también pueden expresar el movimiento como vivenciado.

- Como vemos, la valoración espacio-temporal es un componente dinámico altamente maleable, pero sobre todo lo es en las técnicas que no dependen del movimiento real registrado. En las técnicas de rotoscopia y captura de movimiento la valoración espacio-temporal provienen del movimiento registrado, hay, por tanto, una innegable recreación de la mecánica. Ésta normalmente no transmite sensaciones cinestésicas y proporciona un carácter homogéneo a la valoración espacio-temporal en las películas realizadas con estas técnicas. Sin embargo, el timing también puede intervenirse en estas técnicas, y, aunque no es frecuente, la alteración podría llegar incluso a provocar expresión vivenciada del movimiento. Luego la expresividad del movimiento puede darse por medio de todas las técnicas; $y$, de igual modo, el movimiento neutro es posible también por medio de todas ellas.

- En último lugar, dado que la valoración espacio-temporal no es el único componente dinámico, sino que interactúa con el resto, ni un timing neutro ni uno vivenciado determinan la expresividad del movimiento de la obra, salvo que la expresividad recaiga sobre este elemento o que el resto de componentes refuercen su carácter como neutro o como vivenciado. 
4. NATURALISMO Y EXPRESIVIDAD DEL MOVIMIENTO EN ANIMACIÓN 

En este capítulo nos adentramos en otra característica de la representación del movimiento en animación, el nivel de naturalismo, con el fin de estudiar si existe una conexión determinante entre éste y la expresividad. A ojos de cualquier espectador hay animaciones más coincidentes con la realidad que otras según diferentes aspectos: el tema, el movimiento, el sonido, el color, etc. Según los términos que desarrollamos en este trabajo, el movimiento vivenciado es la representación que sugiere las sensaciones móviles de su experiencia, y en el extremo opuesto de la expresividad se hayan aquellas representaciones que muestran el movimiento de manera neutra. Pero estas animaciones ¿se alejan de la realidad dinámica o se acercan a ella? La definición de movimiento vivenciado y movimiento neutro que propusimos en el capítulo 1 no especifica el nivel de naturalismo porque, como veremos a lo largo del presente capítulo, aunque hay puntos comunes entre movimiento vivenciado y representación alejada de la realidad, y entre movimiento neutro y naturalismo, veremos que el nivel de expresividad no determina ni viene dado por el grado de naturalismo.

Comenzaremos tratando una serie de conceptos presentes en el debate sobre la interpretación y la copia de la realidad dinámica en animación (4.1). A continuación estudiaremos los puntos comunes entre el movimiento vivenciado y la representación alejada de la apariencia real del movimiento (4.2), así como la relación entre movimiento neutro y representación naturalista del movimiento (4.3). También hablaremos de obras de animación en las que no se cumplen estas características y que desmienten la relación de causa-consecuencia entre expresividad y nivel de naturalismo (4.2.2. y 4.3.2.). Para finalizar, se observa la relación entre el nivel de naturalismo del móvil y la naturaleza fantástica o realista de los acontecimientos representados y cómo afecta esto a la expresión del movimiento vivenciado y neutro (4.4). 
Movimiento vivenciado y movimiento neutro. Estudio sobre la expresividad de la representación del movimiento en animación 


\subsection{NATURALISMO DEL MOVIMIENTO EN ANIMACIÓN}

A través de este parágrafo pretendemos generar un marco de aclaración de conceptos previo a la argumentación de los dos siguientes parágrafos del capítulo (4.2. y 4.3.), en los cuales se trata la asociación entre movimiento vivenciado e invención del movimiento, y movimiento neutro y naturalismo de la representación. Para ello comenzaremos este parágrafo hablando de la naturaleza interpretativa de la representación plástica del movimiento en animación (4.1.1.); y en el apartado 4.1.2. analizaremos qué se entiende por movimiento naturalista o inventivo en animación. Finalmente, en 4.1.3. analizamos el lenguaje cinematográfico y el lenguaje plástico en animación, cada uno de los cuales resalta unos valores de la representación del movimiento.

\subsubsection{CONSIDERACIONES SOBRE EL NATURALISMO EN EL ARTE APLICADAS A LA ANIMACIÓN}

\section{Representar es interpretar}

La representación, como explicamos en el capítulo 1, mantiene una relación de analogía entre el modelo - existente en la realidad visible o en la imaginación - y la manifestación plástica que lo plasma. El proceso de representación es un acto intelectual, lo que implica la interpretación del modelo. Por lo tanto toda representación es una interpretación de la realidad. La interpretación es inherente a la representación, sea ésta más o menos coincidente con la realidad. Como dice Fromentin:

[...] ese gran arte de servirse de la naturaleza sin estereotiparla, de copiarla unas veces hasta la servidumbre, de descuidarla otras hasta el olvido; ese difícil equilibrio de las verosimilitudes que obliga a permanecer sincero sin ser exacto, a pintar y no a describir, a dar no la ilusión sino la impresión de vida, todo eso se traduce por una palabra ordinaria, que da lugar a muchos equívocos quizá porque nunca se la ha definido bien: quiero decir la interpretación. ${ }^{1}$

En la práctica, la copia exacta de la realidad no es posible; del mismo modo, ninguna animación puede ser copia exacta del movimiento real. Así, al contrario

\footnotetext{
${ }^{1}$ Fromentin, 1859, en Plazaola, 2007, pág. 377
} 
que en el relato de Borges sobre la creación de un mapa que, a fuerza de ser tan exacto, acaba cubriendo el país que cartografía ${ }^{2}$, la mera elección de los elementos a mostrar en el espacio fílmico supone un proceso intelectual de selección de la realidad y, por tanto un punto de vista respecto a ésta. Sin embargo, si analizamos la correspondencia entre lo real y la obra plástica, y en el caso de la animación entre el movimiento real y el movimiento animado, observamos distintos niveles de naturalismo. No podemos dejar de notar que unas animaciones son más realistas que otras, algunas son tan parecidas a la realidad visible que nos cuesta diferenciarlas del cine de acción real, pero aun así: "Todo arte se origina en la mente humana, en nuestras relaciones ante el mundo más que en el mundo visible en si". ${ }^{3}$

\section{Lógica e intuición}

El nivel de naturalismo de la imagen plástica se debe en parte al tipo de criterios que guían la representación. Uno de los debates de la estética es la idea de que para representar algo hay que conocerlo y que, por tanto, quien mayor conocimiento tenga de ello mejor lo expresará. En animación, este concepto estético tiene importantes connotaciones sobre la expresión dinámica. Efectivamente, la comprensión del movimiento es fundamental para su expresión ¿Pero qué clase de conocimiento nos acerca a él? La expresión plástica del movimiento en animación, así como toda creación plástica, puede llevarse a cabo desde el conocimiento intuitivo o el conocimiento lógico. A través de la intuición comprendemos la naturaleza intrínseca del movimiento, mientras que por medio del conocimiento lógico explica el fenómeno racionalmente. Pero, ni el conocimiento intuitivo ni el lógico ligan el aspecto del movimiento resultante en mayor o en menor medida a la realidad. Recordemos las explicaciones científicas sobre las leyes físicas que actúan en el movimiento de una pelota que bota, las cuales, a pesar del discurso racional, se materializan en animación simplemente como una acentuada exageración del movimiento (Figs. 3, 4 y 5 del capítulo 3, pág. 277); que la animación sea más o menos realista depende de la manera en que se dé forma a tales conocimientos.

\footnotetext{
2 "En aquel Imperio, el Arte de la Cartografía logró tal Perfección que el mapa de una sola Provincia ocupaba toda una Ciudad, y el mapa del imperio, toda una Provincia. Con el tiempo, esos Mapas Desmesurados no satisfacieron y los colegios de Cartógrafos levantaron un Mapa del Imperio, que tenía el tamaño del Imperio y coincidía puntualmente con él. Menos adictas al Estudio de la Cartografía, las Generaciones Siguientes entendieron que ese dilatado Mapa era inútil y no sin Impiedad lo entregaron a las Inclemencias del Sol y de los Inviernos. En los desiertos del Oeste perduran despedazadas Ruinas del Mapa, habitadas por Animales y por Mendigos; en todo el País no hay otra reliquia de las Disciplinas Geográficas. Suárez Miranda, Viajes de varones prudentes. Libro cuarto, cap. XLV, Lérida, 1658" Borges, Del rigor en la ciencia, en El Hacedor, 1960

${ }^{3}$ Gombrich E. H., 1960, págs. 76-78
} 
Kandinski opina, como manifestó en 1914 en una conferencia en Colonia, que ambos tipos de conocimiento participan en la creación favorablemente para la "materialización de la obra". ${ }^{4} \mathrm{Y}$ así podemos comprobarlo en el terreno de la animación, en la que, como vimos en el capítulo 3, hay diversos modos de estudiar y representar el movimiento, desde los que se ajustan más a la mecánica hasta los que se alejan más de ella, y de todos ellos se puede extraer resultados expresivos y neutros, según el objetivo del director.

Al hablar de intuición e imaginación no dejamos al margen la reflexión y planificación necesarias que por sus peculiaridades técnicas forman parten del proceso creativo en animación. Ambas actividades mentales conviven en la creación sin que por ello sea mermada la expresión del movimiento vivenciado y el movimiento de carácter inventivo.

De la preponderancia de la intuición sobre la lógica (que como vemos no están en oposición) se desprende una postura estética que sostiene que el artista es capaz de ver la naturaleza profunda de las cosas; a través del arte, la desvela al resto del mundo, y al destacar estos aspectos "secretos" o "inaccesibles" para los que no tienen tal sensibilidad, producen obras que se acercan más a la esencia de la realidad. El animador puede tener la misma impresión en su trabajo. Al comparar el resultado de una cámara cinematográfica y una animación Thomas y Johnston concluyen que:

Un artista muestra lo que ve ahí, especialmente aquello que puede no ser percibido por otros. Sus dibujos pueden estar más próximos al verdadero realismo de un objeto porque él puede ser selectivo y personal en lo que elije mostrar. ${ }^{5}$

El artista, al no observar el mundo desde una perspectiva práctica, percibe lo que los demás no pueden, posee una visión "más directa de la realidad" ${ }^{6}$. Gombrich, sin embargo, considera que todas las personas tienen la misma capacidad visual, y que lo que diferencia a los artistas es su habilidad para expresar esto a través de la plástica:

el acceso que el artista tiene a su experiencia visual no es superior a la de cualquier otra persona. Pero él se ha adiestrado para observar su respuesta a la imagen a medida que la va dando forma con su mano. Si su objetivo es emular el mundo visual, utilizará cualquier recurso que se lo sugiera. Si acierta con su obra, cabe suponer

\footnotetext{
${ }^{4}$ Kandinsky \& Fundació Caixa Catalunya, 2003, pág. 7

${ }^{5}$ Thomas \& Johnston, 1981, pág. 323, (trad. a): ) an artist shows what he sees is there, especially that which might not be perceived by others. His drawings can be closer to the true realism of an object because he can be selective and personal in what he chooses to show.

${ }^{6}$ Bergson, 1934, pág. 128
} 
que también sugiera tal experiencia a otros contempladores. ${ }^{7}$

\section{Voluntad de verdad y voluntad de invención}

Foucault se refiere a la "voluntad de verdad" como la derivación de una inicial "voluntad de saber" propia del discurso en campos del conocimiento que fue aplicada a otros ámbitos, como la literatura. El autor explica que esta tendencia que apareció en los siglos XVI y XVII, especialmente en Inglaterra, acabó convirtiéndose en el criterio a través del cual el discurso se dota de carácter verosímil, apoyándose en la lógica y la ciencia:

creo que esta voluntad de verdad, apoyada en una base y una distribución institucional, tiende a ejercer sobre los otros discursos - hablo siempre de nuestra sociedad - una especie de presión y de poder de coacción. Pienso en cómo la literatura occidental ha debido buscar apoyo desde hace siglos sobre lo natural, lo verosímil, sobre la sinceridad, y también sobre la ciencia. ${ }^{8}$

La voluntad de verdad establece que la obra artística es válida en la medida en que respeta un criterio objetivo, determinando lo que es una representación "correcta". Respecto a esta actitud, Su Tung-p'o hizo una sentencia de sabiduría Contra la verosimilitud y la corrección en el arte:

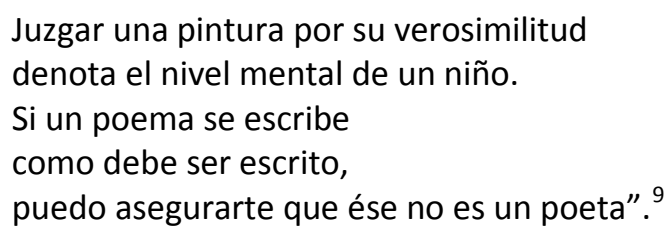

La crítica de Foucault a la literatura puede aplicarse también a la creación plástica. En la representación del movimiento en la animación, esto tiene su reflejo en los discursos más o menos científicos que parten del conocimiento de la mecánica y los principios físicos para justificar la representación dinámica, como vimos en el apartado C. de 3.2.1. pág. 276). En otros casos la voluntad de verdad se manifiesta sencillamente en la prioridad por recrear la mecánica; tal es el caso de la película Beowulf (Zemeckis, 2007), en la que, en pro de una mayor calidez en la mirada de los personajes, se ideó un sistema para recrear la pulsación del globo ocular ${ }^{10}$, detalle que normalmente pasa por alto cuando observamos el movimiento del rostro humano al natural. En esta película el efecto de la mirada inerte (caracte-

\footnotetext{
${ }^{7}$ Gombrich E. H., 1982, pág. 254

${ }^{8}$ Foucault, 1970, págs. 22-23

${ }^{9}$ Su Tung-p'o, s. XI y XII, en Racionero, 1983, pág. 179

${ }^{10}$ Vegas, 2008, pág. 58
} 
rístico de los personajes de las películas anteriores realizadas la técnica motion capture), se obtuvo recreando el movimiento real del ojo.

Del mismo modo que Foucault habla de la voluntad de verdad para referirse a la imposición de la razón sobre otros medios de conocimiento, podríamos hablar de una "voluntad de invención" por la cual la imaginación prevalece sobre la razón. Así pues, siendo toda animación una interpretación del movimiento real, el carácter más o menos inventivo de tal representación es "escogido" a voluntad por el artista, y no proviene de la casualidad a la que (a pesar la planificación necesaria) están abiertas las técnicas de animación. Gaston Bachelard considera la imaginación como acción deliberada en el proceso de creación de la poesía y propone esta manera de ejercitarla:

\begin{abstract}
A propósito de toda imagen que nos impresiona debemos preguntar: ¿Qué fuga lingüística desencadena esta imagen en nosotros? ¿Cómo la desentrañamos del fondo demasiado estable de nuestros recuerdos familiares? Para experimentar de veras el papel imaginador del lenguaje, es preciso buscar pacientemente, respecto a todas las palabras, los deseos de alteración, de doble sentido, de metáfora. De un modo más general hay que revisar todos los deseos de abandonar lo que se ve y lo que se dice en favor de lo que se imagina. Así tendremos la oportunidad de devolver a la imaginación su papel de seductora. Con ella abandonamos el curso ordinario de las cosas. $^{11}$
\end{abstract}

También el animador puede plantearse estas preguntas ante la creación; en su caso las materias sensibles son la imagen y el movimiento, como lo son las palabras para el poeta; y su expresión puede ser tan flexible como él lo desee.

\title{
Mímesis
}

En la Antigüedad "mimesis" se entendía como imitación de la naturaleza y el concepto poseía matices diferentes según la corriente filosófica que lo definía. Aristóteles aplica el concepto a las artes en general, no sólo a la pintura, por lo que se comprende que no significaba "mímesis de la apariencia". La mímesis aristotélica es imitación de la naturaleza en cuanto a su función creadora, proceso en el cual se reconoce un lugar para la fantasía. Estos principios volvieron a ser eje de la plástica en el Renacimiento, periodo durante el cual la concepción clásica se desvirtuó al convivir con la concepción de mímesis como "copia exacta de la naturaleza" ${ }^{12}$.

\footnotetext{
${ }^{11}$ Bachelard, 1943, págs. 11-12

${ }^{12}$ Lee, 1940, págs. 23-24
} 
A pesar de que no todos los artistas aplicaban la mímesis en sus obras en el sentido estricto de "copia", como explica Plazaola: "Por este realismo, todo el arte occidental va a contraer una de sus más prolongadas y endémicas limitaciones, poniendo la ciencia y la técnica al servicio casi exclusivo de la apariencia sensible". ${ }^{13}$ En la actualidad uno de los significados más extendidos del término mímesis, es el de copia exacta de la realidad visible. Pero debido a que el término mímesis tiene diversas acepciones, en su lugar usaremos "naturalismo" para referirnos a las citadas cualidades, aunque en otras ocasiones utilizaremos también "objetivo" o "realista". Hablaremos sobre la representación naturalista en animación más detalladamente en el apartado 4.1.2.

\section{Evocación e información}

Se ha debatido respecto al realismo de las imágenes según su grado de definición (una imagen más borrosa sería menos realista que una de alta definición, o al contrario). Gombrich reflexiona sobre porqué la experiencia subjetiva de la visión, siendo "en verdad tan privada y esquiva", puede haber sido elevada a "criterio de fidelidad" y explica que "estos criterios [...] no se basan en una comparación del motivo con la imagen, sino en la capacidad potencial de la imagen para evocar el motivo." ${ }^{14}$. El movimiento vivenciado es precisamente eso: evocación de la sensación cinética vivida u observada.

La oposición entre evocación e información fue expuesta por Reynolds en sus escritos sobre arte al hablar de pinturas de formas "difusas". Según Reynolds, este tipo de imágenes requiere que el espectador conozca el modelo pintado pues, si no, podría sugerir cualquier otro modelo. Pero Gombrich observa que "la fórmula no nos dice qué tipo de información necesitamos para dar vida a la imagen incompleta" ${ }^{15}$ y apunta que el poder evocador no apela al conocimiento, sino a la imaginación. Esta cuestión es relevante en la expresión móvil en animación, ya que, siguiendo el argumento de Gombrich, tampoco el movimiento expresado como vivenciado tiene porqué ser conocido para ser comprensible o reconocible para el espectador (a pesar de no ser descriptivo en términos objetivos). Y del mismo modo consideramos que esta máxima también puede ser aplicada a la creación: es posible animar un tipo de acción determinada sin vivirla directamente o sin conocer en detalle su mecánica, pues la imaginación y la intuición ayudan a alcanzar el conocimiento necesario.

\footnotetext{
${ }^{13}$ Plazaola, 2007, pág. 361

${ }^{14}$ Gombrich E. H., 1982, pág. 254

${ }^{15}$ Gombrich E. H., 1982, pág. 254
} 
Por el contrario, el movimiento neutro representa las cualidades fundamentales del movimiento (dirección, sentido, velocidad y aceleración), ajeno a las particulares de su experiencia, que son propias del movimiento vivenciado. En este sentido el movimiento neutro es expositivo, informa, mientras que el vivenciado evoca. Esta relación de complementariedad también se da en la siguiente dicotomía: interno-externo.

\title{
Lo interno-lo externo
}

Con naturalismo nos referimos al nivel de parecido de la superficie plástica (y en el caso de la animación al movimiento) con la realidad. Pero ¿qué realidad? Los orientales la llamaron "naturaleza interna", aludiendo a que es inherente al ser. Tsung-ch'ien en el Arte de la pintura (1781) expresa así esta idea: "Pero plasmada de un modo u otro, la naturaleza interna de las cosas, su razón de ser, será siempre la misma. Por tanto no hay que contentarse con pintar sólo la parte exterior de las cosas." ${ }^{16}$ Esta manera metafórica de definir la esencia como la naturaleza interna refuerza la idea de que en todo caso la apariencia externa no define las cosas. En esta misma línea, Arnheim explica que la recreación exacta de la forma no contiene en sí más que la apariencia:

Es bien sabido que las mascarillas mortuorias y vaciados de escayola de personas reales, que son mecánicamente fieles a la realidad, a menudo tienen, sin embargo, una presencia puramente material, y suelen defraudarnos cuando esperamos que interpreten el carácter a través de la apariencia visual. ${ }^{17}$

Benedetto Croce es todavía más tajante cuando observa que la copia de la apariencia en las artes plásticas no produce sensaciones estéticas:

\begin{abstract}
Si por imitación de la naturaleza se entiende que el arte estriba en reproducciones mecánicas, que constituyen duplicados más o menos perfectos de objetos naturales, ante las que se renueva el mismo tumulto de impresiones que producen los objetos naturales, la proposición es, evidentemente, errónea. Las estatuas de cera pintada que simulan seres vivientes y ante los que nos detenemos estupefactos en los museos del género, no nos dan intuiciones estéticas. ${ }^{18}$
\end{abstract}

Así pues, vemos que, al igual que en la plástica, el naturalismo en animación también se asocia a la copia de lo externo, a lo visible. En cuanto a las técnicas plásticas, actualmente es sin duda el 3D generado por ordenador el que tiene el carácter más parecido a las figuras de cera a las que hace referencia Croce (Fig. 1).

\footnotetext{
${ }^{16}$ Tsung-ch'i, 1781, en Racionero, 1983, pág. 162

${ }^{17}$ Arnheim, 1979, pág. 146

${ }^{18}$ Croce, 1908, págs. 101-102
} 
Pero respecto al dinamismo, la descripción de Croce es aplicable al movimiento generado por rotoscopia (transformando la apariencia plástica de las imágenes que forman el vídeo capturado) y por captura de movimiento (en el que la información de coordenadas de posición es registrada por los sensores adheridos a un cuerpo móvil), tenga la imagen plástica resultante una forma más o menos realista (Fig. 2) y siempre que no se modifique el movimiento capturado original.

Respecto a la apariencia de la acción real transformada en animación, Halas dice que: "uno aprende, por experiencia, que el tiempo real fotografiado por una cámara de acción real parece innatural en animación. El tiempo en animación tiene su propio ritmo, sus propios principios estructurales. Cada movimiento requiere un planteamiento diferente" ${ }^{19}$

Fig. 1. Reinhard Klooss (2013). Tarzán.
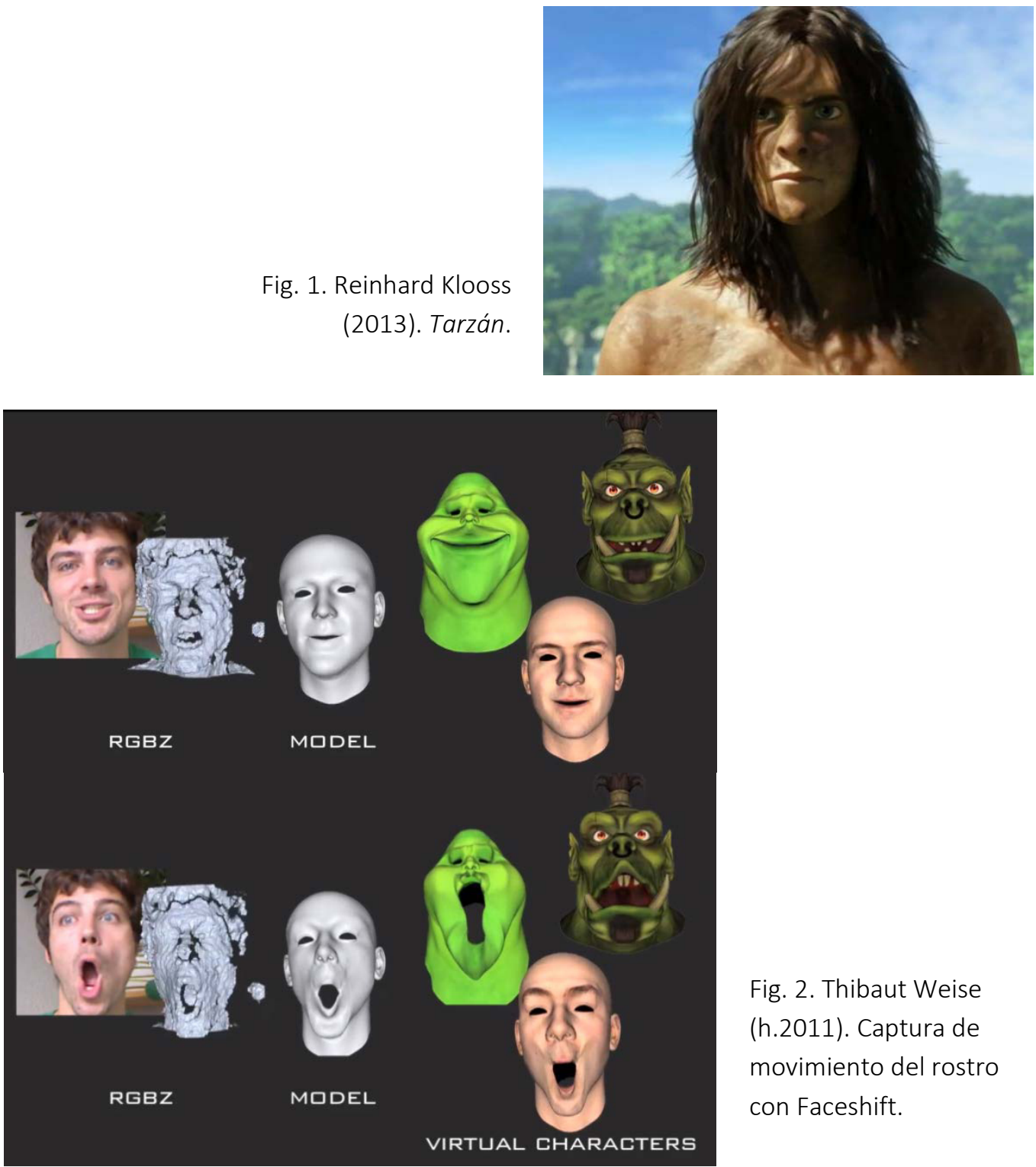

Fig. 2. Thibaut Weise (h.2011). Captura de movimiento del rostro con Faceshift.

\footnotetext{
${ }^{19}$ Halas, 1990, pág. 17, (trad. a.): One learns by experience that realistic time photographed by a liveaction camera looks unnatural in animation. Animation time has its own rhythm, its own structural principles. Each movement demands a different approach.
} 
Así mismo, Paul Wells, al referirse al documental animado Some Protection ( $A$ lgo de protección) (Rimminen, 1987) - de la serie Blinde Justice (Justicia ciega) (Channel 4, 1987) - sobre una mujer encarcelada, llama la atención sobre el hecho de que el mundo exterior se muestra colorido mientras que la prisión es monocromática. Sobre esta diferencia en la representación, Wells comenta que "Ambos aspectos [el de la cárcel y el exterior] pueden ser vistos en cierto modo como 'irreales', pero ciertamente parecen mucho más cercanos a reflejar la 'verdad'“20 $^{20}$. De esta manera, paradójicamente, la representación que pretende acercarse a la realidad externa se aleja de ella. Mientras que al mostrar facetas no objetivas que atienden a la vivencia personal, se conecta con la realidad de manera más audaz; en el caso del movimiento se trataría de transmitir la sensación cinética o emocional que éste transmite o imprime en la persona que lo vive o lo observa.

Pero respecto a esta capacidad de la imagen para reflejar la realidad en la medida en que lo externo se "oculta", es interesante atender a la reflexión de Gombrich sobre las imágenes estáticas cuyas formas no tienen todos los contornos definidos, sino difusos, en la que advierte de la complejidad de determinar cuáles son los criterios de fidelidad de la imagen estática:

No hay que ceder a esta tentación a la que tantas veces ha sucumbido la filosofía del arte: declarar que esta imagen es más fidedigna que la fotografía detallada. Esta especie de arte de aventajar a los demás estético no conduce a ninguna parte. Pero podría ser fidedigno de un modo diferente, más evocativo de algo que no es información, sino más bien un género peculiar de experiencia que podemos comprender lo mismo si hemos estado en África que si no. ${ }^{21}$

De este modo las imágenes son fidedignas según el criterio bajo el que se realicen, siendo su poder evocador accesible para todo tipo de espectador, sea cual sea su experiencia. Aquí encontraríamos una respuesta a la paradoja del realismo en la representación dinámica que a menudo se da cuando el movimiento se expresa como vivenciado: éste, sin poseer exactitud científica, se aproxima a la realidad sensorial, pues evoca la experiencia visual y cinética del movimiento, con la que todo el mundo está familiarizado. Así, en la animación Life in the womb ( 9 months in 4 minutes) (La vida en el vientre materno (9 meses en 4 minutos)) (Medicine Forever, h. 2014) [en DVD] vemos el proceso del embarazo desde la concepción hasta el parto, en el que se describe la posición y el recorrido del bebé al

\footnotetext{
${ }^{20}$ Wells, 2007, pág. 43, (trad. a.): Both aspects may viewed as in some way ‘unreal', but certainly they seem much closer to actually reflecting the 'truth'.

${ }^{21}$ Gombrich E. H., 1982, pág. 260
} 

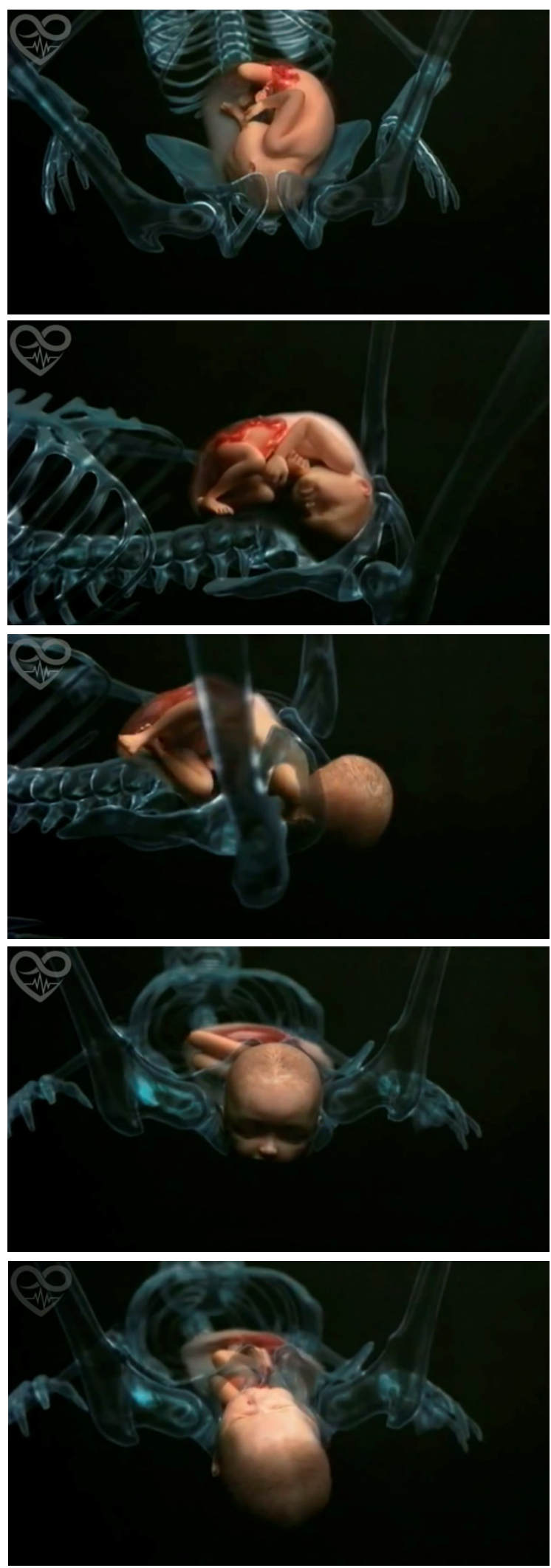

Fig. 3. Medicine Forever (h.2014). Life in the womb (9 months in 4 minutes) (La vida en el vientre materno (9 meses en 4 minutos)). Serie de fotogramas.

Fig. 4. Chris Hinton (2002). Flux. Serie de fotogramas.
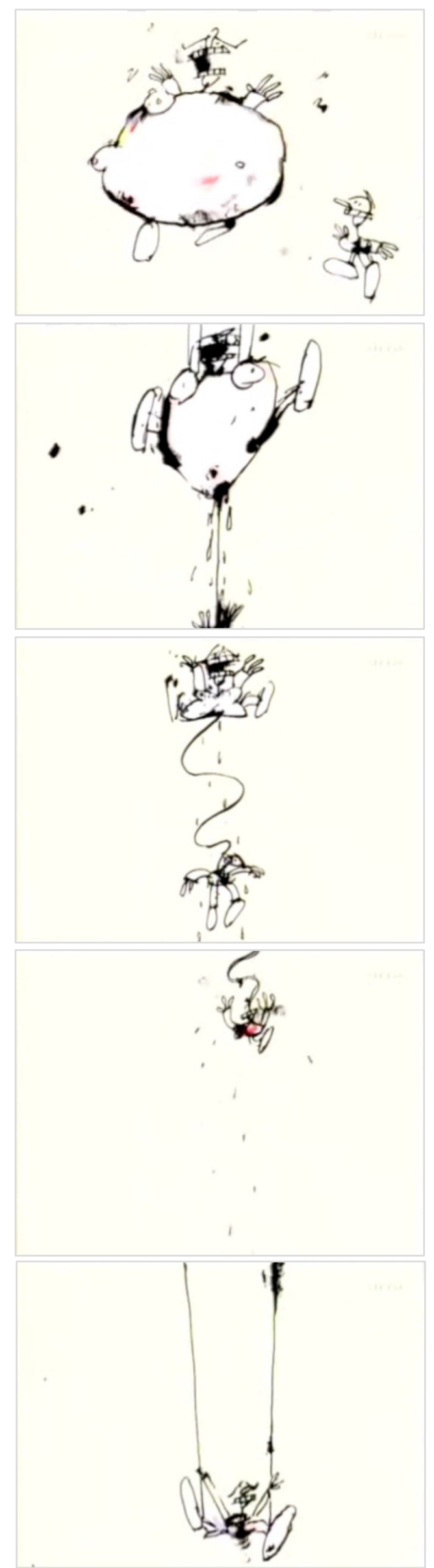
salir del vientre materno (00:03:53) (Fig. 3). Mientras que en Flux (Hinton, 2002)(00:06:33) [en DVD] todo el proceso biológico se resume por medio de imágenes casi abstractas aunque muy comprensibles de la concepción; y el embarazo se resume en el aumento desmesurado del vientre de la mujer, hasta que el bebé sale despedido, como una forma abstracta, desde la parte superior de la pantalla y queda pendiendo del cordón umbilical, que acto seguido se transforma en un columpio en el que se balancea (ya como una niña más mayor) y del que se cae apenas unos segundos más tarde (Fig. 4). La primera de estas animaciones informa, mientras que la segunda evoca la potencia del movimiento (del que se ha destacado la expulsión, más que la dificultad del proceso) y además lo compara con la pérdida de la seguridad que proporciona el seno de la madre (cordón umbilical-cuerdas del columpio) al salir de éste (caída del columpio).

\subsubsection{QUÉ ES REPRESENTAR DE FORMA NATURALISTA EL MOVIMIENTO EN ANIMACIÓN}

Se ha dicho de la animación, en oposición al dibujo y la pintura, que el hecho de mostrar el movimiento la hace más próxima a la realidad que los otros medios plásticos, desvelando por completo el misterio que hace interesante a la obra de arte. Sin embargo, la representación del movimiento en animación tiene una conexión muy flexible con la realidad, por lo que puede ser igualmente sugerente y estimular la imaginación del espectador ¿Pero qué es representar de manera naturalista el movimiento en animación? La cuestión no es tan sencilla como parece, no se reduce al parecido con la acción real o con la mecánica, como veremos a continuación. Trataremos este tema a través de varios aspectos: la posibilidad interpretativa del cine de acción real y de la animación, en qué sentido la fotografía y la acción real son considerados modelos de naturalismo, y qué se comprender por animación naturalista y por animación no naturalista.

\section{Cine de acción real y animación. Dos medios de interpretación del movimiento}

Para empezar, tanto animación como cine de acción real, a pesar de sus diferencias, son técnicas cinematográficas, término con el que se hace referencia a su carácter de imagen en movimiento (kine: movimiento, graphos: imagen). Ambas técnicas tienen en común que el movimiento se expresa en transcurso, es decir, existen como obra que se transforma a lo largo de su duración. Y pese a la dife- 
rencia del movimiento que cada uno de estos medios muestra en pantalla, en ambos casos se interpreta el movimiento. Esto que en animación puede ser más evidente, también se da en la acción real cuando ésta es usada como medio de expresión, dejando de ser simple registro del movimiento real. Respecto a la obra audiovisual Narcisus de McLaren (1987), en la que se parte del movimiento real de los bailarines, Bakedano dice:

\begin{abstract}
McLaren manipula los bailes pasando las imágenes por la máquina de imprenta óptica. Hace que los cuerpos se unan, multipliquen, que "parpadeen", y que se apaguen gradualmente; son decelerados, yuxtapuestos y borrados. Luminosos en una escena oscura, parecen estar suspendidos en el tiempo y el espacio. Un ambiente de sensualidad rodea cada movimiento. La película resume la fascinación de McLaren por la manipulación del movimiento en las películas, que es la esencia del cine. ${ }^{22}$
\end{abstract}

De esta manera el autor afirma que también a través de la acción real se expresa el movimiento a voluntad del artista. Sin embargo el propio McLaren, a propósito de la relación entre imagen real y animación, expresó que en la animación es posible representar el movimiento con autonomía de las leyes físicas que rigen el mundo real, lo que dota a la animación de mayor flexibilidad creativa:

\begin{abstract}
Hay que tener en cuenta también que las películas animadas no son en ningún sentido un sustituto de las películas "en vivo". Sería una tontería esperar que fuera así; abren un mundo nuevo a la imaginación, un mundo que está libre de las normas de la gravedad, de la sustancia y de la continuidad. Es posible casi todo en una película animada y la gama entera de las posibilidades cinemáticas es ampliada. ${ }^{23}$
\end{abstract}

Y es que a pesar de que ambos son medios interpretativos, las imágenes que forman una animación son creaciones plásticas y no capturas fotográficas, lo que convierte al cine y a la animación en lenguajes distintos. Al ser la animación expresión plástica del movimiento y al no depender de un movimiento real registrable, supone un medio de creación altamente imaginativo que tiene cualidades potenciales que no existen en la representación del movimiento por acción real.

¿En qué consisten tales posibilidades? Debido a que los fotogramas se realizan uno a uno (en la mayoría de las técnicas), los componentes dinámicos son más dúctiles, sobre todo en aquellas técnicas que tampoco requieren la fotografía de marionetas, recortes, objetos o personas. A grandes rasgos esta flexibilidad se evidencia en:

- La valoración espacio-temporal. Como vimos en el capítulo 3 (enteramente dedicado a este componente dinámico), controlar el cambio de los elemen-

\footnotetext{
${ }^{22}$ Bakedano, 1987, pág. 179

${ }^{23}$ Bakedano, 1987, pág. 222
} 
tos en el espacio (dónde) y en el tiempo (cuándo) hace que el movimiento puede ser interpretado con gran flexibilidad.

- También el cambio de imagen es más maleable a través de la vibración del trazo, del color, de la textura, etc. y por medio de la combinación de diferentes fips (frecuencia de imágenes por segundos), aunque la manipulación de la fips también se puede hacer en acción real.

- La composición móvil es otro de los componentes espacio-temporales que más flexible es respecto a la acción real, debido a la ductilidad de la valoración espacio-temporal.

- Los otros dos componentes (la distribución de la intensidad cinética y el relato) son igualmente manipulables en acción real y en animación.

A pesar de que el cine de acción real es también una interpretación de la realidad móvil, el registro mecánico del movimiento la eleva a modelo de naturalismo, tema no exento de debate, como veremos a continuación.

\section{Fotografía y acción real ¿Modelos de movimiento naturalista en animación?}

En animación, la relación de la expresión móvil con la mecánica del movimiento (conocida por medio de la fotografía y la acción real) es uno de los grandes temas en el debate sobre el naturalismo de la representación móvil, por lo que nos detendremos en él en este apartado.

En la representación del movimiento, la animación es al cine de acción real lo que la imagen plástica a la fotografía. Como vimos en el punto C. de 2.1.3. y en el capítulo 3, la animación y el cine de acción real tienen en común todos los componentes dinámicos excepto la valoración espacio-temporal, la cual en acción real se obtiene de la captura del movimiento real, mientras que en animación resulta de la creación pormenorizada de los fotogramas. En esta diferencia estriba la capacidad potencialmente imaginativa de la animación y de la imagen plástica para expresar el movimiento, ya que la valoración espacio-temporal queda libre del registro mecánico, por lo que el resto de componentes dinámicos adquiere maleabilidad, como acabamos der ver en el punto anterior.

En la captura fotográfica y cinematográfica, el registro en sí (y no otro tipo de acciones que forman parte de la creación, como escoger el motivo, el encuadre, etc.), por realizarse de manera mecánica, es un acto objetivo. Bazin definió el acto fotográfico como "génesis automática" ${ }^{24}$. En el caso del cine, la valoración espa-

\footnotetext{
${ }^{24}$ Bazin en Dubois, 1986, págs. 30-31
} 
cio-temporal (timing) no parte de la interpretación plástica del movimiento, ni siquiera de la interpretación de la mecánica. Por este motivo se otorga a ambos medios estatus de fidelidad a la realidad móvil. No obstante, la cualidad objetiva de la fotografía fue discutida desde el comienzo de su historia a causa de todos los factores humanos que participan en el proceso fotográfico (desde el encuadre al revelado) reduciendo la exposición al único momento de "no intervención humana", de pura mecánica. Así mismo, su capacidad para captar la realidad fue y es criticada por la deformación de la proporción según la distancia, por el color y, por supuesto, por el movimiento. Una de las más valiosas notas respecto a la verosimilitud de la fotografía es la de Dubois, quien explica, a partir de la idea de "génesis automática" (de Bazin) y del carácter de realidad y de pasado de la fotografía (de Roland Barthes ${ }^{25}$ ), que:

La fotografía, por su génesis automática, manifiesta irreductiblemente la existencia del referente pero esto no implica a priori que se le parezca. El peso de lo real que la caracteriza proviene de su naturaleza de huella y no de su carácter mimético. ${ }^{26}$

Así pues, en todo caso la huella lumínica, como registro sobre material fotosensible (plancha, película, etc.), prueba que ello "estuvo ahí", pero no prueba que ello "fuera así". Al extender la observación de Dubois a la captura cinematográfica, podemos decir que ésta prueba que la acción tuvo lugar, pero no que el movimiento fuera así. La acción real, como la fotografía, implica presencia y pasado, pero su parecido con el movimiento real es discutible. Así pues, tanto con la fotografía como con la captura de vídeo no obtenemos una imagen fiel a la realidad, sino una imagen que asociamos a la realidad objetiva.

La cronofotografía a finales del siglo XIX y posteriormente la captura cinematográfica permitieron analizar pormenorizadamente la mecánica del movimiento, haciendo de ella un elemento objetivo. Surgió entonces la opinión de que la cronofotografía desvelaba por fin el misterio del movimiento (hasta entonces esquivo a la visión humana), revelando que los artistas habían estado haciendo representaciones "erróneas" del movimiento. Aaron Scharf recoge la descripción que Damine, ayudante del fotógrafo Étienne Jules Marey, hace de la reacción del pintor Ernest Meissonier ante las fotografías de Muybridge, en 1881:

El gran pintor Meissonier (...) vino a nuestro laboratorio preocupado por la andadura del caballo, que él trataba de reproducir exactamente. Cuando vio los primeros análisis fotográficos que le mostramos, dio un grito de asombro y acusó a nuestra cámara fotográfica de ver las cosas falsamente. "Cuando me mostréis un caballo galo-

\footnotetext{
${ }^{25}$ Barthes, 1980, pág. 119, en Dubois, 1986, pág. 46

${ }^{26}$ Dubois, 1986, pág. 31
} 
pando como galopa éste», y mostró uno de sus propios esbozos, "me sentiré satisfecho con vuestro invento». Pero la fotografía ha demostrado que son los pintores lo que se equivocan, y son ellos los que han tenido que modificar la andadura de sus caballos, de modo que Meissonier, como los demás, no han tenido más remedio que acabar por obedecer a la fotografía."27

La confianza en la superioridad de la cronofotografía frente a la visión humana puede llegar a límites tales como afirmar, como hace Scharf, que las pinturas de Degas Le pas battu y Cuadro de baile, de 1879, en el que unas bailarinas aparecen saltando suspendidas en el aire, no fueron posibles sin las fotografías de Muybridge (publicadas ese mismo año en París), en las que se ve que el caballo al correr en un momento concreto no apoya ninguna de sus patas ${ }^{28}$. Efectivamente la instantánea fotográfica fue y es utilizada por algunos artistas como referente para representar el movimiento en la plástica, al igual que la acción real es tomada como modelo en animación (bien para estudiar la locomoción del móvil, bien como base para rotoscopia). Pero esto no implica que las obras resultantes sean naturalistas, lo cual depende de cómo se use esa información, ni significa que la animación realizada sin estos referentes no pueda representar el movimiento de manera eficaz, ya que la clave de la representación del movimiento no se sustenta en la mecánica, sino que hay otros factores a tener en cuenta, por eso Arnheim da la razón Meissonier de esta manera:

los artistas sostuvieron, no sin razón, que eran las instantáneas las equivocadas, y los artistas quienes estaban en lo cierto; pues sólo la máxima extensión de las patas traduce a dinámica pictórica la intensidad del movimiento material, aunque ningún caballo pueda adoptar esa posición salvo durante el salto. ${ }^{29}$

En definitiva, nos encontramos ante el debate entre la representación de lo externo o lo interno ante el que cada artista se posiciona de una manera. No todos los pintores ni animadores consideraron entonces ni hoy que debieran adaptar la expresión del movimiento a la mecánica. Esto plantea la cuestión que Meissonier parecía reivindicar: ¿por qué para que la expresión del movimiento se considere válida debe ser fiel a las secuencias fotográficas y no al juicio del artista? Pero también existen posiciones conciliadoras al respecto, las que proponen el uso de la información que aporta la captura de vídeo pero transformándola según las necesidades o gustos expresivos; usando referencia de video para estudiar la mecánica, puede haber interpretación de ésta, como es la forma más habitual en que Disney usa la referencia de video, como vimos en el punto B. de 3.2.1., pág. 273.

\footnotetext{
${ }^{27}$ Damine en Scharf, 1994, pág. 227

${ }^{28}$ Scharf , 1994, págs. 216-217

${ }^{29}$ Arnheim, 1979, pág. 425
} 
Comparemos varios planos de animación en los que se usa la acción real y en los que no. En Muybridge's strings (Las cuerdas de Muybridge) (2011) Koji Yamamura muestra las imágenes del fotógrafo con ligera variación en la forma del caballo, donde se reconoce el movimiento natural del animal a pesar de la transformación gráfica (Fig. 5). Mientras que en Tout rien (Todo nada) (1978), Frédéric Back, sin referencia de vídeo, interpreta la locomoción del caballo acentuando la majestuosidad y potencia del movimiento (00:01:39) (Fig. 6), cualidades que resultan anodinas en la recreación de las famosas fotografías. Sen noci svatojanske (Sueño de una noche de verano), de Jiri Trnka (1959), es otra animación en la que encontramos el movimiento del caballo expresado prescindiendo del vídeo. En la escena de la cacería, el encuadre sólo muestra la parte superior de los caballos, de modo que los jinetes tienen el protagonismo (00:49:22). En esta escena apenas se
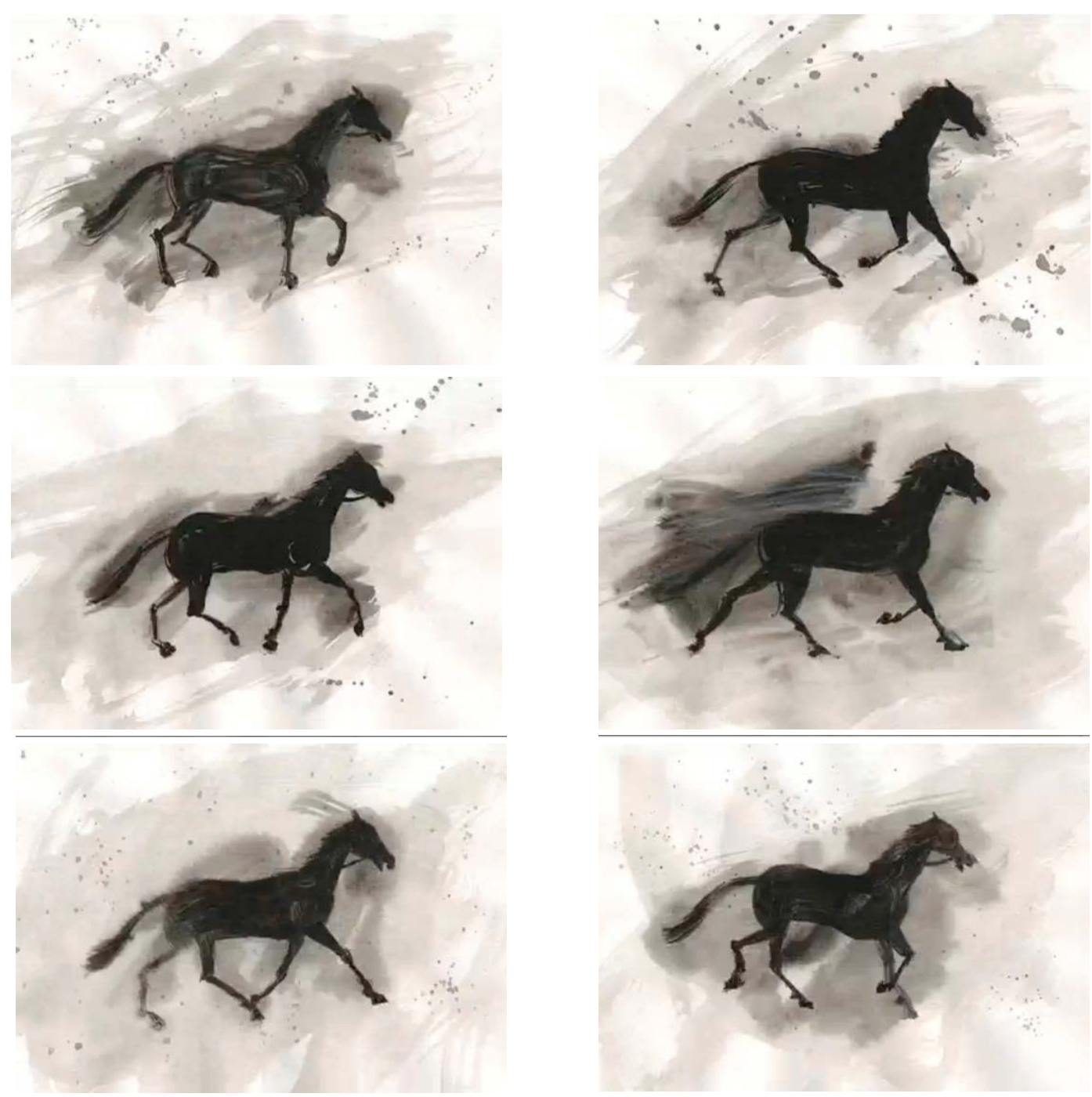

Fig. 5. Koji Yamamura (2011). Muybridge's strings (Las cuerdas de Muybridge). Serie de fotogramas. 

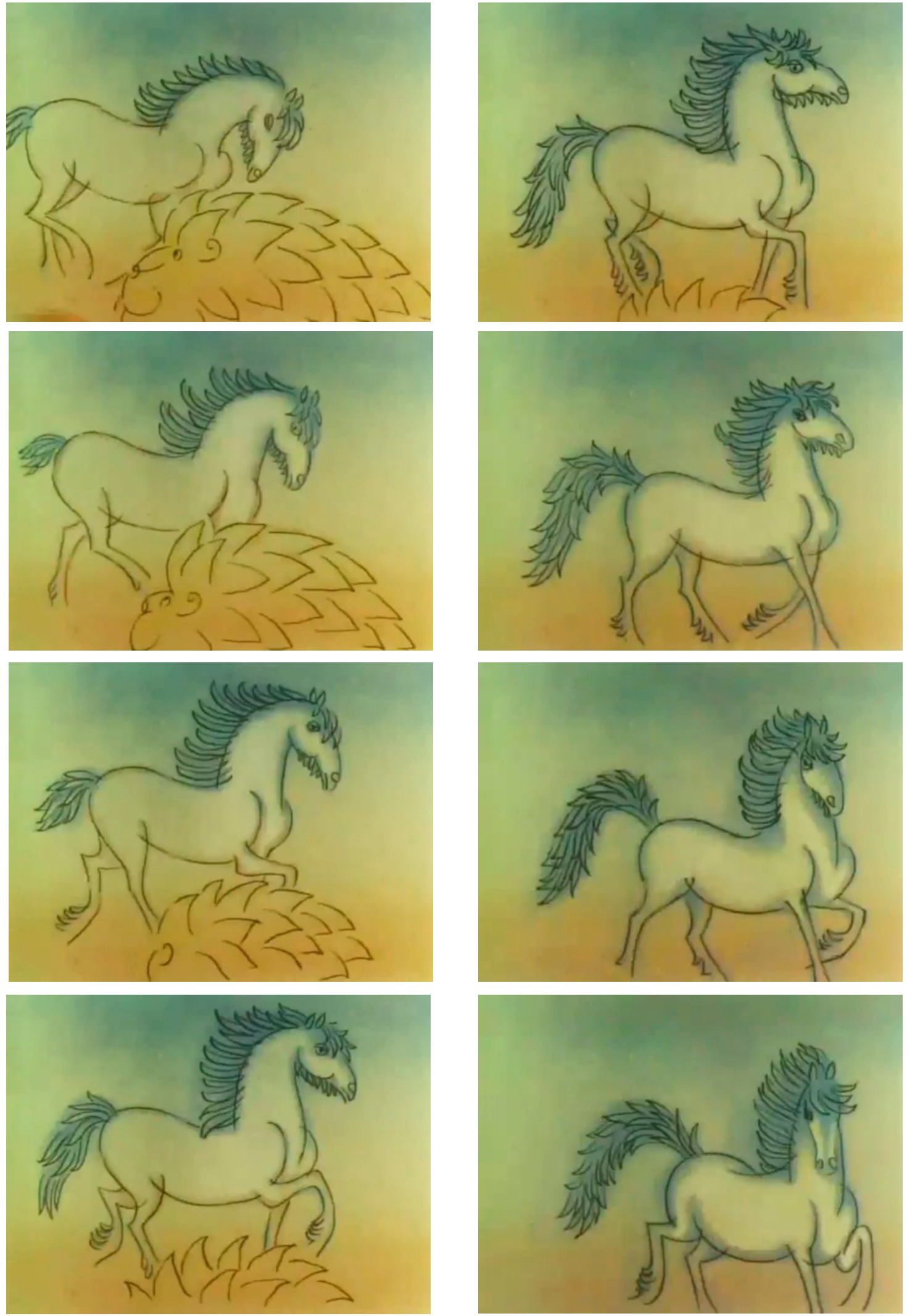

Fig. 6. Frédéric Back (1978). Tout rien (Todo nada). Serie de fotogramas. 

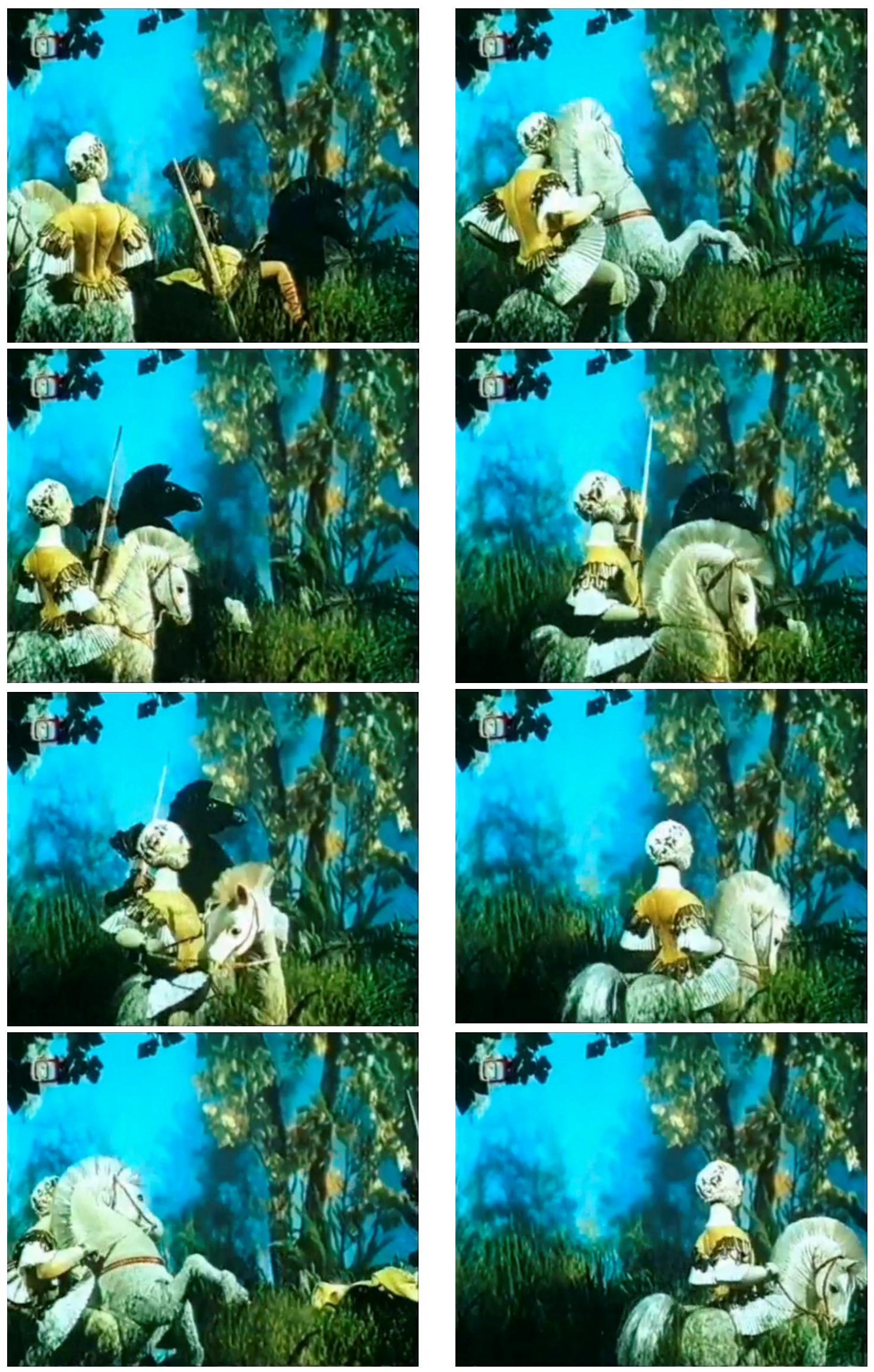

Fig. 7. Jiri Trnka (1912-1959). Sen noci svatojanske

(Sueño de una noche de verano). Serie de fotogramas. 
ve el movimiento de las patas, y sin embargo es una manifestación rotunda del dinamismo total del animal, lo que demuestra que el movimiento nervioso del caballo (adelante y atrás, y elevándose sobre las patas traseras) es más relevante que la dinámica de las cuatro patas (Fig. 7), en las que habitualmente se centra la representación animada.

Así pues, la acción real (captura cinematográfica) es considerada una representación objetiva del movimiento, pero al transformarla en animación (mediante la rotoscopia), el movimiento resulta carente de cualidades que observamos en la realidad, no obstante su exactitud como registro de la mecánica. A pesar de ello, la recreación de la mecánica es aceptada como uno de los fundamentos de la representación naturalista en animación, pero no el único, tema que tratamos a continuación.

\section{Representación naturalista y no naturalista en animación}

Por representación naturalista del movimiento en animación se entiende aquella que se asemeja al movimiento real, pero el criterio varía según diferentes pensadores y animadores. Puede ser por medio de la recreación de la mecánica, o mediante la representación de las leyes físicas del movimiento, o buscando el parecido con la acción real (la cual es aceptada mayoritariamente como coincidente con la realidad móvil) y, por extensión, con el lenguaje cinematográfico. También la técnica de animación 3D digital y las experiencias de cine estereoscópico e inmersivo suponen herramientas en el camino hacia la conquista de las tres dimensiones, las cuales suele ir unidas a la representación realista en animación (aunque no necesariamente).

Paul Wells considera los largometrajes de Disney el paradigma de la representación hiperrealista en animación, de modo que una película es "no-realista" cuanto más se separa de estas características, y habla de realismo como algo que puede darse en varios elementos plásticos y narrativos de la animación. Menciona precisamente el parecido de la imagen animada con la acción real y la representación de las leyes físicas del mundo real, ambas características habitualmente presentes en las representaciones de movimiento neutro (desarrollaremos la cuestión de la relación entre el movimiento neutro y la representación naturalista del movimiento en animación en el parágrafo 3.3.): 
de "realismo". En otras palabras, las películas de animación pueden ser definidas como no-realistas o abstractas cuanto más se desvían del modelo de "híperrealismo" localizado en Disney, y principalmente en largometrajes como Bambi (1942). Consecuentemente, la relatividad del "realismo" en el contexto de la animación puede llegar a ser una herramienta de análisis válida porque algunas películas pueden ser clasificadas como más "realistas" que otras [...]. ${ }^{30}$

De las características de las que habla Wells, las siguientes se refieren al movimiento:

- El parecido con el cine de acción real.

- El cumplimiento de las leyes físicas de mundo real.

- El movimiento del cuerpo y comportamiento psicológico de los personajes son análogos a los que tendrían lugar en el mundo real.

Todas estas características contribuyen a que la imagen animada guarde parecido con el cine de acción real. Sin embargo, explica Wells, "los animadores de Disney creen que en sus obras se mueven más allá de los modos tradicionales de representación realista, y mantienen un hiperrealismo que ni es completamente una versión exacta del mundo real ni una reivindicación de la forma animada." ${ }^{31}$ Efectivamente, en las primeras películas del productor se observa realismo, ante todo en la tridimensionalidad del espacio y en los fenómenos de la naturaleza ${ }^{32}$ : la cascada en The Jungle Book (El libro de la selva) (Reitherman, 1967) es acción real integrada con la imagen animada, o diversos efectos de lluvia en Bambi (Hand, y otros, 1942) y Snow White and the Seven Dwarfs (Blancanieves y los siete enanitos) (Hand, Cottrell, Morey, Pearce, \& Sharpsteen, 1937), o por medio de la rotoscopia (solución que nunca consideraron ideal, sino más barata ${ }^{33}$ ), elementos que en cierto modo permanecerán y por otro lado se harán menos realistas durante la larga trayectoria de la compañía. Pero si nos centramos en la animación de personajes, lo que vemos tiene poco que ver con la realidad móvil. Además, cabe tener en cuenta que los animadores de Disney, si bien pretenden que las películas transmitan ilusión de vida, son conscientes de que no están haciendo una copia de la realidad, ni pretenden hacerlo ${ }^{34}$. Thomas y Johnston recogen esta opinión:

\footnotetext{
${ }^{30}$ Wells, 1998, pág. 25, (trad. a.): 'Realism' as I have already suggested is a relative term, but within animation it is useful to locate the 'hyper-realism' of the Disney films as the yardstick by which other kinds of animation can be measured for its relative degree of 'realism'. In other words, the animated film may be defined as non-realist or abstract the more it deviated from the model of 'hyper-realism' located in the Disney film, and principally a full-length feature like Bambi (1942), [...]. Consequently, the relativity of 'realism' within the context of animation may prove to be a valid analytical tool because some films may be categorized as more 'realistic' than others [...].

${ }^{31}$ Wells, 1998, pág. 27, (trad. a.): Disney animators believe that they do move beyond traditional modes of realist representation in their work, and maintain a hyper-realism which is neither a completely accurate version of the real world nor a radical vindication of the animate form.

${ }^{32}$ Thomas \& Johnston, 1981, pág. 257

${ }^{33}$ Thomas \& Johnston, 1981

${ }^{34}$ Thomas \& Johnston, 1981, págs. 37, 323
} 
Cuando Walt pedía realismo, él quería una caricatura del realismo. Un artista lo analizó correctamente cuando dijo "No creo que él se refiriera a 'realismo'. Yo creo que él se refería a algo que fuera más convincente, que hiciera un mayor contacto con la gente[...]". ${ }^{35}$

Y más tajantemente Don Hahn (productor de algunas de las películas más conocidas de los Walt Disney Studios) dice: "Por favor, que no se confunda "verosímil" con "realista". El mundo de una película de animación no está destinado a ser la realidad, sino más bien una caricatura de la realidad" ${ }^{36}$, con lo que queda claro que no tienen intención realista. Consideramos que las películas de Disney, aunque en muchos aspectos sean una versión animada del lenguaje cinematográfico, distan mucho de ser hiperrealistas.

En todo caso, el carácter realista del movimiento en animación se consigue a través de diferentes medios para aproximarse al movimiento real. Consideramos que el movimiento puede ser realista en base a varios aspectos (algunos de los cuales Wells también localiza en las películas de Disney):

- La mecánica real del movimiento: actualmente el listón más alto de hiperrealismo en la representación móvil no se sitúa en las películas de Disney, sino en la rotoscopia sin modificación del movimiento y el motion capture. Como vimos en el capítulo 3, estas técnicas reproducen el movimiento real a partir del registro de video y la captura de movimiento por sensores situados en las articulaciones y puntos clave de un cuerpo u objeto móvil real.

- El parecido con el movimiento que vemos en la captura de vídeo (acción real).

- La ausencia de vibración de la imagen. En parte se debe a que tal vibración no se da en la realidad, pero también a que no existe en el movimiento de la captura de vídeo.

- La representación de acontecimientos realistas o cotidianos, no fantásticos.

- La representación de las leyes físicas del movimiento. Esto se puede considerar también como parte de la representación de acontecimientos realistas, ya que los efectos de las leyes físicas, tal y como explicamos en el punto $C$. de 3.2.1., no son modelos visibles, sino deducibles (no vemos que la ley de la gravedad atraiga un objeto al suelo, sino que vemos caer un objeto).

- La inserción de los acontecimientos es un espacio de perspectiva geométrica.

\footnotetext{
${ }^{35}$ Thomas \& Johnston, 1981, págs. 65-66, (trad. a.): When Walt asked for realism, he wanted a caricature of realism. One artist analyzed it correctly when he said, 'I don't think he meant 'realism.' I think he meant something that was more convincing, that made a bigger contact with people.

${ }^{36}$ Hahn, 2008, pág. 48, (trad. a.): (Please don't confuse "plausible” with "realistic." The world of an animated film is never meant to be reality, but rather a caricature of reality.)
} 
Cuantas más de estas características reúna la película, más naturalista será el movimiento; pero estas características también pueden presentarse en diversos grados e incluso darse de manera aislada en convivencia con cualidades opuestas.

\subsubsection{EL LENGUAJE CINEMATOGRÁFICO Y EL PLÁSTICO}

Como hemos visto, toda representación es un modo diferente de concebir y ordenar la realidad. La copia exacta del movimiento real no existe, ni siquiera lo son las grabaciones de acción real, ya que la mera elección de los elementos que se muestran en pantalla (el encuadre) supone una interpretación, así como el orden de la historia y muchos otros factores.

Aunque el naturalismo en la expresión del movimiento consiste principalmente en el parecido de acciones y sucesos con el movimiento real y con la captura de acción real (en cuanto a la valoración espacio-temporal, es decir, el timing), no obstante también se asocia al lenguaje del cine de acción de real. De hecho, uno de los elementos que generalmente es aceptado como criterio de naturalismo en animación es la semejanza con el cine de acción real, mientras que el distanciamiento de éste lenguaje visual se asocia con la representación no naturalista.

Efectivamente las características del lenguaje cinematográfico se dan con más frecuencia en animaciones naturalistas, mientras que las cualidades plásticas que asociamos a la pintura se dan a menudo en animaciones no realistas. Y es que la animación cinematográfica es en cierto modo un discurso visual con intención realista en cuanto a que, al imitar al cine de acción real, establece un paralelismo entre los elementos plásticos y los reales. Sin embargo, el lenguaje cinematográfico en animación no es exclusivo del naturalismo ni su omisión implica alejamiento de la realidad. Por ejemplo, las técnicas stop-motion de marionetas y objetos y la pixilación están ligadas indiscutiblemente al lenguaje cinematográfico, sin embargo esto no define su nivel de parecido con la realidad móvil. Además, los recursos propios del cine de acción real y los de la pintura pueden convivir en una misma obra.

A continuación explicamos cómo el lenguaje cinematográfico se recrea en animación y analizamos los valores plásticos más destacables del medio. 


\section{A. EL LENGUAJE CINEMATOGRÁFICO PROPIO DEL CINE DE AC- CIÓN REAL EN ANIMACIÓN}

Como bien explica Paul Wells, Disney supuso un hito en la imitación del cine de acción real en animación:

Disney perfeccionó un lenguaje determinado para el cartoon y el largometraje que tomó su modelo de las películas de acción real. Esto eclipsó otros tipos de innovación y estilos de animación que han ampliado las posibilidades de la forma y han permitido que se hagan otros tipos de películas. Por lo tanto, e irónicamente, el dominio de Disney sobre el medio coloca el tema del "realismo" en el centro de cualquier discusión sobre animación. ${ }^{37}$

Pero el giro hacia el realismo no sólo se da en los aspectos plásticos y narrativos, sino también al elevar a la categoría de "actores" a los personajes de las películas, extendiendo en cierto modo el star system a la animación (como bien es sabido).

El lenguaje cinematográfico se recrea en animación a través del uso específico de la composición móvil y el cambio de imagen, así como mediante la recreación de efectos ópticos de la cámara cinematográfica. En síntesis, se trata de crear la ilusión de que la acción transcurre en un espacio tridimensional que es "filmado". En las técnicas stop-motion de marionetas, objetos y personas reales, esta condición existe realmente; son las técnicas de dibujos, recortes, etc. las que la recrean. El lenguaje cinematográfico también se recrea en animación estableciendo un paralelismo entre los actores y los personajes de animación (paralelismo que alcanza a los animadores); y entre los sets cinematográficos y espacios reales, y el espacio representado.

\section{Composición móvil}

La composición móvil (la evolución de la imagen en los planos y a lo largo de toda la película) se realiza mediante los recursos habituales del cine de acción real, principalmente mediante la planificación (el encuadre y las trayectorias de los personajes), el corte como transición preferente entre planos, y los movimientos de cámara zoom in/zoom out, tilt y paneo.

\footnotetext{
${ }^{37}$ Wells, 1998, pág. 24, (trad. a.): Disney perfected a certain language for the cartoon and the fulllength feature which took its model from live-action film-making. This overshadowed other types of innovation and styles of animation which have extended the possibilities of the form and enabled other kinds of film to be made. Consequently, and ironically, Disney's dominance of the medium places the issue of 'realism' at the centre of any discussion of animation.
} 

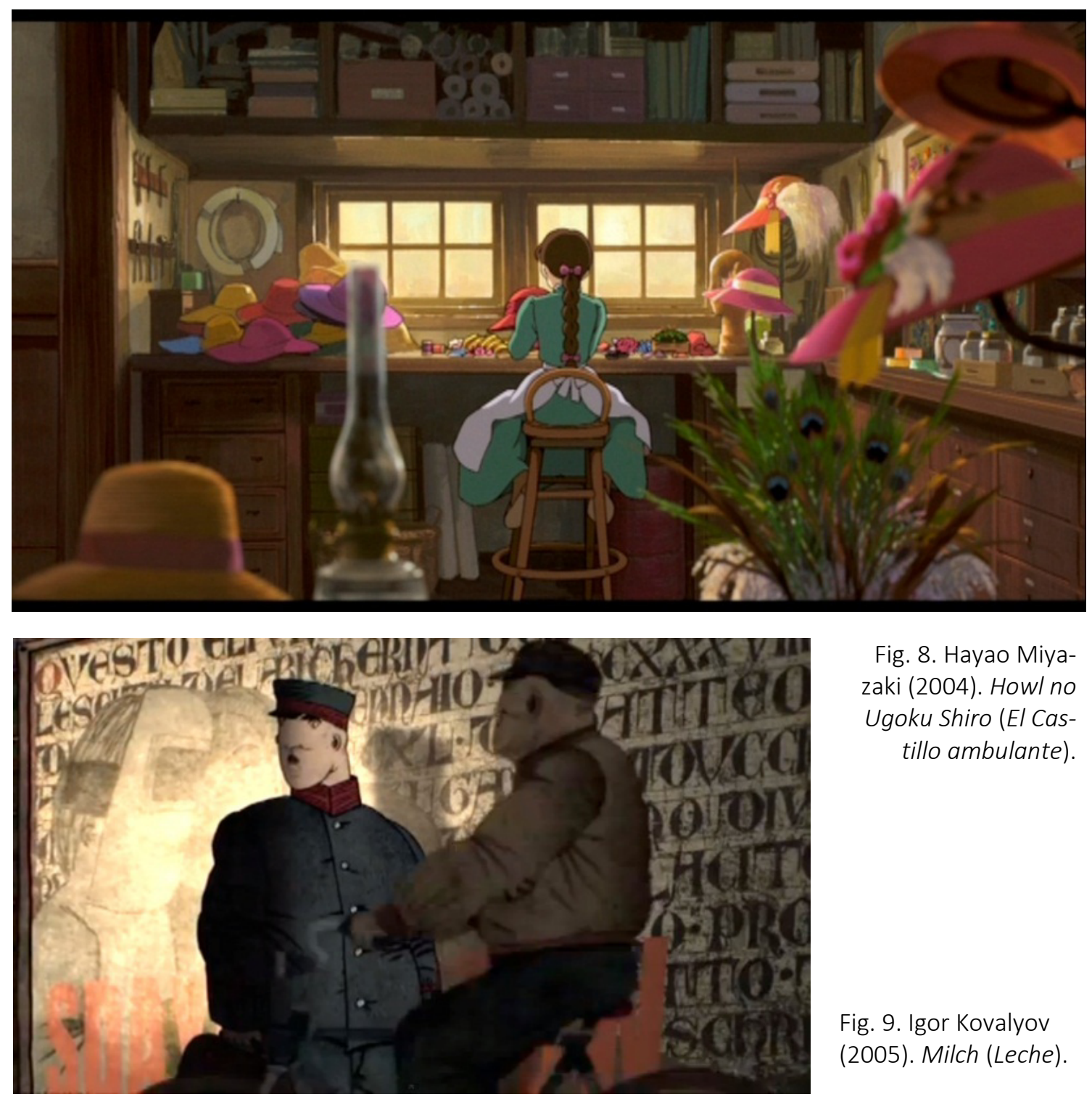

Fig. 8. Hayao Miyazaki (2004). Howl no Ugoku Shiro (El Castillo ambulante).

Fig. 9. Igor Kovalyov (2005). Milch (Leche).

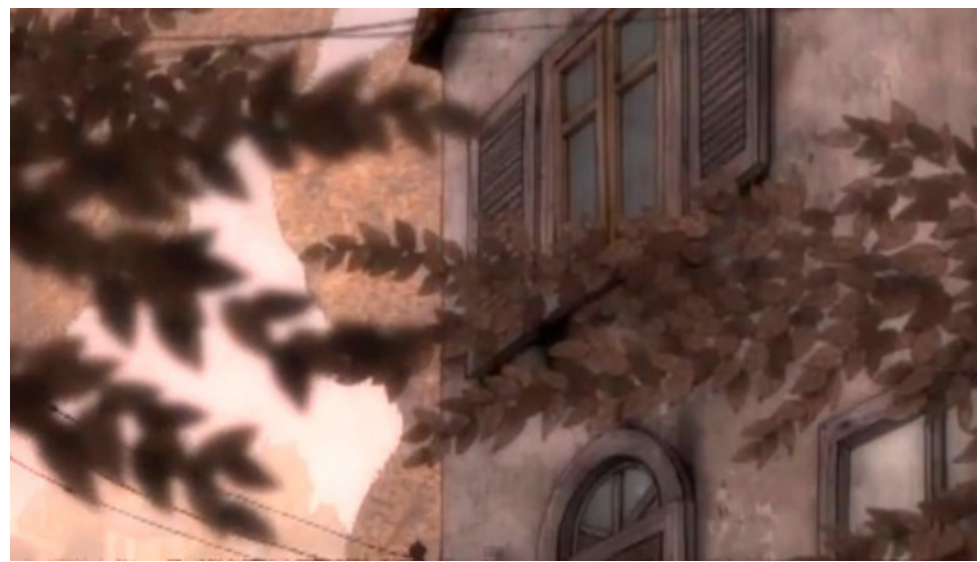

Fig. 10. Igor Kovalyov (2005). Milch (Leche).

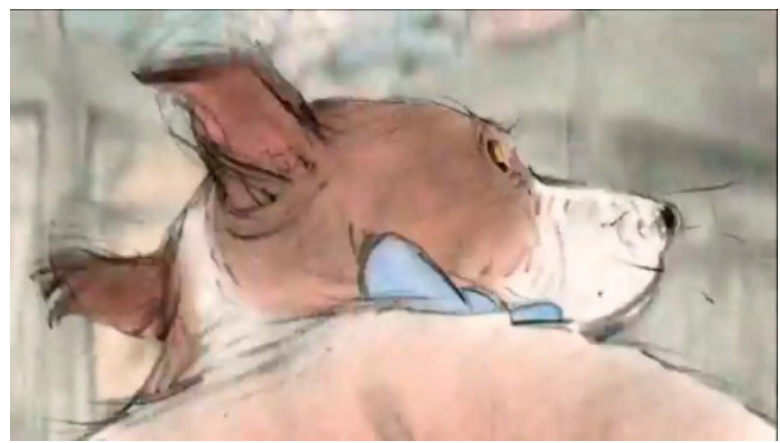

Fig. 11. Joanna Quinn (2006). Dreams And Desires. Family Ties (Sueños y deseos. Lazos familiares). Serie de fotogramas. 


\section{Imitación de efectos ópticos}

Se trata de recrear efectos que se producen al grabar la acción real o al fotografiar un suceso, como la profundidad de campo (Figs. 8, 9, 10,11) o imágenes borrosas para crear la ilusión de que la cámara no puede captar con definición el objeto en movimiento. Mediante la planificación y los efectos ópticos propios de la cámara fotográfica, se genera la ilusión de que los acontecimientos están siendo filmados, reforzando la idea de que lo que se muestra en pantalla existe. Esto se aplica en las técnicas de animación de dibujo (e incluso de recortes), pero no en la animación de marionetas, objetos reales y pixilación, en las que la fotografía, al ser también elemento plástico, presenta estos recursos como parte de las posibilidades inherentes al medio.

El uso de la cámara multiplano para recrear la profundidad de campo resultó ser uno de los elementos que más críticas provocó por el realismo que proporcionaba $^{38}$. Hoy en día se pueden generar efectos similares con las capas 3D (separadas virtualmente unas de otras mediante programas de ordenador). Pero la profundidad de campo no es el único efecto "fotográfico" que se imita en la animación de dibujo. En los estudios Disney con el propósito de ser más precisos observaron, entre otras cosas, los efectos visuales que se producen al fotografiar el movimiento:

Tan pronto como alguien se dio cuenta que la imagen de un objeto real que se mueve rápidamente es borrosa, todos los animadores intentaron hallar su propia manera de dibujar una imagen borrosa en términos de cartoon. Al tratar de superarse unos a otros, estos animadores crearon formas que se convirtieron en dibujos en sí mismos que dominaban la escena, y los entintadores estaban desconcertados respecto a cómo debían entintarse estas invenciones, pintarse sobre el acetato, pintarse con pincel seco o hacerlos en diferentes colores.

Uno de los recursos favoritos para plasmar un brazo o una pierna en movimiento muy rápido era dibujar una serie de pos-imágenes. ${ }^{39}$

Además de la imagen borrosa, se incorporó la multiplicación de la forma para acciones muy veloces, de modo que la trayectoria del movimiento permanece como un rastro visual.

\footnotetext{
${ }^{38}$ Sifianos, 2012, pág. 273

${ }^{39}$ Thomas \& Johnston, 1981, pág. 251, (trad. a.): as soon as someone noted that the image of a real object moving fast is blurred on film, every animator tried to find his own way of drawing a blurred image in cartoon terms. In attempting to outdo each other, these animators created shapes that became designs in themselves, dominating the scenes, and the inkers were puzzled as to whether these concoctions should be traced in ink, painted on top of the cel, dray brushed, or done in different colors.

A favorite device for portraying an arm or a leg moving very fast was to draw a series of after images following along.
} 


\title{
Se evita la vibración de la imagen
}

Los fotogramas realizados plásticamente producen una vibración al visionarlos en continuidad, si tal vibración se evita, se da estabilidad a la imagen, acercando la animación al cine de acción real.

\section{El lenguaje corporal de los personajes animados imita los recursos del arte dra- mático}

Considerar que el animador debe tener nociones de arte dramático procede de la idea de que la comprensión y expresión plástica del movimiento se alcanza a través del conocimiento especializado o técnico del motivo a representar. Sin embargo, es inadecuado equiparar el trabajo del animador con el del actor, porque aunque ambos expresen el movimiento, el animador lo hace plásticamente, mientras que el actor lo interpreta con su propio cuerpo. Sólo en los casos de pixilación existe un actor y éste, dependiendo del director, puede tener un papel más dramático o más objetual.

La recreación del movimiento del actor forma parte de la influencia del lenguaje cinematográfico en éste medio plástico. Tras su experiencia como profesor de acting para animadores, Ed Hooks concluye que los aspectos que éstos observan del arte dramático es la descripción física del movimiento y la manera de mostrar las emociones a través del cuerpo y el rostro:

\begin{abstract}
Desde la perspectiva de un actor de escena formado, la manera en que los animadores se acercan a la materia es al revés. Un animador se preocupa por cómo las cejas de un personaje deben elevarse para mostrar curiosidad, cuántas veces se parpadea en un momento de excitación, si se trata de la cabeza o son los hombros los que giran primero para mirar de reojo, cómo indicar las emociones; los actores, por el contrario, piensan en tales cosas raramente, ya que no se les enseña a dramatizar resultados. $^{40}$
\end{abstract}

Cuando el movimiento de la figura humana en animación imita la del actor, se aproxima al cine de acción real. Cuando se recurre a un lenguaje dramático amateur, la expresión móvil puede quedar unificada por los clichés; además, confiar en el modelo-actor no profesional es delicado, ya que ni se trata de una dramatización profesional ni del movimiento natural, de modo que se producen resultados como los de Brave (Andrews, Chapman, \& Purcell, 2012) [en DVD], en la que

\footnotetext{
${ }^{40}$ Hooks, 2003, pág. xii, (trad. a.): From a trained stage actor's perspective, the way animators come at the subject is upside down. An animator is concerned with whether a character's eyebrows should be raised to show curiosity, how many blinks occur in an excited moment, whether it is the head or the shoulders that first turns for a sideways glance, how to indicate emotions; actors, by contrast, think about such things rarely, if ever because they are taught not to play results.
} 
la protagonista no cesa de repetir un tick propio del actor aficionado. Thomas y Johnston explican que "Nuestros propios storymen que tenían un talento especial para la dramatización fueron arrastrados a la fase de sonido, y los animadores incluso se fotografiaban unos a otros" para grabar tomas de acción real que sirvieran como material para estudiar a los personajes o el mecanismo detallado de la acción $^{41}$. Pero a pesar de esta primera experiencia, la compañía suele recurrir a actores profesionales, también como sello distintivo y parte del marketing, y ellos mismos son críticos respecto a los inconvenientes de este método de trabajo:

\begin{abstract}
Básicamente, el animador es el actor en las películas de animación. Así mismo, él es muchas otras cosas; sin embargo, en sus esfuerzos por comunicar su ideas, el acting se convierte en su dispositivo más importante. Pero el animador tiene un problema especial: sobre el escenario, todos los símbolos [...] están acompañados por una especie de magnetismo personal que puede comunicar los sentimientos y las actitudes del mismo modo que la propia acción. Hay un espíritu en este tipo de comunicación que es extremadamente vivo y vital. Sin embargo, maravilloso como es el mundo de la animación, es muy crudo capturar completamente ese tipo de sutileza. ${ }^{42}$
\end{abstract}

Al trasponer las cualidades compositivas y efectos fotográficos del cine de acción real a la animación, al convertir a los personajes en actores y el espacio en el que tiene lugar el movimiento en el escenario en el que se rueda la película, se dota a la animación de carácter de realidad, pues convierte lo acontecido en algo que es capturado del mismo modo que se filman las películas de acción real. Este concepto de animación es el habitual en el cine comercial, pero también tiene presencia en la animación independiente.

\title{
Diferentes niveles de recreación del lenguaje del cine de acción real
}

Existen películas con diferente grado de imitación del lenguaje cinematográfico. Milch (Leche) (2005) es más cinematográfica en comparación con Hen his wife (Gallina, su esposa) (1990), ambas de Igor Kovalyov: la primera tiene un aspecto mecánico en los movimientos de cámara realizados por ordenador e imita efectos fotográficos (principalmente profundidad de campo). Esto, unido a la abundancia de cortes entre planos y la estabilidad de la textura (sin vibración), transmite la sensación de estar viendo una película de acción real, pero hecha con animación.

\footnotetext{
${ }^{41}$ Thomas \& Johnston, 1981, pág. 320, (trad. a.): Our own storymen who had a special talent for acting were dragged to the sound stage, and animators even photographed each other.

42 Thomas \& Johnston, 1981, pág. 18, (trad. a.): Basically, the animator is the actor in animated films. He is many other things as well; however, in his efforts to communicate his ideas, acting becomes his most important device. But the animator has a special problem. On the stage, all of the foregoing symbols are accompanied by some kind of personal magnetism that can communicate the feelings and attitudes equally as well as the action itself. There is a spirit in this kind of communication that is extremely alive and vital. However, wonderful as the world of animation is, it is too crude to capture completely that kind of subtlety.
} 
En este cortometraje la valoración espacio-temporal es el elemento dinámico que más dista del cine de acción real.

También en la serie de cortometrajes Les tragédies minuscules (Las tragedias minúsculas) (Felicioli \& Gagnol, 1999), el relato se construye por escenas y planos unidos por corte cinematográfico, pero los personajes se mueven de manera tan plástica que, como ya explicamos en el capítulo 3 (pág. 287), resulta vivenciada. Además, la acción tiene lugar en un espacio de singular perspectiva y ni la forma del móvil ni su movimiento son realistas; así pues, el lenguaje cinematográfico tiene presencia mínima. Mientras que en Dreams and desires, family ties (Sueños y deseos, lazos familiares) (Quinn, 2006) la historia es contada a través de una vi-
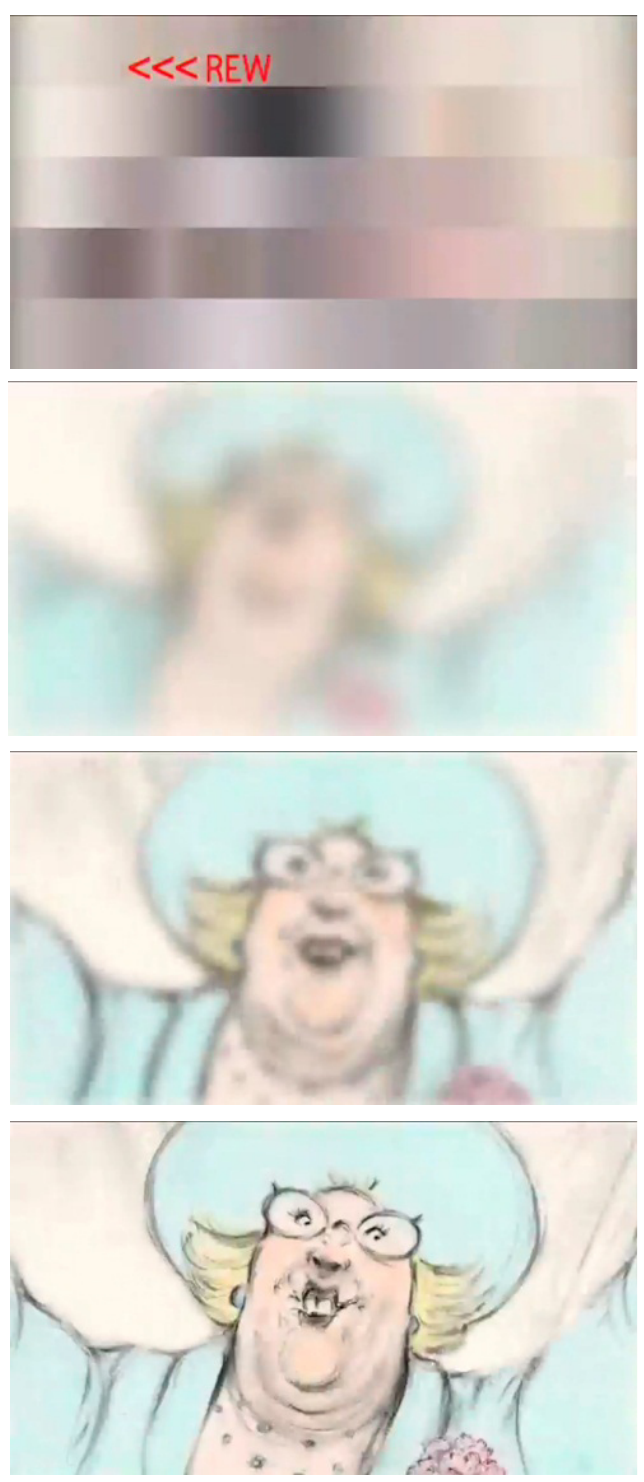

Fig. 12. Joanna Quinn (2006). Dreams And Desires. Family Ties (Sueños y deseos. Lazos familiares). Serie de fotogramas.
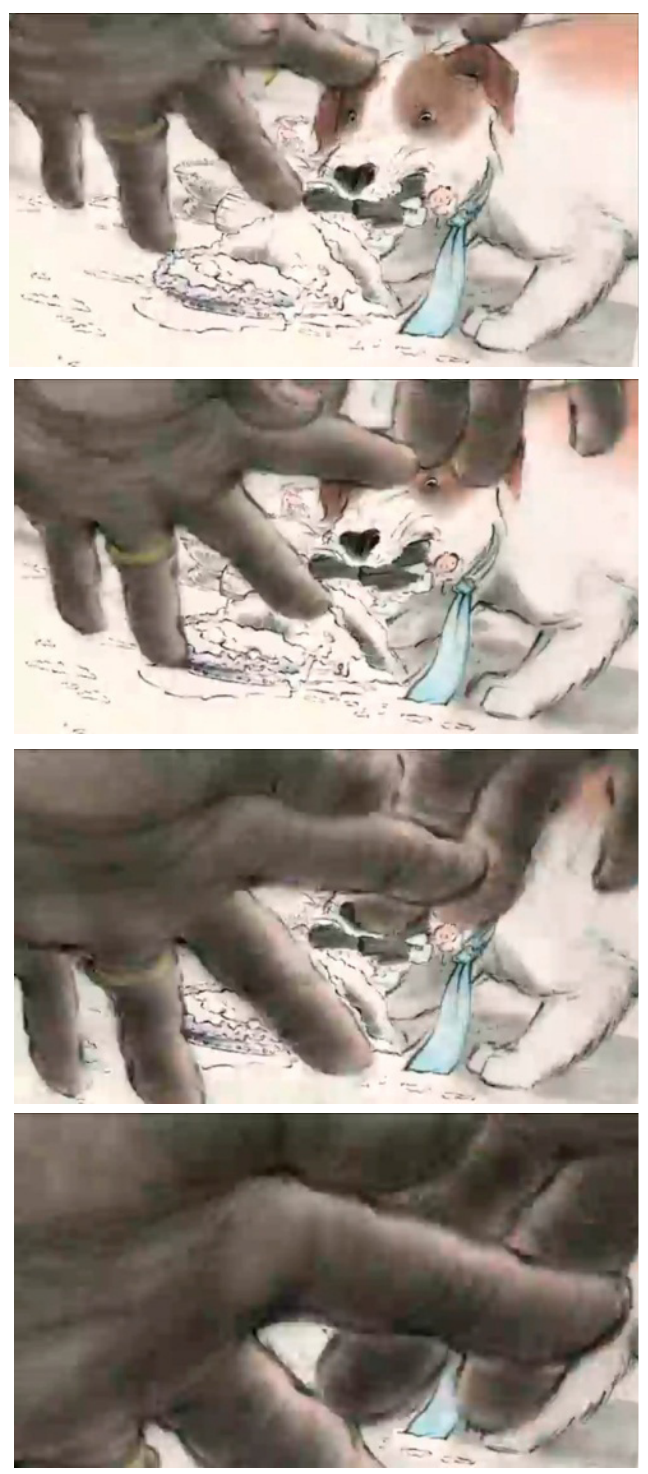

Fig. 13. Joanna Quinn (2006). Dreams And Desires. Family Ties (Sueños y deseos. Lazos familiares). Serie de fotogramas. 
deocámara ficticia. Las características del video casero están presentes en el encuadre errante, el enfoque automático al inicio de cada toma (Fig. 12), las manos que tapan el objetivo (Fig. 13), la nieve entre planos, etc. Así se obtiene un doble nivel retórico: la cámara inexistente registra un universo imaginario; y, al mismo tiempo, el falso video casero enseña una vida cotidianidad ficticia, procurando la
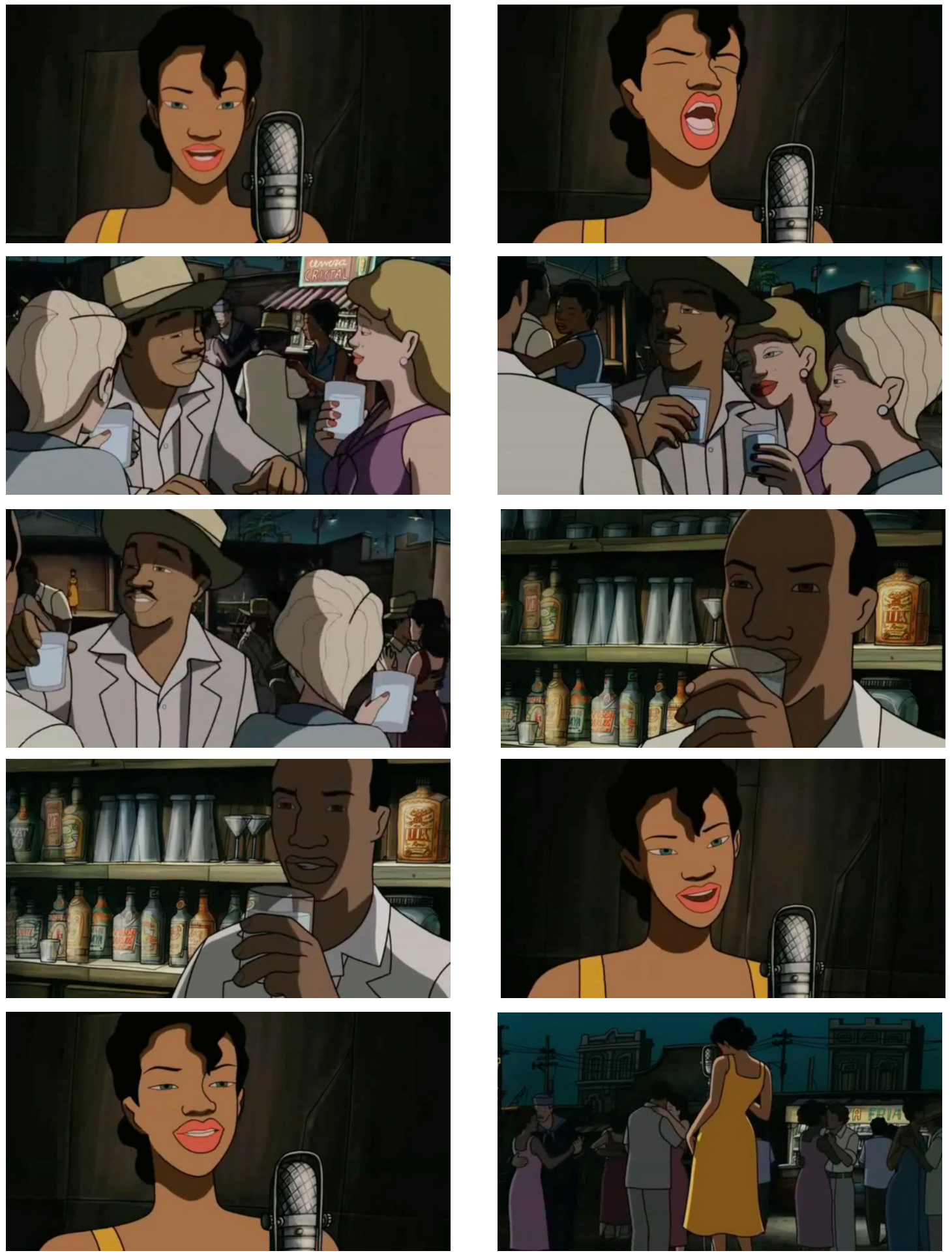

Fig. 14. Tono Errando, Javier Mariscal y Fernando Trueba (2010). Chico y Rita. Serie de fotogramas. 
misma sensación de realidad que el falso documental ("es real porque está grabado"). Las escenas "filmadas" contrastan con los sueños que tiene la protagonista, en los que los efectos de la cámara desaparecen y la frecuencia de imágenes es menor a doce por segundo. Chico y Rita (Errando, Mariscal, \& Trueba, 2010), está en un nivel todavía más alto de similitud con el cine de acción real por la planificación, los cortes entre planos, los movimientos de cámara (zooms y travelings), y además el movimiento de los personajes está realizado con una rotoscopia que modifica más la apariencia plástica que el movimiento capturado. Todo junto proporciona como resultado una animación muy parecida a un film de acción real, pero formado por dibujos en lugar de fotografías (Fig. 14).

Como vemos, el lenguaje cinematográfico implica realismo per se en cuanto a que indica la presencia de una cámara que filma lo que acontece ante ella. Como todo recurso, su uso indiscriminado puede generar homogeneidad entre películas, pero el lenguaje cinematográfico en sí no proporciona movimiento neutro, luego aunque existe una conexión directa entre naturalismo y lenguaje cinematográfico, el lenguaje cinematográfico no implica expresión del movimiento neutro.

\section{B. ÉNFASIS EN LAS CUALIDADES PLÁSTICAS DE LA ANIMACIÓN. INDEPENDENCIA DEL LENGUAJE CINEMATOGRÁFICO}

Debido al deseo de invención, la animación con movimiento no naturalista con frecuencia hace énfasis en las cualidades plástica del medio (aunque no necesariamente); sobre todo nos referimos a las cualidades plásticas que separan la animación del lenguaje cinematográfico. Esta cualidad afecta a la totalidad del film. Al hacer uso de las cualidades propias de la animación, ésta tiende a evidenciar que no se trata de imágenes reales.

\section{Composición móvil}

La animación presenta posibilidades de composición móvil muy versátiles dado que muchas de las técnicas parten de la creación desde cero de los fotogramas que las conforman. En estas imágenes realmente todo es posible, mientras que el montaje cinematográfico depende de la realidad física (aunque esto no lo convierte en un medio limitado); debido a esto, en animación es fácilmente representable una metamorfosis, por ejemplo, para cambiar de plano; o aproximar el personaje a la pantalla en pocos segundos, haciéndole ocupar el espacio compositivo, etc. Esta flexibilidad ofrece grandes posibilidades plásticas y también retóricas. 


\section{Superficie plástica}

El color, la gráfica, la forma, la composición y el movimiento son los elementos materiales del objeto estético. En el caso de la animación de marionetas, recortes, objetos y pixilación, la fotografía es el soporte plástico (al igual que en la acción real), además de la propias marionetas y recortes, el color, la iluminación, etc. (Fig. 15 y 16).

\section{Vibración de la imagen}

En el caso de la animación de dibujo y pintura, la plasticidad del trazo implica la vibración de la imagen (ver parágrafo B.3 de 2.2.1.) ya que, necesariamente, al ser trazado manualmente, a pesar de la precisión de la línea y la mancha, la superficie plástica varía entre fotogramas contiguos.

\section{Representación de emociones y sentimientos por medio de la expresión plástica} del movimiento

La animación es independiente del arte dramático (el acting para animación) para la representación del movimiento del cuerpo humano y personajes antropomorfos. En The black dog (El perro negro) (de Vere, 1987) (Fig. 17 Y 18), la protagonista pasa por distintos estados de humor, manifestados por su movimiento y actitud. En su representación es imposible reconocer el movimiento dramático habitual de los actores de cine y teatro. La expresión dramática se realiza por medio del dibujo del movimiento, cuya apariencia es independiente de las técnicas interpretativas del actor. De hecho, visualmente esta animación es más próxima a la pintura y al dibujo que al cine de acción real.

En Sen noci svatojanske (Sueño de una noche de verano) (Trnka, 1959) podemos ver la diferencia entre la dramatización teatral (clásica en este caso) y la animación. La acción de Hermia al despertarse y buscar a su amado Lisandro es expresada con gran riqueza dinámica y, al mismo tiempo, mantiene un carácter independiente de la dramatización teatral (00:37:43) (Fig. 19). Esta característica se hace evidente en la escena en la que se representa la obra teatral, en la que se dramatiza una acción similar (Píramo busca a Tisbe) pero recreándose en los gestos propios del arte dramático (00:59:57) (Fig 20). Cabe destacar que en ambos casos la acción se expresa como vivenciada. 

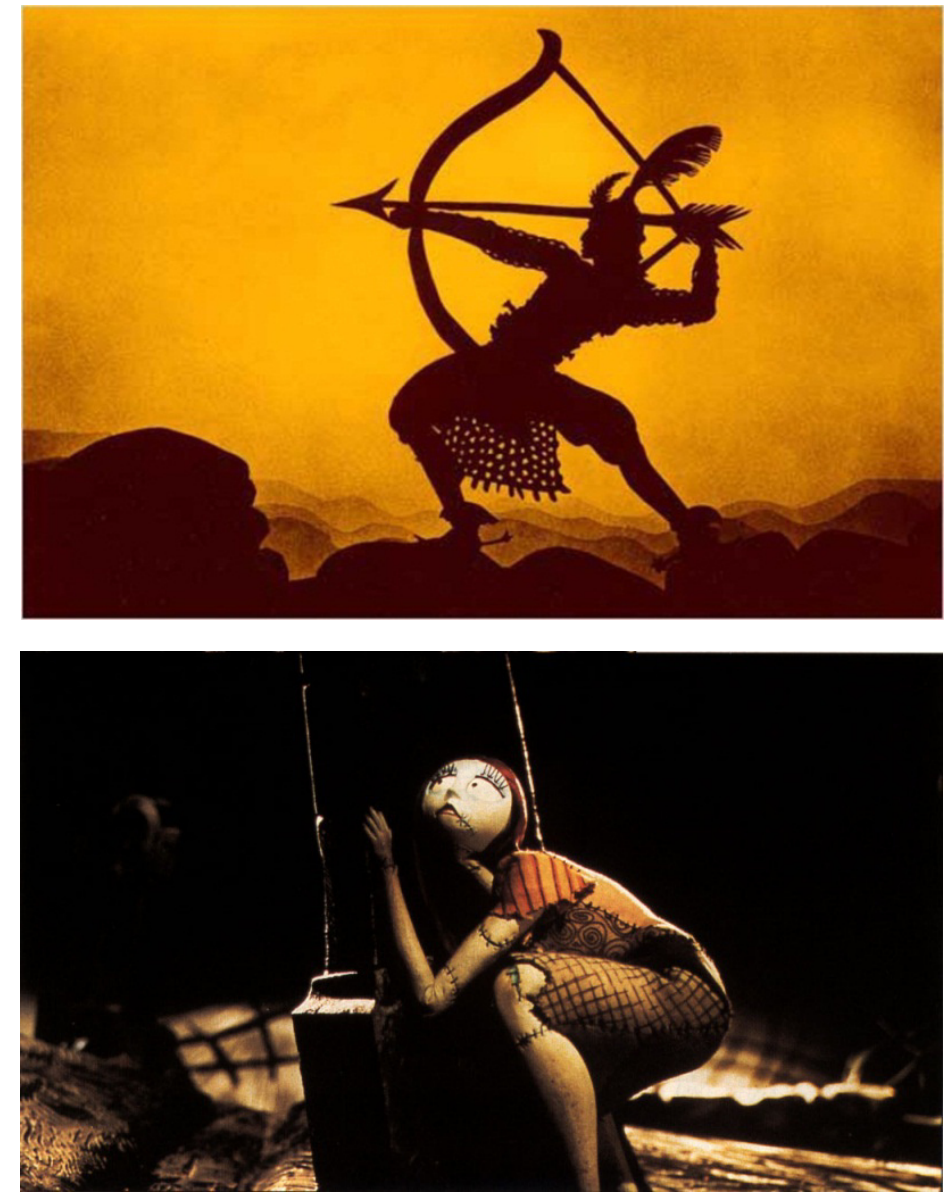

Fig. 15. Lotte Reiniger (1926).

Die Abenteur des Prinzen

Achmed (Las aventuras del príncipe Ahmed).
Fig. 16. Henry Selick (1993).

The Nightmare Before Christmas (Pesadilla antes de Navidad).

Fig. 17. Alison de Vere (1987). The black dog (El perro negro).

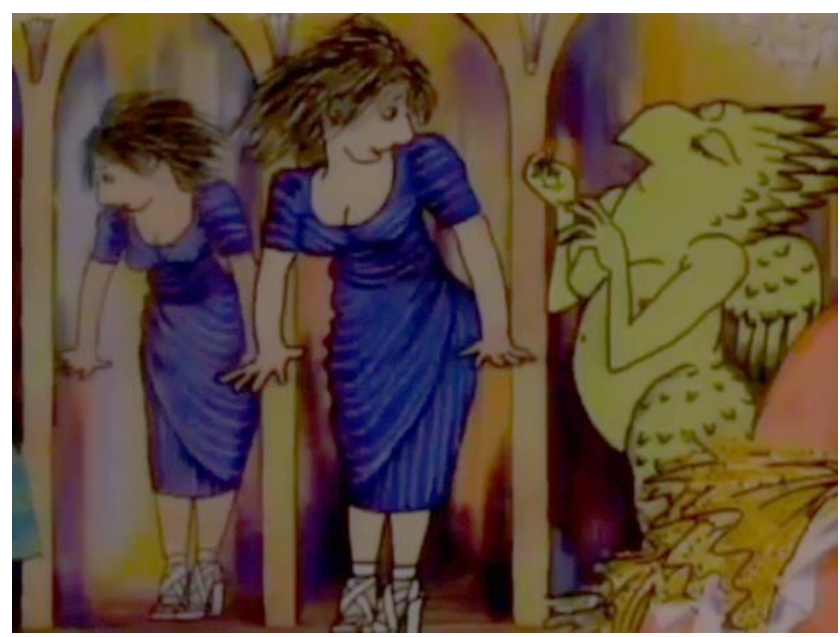

Fig. 18. Alison de Vere (1987). The black dog (El perro negro).

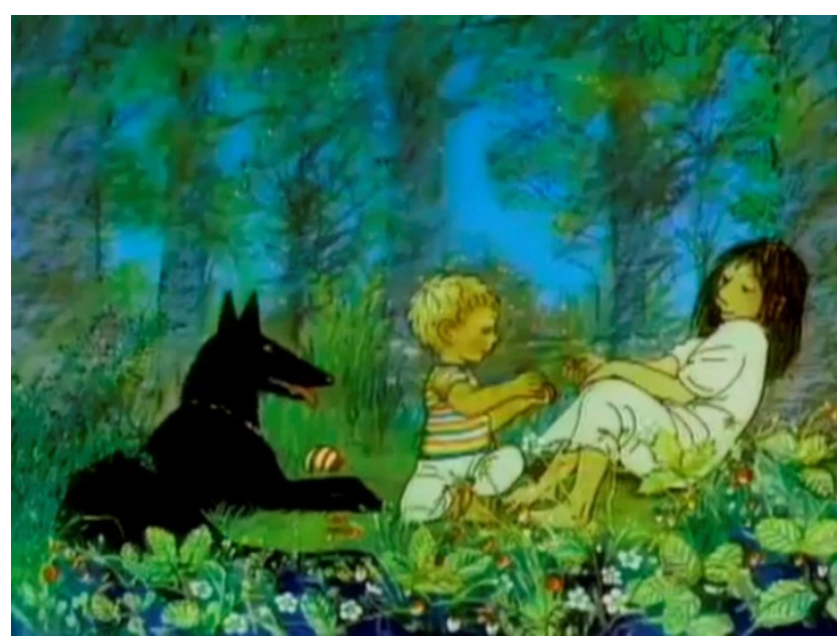



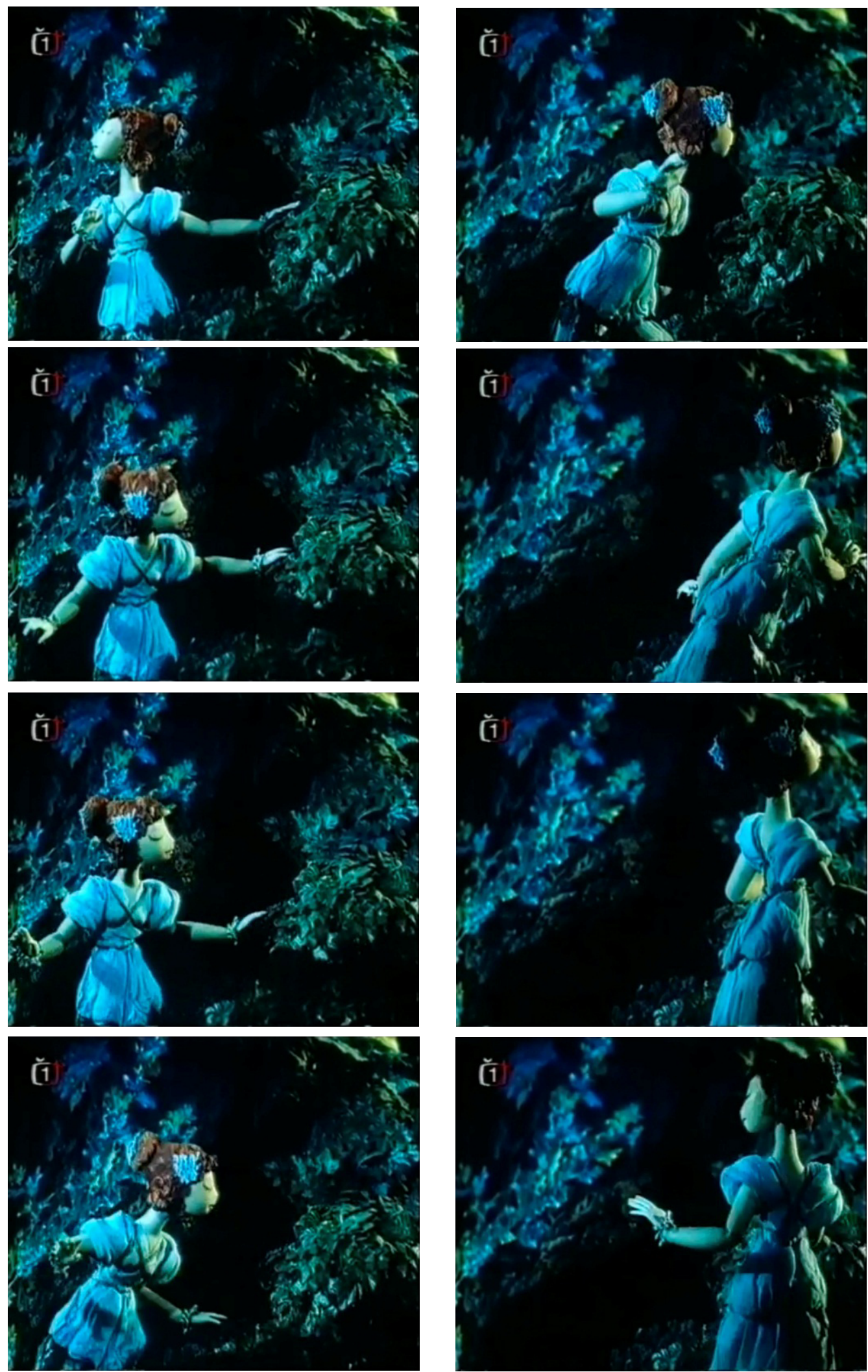

Fig. 19. Jiri Trnka (1912-1959). Diseño para Sen noci svatojanske (Sueño de una noche de verano). Serie de fotogramas. 

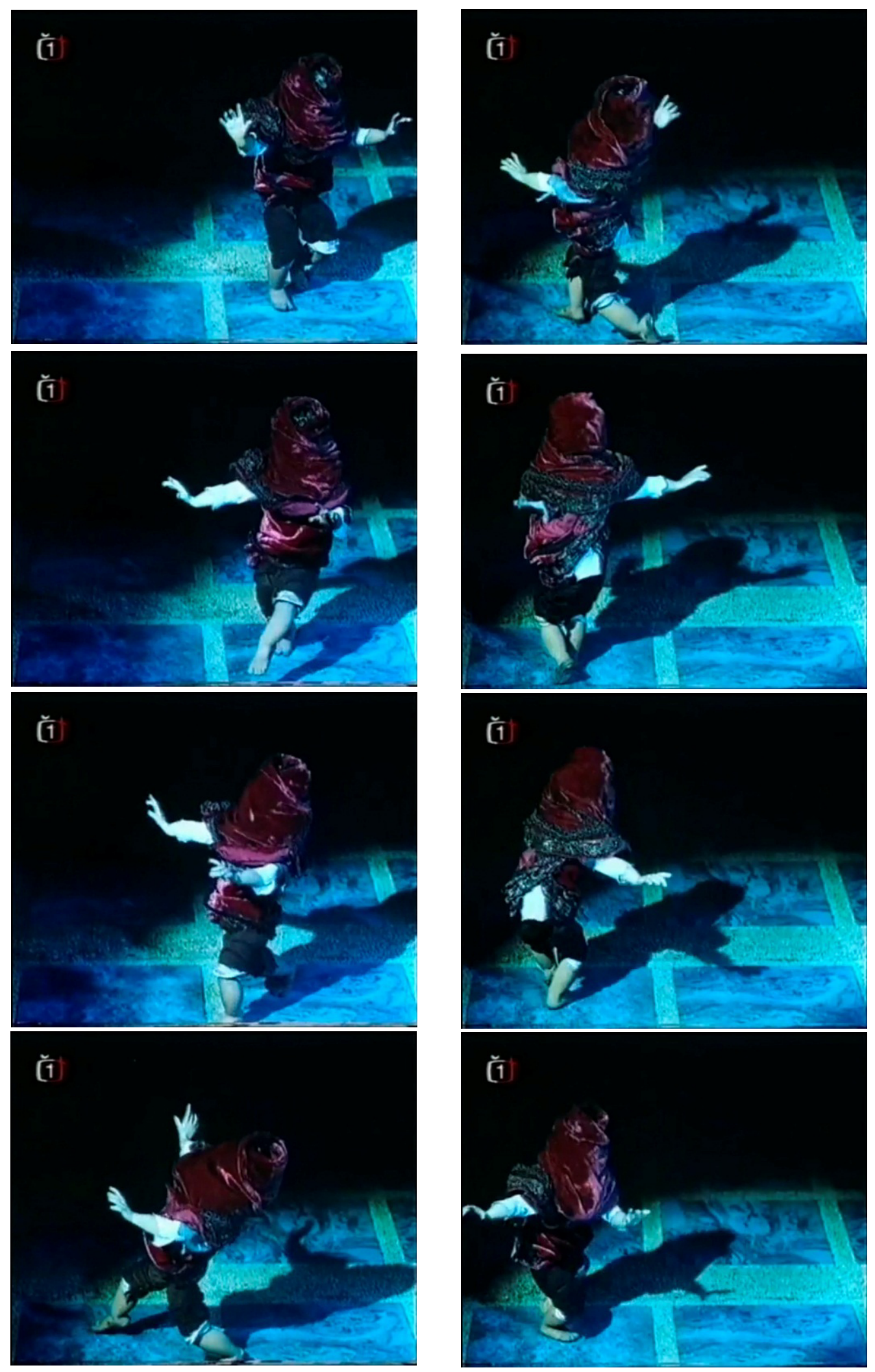

Fig. 20. Jiri Trnka (1912-1959). Sen noci svatojanske

(Sueño de una noche de verano). Serie de fotogramas. 


\subsection{RELACIÓN ENTRE MOVIMIENTO VIVENCIADO Y MOVI- MIENTO NO NATURALISTA}

En este parágrafo estudiamos las características que tienen en común la expresión del movimiento vivenciado y la expresión dinámica no naturalista en animación. El movimiento vivenciado es la expresión móvil que transmite las sensaciones cinéticas que experimentamos al observar el movimiento en el mundo que nos rodea, así como al vivirlo en primera persona, propiedades ambas que con frecuencia se representan al margen de la realidad móvil objetiva. Pero no siempre se da esta conjunción, como veremos en 4.2.3. Representación naturalistamovimiento vivenciado.

\subsubsection{PUNTOS COMUNES}

La relación entre el carácter inventivo de la expresión móvil y el movimiento vivenciado se da en animación a través de los siguientes puntos comunes: la independencia de métodos racionales de representación móvil, la alteración de la mecánica, la inserción de los acontecimientos en un espacio no naturalista y la tendencia a la variedad de lenguajes de expresión.

\section{Alteración de la mecánica}

A través de la representación no naturalista se puede evocar la sensación cinética de manera muy inmediata (lo que llamamos movimiento vivenciado), generando una sensación de realidad que recuerda a la experiencia real, incluso más que en obras naturalistas. Tom Daly así lo percibe en la obra de Norman McLaren y considera ésta cualidad como resultado de la capacidad del autor para percibir sin prejuicios:

En sus películas, inventa mundos totalmente nuevos que tienen unas leyes originales y muy suyas. $Y$ en las historias y anécdotas que nacen de esas leyes se entiende de forma aún mucho más clara el significado de las reglas que rigen el mundo "real" en el que vivimos.

Uno siempre se sorprende al constatar que nuestra facultad de percepción es infinitamente más rica de lo que se suponía. Norman consigue tantas veces eliminar las 
anteojeras, las gafas negras que nos impiden recobrar nuestras visiones primitivas, nuestras visiones de niño. ${ }^{43}$

Para lograr esto es necesario prescindir de los aspectos superficiales del movimiento y potenciar el poder evocador de la representación móvil antes que la exactitud mecánica.

En Cockaboody (Faith Hubley y John Hubley, 1973) la mayoría de las acciones de las niñas protagonistas están realizadas con unos pocos fotogramas y resaltando las pausas, casi siendo posible distinguir las imágenes que las componen (poniéndole el pañal a su muñeca, peinándose, peleando entre ellas por un juguete, etc.). Además el movimiento es acorde al ritmo del habla de las niñas (elevando el volumen en palabras concretas, entrecortando las frases). De esta manera la apariencia del movimiento no es naturalista, pero transmite la sensación del movimiento infantil con gran audacia, llegando directamente al espectador; así pues, en esta animación el movimiento es vivenciado (Fig. 21). En Taratatá la parade (Back, 1977), unos soldados desfilan tocando la flauta; es tan importante su avance rítmico pero deslizante en posición erguida, como el rápido movimiento de los dedos. Ni el movimiento de las piernas ni el de las manos corresponde a la locomoción de tales acciones, sin embargo transmite resueltamente una impresión visual similar a la acción que representa. Cada uno de los movimientos del desfile sigue este principio: los soldados a caballo, las majorettes, los músicos, los indios, etc. Todos realizan acciones representadas con sencillez y expresividad; y ninguna de ellas procede del estudio de la mecánica (Fig. 22). En este caso hablamos claramente de síntesis de valor estético; es un bello resumen del dinamismo, aunque a veces se separa de las sensaciones cinéticas que caracterizan el movimiento vivenciado.

A la pregunta de si encuentra difícil dibujar o animar un personaje, Schwizgebel responde con la siguiente reflexión a la que alude a la plasticidad y expresividad del movimiento:

No diría que tengo dificultades, pero algunos ángulos son menos estéticos. Organizar satisfactoriamente la composición de un fotograma es el problema, especialmente si se mueve en el espacio o si un personaje cambia su posición. Cuando un personaje proviene de la memoria, lo opuesto a la rotoscopia o a dibujar del natural, podemos engañar. Con imágenes CG algunos ángulos son lógicos en términos de "proceso", pero deformes; escorzos precisos que son visualmente incorrectos. Esta es también la razón por lo que dejé la técnica de la rotoscopia, a fin de tener más li-

${ }^{43}$ Bakedano, 1987, pág. 249 
bertad. Un dibujo basado en la imaginación que está mal es a menudo más interesante que uno que es correcto. ${ }^{44}$

Si comparamos la misma acción representada en una animación que sigue la mecánica y en otra que no, podemos observar la diferencia que comenta Schwizgebel. Partimos de su propia obra Fugue (Fuga) (1975) en la que una niña se balancea en un columpio en un plano muy concreto (00:01:57), y de las escenas inicial y final de Flux (Hinton, 2002) en las que se representa la misma acción. En Fugue el movimiento del columpio se ha realizado a través de una escrupulosa medición, mientras que en Flux la acción se concentra en un exagerado alejamiento y acercamiento de la niña a la "cámara", en el que ni siquiera se ve el recorrido curvo del columpio. Aunque cabe añadir que el columpio en la película de Schwizgebel se acompaña de un audaz movimiento del espacio, más relevante para la expresividad de la escena que la mecánica de la acción. En el apartado C. de 3.2.2., sobre alteración de la mecánica, analizamos diversos ejemplos de estas mismas características.

Sin embargo, al señalar el alejamiento del movimiento real como punto de encuentro entre movimiento vivenciado y la representación no naturalista, no situamos esta condición en la síntesis de la representación móvil, es decir, el movimiento vivenciado no se define por ser síntesis del movimiento. El movimiento vivenciado es un fenómeno complejo con entidad propia y no se da incondicionalmente siempre que se expresa el movimiento en síntesis. Para que así sea, la síntesis debe referirse a la sensación dinámica que provoca en la persona y no sólo a elementos básicos del fenómeno, como la dirección y la velocidad de la acción. Expresar el movimiento en síntesis implica resumir lo acontecido, pero expresar el movimiento como vivenciado implica la transmisión de las sensaciones vividas, ya sean de manera sintética o analítica. En la película Gake no ue no Ponyo (Ponyo en el acantilado) (Miyazaki, 2008), la escena de la tormenta muestra un mar de olas gigantescas con peces también gigantes que se transforman en la espuma del mar (00:46:00); la minuciosidad de la representación del movimiento de los peces y el agua es un ejemplo de movimiento no realista por medio de representación no sintética; el detalle de la acción, que forma parte del lenguaje dinámico y visual de la película, no corresponde a la evolución real de la olas (sin tener

\footnotetext{
${ }^{44}$ Schwizgebel en Cotte, 2004, págs. 85-87, (trad. a.): I wouldn't say I have difficulties, but some angles are less aesthetic. Satisfactorily organising the composition of the frame is the problem, especially if moving in space, or if a character changes its position. When a character is drawn from memory, the opposite of rotoscope or life drawing, we can cheat. With computer graphic images, some angles are logical in terms of "process", but misshapen; accurate foreshortenings that are visually wrong. That's also why I quit the rotoscope technique, in order to have more freedom. A drawing based on imagination that is wrong is often more interesting than one which is correct.
} 
en cuenta el hecho fantástico de la metamorfosis de los peces), pero expresa de manera muy potente la fuerza del oleaje.

\section{Vibración de la imagen}

La vibración de la imagen es una de las cualidades de la animación no realista, ya que al evidenciar el medio plástico (el trazo, la textura, etc.) y el dispositivo de reproducción de video (evidencia que los fotogramas se suceden unos a otros), desaparece la ilusión de realidad. Como vimos en el apartado B.3. de 2.2.1., esta textura visual puede ser un elemento que propicie el movimiento vivenciado, según como se emplee.
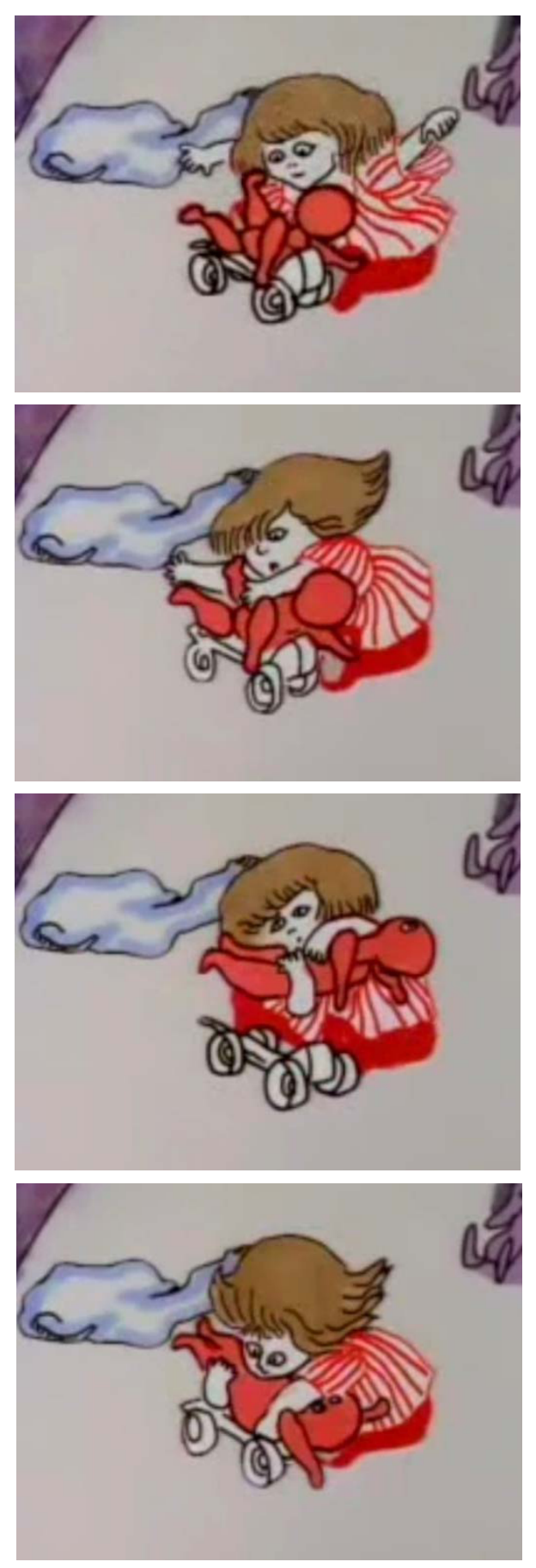

Fig. 21. Faith Hubley y John Hubley

(1974). Cockaboody.

Serie de fotogramas. 

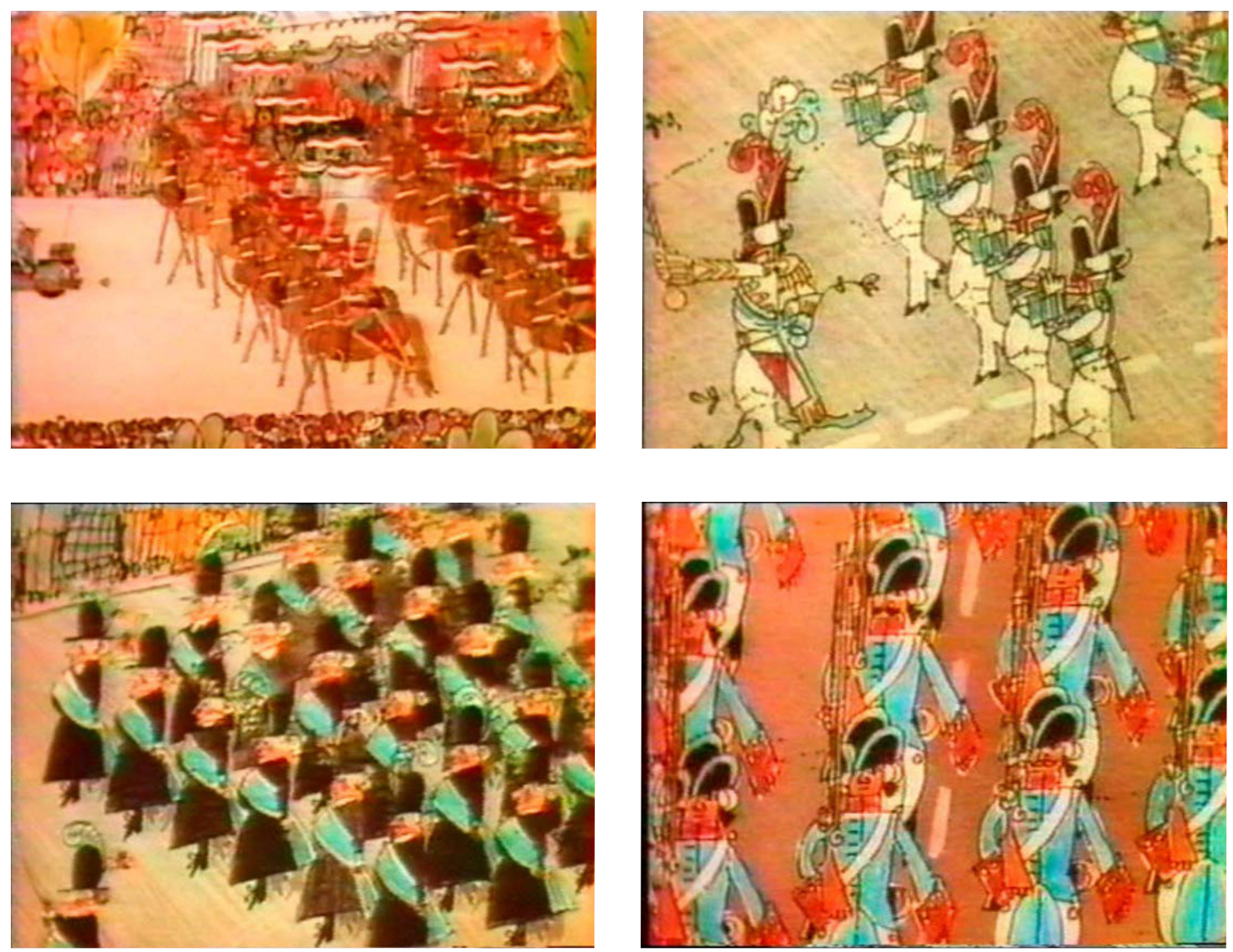

Fig. 22. Frédéric Back (1977). Taratata la parade. Fotogramas de varios planos.

Inserción de los acontecimientos en un espacio independiente de la perspectiva de geometría proyectiva

La representación de la perspectiva por medio de la geometría proyectiva es uno de los sistemas más reconocidos como representación realista del espacio, aunque presenta, como ya sabemos, toda una complejidad debido a las "deformaciones" que provoca, las cuales a veces poco tienen que ver con el aspecto real del objeto o espacio representado (como la representación de las curvas en perspectiva caballera, por ejemplo). Pero en general la representación del espacio que omite las reglas de la perspectiva resulta no realista. En el capítulo 1 vimos que a menudo en este tipo de representación espacial se desarrolla el movimiento vivenciado.

\section{Tendencia a la variedad de lenguajes}

Como ya hemos apuntado en diversos apartados de la presente tesis, el movimiento vivenciado es rico en variedad de lenguajes de representación móvil, lo cual deriva de una de sus características definitorias: la expresión de cualidades particulares del movimiento (ya que cada artista hace énfasis en unas 


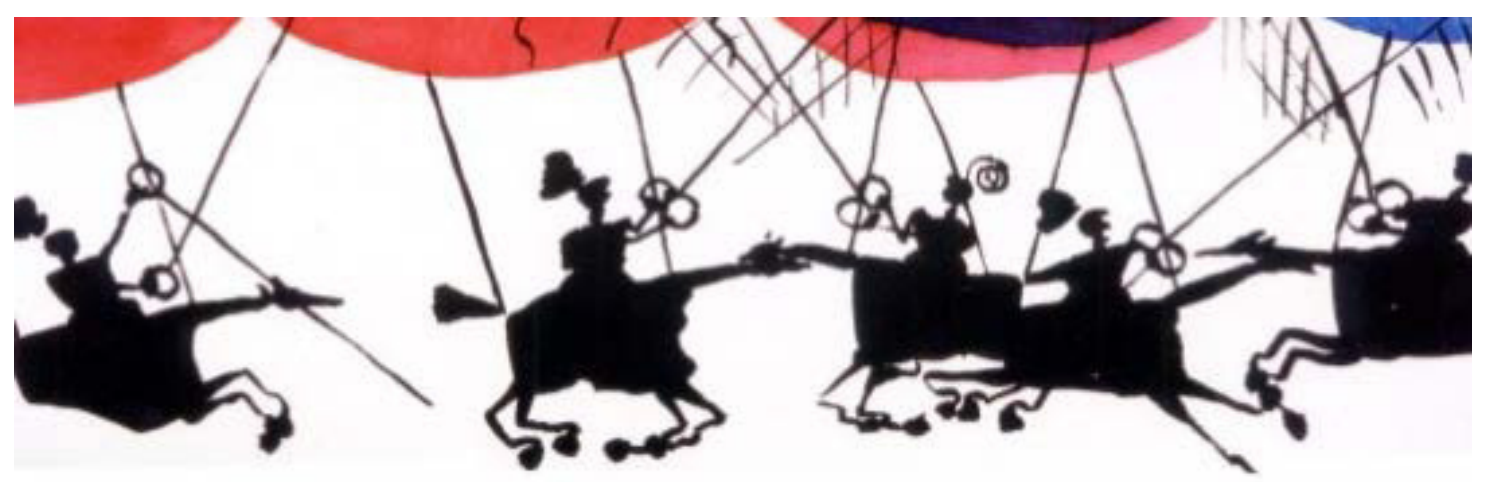

Fig. 23. Gil Alkabetz (1991). Swamp nyz sumpf (Pantano).

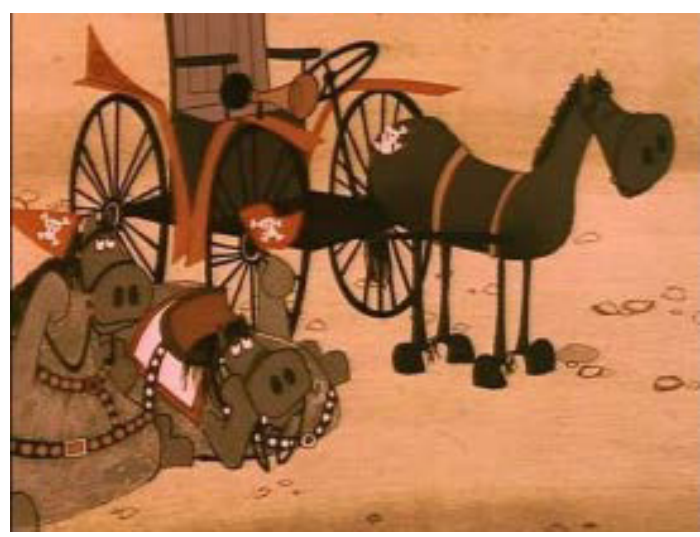

Fig. 24. Bruno Bozzetto (1965). West and Soda.

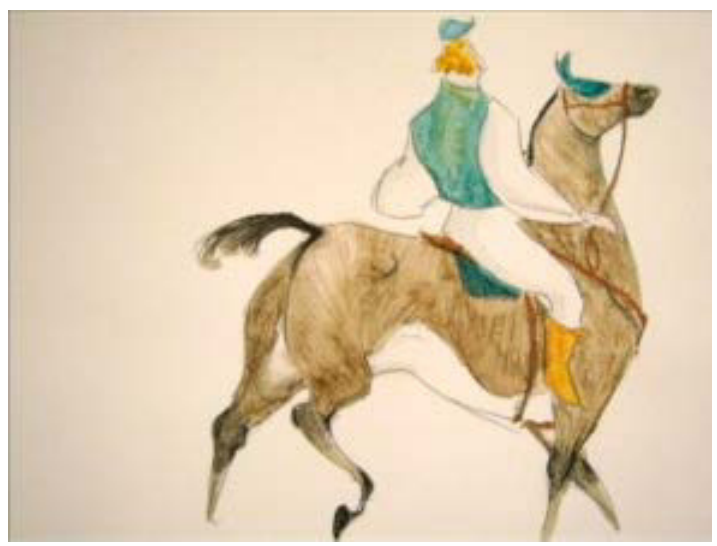

Fig. 25. Rosa Peris (2007). Corre, caballito.

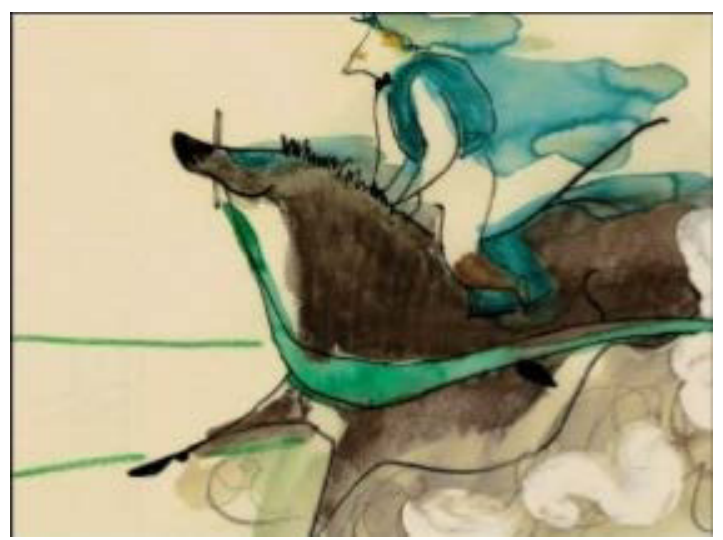

Fig. 26. Mercedes Peris (2007). Corre, caballito.

Fig. 30. Ivan Ivanov-Vano (1976). Konyok-gorbunok (El caballito jorobado).

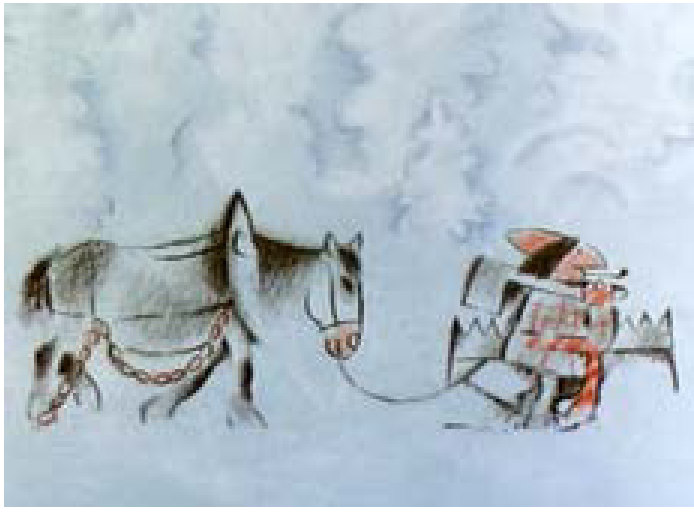

Fig. 27. Frédéric Back (1981). Crac!

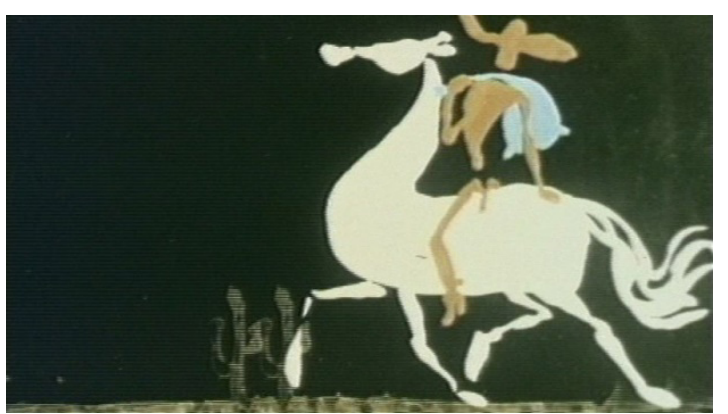

Fig. 28. Witold Giersz (1961). Maly Western.

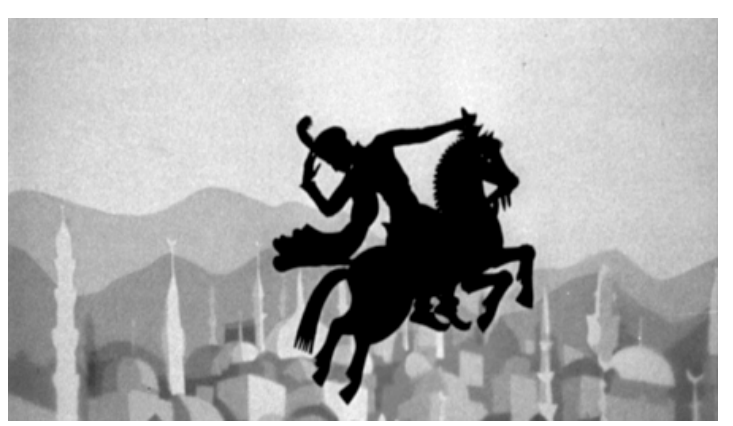

Fig. 29. Lotte Reiniger (1953).

The magic horse (El caballo mágico).

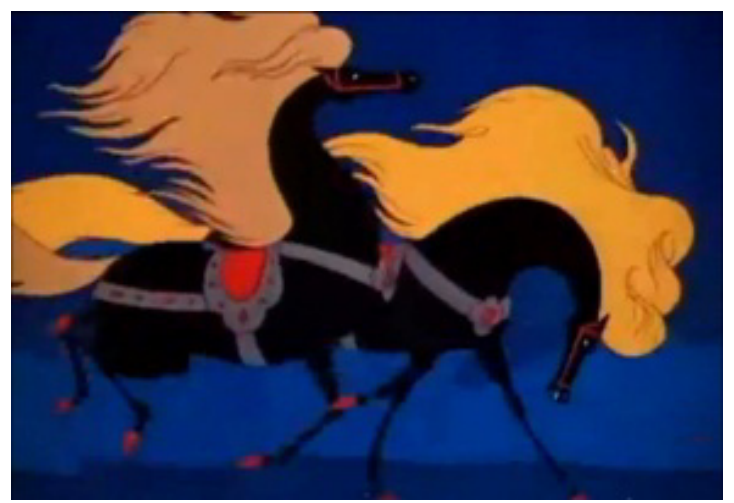


características de la acción, resaltando lo que para él es más llamativo, especial, importante para la historia, etc.). Por su parte, la representación no naturalista, al desvincularse en mayor grado del modelo real del que parte, explora también gran diversidad de formas plásticas y resultados móviles. Este es un punto en común entre ambos enunciados: al desvincularse del desarrollo exacto del movimiento de referencia y observar su carácter móvil sensorialmente (atendiendo a las sensaciones visuales y cinéticas que sugiere, a las emociones que despierta, etc.), se abre el abanico de la representación a innumerables modos de alterar lo que se percibe como movimiento realista. Aunque no toda representación no naturalista (ni toda alteración de la mecánica, como vimos en el capítulo 3), proporciona movimiento vivenciado (a veces es la base para la representación del movimiento neutro). En las figuras 23-30 se recogen varios diseños que parten de un mismo modelo (el caballo). Todos ellos se desvinculan en mayor o menor medida de la forma natural del animal, así como de su movimiento. Aunque no todas estas películas presentan movimiento vivenciado y el diseño del móvil no implica el grado de naturalismo del movimiento, a través de la variedad de las imágenes puede entenderse a qué nos referimos con variedad de resultados móviles.

\subsubsection{REPRESENTACIÓN NATURALISTA - MOVIMIENTO VIEN- CIADO}

A pesar de los puntos de encuentro entre la expresión vivenciada del movimiento y la animación que se separa de la realidad móvil, el camino para lograr el movimiento vivenciado no requiere alejarse de la representación mimética. No debe pensarse que de la representación alejada del movimiento real resulta la expresión del movimiento vivenciado, ésta es una cláusula errónea, ya que la representación no naturalista del movimiento no implica mayor expresividad y, por tanto, la expresión del movimiento como vivenciado o como neutro no es dado por el nivel de naturalismo. Por ello, la animación naturalista del movimiento también puede ser vivenciada.

Aunque existen obras de animación en las que el movimiento se presenta de manera muy naturalista y que no transmiten sensaciones cinestésicas, las animaciones realistas también pueden tener cualidades del movimiento vivenciado, inclusive la capacidad de evocar la sensación dinámica que se experimenta al vivir el movimiento. Esto se debe a que el análisis del movimiento no provoca que la expresión sea neutra. 
Son numerosos los casos de animaciones en que conviven las cualidades a las que nos referimos. Las animaciones de Ray Harryhausen insertas en películas de acción real son un ejemplo evidente, en el que la integración de criaturas animadas en la imagen de acción real dan cuenta de su naturalismo. Pero, al mismo tiempo, el espectador ve en estas criaturas un dinamismo muy particular. En la escena de la lucha entre Perseo y Medusa en Clash of the Titans (Furia de Titanes) (Davis, 1981) (01:21:30) [escena en DVD] (Fig. 31), Medusa presenta una gran riqueza de movimiento, tanto en el rostro como en el resto del cuerpo (las serpientes de la cabeza y la cola se retuercen silenciosas sin parar, mientras que los
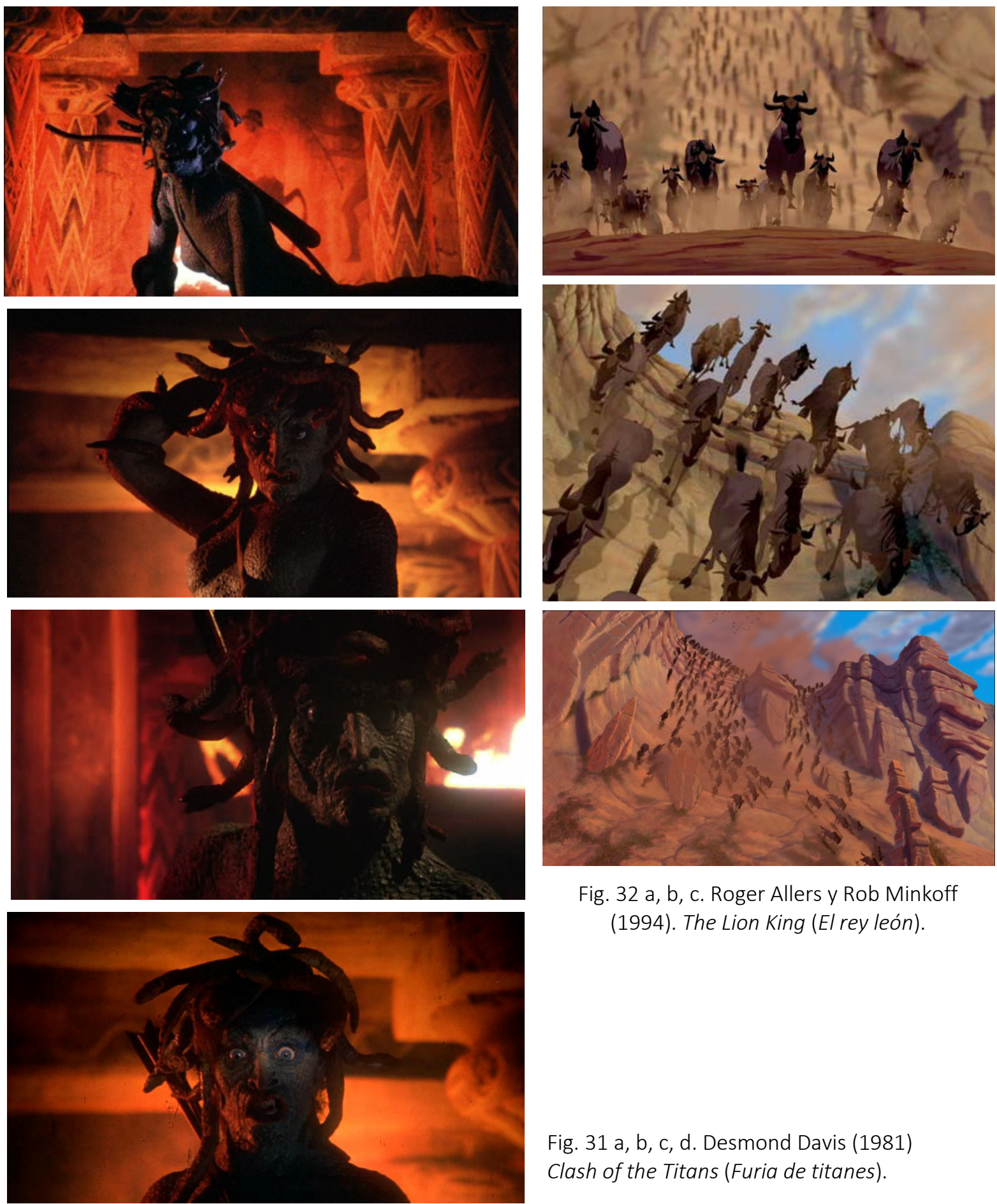

Fig. 32 a, b, c. Roger Allers y Rob Minkoff (1994). The Lion King (El rey león).

Fig. 31 a, b, c, d. Desmond Davis (1981) Clash of the Titans (Furia de titanes). 
ojos de la Gorgona miran de lado a lado, tratando de descubrir a sus oponentes). En todas sus acciones hay una gran vivacidad. Cabe destacar que no sólo la valoración espacio-temporal del personaje animado, sino también la escenificación y planificación contribuyen a crear el movimiento vivenciado por diversos motivos: el espectador comparte el punto de vista del protagonista (aunque sin ocularización), los planos cercanos y los contrastes de luz transmiten un ambiente casi claustrofóbico, etc.
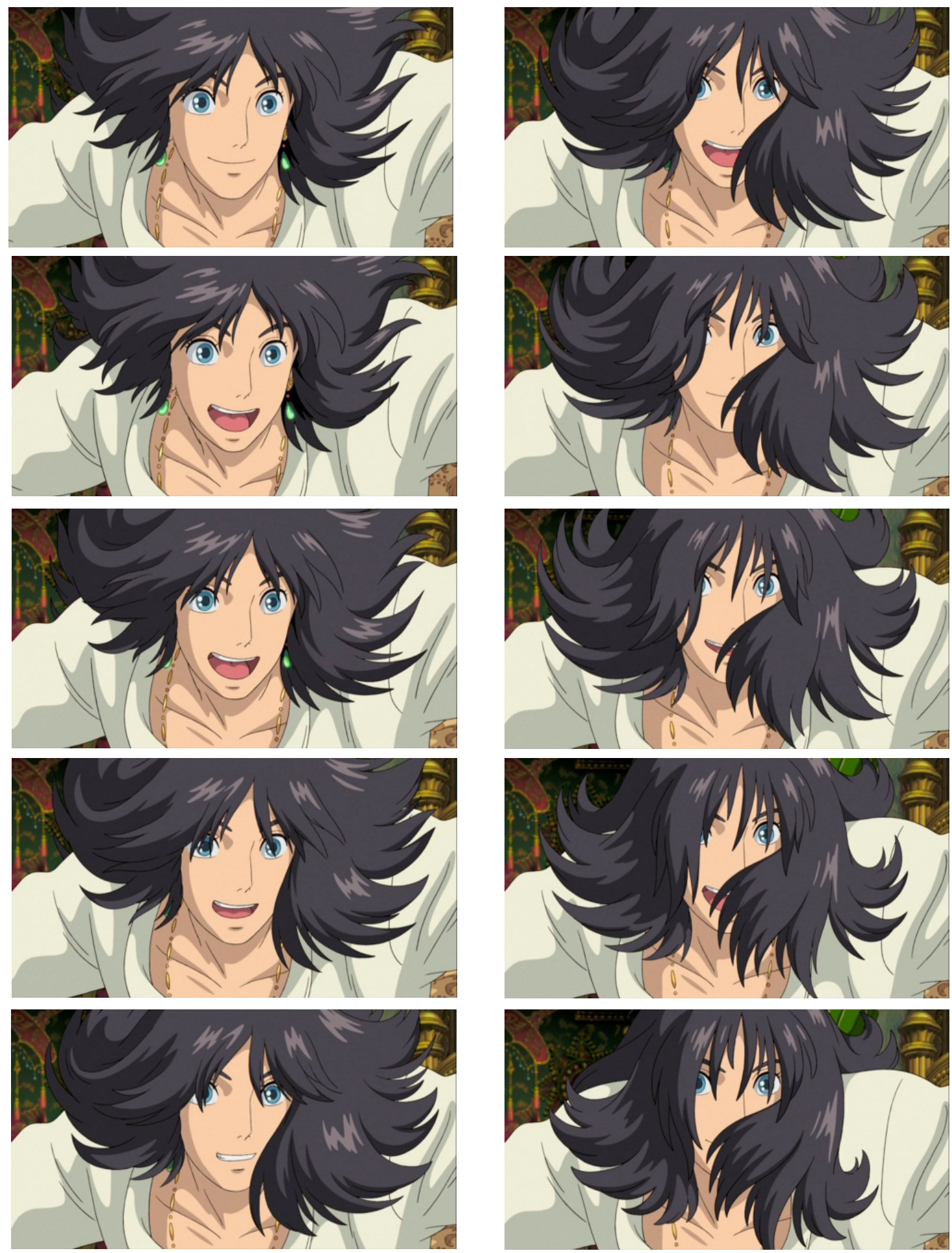

Fig. 33. Hayao Miyazaki (2004). Howl no Ugoku Shiro (El Castillo ambulante).

Serie de fotogramas 
La secuencia de la estampida de ñus en The Lion King (El rey león) (Minkoff \& Allers, 1994) (00:32:05) (Fig. 32) muestra el movimiento de la manada con gran detallismo. La locomoción de los individuos está claramente basada en la mecánica real, que dista mucho del ñu de The wind subsides (El viento se calma) (Jevremovic, 1997) (ver fig. 9 capítulo 3, pág. 290). El numeroso grupo de animales corre por el desfiladero con violencia; se desliza, en los primeros segundos de la secuencia, bajando por una superficie vertical, hecho que se muestra de tal manera que evoca sensaciones de movimiento. Además, el conjunto de la acción se desarrolla con gran intrepidez visual: la sucesión de planos, la velocidad, los acentuados ángulos desde los que se muestra el suceso, además de la empatía que el espectador puede sentir por el personaje, también son elementos que nos llevan a definir la secuencia como expresión vivenciada.

A continuación nos remitimos a otros dos ejemplos en los que el movimiento es naturalista y vivenciado: Avatar (Cameron, 2010) y en general la obra de Hayao Miyazaki. Aunque la cualidad expresiva varía un poco a lo largo de estas obras y hay mayor expresividad dinámica en unas escenas que en otras, en general podemos decir que es vivenciado.

En la obra de Miyazaki la acción de los personajes, así como de objetos y efectos atmosféricos, presenta un análisis profundo de la mecánica y demuestra la observación de los detalles de la acción natural. Se trata de una animación preciosista, en la que el más mínimo detalle de la acción tiene relevancia. Pero también presenta una distorsión, sobre todo en la velocidad, que acentúa las sensaciones cinestésicas. Así mismo, se hace énfasis en el carácter del movimiento (fuerte, blando, fluido, dificultoso, etc.) que evoca las sensaciones dinámicas de las acciones reales y sugiere las de aquellas fantásticas. Sobre todo destacan algunos fragmentos en los que predomina el movimiento de elementos atmosféricos (el mar, una tormenta, etc.) o acontecimientos en los que participan masas de gente. También sobresalen las acciones en las que el tiempo es voluntariamente dilatado; encontramos un ejemplo de este tipo de alteración en una escena de Howl no Ugoku Shiro (El castillo ambulante) (Miyazaki, 2004), en la que la rápida gestualidad del rostro de Howl evidencia el movimiento ralentizado de su cabello (00:48:25) (Fig 33).

Avatar es una de las películas de captura de movimiento que, a pesar de que desde su realización han pasado 6 años (y teniendo en cuenta el incesante avance de las técnicas digitales), presenta ya un nivel de realismo del movimiento capturado que el espectador contempla como natural sin percibir la apariencia ortopédica que caracterizaba la técnica poco antes. La fidelidad a la mecánica del cuerpo 
humano se ve transformada, pero perfectamente reconocible, en el cuerpo de los extraterrestres, de proporciones diferentes a las del cuerpo humano. Empezando por la dramatización de los actores (registrada al milímetro) hasta la planificación, todos los componentes de la película crean de manera realista el movimiento fantástico de estos seres y al mismo tiempo, como ocurre en la animación de Harryhausen, evocan sensaciones cinestésicas (Figs. 34 y 35).

En los cuatro casos descritos, la planificación es la propia del cine de acción real, se recrean efectos fotográficos como la profundidad de campo, y los espacios en los que se desarrollan los acontecimientos siguen una representación coherente geométrica y/o fotográficamente, elementos que, como vimos en 4.1.3., forman parte del discurso de la representación naturalista en animación.

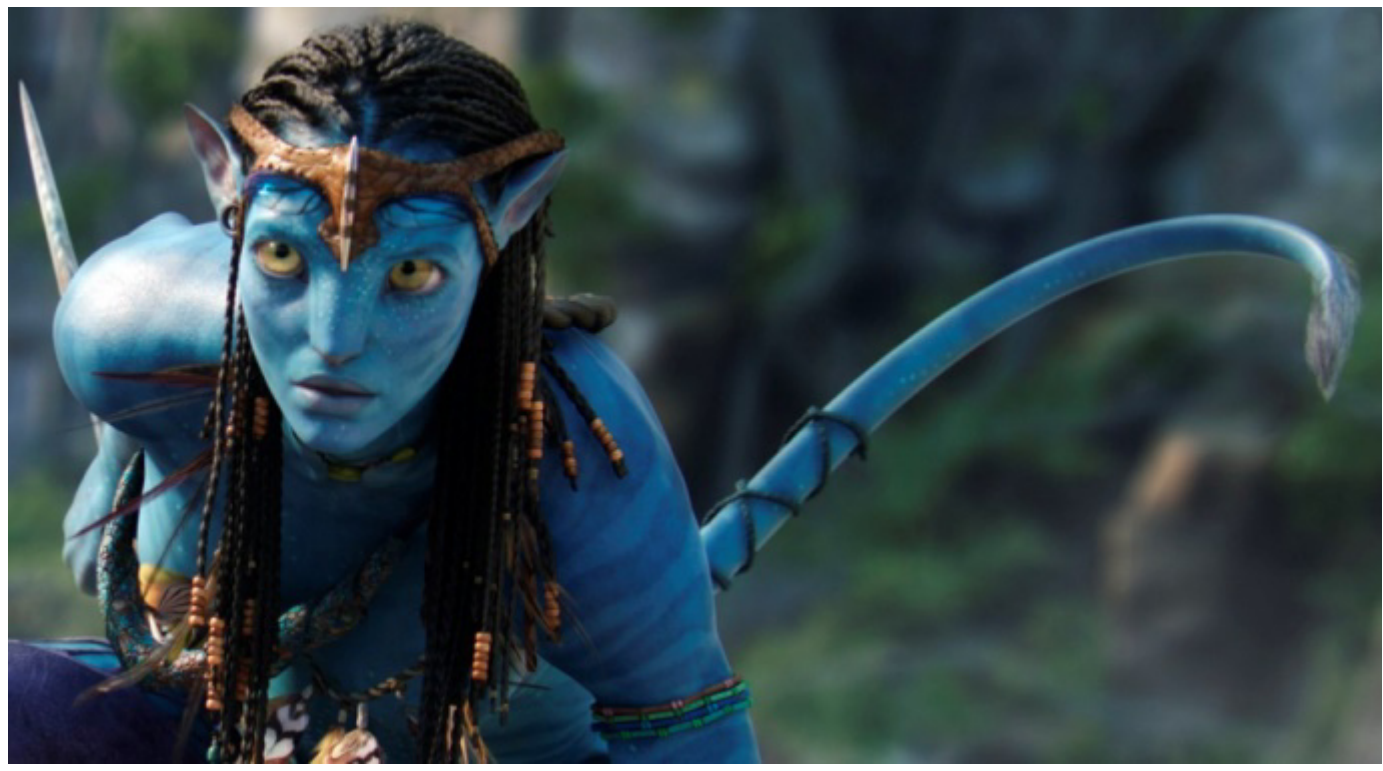

Fig. 34.

James Cameron (2010). Avatar.

Fig. 35. James Cameron (2010). Avatar.

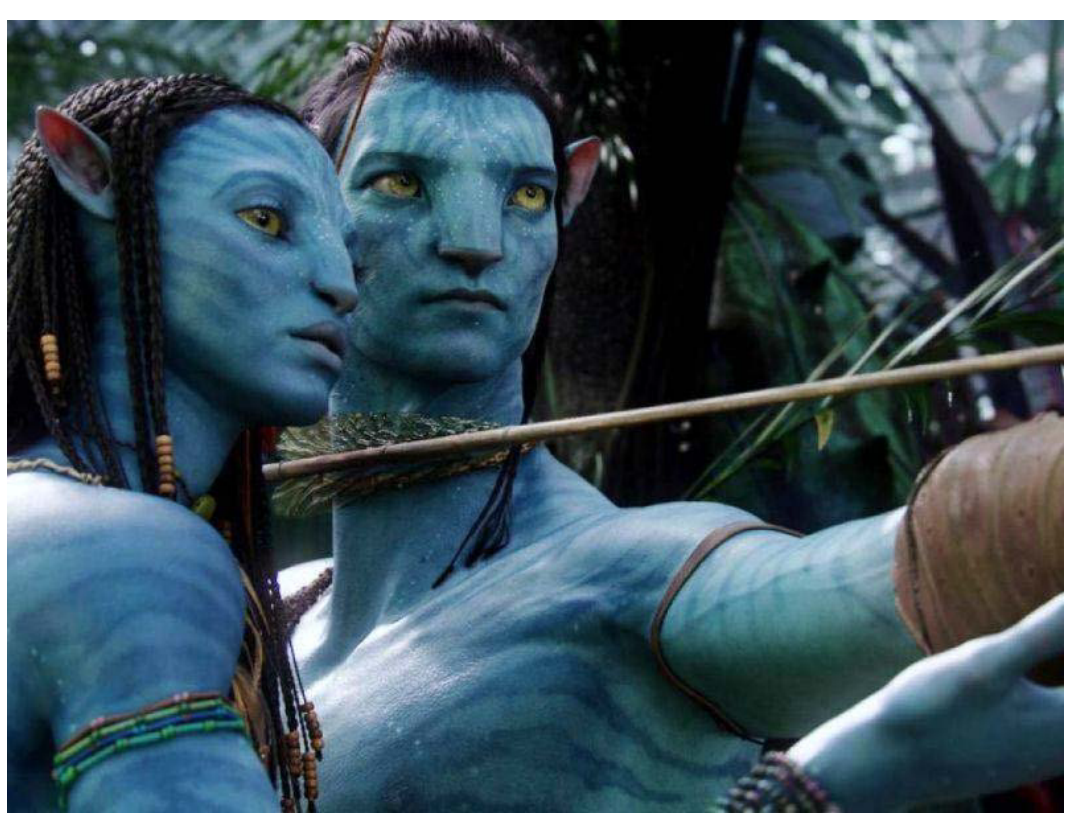


Movimiento vivenciado y movimiento neutro. Estudio sobre la expresividad de la representación del movimiento en animación 


\subsection{RELACIÓN ENTRE MOVIMIENTO NEUTRO Y REPRE - SENTACIÓN NATURALSITA EN ANIMACIÓN}

Existen animaciones realistas en las que el dinamismo carece de expresividad, no poseen la capacidad de excitar la sensación móvil en el espectador, sin embargo, el movimiento neutro se da también en animaciones que se separan notablemente de lo que reconocemos como realidad móvil. En el presenta parágrafo estudiamos las características comunes entre expresión del movimiento neutro y la representación naturalista (en 4.3.1.). Así mismo en 4.3.2.estudiamos casos de obras de animación que, por presentar movimiento no naturalista pero expresividad neutra, desmienten que haya un vínculo de causa-efecto entre movimiento neutro y naturalismo.

\subsubsection{PUNTOS COMUNES}

\section{La mecánica del movimiento}

La mecánica, como explicamos en el punto A. de 3.2.1., es un criterio habitual de fidelidad a la realidad móvil, aunque también puede ser tomada como modelo a partir del cual interpretar la acción. En la representación fidedigna del movimiento a través de la recreación de la mecánica (conocida pormenorizadamente inicialmente por la cronofotografía y poco después por el cine), ésta no es interpretada o variada de manera alguna, y presenta el movimiento de manera más comedida, hasta tal punto de dificultar la evocación de la vivencia de la experiencia móvil. Ésta es una cualidad en común con el movimiento neutro. Pero también hay representaciones del movimiento neutro nada relacionadas con la mecánica (Fig. 10 cap. 3).

\section{Se evita la vibración de la imagen}

Con "vibración de la imagen" nos referimos al movimiento derivado del trazo naturalmente irregular de unos fotogramas a otros y que se produce al proyectar la película. Se evita la vibración en las técnicas susceptibles de ello (el dibujo y la pintura) con el fin de obtener un efecto realista. Borrar la presencia del dispositi- 
vo es la tendencia normal de la creación de la animación naturalista. Recordemos que esta visión concibe la animación como una recreación del movimiento tal cual existe en la naturaleza. El dispositivo es pues un medio para la recreación de la realidad, pero su presencia debe pasar inadvertida, para ello se evita percibir el cambio de imagen por medio de colores planos, líneas muy definidas, etc.).

Trabajar sin acetato y dibujar sobre papel de arroz, como hacía McCay, proporciona tensión a la línea, que vibra y "hierve" cuando es proyectada. Los últimos trabajos de McCay y los animadores que los siguieron trataron de eliminar este error, que era visto como otra aberración que detenía el progreso hacia un mayor realismo. ${ }^{45}$

Y como parece que, se haga lo que se haga, nunca se puede satisfacer a todo el mundo, McCay también fue criticado por pretender representar el movimiento de manera naturalista evitando la vibración del trazo ${ }^{46}$. Ciertamente la vibración en las películas de McCay es casi imperceptible si se comparan con algunas obras de McLaren, pero es visible si se compara con una película de acción real. Pero lo que está claro es que, sea más o menos perceptible, e incluso cuando tiene muy poca presencia, la vibración aporta un toque distintivo a la animación de dibujo y pintura que trata de evitarse cuando se aspira a un movimiento natural.

\section{Inserción de los acontecimientos en un espacio perspectivo de geometría pro- yectiva}

Las representaciones del espacio por medio de la perspectiva proyectiva son las que se reconocen como las más parecidas a la realidad, aunque como es sabido, también pueden diferir notablemente de ésta debido a las distorsiones que se producen cuanto más se aleja la forma representada del punto ideal (ni muy cerca ni muy lejos del punto de fuga). Encontramos animaciones de movimiento neutro en las que los acontecimientos transcurren en un espacio de apariencia realista; pero como el movimiento neutro queda determinado por la inexpresividad y ésta no se deriva del grado de naturalismo, también hay animaciones en las que el espacio indefinido o incluso distorsionado tampoco aporta mayor expresividad a la representación móvil.

En el capítulo 1 dijimos que una de las maneras de reconocer el movimiento neutro es por su inserción en un espacio matemático-neutro acorde con el con-

\footnotetext{
${ }^{45}$ Noake, 1988, pág. 11, (trad. a.): Working without cel and drawing onto rice paper, as McCay did, gives a tension to the line which flickers and "boils" when projected. The later work of McCay and the animators following him set out to eliminate this error, which was seen as another aberration holding back progress towards greater realism.

${ }^{46}$ Bakedano, 1987
} 


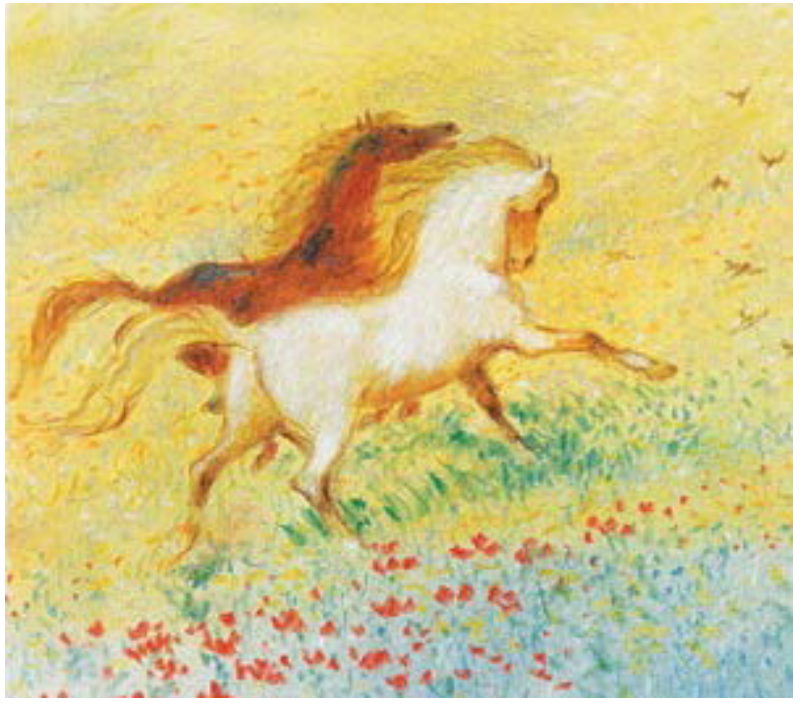

Fig. 36. Fréderick Back (1987). L'homme qui plantait des arbres (El hombre que plantaba árboles).

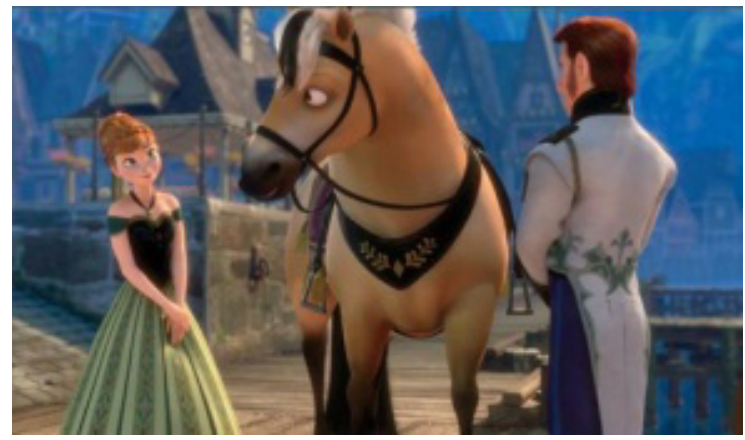

Fig. 37. Chris Buck y Jennifer Lee (2013). Frozen, el reino del hielo.

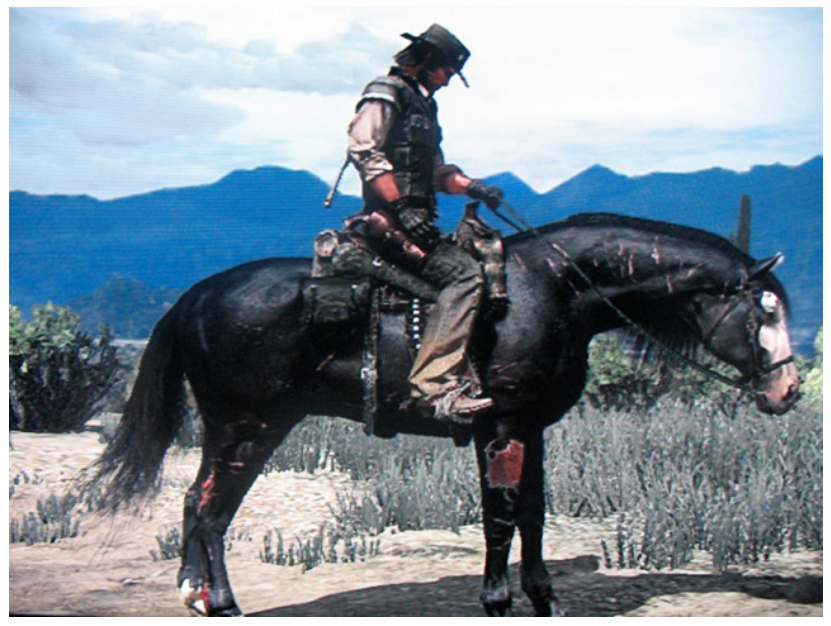

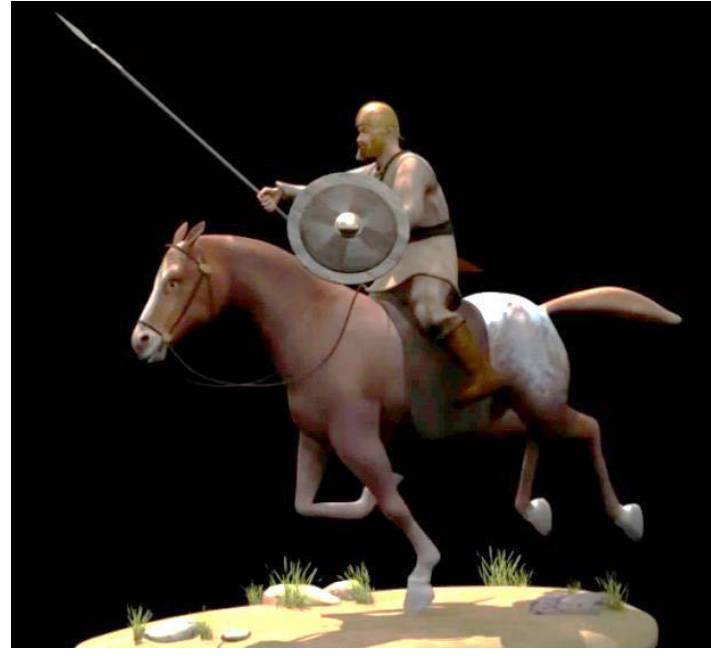

Fig. 39. Alfredo Jimeno Martínez y Jose Ignacio de la Torre Echávarri (2009). Numancia.

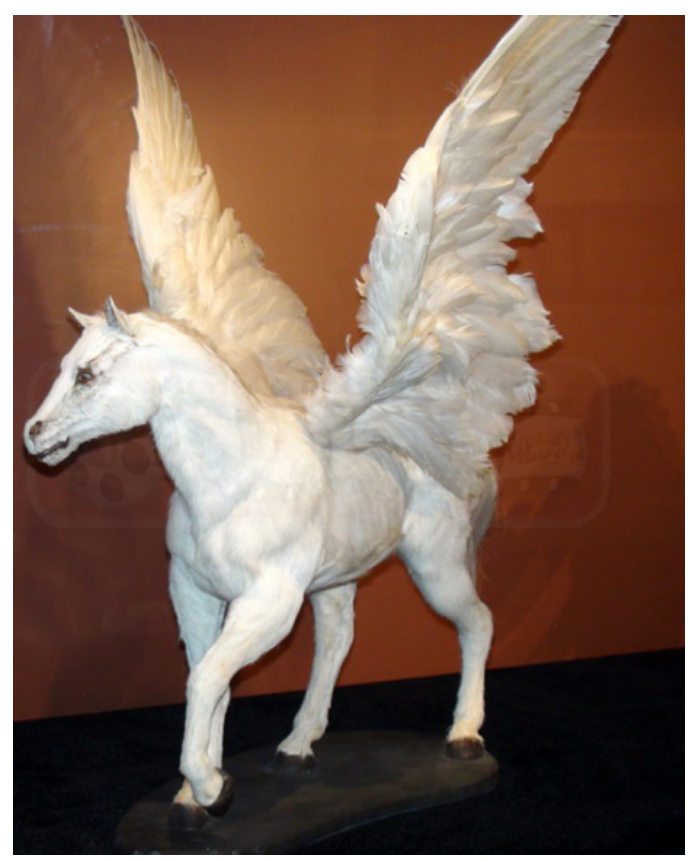

Fig. 40. Ray Harryhausen (1981).

Diseño para Pegaso en Clash of the Titans (Furia de Titanes).

Fig. 38. Christian Cantamessa, Leslie Benzies, Alan Blaine, Silas Morse (2010). Dark Horse; Red Dead Redemption.

cepto de espacio matemático de Bollnow, en el sentido de que está realizado y es medible objetivamente (él mismo se refiere a la representación objetiva del espacio a través de las matemáticas y la cartografía ${ }^{47}$, aunque en arte el espacio neutro no se trata necesariamente de una creación por métodos matemáticos y es

\footnotetext{
${ }^{47}$ Bollnow, 1969, págs. 99-100, 175
} 
principalmente un espacio que no participa en el contenido emocional ni en el dinamismo de la obra. Del mismo modo, la recreación de la tercera dimensión no es símbolo inequívoco de espacio neutro, ya que las recreaciones espaciales en la animación estereoscópica e inmersiva sin duda aportan un componente tridimensional y envolvente que puede alimentar en el espectador la sensación de estar en lugares reales o ser contemplador de hechos tangibles con más potencia que el cine convencional, por lo que podrían ser una herramienta para crear movimiento vivenciado.

\section{Tendencia a la homogeneidad}

Las representaciones naturalistas, al tener como objetivo acercarse al modelo, tienen más rasgos comunes que aquellas que se separan de éste. Éste es un punto en común con el movimiento neutro, que se define en parte por la homogeneidad. Al expresar el movimiento como neutro, la creación se centra en criterios impersonales que acotan la representación a una interpretación objetiva, delimitando el campo de actuación, preponderando las características básicas de la acción (dirección, sentido, velocidad y aceleración) y dejando al margen otras características particulares que son sugeridas al experimentar el movimiento, por la vivencia. En las figuras 36-40 vemos una muestra de fotogramas de animaciones que tienen en común un nivel de naturalismo más o menos similar. Aunque el diseño del móvil no determina la expresividad o el realismo del movimiento, la similitud que la forma presenta en estos casos también se da en el movimiento. Estas imágenes pueden compararse con las figs. 23-30, que representan el caso opuesto. A pesar de ello, la representación del movimiento en animación puede aproximarse al movimiento real de diversas maneras, por lo que también existe riqueza de lenguajes de representación móvil entre animaciones con esta característica.

\subsubsection{REPRESENTACIÓN NO NATURALISTA-MOVIMIENTO NEUTRO}

A pesar de que el movimiento neutro y la representación naturalista tienen en común las características que acabamos de ver, la expresión neutra del movimiento también se da en animaciones desvinculadas de la apariencia real del movimiento, lo cual evidencia que el naturalismo no es una característica definitoria del movimiento neutro, y que uno no lleva al otro. Este es el caso de los signos móviles como, por ejemplo, los semáforos: la figura animada que camina no tiene 

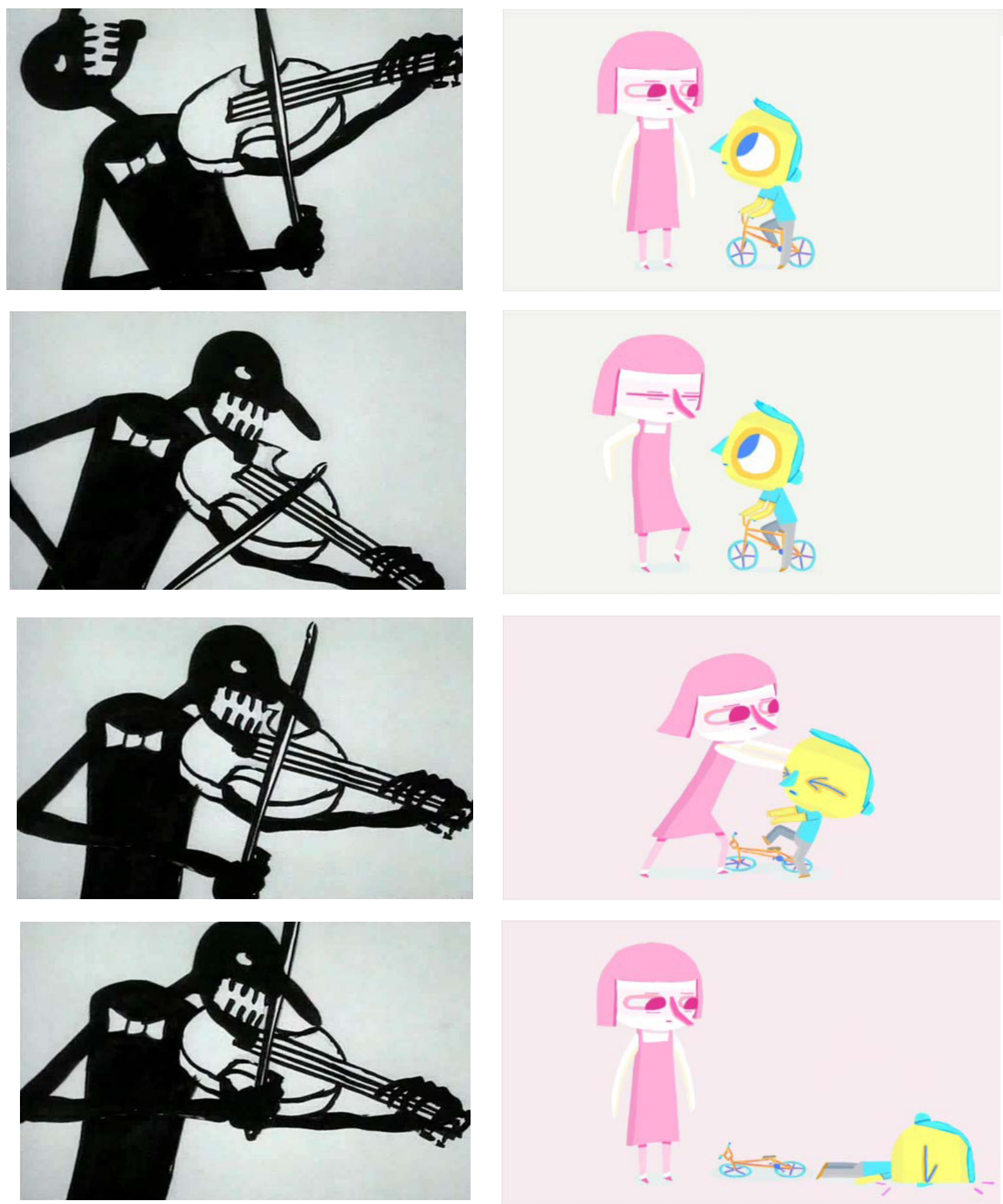

Fig. 41. Phil Mulloy (1992). The sound of music (El sonido de la música). Serie de fotogramas.

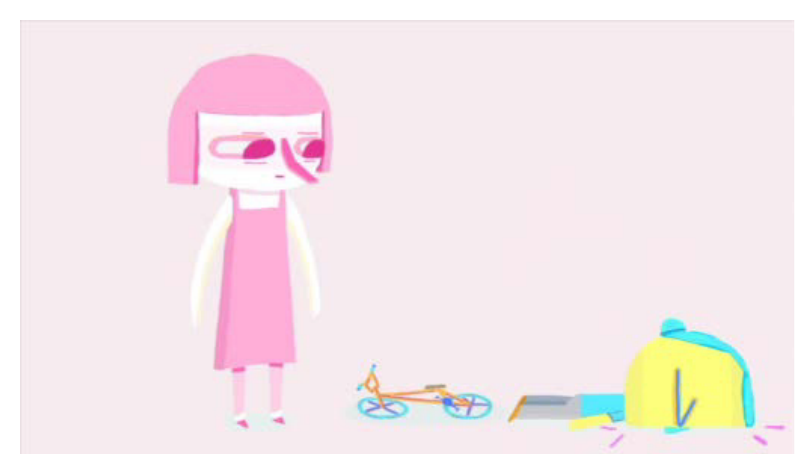

Fig. 42. Eamonn O'Neill (2011). I'm Fine Thanks (Estoy bien, gracias). Serie de fotogramas.

una movilidad naturalista, pero tampoco es expresión estética de ese movimiento; sencillamente es eficaz como signo porque trasmite el mensaje pretendido (se puede caminar). Encontramos este tipo de movimiento en las animaciones de Phil Mulloy (por ejemplo The Sound of Music - El sonido de la música - 1992) (Fig. 41), donde la transmisión del mensaje se sustenta en la imagen como icono antes que 
en su dinamismo. El esquematismo de las acciones es acompañado de otros signos gráficos móviles como la nube de polvo que levanta el coche que arranca, o líneas que indican que alguien llama a la puerta.

En otros casos el distanciamiento del movimiento real y la síntesis tienen un carácter más estético, pero la expresividad se centra tal vez en la narración, o incluso en la composición, pero la valoración espacio-temporal se mantiene poco expresiva. Este es el caso de algunas acciones de Sen noci svatojanske (Sueño de una noche de verano) (Trnka, 1959) en las que la dramatización unas veces es próxima a los sencillos movimientos que un niño hace "interpretar" a sus juguetes, describiendo amplias trayectorias rectas o curvas, manteniendo el cuerpo rígido, como
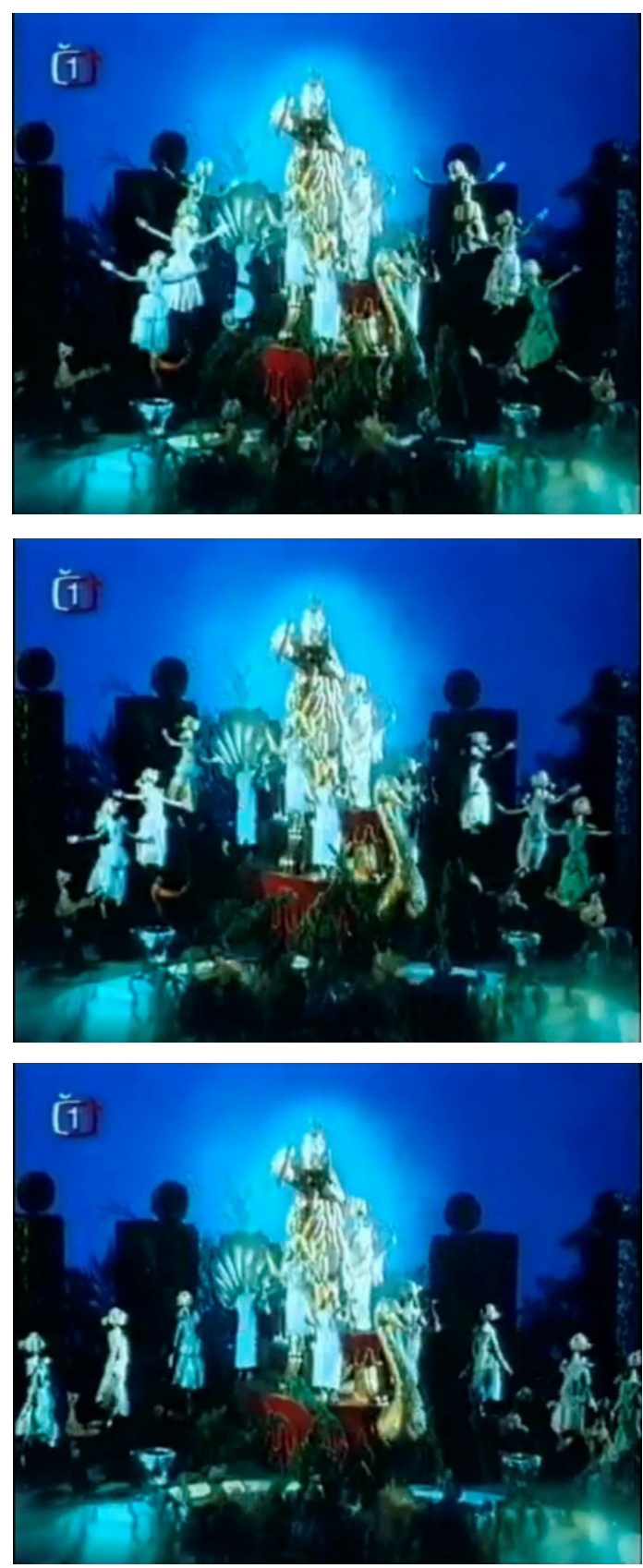

Fig. 43. Jiri Trnka (1912-1959).

Sen noci svatojanske

(Sueño de una noche de verano).

Serie de fotogramas. 

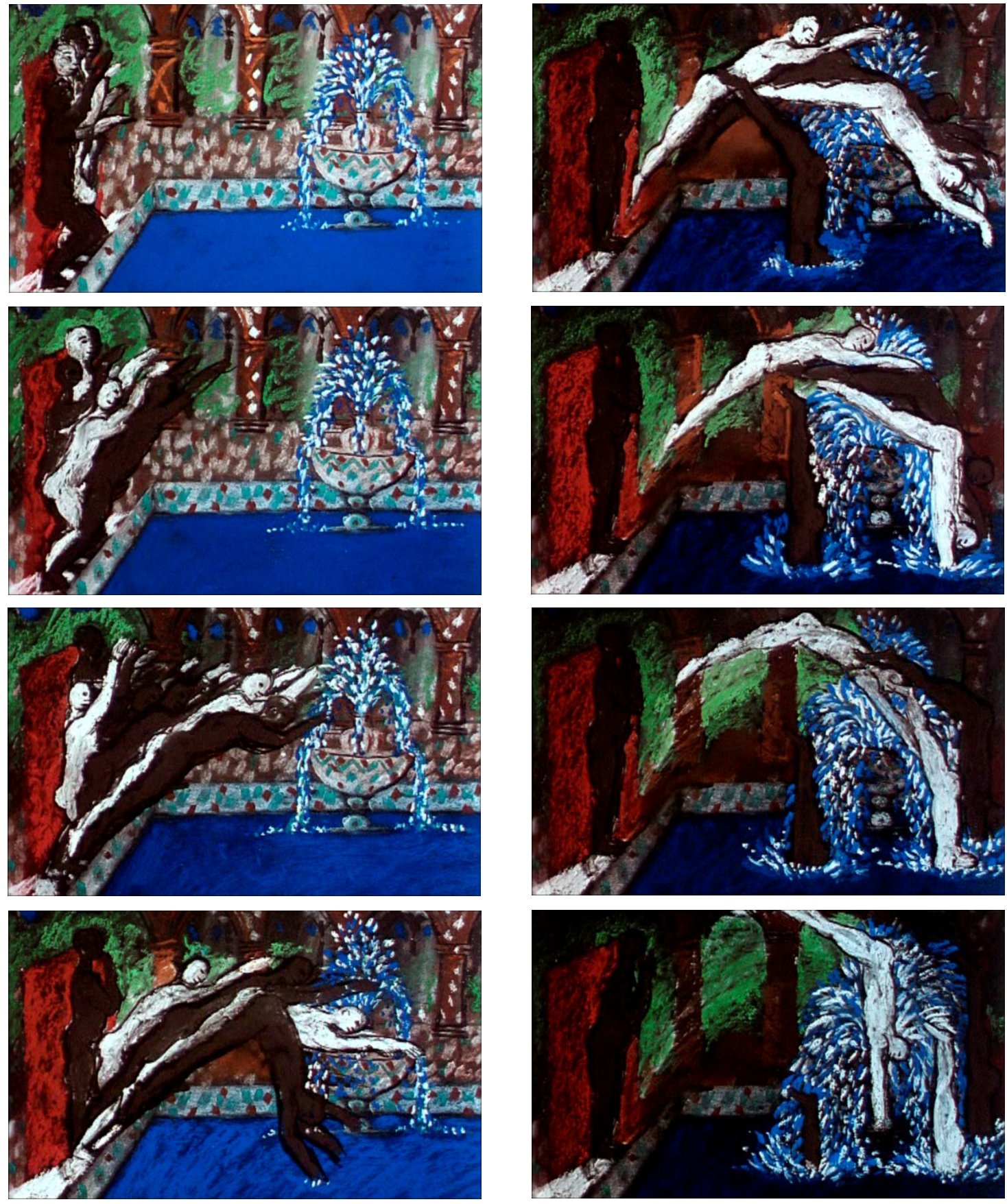

Fig. 44. Florence Miailhe (1995). Schéhérazade. Serie de fotogramas.

vemos en el espectáculo que tiene lugar en la celebración de la triple boda (Fig. 43). Este tipo de expresión móvil, sin embargo, no llega a ser vivenciada, pues no trasciende de la representación simbólica de un movimiento; el movimiento es esquemático, es una síntesis, pero no es cinestésico ni transmite características particulares de la acción natural que representa. Así miso, en Schéhérazade (Miailhe, 1995) el movimiento de los personajes se aleja de la realidad visible deliberadamente, pero no evoca sensaciones cinéticas, hasta tal punto que, en este sentido, es movimiento neutro; en esta película la expresión móvil es más directa 
en los fotogramas individuales (de gran plasticidad) que en las imágenes en transcurso, de las que resulta un movimiento regular y moroso, sea lo que sea lo acontecido (Fig. 44).

También vemos un fuerte alejamiento del movimiento natural en I'm Fine Thanks (Estoy bien, gracias) (O'Neill, 2011), en la que la movilidad no realista de los personajes tampoco transmite sensaciones cinéticas, incluso aunque se sirve de recursos de representación dinámica como el movimiento overlap del pelo interpretado a partir de la animación americana (que suele tener una movilidad muy llamativa) (Fig. 42). 


\subsection{DIFERENTES NIVELES DE NATURALISMO EN EL DISE- ÑO DEL MÓVIL Y LAS ACCIONES QUE REALIZA EN RELACIÓN A LA EXPRESIVIDAD DE SU MOVIMIENTO}

El grado de realismo puede diferir entre los elementos que abarca la animación, tanto los plásticos (entre los que se incluye en movimiento y el diseño de los personajes y demás componentes) como el contenido. Aunque en la creación artística y en su posterior percepción, forma y movimiento son inseparables, pueden no obstante abordarse en distinto grado de realismo.

A continuación analizaremos la expresividad de la representación del movimiento en relación al grado de naturalismo del diseño de los personajes y otros elementos móviles (4.4.1.), y en relación al nivel fantástico de la temática representada (4.4.2.). Mediante el contraste de estos elementos pretendemos entender en qué medida éstos afectan a la expresividad de la representación dinámica.

\subsubsection{FORMA Y DINAMISMO: EL DISEÑO DEL MÓVIL Y LA EXPRESIÓN DE SU MOVIMIENTO}

\section{A. CONSIDERACIONES}

El nivel de naturalismo de la forma de los personajes (y demás móviles) y de su movimiento no siempre es equivalente. El objetivo de este parágrafo es determinar en qué medida el diseño del móvil influye en la expresión dinámica, en concreto en la representación del movimiento vivenciado o neutro.

El movimiento está intrínsecamente ligado a la forma de los elementos móviles. Esto se evidencia en la animación de recortes, objetos y marionetas tridimensionales, técnicas en las que la maleabilidad del material, la longitud de los miembros y la flexibilidad de las articulaciones determinan la ejecución de las acciones. Sifianos analiza la diferencia de movimientos dependiendo de las articulaciones de las marionetas de recortes. Las marionetas con más articulaciones optan a mayor abanico de posibilidades móviles; y compara la diferencia entre las marionetas 
de Lotte Reiniger (formadas de numerosas piezas, con las que la autora crea movimientos ondulantes) y las de Bartosch (más sencillas, con las que se representa un movimiento más rígido) ${ }^{48}$. Como vimos en el apartado C. del apartado 3.2.2. (Alteración de la mecánica), la sencillez de los recortes está unida a la representación del movimiento no realista. En la creación de una película de animación, móvil y movimiento se conciben unitariamente (como elementos inseparables) antes que linealmente (diseñando primero el objeto móvil y explorando posteriormente sus posibilidades dinámicas), ya que los móviles se diseñan conforme al movimiento que se desea realizar a través de ellos.

Raúl García, respecto a la relación entre forma y movimiento, opina que:

Un estilo muy realista [de movimiento] tolerará menos el dibujo distorsionado que un diseño caricaturesco donde los principios de la animación pueden ser aplicados de forma exagerada sin que se pierda la verosimilitud del movimiento.

No obstante la vinculación práctica entre el móvil y su dinamismo, el vínculo entre ellos es flexible, por lo que el grado de invención de ambos no tiene porqué ser igual. De esta manera encontramos animaciones con móviles de diseño naturalista a través de los cuales se expresa el movimiento como vivenciado, y móviles de diseños alejados de la realidad a través de los cuales se obtiene movimiento neutro.

En todo caso, en la representación del movimiento la forma queda en segundo plano, siendo mucho más determinante la expresión dinámica. Las películas de Norman McLaren en las que la sencillez de la forma es máxima son una muestra de ello; McLaren hace referencia a la prioridad del movimiento sobre la forma de la siguiente manera:

Figuras sencillas de pala (Matchstick) [cerillas] pueden comportarse tan intensa, tan graciosa, tan trágicamente, o de cualquier otra forma, que, según desarrolla, pueden convertirse en personajes enriquecidos, complicados en las mentes de la audiencia, aunque sigan siendo muy sencillos en la superficie de la pantalla. ${ }^{49}$

George Sifianos habla de las posibles combinaciones teniendo en cuenta los grados de analogía del movimiento y la imagen, y extrae las siguientes tres combinaciones: "imagen «analógica» / movimiento no «analógico»; imagen no "analógica» / movimiento no «analógico»; imagen no «analógica» / movimiento «ana

\footnotetext{
${ }^{48}$ Sifianos, 2012, pág. 222

${ }^{49}$ McLaren, 1955, La película experimental y la película de bajo presupuesto, NFB, en Bakedano, 1987, pág. 225
} 


\begin{tabular}{|c|c|c|c|}
\hline & $\begin{array}{c}\text { Expresividad } \\
\text { del } \\
\text { movimiento }\end{array}$ & $\begin{array}{c}\text { Diseño del } \\
\text { móvil }\end{array}$ & EJEMPLOS \\
\hline 1 & $\begin{array}{l}\text { Movimiento } \\
\text { vivenciado }\end{array}$ & No naturalista & $\begin{array}{l}\text { L'italiana in Algeri (Luzzati \& Gianini, , 1968) } \\
\text { Crac! (Back, 1981) } \\
\text { Hen, his wife (Kovalyov, 1989) } \\
\text { The Message (Krumme, 2000) } \\
\text { Le moine et le poisson (Dudoc de Wit, 1994) } \\
\text { Les tragédies minuscules (Felicioli \& Gagnol, 1999) } \\
\text { Rame Dames (Guiol, 2010) } \\
\text { L’Oeil du Cyclone (Bisaro, 2006) } \\
\text { Carnival (Young, 1986) } \\
\text { Quand le chat est là... (Saidan, 2011) } \\
\text { Grain Coupon (Xi \& An, 2001) }\end{array}$ \\
\hline 2 & $\begin{array}{l}\text { Movimiento } \\
\text { vivenciado }\end{array}$ & Naturalista & $\begin{array}{l}\text { A Chairy Tale (Jutra \& McLaren, 1957) } \\
\text { Renaissance (Borowczyk, 1964) } \\
\text { Furia de Titanes (animación de Harryhausen, 1981) [frag- } \\
\quad \text { mento en DVD] } \\
\text { Avatar (Cameron, 2010) } \\
\text { How wings are attached to the back of angels (Welch, 1996) } \\
\quad \text { (escenas de pixilación) } \\
\text { Luminaris (Zaramella, 2011) }\end{array}$ \\
\hline 3 & $\begin{array}{l}\text { Movimiento } \\
\text { neutro }\end{array}$ & No naturalista & $\begin{array}{l}\text { Animación educativa: StudioHistoria (Serotonin Tech, 2013) } \\
\text { I'm fine thanks (O'Neill, 2011) } \\
\text { John and Karen (Walker, 2007) } \\
\text { Plaid: Eyen (Chansay, 2001) } \\
\text { Histoire d'un prince devenu borgne et mendiant (Miailhe, } \\
\quad \text { 1996) [en DVD] } \\
\text { Eros y Psique (de Vere, 1994) [en DVD] } \\
\text { Sprößling (Breymann, 2006) } \\
\text { Beluga (Hashimoto, 2011) } \\
\text { La douce (Larricq, 2011) } \\
\text { Milk Teeth (Banoczki, 2007) }\end{array}$ \\
\hline 4 & $\begin{array}{c}\text { Movimiento } \\
\text { neutro }\end{array}$ & Naturalista & $\begin{array}{l}\text { Bones (Hidaka, 2006) } \\
\text { Life in the womb (9 months in } 4 \text { minutes) (Medicine Forever, } \\
\quad \text { h.2014) [en DVD] } \\
\text { Numancia (Jimeno Martínez \& de la Torre Echávarri, 2009) } \\
\quad \text { [en DVD] } \\
\text { L'Animateur (Hilligoss, 2007) } \\
\text { Lluvia (Agudo Pinilla, 2002) } \\
\text { Tchaikovsky - An Elegy (Purves, 2011) } \\
\text { Dell'ammazzare il maiale (Massi, 2011) } \\
\text { Les Conquérants (Banoczki y Szabo, 2011) }\end{array}$ \\
\hline
\end{tabular}

Tabla 1. Expresividad del movimiento en relación al diseño del móvil 
lógico ${ }^{50}$. En nuestro estudio, si bien atendemos al nivel de naturalismo de la forma, no observamos el parecido con la realidad del movimiento, si no el nivel de expresividad.

\section{B. COMBINACIONES}

En la tabla 1 (pág. 403) se han contrastado los dos niveles extremos de expresividad que desarrollamos en el presente estudio (movimiento vivenciado y movimiento neutro) con dos grados de representación plástica de los personajes y otros móviles según su semejanza con la realidad visual (naturalistas y nonaturalistas). En la tabla se muestran las cuatro combinaciones posibles de los valores absolutos que la configuran; los ejemplos que en ella figuran se ajustan en mayor o menor medida a las características enunciadas, bien en la totalidad o en la mayor parte de la película (ya que a veces hay variaciones dentro de una misma película). Pero estos valores muchas veces no se dan en estado puro. El objetivo de la configuración de esta tabla es abordar teóricamente la armonía, contraste o disonancia entre la expresión móvil y el diseño de los elementos móviles, pretendiendo hacer una clasificación que facilite la comprensión de la variedad de combinaciones existentes, aunque somos conscientes de que existen muchos más gradientes que los que quedan reflejados en esta tabla y, por tanto, la gama de variantes es mucho más amplia.

A continuación observamos los aspectos más relevantes de cada tipo.

\section{$\underline{1^{\mathrm{er}} \text { caso: Movimiento vivenciado - móvil no naturalista }}$}

En las animaciones en las que la interpretación del movimiento como vivenciado se da sobre diseños de personajes (y otros móviles) que se alejan de la realidad móvil en mayor o en menor grado, encontramos grandes niveles de expresividad visual por medio del movimiento y la forma. Las obras de estas características son propias del ámbito de la animación artística, donde es valiosa la percepción personal del mundo que conocemos, aunque esto también se plasma a través de otros factores de las películas, como el contenido, por lo que películas con otras características formales y dinámicas también pueden ser muy estéticas.

\footnotetext{
${ }^{50}$ Sifianos, 2012, págs. 46-47
} 
Algunas películas con estas características son: L' italiana in Algeri (La italiana en ALgeria) (Luzzati \& Gianini, 1968) (fig. 45), Crac! (Back, 1981) (fig. 11 cap. 2), The Message (El mensaje) (Krumme, 2000) (fig. 40 cap. 3), Les tragédies minuscules (las tragedias minúsculas) (Felicioli \& Gagnol, 1999) (fig. 7 cap. 3), Carnival (Carnaval) (Young, año) (fig. 24 cap. 1) y Grain Coupon (Cupón de grano) (Xi \& An, 2001) (fig. 46).

El carácter no-naturalista del móvil no indica si es o no atractivo o expresivo, sino simplemente que no corresponde con la realidad visual. Unas veces la estética de los diseños tiene mayor protagonismo expresivo que el movimiento y viceversa, o son correspondientes. Por ejemplo en L'Oeil du Cyclone (El ojo de la tormenta) (Bisaro, 2006) y en Estória do gato e da lua (Historia del gato y la luna)

Fig. 45. Giulio Gianini y

Emanuele Luzzati

(1968). L'italiana in Algeri (La italiana en Argelia).
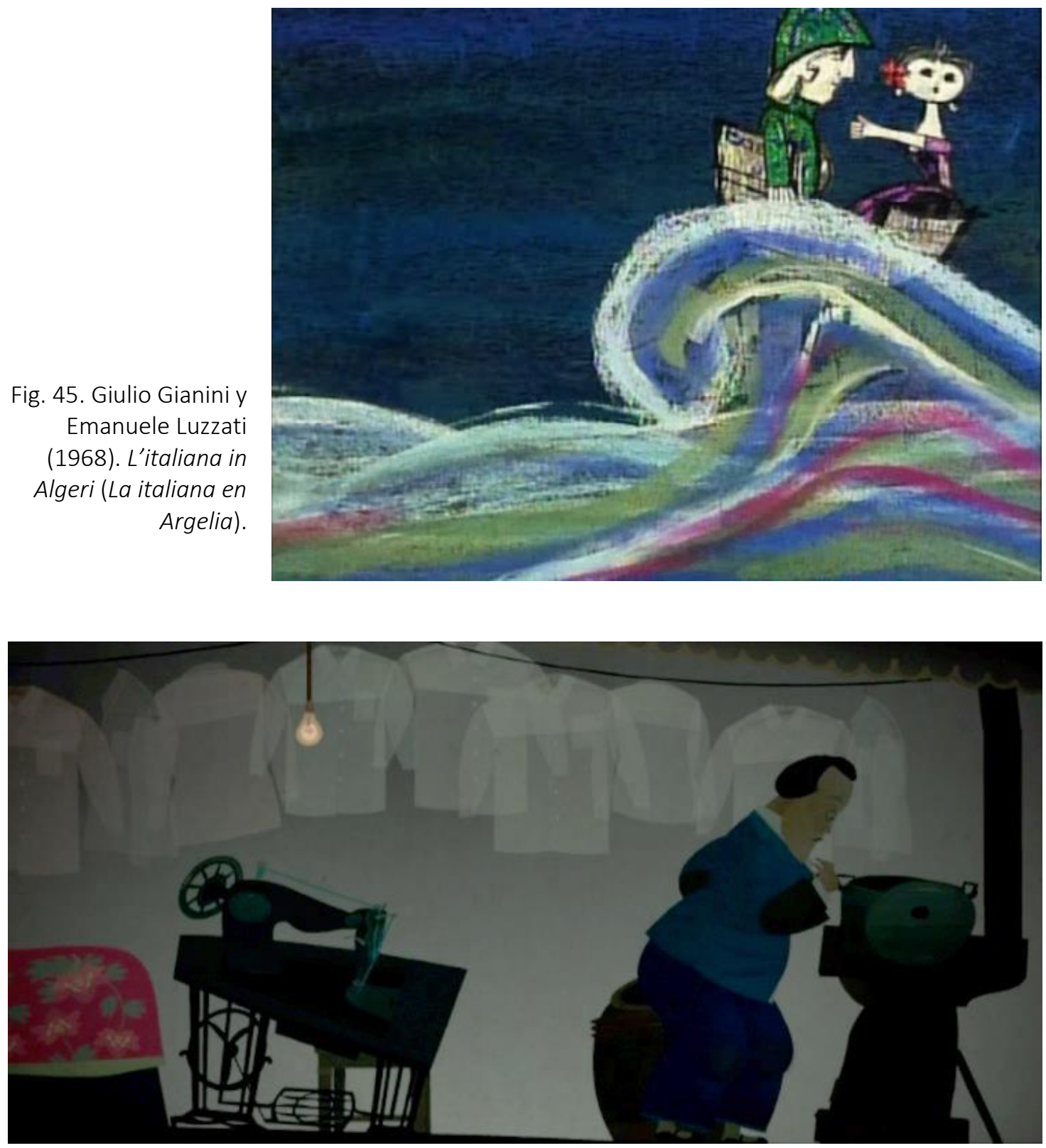

Fig. 46. Chen Xi y Xu An (2001). Grain coupon (El cupón de grano). 

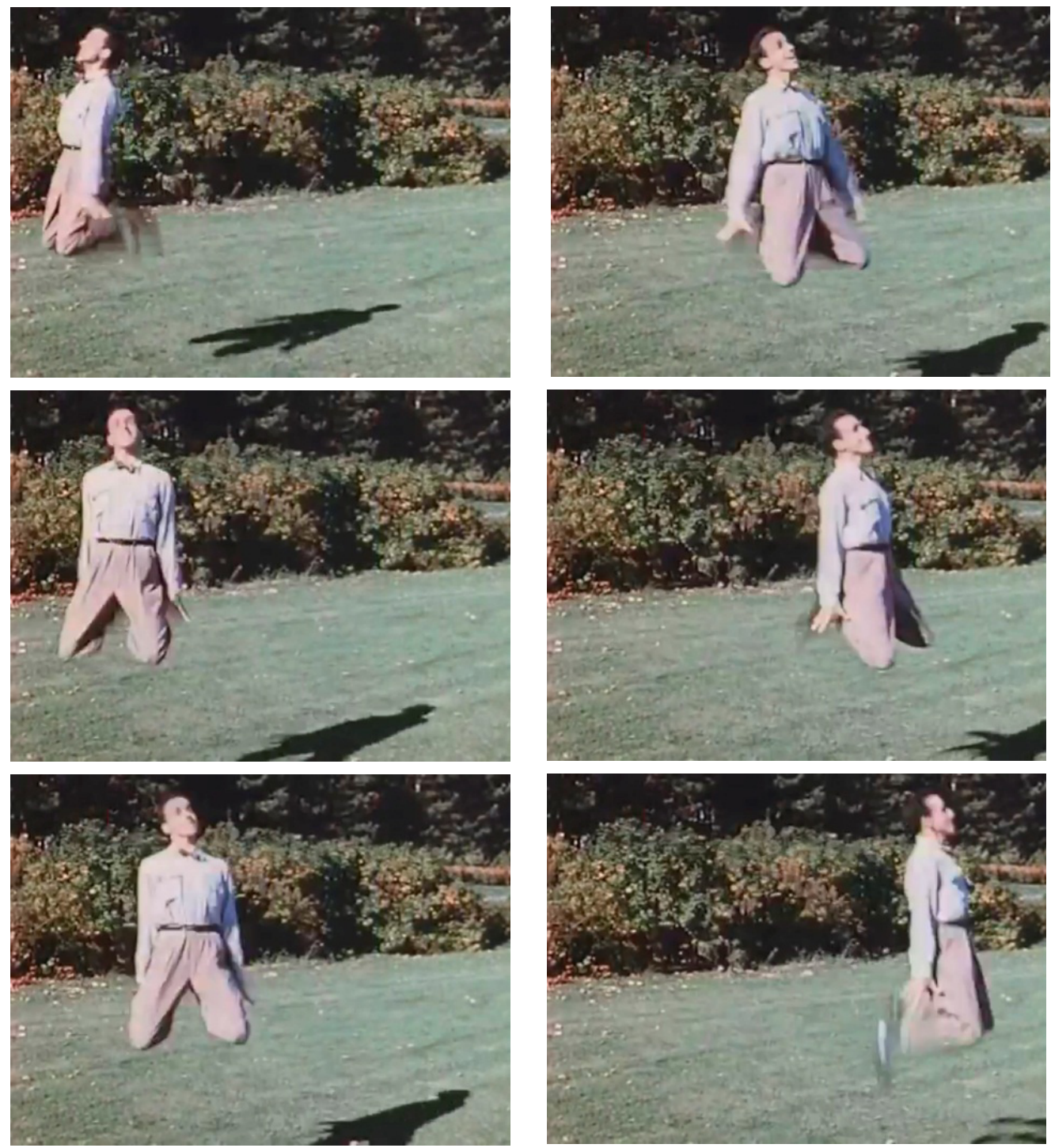

Fig. 47. Norman McLaren (1952). Neighbours (Vecinos). Serie de fotogramas.

(Serrazina, 1995) (Fig. 43 de capítulo 3 pág. 323), aunque ambas son visualmente sugestivas, el dinamismo tiene tanta relevancia como el diseño gráfico en la primera (de movimiento es expresivo), mientras que en la segunda la expresión dinámica destaca sobre el diseño.

\section{0 caso: Movimiento vivenciado - móvil naturalista}

El movimiento vivenciado también se da sobre formas naturalistas, como ocurre en aquellas obras en las que el dibujo naturalista y la fotografía presentan movimiento muy expresivo, ya sea más o menos alejado de la realidad. Éste fenómeno se da en las animaciones de Ray Harryhausen; como ya comentamos en 4.2.2., en los insertos de animación de las películas de acción real en las que participó, el móvil se integra formalmente con los actores y los espacios tangibles en los que tiene lugar la acción, pero la expresión dinámica es de una plasticidad tan 
potente que se distingue de la acción real ipso facto (fig. 31). Éste también es el caso de las animaciones de objetos y pixilación con movimiento vivenciado. En estas obras el móvil - objeto o persona real - tiene un movimiento completamente anti-naturalista, sorprendiendo así al espectador. En Luminaris (Zaramella, 2011) las personas avanzan deslizándose en lugar de caminando; como en Neighbours (Vecinos) (McLaren, 1952), en la que no sólo se deslizan en diversas posiciones, sino que también levitan en diferentes actitudes (Fig. 47).

\section{$3^{\mathrm{er}}$ caso: Movimiento neutro - móvil no naturalista}

En este caso la importancia recae antes sobre el diseño que sobre el dinamismo; el movimiento del móvil carece de la fuerza expresiva que anuncia su aspecto. Estéticamente, las animaciones de este caso pueden ser más o menos sugerentes. Así lo vemos en O'moro (C. Callissoni y E. Offrédo, 2009), Histoire d'un prince devenu borgne et mendiant (Historia de un príncipe que se convirtió en tuerto y mendigo) (Miailhe, 1996) (Fig. 49) [en DVD], Jamón (López, 2013) (Fig. 51) o Milk Teeth (Dientes de leche) (Banoczki, 2007).

Psyche \& Eros (de Vere, 1994) (Fig 50) [en DVD] tiene estas características. De esta obra de Alison de Vere se ha dicho que "es muy posiblemente su obra de animación más rica visualmente." ${ }^{51}$ Sin embargo la riqueza visual se concentra en el dibujo y el color, mientras que la expresión móvil tiene un ritmo marcadamente moroso que dificulta la lectura del movimiento; a cada pequeña acción sigue una pausa, y las acciones se limitan a elementos pequeños o tienen lugar por fundidos encadenados entre imágenes no consecutivas.

Fig. 48. Shin Hashimoto (2011). Beluga.

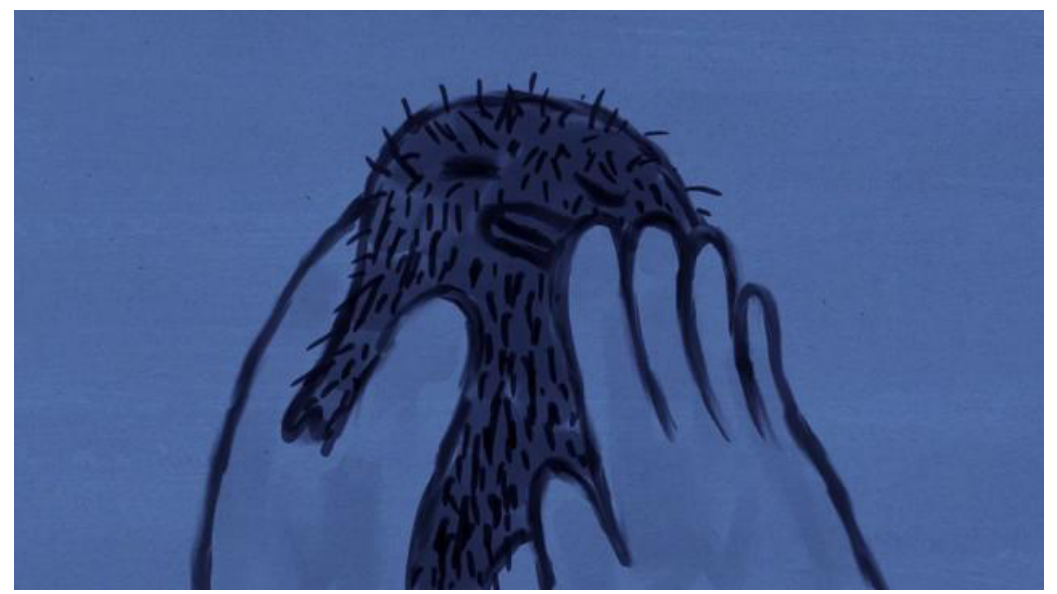

\footnotetext{
${ }^{51}$ Alison de Veres's Psyche and Eros , 2011, (trad. a.): Psyque \& Eros is quite possibly her most visually rich piece of animation.
} 


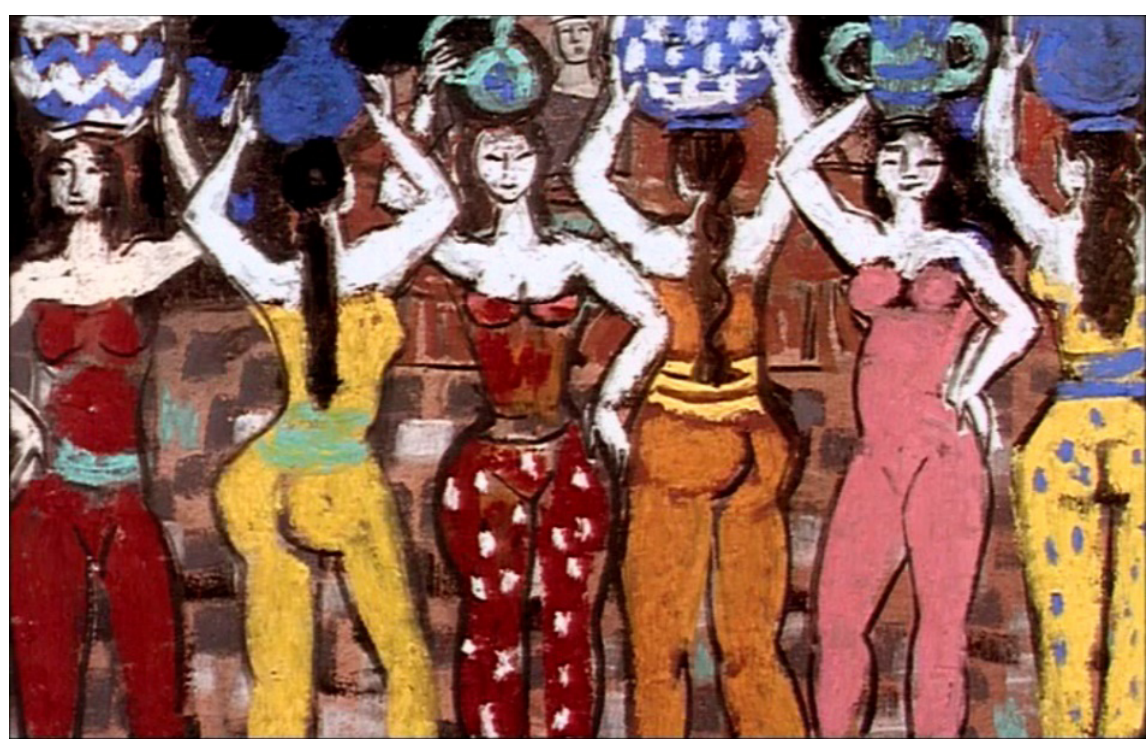

Fig. 49. Flo-

rence Miailhe

(1996). His-

toire d'un

prince devenu

borgne et

mendiant

(Historia de

un príncipe

que se con-

virtió en tuer-

to y mendigo).

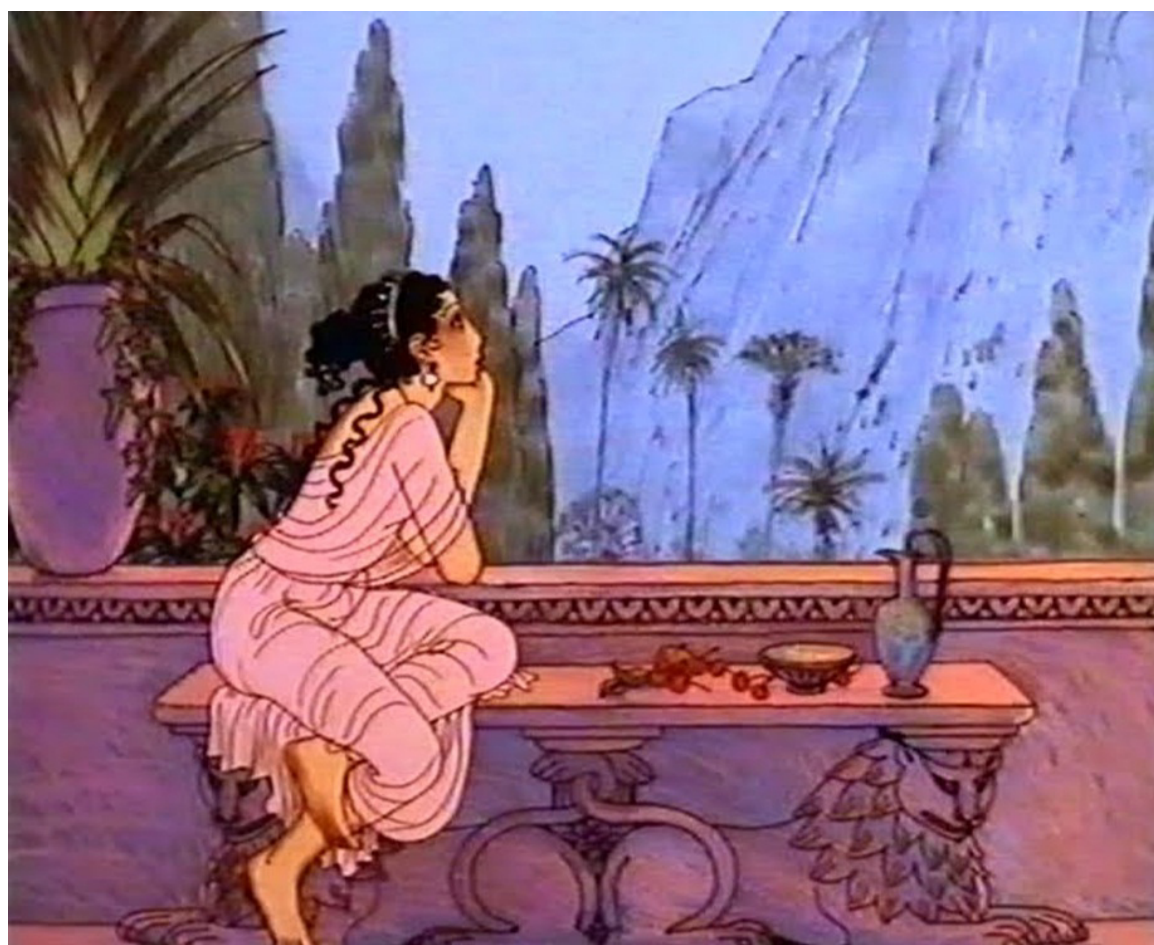

Fig. 50. Alison de Vere

(1994). Psyche and Eros (Pique y Eros).

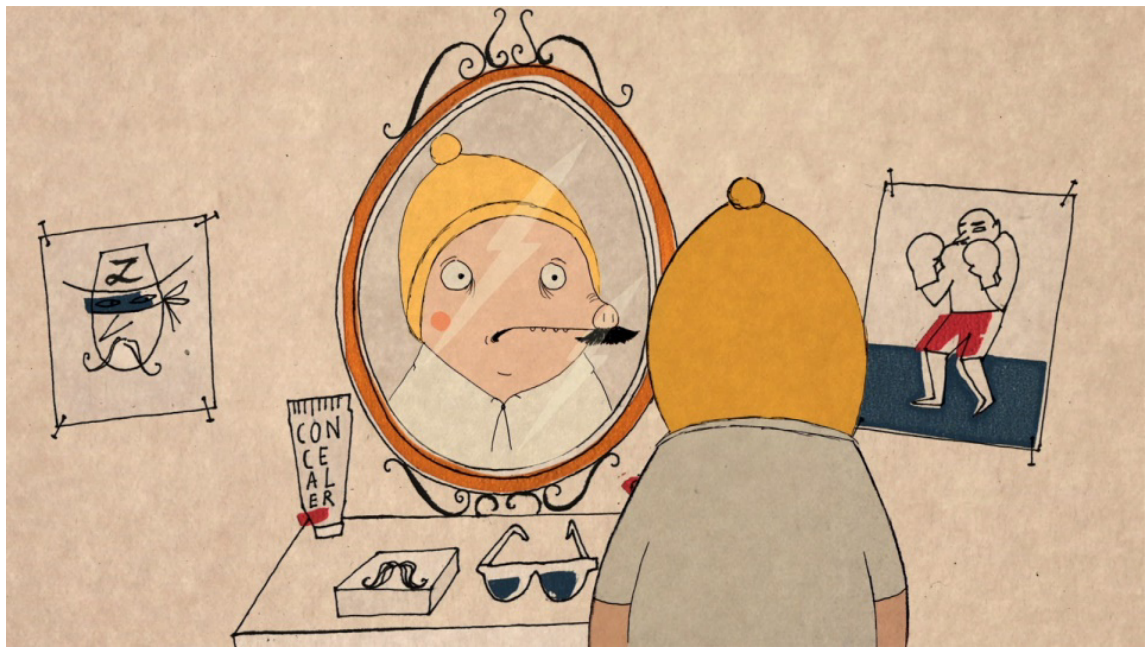

Fig. 51. Iria López (2013). Jamón. 
Otras veces el protagonismo en estas obras audiovisuales no recae ni siquiera en la forma, sino en el contenido (aunque tanto forma como movimiento participan en el mensaje de la obra). Por ejemplo, en John and Karen (Walker, 2007), el diálogo mantenido por la pareja es mucho más relevante que ningún otro elemento audiovisual; y Cowboys: Murder! (Cowboys: iAsesinato!) (Muloy, 1991) y Beluga (Hashimoto, 2011) (Fig. 48) tienen una carga moral sobresaliente, pero, por lo que respecta al movimiento, en ninguna de las dos es destacable.

Como nota personal, añadimos que las obras de este tipo a veces decepcionan al espectador que conoció la película previamente a través de imágenes individuales de la película (en campañas de promoción, en programaciones de festivales, etc.). Esto evidencia la relevancia del movimiento sobre la forma del móvil. En estas animaciones el movimiento es poco expresivo, pero la plasticidad de la imagen hace que el cortometraje resulte visualmente atractivo.

\section{0 caso: Movimiento neutro - móvil naturalista}

El movimiento neutro en móviles naturalistas se presenta como ideal para mostrar con mayor objetividad el movimiento, como en Life in the womb ( 9 months in 4 minutes) (La vida en el vientre materno ( 9 meses en 4 minutos)) (Fig. $3)$, o bien el interés estético y expresivo puede recaer en otros elementos, aunque el movimiento no se exprese como vivenciado. Por ejemplo, en la obra de Barry Purves (de movimiento y personajes naturalistas), la escenografía es muy poética, como ocurre en Tchaicovsky - an Elegy (Tchaicovsky - Una elegía) (Fig. 52), o es muy dinámica, como en Screen Play (1992).

Al comparar este caso con el 2ㅇ (movimiento vivenciado - móvil naturalista) se percibe nuevamente el papel decisivo que juega el movimiento vivenciado en la expresión móvil en animación. Pero otras veces el movimiento neutro puede transmitir una frialdad apropiada para el discurso artístico, como en Les Conquérants (Los conquistadores) (Banoczki \& Szabo, 2011), en la que unos robinsones sobreviven en una tierra de insectos gigantes. En esta película, el movimiento neutro resulta acorde al desasosiego y desarraigo que sienten los personajes en una tierra en la que la vida no es nada fácil. Además, resalta el contraste entre el realismo de los personajes (recortes digitales a partir de fotografía) y el movimiento anti-naturalista (Fig. 53).

Como hemos visto, la expresión móvil menos estimulante no resta valor estético a la obra, sino que éste se centra en otras características audiovisuales, como 
la historia narrada, el mensaje transmitido, la plasticidad de la imagen, y además también puede tener valor estético precisamente por ser neutro.

En todos estos casos vemos que pasa lo mismo que observamos en 4.2. y 4.3., pero referido a la forma del móvil en lugar de la representación del movimiento: todas las combinaciones son posibles, la expresividad depende de los casos concretos; y el diseño del móvil desde luego no hace que el movimiento sea más o menos expresivo, aunque afecta a la estética general de la obra y por tanto a su discurso.

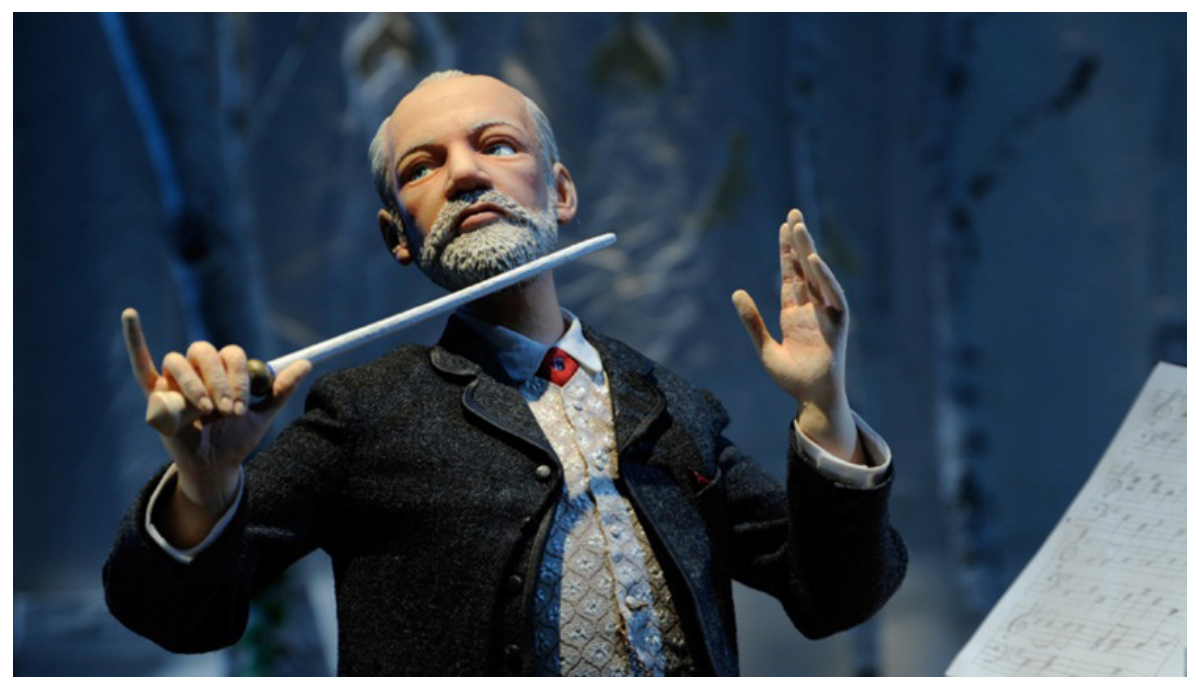

Fig. 52. Barry Purves (2011). Tchaikovsky - An Elegy (Tchaikovsky - Una elegía).

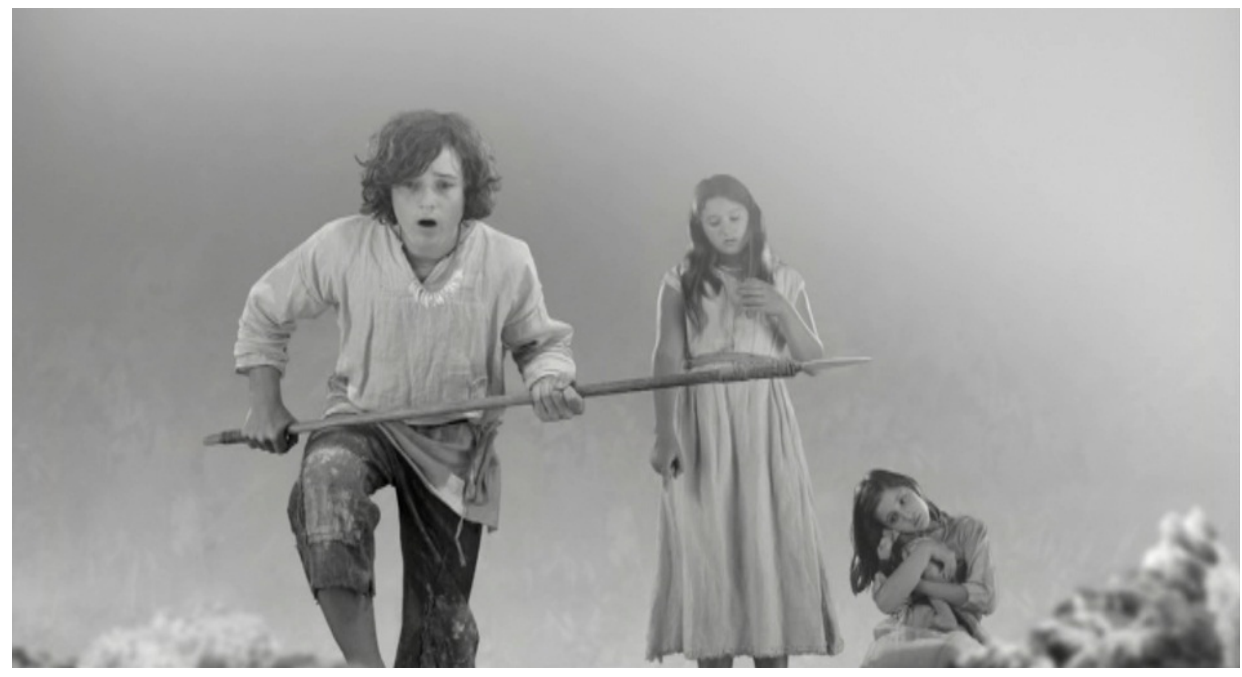

Fig. 53. Tibos Banoczki y Sarolta Szabo (2011). Les Conquérants (Los conquistadores). 


\subsubsection{LA EXPRESIÓN DEL MOVIMIENTO EN RELACIÓN AL CARÁCTER FANTÁSTICO O REALISTA DE LOS ACON- TECIMIENTOS}

En el presente parágrafo analizaremos cómo se conjugan en animación dos ítems inseparables: el tipo de acontecimientos representados y su expresión móvil (qué y cómo), con el fin de determinar cómo influye en la expresividad del movimiento la relación entre la interpretación móvil y el contenido.

\section{A. CONSIDERACIONES}

Paul Wells resalta la capacidad de la animación para representar acciones imposibles en la vida real como el elemento principal de toda película de animación. Ejemplifica esta cualidad del medio a través de la película Soda Jerks (Bowers \& Fisher, 1925), animación en la que suceden acciones imposibles por incompatibilidad espacio-temporal, en concreto, que un personaje pasa el brazo, literalmente, a través del teléfono para golpear a la persona a la que llama ${ }^{52}$. Sin duda, la elección del tema es parte del proceso de creación en el arte y, por tanto, también en el caso particular de la animación. Pero en lo que a la expresión artística se refiere, la cualidad fantástica de la temática no determina el grado de creatividad. Dicho en palabras de Arnheim: "Hay más imaginación en una mano pintada por Ticiano que en cientos de pesadillas surrealistas representadas de manera sosa y convencional." ${ }^{53}$ En armonía con esta idea, para R.M. Rilke los objetos, personas y vivencias de cada día, lo que nos es cercano, pueden ser fuente de inspiración para el poeta y señala que si el creador no encuentra interés en ello, es debido a que no tiene suficiente imaginación para ver las posibilidades creativas que le ofrece:

Diga todo eso con la más honda, serena y humilde sinceridad, y utilice para expresarse las cosas que lo circundan, las imágenes de sus ensueños y los temas de su recuerdo. Si su vida cotidiana le parece pobre, no la culpe, cúlpese usted: dígase que no es lo bastante poeta para suscitar sus riquezas. ${ }^{54}$

Es decir, la riqueza de la obra reside en la expresión y no en la temática escogida. Sin embargo esta actitud imaginativa también existe cuando se representan temas fantásticos. Harryhausen se refiere a sus animaciones con estas palabras:

\footnotetext{
${ }^{52}$ Wells, 1998, pág. 19

${ }^{53}$ Arnheim, 1979, pág. 148

${ }^{54}$ Rilke, 1929, pág. 25
} 
La fantasía es esencialmente un mundo de sueños, un mundo imaginado. Y creo que no quieres que sea muy real. Estás haciendo una interpretación. Y el stop-motion, según mi opinión, aporta un valor añadido del mundo de los sueños que no puede lograrse si se intenta hacer muy real. Y esa es la esencia de la fantasía, transformar lo real en imaginario ${ }^{55}$.

Normalmente en cine se habla de la capacidad del medio para mostrar como real aquello que no lo es, sin embargo Harryhausen, al opinar que el poder de la fantasía es el de transformar lo real en imaginario, invierte el orden que generalmente se da a la dicotomía fantasía-realidad. Esta cualidad de trasformar lo conocido en fantástico está también relacionada con la teoría de la alienación de Bertolt Brecht. El efecto de alienación de Bertol Brecht consiste precisamente en expresar lo cotidiano a través de un movimiento no realista, de modo que lo conocido se percibe como desconocido, extraño ${ }^{56}$. En sus obras podemos ver, como dice L.M. Bogad, a una mujer limpiando la casa con movimientos exageradamente rápidos, mientras que su marido se mueve de manera ralentizada ${ }^{57}$. Para Brecht la separación de la representación realista tiene como objetivo el distanciamiento emocional del espectador (con una intensa carga de crítica política), mientras que en la expresión del movimiento vivenciado, el distanciamiento con la realidad móvil se da para resaltar la sensación dinámica o para transmitir el contenido emocional.

\section{B. COMBINACIONES}

Hemos contrastado los siguientes factores: realismo de los acontecimientos representados y nivel expresivo con el que se abordan. Por un lado tomamos la temática fantástica y la realista como los dos extremos referidos al contenido del film. Por otro lado establecemos el movimiento vivenciado y el neutro como niveles extremos de la expresividad de la representación del movimiento. Con estos ítems elaboramos la tabla 2 (pág. 413). Los términos que componen esta tabla son absolutos y los ejemplos que figuran en ella son total o predominantemente de las temáticas y el tipo de movimiento especificado. No obstante, en las películas pocas veces se encuentran en estado puro; una misma película puede contener diferentes modos de expresión móvil, que pueden variar de unas escenas a otras e incluso entre acciones. Del mismo modo, realidad y fantasía se entremezclan

\footnotetext{
${ }^{55}$ Harryhausen, en Schickel, 1997, (trad. a): Fantasy is essentially a dream world, an imagined world. And I don't think you want make it quite real. You are doing an interpretation. And stop-motion, to me, gives an added value of a dream world that you can't catch if you try to make it too real. And that is the essence of Fantasy, it' transforming reality into the imagination.

${ }^{56}$ Brecht, 1948

${ }^{57}$ Bogad, s/f
} 
con frecuencia. En Windy Day (Día ventoso) (Hubley \& Hubley, 1974), se muestran dos niñas jugando en un jardín, quienes imaginan ser personajes de una obra de teatro; las acciones cotidianas (las niñas tumbadas en el suelo, jugando con una espada o columpiándose en un neumático) se transforman en acciones fantásticas (luchando contra un dragón o convirtiéndose en diversos animales). En Di Abenteuer des Prinzen Achmed (Las aventuras del príncipe Ahmed) (Reiniger, 1926) escenas posibles en la vida real, como el baño en el lago, el harén o la llegada del Califa a la ciudad, se alternan con escenas de pura fantasía: el mago preparando sus conjuros, el caballo volador o el duelo entre el hechicero y la bruja.

\begin{tabular}{|c|c|c|c|}
\hline & $\begin{array}{c}\text { Expresividad } \\
\text { del movimiento }\end{array}$ & Temática & Ejemplos \\
\hline 1 & $\begin{array}{l}\text { Movimiento } \\
\text { vivenciado }\end{array}$ & Fantástica & $\begin{array}{l}\text { Možnosti dialogu (Svankmajer, 1983) } \\
\text { Jason and the Argonauts (animación de Harryhausen, } \\
\text { 1963) } \\
\text { The flying man (Dunning, 1962) } \\
\text { Otesánek (Svankmajer, 2000) }\end{array}$ \\
\hline 2 & $\begin{array}{l}\text { Movimiento } \\
\text { vivenciado }\end{array}$ & Realista & $\begin{array}{l}\text { L'Italiana in Algeri (Gianini \& Luzzati, 1968) } \\
\text { The Street (Leaf, 1974) } \\
\text { Stressed (Kelly, 1994) } \\
\text { Every child (Federenko, 1979) } \\
\text { Sisyphus (Marcell, 1974) [en DVD] }\end{array}$ \\
\hline 5 & $\begin{array}{l}\text { Movimiento } \\
\text { neutro }\end{array}$ & Fantástica & $\begin{array}{l}\text { Bones (Hidaka, 2006) } \\
\text { Histoire d'un prince devenu borgne et mendiant (Miailhe, } \\
\quad \text { 1996) } \\
\text { Eros y Psique (de Vere, 1994) [en DVD] } \\
\text { Bottom's dream (Canemaker, 1984) } \\
\text { Les Conquérants (Banoczki \& Szabo, 2011) }\end{array}$ \\
\hline 6 & $\begin{array}{l}\text { Movimiento } \\
\text { neutro }\end{array}$ & Realista & $\begin{array}{l}\text { Chico y Rita (Errando, Mariscal, \& Trueba, 2010) } \\
\text { Paths of hate (Nenow, 2010) } \\
\$ 9.99 \text { (Rosenthal, 2008) [en DVD] } \\
\text { Azur y Asmar (Ocelot, 2006) } \\
\text { Chainsaw (Tupicoff, 2007) } \\
\text { Hammam (Miailhe, 1992) } \\
\text { Viagem a Cabo Verde (Ribeiro, 2010) } \\
\text { Au premier dimanche d'août (Miailhe, 2000) }\end{array}$ \\
\hline
\end{tabular}

Tabla 2. Expresividad del movimiento en relación a la temática representada

A continuación analizaremos los casos contemplados en la tabla: 


\section{1er caso: Movimiento vivenciado - temática fantástica}

El movimiento vivenciado dota de carácter imaginativo al movimiento animado sea cual sea la temática de la historia, y al presentar los acontecimientos fantásticos de tal manera expresiva, se resalta su naturaleza ajena al mundo real. En Možnosti dialogu (Dimensiones del diálogo) (Svankmajer, 1983) (Fig. 54), las acciones imposibles de papeles doblando, cortando y arrugando metal cobran una dimensión aún más mágica al estar expresadas por medio del movimiento vivenciado, ya que éste refuerza la naturaleza extraordinaria de la acción. Nuevamente nos remitimos a las animaciones de Harryhausen insertas en películas de acción real; él mismo resalta el carácter extraordinario que otorga el movimiento animado $^{58}$, aunque en realidad el resultado no sólo se debe a la técnica (stopmotion), sino a cómo éste autor la maneja. Así mismo, las escenas de fantasía de
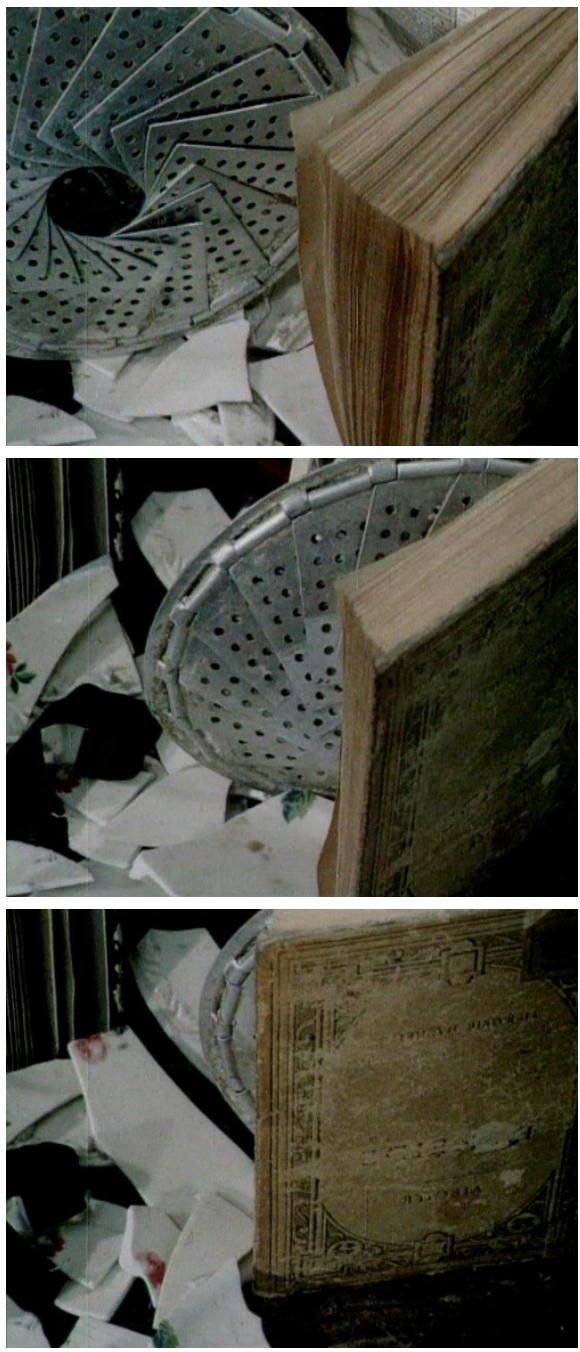
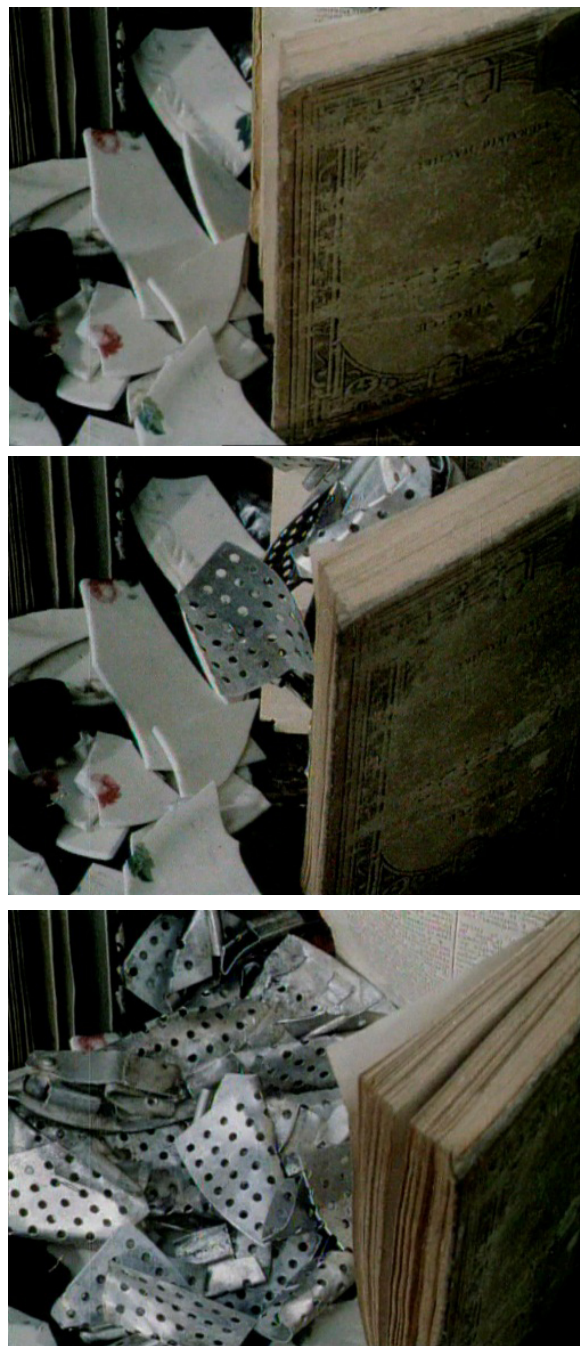

Fig. 54. Jan Svankmajer (1982). Možnosti dialogu (Dimensiones del diálogo). Serie de fotogramas.

\footnotetext{
${ }^{58}$ Harryhausen, en Schickel, 1997
} 
las películas de Miyazaki permiten comprender fácilmente cómo el movimiento vivenciado puede ser muy estimulante cuando se da en acciones que no existen en la vida real; en la obra de este autor, los personajes deben gran parte de su personalidad al movimiento, así, la bruja de Howl no Ugoku Shiro (El castillo ambulante) (2004) cambia de tamaño y de textura según su estado de ánimo y su energía física, destacándola como ser mágico; del mismo modo, los duendes de hollín de Sen to Chihiro no kamikakushi (El viaje de Chihiro) (2001) son inocentes, sagaces y cariñosos por su movimiento delicado y meticuloso, así como por las diferentes maneras en que se desplazan (Fig. 55).

Fig. 55. Hayao Miyazaki (2001). Sen to Chihiro no Kamikakushi (El viaje de Chihiro).

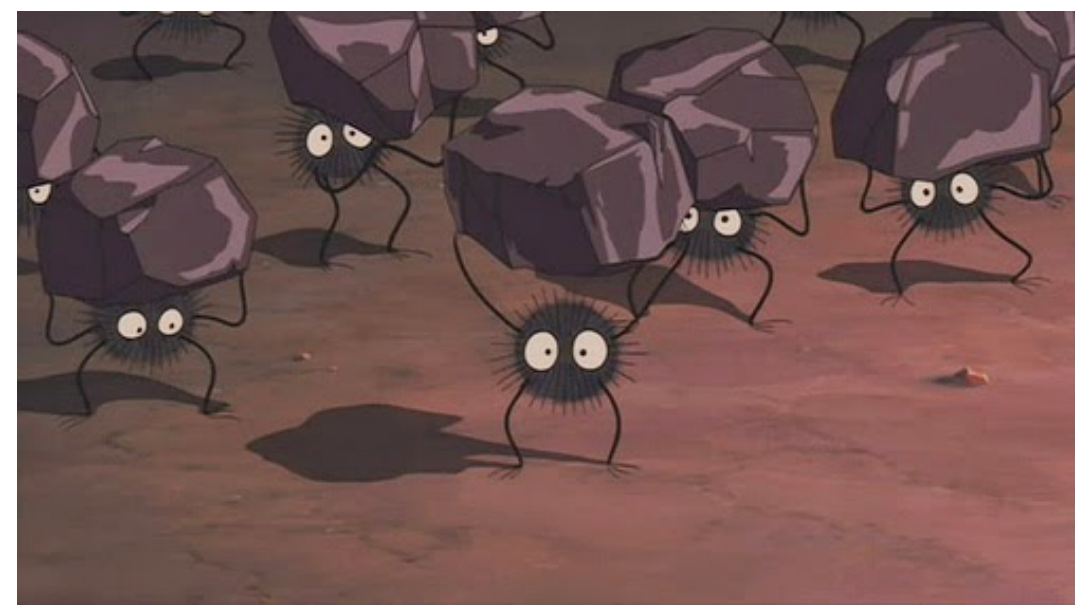

Fig. 56. Jan Svankmajer

(2000). Otesánek

(El pequeño Otik).

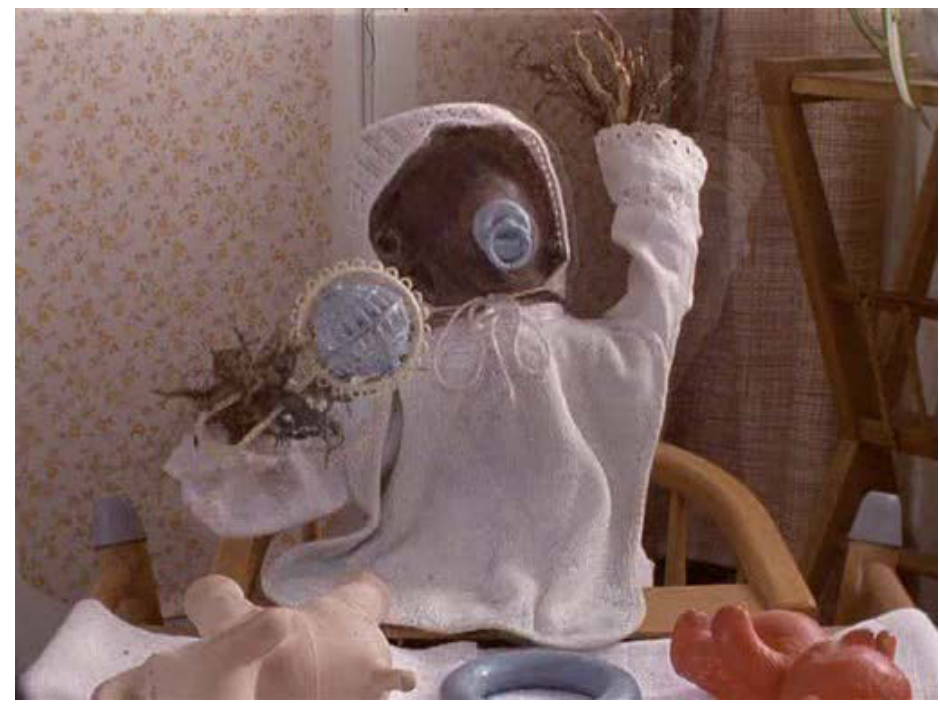

\section{0 caso: Movimiento vivenciado - temática realista}

El carácter sorprendente del movimiento vivenciado también se presenta sobre temáticas realistas. L'Italiana in Algeri (Luzzati \& Gianini, 1968) es narrada mediante acciones reales de seres humanos que se desplazan andando, corrien- 
do, saltando, en una persecución a través de la ciudad y el mar. Pero la expresión dinámica de tales acciones poco tiene que ver con la locomoción real del ser humano, lo que la hace altamente llamativa y crea un lenguaje dinámico muy directo: con esta interpretación de la acción, la animación comunica el carácter simpático del dramma giocoso al que da imagen.

El movimiento vivenciado sobre acciones cotidianas puede mostrar de manera impactante una acción conocida. En Otesánek (El pequeño Otik) (Svankmajer, 2000) (Fig. 56), película que combina acción real y animación, el diseño del bebé (un bebé que es el tocón de un árbol) es fundamentalmente distinto a los actores, distinción que se da también en el movimiento. Para empezar, la animación tiene una frecuencia menor de fotogramas por segundo que la acción real, lo que le otorga una textura diferente, esto, unido a la valoración espacio-temporal (es decir, a la interpretación de la acción), hace resaltar el carácter irreal de los hechos. Un ejemplo concreto es la escena en la que el pequeño Otick llora por primera vez: tiene un movimiento muy alejado del de un bebé, pero al mismo tiempo nos transmite la sensación de la pataleta con gran crudeza.

\section{3o caso: Movimiento neutro - temática fantástica}

Cuando las acciones fantásticas se representan con movimiento neutro, el peso expresivo de la acción irreal recae en otros elementos que no son el movimiento. De esta manera, el movimiento da vida a la acción de fantasía, pero no transmite, como las películas del caso 1, su carácter extraordinario. Esto queda reflejado antes por la narración que por la interpretación dinámica. En Histoire d'un prince devenu borgne et mendiant (Historia de un príncipe que se convirtió en tuerto y mendigo) (Mialhe, 1996) y Psyche \& Eros (de Vere, 1994) se da esta combinación. El resultado es visualmente atractivo por el color, la forma y otras cualidades de la imagen que sobresalen respecto al movimiento, pero éste queda en segundo plano. En Bones (Huesos) (Hidaka, 2006), sin embargo, el movimiento neutro tiene un papel más activo; en esta animación un esqueleto camina por el desierto y se encuentra ante un siniestro dilema: un microondas que, al introducir la espina de un pez, le devuelve la vida. La representación poco expresiva del movimiento (hecha con animación 3D no muy refinada) otorga un toque todavía más absurdo a la historia; de algún modo, este dinamismo participa directamente en la expresividad del esqueleto, le imbuye una actitud inocente. Algo parecido ocurre en Les Conquérants (Los conquistadores) (Banoczki \& Szabo, 2011), en la que, como ya digimos, el moviminto neutro paradojicamente aporta carácter a los acontecimientos. 
Fig. 57.

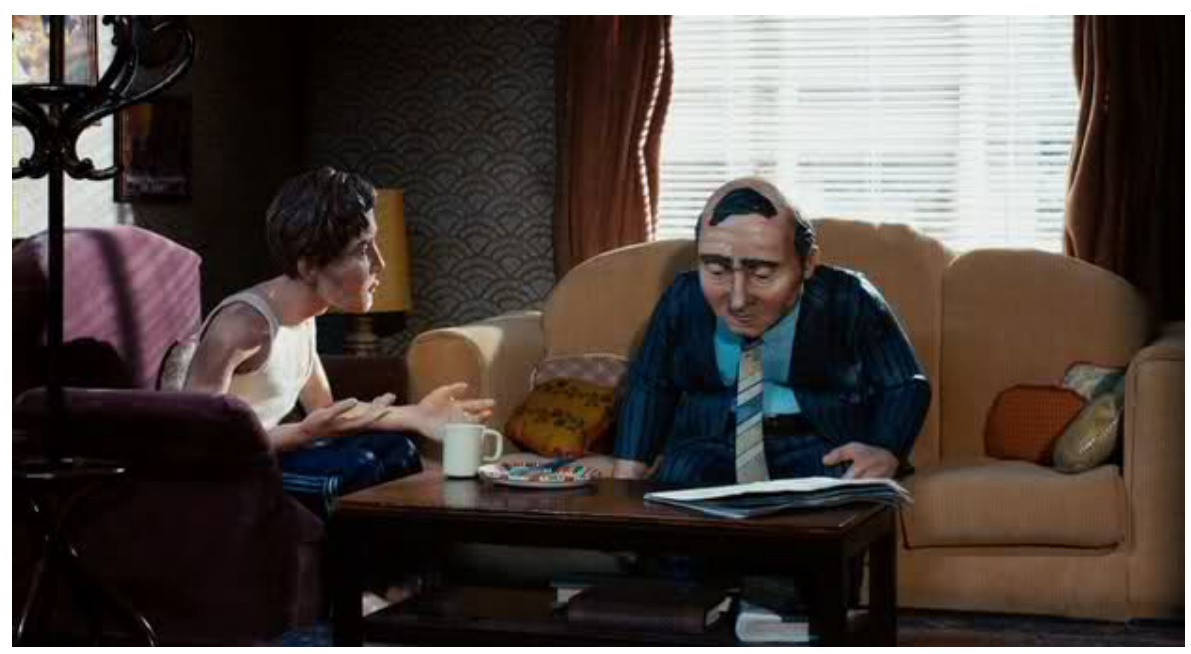

Tatia Rosenthal

(2008). 9.99\$
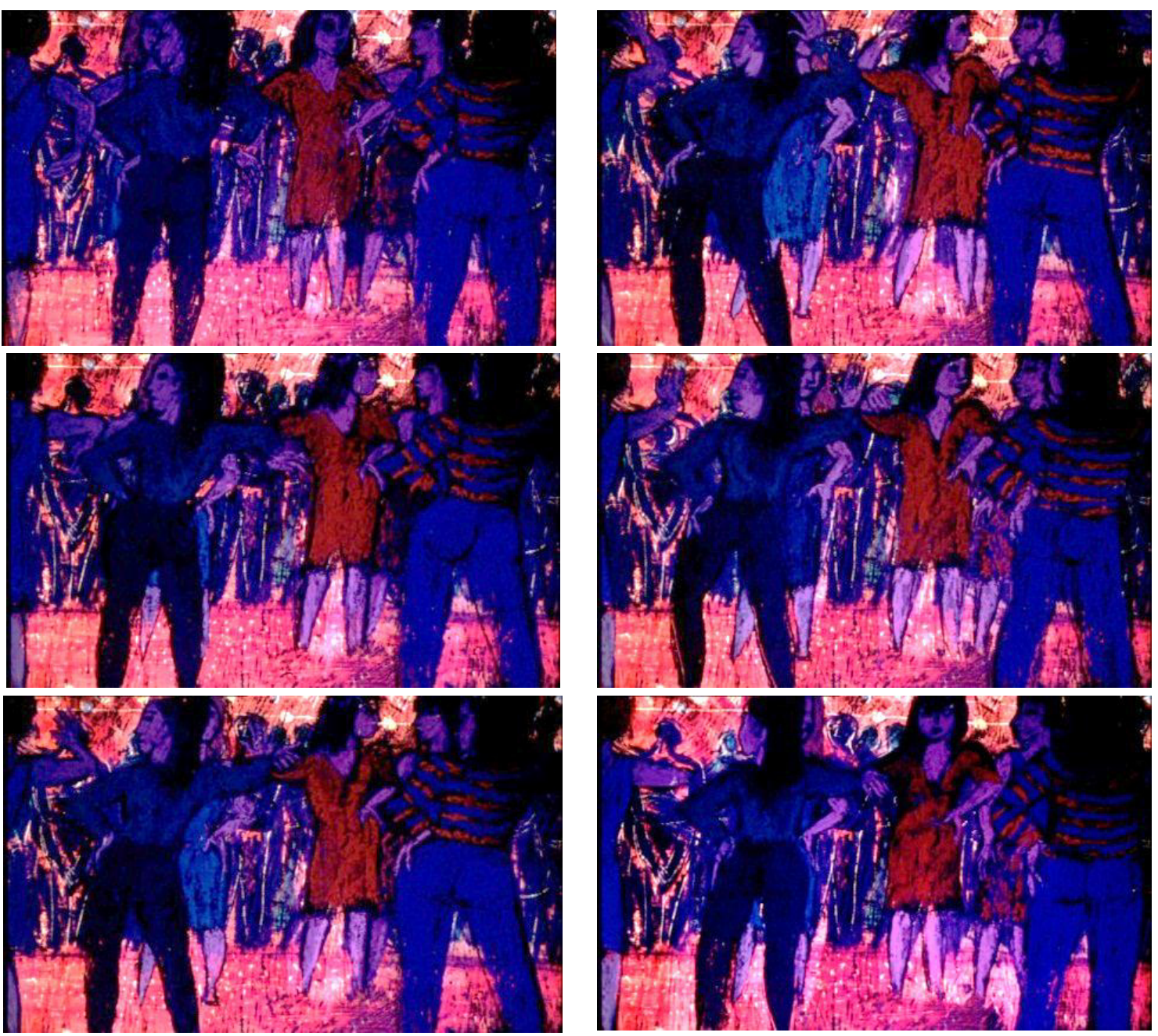

Fig. 58. Florence Miailhe (2002). Au premier dimanche d'août (El primer domingo de agosto). Serie de fotogramas. 


\section{0 caso: Movimiento neutro - temática realista}

En este caso encontramos que, como en el anterior, el peso expresivo recae en la cualidad plástica y otros elementos de la obra antes que en la representación del movimiento. Au premier dimanche d'août (Miailhe, 2000) (Fig. 58), las fundamentalmente realistas Chico y Rita (Errando, Mariscal, \& Trueba, 2010) y \$9.99 (Rosenthal, 2008) (Fig. 57) [en DVD], así como los ya mencionados videos educativos y explicativo correponden a este tipo de combinación de temática y movimiento. En ellas el movimiento neutro puede ser una necesidad, como en los videos expositivos; bien formar parte del lenguaje estético de la obra, como en Chico y Rita y \$9.99; o puede tener una presencia en segundo plano, como en Au premier dimanche d'août, en la que la acción lenta y regular no es la más acorde a la temática que representa: un baile de verano.

La cualidad expresiva de la representación del movimiento vivenciado en animación trasciende las temáticas y se manifiesta tanto en aquellas no existentes en la vida real como en aquellas que siguen las normas de la naturaleza o la lógica. Por otro lado, el movimiento neutro también existe en obras de diversas temáticas, no sólo, como cabría esperar, en aquellas de temática realista, que podrían considerarse a priori como las que requerirían por excelencia el movimiento poco expresivo. 


\section{CONCLUSIONES}

- Toda representación es una interpretación de la realidad. El nivel de naturalismo de una obra de animación depende, como en toda disciplina, de varios factores. Por un lado, la animación permite representar el movimiento, si así se desea, con un gran nivel de análisis gracias a la representación minuciosa de la mecánica; además, el cine estereoscópico y la realidad virtual juegan también con las tres dimensiones y la experiencia inmersiva para generar la ilusión de realidad. Por otro lado, la ilusión de movimiento no convierte a este medio en paradigma de la representación naturalista, ya que éste puede representarse de diversas maneras, a veces totalmente desvinculado del movimiento real.

- La representación naturalista del movimiento en animación normalmente involucra varios factores: el parecido con la mecánica real, el parecido con la captura de vídeo y el uso del lenguaje del cine de acción real (inclusive la recreación de efectos ópticos que produce la cámara cinematográfica). El cine de acción real es también un medio en el que se interpreta el movimiento, pero no lo es en la valoración espacio-temporal, es decir, en la representación detallada del movimiento mediante los fotogramas (que corresponden en cine a fotografías), por eso se identifica con la representación naturalista. Además, el lenguaje cinematográfico en animación, por crear la ilusión de que los fenómenos representados (de naturaleza plástica) tienen lugar en un mundo que es registrado por una cámara imaginaria, se asocia con el naturalismo (esto es sobre todo aplicable a la animación de dibujo y recortes, ya que otras técnicas sí emplean la fotografía en condiciones similares al cine de acción real). Por el contrario, la representación del movimiento se considera no naturalista en la medida en que se aleja de los factores mencionados. Pero aunque todas estas características acercan en cierto modo la representación dinámica a la realidad, su presencia en una película no indica indiscutiblemente que la representación del movimiento sea naturalista.

- En cuanto a la expresividad, vemos que el movimiento vivenciado presenta una serie de aspectos en común con la representación no naturalista: la frecuente desvinculación de la mecánica real, la vibración de la imagen, la inserción de los acontecimientos en un espacio vivencial y la tendencia a la variedad de resultados móviles. No obstante, estas cualidades no definen el movimiento vivenciado, por eso hay obras que no cumplen estas características y que, sin embargo, sugieren 
la sensación de vivir el movimiento; y tampoco la presencia de estas características provoca siempre que el movimiento sea expresivo. Así pues, pese a los puntos de coincidencia, no existe una relación de causa-consecuencia entre el movimiento vivenciado y la representación no-naturalista.

Así mismo, el movimiento neutro presenta una serie de elementos en común con la representación naturalista: la recreación exacta de la mecánica, la inserción de los acontecimientos en un espacio de perspectiva proyectiva, la ausencia de vibración de la imagen y la homogeneidad del movimiento entre películas. Pero el movimiento neutro se da en animaciones de diversos niveles de naturalismo, lo que demuestra que no hay una relación causa-efecto entre ellos. Cabe matizar que aunque la expresión neutra se define por la homogeneidad de los resultados dinámicos, la representación naturalista muestra tan sólo una tendencia a la similitud de resultados, pues también presenta mucha riqueza y variedad de lenguajes.

- En cuanto al nivel de síntesis o análisis del movimiento, hemos observado que esto no determina la expresividad: el movimiento vivenciado y el neutro se dan tanto en animaciones de representación en síntesis como en animaciones muy analíticas.

- Respecto a la relación entre el diseño del móvil y su movimiento, vemos que el movimiento vivenciado y el neutro se dan sobre todo tipo de formas, y que, aunque el diseño de personajes y otros elementos móviles afecta a la estética de la película, no condiciona la expresividad dinámica.

- Finalmente, nos preguntamos acerca de la viabilidad de expresar de manera vivenciada movimientos no existentes en la realidad, ya que la expresión vivenciada consiste en transmitir la experiencia dinámica como si se viviera u observara en primera persona. Vemos que todo arte representa temas inexistentes o fantásticos, también la animación, y del mismo modo que en el resto de disciplinas, se pueden expresar vívidamente experiencias que no han tenido lugar en la realidad física. Así mismo, la concordancia entre el realismo de los acontecimientos y el nivel de naturalismo con el que se representan tampoco implica que el movimiento sea vivenciado o neutro, sin embargo, destacamos que los hechos realistas o cotidianos se revisten de un atractivo especial cuando se representan con un movimiento alejado de la realidad. 


\section{CONCLUSIONES FINALES}





\section{CONCLUSIONES FINALES}

- La representación del movimiento en animación se aborda desde distintas perspectivas. Observamos que en las representaciones plásticas en general y también en animación, el movimiento se transmite con diferentes grados de intensidad. Para dar nombre y explicar este fenómeno nos hemos basado en los conceptos de "espacio vivencial" y "espacio matemático" desarrollados por Otto Friedrich Bollnow. El primero es el espacio de la experiencia del hombre, definido por las posibilidades de movimiento y que tiene implicaciones emocionales; y el espacio matemático es principalmente el determinado por los ejes de altura, anchura y profundidad, y en general el espacio entendido desde todo sistema que lo hace objetivo, impersonal o regular.

Hemos denominado "movimiento vivenciado" a las representaciones dinámicas más expresivas, aquellas que evocan las sensaciones cinestésicas que sentiríamos al experimentar el movimiento en primera persona o las impresiones que transmite su observación; en el extremo opuesto estarían las representaciones en las que el objetivo del movimiento se concentra en informar de sus cualidades básicas: dirección, sentido, velocidad y aceleración, libre de connotaciones subjetivas; este tipo de expresión lo hemos denominado "movimiento neutro".

Además de transmitir o no sensaciones cinestésicas, hay otras cualidades que colaboran en que la representación móvil sugiera la vivencia personal del movimiento o que, por el contrario, se despersonalice. Estas cualidades, que también definen los conceptos que presentamos, son la capacidad para transmitir el contenido emocional por medio del movimiento (muchas veces a través de metáforas o comparaciones), la transmisión u omisión de peculiaridades del movimiento que responden a la percepción subjetiva, así como la ubicación de los acontecimientos en un espacio vivencial o matemático-neutro acorde con los conceptos de Bollnow sobre el espacio.

Las cualidades que definen la expresividad del movimiento pueden darse juntas o de manera aislada; así mismo, una obra también puede presentar a la vez cualidades del movimiento vivenciado y del neutro. En tal caso, el protagonismo de unas $u$ otras es lo que determinará la expresividad de la obra. Además, estas 
cualidades se presentan en diferentes grados de "pureza" o intensidad y no siempre en toda la película.

- La representación del movimiento en animación es muy variada en soluciones dinámicas y plásticas, ya que todos los componentes dinámicos son versátiles y pueden emplearse de infinidad de maneras. La riqueza visual del movimiento vivenciado es más amplia que la del movimiento neutro debido a que, al centrarse en la subjetividad de la experiencia cinética, abre el abanico a multitud de soluciones, frente al movimiento neutro, del que precisamente la homogeneidad de la representación del movimiento es una de sus características distintivas. No obstante, el movimiento neutro es también muy variado y presenta formas originales.

Sin entrar en el campo de la psicología de la creación, sino como propuesta de creación plástica, creemos que para representar el movimiento como vivenciado es prioritario el trabajo introspectivo y de recordación de aquello que se siente física y emocionalmente en la experiencia de un movimiento o un acontecimiento. Esto también es aplicable a las representaciones de hechos o acciones fantásticas, no sólo reales, ya que también se pueden evocar sensorialmente mediante la imaginación. Mientras que para expresar el movimiento de manera neutra, la representación debe mantenerse alejada de la perspectiva personal y ceñirse a la transmisión libre de interpretaciones personales, prevaleciendo la representación objetiva, ya sea por medio de la despersonalización o centrándose en qué ocurre y no en cómo ocurre. De este modo el movimiento vivenciado se obtiene al enfatizar aquello que hace que la animación despierte en el espectador el recuerdo del movimiento vivido $\mathrm{u}$ observado, o haga imaginar lo que se sentiría físicamente. Mientras que el movimiento neutro se consigue priorizando la transmisión del mensaje objetivo frente a los valores estéticos y sensoriales del movimiento.

Pero al analizar detenidamente cada componente dinámico de la animación (el cambio de imagen, la valoración espacio-temporal, la composición móvil, la distribución de la intensidad cinética y el relato), observamos que no existen maneras determinadas de emplearlos de modo que proporcionen incondicionalmente movimiento vivenciado o neutro. La expresividad del movimiento no se obtiene mediante un uso específico de elementos concretos, ni por la aplicación de ciertos recursos, sino por cómo se emplean éstos en cada obra de animación, según las necesidades expresivas. Los elementos, recursos y técnicas no son portadores de un grado de expresividad concreto. 
La expresividad proviene del dinamismo que se crea a través de los componentes dinámicos, en su interacción. Para que el movimiento resultante sea vivenciado no es necesario que todos los componentes dinámicos de la película sean igual de expresivos. A veces el peso expresivo recae sobre uno de ellos, siendo suficiente para evocar sensaciones cinestésicas o transmitir emociones por medio del movimiento. Así, por ejemplo, si la valoración espaciotemporal es poco expresiva, esto puede compensarse por medio de la composición móvil. Sin embargo, debido a esto, para que el movimiento sea neutro normalmente es necesario dirigir todo los componentes, o al menos los más llamativos, hacia la neutralidad.

No hay jerarquía entre los componentes dinámicos, sin embargo, a diferencia de los demás componentes dinámicos, el relato, si bien participa en la configuración y apreciación estética de la obra, tiene una influencia indirecta sobre la representación del movimiento; no obstante, mediante el relato se pueden mostrar los acontecimientos desde el punto de vista de un personaje, lo que sería un punto de partida para expresar el movimiento vivenciado.

La valoración espacio-temporal (el cambio progresivo de la imagen a través de los fotogramas) tiene un papel peculiar, ya que es el componente que más difiere entre el cine de acción real y la animación. El desarrollo pormenorizado de la acción depende de la técnica de animación y puede abordarse con mayor o menor desvinculación de la mecánica real. Aunque las técnicas basadas en la captura de movimiento y la recreación menos interpretativa de la mecánica tienden a no transmitir sensaciones cinestésicas, el movimiento vivenciado puede obtenerse por medio de cualquier técnica y la utilización de la mecánica no desemboca incondicionalmente en representación neutra.

- El nivel de naturalismo no determina que el movimiento sea vivenciado o neutro. Es cierto que el movimiento neutro y la representación naturalista tienen características que se dan juntas con relativa frecuencia, como la recreación exacta de la mecánica real, la ausencia de vibración, la inserción de los acontecimientos en un espacio perspectivo de geometría proyectiva y una menor variedad en la representación del movimiento, sin embargo todas estas cualidades también se dan en películas que expresan el movimiento vivenciado. Del mismo modo, las animaciones con movimiento vivenciado suelen presentar una serie de características comunes a la animación no-naturalista: la alteración de la mecánica, la vibración de la imagen, la ubicación de los acontecimientos en un espacio vivencial y una amplia variedad en la representación del movimiento. Pero también hay animaciones con estas propiedades que no presentan movimiento vivenciado. Esto 
demuestra que no hay relación de causa-consecuencia entre la expresividad del movimiento y el nivel de parecido con la realidad del movimiento.

Del mismo modo que la síntesis o análisis del movimiento no es indicativo del nivel de naturalismo, tampoco señala ni provoca que la expresión sea vivenciada o neutra, ya que ambos tipos de expresión se presentan tanto en animaciones que sintetizan el movimiento como en animaciones más analíticas.

En cuanto al lenguaje cinematográfico o el énfasis en las cualidades plásticas del medio pictórico, aunque puedan estar más o menos asociadas a la animación naturalista y no-naturalista respectivamente, no influyen en la expresividad del movimiento. Así mismo, la cualidad expresiva de la obra tampoco está determinada por el tipo de acciones representadas ni por el diseño del móvil, aunque todos los elementos, sin duda, influyen en la estética de la obra.

Además de dar respuesta a los objetivos planteados, a lo largo del estudio hemos alcanzado una visión profunda del tema, que nos ha permitido extraer las siguientes ideas:

- Cada tipo de expresividad es adecuada para unos contextos. Por la capacidad para expresar el movimiento de manera sensorial, el movimiento vivenciado es un tipo de expresión dinámica que suele encontrarse en el arte; mientras que el movimiento neutro es ideal para el ámbito científico y educativo por ser principalmente expositivo. Aunque esto también es muy flexible, ya que las animaciones de ámbito científico y educativo pueden aprovechar las cualidades expresivas del movimiento vivenciado para transmitir otro tipo de valores además de la información objetiva (como despertar interés o promover una actitud) y el movimiento neutro puede aprovecharse en el ámbito artístico (por ejemplo con fines retóricos o estéticos).

- En definitiva, el movimiento vivenciado y el neutro no se definen por características cinematográficas o plásticas, ni por el uso de una técnica o recursos estilísticos específicos, ni por el nivel de naturalismo, ni tampoco por el ámbito al que vaya destinada la obra; aunque todos estos elementos influyen en la estética y en el conjunto de la obra, lo que define el movimiento vivenciado y el neutro son las sensaciones que provocan en el espectador, y no hay fórmulas que permitan aproximarse a uno $u$ a otro. Determinar un modo de hacer el movimiento vivenciado y el neutro sería condenar unas formas, unas características cinematográficas, unos recursos, etc. como expresivos o no 
expresivos, y si, hipotéticamente, esa fórmula se siguiera siempre, ambos tipos de representación acabarían perdiendo la riqueza dinámica y formal que presentan. 

FINAL CONCLUSIONS 



\section{FINAL CONLUSIONS}

- The depiction of movement in animation is addressed from different perspectives. We observe that within visual depictions in general, and also in animation, movement is conveyed with different degrees of intensity. In order to name and explain this phenomenon we have relied on the concepts of "livedspace" and "mathematical space", as developed by Otto Friedrich Bollnow. The former is the space of the experience of man, defined by the possibilities of movement, and which has emotional implications; and the mathematical space is mainly the one determined by the height, length, and width axes, and generally, the space as conceived by any system that makes it objective, impersonal or regular.

We have called "lived-movement" to the most expressive dynamic representations, those which evoke the kinaesthetic sensations we would feel when first-personally experiencing the movement, or the impressions that its perception transmits; in the other extreme we find the depictions in which the goal of the movement is to inform of its basic qualities: direction, sense, speed, and acceleration, free of subjective connotations; this type of expression has been denominated "neutral movement".

Besides transmitting (or not) kinaesthetic sensations, there are other features that contribute to suggest the personal experience of movement, or else, on the opposite, to the depersonalization of such experience. These features, which also define the concepts we present, are the capacity to transmit emotional content by means of movement (on many occasions through metaphors or comparisons), the transmission or omission of the peculiarities of movement that respond to the subjective perception, as well as the localization of events in an lived or mathematical-neutral space (according with Bollnow's concepts about space).

The qualities that define the expressiveness of movement can obtain jointly or in isolation. Likewise, one work can present simultaneously features of both lived and neutral movement. In such case, the prominence of one or the other will determine the expressiveness of the work. In addition, these qualities appear with different degrees of "purity" or intensity, and not always along the whole film

- The depiction of movement in animation is diverse in dynamic and visual solutions, given that all the dynamic components are quite versatile and can be employed in a variety of ways. The visual richness of lived-movement is wider than that of neutral one, due to the fact that, in focusing on the subjectivity of 
kinaesthetic experience, it allows for a wide range of solutions, as opposed to neutral movement, which is precisely characterized in terms of the homogeneity of depiction of movement. Nevertheless, neutral movement is also quite diverse and presents original forms.

Without addressing the psychology of creation field, but as a proposal of artistic creation, we think that the tasks of introspecting and remembering that which is physically and emotionally felt in the experience of a movement or event are essential in order to represent lived-movement. This also applies to representations of fantastic facts or actions, not only real, as it also can evoke sensory through imagination. While to express movement in neutral terms, the representation should stay away from the personal perspective and be limited to the a depiction which be free of personal interpretations, prevailing objective representation, either through depersonalization or focusing on what happens, not how It happens. Thus lived-movement is obtained by emphasizing what makes animation awaken in the viewer the memory of lived or observed movement, or helping to imagine what it would be felt physically. While neutral movement is achieved by giving priority to the transmission of the objective message above the aesthetic and sensorial values of movement.

But in closely analysing each of the dynamic components of animation (change of image, timing, moving composition, distribution of kinetic intensity, and narrative), we observe that there are no determinate manners to employ them in such a way that they unconditionally provide lived or neutral movement. The expressiveness of movement is not attained by means of a specific usage of particular elements, nor by the application of certain resources, but by the way in which these elements and resources are employed in a particular animated work, according to the expressive necessities of the artist. The elements, resources, and techniques do not possess a determined degree of expressiveness.

Expressiveness comes from the dynamism created through the dynamic components in their interaction. In order for the resulting movement to be lived, it is not necessary that all the dynamic components in the film be equally expressive. Sometimes, the expressive weight lies over one of them, being enough to evoke kinaesthetic sensations, or transmit emotions by means of movements. Thus, for instance, if the timing is not much expressive, this can be compensated by means of moving composition. However, for this reason, in order for the movement to be neutral it is normally required to address all the components, or at least the most prominent, towards neutrality. 
There is no hierarchy between the dynamic components. However, narrative (as opposed to other dynamic components), which contributes to the configuration and aesthetic appraisal of the artwork, also has a direct influence over the depiction of movement. Nevertheless, by means of the narrative events can be presented from a character's point of view, an aspect which constitutes a departure point for the expression of lived-movement.

Timing (progressive change of the image along the different frames) has a peculiar role, given that is the component that differs the most with life action cinema and animation. The detailed development of the action depends on the technique of animation and can be addressed with lesser or greater detachment from real mechanics. Even if the techniques based on the motion capture and the depictions less interpretive of the mechanics have a tendency to not transmit kinaesthetic sensations, lived-movement can be obtained by means of any technique, and the usage of mechanics does not unconditionally lead to neutral representation.

- The degree of naturalism does not determine the fact that the movement depiction be lived or neutral. Certainly, neutral movement and naturalistic representation have features that frequently co-exist, such as the exact depiction of actual mechanics, absence of vibration, the insertion of elements in a perspective of projective geometry and a less variety in depiction of movement. However, we also find all these features in films which express lived-movement. Likewise, animations with lived-movement usually present certain features which are common to non-naturalistic representation: alteration of the mechanics, the flicking image, the location of the events within a non-realist space and a great range of variety in depiction of movement. But there are also animations sharing these features which nonetheless depict lived-movement. This reveals that there is no cause-consequence relation among the expressiveness of movement and the degree of similarity with movement in reality.

Besides not being indicative of the degree of naturalism, the synthesis and analysis of movement does not indicate that the expression be lived or neutral, for both types of expression appear in animations which synthesize movement, as well as in more analytic animations.

With respect to the cinematographic language or the emphasis in the visual qualities of the pictorial medium, in spite of the fact that they can be associated to naturalist and non-naturalist animation, respectively, they not have influence in the expressiveness of movement. Likewise, the expressive quality of the work is 
neither determined by the sort of represented actions, nor by the design of the mobile, although all these elements doubtlessly affect the aesthetics of the work.

In addition to responding to the objectives, along the study we have achieved a deep vision of the subject, which has allowed us to extract the following ideas:

- Each kind of expressiveness is adequate to some contexts. By its capacity to express movement in a sensory way, lived-movement is a kind of dynamic expression often found in art, whereas neutral movement is ideal for scientific and educational fields, because it is fundamentally expositive. But this is also quite flexible, because the animations belonging to scientific and educational field can also take profit of the expressive qualities of lived-movement, in order to transmit other sort of values besides objective information (such as arising interest or promoting an attitude), and the neutral movement can be used in the artistic field as well (for instance with rhetorical or aesthetic purposes).

- To sum up, lived and neutral movement are not defined by their cinematographic or visual features, nor by the use of certain specific techniques or artistic resources, nor by the degree of naturalism, nor by the field the work is addressed to. Although all these elements influence the aesthetics and the whole of the work, what define each kind of movement are the sensations they arise in the spectator, and there is no formula that allows us to attain one or the other. Determining a way of creating lived and neutral movement would be to condemn certain forms, certain cinematographic features, resources, etc., as expressive or non-expressive. And if, hypothetically, this formula were always implemented, both kinds of expression would lose the dynamic and formal wealth they present. 


\section{Movimiento vivenciado y movimiento neutro. Estudio sobre la expresividad de la representación del movimiento en animación}

\section{RESUMEN}

Existe gran diversidad en la representación del movimiento en animación, no sólo en el arte, sino también en el campo científico, educativo y en todos los contextos y formatos imaginables a los que este medio de expresión ha llegado. La animación forma parte de nuestra vida cotidiana, tanto que no nos extraña, por ejemplo, ver en televisión una animación 3D en la esquina de la pantalla que anticipa el salto que va realizar un nadador en la competición retransmitida, animación radicalmente diferente al último largometraje familiar en cartelera o a las animaciones clásicas que aún hoy se siguen emitiendo en televisión. Entre todas estas obras observamos que el movimiento se transmite en diferentes grados de intensidad, que pueden ser desde los más potentes y audaces hasta los más anodinos. Sin embargo, si analizamos aspectos dinámicos y técnicos, como el tipo de acciones representadas, la trayectoria, la técnica de animación, la frecuencia de imágenes por segundo, el nivel de naturalismo o incluso el contexto, encontramos que, pese a las evidentes diferencias, no es tan sencillo asociar estos aspectos con un nivel mayor o menor de expresividad.

Con el objetivo de definir las cualidades que caracterizan los dos extremos de intensidad expresiva del movimiento y profundizar en cómo se presentan en la animación, hemos denominado estos fenómenos "movimiento vivenciado" y "movimiento neutro". Para ello hemos partido de los conceptos "espacio vivencial" y "espacio matemático" de Otto Friedrich Bollnow, quien describe el primero como el espacio de la experiencia física y emocional humana, y el segundo como toda manera objetiva de explicar el espacio. En síntesis, el movimiento se expresa como vivenciado cuando se evoca la sensación de vivir el movimiento en primera persona o cuando se trasmiten las sensaciones visuales y emocionales que suscita su experiencia. El movimiento neutro es opuesto en expresividad, su prioridad es la comunicación más objetiva posible, expositiva y explicativa, libre de connotaciones personales. Además, el movimiento neutro tiene otra característica definitoria: la homogenización de la representación.

Por medio del análisis de películas de animación figurativas de diversas técnicas, así como a través de la práctica artística personal, hemos estudiado 
pormenorizadamente los componentes dinámicos de la animación, que hemos clasificado como: cambio de imagen, valoración espacio-temporal (timing), composición móvil, distribución de la intensidad cinética y presentación de la historia (relato); y hemos observado la influencia de éstos sobre la expresividad del movimiento. Esto incluye el papel de la técnica, la amplia variedad en que se representa la mecánica y la aplicación de un estilo de animación específico, entre otros.

Así mismo, hemos estudiado la relación entre el nivel de expresividad del movimiento y el grado de naturalismo, dada la existencia de elementos que suelen tener en común la representación vivenciada con la no-naturalista, y el movimiento neutro con el movimiento que se acerca más a la apariencia real.

La conclusión fundamental de esta investigación es que el movimiento vivenciado y el neutro no quedan determinados por cómo se emplean los componentes dinámicos, ni por la técnica empleada, ni por el grado de naturalismo. Estos modos de expresión se definen por las sensaciones que evocan en el espectador. La riqueza que ambos tipos de expresión presentan demuestra que no es posible determinar fórmulas para obtener el movimiento vivenciado o el neutro; esto supondría encasillar los recursos, técnicas, y demás elementos como propios de un grado de expresividad concreto. 


\section{Lived-Movement and Neutral Movement. A Study on Expressiveness in the Depiction of Movement in Animation}

\section{SUMMARY}

There is great diversity in the depiction of movement in animation, not only in art, but also in the scientific and educational fields, and in all imaginable contexts and formats reached by this means of expression. Animation is part of our everyday life, so much so that it not surprises us, for instance, to see in television a 3D animation anticipating the jump that a swimmer is going to perform in a broadcasted competition, an animation that is radically distinct to the last feature film in theatres or the classic cartoons that still today are broadcasted on TV. Between all these different works we observe that the movement is transmitted with different degrees of intensity, from the most powerful to the most anodyne. However, if we analyse the dynamic and technical aspects, like the kind of represented actions, the trajectory, the animation technique, the frequency of frames per second, the degree of naturalism or even the context, we find that, in spite of the evident differences, it is not so simple to associate these aspects with a greater or lesser degree of expressiveness.

With the aim of dining the features that characterize the two extremes of expressive intensity of movement, and deepening in how they are presented in animation, we have labelled these phenomena "live-movement" and "neutral movement". In order to do so we have proceeded upon the concepts of "livedspace" and "mathematical space" from Otto Friedrich Bollnow, who describes the former as the space of physical and emotional human experience, and the latter as any objective way to explain such space. In short, the movement is expressed as lived when it evokes the sensation of experiencing it first-personally, or when the visual and emotional sensations that its experience raises are depicted. Neutral movement is opposed in expressiveness, its priority is maximal objectivity, expositive, explanatory, and devoid of any personal connotation. Moreover, neutral movement has another defining feature: homogenization in depiction.

By means of the analysis of figurative animation films in different techniques, as well as personal artistic practice, we have studied in detail the dynamic 
components of animation, which we have classified as: image change, timing, moving composition, distribution of kinetic intensity and presentation of the story (narrative); and we have observed the influence that those exert over the expressiveness of movement. These include the role of technique, the wide variety of ways in which the mechanics are depicted and the application of a particular animation style, among others.

Likewise, we have studied the relation between the degree of expressiveness of movement and the degree of naturalism, given the existence of elements that have in common lived-movement with the non-naturalist depiction, and the neutral movement with the animated movement that is closer to the real appearance.

The main conclusion of this research is that lived and neutral movement are determined neither by the way the dynamic components are employed, nor by the technique employed, nor by the degree of naturalism. These sorts of expression are defined by the sensations they evoke in the spectator. The richness that both expression types present shows that it is not possible to provide formulas to get lived or neutral movement; this would imply classifying the resources, techniques, and other elements as distinctive features of a specific degree of expressiveness. 


\section{Moviment vivenciat i moviment neutre. Estudi sobre l'expressivitat de la representació del moviment en animació}

\section{RESUM}

Existeix gran diversitat en la representació del moviment en animació, no solament en l'art, sinó també en el camp científic, educatiu i en tots els contextos i formats imaginables als quals aquest mitjà d'expressió ha arribat. L'animació forma part de la nostra vida quotidiana, tant que no ens estranya, per exemple, veure en televisió una animació 3D en la cantonada de la pantalla que anticipa el salt que va a realitzar un nadador en la competició retransmesa, animació radicalment diferent a l'últim llargmetratge familiar en cartellera o a les animacions clàssiques que encara avui se segueixen emetent en televisió. Entre totes aquestes obres observem que el moviment es transmet en diferents graus d'intensitat, que poden ser des dels més potents i audaços fins als més anodins. No obstant això, si analitzem aspectes dinàmics i tècnics, com el tipus d'accions representades, la trajectòria, la tècnica d'animació, la freqüència d'imatges per segon, el nivell de naturalisme o fins i tot el context, trobem que, malgrat les evidents diferències, no és tan senzill associar aquests aspectes amb un nivell major o menor d'expressivitat.

Amb l'objectiu de definir les qualitats que caracteritzen els dos extrems d'intensitat expressiva del moviment $\mathrm{i}$ aprofundir en cóm es presenten en l'animació, hem denominat aquests fenòmens "moviment vivenciat" i "moviment neutre". Per això hem partit dels conceptes "espai vivencial" i "espai matemàtic" d'Otto Friedrich Bollnow, qui descriu el primer com l'espai de l'experiència física i emocional humana, i el segon com tota manera objectiva d'explicar l'espai. En síntesi, el moviment s'expressa com vivenciat quan s'evoca la sensació de viure el moviment en primera persona o quan es transmeten les sensacions visuals $i$ emocionals que suscita la seua experiència. El moviment neutre és oposat en expressivitat, la seua prioritat és la comunicació més objectiva possible, expositiva i explicativa, lliure de connotacions personals. A més, el moviment neutre té una altra característica definitòria: la homogeneïtzació de la representació.

Mitjançant l'anàlisi de pel-lícules d'animació figuratives de diverses tècniques, així com a través de la pràctica artística personal, hem estudiat detalladament els components dinàmics de l'animació, que hem classificat com: canvi d'imatge, 
valoració espai-temporal (timing), composició mòbil, distribució de la intensitat cinètica i presentació de la història (relat); i hem observat la influència d'aquests sobre l'expressivitat del moviment. Açò inclou el paper de la tècnica, l'àmplia varietat en que es representa la mecànica i l'aplicació d'un estil d'animació específic, entre altres.

Així mateix, hem estudiat la relació entre el nivell d'expressivitat del moviment i el grau de naturalisme, donada l'existència d'elements que solen tenir en comú la representació vivenciada amb la no-naturalista, i el moviment neutre amb el moviment que s'acosta més a l'aparença real.

La conclusió fonamental d'aquesta recerca és que el moviment vivenciat i el neutre no queden determinats per com s'empren els components dinàmics, ni per la tècnica empleada, ni pel grau de naturalisme. Aquestes maneres d'expressió es defineixen per les sensacions que evoquen en l'espectador. La riquesa que tots dos tipus d'expressió presenten demostra que no és possible determinar fórmules per a obtenir el moviment vivenciat o el neutre; açò suposaria encasellar els recursos, tècniques, i altres elements com a propis d'un grau d'expressivitat concret. 
ANEXOS 



\section{Anexo 1}

DESCRIPCIÓN DE LAS ANIMACIONES DE REALIZACIÓN PROPIA

PREMIOS Y PROYECCIONES DE ESTAS PELÍCULAS

\section{Elementos principales relacionados con la representación del movimiento en cada animación:}

LORENA: Transición de fotogramas por fundidos encadenados.

TÁNTALO: Transición de fotogramas por fundidos encadenados, variación de la frecuencia de imágenes por segundo y metamorfosis detmóvilflos personajes.

LIBIDINIS: Relato no narrativo, sensación de movimiento en los fotogramas, la composición móvil se configura a través de movimientos recurrentes (trayectorias curvas y rotaciones)

SANRESIONE: Movimiento de cámara por animación. Protagonismo de las trayectorias. Sensación de movimiento en cada fotograma.

BÁLADI: movimiento del espacio Sensación de movimiento en los fotogramas. Combinación de los conocimientos técnicos de la danza del vientre en combinación la invención de una mecánica imposible.

TARONXADA (créditos): movimiento de cámara

MíO, TUYO, NUESTRO Narración y movimiento de cámara por animación. Protagonismo de la composición, tanto por la distribución de los elementos en cada plano como por la sucesión de acciones. Distribución de la intensidad cinética.

HOUYHNHNM: narración Protagonismo de la composición, tanto por la distribución de los elementos en cada plano como por la sucesión de acciones. Distribución de la intensidad cinética.

EXPERIMENTACIÓN Movimiento por fases yuxtapuestas. Estos experimentos surgieron a raíz de la intensidad cinética que pretendía obtener en algunas escenas de la película en proyecto Houyhnhnm.

TUTUTÚ: Movimiento vivenciado por representación de espacio vivencial, por evocación de sensaciones kinestésicas (por medio de la alteración temporal de las acciones) y por representación metafóricamente los sentimiento de los personajes por medio del movimiento.

VIAJE ASTRAL: movimiento de cámara por animación como ocularización. Fundidos encadenados entre imágenes, efectos ópticos por vibración de color. 


\section{Características técnicas comunes:}

- Animación de dibujo.

- Se ha prescindido la regleta, herramienta comúnmente usada en la realización de animación; y algunas también se han hecho sin mesa de luz.

- Digitalización de dibujos con cámara fotográfica o escáner.

- Montaje de imagen con Adobe After Effects y Adobe Premiere.

- Montaje de sonido con Adobe Premiere.

\section{CORRE, CABALLITO}

AÑO: 2007

DURACIÓN: 4min. $4 \mathrm{seg}$.

TÉCNICA DE ANIMACIÓN: dibujo

TÉCNICA GRÁFICA: lápiz, lápices acuarelables, pastel, gouache y tinta sobre papel y acetato.

AUTORAS: Mercedes Peris y Rosa Peris

Esta animación fue el trabajo fin de carrera. Aunque se realizó con anterioridad a los estudios de Doctorado, hemos querido recogerla en este anexo.

Corre, caballito muestra la vida de un caballo de carreras. En su realización, las autoras no propusimos como premisas no utilizar corte cinematográfico, por lo que las transiciones entre planos tienen lugar por metamorfosis, movimientos de cámara y entrada y salida de campo de los personajes. También se utiliza la frecuencia de imágenes por segundo para representar el movimiento, o más bien la quietud: cuando el caballo muere, la velocidad de imágenes desciende al tiempo que escapa su vida. Tras varios segundos de quietud total (la muerte), la velocidad de fotogramas aumenta hasta recuperar la velocidad de 12ips: el caballo ha resucitado.

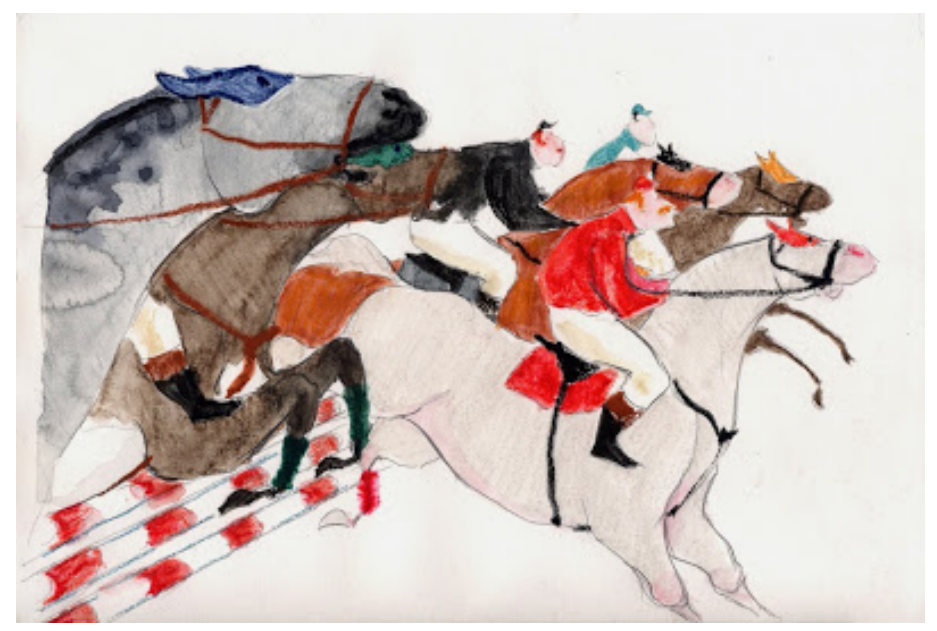




\section{LORENA}

AÑO: 2009

DURACIÓN: 1 min. 9 seg

TÉCNICA DE ANIMACIÓN: dibujo

TÉCNICA GRÁFICA: carboncillo sobre papel

AUTORA: Rosa Peris

Esta animación muestra el movimiento del rostro de una mujer. Las expresiones del rostro denotan una sucesión de emociones: melancolía, risa, euforia, bienestar, coquetería y tristeza. También aparecen las manos como partes importantes del cuerpo para expresar las emociones.

La animación se configura a través de un único plano cuyo final coincide con el inicio, es decir no hay uso de cortes cinematográficos y la estructura es cíclica.

La técnica empleada ha sido la animación directa, es decir, los dibujos se han realizado de uno en uno en orden de aparición y no determinando fotogramas clave entre los cuales hacer fotogramas intermedios.

Cabe destacar la característica especial del montaje: en ésta animación no se ha empleado la habitual frecuencia de fotogramas por segundo (24 ó 12); Los fotogramas permanecen en pantalla un tiempo variable y la transición entre ellos es por medio de fundidos encadenados, de modo que se ven dos imágenes superpuestas en casi todo momento.

Lorena es una de las obras que fue realizada durante el Máster de Producción Artística.

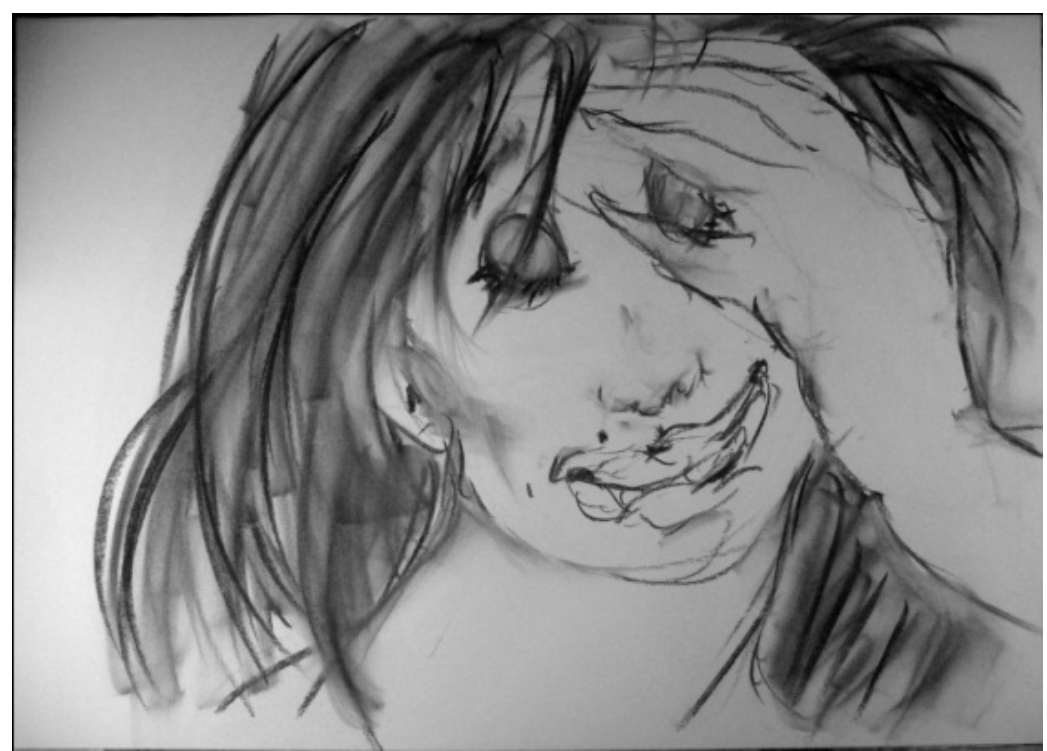




\section{TÁNTALO}

AÑO: 2010 (versión con sonido definitivo)

DURACIÓN: 2min. 39seg.

TÉCNICA DE ANIMACIÓN: dibujo

TÉCNICA GRÁFICA: lápiz y acuarela sobre papel

AUTORA: Rosa Peris

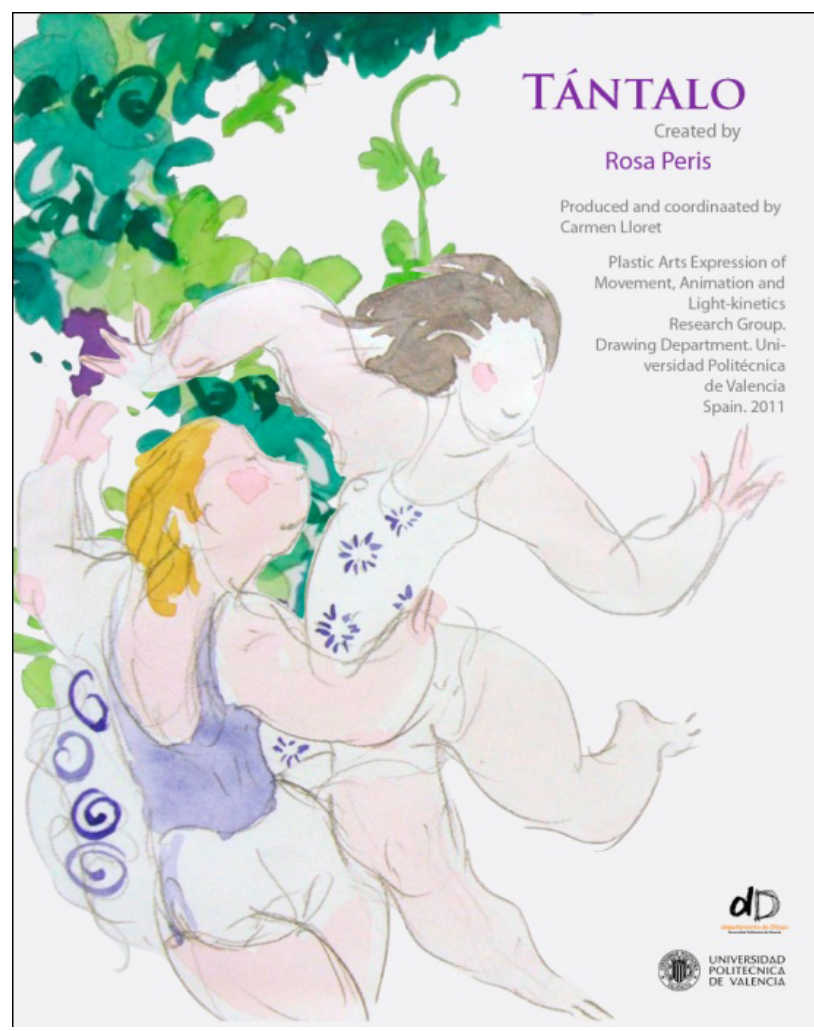

Esta animación se realizó con el objetivo de expresar de diferentes maneras un mismo hecho: el no alcanzar aquello que se desea. Mediante esta animación se ahonda en el estudio del cambio de la frecuencia de fotogramas por segundo utilizada con fines expresivos.

Se tomó el mito de Tántalo como punto de partida: Tántalo fue expulsado del Olimpo y castigado a estar sumergido en un lago con el agua a la altura del pecho. Si tenía sed y agachaba la cabeza para beber, el agua descendía; si por hambre elevaba las manos para coger los racimos de uvas que había sobre su cabeza, estos subían, haciéndose inaccesibles. Tántalo fue condenado a no alcanzar lo que tan cerca tenía. Su castigo consistía en no consumar su deseo. Pero en esta versión del castigo de Tántalo muestra el anhelo como una sensación placentera. Esta es la idea tomada como leitmotiv de la obra.

Se presentan variaciones sobre esta misma idea; se utilizan tanto la abstracción como la figuración. Los protagonistas del cortometraje son un hombre y una mujer que se transforman en formas abstractas $u$ otros elementos. Él siempre intenta asir a la mujer. La frecuencia de fotogramas cambiantes se ha diseñado para transmitir visualmente la misma sensación, de algo que no puede asirse; se pretende comunicar que la búsqueda no es sólo cuestión de aproximación física, sino el anhelo mismo: las imágenes aparecen y desaparecen ante nuestra vista, mostrando dos y tres dibujos al mismo tiempo, fundidos entre sí, sin llegar a distinguir imágenes definidas.

Esta animación se realizó como parte del Proyecto final de Máster. 


\section{LIBIDINIS}

AÑO: 2011 (versión con sonido)

DURACIÓN: 4min. 17seg.

TÉCNICA DE ANIMACIÓN: dibujo

TÉCNICA GRÁFICA: lápiz, pastel, gouache, tinta y rotulador sobre papel y acetato.

AUTORAS: Mercedes Peris y Rosa Peris

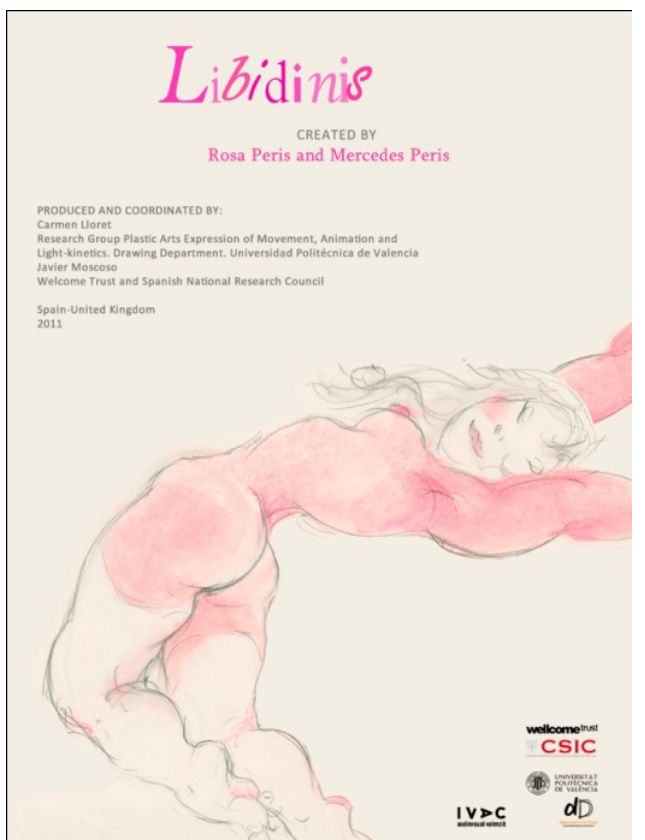

Se ha tomado como premisas plásticas expresar el movimiento a través de la continuidad visual y la variedad de acciones y trayectoria, manteniendo la trayectoria curva como elemento compositivo principal.

Libidinis tiene como punto de inicio la expresión "arrancarse la piel". A partir de esto, la ideo que se pretende reflejar en la película es que bajo la piel, bajo el cuerpo desnudo, puede haber más desnudez. Esto se hace visible por medio de un hombre y una mujer que se libran de su propia piel, quitándosela el uno al otro en acto íntimo. Se establece así un paralelismo entre la piel y la ropa. Alternándose con los adultos, se muestra una pareja de niños que los imita y que finalmente crecen, repitiéndose la historia. De esta manera la estructura del relato es cíclica. Esta cualidad cíclica también es formal: La misma trayectoria circular con la que comienza el corto (descrita por el hombre y la mujer entrelazados) es retomada por los niños (ya adultos) en el plano final.

La acción no transcurre en paralelo al plano de representación. Los móviles siguen trayectorias curvas y rotaciones sin cesar, encadenándose una con otras, creando así una composición en transformación continua. La continuidad visual existe a través de las trayectorias de los móviles, así como por la inexistencia de corte cinematográfico. Los cambios de plano se realizan por movimiento local y metamorfosis, entradas y salidas de campo, y movimientos de cámara.

La intensidad cinética se distribuye de manera regular a lo largo de la película porque esta animación se diseñó para formar parte de una exposición de obra plástica y otros objetos de valor estética, por lo que las autoras pretendimos hacer un "cuadro en movimiento".

Existe un cambio sustancial progresivo que tiene lugar a lo largo de toda la película: el cambio de color de las figuras. El cambio de color se extiendo al conjunto de la imagen; el blanco predominante al principio se va convirtiendo en rosa. Otros cambio sustancial es la transformación final de los niños en adultos. 


\section{SANRESIONE}

AÑO: 2010

DURACIÓN:

TÉCNICA DE ANIMACIÓN: dibujo

TÉCNICA GRÁFICA: lápiz

AUTORA: Rosa Peris

El planteamiento de un proyecto personal de animación fue el eje principal del curso-taller Animac, en el marco del Laboratorio de imagen en movimiento, ofrecido por Arteleku. Éste curso dirigido por Raimund Krumme se incentivó el replanteamiento de los hábitos en la creación artístico, con el fin de encontrar nuevos procesos creativos. Sanresione es la obra personal que resultó de esta experiencia. La esencia del proyecto es la expresión de la emociones. En la primera fase de trabajo se investigó por medio del dibujo la expresión de los sentimientos a través del movimiento. Otra de las bases de trabajo fue buscar el equilibrio entre la planificación y la espontaneidad, con el fin de que las exigencias técnicas propias de la animación no coarten en el proceso creativo, sino que lo impulsen y enriquezcan.

En Sanresione por medio de la representación de las emociones como formas abstractas, se cuenta cómo surge el amor entre un hombre y una mujer. Éstos no encarnan personas concretas, pues no se pretendía narrar una historia de amor, sino una historia sobre el amor (matiz que en su día me pareció importante).

El corto consiste en un único plano secuencia que se transforma para mostrar distintos encuadres y puntos de vista. El cortometraje se encuentra en fase de realización. En la animática que se incluye en el DVD se muestran diversas frecuencias de fotogramas por segundo, (hay escenas de animación completa a 12 fps y otra, también completa, de fundidos encadenados; el resto se compone de los fotogramas clave).

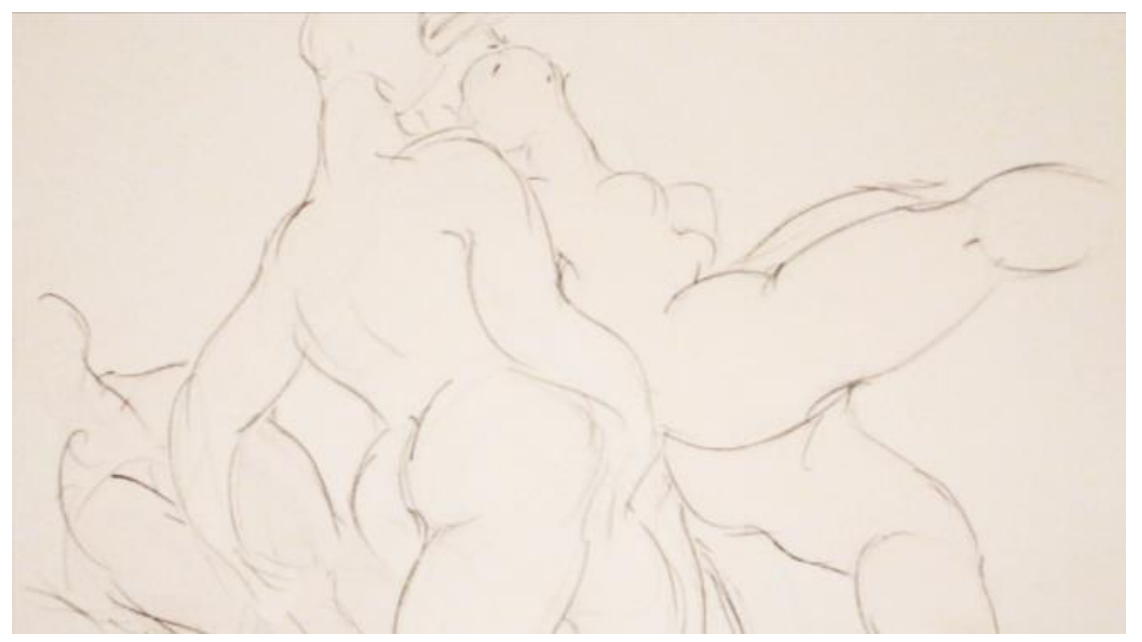




\section{BÁLADI}

AÑO: 2010

DURACIÓN: 24 seg.

TÉCNICA DE ANIMACIÓN: dibujo

TÉCNICA GRÁFICA: lápiz y rotulador sobre papel y acetato.

AUTORA: Rosa Peris

En Báladi se muestra a una mujer bailando. El movimiento de cámara sigue a la figura en su desplazamiento. El espacio, en cierto modo, se transforma a su paso, transmitiendo la idea de un espacio orgánico.

La técnica plástica utilizada es lápiz sobre papel y tinta diluida sobre acetato.

Esta breve pero intensa animación es la que considero más próxima a la expresión del movimiento vivenciado por la evocación de sensaciones dinámicas, así como por la representación del espacio que podría llamarse vivencial.

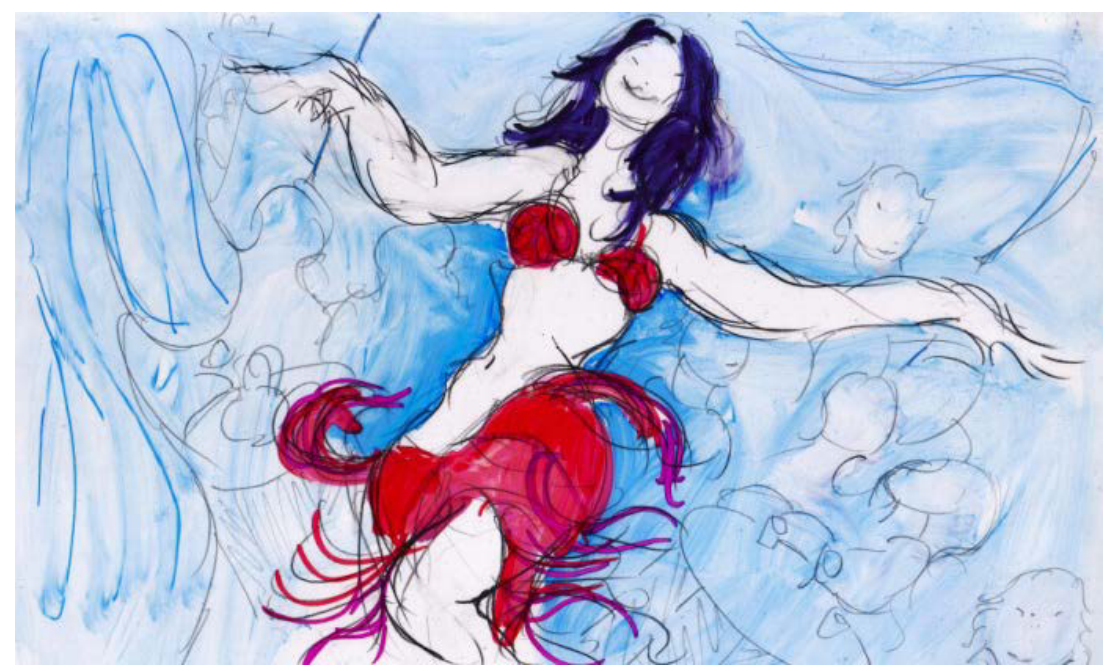




\section{TARONXADA (Créditos)}

AÑO: 2010

DURACIÓN: 6min. 38 seg (créditos 30seg.)

TÉCNICA DE ANIMACIÓN: dibujo

TÉCNICA GRÁFICA: lápiz y pastel sobre papel.

AUTORAS: Mercedes Peris y Rosa Peris

Otra de las prácticas plásticas se realizó en el contexto de la asignatura El movimiento en la animación artística y experimental (3er ciclo, Master Oficial en Producción Artística). Se realizaron los créditos del cortometraje Taronxada, creado en grupo por los alumnos de la asignatura.

Ésta animación tiene como elemento protagonista la naranja. Está formada por una serie de variaciones respecto al tema, escenas que se enlazan visualmente, pero cada una de ellas un sentido propio y, al mismo tiempo, sentido dentro del conjunto. Los créditos de este cortometraje constituyen una variación más sobre el tema de la naranja.

Los títulos de créditos se muestran en los elementos móviles de una animación figurativa (en las naranjas, en la superficie de una mesa, en un vaso, etc.) como vemos en créditos animados de otras películas. En esta animación se ha trabajado el movimiento de cámara, que a veces representa directamente el punto de vista de los personajes a los que sólo se les ven las manos). La prácticamente naranja no varía su posición respecto a la pantalla, pero su traslación se percibe por la el cambio del espacio.

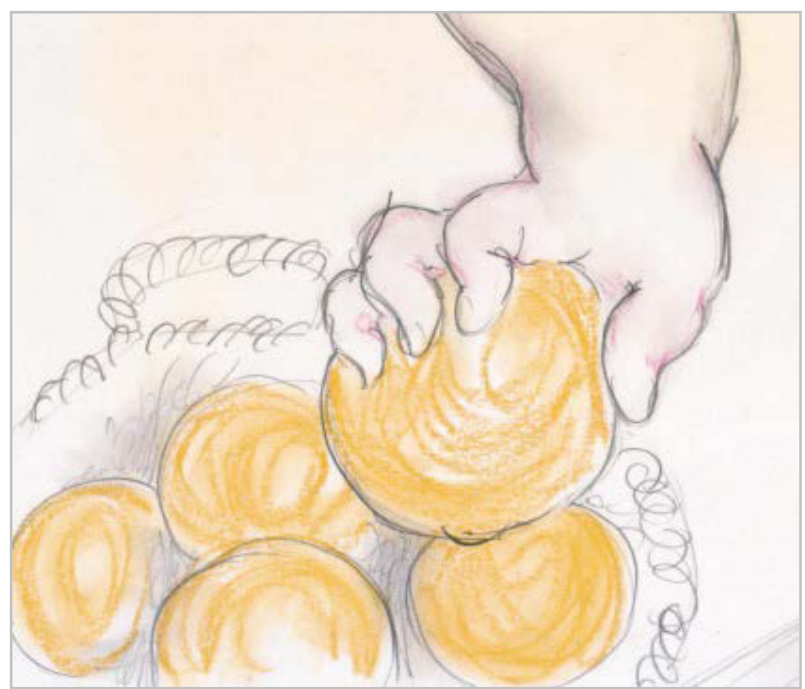




\section{MÍO, TUYO, NUESTRO}

AÑO: 2011

DURACIÓN:

TÉCNICA DE ANIMACIÓN: dibujo

TÉCNICA GRÁFICA: dibujo digital

AUTORA: Rosa Peris

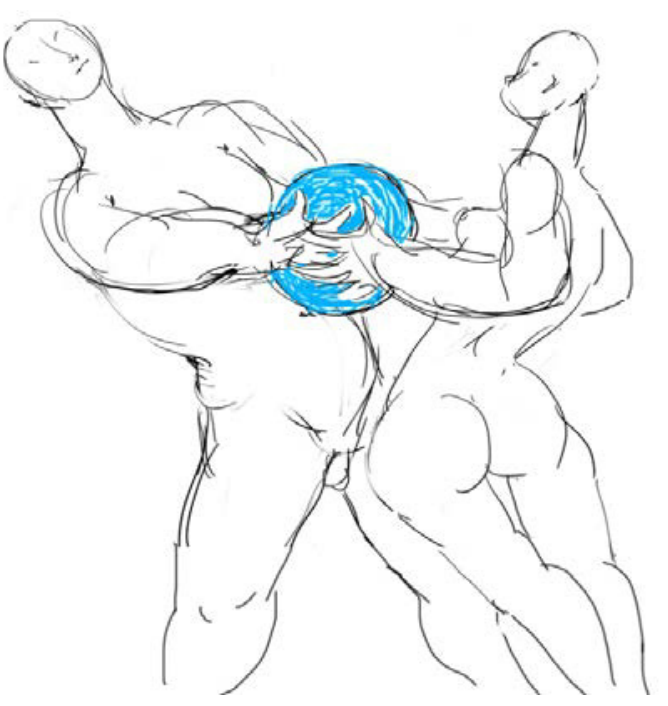

A través de la animación titulada Mío, tuyo, nuestro, se ha estudiado la composición móvil, la distribución de la intensidad cinética y el movimiento de la figura humana. La historia se configura a través de un hombre, una mujer, una esfera y un círculo (que determina el espacio en el que transcurre la acción). Mediante la interacción de estos cuatro elementos se expresa una secuencia de emociones: curiosidadposesión-generosidad. La metamorfosis es clave en la historia, pues mediante ésta la esfera cambia de tamaño, peso y densidad; se convierte en globo, balón, canica, etc. pero resultando, en cada ocasión, por un motivo u otro, difícil de manejar. La historia se narra en orden lineal (€øn planteamiento, nudo y desenlace).

La animación ha sido realizada dibujo a dibujo y mediante la técnica gráfica de dibujo digital. TVPainting ha sido el programa de dibujo utilizado y tuve el privilegio de ejecutarla en una pantalla Wacom, lo que supuso una experiencia nueva (a diferencia de las tabletas gráficas, la pantalla de dibujo permite trazar el dibujo en la misma superficie en la que éste se configura, el monitor).

La película se encuentra en fase de realización. Se realizó la animática completa, que está compuesta con algunas escenas de animación completa y dibujos principales. La animación muestra gran variedad compositiva por distribución de elementos y con una gran variedad de acciones y modos de desplazamiento: caminando, saltando, por deslizamiento, por rotación, etc. así como variedad de trayectorias curvas y rectas, con direcciones en paralelo a la pantalla y en profundidad, de arriba a abajo, en diagonal, etc. La acción se muestra desde distintos de puntos de vista, el cual cambia por movimiento de cámara. Además del movimiento local, también se muestran distintos cambios sustanciales: transformación (de tamaño, de transparencia, de peso) y metamorfosis (la esfera se une al cuerpo de la mujer a modo de vientre de embarazada).

Este proyecto se desarrolló en la Escuela de Artes Media de Colonia. 


\section{HOUYHNHNM}

AÑO: 2011

DURACIÓN:

TÉCNICA DE ANIMACIÓN: dibujo

TÉCNICA GRÁFICA: tinta sobre papel

AUTORA: Rosa Peris

Houyhnhnm narra la historia de un jinete que pierde su caballo, hecho que le separa del grupo de jinetes al que pertenecía. Sin cuestionárselo, intenta seguir unido al grupo, para darse cuenta, finalmente, de que los caballos (y no su antiguo grupo social), por su sensibilidad, ofrecen una alternativa más preferible que continuar con su anterior vida. El título de la película es el nombre de la raza de caballos inteligentes que Jonathan Swift describe en Los viajes de Gulliver. Esta historia está inspirada en este episodio de la novela.

La técnica escogida para su realización es la animación dibujo a dibujo en combinación con una técnica inspirada en la animación de película pintada. La experimentación que se desarrolló a partir de esta película se recoge pormenorizadamente en el apartado B. de 3.2.3.

Actualmente la animación se encuentra en fase de desarrollo. En el DVD del anexo 3 se incluye parte del guión gráfico.

Este proyecto se desarrolló en la Escuela de Artes Media de Colonia

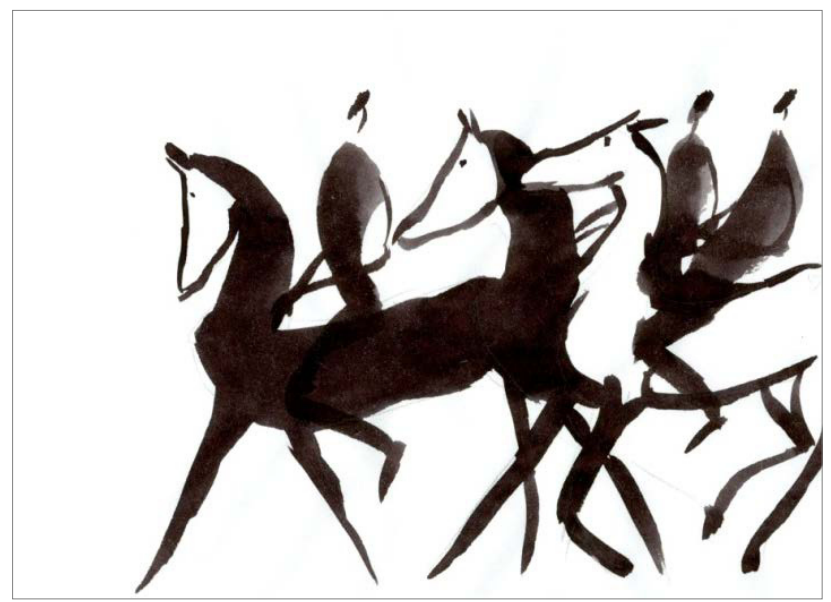

\section{EXPERIMENTACIÓN Movimiento por fases yuxtapuestas.}

Ver Apartado B. de 3.2.3. 


\section{TUTUTÚ}

AÑO: 2012

DURACIÓN:

TÉCNICA DE ANIMACIÓN: dibujo

TÉCNICA GRÁFICA: lápiz, tinta sobre papel y acetato. Las imágenes del guión gráfico se han realizado con lápiz y color digital.

AUTORA: Rosa Peris

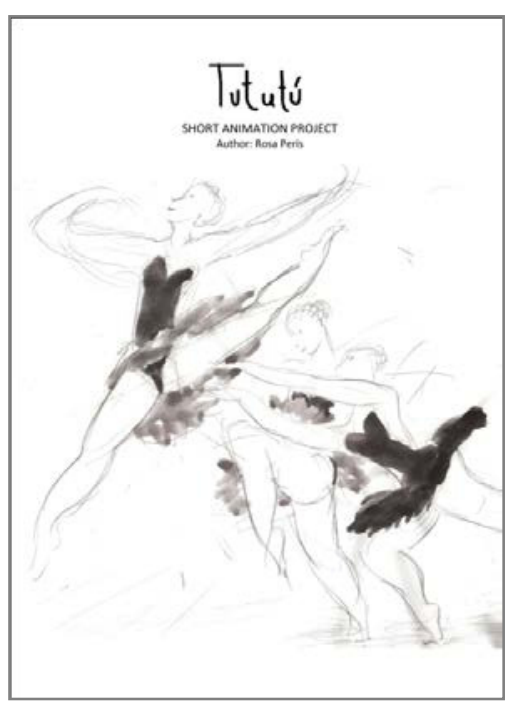

Durante el último periodo de beca se ha planificado un cortometraje de animación partiendo de los proyectos planteados en la Kunsthcschule für Medien Köln.

En este proyecto se expresa el peso y la ingravidez de manera metafórica: como manifestación del estado de ánimo de los personajes: seguridad-gravedad, peso; ensoñación-flotabilidad; desesperación- caída al abismo.

Una bailarina ensueña con un "príncipe azul", momentos en los que se transporta aun mundo de extremada ligereza en el que flota como una pluma. Pero el peso de la realidad le obliga a poner los pies en la tierra. Después de varias incursiones de ida y vuelta a su mundo de fantasía particular, la bailarina aprenderá a reconocer que sus sueños de ingravidez son posibles en el mundo real.

El objetivo es crear una película sinestésica, evocar la sensación móvil a través de la imagen y el sonido. El peso de los cuerpos será expresado por el movimiento, la textura del dibujo y el sonido. El sonido tundra una particular importancia: el suelo de madera cruje bajo el peso, el sonido de los pies deslizándose sobre el suelo, el sonido de los bailarines aterrizando ruidosamente, etc. El peso y la fuerza de la gravedad serán representados con progresivo énfasis.

Compositivamente se ha buscado la variedad a través del encuadre y la riqueza de acciones, en contraste con escenas en las que predomina la quietud y las acciones sencillas.

Este proyecto obtuvo el premio Abbaye de Fontevraud en el Festival Internacional de Animación de Annecy, en la competición de proyectos que acoge Creative Focus. La abadía de Fontevraud financió un mes de producción, y supondrá un gran apoyo en la promoción de la película, que todavía no está terminada. La residencia de escritura de guión en la Abadía Real de Fontavraud supuso una gran experiencia, gracias al contacto con otros animadores con trayectorias artísticas muy diferentes. 


\section{VIAJE ASTRAL}

AÑO: 2014

DURACIÓN: 1min. 36seg.

TÉCNICA DE ANIMACIÓN: dibujo

TÉCNICA GRÁFICA: lápiz y rotuladores sobre papel y acetato, y dibujo digital.

AUTORAS: Mercedes Peris y Rosa Peris

Esta animación que da imagen al poema Música de José Aguilar. Se ha tratado de complementar el contenido del poema con imágenes que no representan literalmente los elementos mencionados (a excepción de una puerta).

En esta animación se ha pretendido representar el movimiento como vivenciado a través del movimiento de cámara que muestra un paisaje a vista de pájaro, transmitiendo la sensación de vuelo. Así mismo, la combinación de fundidos encadenados, vibración de la imagen por cambio drástico de color y la frecuencia de ips irregular se ha generado una atmósfera hipnótica.

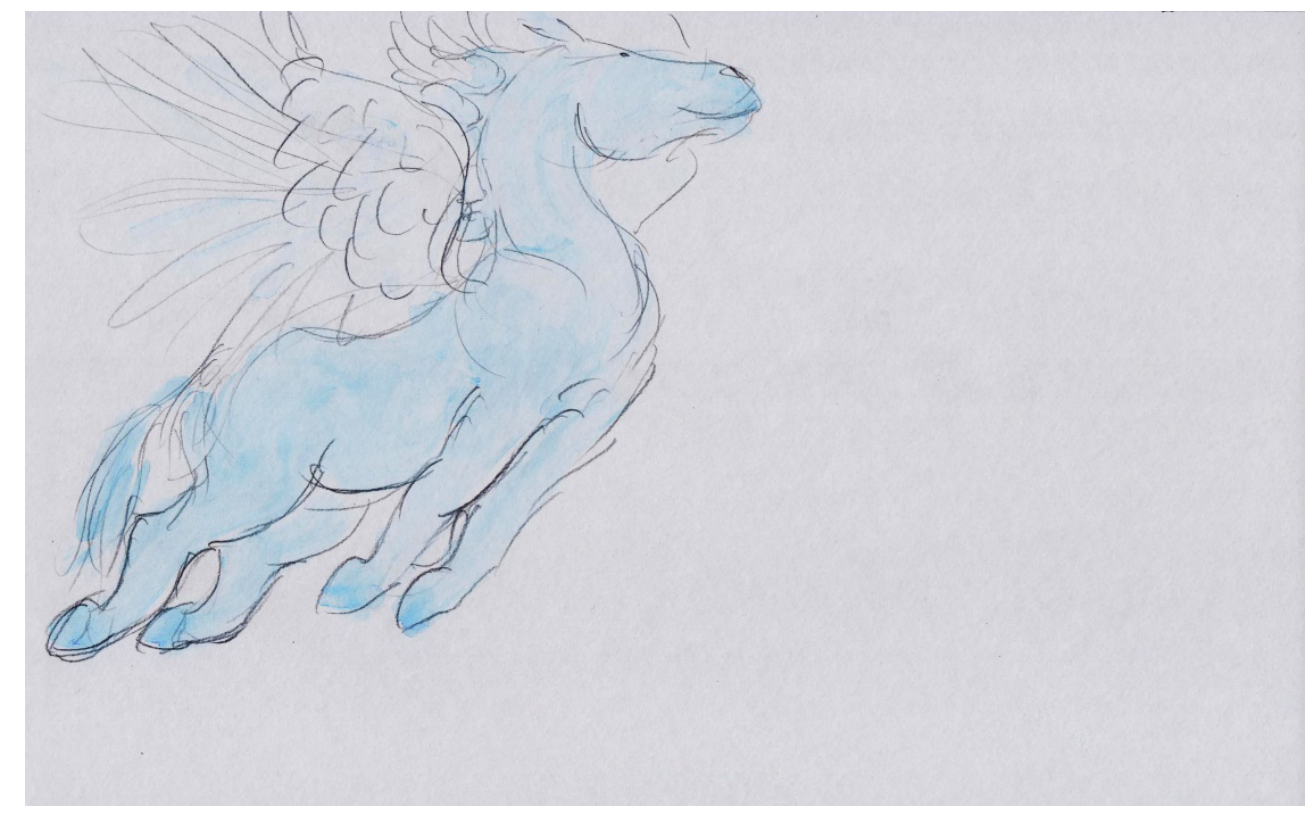




\section{Premios obtenidos}

\section{Premio Abadía de Fontevraud}

Obra: Tututú

Entidad que concede: Festival International du film d'animation d'Annecy y Abbaye Royale de Fontevraud

Ciudad: Annecy, Francia

Fecha de concesión: 06/06/2012

3er premio

Obra: Libidinis

Entidad que concede: Three Rivers Film Festival 2012

Ciudad: Pittsburgh, Pensilvania, EEUU

Fecha de concesión: 16/11/2012

\section{Best Student Short}

Obra: Libidinis

Entidad que concede: Animazing Spotlinght! AniMazSpot 2012 Festival

Ciudad: Burbank, California, EEUU

Fecha de concesión: 16/09/2012

\section{Award of Excellence}

Obra: Libidinis

Entidad que concede: Canada International Film Festival

Ciudad: Vancouver, Canada

Fecha de concesión: 06/07/2012

Royal Reel Award

Obra: Tántalo

Entidad que concede: Canada International Film Festival

Ciudad: Vancouver, Canadá

Fecha de concesión: 25/03/2012

\section{Award of Excellence}

Obra: Libidinis

Entidad que concede: The Indie Fest 2012

Ciudad: La Jolla, California

Fecha de concesión: 26/03/2012

\section{Aloha Accolade Award}

Obra: Libidinis

Entidad que concede: Honolulu Film Awards 2012

Ciudad: Hawai

Fecha de concesión: 26/03/2012

Premio del jurado a la mejor animación

Obra: Libidinis

Entidad que concede: BCN Visual Sound, festival audiovisual de creación joven

Ciudad: Barcelona 
Fecha de concesión: 17/02/2012

Premio a la mejor animación

Obra: Libidinis

Entidad que concede: V CORTOCOMENIUS Film Festival 2011

Ciudad: Valencia

Fecha de concesión: 11/11/2011

Segundo Premio en Animainzón

Obra: Libidinis

Entidad que concede: Concurso Nacional de Cine de Animación "Animainzón", Ciudad: Ainzón, Aragón

Fecha de concesión: 02/10/2011

Curts'11, Mejores producciones audiovisuales de la Comunidad Valenciana 2011

Obra: Libidinis

Entidad que concede: IVAC Instituto Valenciano del Audiovisual y la Cinematografía

Ciudad: Valencia

Fecha de concesión: 03/05/2011

Premio extraordinario. Certamen Cultural del Ministerio de Industria Turismo y Comercio (Competición de pintura).

Entidad que concede: Ministerio de Industria, Turismo y Comercio

Ciudad: Madrid

Fecha de concesión: 2005

Segundo premio. Certamen Cultural del Ministerio de Industria Turismo y Comercio (Competición de pintura).

Entidad que concede: Ministerio de Industria, Turismo y Comercio

Ciudad: Madrid

Fecha de concesión: 2004 


\section{Proyecciones en festivales}

Viaje astral

- Día Mundial de la Animación 2014, Escuela nacional de artes plásticas UNAM. 27-31/10/2014. México DF

Libidinis:

- $5^{\text {th }}$ The Los Angeles New Wave International Film Festival, California, EEUU, 17-21/04/2013

- $4^{\text {th }}$ AHOF's Savannah International Animation Festival 2013, Georgia, EEUU, 13-13/04/2013

- 15th San Francisco Independent Film Festival 2013, San Franscisco, Estado Unidos, 7-21/02/2013

- $6^{\text {th }}$ WAMM (Women And Minorities in Media Festival), Edwardsburg, Michigan, EEUU, 04-2013

- Monstra 2013, Lisbon Animated Film Festival, Portugal, 03/2013.

- $6^{\text {th }}$ Portland Oregon Women's Film Festival, Oregon, EEUU, 03/2013

- $3^{\text {th }}$ Love Your Shorts Film Festival, Florida, EEUU, 15-17/02/2013

- Animacam, La Coruña, España 02/2013

- Libélula International Animation Festival, Rusia, 2013

- Zinexín 2012, IX Festival de Cine de La Roda, Albacete, España, 26/12/2012

- Libélula International Animation Festival, Lloret de Mar, España, 22/11/2012

- Three Rivers Film Festival 2012, Pittsburgh, Pensilvania, USA., Noviembre 2012

- Cornwall Film Festival, Cornualles, Reino Unido, 11/2012

- SoDak Animation Festival, Brookings, South Dakota, EEUU, 1720/10/2012

- La Longue Nuit du Court, 2012, Nantes, Francia, 5/10/2012

- BALKANIMA 2012, 9th European Animated Film Festival, Novi Beograd, Serbia/Montenegro, 10-2012

- FIC.Puebla Festival Internacional de Cine 20, Puebla, México, 09/2012

- AniMazSpot 2012, Burbank, California, 16/09/2012

- $\mathbf{1 7}^{\text {th }}$ Split Film Festival, Split, Croacia, 15/09/2012

- 7th International Short Film Festival "Vilnius Film Shorts", Vilnius, Lithuania, 6/09/2012.

- Pentedattilo Film Festival, Reggio Calabria, Italia, 24-08-2012

- Acquedolci Independent Film Festival, Acquedolci, Sicilia, Italia, 24-082012

- Hiroshima 2012. The $14^{\text {th }}$ International Animation Festival, Hiroshima, Screening: Best of the World (out of competition), 23-08-2012,

- Anibar International Animation Festival, Peja, Kosovo, 22-27/08/2012

- Baixada Animada, 6a Mostra de Cinema de Animaçao da Baixada Fluminense, Río de Janeiro, Brasil, 07 agosto 2012

- $6^{\text {th }}$ International Film Festival Kratkofil Plus 2012, Banjaluka, BosniaHerzegovina, 18-22/07/2012 
- Festival Internacional cinematográfico de Toluca, México, 4-08-2012

- International Summer Corto Cafe Festival, Arena Ressa, Italia, 14-062012

- Toronto Animation Arts Festival International, Canada, 6 -07-2012

- FEMINA - International Women's Film Festival, Rio de Janeiro, Brasil, 207-2012

- The Pineapple Underground Film Festival, Hong Kong, China, 8-0620127

- California International Animation Festival, California, EEUU, 06-2012

- Honolulu Film Awards 2012, Hawai, U S A, 12-05-2012

- Curtocircuito Festival Internacional de Cortometrajes de Santiago de Compostela, Santiago de Compostela, España, 2-11/05/2012

- $11^{\text {th }}$ AniFest, International Festival of Animated Films Czech Republic, Teplice \& Duchcov, Teplice, República Checa, 26-04-2012

- Canada International Film Festival, Vancouver, Canada, 2012.

- Monstra 2012, Lisbon Animated Film Festival, Portugal, 03-2012

- UBIK CAFÉ, Cine independiente, IVAC, Valencia, España, 29/02/2012

- Posivideo, IV Certamen Nacional de Cortometrajes, Almería, España, 20-25/02/2012

- The Indie Fest 2012. La Jolla, California, USA, 20-02-2012

- Cromafest. Concurso Internacional CROMA de Animación y Efectos Visuales, México, 13-02-2012

- BCN Visual Sound 2012, Festival Audiovisual de Creación Joven, Barcelona, 7-02-2012

- Rivendell, IVAC, Valencia, España, 02-02-2012

- FIBABC 2012, Festival Iberoamericano de Cortometrajes ABC, España, $01-2012$

- The 8th ION International Film Festival, Queretaro, México, 16-12-2011.

- Certamen de Curtmetratges Ca' Revolta. Valencia, España. 12-12-2011.

- ProyectAragón, Muestra Audiovisual Aragonesa, Zaragoza, España 1212-2011

- Getafe in Cinema. Festival de Cine de Getafe, Getafe, España, 21-112011

- ALCINE 41 Festival de cine de Alcalá de Henares, España, 12-11-2011.

- FNAC Zaragoza, Zaragoza, España, 12-11-2011

- Festival de Cortometrajes Ciudad de Soria, Soria, España 11-11-2011

- Zinebi. 53 ed Festival Internacional de Cine Documental y Cortometraje de Bilbao, España, 11-11-2011.

- V CORTOCOMENIUS Film Festival 2011. Valencia, España, 7-11-2011

- Muestra de cine. La Mujer en Escena, Málaga, España, 3-11-2011

- Cartón, International Animation Film festival. Buenos Aires, Argentina, 2-11-2011

- CINETORO, Festival Internacional de Experimentación, Colombia, 2-112011.

- ANIMAR Festival de Cine de Animación de Reinosa, España, 28-102011.

- Festival Internacional de Cine de Providencia, Chile, 27-10-2011 
- 4a Semana Internacional de Cine Ciudad de Utrera, Utrera, España, 2410-2011

- Mercado 3D Wire. Mercado Internacional de Animación y Videojuegos, España, 15-10-2011.

- Bobinas. Aragón Televisión, Zaragoza, España, 7-10-2011

- FLimmer Film Festival, Norrköping, Suecia, 30-09-2011.

- Animainzón. Jornadas de Cine de Ainzón 2011, España, 29-09-2011

- c. 02 Festival de creación audiovisual joven Baumann, Terrassa, España, 19-09-2011.

- Portobello Film Festival 2011, Londres, 1-09-2011.

- Visualízame Festival Audiovisual y Mujer, España, 1-09-2011.

- AVE - Trayecto en corto. IVAC Instituto Valenciano del Audiovisual y la Cinematografía. Madrid, Cuenca, Valencia, 2011

- Institut Valencià de l'Audiovisual i de la Cinematografia. España. 062011

- Formentera Film, International Festival of short films, documentaries and videoart, Formentera, España, 6-05-2011.

Tántalo:

- Short Sharp Film Festival, Coffs Harbour, Australia. 28/07/20112

- La Nostra Film Festival, Valencia, España, 07/2012

- The Pinapple Underground Film Festival, Hong Kong, China. 08/06/2012

- Norwich Film Festival 2012, Norwich, Reino Unido, 30/03/2012-07/04 2012

- Dia mundial de la animación, Universidad Nacional Autónoma de México, México DF, 27-28/10/2012

- Canada International Film Festival, Vancouver, Canadá. 25/03/2012

- Blu Plum Animation Festival, Johnson City, USA, 2012

- Monstra 2011. Lisbon Animated Film Festival, Portuga . /03/2011

- Baumann short film animation festival. Terrasa, España. 09/2010

\section{Báladi:}

- Monstra 2011. Lisbon Animated Film Festival, Portugal.

- Minimotion 2010. Competition for 10 Seconds Animation. Zurich

- One Minute Film\&Video Festival, Aarau, Suiza, 2012

Corre, caballito:

- Un recorrido por la animación, Universidad Nacional Autónoma de México, 12/2009

- Baumann short film animation festival. Terrassa, España, 2009

- Internacional Holland Animation Film Festival. 2008 XII edición Finalista en HaffTube, Holanda

- Animadrid. Festival Internacional de Imagen Animada 2008. Competición de Escuelas de Animación. Madrid

- Flip, IV International Festival of cinema of animation 2008 (organizado por la Cineteca Pontificia Universidad Católica de Valparaiso). 
- X Premis Tirant 2008 a la Industria del Audiovisual Valenciano, Competición de Animación, Valencia; Premis Tirant en Ca Revolta (proyección), Valencia, 03/2008

- Creanimax Segundo Certamen para el Desarrollo de la Animación y el Videojuego 2008. Guadalajara, México.

- Cubanima Tercer Festival Internacional del Audio-Visual para la Infancia y la Adolescencia, La Hanana, 2008.

- IX Certamen de Cortometrajes de Animación Ibercaja la Rioja. España. 2008.

¡Al ritmo del color!:

- Creanimax Segundo Certamen para el Desarrollo de la Animación y el Videojuego 2008. Guadalajara, México.

- Animadrid International Festival of Animated Picture 2007.Madrid, España, Competición de Cortinillas.

Prostitución infantil:

- Creanimax Segundo Certamen para el Desarrollo de la Animación y el Videojuego 2008. Guadalajara, México.

- X Foro Internacional Infancia y Violencia 2007, organizado por el Centro Reina Sofía para el Estudio de la Violencia. Valencia.

Spot Comunidad Valenciana

- Creanimax Segundo Certamen para el Desarrollo de la Animación y el Videojuego 2008. Guadalajara, México. 
Anexo 2

DVD CON ANIMACIONES DE REALIZACIÓN PROPIA

\section{Contenido DVD}

1. Corre, caballito (animación completa)

2. Lorena (animación completa-sin audio)

3. Tántalo (animación completa)

4. Libidinis (animación completa)

5. Sanresione (fragmento animática)

6. Báladi (animación completa)

7. Taronxada (créditos finales)

8. Mío, tuyo, nuestro (fragmento animática)

9. Houyhnhnm (fragmento guión gráfico)

10. Animación por fases yuxtapuestas (pruebas de animación sin audio)

11. Tututú (fragmento guión gráfico)

12. Viaje astral (animación completa-sin audio) 

Anexo 3

DVD CON ALGUNAS DE LAS ANIMACIONES QUE EJEMPLIFICAN EL DISCURSO

\section{Contenido DVD}

1. Jumping (Tezuka, 1984)

2. Fumiko no Kokuhaku (Ishida, 2009)

3. Tekkonkinkret (Arias, 2006) [fragmento]

4. Flux (Hinton, 2002)

5. Sisyphus (Jankovics, 1974)

6. La ravissement de Frank N. Stein (Schwizgebel, 1982)

7. Brave (Andrews, Chapman, \& Purcell, 2012) [fragmento ]

8. Passage (Krumme, 1994)

9. La Saint Festin (Daffis \& Marchand, 2007)

10. Clash of the Titans (Harryhausen, 1985) [fragmento]

11. Normas de seguridad LAN Airlines (LAN Airline, h.2007)

12. Numancia (Jimeno Martínez \& de la Torre Echávarri, 2009)

13. Life in the womb (9 months in 4 minutes) (Medicine Forever, h. 2014)

14. Psyche and Eros (de Vere, 1994) [fragmento]

15. Histoire d'un prince devenu borgne et mendiant (Miailhe, 1996)

16.\$9.99 (Rosenthal, 2008) [fragmento] 



\section{Anexo 4 \\ MUESTRA DE ANÁLISIS CON LOS QUE SE HAN ESTUDIADO LAS PELÍCULAS}

ANÁLISIS DE LA EXPRESIVIDAD DEL MOVIMIENTO EN ANIMACIÓN

DATOS DE LA OBRA

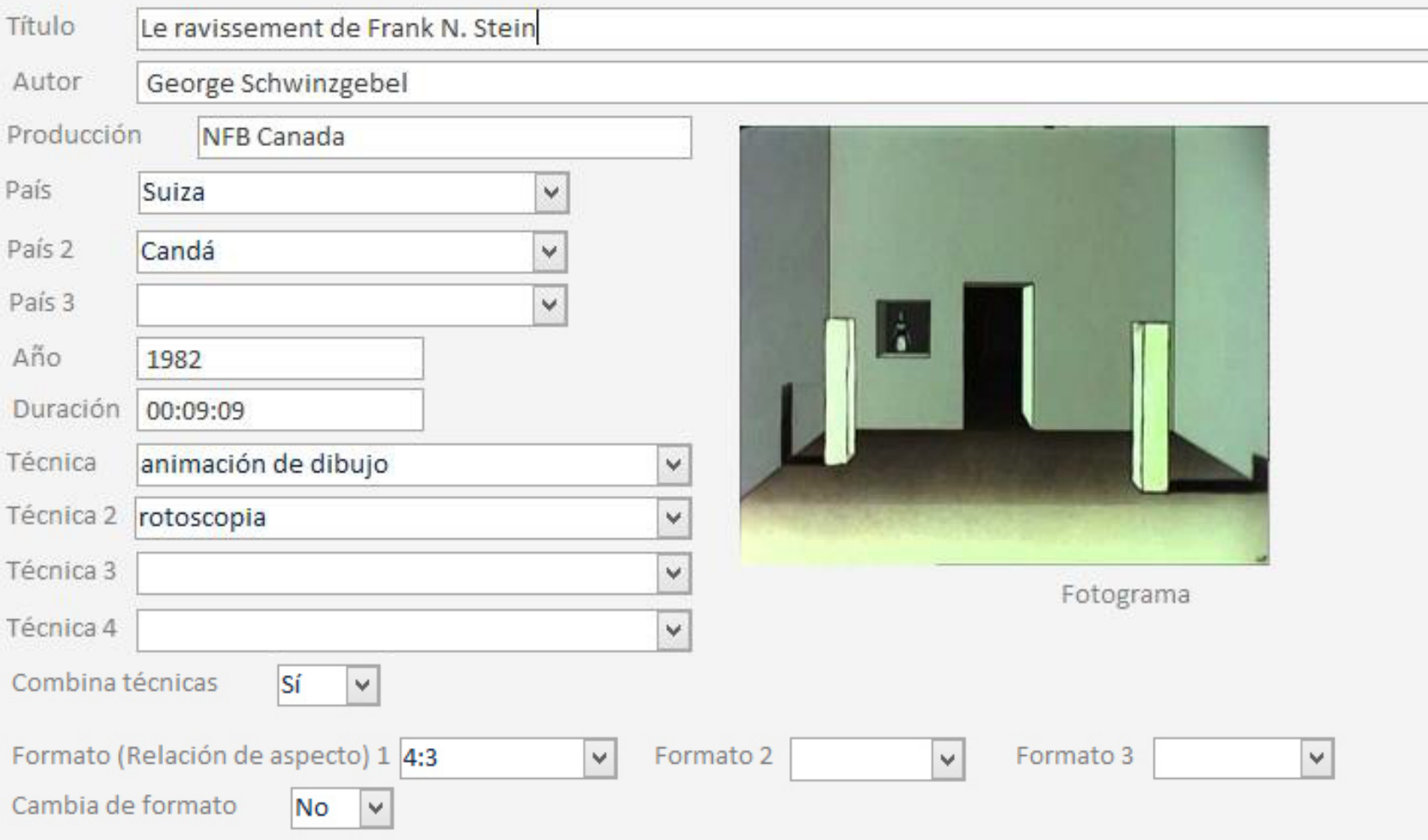

EXPRESIÓN MOVIMIENTO COMO VIVENCIADO O COMO NEUTRO

Provoca sensaciones cinéticas

Transmite carcaterísticas particulares de la acción

Homogenización de la expresión móvil

La acción se ubica en un espacio vivencial o matemat/neutro

\begin{tabular}{|l|c|}
\hline bastante & $\checkmark$ \\
\hline no & $\checkmark$ \\
\hline punto medio & $\checkmark$ \\
\hline espacio vivencial & $\checkmark$ \\
\hline
\end{tabular}

TOTAL movimiento vivenciado/neutro $13 \quad 13 \quad \checkmark \quad$\begin{tabular}{ll|l|l|}
\hline & 13
\end{tabular}

ALGUNAS CARACTERÍSTICAS DE LA IMAGEN

Nivel de naturalismo del móvil

Nivel de homogenización del móvil

Nivel de plasticidad de la imagen

TOTAL características de la imagen

\begin{tabular}{|l|l|}
\hline naturalista $>$ no naturalista & $\checkmark$ \\
\hline punto medio & $\checkmark$ \\
\hline bastante & $\checkmark$ \\
\hline $9 \quad 6 \quad 6 \quad \checkmark$ \\
\hline
\end{tabular}

CARCATERÍSTICAS DE LA REPRESENTACIÓN DEL MOVIMIENTO

Nivel de naturalismo del movimiento

Frecuencia de acontecimientos fantásticos o realistas

punto medio

punto medio 


\section{COMPONENTES DINÁMICOS}

\section{Movimiento presente}

G01_Variedad de frecuencia de imágenes por segundo

G02_Vibración producida por la iregularidad de trazo y mancha

G03_La vibración potencia las particularidades del mov

G04_Utiliza el movimiento óptico con fines expresivos

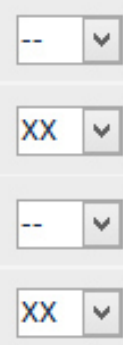

\section{Valoración espacio-temporal}

G05_La interpretación espacio-temporal es original

G06_Variedad de acciones y sucesos

G07_Variedad de trayectorias y velocidad

G08_Variedad de mov de los existentes, del espacio y de cámara

G09_Hay metamorfosis de los personajes y/o del espacio

G10_Sensación dinámica en los fotogramas

G11_Utiliza metáforas relacionadas con el movimiento

G12_La representación del mov es un código de animación

G13_Tiene acciones por interpolación (animación CGI)

G14_El movimiento se obtiene por captura de video

G15_El mov se obtiene por captura de movimiento por sensores

G16_La repr del movimiento se fundamenta en la mecánica

G17_Utiliza líneas cinéticas/signos dinámicos

G18_Las trayectorias son confusas

G19_No hay variedad de acciones y sucesos
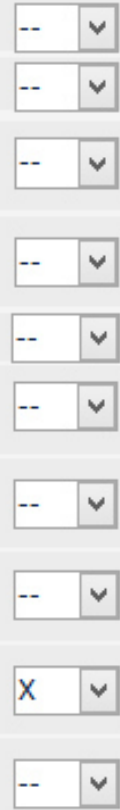

$\mathrm{XX}$

\section{Composición móvil}

G20_Corte cinematográfico

G21_Cortes entre acciones concatenadas

G22_Cortes entre acciones que interrumpen el movimiento

G23_Fundidos entre planos

G24_Presenta planos-secuencia

G25_Abundancia de planos largos

G26_Abundancia de planos cortos

G27_Continuidad de trayectorias

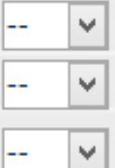

\begin{tabular}{|l|}
\hline-- \\
\hline
\end{tabular}

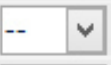

$\mathrm{XX} \quad \checkmark$

$--\quad \vee$

$--\quad v$

$\mathrm{XX} \vee \checkmark$

G28_Tiene movimientos de cámara por animación

G29_Se muestran diferentes composiciones

G30_Las trayectorias generan el cambio compositivo

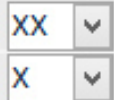

G31_Continuidad visual

G32_Utiliza planos subjetivos (mirada del personaje)

G33_La composición ayuda a transmitir la sensación móvil

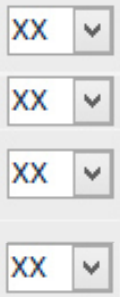

Distribución de la intensidad cinética

G34_Ritmo cinético discontinuo

G35_Ritmo cinético uniforme

G36_Ritmo cinético de intensidad creciente

G37_Ritmo cinético de intensidad decreciente

G38_EL ritmo cinético potencia o genera la sensación cinética

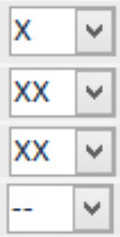

G39_El relato y el ritmo cinético son equivalentes

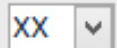

$\mathrm{XX} \vee$

Presentación de la historia - el relato

G40_Orden lineal vectorial progresivo

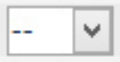

\begin{tabular}{l|l|}
\hline- & $\checkmark$ \\
\hline
\end{tabular} inverso/palíndromo/lineal no vect

G42_Orden no lineal/circular/cíclico/anacrónico

G43_Frecuencia simple

G44_Frecuencia: múltiple/repetitiva/frecuentativ

G45_Duración normal (absoluta-relativa)

G46_Duración anormal (contracción/dilatación)

G47_Orden, duración y/o frecuencia potencia la sensación móvil
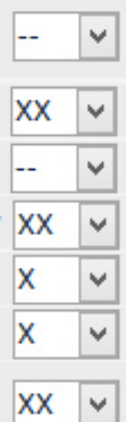


\section{DATOS DE LA OBRA}

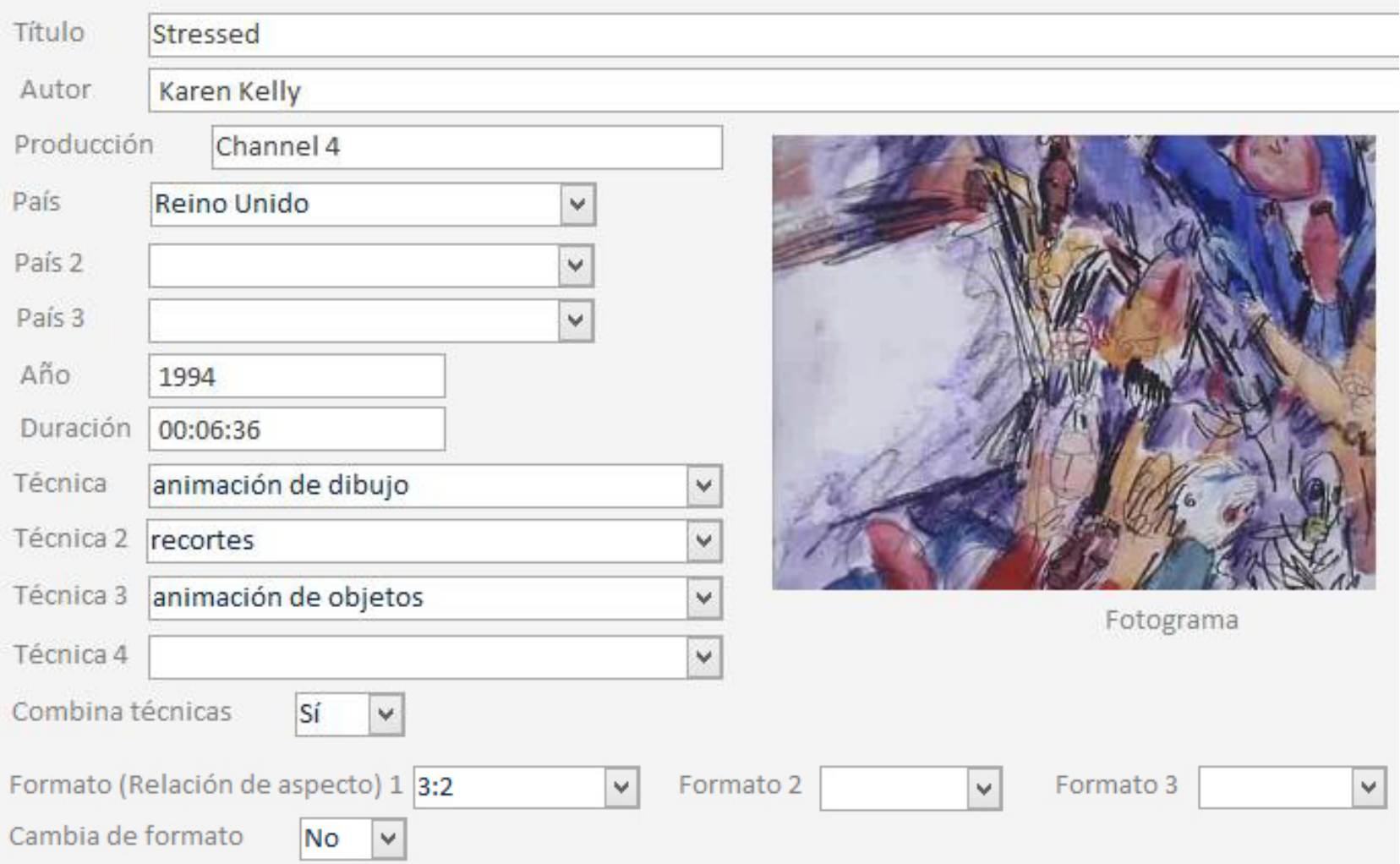

\section{EXPRESIÓN MOVIMIENTO COMO VIVENCIADO O COMO NEUTRO}

Provoca sensaciones cinéticas

Transmite carcaterísticas particulares de la acción

Homogenización de la expresión móvil

La acción se ubica en un espacio vivencial o matemat/neutro

\begin{tabular}{ll|l|l|} 
TOTAL movimiento vivenciado/neutro & 20 & $\checkmark$ \\
\hline
\end{tabular}

\begin{tabular}{|l|l|}
\hline si/mucho & $\checkmark$ \\
\hline si/mucho & $\checkmark$ \\
\hline no/nada & $\checkmark$ \\
\hline espacio vivencial & $\checkmark$ \\
\hline
\end{tabular}

\section{ALGUNAS CARACTERÍSTICAS DE LA IMAGEN}

Nivel de naturalismo del móvil

Nivel de homogenización del móvil

Nivel de plasticidad de la imagen

TOTAL características de la imagen

\begin{tabular}{|l|l|}
\hline no naturalista $>$ naturalista & $\checkmark$ \\
\hline no/nada & $\checkmark$ \\
\hline si/mucho & $\checkmark$ \\
\hline 14 \\
\hline \begin{tabular}{|l|l|}
\hline 14 & $\checkmark$ \\
\hline
\end{tabular}
\end{tabular}

\section{CARCATERÍSTICAS DE LA REPRESENTACIÓN DEL MOVIMIENTO}

Nivel de naturalismo del movimiento

Frecuencia de acontecimientos fantásticos o realistas no naturalista $>$ naturalista

más acontecimientos realistas que fantásticos 


\section{COMPONENTES DINÁMICOS}

\section{Movimiento presente}

G01_Variedad de frecuencia de imágenes por segundo

G02 Vibración producida por la iregularidad de trazo y mancha

G03_La vibración potencia las particularidades del mov

G04_Utiliza el movimiento óptico con fines expresivos

\section{Valoración espacio-temporal}

G05_La interpretación espacio-temporal es original

G06_Variedad de acciones y sucesos

G07_Variedad de trayectorias y velocidad

G08_Variedad de mov de los existentes, del espacio y de cámara

G09_Hay metamorfosis de los personajes y/o del espacio

G10_Sensación dinámica en los fotogramas

G11 Utiliza metáforas relacionadas con el i movimiento

G12 La representación del mov es un código de animación

G13 Tiene acciones por interpolación (animación CGI)

G14_El movimiento se obtiene por captura de video

G15_El mov se obtiene por captura de movimiento por sensores

G16_La repr del movimiento se fundamenta en la mecánica

G17_Utiliza líneas cinéticas/signos dinámicos

G18_Las trayectorias son confusas

G19_No hay variedad de acciones y sucesos

\section{Composición móvil}

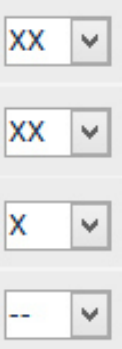

G20_Corte cinematográfico

G21_Cortes entre acciones concatenadas

G22_Cortes entre acciones que interrumpen el movimiento

G23_Fundidos entre planos

G24_Presenta planos-secuencia

G25_Abundancia de planos largos

G26_Abundancia de planos cortos

G27_Continuidad de trayectorias

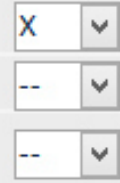

\begin{tabular}{lll}
\hline$x$ & $\vee$ \\
\hline
\end{tabular}

\begin{tabular}{|l|l|}
\hline$x x$ & $\checkmark$ \\
\hline$x x$ & $\bullet$ \\
\hline
\end{tabular}

XX $\checkmark$

\begin{tabular}{|l|l|}
\hline-- & $\vee$ \\
\hline
\end{tabular}

$\mathrm{XX} \vee \mathrm{V}$

G28_Tiene movimientos de cámara por animación XX G29 Se muestran diferentes composiciones

G30_Las trayectorias generan el cambio compositivo

G31_Continuidad visual

G32_Utiliza planos subjetivos (mirada del personaje)

G33_La composición ayuda a transmitir la sensación móvil

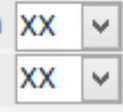

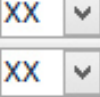

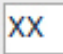

$\mathrm{XX}$

$\mathrm{XX}$
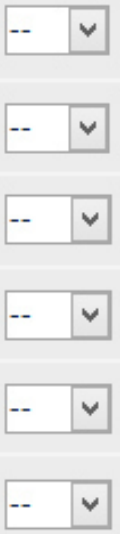

\begin{tabular}{l|l|}
$x$ & $\checkmark$ \\
\hline
\end{tabular}

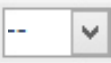

$-\vee v$

\section{Distribución de la intensidad cinética}

G34 Ritmo cinético discontinuo

G35_Ritmo cinético uniforme

G36 Ritmo cinético de intensidad creciente

G37_Ritmo cinético de intensidad decreciente

G38 EL ritmo cinético potencia o genera la sensación cinética

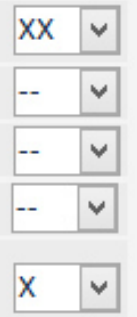

G39_El relato y el ritmo cinético son equivalentes

\section{Presentación de la historia - el relato}

G40_Orden lineal vectorial progresivo

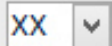

G41_Orden lineal vectorial

inverso/palíndromo/lineal no vect

G42_Orden no lineal/circular/cíclico/anacrónico

G43_Frecuencia simple
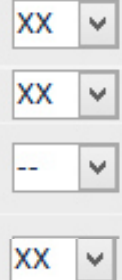

G44_Frecuencia: múltiple/repetitiva/frecuentativ

G45_Duración normal (absoluta-relativa)

G46_Duración anormal (contracción/dilatación)

G47_Orden, duración y/o frecuencia potencia la sensación móvil 
DATOS DE LA OBRA

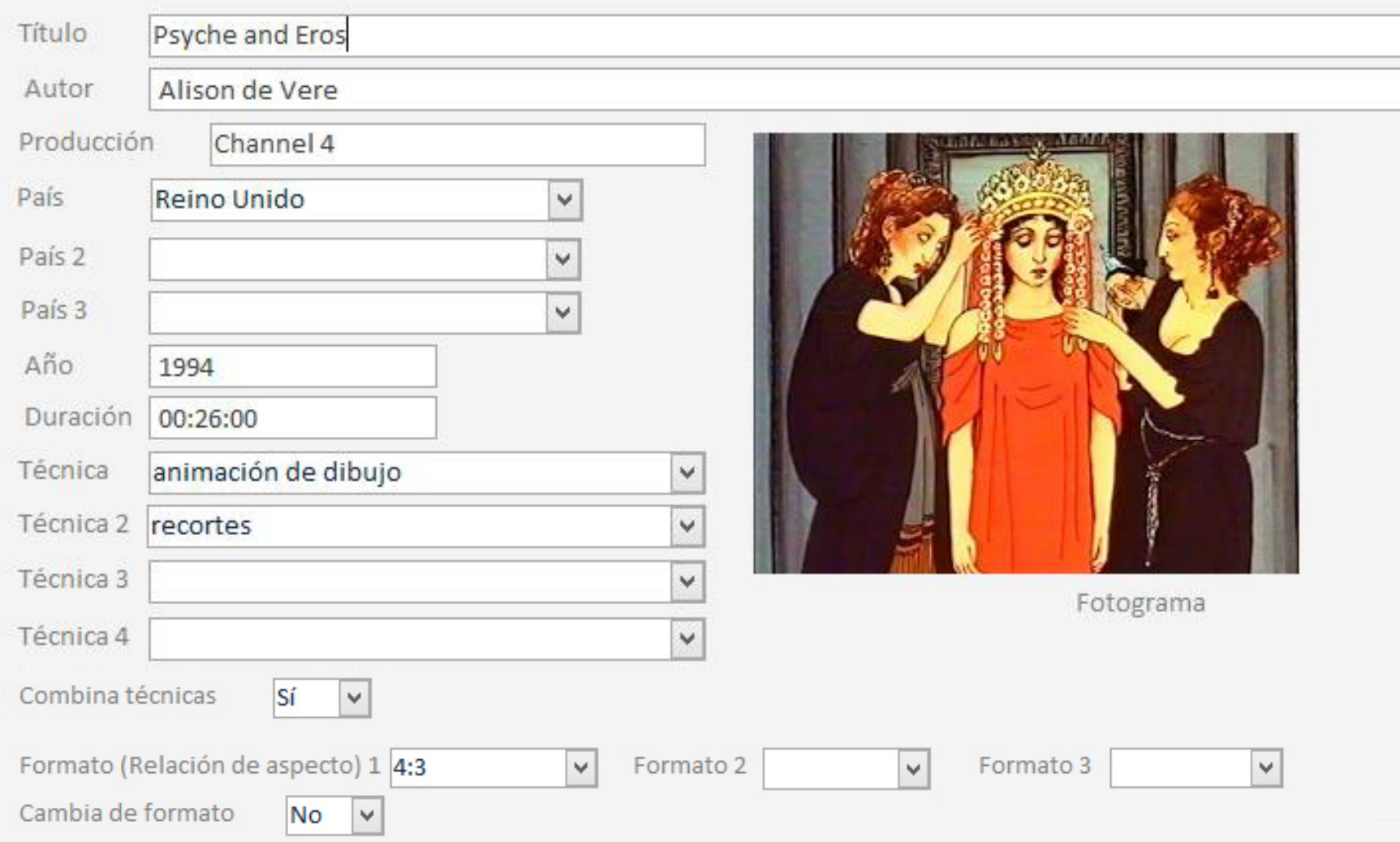

\section{EXPRESIÓN MOVIMIENTO COMO VIVENCIADO O COMO NEUTRO}

Provoca sensaciones cinéticas

Transmite carcaterísticas particulares de la acción

Homogenización de la expresión móvil

La acción se ubica en un espacio vivencial o matemat/neutro

\begin{tabular}{|l|l|}
\hline no & $\checkmark$ \\
\hline un poco & $\checkmark$ \\
\hline no/nada & $\checkmark$ \\
\hline vivencial > neutro & $\checkmark$ \\
\hline
\end{tabular}

TOTAL movimiento vivenciado/neutro

12

$12 \checkmark$

\section{ALGUNAS CARACTERÍSTICAS DE LA IMAGEN}

Nivel de naturalismo del móvil

Nivel de homogenización del móvil

Nivel de plasticidad de la imagen

TOTAL características de la imagen

\begin{tabular}{|l|l|}
\hline naturalista $>$ no naturalista & $\checkmark$ \\
\hline no/nada & $\checkmark$ \\
\hline si/mucho & $\checkmark$ \\
\hline 12 \\
\hline \begin{tabular}{|l|l|}
\hline 12 & $\checkmark$ \\
\hline
\end{tabular}
\end{tabular}

\section{CARCATERÍSTICAS DE LA REPRESENTACIÓN DEL MOVIMIENTO}

Nivel de naturalismo del movimiento

Frecuencia de acontecimientos fantásticos o realistas naturalista $>$ no naturalista

punto medio 


\section{COMPONENTES DINÁMICOS}

\section{Movimiento presente}

G01_Variedad de frecuencia de imágenes por segundo

G02_Vibración producida por la iregularidad de trazo y mancha

G03_La vibración potencia las particularidades del mov

G04_Utiliza el movimiento óptico con fines expresivos

\section{Valoración espacio-temporal}

G05_La interpretación espacio-temporal es original

G06_Variedad de acciones y sucesos

G07_Variedad de trayectorias y velocidad

G08_Variedad de mov de los existentes, del espacio y de cámara

G09_Hay metamorfosis de los personajes y/o del espacio

G10_Sensación dinámica en los fotogramas

G11 Utiliza metáforas relacionadas con el movimiento

G12_La representación del mov es un código de animación

G13_Tiene acciones por interpolación

(animación CGI)

G14_El movimiento se obtiene por captura de video

G15_El mov se obtiene por captura de movimiento por sensores

G16_La repr del movimiento se fundamenta en la mecánica

G17_Utiliza líneas cinéticas/signos dinámicos

G18_Las trayectorias son confusas

G19_No hay variedad de acciones y sucesos

\section{Composición móvil}

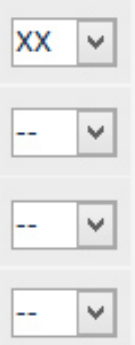

G20_Corte cinematográfico

G21_Cortes entre acciones concatenadas

G22_Cortes entre acciones que interrumpen el movimiento

G23_Fundidos entre planos

G24_Presenta planos-secuencia

G25_Abundancia de planos largos

G26_Abundancia de planos cortos

G27_Continuidad de trayectorias

G28_Tiene movimientos de cámara por animación

G29_Se muestran diferentes composiciones

G30_Las trayectorias generan el cambio compositivo

G31_Continuidad visual

G32_Utiliza planos subjetivos (mirada del personaje)

G33_La composición ayuda a transmitir la sensación móvil
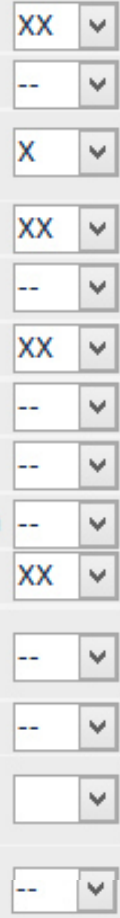

Distribución de la intensidad cinética

G34_Ritmo cinético discontinuo

G35 Ritmo cinético uniforme

G36_Ritmo cinético de intensidad creciente

G37 Ritmo cinético de intensidad decreciente

G38_EL ritmo cinético potencia o genera la sensación cinética

G39_El relato y el ritmo cinético son equivalentes
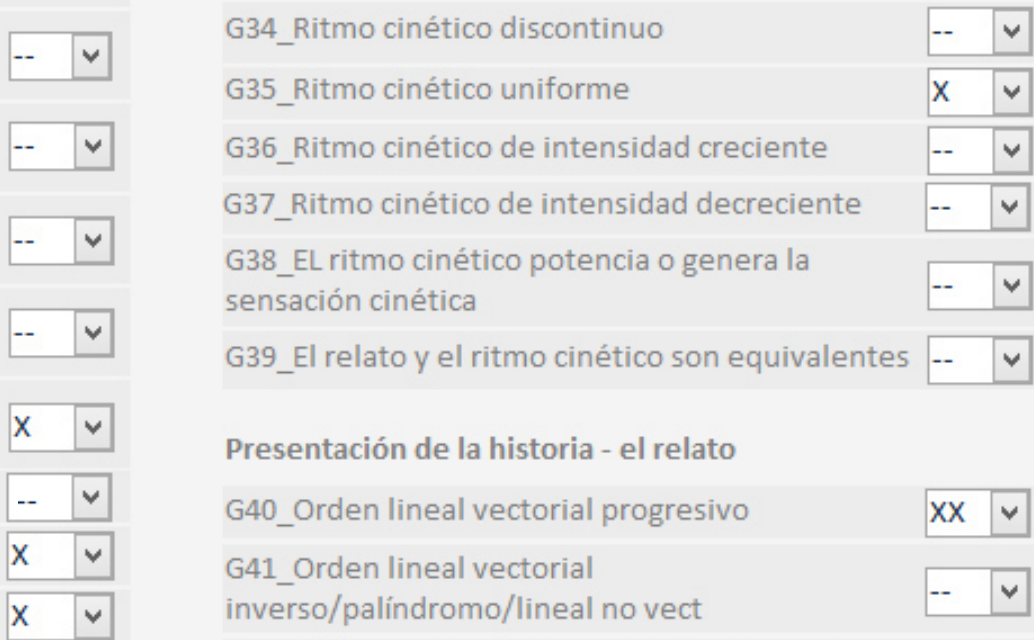

Presentación de la historia - el relato

G40_Orden lineal vectorial progresivo

$\mathrm{xX}$

G41_Orden lineal vectorial

inverso/palíndromo/lineal no vect
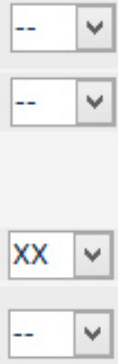

G42_Orden no lineal/circular/cíclico/anacrónico

G43_Frecuencia simple

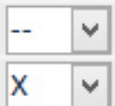

G44_Frecuencia: múltiple/repetitiva/frecuentativ

G45_Duración normal (absoluta-relativa)

G46_Duración anormal (contracción/dilatación)

G47 Orden, duración y/o frecuencia potencia la sensación móvil

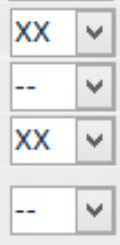




\section{LISTA DE IMÁGENES}

\section{Capítulo 1}

Fig. 1. Ernst Mach (1987). Dibujo del campo visual monocular. (Fuente: Ardila 1980, 278).

Fig. 2. Peralte de una carretera.

Fig. 3. Giambattista Tiepolo (1739). Céfiros con un caballo de Apolo. Nueva York, The Pierpont Morgan Library, (Fuente:). KNOX, G. (1970). Tiepolo: a bicentenary exhibition, 17701970: drawings, mainly from American collections, by Giambattista Tiepolo and the members of his circle. Cambridge, Massachusetts: Fogg Art Museum, Harvard University. ISBN 0-8240-1954-7. Fig. 19).

Fig. 4. Jiri Trnka (1912-1959). Diseño para Sen noci svatojanske (Sueño de una noche de verano). Disponible en: 〈http://orphine.wordpress.com/2011/09/12/iiri-trnka/\#ipcarousel-7067) (Consulta 02/02/014).

Fig. 5. Jiri Trnka (1912-1959). Diseño para Sen noci svatojanske (Sueño de una noche de verano). Disponible en: 〈http://www.susanardelie.com/2013/08/04/weekly-crushlinks-july-29-august-4/> (Consulta 02/02/014).

Fig. 6. Rosa Peris (2010). Nadadores.

Fig. 7. Juliette Bailly (S/f). Investigación gráfica para Et hop!, (Fuente: Kawa-Topor, Fig. 21).

Fig. 8. Maurits Cornelis Escher (1960). Ascenso y descenso. Disponible en: 'http://www.mcescher.com/gallery/impossible-constructions/ascending-anddescending/ ' (Consulta 11/12/2014).

Fig. 9. Andrea Pozzo (1626). Apoteosis de San Ignacio (detalle). Roma, Sant' Ignazio di Loyola. Disponible en: ‘https://losolfamidas.files.wordpress.com/2012/10/detalle-apoteosisde-san-ignacio-padre-pozzo.png) (Consulta: 24/09/2012).

Fig. 10. Edvard Munch (1910). El asesino. Oslo, Museo Munch. (Fuente: López Blázquez, M. (2005). Munch. Madrid: Globus Comunicación S.A. ISBN 84-8223-266-5. pág. 20).

Fig. 11. Bill Plympton (1998). One of those days (Uno de esos días).

Fotogramas de diversas escenas. Reino Unido. (Fuente: Plympcorp [VHS]).

Fig. 12. Osamu Tezuka (1984). Jumping (Saltar). Serie de fotogramas. Disponible en: 〈http://vimeo.com/22840924〉 (Consulta 05/06/2012).

Fig. 13. Koji Yamamura (1984). Atama Yama (Monte Cabeza), serie de fotogramas. (Fuente: CICA , Centre International du Cinéma d'Animation [DVD]).

Fig. 14. Jimmy T. Murakami (1996). When the Wind Blows (Cuando el viento sopla). Serie de fotogramas. (Fuente: Channel 4 Television Corporation [VHS]).

Fig. 15. Frédéric Back (1981). Crac!. Serie de fotogramas. (Fuente: Les Films du Paradoxe and Panda Films [VHS]).

Fig. 16. Chris Hinton (2002). Flux. Fotogramas consecutivos. (Fuente: National Film Board Canada [VHS]). 
Fig. 17. Raimund Krumme (1996). Sandwich, comercial para la campaña publicitaria Got Milk? para California Milk Processor Board. Serie de fotogramas. Disponible en: 〈http://www.acmefilmworks.com/work/spot/sandwich/〉 (Consulta 15/08/2014).

Fig. 18. Raimund Krumme (1996). Flakes, comercial para la campaña publicitaria Got Milk? para California Milk Processor Board. Serie de fotogramas. Disponible en: 〈http://www.acmefilmworks.com/work/spot/flakes/〉 (Consulta 15/08/2014).

Fig. 19. Eamonn O'Neill (2011). I'm Fine Thanks (Estoy bien, gracias). Fotogramas consecutivos. (Fuente: Royal College of Art [DVD]).

Fig. 20. Gil Alkabetz(s/f). Hände weg! (iManos fuera!) (Fuente: Acme Filmworks [DVD]).

Fig. 21. Robert Zemeckis (1988). Who Framed Roger Rabbit? (¿Quién engañó a Roger Rabbit?). Serie de fotogramas. (Fuente: Touchstone Home Video [DVD].)

Fig. 22. Hiroyasu Ishida (2009). Fumiko no Kokuhaku (La confesión de Fumiko). Serie de fotogramas. Disponible en: (https://www.youtube.com/watch?v=dO9toCiXBTc) (Consulta 11/11/2012).

Fig. 23. Etienne Guiol (2010). Rame Dames. Serie de fotogramas. Disponible en: 〈http://vimeo.com/39095149〉 (Consulta 04/09/2013).

Fig. 24. Susan Young (1986). Carnival (Carnaval). Serie de fotogramas. (Fuente: Royal College of Art [DVD]).

Fig. 25. Frédéric Back (1993). Le fleuve aux grandes eaux (El poderoso río). Serie de fotogramas. (Fuente: Les Films du Paradoxe and Panda Films [VHS]).

Fig. 26. Josef Lamka (1985). O Človíčkovi (El hombrecito). Serie de fotogramas. Disponible en: 〈https://www.youtube.com/watch?v=WfZ-o3enoss〉 (Consulta 03/03/2012)

Fig. 27. Eric Goldberg (1999). Rhapsody in Blue; Fantasia 2000. Serie de fotogramas. (Fuente: Walt Disney Home Video, Buena Vista Home Entertainment, S.A. [VHS]).

Fig. 28. Karen Kelly (1994). Stressed (Estresados). Fotogramas consecutivos. (Fuente: Channel 4 Television Corporation [VHS]).

Fig. 29. Eric Goldberg (1999). Rhapsody in Blue; Fantasia 2000. Serie de fotogramas. (Fuente: Walt Disney Home Video, Buena Vista Home Entertainment, S.A. [VHS]).

Fig. 30. René Goscinny; Henri Gruel; Albert Uderzo; Pierre Watrin (1976). Les douze travaux d'Astérix (Las doce pruebas de Asterix). Fotogramas consecutivos. (Fuente: Filmax Home Video [VHS]).

Fig. 31. Gaëtan Brizzi, Paul Brizzi (1985). Astérix et la surprise de César (Asterix y la sorpresa del César). Fotogramas consecutivos. (Fuente: Filmax Home Video [VHS]).

Fig. 32. Jean-Loup Felicioli y Alain Gagnol (1999). Ça aurait du être moi ; Les tragédies minuscules (Debería haber sido yo; Las tragedias minúsculas). Francia. (Fuente: Folimage [VHS]).

Fig. 33. Jean-Loup Felicioli y Alain Gagnol (1999). Un couteau dans les fourchettes: Les tragédies minuscules (Un cuchillo entre los tenedores: Las tragedias minúsculas). Francia. (Fuente: Folimage [VHS]).

Fig. 34. Jean-Loup Felicioli y Alain Gagnol (1999). Si tu savais ce que s'en pense; Les tragédies minuscules (Si supieras lo que pienso; Las tragedias minúsculas). Francia. (Fuente: Folimage [VHS]).

Fig. 35. Jan Švankmajer (1987). Alice (Alicia). Serie de fotogramas. (Fuente: BFI [DVD]).

Fig. 36. Georges Schwizgebel (1998). Fugue (Fuga). Serie de fotogramas. (Fuente: National Film Board of Canada [DVD]). 
Fig. 37. Karen Kelly (1994). Stressed (Estresados). Serie de fotogramas. (Fuente: Channel 4 Television Corporation [VHS]).

Fig. 38. Raimund Krumme (1991). Die Kreuzung (La encrucijada). Fotogramas. (Fuente: ACME Film Works [DVD]).

Fig. 39. Rosa Peris y Mercedes Peris (2011). Libidinis. Fotogramas. (Fuente: copia privada).

Fig. 40. Robert Zemeckis (1988). Who Framed Roger Rabbit? (¿Quién engañó a Roger Rabbit?). Serie de fotogramas. (Fuente: Touchstone Home Video [DVD].)

Fig. 41. Julien Bisaro (2006). L'Oeil du Cyclone (El ojo de la tormenta). Serie de fotogramas. (Fuente: Copia privada).

Fig. 42. Christa Moesker (1997). Sientje. Serie de fotogramas. Disponible en: 〈https://www.youtube.com/watch?v=AgYn7j-iEnc〉 (Consulta 08/08/2014).

Fig. 43. Yoshio Takeuchi (1997). Janguru taitei (Kimba, el león blanco). Serie de fotogramas. Disponible en: 〈https://www.youtube.com/watch?v=cHbSI7mQFel) (Consulta 15/12/2014).

Fig. 44. Michael Arias (2006). Tekkonkinkret. Serie de fotogramas. (Fuente: Sony Pictures Home [DVD]).

Fig. 45. Michael Arias (2006). Tekkonkinkret. Serie de fotogramas. (Fuente: Sony Pictures Home [DVD]).

Fig. 46. Francesc Punsola (s/f). Cómo hacerse el nudo de la corbata: a la española, a la inglesa, a la americana, a la italiana o hazte un lazo. Disponible en: 〈http://makememinimal.com/category/instrucciones/〉 (Consulta 11/12/2014).

Fig. 47. IKEA (s/f). Instrucciones de montaje para la escalera-banco BECKVAM. Disponible en: 〈http://packardjennings.com/?page id=2〉 (Consulta 11/12/2014).

Fig. 48. Packard Jennings (2006). Business Replay Disponible en: 〈http://packardjennings.com/?page id=2) (Consulta 11/12/2014).

Fig. 49. Duane Hanson (1969). Footbah Vignette. Viena. Museum Moderner Kunst Stiftung Ludwig. Disponible en: 〈http://www.g-truc.net/post-0365.html〉 (Consulta 11/12/2014).

Fig. 50. Richard Uglik (h. 2000). La Libertad guiando al pueblo. Disponible en: 〈http://tempsreel.nouvelobs.com/galeries-photos/photo/20130313.OBS1668/lesplaymobil-dans-tous-leurs-etats-de-richard-unglik.html> (Consulta 11/12/2014).

Fig. 51. Richard Uglik (h. 2000). La lechera. Disponible en: 〈http://lasmilvidas.blogspot.com.es/2014/02/exposicion-el-museo-imaginariode.html> (Consulta 11/12/2014).

Fig. 52. Wataru Yoshizumi (1992-1995). Mermelade Boy (La familia crece). Disponible en: 〈http://mangau.com/m/marmalade-boy-la-familia-crece/tomo-2/9/〉 (Consulta el 16/12/2014).

Fig. 53. Gardner Fox, Gil Kane y Sid Greene (1968). Batgirl's Costume Cut Ups (El traje de Batgirl se rompe) (detalle). Disponible en: 〈http://dccomicsartists.com/batman/NewLook.htm〉 (Consulta 16/12/2014).

Fig. 54. Jim Davis (1991). Gardfield (detalle de la tira publicada el 6/1/1991). Disponible en: 〈http://pt.jikos.cz/garfield/1991/〉 (Consulta 16/12/2014).

Fig. 55. Frank Thomas (1942). Dibujos preparatorios para Bambi. (Fuente: Thomas \& Johnston, 1981, págs. 162-163). 
Fig. 56. Antonio Bazzi (1517). Bodas de Alejandro y Roxana. Roma, Villa Farnesina. Disponible en: 〈http://www.settemuse.it/arte bio I/il sodoma.htm〉 (Consulta: 03/06/2015).

Fig. 57. Chris Lavis y Maciek Szczerbowski (2007). Madame Tutli-Putli. Disponible en: 〈http://vimeo.com/8120949〉 (Consulta 20/11/2010).

Fig. 58. Dave Fleischer y Shamus Culhane (1932). Betty Boop's Bamboo Isle (Betty Boop's, la isla del bambú). Fotogramas de dos escenas Disponible en: 〈https://www.youtube.com/watch?v=dkuLKTkJG4M) (Consulta 16/12/2014).

Fig. 59. Ralph Bakshi (1983). Fire and Ice (Fuego y hielo). Disponible en: 〈http://filmconnoisseur.blogspot.com.es/2010/08/fire-and-ice-1983.html〉 (Consulta 16/12/2014).

Fig. 60. Richard Linklater (2006). A Scanner Darkly. (Fuente: Warner Independent Pictures [DVD]).

Fig. 61. Alison de Vere (1994). Psyche and Eros (Pique y Eros). Serie de imágenes consecutivas. (Fuente: Channel 4 Televison Corporation [VHS]).

Fig. 62. Akinori Yabe (1994-1995). Mermelade Boy (La familia crece). Capítulo 1: Quiero enamorarme. Es guapo pero no le soporto, Serie de fotogramas. Disponible en: 〈https://www.youtube.com/watch?v=RgtrLf02n84) (Consulta 07/05/2012).

Fig. 63. s/a (s/f). El cuerpo humano para niños. Disponible en: 〈https://www.youtube.com/watch?v=-9qXJp9dqdl〉 (Consulta el 07-01-2015).

Fig. 64. Philip Artus (2011). Snail Trail. Escultura láser. Disponible en: 〈http://vimeo.com/27659555〉 (Consulta 04/04/2013).

Fig. 65. Chuck Jones (1951). Wile E. Coyote and the Road Runner (El coyote y el correcaminos). Serie de fotogramas. Disponible en: 〈https://www.youtube.com/watch?v=S3Nos85TpBE〉 (Consulta 10/05/2014).

Fig. 66. Chris Buck y Jennifer Lee (2013). Frozen, el reino del hielo. Boceto. Disponible en: ‘https://scontent-a-cdg.xx.fbcdn.net/hphotosash3/1003877 10152169457814239464652703 n.jpg) (Consulta 16/04/2014).

Fig. 67. SHED (2013). IGA - Aide Gourmet. Disponible en: 〈http://vimeo.com/65561144) (Consulta 15/04/2014).

Fig. 68. David Plaza (2014). Mario Animum, el primer monologuista 3D. Disponible en: 〈http://lacriaturacreativa.com/2014/02/una-escuela-de-animacion-conviertefacebook-en-la-sala-de-cine-mas-grande-del-mundo/' (Consulta 30/09/2014).

Fig. 69. Richard Hickey (2013). Francis. Disponible en: 〈https://www.youtube.com/watch?v=19xX6IQ gdY) (Consulta 23/05/2014).

Fig. 70. Jorge Blanco, Javier Abada y Martínez (2009). Planet 51. (Fuente: Warner [DVD]).

Fig. 71. Tomomi Mochizuki, Koji Sawai, Junji Nishimura y Tsutomu Shibiyama (1989-1992). Ramma 1/2. Disponible en: 〈http://4.bp.blogspot.com/ j0vGc3Vzs0/SJcimchBc3l/AAAAAAAAAVM/Wi DvQducn 4/s1600-h/83437648 390adf8820 o.jpg> (Consulta 18/12/2014).

Fig. 72. Kōzō Morishita (1972-1974). Las cadenas de la anmistad; Saint Seiya (Caballeros del zodiaco).

Fig. 73. Tadao Nagahama, Osamu Dezaki (1979-1980). Berusaiyu no Bara (La rosa de Versalles). Disponible en: 〈http://www.terra.com.ec/noticias/galerias/400861/fotosde-10-animes-que-marcaron-tv-peruana-noventa.html> (Consulta en 18/12/2014). 
Fig. 74. Tomoharu Katsumata. Studio Toei Animation (1972-1974). Majingā Zetto (Mazinger Z). Disponible en: (http://mazingerzgreatkaiser.wikia.com/wiki/Mazinger Z (series)?file=Mazinger Z DVD vol1 \%25282004\%2529.jpg) (Consulta en 18/12/2014).

Fig. 75. Raul García (s/f). Dibujo en perspectiva. (Fuente: García, 2000, pág. 112).

Fig. 76. Patrick Smith (2002). Delivery (Entrega). Fotogramas de dos escenas. (Fuente: Square Footage Films [DVD]).

Fig. 77. Francisco Ruiz y Sean McNally (2006). A Gentelmen's Duel (Duelo de caballeros). Disponible en: 〈http://vimeo.com/8379529〉 (Consulta 08/08/2014).

Fig. 78. Ignacio Ferreras (2002). How to Cope With Death (Cómo lidiar con la muerte). (Fuente: Sitges-Festival Internacional de Cinema de Catalunya [DVD]).

Fig. 79. Lotte Reiniger (1926). Die Abenteur des Prinzen Achmed (Las aventuras del príncipe Ahmed). Fotogramas de dos escenes. (Fuente: BFI [DVD]).

Fig. 80. Rafiq Elmansy (s/f). Fondos para animación. Disponible en: 〈http://www.graphicmania.net/cartoon-wallpapers-and-backgrounds-collection/〉 (Consulta 28/09/2014).

Fig. 81. Rafiq Elmansy (s/f). Fondos para animación. Disponible en: 〈http://www.graphicmania.net/cartoon-wallpapers-and-backgrounds-collection/〉 (Consulta 28/09/2014).

Fig. 82. Fig. 83. Eduardo Barragán (h. 2012). Casa del Fauno. Fotograma. Disponible en (https://www.youtube.com/watch?v=PZi-10HxnhA\&index=5\&list=PLLP06DgJ7LTYq1iVTR7mbMk50KryRJrH> (Consulta 10/03/2015).

Fig. 83. Airberlin (s/f). Safety Video Airberlin A320 (Video de seguridad Airberlin A320). Disponible en: ‘https://www.youtube.com/watch?v=8xMzreJlwh8) (Consulta 10/03/2015).

\section{CAPÍTULO 2}

Fig. 1. Co Hoedeman (1977). The Sand Castle (El castillo de arena). Disponible en: 〈http://www.dailymotion.com/video/x772hf the-sand-castle-co-hoedeman1977 creation) (Consulta 12/01/2015).

Fig. 2. s/a (s/f). Movimiento óptico. Disponible en: 〈http://www.taringa.net/post/imagenes/17481730/Imagenes-Con-Efectos-opticosimpresionantes.html) (Consulta 04/05/2015).

Fig. 3. s/a (s/f). Movimiento óptico. Disponible en: 〈http://www.taringa.net/post/imagenes/17481730/Imagenes-Con-Efectos-opticosimpresionantes.html) (Consulta 04/05/2015).

Fig. 4a. Gil Alkabetz (1991). Swamp nyz sumpf (Pantano). Fotograma. (Fuente: Acme Filmworks [DVD]).

Fig. 4b. Gil Alkabetz (1991). Swamp nyz sumpf (Pantano) Efecto óptico de multiplicación. (Fuente: Acme Filmworks [DVD]). 
Fig. 5. Wolfgang Reitherman (1970). The Aristocats (Los Aristogatos). Disponible en: 〈https://www.lewiswaynegallery.com/the-aristocats-lobby-card-set-1970-vf-nmwalt-disney-p-2255.html> (Consulta 03/05/2015).

Fig. 6. Rob Minkoff, Roger Allers (1994). The Lion King (El rey león). Disponible en: 〈http://www.fanpop.com/clubs/disney/images/19902748/title/lion-king-screencap〉 (Consulta 03/06/2015).

Fig. 7. Sébastien Laudenbach (2004). Des câlins dans les cuisines (Abrazos en la cocina). (Fuente: Copia privada).

Fig. 8. Fleming, Le Roy, Thorpe y Vidor (1939). The Wizard of Oz (El mago de Oz). Disponible en: ‘http://www.taringa.net/posts/imagenes/13917422/Un-Mono-Volador-de-laPrecuela-de-El-Mago-de-Oz.html) (Consulta 04/05/2015).

Fig. 9. Fleming, Le Roy, Thorpe y Vidor (1939). The Wizard of Oz (El mago de Oz). Disponible en: ‘ http://misterioparanormal.com/2013/10/20/origen-ocultista-de-la-pelicula-elmago-de-oz/> (Consulta 04/05/2015).

Fig. 10. Fleming, Le Roy, Thorpe y Vidor (1939). The Wizard of Oz (EI mago de Oz). Disponible en: «https://frommyglasses.wordpress.com/2013/03/07/ciudad-de-esmeralda/〉 (Consulta 04/05/2015).

Fig. 11. Frédéric Back (1981). Crac!. Serie de fotogramas. (Fuente: Les Films du Paradoxe and Panda Films [VHS]).

Fig. 12. Erica Russell (1994). Triangle (Triángulo). Serie de fotogramas. Disponible en: 〈https://www.youtube.com/watch?v=2UsFIHyNmQI〉 (Consulta 08/08/2011).

Fig. 13. Erica Russell (1994). Triangle (Triángulo). Serie de fotogramas. Disponible en: 〈https://www.youtube.com/watch?v=2UsFIHyNmQl) (Consulta 08/08/2011).

Fig. 14. Rosa Peris (2015). Simulación de película cinematográfica con imágenes de The man with the beautifull eyes (Hogdson, 2000).

Fig. 15. Rosa Peris (2015). Simulación de película cinematográfica con imágenes de The man with the beautifull eyes (Hogdson, 2000).

Fig. 16. Rosa Peris (2010). Tántalo. Fundidos encadenados. (Fuente: Copia privada).

Fig. 17. Michel Ocelot (1982). La légende du pauvre bossu (La leyenda del pobre jorobado). Serie de fotogramas. Disponible en: ‘https://www.youtube.com/watch?v=JvlknCt vg> (Consulta 15/08/2014).

Fig. 18. George Dunning (1968). Lucy in the Sky with Diamonds. Yellow Submarine (EI submarino amarillo). Fotogramas consecutivos. (Fuente: MGM [DVD]).

Fig. 19. Ryan Larkin (1972). Street Musique (Calle Música). Fotogramas consecutivos. (Fuente: Office National du Film du Canada [DVD]).

Fig. 20. Caroline Leaf (1987). The Metamorphosis of Mr. Samsa (La metamosfosis del señor Samsa). Serie de fotogramas. Disponible en: 〈https://www.youtube.com/watch?v=PI5HCAwh8ul〉 (Consulta 28/08/2010).

Fig. 21. Marcell Jankovics (1974). Sisyphus (Sísifo). Disponible en: 〈http://graphicinema.blogspot.com.es/〉 (Consulta 04/01/2013).

Fig. 22. Asignun GmbH (2014). Animación vertical en LCD Screen Asignun. Pantalla de smartphone. Disponible en: (https://www.youtube.com/watch?v=EX SAuLNOTl) (Consulta 26-01-2015).

Fig. 23. Borivoj Dovnikovic-Bordo (1989). The Exciting Love Story (Una excitante historia de amor). (Fuente: Laurence King [DVD]). 
Fig. 24. Paul Driessen (1996). The End of the World in Four Seasons (El fin del mundo en cuatro estaciones). (Fuente: NIS Film Distribution Holland [VHS]).

Fig. 25. Kathy Rose (1991). Oriental Interplay. Performance con animación. Disponible en: 〈https://www.youtube.com/watch?v=b0UQU30ErU4〉 (Consulta 09/08/2010).

Fig. 26. Diana Menestrey (2011). Anomalis - Near but blint (Anomalía - Cerca pero ciegos). Instalación con proyección láser. (Fuente: fotografía propia).

Fig. 27. Nick Park (1989). Creature Comforts (Comodidades de la criatura). Disponible en: 〈https://www.youtube.com/watch?v=pjSIB9WfpF4〉 (Consulta 07/03/2015).

Fig. 28. Renzo Kinoshita (1977). Japonese. (Fuente: ASIFA-Japan [DVD]).

Fig. 29. Rosa Peris (2006). Prostitución infantil. Fotogramas consecutivos. (Fuente: Copia privada).

Fig. 30. Ivan Ivanov-Vano (1976). Konyok-gorbunok (El caballito jorobado). (Fuente: Alta Films Vídeo [VHS]).

Fig. 31. Sanni Lahtinen (2010). Kuka kehtaa? (¿Quién osa?). Serie de fotogramas. Disponible en: 〈https://vimeo.com/13907826) (Consulta 06/08/2012).

Fig. 32. Frédéric Back (1978). Tout rien (Todo nada). Serie de fotogramas. (Fuente : Les Films du Paradoxe and Panda Films [VHS]).

Fig. 33. Frédéric Back (1978). Tout rien (Todo nada). Serie de fotogramas. (Fuente : Les Films du Paradoxe and Panda Films [VHS]).

Fig. 34. Caroline Leaf (1974). The OwI Who Married a Goose (La lechuza que se casó con una gansa). Serie de fotogramas. Disponible en:

〈https://www.youtube.com/watch?v=fusYZ7elhps〉 (Consulta 15/03/2015).

Fig. 35. Jonathan Hogdson (2000). The man with the beautifull eyes (El hombre de los ojos bonitos). Serie de fotogramas. Reino Unido. Disponible en:

〈https://www.youtube.com/watch?v=JW12Ealvi0s〉 (Consulta 03/03/2015).

Fig. 36. Frédéric Back (1981). Crac!. Serie de fotogramas. (Fuente: Les Films du Paradoxe and Panda Films [VHS]).

Fig. 37. Ivan Ivanov-Vano (1976). Konyok-gorbunok (El caballito jorobado). Serie de fotogramas. (Fuente: Alta Films Vídeo [VHS]).

Fig. 38. Chen Xi y Xu An(2001). Grain coupon (El cupón de grano). (Fuente: Copia privada).

Fig. 39. Kōzō Morishita y Kazuhito Kikuchi (1986-1988).Sancturay daikessen! Atena saidai no kiki (La gran batalla del Santuario)capítulo 41 tempora 1 El santuario. Saint Seiya (Caballeros del zodiaco). Disponible en:

(http://www.dailymotion.com/video/xfpj96 caballeros-del-zodiaco-aioria-de-leo-vsshaka-de-virgo videogames) (Consulta 03/03/2015).

Fig. 40. Erica Russell (1994). Triangle (Triángulo). Serie de fotogramas. Disponible en: 〈https://www.youtube.com/watch?v=2UsFIHyNmQlı (Consulta 08/08/2011).

Fig. 41. Rosa Peris (2006). Prostitución infantil. Serie de fotogramas. (Fuente: Copia privada).

Fig. 42. Annelaure Daffis y Léo Marchand (2007). La Saint-Festin. Serie de fotogramas. Disponible en: 〈https://vimeo.com/6687000) (Consulta 03/10/2012).

Fig. 43. Craig Welch (1996). How Wings are Attached to the Back of Angels (Cómo las alas están unidas a la espalda de los ángeles). Serie de fotogramas. Disponible en: 〈https://www.youtube.com/watch?v=NRHVzbJVx81〉 Consulta 03/10/2012).

Fig. 44. Frédéric Back (1973). La création des oiseaux (La creación de los pájaros). Serie de fotogramas. (Fuente: Les Films du Paradoxe and Panda Films [VHS]). 
Fig. 45. Joanna Quinn (1993). Britannia. Serie de fotogramas. Disponible en: 〈https://www.youtube.com/watch?v=zJ2q508gzao) (Consulta 05/03/2015).

Fig. 46. Paul Driessen (1977). The Killing of an Egg (Asesinato de un huevo). Fotogramas. Disponible en: 〈https://www.youtube.com/watch?v=1z-XTeyV8Dk) (Consulta 05/03/2015).

Fig. 47. Noémie Marsily et Carl Roosens (2014). Moustique (Mosquito). (Fuente: Copia privada).

Fig. 48. Georges Schwizgebel (1992). La curse à l'abîme (La maldición del abismo). (Fuente: National Film Board of Canada [DVD]).

Fig. 49. Michel Ocelot (1980). Les trois inventeurs (Los tres inventores). Fotogramas de diversas escenas. Disponible en: (https://www.youtube.com/watch?v=A002vUNJtA8) (Consulta 05/03/2015).

Fig. 50. Alfredo Jimeno Martínez y Jose Ignacio de la Torre Echávarri (2009). Numancia. Serie de fotogramas. Disponible en: (https://www.youtube.com/watch?v=|3z SZbw1 4) (Consulta 25/12/2014).

Fig. 51. s/a (s/f). Sincronización entre música y movimiento para una animación. (Fuente: Halas, 1990, pág. 70).

Fig. 52. Tetsuya Nomura y Takeshi Nozue (2005). Final Fantasy VII. Advent Children (Fantasía final VII. Los hijos del advenimiento). Serie de fotogramas. Disponible en: 〈https://www.youtube.com/watch?v=WyPlwtBTXpk〉 (Consulta 03/03/2015).

Fig. 53. Ronald Searle (1965). Créditos animados de Those Magnificent Men in Their Flying machines or How I Flew from London to Paris in 25 hours 11 minutes (Esos chalados en sus locos cacharros o cómo volé de Londres a Paris en 25 horas y 11minutos). (Fuente: 20th CENTURY FOX [DVD].)

Fig. 54. Rosa Peris (2015). Gráfico de intensidad cinética de la película Swamp nyz sumpf (Alkabetz, 1991).

Fig. 55. Frédéric Back (1975). Illusion? (¿llusión?). Dos series de fotogramas. (Fuente : Les Films du Paradoxe and Panda Films [VHS]).

Fig. 56. Rosa Peris (2015). Gráfico de intensidad cinética de la película La ravissement de Frank N. Stein (Schwizgebel, 1982).

Fig. 57. Rosa Peris (2015). Gráfico de intensidad cinética de la película La poulette grisse (McLaren, 1947).

Fig. 58. Rosa Peris (2015). Gráfico de intensidad cinética de la película Tututú (Rosa Peris, 2012).

Fig. 59. Claudius Gentinetta y Frank Braun (2011). Schlaf (Dormir). Fotogramas de varios planos. Disponible en: 〈https://vimeo.com/82308126〉 (Consulta 04/08/2014).

Fig. 60. LAN Airlines (h.2007). LAN Airlines: Safety Video Airbus 320, instrucciones de seguridad de la compañía aérea LAN Airlines. Fotogramas de varios planos. Disponible en: 〈https://www.youtube.com/watch?v=ICDCE8rdeGw〉 (Consulta 13/04/2015). 


\section{CAPÍTULO 3}

Fig. 1. Walt Disney Studios (1959). Sleeping Beauty (La bella durmiente). (Fuente: Thomas \& Johnston, 1981, pág. 322).

Fig. 2. Mark Andrews; Brenda Chapman y Steve Purcell. Brave (Brave. Indomable). Serie de fotogramas. (Fuente: Walt Disney Pictures [DVD]).

Fig. 3. Raúl García (2000). Pelota botando. (Fuente: García, 2000, pág. 26).

Fig. 4. Walt Disney Studios (s/f). Pelota botando. (Fuente: Thomas \& Johnston, 1981, pág. 51).

Fig. 5. Raúl García (2000). Movimiento del pelo. (Fuente: García, 2000, pág. 44).

Fig. 6. Giulio Gianini y Emanuele Luzzati (1968). L'italiana in Algeri (La italiana en Argelia). Disponible en: 〈https://www.youtube.com/watch?v=PGHpt80WYnw) (Consulta 27/08/2014).

Fig. 7. Jean-Loup Felicioli y Alain Gagnol (1999). L'egoïste; Les tragédies minuscules (EI egoísta; Las tragedias minúsculas). Serie de fotogramas. (Fuente: Folimage [VHS]).

Fig. 8. Raimund Krumme (1994). Passage (El paso). Serie de fotogramas. (Fuente: Acme Filmworks [DVD]).

Fig. 9. Vuk Jevremovic (1997). The wind subsides (El viento se calma). Serie de fotogramas. (Fuente: Copia privada).

Fig. 10. Serotonin Tech (2013). Animación educativa: StudioHistoria. Serie de fotogramas. Disponible en: (https://www.youtube.com/watch?v=uNuuSaccUTw) (Consulta 13/04/2015)

Fig. 11. Walt Disney Studios (s/f). Squash and Strech. (Fuente: Thomas \& Johnston, 1981, pág. 47).

Fig. 12. Les Clark (1936). The Country Cousin (El primo de campo). (Fuente: Thomas \& Johnston, 1981, pág. 48).

Fig. 13. Bill Tytla (1937). Snow White and the Seven Dwarfs (Blanca Nieves y los siete enanitos). (Fuente: Thomas \& Johnston, 1981, pág. 60).

Fig. 14. John Halas y Harold Whitaker (s/f). Slow in - slow out. (Fuente: Halas \& Whitaker, 1981, pág. 47).

Fig. 15. Estudios Disney (s/f). Arcos de acción. (Fuente: Blair, 1994, Pág. 140).

Fig. 16. John Halas y Harold Whitaker (s/f). Anticipación. Fuente: Halas \& Whitaker, 1981, pág. 58).

Fig. 17. Walt Disney Studios (s/f). Donald Duck. (Fuente: Thomas \& Johnston, 1981, pág. 52).

Fig. 18. Ralph Bakshi (1992). Cool World (Una rubia entre dos mundos). Serie de fotogramas. Disponible en: 〈https://www.youtube.com/watch?v=56yuq0kB-8k) (Consulta 30/04/2012).

Fig. 19. Joanna Quinn (1990). Body Beautiful (Cuerpo hermoso). Fotogramas consecutivos. (Fuente: Beryl Productions International Ltd [DVD]).

Fig. 20. Bill Roberts (1936). Alpine Climbers (Escaladores alpinos). (Fuente: Thomas \& Johnston, 1981, pág. 149).

Fig. 21. Sanni Lahtinen (h.2013). Tanssi (Danza). Fotogramas consecutivos. Disponible en: 〈http://vimeo.com/79478135) (Consulta 30/08/2012).

Fig. 22. Annelaure Daffis y Léo Marchand (2007). La Saint-Festin. Fotogramas consecutivos. Disponible en: (https://vimeo.com/6687000) (Consulta 03/10/2012). 
Fig. 23. Chris Hinton (2002). Flux. Fotogramas consecutivos. (Fuente: National Film Board Canada [VHS]).

Fig. 24. Kōzō Morishita y Kazuhito Kikuchi (1986-1989). Saint Seiya (Caballeros del Zodiaco), Temporada 1, capítulo 21: La Pirámide de hielo. Fotogramas consecutivos. (Fuente: Paramount [DVD])

Fig. 25. José Antonio Sastiaga (1970). Ere erera baleibu icik subua aruaren. Celuloide pintado. Disponible en: 〈http://www.cataclismo.net/comprar.php?id=754〉 (Consulta 02/01/2013).

Fig. 26. Rosa Peris (2011). Fotogramas consecutivos de la animación dibujo a dibujo. Animación 1. Experimentación plástica de animación por fases yuxtapuestas. (Fuente: Copia privada).

Fig. 27. Rosa Peris (2014). Fotogramas consecutivos de la animación 6. Experimentación plástica de animación por fases yuxtapuestas. (Fuente: Copia privada).

Fig. 28. Rosa Peris (2011). Fragmento de banda de imagen de la animación 2 con líneas verticales que indican la división entre fotogramas. Experimentación plástica de animación por fases yuxtapuestas. (Fuente: fotografía propia).

Fig. 29. (Rosa Peris (2011). Fragmento de banda de imagen de la animación 3. Experimentación plástica de animación por fases yuxtapuestas (Fuente: fotografía propia).

Fig. 30. Rosa Peris (2011). Detalle de banda de imagen de la animación 3. Experimentación plástica de animación por fases yuxtapuestas (Fuente: fotografía propia).

Fig. 31. Rosa Peris (2011). Fragmento de banda de imagen de la animación 4.

Experimentación plástica de animación por fases yuxtapuestas (Fuente: fotografía propia).

Fig. 32. Rosa Peris (2011). Banda de imagen de la animación 5. Experimentación plástica de animación por fases yuxtapuestas (Fuente: fotografía propia).

Fig. 33. Rosa Peris (2011). Una de las bandas curvas y dos de los círculos de la animación 6. Experimentación plástica de animación por fases yuxtapuestas (Fuente: fotografía propia).

Fig. 34. Rosa Peris (2011). Detalle de banda de imagen de la animación 6. Experimentación plástica de animación por fases yuxtapuestas (Fuente: fotografía propia).

Fig. 35. Pieter Paul Rubens (1639 - 1640). Diana y sus ninfas sorprendidas por sátiros. Madrid, Museo del Prado. Disponible en:

〈https://abrancoalmeida.files.wordpress.com/2010/11/rubens-diana-y-sus-ninfassorprendidas-por-satiros-1638-1640.jpg) (Consulta 02/01/2013).

Fig. 36. Marc Chagall (1969). Ballet. Daphnis y Cloe. Upton (Massachusetts), Spaightwood Galleries. Disponible en: 〈http://www.spaightwoodgalleries.com/Pages/Chagall Lovers.html〉 (Consulta 01/03/2013)

Fig. 37. Rosa Peris (2012). Tututú. Dibujos preparatorios. (Fuente: fotografía propia).

Fig. 38. Rosa Peris (2012). Tututú. Dibujos preparatorios. (Fuente: fotografía propia).

Fig. 39. Rosa Peris (2011). Mío, tuyo, nuestro. Dibujos preparatorios. (Fuente: fotografía propia).

Fig. 40. Raimund Krumme (2000). The Message (El mensaje). (Fuente: Acme Filmworks [DVD]). 
Fig. 41. Joanna Quinn (1990). Body Beautiful (Cuerpo hermoso). Fotogramas consecutivos. (Fuente: Beryl Productions International Ltd [DVD]).

Fig. 42. Cavaliere d'Arpino (1603-1606). Diana y Acteón. Budapest, Museum of Fine Arts. Disponible en: (http://dexedrina.blogspot.com.es/2011/09/diana-y-acteon-y-iii.html) (Consulta 25/03/2011).

Fig. 43. Pedro Serrazina (1996). Estória do gato e da lua (Historia del gato y la Luna). Páginas de flipbook. (Fuente: Estória do gato e da lua (flipbook). Oporto: Filmógrafo. 1996.

Fig. 44. Abi Feijó (2000). Clandestino. Páginas de flipbook. (Fuente: Clandestino (flipbook). Oporto: Filmógrafo. 2000.

Fig. 45. Karen Kelly (1994). Stressed (Estresados). Serie de fotogramas. (Fuente: Channel 4 Television Corporation [VHS]).

Fig. 46. Mercedes Peris (2010). Nadando en el aire. Serie de fotogramas. (Fuente: Copia privada).

Fig. 47. Rosa Peris (2011). Báladi. Fotogramas consecutivos. (Fuente: Copia privada).

Fig. 48. Jiri Trnka (1912-1959). Sen noci svatojanske (Sueño de una noche de verano). Serie de fotogramas. Disponible en: (https://www.youtube.com/watch?v=m5u09h2eaRw ) (Consulta 02/02/014).

Fig. 49. Barry Purves (1990). Next! (iSiguiente!). Serie de fotogramas. Disponible en: 〈https://www.youtube.com/watch?v=V3dQFR8oWb4〉 (Consulta 07/04/2012).

Fig. 50. Captura del movimiento del rostro en Pirates of the Caribbean: Dead Man's Chest (Piratas del Caribe: el cofre del hombre muerto) (2006). Disponible en: (http://listas.20minutos.es/lista/peliculas-de-motion-capture-333458/) (Consulta 05/07/2013).

Fig. 51. s/a (s/f). Estadios de producción de captura de movimiento. Disponible en: 〈https://upload.wikimedia.org/wikipedia/commons/6/6d/Activemarker2.PNG) (Consulta 05/07/2013).

Fig. 52. Peter Foldes (1974). La Faim (Hambre). Disponible en: 〈http://www.dailymotion.com/video/x701pi la-faim-peter-foldes-1974 creation` (Consulta 23/08/2010).

Fig. 53. Lee Unkrich (2010). Toy Story 3. Disponible en: 〈http://www.fanpop.com/clubs/pixar/images/13593043/title/toy-story-3screencaps-screencap) (Consulta 03/06/2015).

Fig. 54. Raimund Krumme (1989). Zuschauer (Espectadores). (Fuente: Acme Filmworks [DVD]).

Fig. 55. Chen Xi y Xu An (2001). Grain coupon (El cupón de grano). (Fuente: Copia privada).

\section{CAPÍTULO 4}

Fig. 1. Reinhard Klooss (2013). Tarzán. Disponible en: 〈http://www.cinedor.es/noticias/primer-trailer-de-tarzan-3d-en-espanol〉 (Consulta 08/08/2011). 
Fig. 2. Thibaut Weise (h.2011). Captura de movimiento del rostro con Faceshift. Disponible en: 〈https://www.youtube.com/watch?v=let0xvjdCus) (Consulta 08/08/2011).

Fig. 3. Medicine Forever (h.2014). Life in the womb (9 months in 4 minutes) (La vida en el vientre materno (9 meses en 4 minutos)). Serie de fotogramas. Disponible en: 〈https://www.youtube.com/watch?v=-jIPdMKPyZY) (Consulta 15/04/2015).

Fig. 4. Chris Hinton (2002). Flux. Serie de fotogramas. (Fuente: National Film Board Canada [VHS]).

Fig. 5. Koji Yamamura (2011). Muybridge's strings (Las cuerdas de Muybridge). Serie de fotogramas. Disponible en: (https://www.youtube.com/watch?v=87GHAqk4C6w) (Consulta 15/08/2014).

Fig. 6. Frédéric Back (1978). Tout rien (Todo nada). Serie de fotogramas. (Fuente : Les Films du Paradoxe and Panda Films [VHS]).

Fig. 7. Jiri Trnka (1912-1959). Sen noci svatojanske (Sueño de una noche de verano). Serie de fotogramas. Disponible en: 〈https://www.youtube.com/watch?v=m5u09h2eaRw) (Consulta 02/02/014).

Fig. 8. Hayao Miyazaki (2004). Howl no Ugoku Shiro (El Castillo ambulante). (Fuente: Aurum Producciones [DVD]).

Fig. 9. Igor Kovalyov (2005). Milch (Leche). Acme Filmworks [DVD].

Fig. 10. Igor Kovalyov (2005). Milch (Leche). Acme Filmworks [DVD].

Fig. 11. Joanna Quinn (2006). Dreams And Desires. Family Ties (Sueños y deseos. Lazos familiares). Serie de fotogramas. Disponible en: 〈https://www.youtube.com/watch?v=Z8S9XJLtLhU〉 (Consulta 08/08/2013).

Fig. 12. Joanna Quinn (2006). Dreams And Desires. Family Ties (Sueños y deseos. Lazos familiares). Serie de fotogramas. Disponible en: 〈https://www.youtube.com/watch?v=Z8S9XJLtLhU〉 (Consulta 08/08/2013).

Fig. 13. Joanna Quinn (2006). Dreams And Desires. Family Ties (Sueños y deseos. Lazos familiares). Serie de fotogramas. Disponible en: 〈https://www.youtube.com/watch?v=Z8S9XJLtLhU 〉 (Consulta 08/08/2013).

Fig. 14. Tono Errando, Javier Mariscal y Fernando Trueba (2010). Chico y Rita. Serie de fotogramas. (Fuente: S.L. The Walt Disney Company Iberia [VHS]).

Fig. 15. Lotte Reiniger (1926). Die Abenteur des Prinzen Achmed (Las aventuras del príncipe Ahmed). (Fuente: BFI [DVD]).

Fig. 16. Henry Selick (1993). The Nightmare Before Christmas (Pesadilla antes de Navidad). (Fuente: Walt Disney Pictures [VHS]).

Fig. 17. Alison de Vere (1987). The black dog (El perro negro). (Fuente: Channel 4 Television Corporation [VHS]).

Fig. 18. Alison de Vere (1987). The black dog (El perro negro). (Fuente: Channel 4 Television Corporation [VHS]).

Fig. 19. Jiri Trnka (1912-1959). Diseño para Sen noci svatojanske (Sueño de una noche de verano). Serie de fotogramas. Disponible en: 〈https://www.youtube.com/watch?v=m5u09h2eaRw 〉 (Consulta 02/02/014).

Fig. 20. Jiri Trnka (1912-1959). Sen noci svatojanske (Sueño de una noche de verano). Serie de fotogramas. Disponible en: 〈https://www.youtube.com/watch?v=m5u09h2eaRw 〉 (Consulta 02/02/014). 
Fig. 21. Faith Hubley y John Hubley (1974). Cockaboody. Serie de fotogramas. Disponible en: 〈https://www.youtube.com/watch?v=NSFKjfQolgY〉 (Consulta 06/02/2011).

Fig. 22. Frédéric Back (1977). Taratatá la parade. Fotogramas de varios planos. (Fuente: Les Films du Paradoxe and Panda Films [VHS]).

Fig. 23. Gil Alkabetz (1991). Swamp nyz sumpf (Pantano). (Fuente: Acme Filmworks [DVD]).

Fig. 24. Bruno Bozzetto (1965). West and Soda. (Fuente: Expanded Entertainment [VHS]).

Fig. 25. Rosa Peris (2007). Corre, caballito. (Fuente: Copia privada).

Fig. 26. Mercedes Peris (2007). Corre, caballito. (Fuente: Copia privada).

Fig. 27. Frédéric Back (1981). Crac!. (Fuente: Les Films du Paradoxe and Panda Films [VHS]).

Fig. 28. Witold Giersz (1961). Maly Western. Disponible en: 〈http://playpoland.org.uk/pokazy-specjalne.html〉 (Consulta 08/10/2012).

Fig. 29. Lotte Reiniger (1953). The magic horse (El caballo mágico). Disponible en: 〈https://mubi.com/films/the-magic-horse) (Consulta 30/08/2010).

Fig. 30. Ivan Ivanov-Vano (1976). Konyok-gorbunok (El caballito jorobado). (Fuente: Alta Films Vídeo [VHS]).

Fig. 31a. Desmond Davis (1981). Clash of the Titans (Furia de titanes). Disponible en: 〈http://www.scifinow.co.uk/top-tens/top-12-best-ray-harryhausen-monsterscreatures-and-creations/> (Consulta 10/06/2015).

Fig. 31b. Desmond Davis (1981). Clash of the Titans (Furia de titanes). Disponible en: uhttp://www.thelandofshadow.com/day-18-of-the-mordor-halloween-countdownthe-scariest-characters-ever-seen-on-film/> (Consulta 10/06/2015).

Fig. 31c. Desmond Davis (1981). Clash of the Titans (Furia de titanes). Disponible en: 〈http://community.eu.playstation.com/t5/General-Discussion-Watch/Clash-Of-TheTitans-1981/td-p/12389740) (Consulta 10/06/2015).

Fig. 31d. Desmond Davis (1981). Clash of the Titans (Furia de titanes). Disponible en: (http://nerdreactor.com/2013/05/13/stop-motion-gods-in-memory-of-rayharryhausen/> (Consulta 10/06/2015).

Fig. 32a. Roger Allers y Rob Minkoff (1994). The Lion King (El rey león). Disponible en: 〈http://es.disney.wikia.com/wiki/Los \%C3\%91us (The Lion King)〉 (Consulta 10/06/2015).

Fig. 32b. Roger Allers y Rob Minkoff (1994). The Lion King (El rey león). Disponible en: 〈http://blogs.disneylatino.com/disney-classic/2014/12/29/10-hechos-que-conociassobre-el-rey-leon/'> (Consulta 10/06/2015).

Fig. 32c. Roger Allers y Rob Minkoff (1994). The Lion King (El rey león). Disponible en: 〈http://lionking.wikia.com/wiki/Wildebeests) (Consulta 10/06/2015).

Fig. 33. Hayao Miyazaki (2004). Howl no Ugoku Shiro (El Castillo ambulante). Serie de fotogramas (Fuente: Aurum Producciones [DVD]).

Fig. 34. James Cameron (2010). Avatar. Disponible en: «ttp://www.diariocordoba.com/noticias/cultura/james-cameron-rodara-tressecuelas-avatar-simultaneamente 725063.html) (Consulta 15/06/2015).

Fig. 35. James Cameron (2010). Avatar. Disponible en: 〈http://siempre889.com/noticias/avatar-sufre-nuevo-retraso/) (Consulta 15/06/2015).

Fig. 36. Fréderick Back (1987). L'homme qui plantait des arbres (El hombre que plantaba árboles). (Fuente: Les Films du Paradoxe and Panda Films [VHS]). 
Fig. 37. Chris Buck y Jennifer Lee (2013). Frozen, el reino del hielo. (Fuente: Walt Disney Pictures [DVD]).

Fig. 38. Christian Cantamessa, Leslie Benzies, Alan Blaine, Silas Morse (2010). Dark Horse; Red Dead Redemption. Disponible en: 〈http://reddead.wikia.com/wiki/Dark Horse?file=IMG 2825.jpg〉 (Consulta $11 / 06 / 2015)$.

Fig. 39. Alfredo Jimeno Martínez y Jose Ignacio de la Torre Echávarri (2009). Numancia. Disponible en: (https://www.youtube.com/watch?v=|3z SZbw1 4) (Consulta 25/12/2014).

Fig. 40. Ray Harryhausen (1981). Diseño para Pegaso en Clash of the Titans (Furia de Titanes). Disponible en: 〈http://www.moviepropcollectors.com/magazine/2010/05/20/exclusive-coverageof-ray-harryhausen-exhibit-at-a-m-p-a-s-a-must-see/all/1/> (Consulta 11/06/2015).

Fig. 41. Phil Mulloy (1992). The sound of music (El sonido de la música). (Fuente: BFI [DVD]).

Fig. 42. Eamonn O'Neill (2011). I'm Fine Thanks (Estoy bien, gracias). Serie de fotogramas. [DVD] Royal College of Art. (Fuente: Royal College of Art [DVD]).

Fig. 43. Jiri Trnka (1912-1959). Sen noci svatojanske (Sueño de una noche de verano). Serie de fotogramas. Disponible en: 〈https://www.youtube.com/watch?v=m5u09h2eaRw 〉 (Consulta 02/02/014).

Fig. 44. Florence Miailhe (1995). Schéhérazade. Serie de fotogramas. (Fuente: Garde Temps Eds Du [DVD]).

Fig. 45. Giulio Gianini y Emanuele Luzzati (1968). L'italiana in Algeri (La italiana en Argelia). Disponible en: 〈https://www.youtube.com/watch?v=PGHpt80WYnw) (Consulta $11 / 08 / 2010)$

Fig. 46. Chen Xi y Xu An (2001). Grain coupon (El cupón de grano). (Fuente: Copia privada).

Fig. 47. Norman McLaren (1952). Neighbours (Vecinos). Serie de fotogramas. (Fuente: Homevision [DVD]).

Fig. 48. Shin Hashimoto (2011). Beluga. Disponible en: 〈https://vimeo.com/56691307) (Consulta 11/08/2013).

Fig. 49. Florence Miailhe (1996). Histoire d'un prince devenu borgne et mendiant (Historia de un príncipe que se convirtió en tuerto y mendigo). (Fuente : Garde Temps Eds Du [DVD]).

Fig. 50. Alison de Vere (1994). Psyche and Eros (Pique y Eros). (Fuente: Channel 4 Televison Corporation [VHS]).

Fig. 51. Iria López (2013). Jamón. Disponible en: 〈https://vimeo.com/108986967〉 (Consulta 22/12/2014).

Fig. 52. Barry Purves (2011). Tchaikovsky - An Elegy (Tchaikovsky - Una elegía). Disponible en: 〈https://www.youtube.com/watch?v=xQ2KdShvQH4 〉 (Consulta 28/12/2012).

Fig. 53. Tibos Banoczki y Sarolta Szabo (2011). Les Conquérants (Los conquistadores). (Fuente: Copia privada).

Fig. 54. Jan Svankmajer (1982). Možnosti dialogu (Dimensiones del diálogo). Serie de fotogramas. (Fuente: BFI DVD Publishing [DVD]).

Fig. 55. Hayao Miyazaki (2001). Sen to Chihiro no Kamikakushi (El viaje de Chihiro). (Fuente: Aurum Producciones [DVD]).

Fig. 56. Jan Svankmajer (2000). Otesánek (El pequeño Otik). (Fuente: Zeitgeist Films [DVD].) 
Fig. 57. Tatia Rosenthal (2008). 9.99\$. (Fuente: E1 Entertainment [DVD]).

Fig. 58. Florence Miailhe (2002). Au premier dimanche d'août (El primer domingo de agosto) Serie de fotogramas. (Fuente: Garde Temps Eds Du [DVD]). 



\section{LISTA DE TABLAS}

Pág.

Tabla 1. Expresividad del movimiento en relación al diseño del móvil 403

Tabla 2. Expresividad del movimiento en relación a la temática representada 413 



\section{Bibliografía}

Alberti, R. (1925-1926). El Alba del Alhelí. Buenos Aires: Losada, 1947.

Alison de Vere's Psyche and Eros. The Lost Continent. Exploring the Art and History of British Animation (04 de 08 de 2011). Disponible en: 〈http://ukanimation.blogspot.com.es/2011/08/alison-de-veres-psyche-anderos.html (Consulta: 03/01/2013).

Ardila, A. (1980). Psicología de la percepción. México D.F.: Editorial Trillas S.A. ISBN 968-240895-4.

Arias, \& Martín, L. (1997). El cine como experiencia estética. Valladolid: Caja España. ISBN 8487739644.

Arnheim, R. (1980). Hacia una psicología del arte: Arte y entropía. (Ensayo sobre el desorden y el orden). Madrid: Alianza. ISBN 8420670138.

Arnheim, R. (1957). El cine como arte. Barcelona: Ediciones Paidós Ibérica, S.A., 1986. ISBN 84-7509-366-3.

Arnheim, R. (1979). Arte y percepción visual. La psicología del ojo creador. Nueva versión. (M. Balseiro, Trad.) Madrid: Alianza Editorial. ISBN: 84-206-8691-3.

Bachelard, G. (1943). El aire y los sueños: Ensayo sobra la imaginacion del movimiento. México: Fondo de Cultura Económica, 1986. ISBN 9681602315.

Bogad, L. M. (s/f). Beautiful trouble, a toolbox for revolution. Theory: Aliention Effect. Disponible en 〈http://beautifultrouble.org/theory/alienation-effect/) (Consulta 26/12/2013).

Bakedano, J. J. (1987). Norman McLaren. Obra completa 1932-198. Bilbao: Museo de Bellas Artes, D.L. ISBN 8450552435

Belda Villena, E. (1961). Mecánica. Tomo I: Mecánica clásica (Vol. I). Bilbao: La Editorial Vizcaína S.A.

Bendazzi, G. (2003). Cartoons: 110 años de cine de animación. (V. Cremer, Trad.) Madrid: Ocho y medio. ISBN 84-95839-44-X.

Bergson, H. (1934). El pensamiento y lo moviente. Madrid: Espasa Calpe. ISBN 8423916154. 
Bollnow, O. F. (1969). Hombre y espacio. (J. L. Martín, Trad.) Barcelona: Ediciones Labor SA.

Borges, J. L. (1960). El Hacedor. Madrid: Alianza Editorial, 2003. ISBN 9788420633336.

Brecht, B. (1948). El Pequeño organon para el teatro escrito. Disponible en 〈http://es.scribd.com/doc/24993807/Brecht-Bertolt-Pequeno-organon-para-el-teatrocompleto-1948) (Consulta 26/12/2013).

Cotte, O. (2004). Georges Schwizgebel. Des peintures animées. Die laufenden Farbbilder. Animated paintings. (D. J. Hanhart, \& E. S. Mallinson, Trads.) Ginebra: Editions Heuwinkel. ISBN 3-9064-10-18-8.

Croce, B. (1908). Estética como ciencia de la expresión y lingüística general. Buenos Aires: Nueva Visión, 1976.

Deleuze, G. (1983). La imagen movimiento. Estudios sobre cine 1. Barcelona: Ediciones Paidós, 1994. ISBN 84-7509-317-5.

Delgado, J. (s/f). Las neuronas espejo: ¿Qué son?. Rincón de la Psicología. Disponible en (http://www.rinconpsicologia.com/2014/01/las-neuronas-espejo-que-son.html) (Consulta 21/09/2015).

Delgado, P. (2000). El cine de animación. Madrid: Ediciones JC, D.L. ISBN 84-89-56421-3.

Drate, S. \& Salavetz, J (2007). Pure Animation. Steps to Creation with 57 Cutting Edge Animators. London, New York: Marrell. ISBN 978-1-8589-4365-7.

Dr. Grob's Animation Review (s/f). The animation film review site. Disponible en 〈http://drgrobsanimationreview.com/tag/erica-russell/〉 (Consulta 26/12/2013).

Dubois, P. (1986). El acto fotográfico. De la representación a la recepción. Barcelona: Paidós Comunicación. ISBN 8475093795.

Dumas, A. (1844). El conde de Montecristo (Sexta edición ed.). (E.V., Trad.) Barcelona: Random House Mandori, 2008. ISBN: 978-84-397-1034-9.

Duran, J. (2008). El cine de animación norteamericano. Barcelona: Editorial UOC. ISBN 8497887700.

Feldman, S. (2001). La composición de la imagen en movimiento (2 2 a reimpresión ed.). Barcelona: Editorial Gedisa. ISBN: 84-7432-579-X.

Foucault, M. (1970). El orden del discurso. Barcelona: Tusquets Editores S.A.

Fundación Autor. (2004). Cortografía: animación. Madrid: Fundación Autor. ISBN 848048635X.

García, R. (2000). La magia del dibujo animado: Actores del lápiz. Alicante: Edicions de Ponent S.L. ISBN 84-89929-16-5.

Gravett, P. (2004). Manga: la era del nuevo cómic. Madrid: H Kliczkowski-Onlybook, cop. ISBN 9788496592056. 
Gombrich, E. H. (1960). Arte e ilusión: estudio sobre la psicología de la representación pictórica (2a edición ed.). Madrid: Debate, 2002. ISBN 8483060876.

Gombrich, E. H. (1982). La imagen y el ojo: Nuevos estudios sobre la psicología de la representación pictócrica. Madrid: Alianza, 1987. ISBN 8420670650.

Guillaume, P. (1937). Psicología de la forma. (A. Beret, Trad.) Buenos Aires: Psique, 1971.

Hahn, D. (2008). The Alchemy of Animation. Making an Animated Film in the Modern Age (19 edición ed.). New York: Disney Editions. ISBN 978-142310476-6.

Halas, J. (1990). The contemporary animator (1a edición ed.). London - Boston: Focal Press. ISBN 0-240-51280-4.

Halas, J., \& Whitaker, H. (1981). Timing for Animation. Northants-Stoneham: Focal Press. ISBN 0-240-51310-X.

Hansend, B. (Dirección). (2005). "Lemonade"- Making Of the Rotoscoped Film ("Limonada"Making Of de la película de rotoscopia). Disponible en: 〈https://www.youtube.com/watch?v=BXIVjePBccc〉 (Consulta 27/09/2014).

Hooks, E. (2003). Acting for Animators: A Complete Guide to Performance Animation, Volumen 1. Pensilvania: Pearson Education. ISBN 0-325-00580-X.

Hugo, V. (1860). Los miserables. Buenos Aires: Editorial Losada, 2005. ISBN 950-03-9382-4.

Kandinsky, V., \& Fundació Caixa Catalunya. (2003). La disolución de la forma 1900-1920. Barcelona: Fundación Caixa Catalunya, cop. ISBN 8489860483.

Kawa-Topor, X. (s.f.). Le Cinéma d'animation. Résidence d'écriture à Fontevraud. Nantes: Éditions 303.

Lee, R. W. (1940). Ut pictura poesis. La teoría humanística de la pintura. Madrid: Cátedra, 1982. ISBN 8437603714.

Lloret Ferrándiz, C. (1985). Movimiento real, virtual y óptico: La revelación de su continuidad en las artes plásticas. Tesis doctoral. Dirección: Francisco Baños Martos. Valencia: Universidad Politécnica de Valencia.

Marcolli, A. (1978). Teoría del campo. Curso de educación visual. Madrid: Xarait. ISBN 84-85434-01-3.

Martín Árias, L. (1997). El cine como experiencia estética. Valladolid: Caja España. ISBN: 8487739644.

Mullen, T. (2007). Introducing Charcater Animation with Blender (Animación de personajes con Blender). (Á. Parra Pérez, Trad.) Madrid: Anaya S.A., 2008. ISBN 978-84-415-2305-0.

Newton, I. (1726). Philosophiae Naturalis Principia Mathematica, EQ, AUR (Editio tertia aucta et emendata ed.). Londres: apud Guil. \& Joh. Innys, Regiæ Societatis typographos. 
Northen Lights (2002). Realism and 'Reality' in Film and Media. Copenague: Museum Tusculanun Press y Universidad de Copenague. ISBN 87-7289-716-3

Pickover, C. A. (2009). De Arquímedes a Hawking. Las leyes de la ciencia y sus descubridores. Barcelona: Crítica. ISBN 9788498920031.

Plazaola, J. (2007). Introducción a la estética. Historia, Teoría, Texto (4a edición ed.). Bilbao:Universidad de Deuto. ISBN 9788498301007.

Racionero, L. (1983). Textos de estética taohista. Madrid: Alianza. 2002. ISBN 8420677728

Raffaelli, L. (1994). Le anime disegnate: il pensiero nei cartoon da Disney ai giapponesi. Roma: Castelvecchi, 1998. ISBN 9788882100759.

Rilke, R. M. (1929). Cartas a un joven poeta. (L. Di lorio, \& G. Thiele, Trads.) Buenos Aires: Ediciones siglo veinte, 1980.

Scharf , A. (1994). Arte y fotografía, 1968-1974. Madrid: Alianza Editorial, S.A. ISBN 420671258

Schickel, R. (Dirección). (1997). The Harryhausen's chronicles [documental]. MGM (Warner) [DVD].

Sifianos, G. (2012). Esthétique du cinéma d'animation (1a edición ed.). París: Editions du Cerf y Editions Corlet. ISBN 9782204098380.

Tendero Vázquez, T. (16 de 01 de 2013). Danza: movimiento vivencial del ser. Univers biocèntric. Disponible en: 〈http://universbiocentric.wordpress.com/2013/01/16/danza-movimiento-vivencial/) (Consulta 15/11/2014).

Thomas, F. \& Johnston, O. (1981). The Illusion Of Life: Disney Animation (2ª edición ed.). New York: Hyperion. ISBN 0-7868-6070-7.

Vegas, F. F. (Septiembre de 2008). Beowulf y la captura de movimiento. Render out! Pixeltale Studio Magazine (6), 55-59.

Wells, P. (1998). Understanding Animation (2ª reimpresión ed.). Londres: Routledge. ISBN 0415115973.

Wells, P. (2007). Scriptwriting. N. developing and creating text for a play, film or broadcast. Lausanne, Switzerland: AVA Publishing S.A. ISBN 2-940373-16-7.

Wells, P. (2007). The beautiful village and the true villages: A Consideration of Animation and the Documentary Aesthetic. Art and Design (Art and Animation) 53, 40-45.

Wright, J. (2005). Animation Writing and Development. From Script Development to Pitch. Burlington Massachusetts: Elsevier, Focal Press. ISBN: 0-240-80549-6.

Xavier, J.-M. (2007). Poética do Movimento. Lisboa: Edições da MONSTRA. ISBN 978-989-20-0660-4. 


\section{Filmografía}

Agudo Pinilla, D. (Dirección). (2002). Lluvia. España. Disponible en: 〈https://www.youtube.com/watch?v=W-47FCGuc2U〉 (Consulta 21/08/2009).

Airberlin (Producción) (s/f). Safety Video Airberlin A320 (Video de seguridad Airberlin A320). Disponible en: 〈https://www.youtube.com/watch?v=8xMzreJlwh8) (Consulta 14/03/2015).

LAN Airlines (Producción). (2010). Cómo pilotar un avión a través de dibujos animados. Disponible en: 〈https://www.youtube.com/watch?v=SZ5fk9m2OqQ) (Consulta 15/04/2014).

LAN Airlines (Producción). (h.2007). Safety Video Airbus 320, instrucciones de seguridad de la compañía aérea LAN Airlines. Disponible en: 〈https://www.youtube.com/watch?v=ICDCE8rdeGw) (Consulta 13/04/2015).

Alkabetz, G. (Dirección). (1984). Bitz Butz. Alemania. Acme Filmworks [DVD].

Alkabetz, G. (Dirección). (1991). Swamp nyz sumpf (Pantano). Alemania. Acme Filmworks [DVD].

Alkabetz, G. (Dirección). (1995). Yankale. Alemania. Disponible en: 〈https://www.youtube.com/watch?v=1CW5kO3CMoA) (Consulta 27/12/2014).

Alkabetz, G. (Dirección). (1997). Rubicon. Alemania. Acme Filmworks [DVD].

Alkabetz, G. (Dirección). (2002). The Da Vinci's Time Code (El código de tiempo de Da Vinci). Alemania. Disponible en: ‘http://vimeo.com/83717701).

Alkabetz, G. (Dirección). (2002). Travel to China (Viaje a China). Alemania. [Copia privada].

Alkabetz, G. (Dirección). (s/f). Hände weg! (iManos fuera!). Alemania. Acme Filmworks [DVD].

Andrews, M., Chapman, B., \& Purcell, S. (Dirección). (2012). Brave (Indomable). Estados Unidos. Walt Disney Pictures [DVD].

Animaciones explicativas de la zona de seguridad emitido en el aeropuerto de Lisboa (2015). Portugal. Emisión: 22/03/2015.

Arias, M. (Dirección). (2006). Tekkonkinkret. Japón. Sony Pictures Home [DVD]. 
Artus, P. (Dirección). (2011). Snail Trial. Alemania. Disponible en: 〈http://vimeo.com/27659555) (Consulta 04/04/2013).

Back, F. (Dirección). (1972). Inon or the Conquest of Fire (Inon o la conquista del fuego). Canadá. Radio-Canada [DVD].

Back, F. (Dirección). (1973). La création des oiseaux (La creación de los pájaros). Canadá. Les Films du Paradoxe and Panda Films [VHS].

Back, F. (Dirección). (1975). Ilusion? (¿llusión?). Canadá. Les Films du Paradoxe and Panda Films [VHS]

Back, F. (Dirección). (1977). Taratatá la parade. Canadá. Les Films du Paradoxe and Panda Films [VHS].

Back, F. (Dirección). (1978). Tout rien (Todo nada). Canadá. Les Films du Paradoxe and Panda Films [VHS].

Back, F. (Dirección). (1978). Tout rien (Todo nada). Canadá. Les Films du Paradoxe and Panda Films [VHS].

Back, F. (Dirección). (1981). Crac!. Canadá. Les Films du Paradoxe and Panda Films [VHS].

Back, F. (Dirección). (1987). L'homme qui plantait des arbres (El hombre que plantaba árboles). Canadá. Les Films du Paradoxe and Panda Films [VHS].

Back, F. (Dirección). (1993). Le fleuve aux grandes eaux (El poderoso río). Canadá. Les Films du Paradoxe and Panda Films [VHS].

Bakshi, R. (Dirección). (1983). Fire and Ice (Fuego y hielo). Estados Unidos. Disponible en: 〈http://filmconnoisseur.blogspot.com.es/2010/08/fire-and-ice-1983.html〉 (Consulta 16/12/2014).

Bakshi, R. (Dirección). (1990). Cool World (Una rubia entre dos mundos). Estados Unidos. Paramount Home Entertainment [DVD].

Banoczki, T. (Dirección). (2007). Milk teeth (Dientes de leche). Reino Unido. Disponible en: ‘https://vimeo.com/17030852، Consulta 26/07/2011).

Banoczki, T., \& Szabo, S. (Dirección). (2011). Les Conquérants (Los conquistadores). Francia. [Copia privada].

Barker, C. (Director). (1988). The Cat Come Back (El gato volvió). Canadá. Disponible en: 〈https://www.youtube.com/watch?v=9Btaluudtx8〉 (Consulta 07/08/2013).

Barragán, E. (Dirección) (h. 2012). Casa del Fauno. España. Disponible en 〈https://www.youtube.com/watch?v=PZi-10HxnhA\&index=5\&list=PLLP06DgJ7LTYq1iVTR7mbMk50KryRJrH> (Consulta 04/01/2012).

Bergqvist, S., Ekstrand, M., Odell, J., \& Ohlson, L. (Dirección). (1993). Revolver. Suecia. Disponible en: 〈https://vimeo.com/11558102〉 (Consulta 13/08/2010). 
Bird, B. (Dirección). (2007). Ratatouille. Estados Unidos. Walt Disney Pictures [DVD].

Bisaro, J. (Dirección). (2006). Oeil du Cyclone (El ojo de la tormenta). Francia. [Copia privada].

Borowczyk, W. (Dirección). (1964). Renaissance (Renacimiento). Francia. Disponible en: 〈http://www.dailymotion.com/video/x12876 renaissance shortfilms〉 (Consulta 22/12/20109.

Bowers, C. R., \& Fisher, B. (Dirección). (1925). Soda Jerks. Estados Unidos. Disponible en: 〈https://www.youtube.com/watch?v=aqpsC1 h-20) (Consulta 16/08/2013).

Bozzetto, B. (Dirección). (1965). West and Soda. Italia. Expanded Entertainment [VHS].

Bozzetto, B. (Dirección). (1990). Cavallette (Langostas). Italia. Disponible en: 〈https://www.youtube.com/watch?v=Jj2Z-secyqQ) (Consulta 24/12/2009).

Breymann, A. (Dirección). (2006). Sprößling (Retoño). Alemania. Disponible en: 〈http://www.dailymotion.com/video/xjat67 sprosling-anne-breymann shortfilms〉 (Consulta 03/08/2013).

Brizzi, G., \& Brizzi, P. (Dirección). (1985). Astérix et la surprise de César (Asterix y la sorpresa del César). Francia. Filmax Home Video [VHS].

Buck, C., \& Lee, J. (Dirección). (2013). Frozen (El reino del hielo). Estados Unidos. Walt Disney Pictures [DVD].

Burton, T. (Dirección). (2005). The Corpse Bride (La Novia cadáver). Estado Unidos. Warner Bros Entertainment [DVD].

Cady, B. (Dirección). (2012). Anomalies. Reino Unido. Royal College of Arts [DVD].

Callissoni, C., \& Offrédo, E. (Dirección). (2009). O'moro. Francia. Disponible en: 〈https://www.youtube.com/watch?v=P6YzhlvxSrA〉 (Consulta 10/10/2012).

Cameron, J. (Dirección). (2010). Avatar. Estados Unidos. Twentieth Century Fox Home Entertainment [DVD].

Canemaker, J. (1984). Bottom's dream (El sueño de Bottom). Estados Unidos. Fragmento disponible en: (https://www.youtube.com/watch?v=maXM-gFi1hQ) (Consulta 26/12/2011).

Cantolla, David; Gallego, Luis; Garcia, Guillermo (Dirección) (2005). Pocoyo. Zinkia Entertainment [TV].

Chaffey, D. (Dirección). (1963). Jason and the Argonauts (Jasón y los argonautas) (animación de Ray Harryhausen). Estados Unidos, Reino Unido. Columbia Pictures [VHS].

Chansay, J.-L. (Dirección). (2001). Plaid: Eyen. Francia. [Copia privada].

Cournoyer, M. (Dirección). (1999). Le chapeau (El sombrero). Canadá. Disponible en: 〈https://www.youtube.com/watch?v=VNO3-yy94HQ) (Consuelta 20/08/2009). 
Daffis, A., \& Marchand, L. (Dirección). (2007). La Saint-Festin. Francia. Disponible en: 〈https://vimeo.com/6687000) (Consulta 03/10/2012).

Davis, D. (Dirección). (1981). Clash of the Titans (Furia de titanes) (animación de Ray Harryhausen). Estados Unidos. MGM (Warner) [DVD].

De Roeck, E. (Dirección). (2011). Malou ou l'hostitilté mécanique (en Ut majeur) (Malou o la hostilidad mecánica (en Fa mayor)). Bélgica. ADIFAC [DVD].

de Vere, A. (Dirección). (1987). The black dog (El perro negro). Reino Unido. Channel 4 Television Corporation [VHS].

de Vere, A. (Dirección). (1994). Psyche and Eros (Psique y Eros). Reino Unido. Channel 4 Televison Corporation [VHS].

Díez, R. (Dirección). (2002). Sr. Trapo. España. Disponible en: 〈https://vimeo.com/15062497) (Consulta 18/03/2014).

Dovnikovic-Bordo, B. (Dirección). (1989). The Exciting Love Story (Una excitante historia de amor). Yugoslavia. Laurence King [DVD].

Driessen, P. (Dirección). (1977). Killing of an Egg (Asesinato de un huevo). Holanda. Disponible en: 〈https://www.youtube.com/watch?v=1z-XTeyV8Dk) (Consulta 05/03/2015).

Driessen, P. (Dirección). (1996). The End of the World in Four Seasons (El fin del mundo en cuatro estaciones). Polonia. NIS Film Distribution Holland [VHS].

Drouin, J. (Dirección). (1994). Ex-enfants (Ex-niños). Canadá. (Disponible en: 〈https://www.youtube.com/watch?v=5vEJ G-wep0〉 Consulta 07/02/2015).

Drouin, J., \& Pojar, B. (Dirección). (1986). L'Heure des Anges (Nightangel). CanadáChecoslovaquia. NFB / Krátký Film Praha [VHS].

Dudok de Wit, M. (Dirección). (1994). Le moine et le poisson (El monje y el pez). Francia. Disponible en: 〈https://www.youtube.com/watch?v=CXfCNE5P6tM) (Consulta 19/07/2011).

Dudok de Wit, M. (Dirección). (2000). Father and Daughter (Padre e hija). Países Bajos. Disponible en: 〈https://www.youtube.com/watch?v=VUqBfBRYI4A) (Consulta 07/08/2013).

Dunning, G. (Dirección). (1962). The Flying Man (El hombre volador). Reino Unido. Disponible en: 〈https://www.youtube.com/watch?v=zaJq4pcNk w) (Consulta 17/10/2014).

Dunning, G. (Dirección). (1968). Yellow Submarine (El submarino amarillo). Reino Unido. MGM [DVD]. 
Dunning, G. (Dirección). (1972). Damon the Mower (Damon la segadora). Reino Unido. Disponible en: 〈http://www.youtube.com/watch?v=PV8TpQ8ZjKk〉 (Consulta, 27/12/2013).

Errando, T., Mariscal, J., \& Trueba, F. (Dirección). (2010). Chico y Rita, España; Reino Unido: S.L. The Walt Disney Company Iberia [VHS].

Federenko, E. (Dirección). (1979). Every child (Todos los niños). Canadá. Disponible en: 〈https://www.youtube.com/watch?v=vUhbbP9X8LE) (Consulta 02/01/2012).

Felicioli, J.-L., \& Gagnol, A. (Dirección). (1999). Ça aurait du être moi ; Les tragédies minuscules (Debería hacer sido yo; Las tragedias minúsculas). Francia. Folimage [VHS].

Felicioli, J.-L., \& Gagnol, A. (Dirección). (1999). L'egoïste; Les tragédies minuscules (El egoísta; Las tragedias minúsculas). Francia. Folimage [VHS].

Felicioli, J.-L., \& Gognol, A. (Dirección). (1999). Si tu savais ce que s'en pense ; Les tragédies minuscules (Si supieras lo que pienso. Las tragedias minúsculas). Francia. Folimage [VHS].

Felicioli, J.-L., \& Gognol, A. (Dirección). (1999). Un couteau dans les fourchettes: Les tragédies minuscules (Un cuchillo entre los tenedores: Las tragedias minúsculas). Francia. Folimage [VHS].

Ferreras, I. (Dirección). (2002). How to Cope With Death (Cómo lidiar con la Muerte). Reino Unidos. Sitges-Festival Internacional de Cinema de Catalunya.

Fleischer, D., \& Culhane, S. (Dirección). (1932). Betty Boop's Bamboo Isle (Betty Boop's, la isla del bambú). Estado Unidos. Disponible en: 〈https://www.youtube.com/watch?v=dkuLKTkJG4M) (Consulta 16/12/2014).

Fleming, V., LeRoy, M., Thorpe, T., \& Vidor, K. (Dirección). (1939). The Wizard of Oz (El mago de Oz). Estados Unidos. Warner Home Video [VHS].

Foldes, P. (Dirección). (1974). La Faim (Hambre). Canadá. Disponible en: 〈http://www.dailymotion.com/video/x701pi la-faim-peter-foldes-1974 creation〉 (Consulta 23/08/2010).

Medicine Forever. (Productor). (h. 2014). Life in the womb (9 months in 4 minutes) (La vida en el vientre materno (9 meses en 4 minutos)). Disponible en: 〈https://www.youtube.com/watch?v=-j|PdMKPyZY〉 (Consulta 15/04/2015).

Furuhashi, K. (Dirección). (2011-2012). Rurouni Kenshin: New Kyoto Arc (Rurouni Kenshin: El nuevo arco de Kyoto). Japón. Disponible en: 〈https://www.youtube.com/watch?v=QqHObo1yvyg) (Consulta 12/03/2015).

Gentinetta, C., \& y Braun, F. (Dirección). (2011). Schlaf (Dormir). Suiza. Disponible en: 〈https://vimeo.com/82308126) (Consulta 04/08/2014). 
Geronimi, C. (Dirección). (1959). Sleeping Beauty (La bella durmiente). Estados Unidos. Walt Disney Studios Home Entertainment [DVD].

Gianini, G., \& Luzzati, E. (Dirección). (1968). L'italiana in Algeri (La italiana en Argelia). Italia. Disponible en: ‘https://www.youtube.com/watch?v=PGHpt80WYnw) (Consulta 27/08/2014).

Giersz, W. (Dirección). (1961). Maly Western. Polonia. Disponible en: 〈http://playpoland.org.uk/pokazy-specjalne.html〉 (Consulta 08/10/2012)

Gluisiec, K. (Dirección). (2012). Velocity (Velocidad). Reino Unido. Royal College of Arts [DVD].

GmbH, A. (Dirección). (2014). Animación vertical en LCD Screen Asignun. Alemania. Disponible en: (https://www.youtube.com/watch?v=EX SAuLNOTl) .

Goldgerb, E. (Dirección). (1999). Rhapsody in Blue (Fantasia 2000). Estados Unidos. Walt Disney Home Video, Buena Vista Home Entertainment, S.A. [VHS].

Goscinny, R., Gruel, H., Uderzo, A., \& Watrin, P. (Dirección). (1976). Les douze travaux d'Astérix (Las doce pruebas de Asterix). Francia. Filmax Home Video [VHS].

Griffin, G. (Dirección). (1994). A Little Routine. Estados Unidos. Square Footage Films [DVD].

Gromskaya, J. (Dirección). (2012). Fiumana (Inundación). Italia. Disponible en: 〈https://vimeo.com/74100658 〉 (Consulta 03/12/2014).

Guiol, E. (Dirección). (2010). Animation Danse Contemporaine 2010 (Animación danza contemporánea 2010). Francia. Disponible en: 〈http://www.dailymotion.com/video/xp5aln animation-danse-contemporaine2010 creations (Consulta 17/10/2014).

Guiol, E. (Dirección). (2010). Rame Dames. Francia. Disponible en: 〈http://vimeo.com/39095149〉 (Consulta 04/09/2013).

Hall, D., Williams, C. (Dirección) (2014). Big Hero 6. Estados Unidos. Walt Disney Studios Home Entertainment [DVD].

Hand, D. Algar J., Roberts, B., Wright, N., Armstrong, S., Satterfield, P., \& Heid, G. (Dirección). (1942). Bambi. Estados Unidos. Walt Disney Home Video [VHS].

Hand, D., Cottrell, W., Morey, L., Pearce, P., \& Sharpsteen, B. (Dirección). (1937). Snow White and the Seven Dwarfs (Blanca Nieves y los siete enanitos). Estados Unidos. The Whalt Disney Company.

Hansen, B. (Dirección). (2006). Lemonade (Limonada). Estados Unidos. Disponible en: 〈https://www.youtube.com/watch?v=lkYYQNLWa2A) (Consulta 20/04/2011).

Hashimoto, S. (Dirección). (2011). Beluga. Japón. Disponible en: 〈https://vimeo.com/56691307〉 (Consulta 11/08/2013). 
Hendel, B. (Dirección). (1999). Pines of Rome; Fantasia 2000 (Pinos de Roma; Fantasía 2000). Estados Unidos. Walt Disney Home Video, Buena Vista Home Entertainment, S.A. [VHS].

Hickey, R. (Dirección). (2013). Francis. Estados Unidos. Disponible en: 〈https://www.youtube.com/watch?v=|9xX6|Q gdY) (Consulta 23/05/2014).

Hidaka, S. (Dirección). (2006). Bones (Huesos). Estados Unidos. Disponible en: 〈https://vimeo.com/41564071) (Consulta 10/08/2012).

Hilligoss, N. (Dirección). (2008). L'Animateur (El Animador). Australia. Disponible en: 〈https://www.youtube.com/watch?v=fJG9DdG6SNk〉 (Consulta 10/05/2011).

Hinton, C. (Dirección). (2002). Flux. Canadá. National Film Board Canada [VHS].

Hitchcock, A. (Dirección). (1958). Vertigo (De entre los muertos). Estado Unidos. Universal [DVD].

Hitchcock, A. (Dirección). (1960). Psycho (Psicosis). Estados Unidos. Universal Pictures [DVD].

Hoedeman, C. (Dirección). (1977). The Sand Castle (El castillo de arena). Canadá. Disponible en: (http://www.dailymotion.com/video/x $772 \mathrm{hf}$ the-sand-castle-co-hoedeman1977 creation> (Consulta 12/01/2015).

Hogdson, J. (Dirección). (2000). The man with the beautifull eyes (EI hombre de los ojos bonitos). Reino Unido. Disponible en: 〈https://www.youtube.com/watch?v=JW12Ealvj0s〉 (Consulta 03/03/2015).

Hubley, F., \& Hubley, J. (Dirección). (1974). Cockaboody. Estados Unidos. Disponible en: 〈https://www.youtube.com/watch?v=NSFKjfQolgY) (Consulta 06/02/2011).

Hubley, J., \& Hubley, F. (Dirección). (1967). A Windy Day (Día ventoso). Estados Unidos. Disponible en: ‘https://www.youtube.com/watch?v=cit6iUEEdyo) (Consulta 06/02/2011).

RMUSL Animation India (Dirección). (1999). Los niños tienen derecho a la protección durante los conflictos armados. India. Unicef [VHS].

Irwing, S. (Dirección). (2008). The Black Dog's progress. Reino Unido. Disponible en: 〈https://www.youtube.com/watch?v=qUn1TriMm3s (Consulta 24/08/2009).

Ishida, H. (Dirección). (2009). Fumiko no Kokuhaku. Japón. Disponible en: 〈https://www.youtube.com/watch?v=dO9toCiXBTc〉 (Consulta 11/11/2012).

Ivanov-Vano, I. (Dirección). (1976). Konyok-gorbunok (El caballito jorobado). Rusia. Alta Films Vídeo [VHS].

Jackson, P. (Dirección). (2001). The Fellowship of the Ring (La comunidad del anillo). Estados Unidos. Aurum Producciones [DVD]. 
Jankovics, M. (Dirección). (1974). Sisyphus (Sísifo). Estados Unidos. Disponible en: 〈http://graphicinema.blogspot.com.es/〉 (consulta 04/01/2013).

Jevremovic, V. (Dirección). (1997). The wind subsides (El viento se calma). Estados Unidos. [Copia privada].

Jevremovic, V. (Dirección). (2000). Tagebuch (Diario). Alemania. [Copia privada].

Jimeno Martínez, A., \& de la Torre Echávarri, J. I. (Dirección). (2009). Numancia. España: Disponible en: 〈https://www.youtube.com/watch?v=l3z SZbw1 4) (Consulta 25/12/2014).

Jones, C. (Dirección). (1951). Wile E. Coyote and the Road Runner. Estados Unidos. Disponible en: 〈https://www.youtube.com/watch?v=S3Nos85TpBE〉 (Consulta 10/05/2014).

Joubert, F. O. (Dirección). (2008). French Roast. Francia. Disponible en: 〈https://www.youtube.com/watch?v=ibFhATUfuow〉 (Consulta 16/12/2014).

Jutra, C., \& McLaren, N. (Dirección). (1957). A Chairy Tale (Un cuento de sillas). Canadá. Homevision [DVD].

Kashkoolinia, M. (Dirección). (2012). Tunnel (Túnel). Irán.

Katsumata, T. (Dirección). (1972-1974). Majingā Zetto (Mazinger Z). Japón. Selecta Visión [DVD].

Keane, G. (Dirección). (2014). Duet. Estados Unidos. Disponible en: 〈https://www.youtube.com/watch?v=FO3m8KT7odY) (Consulta 17/10/2014).

Kelly, K. (Dirección). (1994). Stressed (Estresados). Reino Unido. Channel 4 Television Corporation [VHS].

Khrjanovsky, A. (Dirección). (1966). There Lived Kozyavin. Rusia. Disponible en: 〈https://www.youtube.com/watch?v=QLFirZwoMx0) (Consulta 03/03/2015).

Kinoshita, R. (Dirección). (1977). Japonese. Japón. ASIFA-Japan [DVD].

Klein, D. (Dirección). (2004). Spring isn't fair (La primavera no es justa). Alemania. Disponible en: 〈https://vimeo.com/3922147〉 (Consulta 25/10/2012).

Klooss, R. (Dirección). (2013). Tarzán 3D. Alemania. Constantin Film [DVD].

Kovalyov, I. (Dirección). (1990). Hen, his wife (La gallina, su esposa). Rusia. Disponible en: 〈https://www.youtube.com/watch?v=fYdaHaNRMKg〉 (Consulta 15/04/2011).

Kovalyov, I. (Dirección). (2005). Milch (Leche). Estados Unidos. Acme Filmworks [DVD].

Krause, F. (Dirección). (2003). Box Factory. Estados Unidos. Square Footage Films [DVD].

Krumme, R. (Dirección). (1986). Seiltänzer (El baile de la cuerda). Alemania. ACME Film Works [DVD]. 
Krumme, R. (Productor). (1989). Zuschauer (Espectadores). Alemania. ACME Film Works [DVD].

Krumme, R. (Dirección). (1991). Die Kreuzung (La encrucijada). Estados Unidos, Alemania. ACME Film Works [DVD].

Krumme, R. (Dirección). (1994). Passage (El paso). Alemania. ACME Film Works [DVD].

Krumme, R. (Dirección). (1996). Flakes, comercial para la campaña publicitaria Got Milk? para California Mill Processor Board. Estados Unidos: Disponible en: 〈http://www.acmefilmworks.com/work/spot/flakes/〉 (Consulta 15/08/2014).

Krumme, R. (Dirección). (1996). Sandwich, comercial para la campaña publicitaria Got Milk? para California Mill Processor Board. Estados Unidos: Disponible en: 〈http://www.acmefilmworks.com/work/spot/sandwich/〉 (Consulta 15/08/2014).

Krumme, R. (Dirección). (2000). The Message (El mensaje). Alemania. ACME Film Works [DVD].

Kurdali, B. (Dirección). (2006). Elephant Dream. Anaya S.A. [DVD].

Lahtinen, S. (Dirección). ( 2010). Kuka kehtaa? (¿Quién osa?). Finlandia. Disponible en: 〈https://vimeo.com/13907826) (Consulta 06/08/2012).

Lahtinen, S. (Dirección). (h.2013). Tanssi (Danza). Finlandia. Disponible en: 〈http://vimeo.com/79478135) (Consulta 30/08/2012).

Lamka, J. (Dirección) (1985). O Človíčkovi, Jak si vykřesal první jiskřičk (El hombrecito, de cómo descubrió el fuego). República Checa. Disponible en: 〈https://www.youtube.com/watch?v=WfZ-o3enoss) (Consulta 03/03/2012).

Larkin, R. (Dirección). (1965). Syrinx (Siringa). Canadá. Office National du Film du Canada [DVD].

Larkin, R. (Dirección). (1972). Street Musique (Calle Música). Canadá. Office National du Film du Canada [DVD].

Larricq, A. (Dirección). (2011). La douce (La dulce). Francia. Disponible en: 〈https://vimeo.com/54087050〉 (Consulta 11/08/2013).

Laudenbach, S. (Dirección). (2004). Des câlins dans les cuisines (Abrazos en la cocina). Francia. [Copia privada].

Lavis, C., \& Szczerbowski, M. (Dirección). (2007). Madame Tutli-Putli. Canadá: Disponible en: 〈http://vimeo.com/8120949〉 (Consulta 20/11/2010).

Leaf, C. (Dirección). (1974). The Owl Who Married a Goose (El búho que se casó con una gansa). Canadá. Disponible en: 〈https://www.youtube.com/watch?v=fusYZ7elhps) (Consulta 03/02/2015). 
Leaf, C. (Dirección). (1976). The Street (La calle). Canadá: Disponible en: 〈https://www.nfb.ca/film/the street) (Consulta 05/05/2011).

Leaf, C. (Dirección). (1987). The Metamorphosis of Mr. Samsa (La metamosfosis del señor Samsa). Canadá: Disponible en: (https://www.youtube.com/watch?v=PI5HCAwh8ul) (Consulta 28/08/2010).

Lemany, N. (Dirección). (2011). Private Eyes (Ojos privados). Canadá. Disponible en: 〈https://vimeo.com/12876042〉 (Consulta 05/06/2015).

Linklater, R. (Dirección). (2006). A Scanner Darkly. Estados Unidos. Warner Independent Pictures [DVD].

López, I. (Dirección). (2013). Jamón. Reino Unido. Disponible en: 〈https://vimeo.com/108986967〉 (Consulta 22/12/2014).

Lye, L. (Dirección). (1935). A Color Box (Caja de color). Canadá. Disponible en: 〈https://www.youtube.com/watch?v=-DksmbDMDUU〉 (Consulta 10/08/2013).

Maestro, J. (Dirección). (2012). El vendedor de humo. España. Disponible en: 〈https://www.youtube.com/watch?v=INhpX2UQsmE〉 (Consulta 05/04/2013).

Marsily, N., \& Roosens, C. (Dirección). (2014). Moustique (Mosquito). Francia. [Copia privada].

Massi, S. (Dirección). (2011). Dell'ammazzare il maiale (Sobre la matanza del cerdo). Italia. Disponible en: ‘https://vimeo.com/62930711) (Consulta 19/08/2014).

McCay, W. (Dirección). (1911). Little Nemo. Estados Unidos. Disponible en: 〈https://www.youtube.com/watch?v=kcSp2ej2S00〉 (Consulta 17/08/2010).

McCay, W. (Dirección). (1921). Flip's Circus. Estados Unidos. Disponible en: 〈https://www.youtube.com/watch?v=BR KhISmliU〉 (Consulta 17/08/2010).

McLaren, N. (Dirección). (1941). Mail Early (Correo matutino). Canadá. Norman McLaren: The Masters Edition [DVD].

McLaren, N. (Dirección). (1942). Hen Hop. Canadá. Homevision [DVD].

McLaren, N. (Dirección). (1943). Dollar Dance (El baile del dólar). Canadá. Homevision [DVD].

McLaren, N. (Dirección). (1947). La poulette grisse (La gallina gris). Canadá. Homevisión [DVD].

McLaren, N. (Dirección). (1949). Begon Dule Care (Fantasía en colores). Canadá. Homevision [DVD].

McLaren, N. (Dirección). (1952). Neighbours (Vecinos). Canadá. Homevision [DVD].

McLaren, N. (Dirección). (1955). Blinkity Blank, Canadá. Homevision [DVD].

McLaren, N. (Dirección). (1983). Narcisus (Narciso). Canadá. Homvision [DVD]. 
Menestrey, D. (Dirección). (2011). Anomalis - Near but blint (Anomalía - Cerca pero ciegos). Colombia-Alemania. [Copia privada].

Miailhe, F. (Dirección). (1992). Hammam. Francia. Garde Temps Eds Du [DVD].

Miailhe, F. (Dirección). (1995). Schéhérazade. Francia. Garde Temps Eds Du [DVD].

Miailhe, F. (Dirección). (1996). Histoire d'un prince devenu borgne et mendiant (Historia de un príncipe que se convirtió en tuerto y mendigo). Francia. Garde Temps Eds Du [DVD].

Miailhe, F. (Dirección). (2002). Au premier dimanche d'août (El primer domingo de agosto). Francia. Garde Temps Eds Du [DVD].

Minkoff, R., \& Allers, R. (Dirección). (1994). The Lion King (El rey león). Estados Unidos. Disponible en: (http://www.fanpop.com/clubs/disney/images/19902748/title/lionking-screencap) (Consulta 03/06/2015).

Miyazaki, H. (Dirección). (1988). Tonari no Totoro (Mi vecino Totoro). Japón. Aurum Producciones [DVD].

Miyazaki, H. (Dirección). (2001). Sen to Chihiro no Kamikakushi (El viaje de Chihiro). Japón. Aurum Producciones [DVD].

Miyazaki, H. (Dirección). (2004). Howl no Ugoku Shiro (El Castillo ambulante). Japón. Aurum Producciones [DVD].

Miyazaki, H. (Dirección). (2008). Gake no ue no Ponyo (Ponyo en el acantilado). Japón. Aurum Producciones [DVD].

Mizue, M. (Dirección). (2011). Modern No.2. Japón. Carte Blanche.

Mochizuki, T., Sawai, K., Nishimura, J., \& Shibiyama, T. (Dirección). (1989-1992). Ramma 1/2. Japón: Jonu Media [DVD].

Moesker, C. (Dirección). (1997). Sientje. Países Bajos. Disponible en: 〈https://www.youtube.com/watch?v=AgYn7j-iEnc〉 (Consulta 08/08/2014).

Morgan, R. (Dirección). (2003). The separation (La separación). España. Sitges-Festival International de Cinema de Catalunya.

Morishita, K. (Dirección). (1972-1974). Las cadenas de la amistad. Saint Seiya (Caballeros del zodiaco). Japón. Selecta Visión [DVD].

Morishita, K., \& Kikuchi, K. (Dirección). (1986-1988). Sancturay daikessen! Atena saidai no kiki (La gran batalla del Santuario) capítulo 41 tempora 1 El santuario. Saint Seiya (Caballeros del zodiaco). Japón. Universal Pictures [DVD].

Morishita, K., \& Kikuchi, K. (Dirección). (1986-1989). Saint Seiya, Temporada 1, capítulo 21: La Pirámide de hielo. Japón. Paramount [DVD]. 
Mulloy, P. (Dirección). (1991). Cowboys: Murder! (Cowboys: iAsesinato!). Reino Unido. BFI [DVD].

Mulloy, P. (Dirección). (1992). The sound of music (El sonido de la música). Reino Unido. BFI [DVD].

Murakami, J. (Dirección). (1996). When the Wind Blows (Cuando el viento sopla). Reino Unido. Channel 4 Television Corporation [VHS].

Nagahama, T., \& Dezaki, O. (Dirección). (1979-1980). Berusaiyu no Bara (La rosa de Versalles). Japón. De Agostini [DVD].

Nenow, D. (Dirección). (2010). Paths of hate (Los caminos del odio). Polonia. Disponible en: 〈https://www.youtube.com/watch?v=CZ1J9Af01PY) (Consulta 13/08/2013).

Neubauer, B. (Dirección). (1998). Feuerhaus. Alemania. [Copia privada].

Nomura, T., \& Takeshi, N. (Dirección). (2005). Final Fantasy VII. Advent Children (Fantasía final VII. Los hijos del advenimiento). Japón. Disponible en: 〈https://www.youtube.com/watch?v=WyPlwtBTXpk〉 (Consulta 03/03/2015).

O'Neill, E. (Dirección). (2011). I'm Fine Thanks (Estoy bien, gracias). Irlanda, Reino Unido. Royal College of Art [DVD].

Ocelot, M. (Dirección). (1980). Les trois inventeurs (Los tres inventores). Francia. Disponible en: 〈https://www.youtube.com/watch?v=A002vUNJtA8〉 (Consulta 05/03/2015).

Ocelot, M. (Dirección). (1982). La légende du pauvre bossu (La leyenda del pobre jorobado). Francia. Disponible en: 〈https://www.youtube.com/watch?v=-JvlknCt vg〉 .

Ocelot, M. (Dirección). (2006). Azur y Asmar. Francia, Bélgica, España , Italia. Divisa HV [DVD].

Park, N. (Dirección). (1989). Creature Comforts (Comodidades de la criatura). Reino Unido. Disponible en: 〈https://www.youtube.com/watch?v=pjSIB9WfpF4». (Consulta 07/03/2015).

Peris, M. (Dirección). (2010). Nadando en el aire. España. [Copia privada].

Peris, M. (Dirección). (2012). Estrella fugaz. España. [Copia privada].

Peris, M., \& Peris, R. (Dirección). (2011). Libidinis. España, Reino Unido. [Copia privada].

Peris, R. (Dirección). (2006). Prostitución infantil. España. [Copia privada].

Peris, R. (Dirección). (2010). Tántalo. España. [Copia privada].

Peris, R. (Dirección). (2011). Báladi. España. [Copia privada].

Peris, R. (Dirección). (2011). Mío, tuyo, nuestro. España; Alemania [Copia privada].

Peris, R. (Dirección). (2012). Tututú. España. [Copia privada]. 
Peris, R., \& Peris, M. (Dirección). (2007). Corre, caballito. [Copia privada].

Plaza, D. (Dirección). (2014). Mario Animum, el primer mologuista 3D. España. Disponible en: 〈https://vimeo.com/84968068〉 (Consulta 30/09/2014).

Plympton, B. (Dirección). (1988). How to kiss (Cómo besar). Reino Unido. Plympcorp [VHS].

Plympton, B. (Dirección). (1988). One of those days (Uno de esos días). Reino Unido. Plympcorp [VHS].

Pompian, M. M. (Dirección). (1989). Honey, I Shrunk the Kids (Cariño, he encogido a los niños). Estados Unidos. Walt Disney Home Video [VHS].

Productions, W. D. (Dirección). (1942). Pluto Junior. Pluto Collection Volum I. Estados Unidos. Buena Vista [VHS].

Purves, B. (Dirección). (1990). Next! (iSiguiente!). Reino Unido. Disponible en: 〈https://www.youtube.com/watch?v=V3dQFR8oWb4) (Consulta 18/03/2012).

Purves, B. (Dirección). (1993). Screen Play. Reino Unido. Disponible en: 〈https://www.youtube.com/watch?v=t0d1EsHJH9Q $\rangle$ (Consulta 18/03/2009).

Purves, B. (Dirección). (2011). Tchaikovsky - An Elegy (Tchaikovsky - Una elegía). Rusia; Reino Unido. Disponible en: 〈https://www.youtube.com/watch?v=xQ2KdShvQH4〉 (Consulta 28/12/2012).

Quest (1996). Alemania. Disponible en: (https://www.youtube.com/watch?v=uTyev60aThg) (Consulta 21/08/2010).

Quinn, J. (Dirección). (1990). Body Beautiful (Cuerpo hermoso). Reino Unido. Beryl Productions International Ltd [DVD].

Quinn, J. (Dirección). (1993). Britannia. Reino Unido. Disponible en: 〈https://www.youtube.com/watch?v=zJ2q508gzao) (Consulta 05/03/2015).

Quinn, J. (Dirección). (1998). The wife of Bath's Tale (La mujer de Bath). Reino Unido. Beryl Productions International Ltd [DVD].

Quinn, J. (Dirección). (2006). Dreams And Desires. Family Ties (Sueños y deseos. Lazos familiares). Reino Unido. Disponible en: 〈https://www.youtube.com/watch?v=Z8S9XJLtLhU〉 (Consulta 19/05/2011).

Reed, C. (Dirección). (1949). The Third Man (El tercer hombre). Reino Unido. Criterion DVD [DVD].

Reiniger, L. (Dirección). (1953). The magic horse (El caballo mágico). Alemania. Disponible en: 〈https://mubi.com/films/the-magic-horse〉 (Consulta 30/08/2010).

Reiniger, L. (Dirección). (1926). Die Abenteuer des Prinzen Achmed (Las aventuras del Príncipe Ahmed). Alemania. BFI [DVD]. 
Reitherman, W. (Dirección). (1967). The Jungle Book (El libro de la selva). Estados Unidos. Filmayer Video [DVD].

Reitherman, W. (Dirección). (1970). The Aristocats (Los Aristogatos). Estados Unidos. Disponible en: https://www.lewiswaynegallery.com/the-aristocats-lobby-card-set1970-vf-nm-walt-disney-p-2255.html) (Consulta 03/05/2015).

Repiso, M. (Dirección). (1999). Todos los niños tienen derecho a una familia. Argentina. Unicef.

Reynaud, É. (Dirección). (1892). Pauvre Pierrot (Pobre Pierrot). Francia. Disponible en: 〈https://www.youtube.com/watch?v=426mqlB-kAY) (Consulta 17/08/2010).

Reynaud, É. (Dirección). (1894). Autour d'une cabine (Alrededor de una caseta de baño). Francia. Disponible en: (https://www.youtube.com/watch?v=A5MXcxaRXNc) (Consulta 17/08/2010).

Ribeiro, J. M. (Dirección). (2010). Viagem a Cabo Verde (Viaje a Cabo Verde). Portugal. Praça Filmes: Praça Filmes [DVD].

Ribeiro, J. M., \& Bouchon, P. (Dirección). (1996). Juegos olímplicos - Nataçao. Portugal. [Copia privada].

Rimminen, M. (Dirección). (1987). Some Protection (Algo de protección). Reino Unido. Yadin Productions [DVD].

Rivero, P., \& Vázquez, A. (Dirección). (2010). Birdboy. España. Disponible en: 〈https://vimeo.com/34658195) (Consulta 18/01/2012).

Rose, K. (Dirección). (1991). Oriental Interplay. Estados Unidos. Disponible en: 〈https://www.youtube.com/watch?v=b0UQU30ErU4〉 (Consulta 09/08/2010).

Rosenthal, T. (Dirección). (2008). \$9.99. Isarael; Australia. E1 Entertainment [DVD].

Ruiz, F., \& McNally, S. (Dirección). (2006). A Gentelmen's Duel (Duelo de caballeros). Estado Unidos. Disponible en: 〈http://vimeo.com/8379529) (Consulta 08/08/2014).

Russell, E. (Dirección). (1994). Triangle (Triángulo). Reino Unido. Disponible en: 〈https://www.youtube.com/watch?v=2UsFIHyNmQl〉 (Consulta 08/08/2011).

Russell, E. (Dirección). (1988). Feet of song. Reino Unido. Disponible en: 〈https://www.youtube.com/watch?v=k0oBUxPNPXY) (Consulta 08/08/2011).

Saidan, S. (Dirección). (2011). Quand le chat est là... (Cuando el gato está ahi). Francia. [Copia privada].

Sastiaga, J. A. (Dirección). (1970). Ere erera baleibu icik subua aruaren. España. Disponible en: 〈http://www.cataclismo.net/comprar.php?id=754〉 (Consulta 02/01/2013).

Schwizgebel, G. (Dirección). (1974). Flight of Icarus (El vuelo de Ícaro), Suiza. National Film Board of Canada [DVD]. 
Schwizgebel, G. (Dirección). (1977). Hors-jeu (Fuera de Juego). Suiza. National Film Board of Canada [DVD].

Schwizgebel, G. (Dirección). (1982). La ravissement de Frank N. Stein (El encanto de Frank N. Stein). Suiza. National Film Board of Canada [DVD].

Schwizgebel, G. (Dirección). (1985). 78 Tours (78 vueltas). Suiza. National Film Board of Canada [DVD].

Schwizgebel, G. (Dirección). (1992). La curse à l'abîme (La maldición del abismo). Estados Unidos. National Film Board of Canada [DVD].

Schwizgebel, G. (Dirección). (1995). L'année du daim (El año del ciervo). Suiza. National Film Board of Canada [DVD].

Schwizgebel, G. (Dirección). (1998). Fugue (Fuga). Suiza. National Film Board of Canada [DVD].

Schwizgebel, G. (Dirección). (2000). La jeune fille et les nuages (La joven y las nubes). Francia, Suiza. National Film Board of Canada [DVD].

Searle, R. (Productor), \& Annakin, K. (Dirección). (1965). Those Magnificent Men in Their Flying machines or How I Flew from London to Paris in 25 hours 11minutes (Esos chalados en sus locos cacharros o cómo volé de Londres a Paris en 25 horas y 11minutos) [Créditos]. Estados Unidos. 20th CENTURY FOX [DVD].

Selick, H. (Productor). (1993). The Nightmare Before Christmas (Pesadilla antes de Navidad). Estados Unidos. Walt Disney Pictures [VHS].

Serrazina, P. (Dirección). (1995). Estória do Gato e da Lua (Historia del gato y la Luna). Portugal. First Rrun Features [DVD].

SHED Studio (Dirección). (2013). IGA - Aide Gourmet. Canadá. Disponible en: 〈http://vimeo.com/65561144〉 (Consulta 15/04/2014).

Shiroki, S. (Dirección). (2001). Woman who stole fingers (La mujer que robaba dedos). Japón. [Copia privada].

Smith, P. (Dirección). (2002). Delivery (Entrega). Estado Unidos. Square Footage Films [DVD].

Smith, P. (Dirección). (2002). Makinf of Delivery (Cómo se hizo Delivery). Estado Unidos. Square Footage Films [DVD].

Arcadia Group SRL. (Dirección). ( h.2011). Concepts in Science: Organic Chemistry 1. (Conceptos de ciencia: Química orgánica I). Argentina. Disponible en: 〈http://www.todoeducativo.com/index.php/edumedia/videoseducativos/video/quimica-organica.html) (Consulta 20/12/2014).

Sun, X., \& Li, Y. (Dirección). (2012). Happy Life (Vida feliz). Alemania; China. Disponible en: 〈http://vimeo.com/43977985) (Consulta 14/07/2014). 
Sutherland, M. (Dirección). (2010). Light Forms (Formas de luz). Canadá. Disponible en: 〈https://vimeo.com/8334834〉.(Consulta 22/10/2012).

Sutherland, M. (Dirección). (2010). Umbra (Sombra). Canadá. Disponible en: 〈https://vimeo.com/14844291〉 (Consulta 28/12/2013).

Svankmajer, J. (Dirección). (1971). Jabberwooky. República Checa. BFI DVD Publishing [DVD].

Svankmajer, J. (Dirección). (1982). Možnosti dialogu (Dimensiones deldiálogo). República Checa. BFI DVD Publishing [DVD].

Svankmajer, J. (Dirección). (1987). Alice (Alicia). Suiza, Alemania Occidental, Reino Unido. BFI [DVD].

Svankmajer, J. (Dirección). (2000). Otesánek (El pequeño Otik). República Checa, Reino Unido, Japón. Zeitgeist Films [DVD].

Takahata, I. (Dirección). (2013). Kaguya-hime no Monogatari (El cuento de la princesa Kaguya). Japón.

Takeuchi, Y. (Dirección). (1997). Janguru Taitei (Kimba, el león blanco). Japón. Disponible en: 〈https://www.youtube.com/watch?v=cHbSI7mQFel〉 (Consulta 15/12/2014).

Serotonin Tech. (Dirección). (2013). Animación educativa: StudioHistoria. Chile. Disponible en: 〈https://www.youtube.com/watch?v=uNuuSaccUTw) (Consulta 13/04/2015).

Tezuka, O. (Dirección). (1984). Jumping (Saltar). Japón. Disponible en: 〈http://vimeo.com/22840924〉 (Consulta 05/06/2012).

Tomioka, S. (Dirección). (1999). Sink (Inmersión). Japón. Laurence King [DVD].

Trnka, J. (Dirección). (1959). Sen noci svatojanske (Sueño de una noche de verano). República Checa. Disponible en: 〈https://www.youtube.com/watch?v=m5u09h2eaRw〉 (Consulta 30/05/2015).

Tunis, R. (Dirección). (1972). Le vent (El viento). Canadá. Disponible en: 〈https://www.nfb.ca/film/vent 〉 (Consulta 24/08/2009).

Tupicoff, D. (Dirección). (2007). Chainsaw (Motosierra). Australia. Disponible en: 〈http://www.dennistupicoff.com/chainsaw.html〉 (Consulta 21/08/2012).

TVE (Dirección). (2013). Documental La luz y el misterio de las catedrales. Catedral de Santiago. Render Recorrido 3D de la recreación de la catedral de Santiago de Compostela. España. Disponible en: 〈http://www.rtve.es/alacarta/videos/la-luz-y-elmisterio-de-las-catedrales/luz-misterio-catedrales-catedral-santiagocompostela/1676417/> (Consulta 05/02/2014).

Unicef (Dirección). (1979). Los niños tienen derecho al descanso. Unicef [VHS]. 
Unkrich, L. (Dirección). (2010). Toy Story 3. Estados Unidos. Disponible en: 〈http://www.fanpop.com/clubs/pixar/images/13593043/title/toy-story-3screencaps-screencap) (Consulta 03/06/2015).

Usev, T. (Dirección). (2013). Gloria Victoria. Canadá [DVD].

Ushev, T. (Dirección). (2006). Torre Bawhuer. Canadá. Disponible en: 〈https://www.youtube.com/watch?v=HbC4GTtcYfM〉 (Consulta 21/03/2015).

Van Dijk, G., \& Renault, M. (Dirección). (1988). Pas a deux. Países Bajos. Disponible en: 〈https://www.youtube.com/watch?v=ZN4TBn9C1Zk (Consulta 15/05/2011).

Verbinski, G. (Dirección). (2006). Pirates of the Caribbean: Dead Man's Chest (Piratas del Caribe: el cofre del hombre muerto). Estados Unidos. The Walt Disney Company Iberia S.L. [DVD].

Villard, J.-C. (Dirección). (1979). L'Emotif (El emotivo). Francia. Disponible en: 〈https://www.youtube.com/watch?v=FE-iXfoC7co) (Consulta 18/06/2011).

Walker, M. (Dirección). (2007). John and Karen. Reino Unido. Acme Filmworks [DVD].

Welch, C. (Dirección). (1996). How Wings are Attached to the Back of Angels (Cómo las alas están unidas a la espalda de los ángeles). Canadá. Disponible en: 〈https://www.youtube.com/watch?v=NRHVzbJVx81〉 (Consulta 03/10/2012).

Wells, S. (Dirección). (2011). Mars Needs Moms! (iMarte necesita madres!) Estados Unidos. Disponible en: ‘http://www.garuyo.com/ni\%C3\%B1os/programacion-de-disneychannel) (Consulta 03/01/2015).

Woodward, R. (Dirección). (2010). Thought of you... (Pensando en ti...). Estados Unidos. Disponible en: 〈https://vimeo.com/14803194〉 (Consulta 09/08/2013).

Xi, C., \& An, X. (Dirección). (2001). Grain coupon (El cupón de grano). China. [Copia privada].

Yabe, A. (Dirección). (1994-1995). Mermelade Boy (La familia crece). Japón. Disponible en: 〈https://www.youtube.com/watch?v=RgtrLf02n84) (Consulta 07/05/2012).

Yamamura, K. (Dirección). (1984). Atama Yama (Monte Cabeza). Japón. CICA , Centre International du Cinéma d'Animation [DVD].

Yamamura, K. (Dirección). (2011). Muybridge's strings (Las cuerdas de Muybridge). Canadá; Japón. Disponible en: 〈https://www.youtube.com/watch?v=87GHAqk4C6w) (Consulta 15/08/2014).

Yersin, B., Maïm, J., Thalmann, D., Haegler, S., Mueller, P., \& Van Gool, L. (Dirección). (2007). Populating Ancient Pompeii with Crowds of Virtual Humans (Poblar la antigua Pompeya con multitud de seres humanos virtuales). Suiza: Disponible en 〈https://www.youtube.com/watch?v=2g26YIbXUTw〉 (Consulta 11/11/2014).

Young, S. (Dirección). (1986). Carnival. Reino Unido: Royal College of Art [DVD]. 
Zaramella, J. P. (Dirección). (2011). Luminaris. Argentina; Francia. Disponible en: 〈https://vimeo.com/24051768 〉 (Consulta 19/08/2011).

Zemeckis, R. (Dirección). (1988). Who Framed Roger Rabbit? (¿Quién engañó a Roger Rabbit?). Estados Unidos. Touchstone Home Video [DVD].

Zemeckis, R. (Dirección). (2007). Beowulf. Estados Unidos. Warner Home Video [DVD]. 


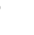




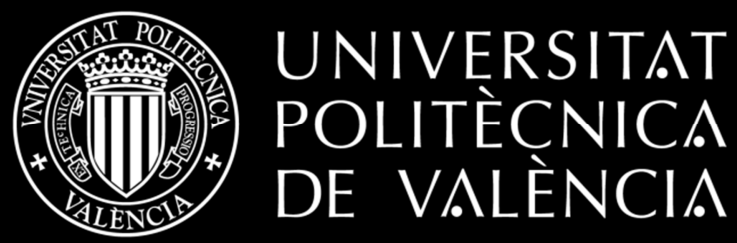

